\title{
Van de stad en de rand
}

SDU uitgeverij, 's-Gravenhage 1990

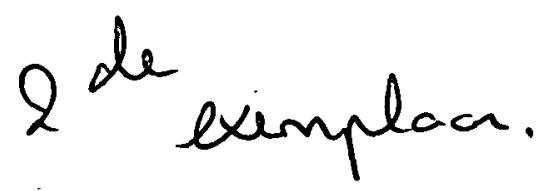

Bibliotheek Wetenschappelijke Raad voor het Regeringsbeleic

Plein 1813 ni, 22514 JN 's-Gravenhage

Postbus 20604. 2500 EA 's-Gravenhage

Tẹteftoen 070 - 564100 toostel 445214454

Wetenschappelijke Raad voor het Regeringsbeleid

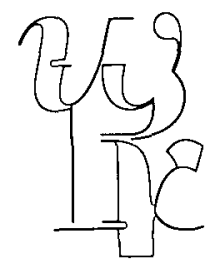




\section{CIP-GEGEVENS KONINKLIJKE BIBLIOTHEEK, DEN HAAG}

Van de stad en de rand

Van de stad en de rand / Wetenschappelijke Raad voor het Regeringsbeleid. 's-Gravenhage: SDU uitgeverij. - (Rapporten aan de regering ; 37) ISBN 90-12-06973-4

SISO 994 UDC [338+316.42](492-21)

Trefw.: grote steden ; Nederland ; economische politiek / maatschappelijke veranderingen. 
Wetenschappelijke Raad voor het Regeringsbeleid
Aan de Minister-President Minister van Algemene Zaken De heer drs. R.F.M. Lubbers Postbus 20001 2500 EA 's-Gravenhage
Uw brief

Onderwerp

rapport nr. 37

Van de stad en de rand

\section{Ons kenmerk} 901249 /JCFB/LT - 06

Doorklesnummer $07.0-3564471$
Kantooradres: Plein 1813, nr. 2 Postbus 20004

2500 EA 's-Gravenhage

Telefoon 070 - 3564600

Telefax $070-3564685$

Datum

3 september 1990

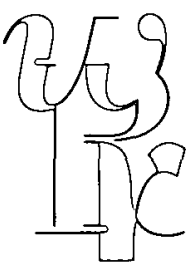

Hierbij doen wij $u$ het rapport "Van de stad en de rand" toekomen.

In dit rapport adviseert de raad meer reliëf te geven aan een grootstedelijk beleid op nationaal niveau. In dit kader dienen de grote steden een ruimere bestuurlijke en financiële armslag te krijgen en meer verantwoordelijkheid te dragen voor de verbetering van hun positie.

In het rapport worden aanbevelingen gedaan met betrekking tot de economische ontwikkeling in de grote steden, de sociale problemen, de matschappelijke voorzieningen en de financieelbestuurlijke verhoudingen.

Volgens de procedure die in de Instellingswet WRR is vastgelegd, ziet de raad graag het bericht van kennisneming door en de bevindingen van de Raad van Ministers tegemoet.

De voorzitter,
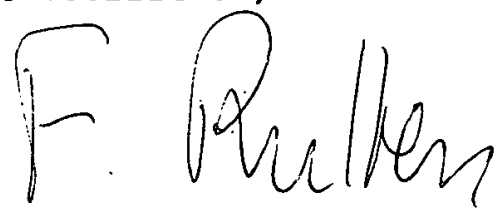

Prof.dr. F.W. Rutten
De secretaris,

W. vara lavinasura.

Dr. w. van Drimmelen 


\section{Inhoudsopgave}

$\begin{array}{lr}\text { Samenvatting } & 9\end{array}$

I. Inleiding 13

2.

Internationale plaatsbepaling en referentiekader 17

2.1 Inleiding 17

2.2 Hoofdkenmerken van de internationale plaatsbepaling $\quad 18$

2.2.1

Positie van de economische bedrijvigheid

Sociale structuur

Maatschappelijke voorzieningen

Financieel/bestuurlijke infrastructuur

$\begin{array}{ll}\text { 2.3.3 Specialisatie in het voorzieningenbeleid } & 29\end{array}$

2.3.4

Inhoudelijke beleidsthema's $\quad 32$

Plaatsbepaling in de internationale context 53

$\begin{array}{ll}\text { De komende periode } & 58\end{array}$ 
4.2.1.1 Omvang bevolking $\quad 90$

$\begin{array}{ll}\text { 4.2.1.2 Bevolkingsopbouw } & 90\end{array}$

4.2.2 Inkomens 93

4.2.3 Werkloosheid $\quad 95$

4.2.4 Concentratie en cumulatie van sociale problemen 96

4.3 Selectieve ontwikkeling van geografische en sociale mobiliteit 96

4.3.1 Selecties in de geografische mobiliteit $\quad 97$

4.3.2 De kloof op de stedelijke arbeidsmarkt 101

4.3.2.1 De arbeidsmarktporadox 101

$\begin{array}{lll}\text { 4.3.2.2 Scholing } & 103\end{array}$

4.3.2.3 Openstaande vraog en moeilijk vervulbare vacatures 104

4.3.3 Materiële beperkingen van de mobiliteit 106

4.3.4 Immateriële beperkingen van de mobiliteit 108

4.4 Samenvatting en opgaven voor de sociale problematiek 109

4.5 Beleidsopgaven ter versterking van de sociale structuur 111

4.5.I De financiële en bestuurlijke mechanismen 111

4.5.2 Het ruimtelijk perspectief 113

$\begin{array}{lll}\text { 4.5.3 De minimuminkomens } & 114\end{array}$

4.5.4 Individuele hulpverlening 118

$\begin{array}{ll}\text { 4.5.5 Bestrijding van werkloosheid } & 119\end{array}$

4.5.5.1 Vertraagde reacties op de werkloosheid 119

4.5.5.2 Mogelijkheden voor bestrijding van werkloosheid 120

$\begin{array}{lll}\text { 4.5.6 Bevordering van ondernemerschap } & 127\end{array}$

5. Allocatie van stedelijke voorzieningen 133

5.1 Inleiding 133

5.2 Onderwijs 135

5.2.1 Inhoudelijke plaatsbepaling 135

5.2.2 Het onderwijsprofiel van de steden 139

5.2.3 Kwaliteit van het aanbod van onderwijsvoorzieningen 146

5.2.4 Ontwikkelingen in de institutionele verhoudingen 150

5.2.5 Beleidsopgaven 153

5.3 Arbeidsvoorziening 157

$\begin{array}{lll}\text { 5.3.1 Algemeen kader } & 157\end{array}$

$\begin{array}{ll}\text { 5.3.2 Profiel van de stedelijke arbeidsmarkt } & 161\end{array}$

$\begin{array}{lll}\text { 5.3.3 Arbeidsvoorzieningsaanbod } & 163\end{array}$

$\begin{array}{lll}\text { 5.3.4 Beleidsopgaven } & 164\end{array}$

5.4 Gezondheid en maatschappelijke dienstverlening 168

$\begin{array}{lll}\text { 5.4.1 Stelselherziening } & 168\end{array}$

5.4.2 Gezondheidsprofiel van de stedelijke bevolking 169

5.4.3 Globale typering van het voorzieningenaanbod 170

5.4.4 Vernieuwing van de institutionele context $\quad 172$

5.4.4.1 De bevordering van de gezondheid 172

5.4.4.2 Curatieve zorg en maatschappelijke dienstverlening 173

$\begin{array}{lll}\text { 5.4.5 Beleidsopgaven } & 177\end{array}$

5.4.5.1 De bevordering van gezondheid 179

$\begin{array}{lll}\text { 5.4.5.2 Thuiszorg } & 179\end{array}$

$\begin{array}{ll}\text { 5.4.5.3 Differentiatie van normuitkeringen } & 179\end{array}$

5.4.5.4 De lokale en regionale uitvoering van het stelsel 180 
6. Financiële en bestuurlijke verhoudingen 183

6.1

Inleiding

183

6.2

De financiële verhouding

Particuliere en publieke uitgaven voor voorzieningen

De verhouding tussen het Rijk en de gemeenten

Trends in gemeentelijke uitgaven

De financiële positie van de grote steden

De steden in de context van Europa

Beleidsopgaven 
In het rapport 'Van de stad en de rand' wijst de raad op het toenemend belang van grootstedelijke gebieden in de internationale economische en maatschappelijke betrekkingen. Naast hun relatief grote aandeel in de nationale economieën, hebben zij een 'schakelfunctie' over landsgrenzen heen, als concentratie- en overslagplaats van goederen, diensten en informatie.

De grote steden moeten, als kern van voornoemde gebieden, deze schakelfunctie goed vervullen; dat is een nationaal belang. Hun economisch en maatschappelijk gewicht brengt voorts mee dat wat in de steden gebeurt, eenieder aangaat.

Ondanks de keer ten goede in de nationale economie, laat de ontwikkeling van de Nederlandse grote steden (Amsterdam, Rotterdam, Den Haag en Utrecht) echter nog altijd te wensen over, zij het in wisselende mate. Zonder extra aandacht en beleidsinzet is een verbetering zoals gewenst, niet te verwachten, zo stelt de raad vast op grond van de voor dit rapport gemaakte analyses.

Bezien op de schaal van het grootstedelijk gebied (stad en rand tezamen), komen de problemen ongeveer neer op het Nederlandse gemiddelde.

De raad wijt het achterblijven van een adequate reactie op de grootstedelijke problematiek vooral aan een scheefgroei van de institutionele verhoudingen. De grote steden zijn financieel en beleidsmatig erg afhankelijk van het Rijk. Daarnaast kan een aantal belangrijke functies die de stedelijke kernen te boven gaan, bij gebrek aan een adequate bestuursvorm niet behoorlijk worden uitgevoerd.

Om zelf een actief beleid te kunnen voeren, zouden de grote steden een ruimere bestuurlijke en financiële armslag moeten krijgen. Ook zouden zij, conform de situatie in andere landen, meer rekenschap moeten dragen voor de economische en sociale ontwikkelingen in hun gebied.

Tegen deze achtergrond doet de raad aanbevelingen met betrekking tot respectievelijk de economische ontwikkeling in de grote steden, de sociale problemen, de maatschappelijke voorzieningen en de financieel-bestuurlijke verhoudingen.

\section{Economische ontwikkeling}

Om de grote steden nauwer te betrekken bij het wel en wee van hun economie, dienen zij meer eigen inkomsten te ontvangen. Aldus worden prikkels gegeven voor snelle en alerte reacties. Hierop wordt teruggekomen onder 'financiële verhoudingen'.

De aantrekkelijkheid als vestigingsplaats in internationaal verband vereist uitbreiding van de fysieke infrastructuur. Met de Vierde Nota over de Ruimtelijke Ordening is hiervoor een goede basis gelegd. De raad zou de prioriteit voor de grote steden echter willen aanscherpen.

Het betreft hier een nationaal belang.

Als concrete projecten die met voorrang tot stand moeten komen, noemt de raad: versterking van de 'mainports' Rotterdam en (vooral) Schiphol, een Randstadrailsysteem, voortbouwend op de bestaande railinfrastructuur, met aantakking aan de hoge-snelheidstrein (TGV) en een samenhangende verbetering van het overige openbaar vervoer in de grootstedelijke gebieden.

Betere toegankelijkheid van de grootstedelijke gebieden voor het zakelijk verkeer is van wezenlijk belang. Dit kan nopen tot reguleringen, met name van het woon-werkverkeer. Voorkomen moet echter worden dat door maatregelen 
zoals tolheffingen, spitsvignetten en dergelijke 'barrières' rondom de steden ontstaan die de concurrentiepositie zouden schaden.

Het Rijk zou, zoals dit ook in andere landen gebeurt, een economisch stimuleringsbeleid dienen te voeren, gericht op - vooral in internationaal verband kansrijke onderdelen van de grootstedelijke economie. De aanzetten die hiertoe reeds zijn gegeven, dienen zo spoedig mogelijk te worden versterkt.

\section{Sociale problemen}

Ook voor de cumulatie en concentratie van sociale problemen in de grote steden zoekt de raad oplossingen door het activeren van lokale verantwoordelijkheden. De steden moeten sterker de noodzaak voelen zelf beleid te voeren.

In dit verband wordt geadviseerd de zwakke sociale structuur te versterken door de eenzijdige verdeling van woningwetwoningen (grote steden) en premie- en vrije sectorbouw (grootstedelijke randgemeenten) om te buigen.

De raad wil de medeverantwoordelijkheid van gemeentebesturen voor de bijstandsuitkeringen vergroten, onder inachtneming van structurele ongelijkheden tussen sterke en zwakke gemeenten. Bij wijze van proef zou in enkele steden het gemeentelijk aandeel in de bijstand kunnen worden verhoogd, onder gelijktijdige beschikbaarstelling van een 'lump sum' ter hoogte van het extra aandeel.

Slagen deze steden erin meer bijstandsgerechtigden te doen uitstromen naar de arbeidsmarkt dan geraamd, dan zouden zij het batig saldo zelf mogen behouden; tegen tegenvallende nationale ontwikkelingen kan een waarborg worden aangebracht.

Een succesvol grootstedelijk bijstandsbeleid zou op deze wijze worden gepremiëerd.

De bestrijding van werkloosheid zou, naast de al gehanteerde instrumenten (werkervaringsplaatsen, banenpools enz.), meer moeten aanknopen bij initiatieven uit de bedrijvensector. Een sterkere wisselwerking is nodig tussen werkgelegenheidsbeleid, scholing, en arbeidsvoorziening, met meer aandacht voor de concrete werkzoekende en het concrete bedrijf.

$\mathrm{Bij}$ bevordering van de ondernemerscultuur in de steden dient uitdrukkelijk ook aandacht te worden besteed aan de sociale-probleemcategorieën.

\section{Maatschappelijke voorzieningen}

Onderwijs, arbeidsvoorziening, gezondheidszorg en maatschappelijke dienstverlening kunnen mede worden gebruikt om economische en sociale ontwikkelingen te beïnvloeden. Hiertoe zou bij de thans ondernomen stelselwijzigingen, in aansluiting op functionele decentralisatie, verder gestalte moeten worden gegeven aan een grootstedelijke inbreng. In de ruimte die thans wordt gecreëerd voor plaatselijke actoren, dienen de gemeentelijke overheden een nieuwe en grotere rol te krijgen.

\section{Financiële verhoudingen}

Conform de wens de steden zelf meer belang te geven bij de ontwikkelingen in hun gebied, pleit de raad ervoor de financiële verhouding Rijk-grote steden verder te decentraliseren.

Thans ontvangen de gemeenten $63 \%$ van hun middelen direct van het Rijk (de specifieke uitkeringen) en nog eens $27 \%$ indirect (via de algemene uitkering uit het Gemeentefonds). De eigen inkomsten uit gemeentelijke belastingen en heffingen bedragen slechts $10 \%$. 
Deze eigen inkomsten dienen meer in evenwicht te worden gebracht met de algemene uitkering uit het Gemeentefonds. De raad acht een stijging tot 20 à $25 \%$ van het totaal voorstelbaar. Op deze wijze kan de aandacht van het lokaal bestuur voor beïnloedbare plaatselijke verschillen in belastingcapaciteit worden vergroot, terwijl toch de vereveningsfunctie van de algemene uitkering gehandhaafd blijft.

De bestedingsvrijheid van de algemene uitkering is voorts een belangrijk aandachtspunt.

Voortzetting van de sanering en overheveling van de specifieke uitkeringen ligt in de lijn van dit advies. Meer dan tot dusver zal hierbij de aandacht moeten gaan naar de relatief kleine groep van omvangrijke specifieke uitkeringen.

Om de eigen inkomsten te verhogen, dienen de gemeentelijke belastinginkomsten te worden vergroot. Hiervoor komt in de eerste plaats de onroerend-goedbelasting in aanmerking. De geldende koppeling tussen het zakelijk en gebruikerstarief is vooral bedoeld als rem op de gemeentelijke belastinginkomsten. Conform de hoofdlijn van dit rapport adviseert de raad de centrale vaststelling van de verhouding tussen zakelijke en gebruikerstarieven ongedaan te maken. Ter verbreding van de lokale belastinginkomsten kan voorts de aandacht uitgaan naar bestaande belastingen als de baat- en aanlegbelasting en de bouwgrondbelasting en naar nieuwe lokale belastingbronnen. Ook tarieven en heffingen, internationaal veel gehanteerd, dienen voor verhoging van eigen inkomsten te worden gebruikt.

\section{Bestuurlijke verhoudingen}

In Nederland zijn, meer dan in andere landen, de beleidssectoren op afstand van elkaar betrokken op nationaal niveau, terwijl in de grote steden juist vele problemen samenkomen. Deze situatie beperkt het grootstedelijk handelingsvermogen en komt de bestuurlijke veerkracht niet ten goede.

De in dit rapport gedane voorstellen voor decentralisatie zouden hierin verbetering moeten brengen. In aanvulling hierop acht de raad echter ook een nauwere binding nodig tussen de besturen van de onderscheiden kernen in de grootstedelijke gebieden dan mogelijk is onder de Wet gemeenschappelijke regelingen. Alleen zo kan een aantal strategische functies op regionaal niveau behoorlijk worden vervuld.

De raad adviseert hiertoe regioverbanden te vormen op de schaal van het grootstedelijk gebied. In deze regioverbanden zouden bevoegdheden van grote stad en randgemeenten moeten worden gebundeld met betrekking tot strategische onderdelen van openbaar vervoer, woningmarkt en milieubeheer.

Een dergelijke constructie zou een grootstedelijk bestuur in Nederland mogelijk maken, zonder de bestaande bestuurlijke organisatie geweld aan te doen.

Gebiedsuitbreiding van de grote steden zou op deze wijze beperkt kunnen blijven tot die gevallen waar dit per se noodzakelijk is (van de in dit rapport behandelde steden alleen bij Den Haag en Utrecht).

De vorming van regioverbanden kan op den duur aanleiding geven tot een aanpassing van de provinciale bevoegdheden, maar dit behoeft eerst op langere termijn te geschieden. 


\section{Inleiding}

In ons land doet zich de noodzaak voor vanuit een nationaal gezichtspunt de gedachten te bepalen over de betekenis van de grote steden en vast te stellen welke beleidsinzet is vereist voor een krachtige revitalisatie van hun economisch functioneren en een meer doeltreffende aanpak van de toenemende sociale problemen aldaar. Deze overtuiging deed de WRR in de raadsperiode 1983-1987 de voorbereidende werkzaamheden aanvangen aan het hier voorliggende rapport. De raad deelde zijn opvatting overigens met anderen, onder wie politici en bestuurders, ook in de grote steden zelf. De Vierde Nota over de Ruimtelijke Ordening stond op het punt van uitkomen. Het bleek het eerste beleidsprogramma van de regering waarin een herbezinning op de grote steden werd neergelegd en uitgewerkt.

De raad vond, naast deze primair op de ruimtelijke ordening gerichte beleidsnota, die terecht de grote steden weer volop in de schijnwerpers zette, een bredere verkenning en beleidsbepaling op zijn plaats. Hierin zouden de belangrijkste ontwikkelingen voor de toekomst van de grote steden moeten worden aangegeven. De voornaamste beleidsopgaven zouden, gedifferentieerd naar beleidsdimensies en -sectoren, in kaart moeten worden gebracht, alsmede de hierbij vereiste beleidsmatige en bestuurlijke aanpassingen op de langere termijn. Bij zijn aantreden in nieuwe samenstelling (1988) maakte de huidige raad de adviesvoorbereiding tot de zijne en nam hij deze op in zijn werkprogramma.

Dit rapport heeft betrekking op de grootstedelijke gebieden van Amsterdam, Rotterdam, Den Haag en Utrecht. Hoewel geen wereldsteden, kunnen deze vier zich qua functionele betekenis en stedelijke uitstraling meten met de doorsnee-groep subtop-steden in West-Europa. De andere Nederlandse steden volgen op afstand, ook Eindhoven, vaker genoemd als vijfde grote stad, die inderdaad in de rangorde steeds meer naar voren komt. Het rapport moet echter niet worden opgevat als een monografie over genoemde steden; het richt zich primair op het verschijnsel grote stad in Nederland. De analyse, conclusies en aanbevelingen gelden derhalve in principe zowel voor deze steden als voor andere die eventueel over enige tijd een soortgelijke status toekomt, ongeacht of dit er vier, vijf of meer zullen zijn.

Dit rapport kent, hoewel omvangrijk, toch enige beperkingen. In de eerste plaats uit hoofde van het onderwerp: de grote stad is een 'container' van alle mogelijke verschijnselen; grootstedelijk beleid bestrijkt zowat elk denkbaar beleidsgebied. Het zou derhalve een illusie zijn een gedetailleerd inhoudelijk en beleidsmatig toekomstperspectief op alle beleidsterreinen uit te tekenen. Er liggen hier veel keuzemomenten voor het beleid die slechts kunnen worden ingevuld in het samenspel tussen betrokken partijen. De omvang van problemen en het potentieel aan kansen zijn immers ook niet in alle grote steden gelijk.

Dit dwong de raad tot een keuze tussen een rapport dat enkele zijns inziens belangrijke thema's zou uitdiepen 'tot op het bot' of een rapport dat inhoud zou geven aan een meer algemene en integrerende benadering. Het is het laatste geworden. Dit heeft als consequentie dat de uitwerking van de aanbevelingen, op enkele uitzonderingen na, summier blijft en dat deze aanbevelingen in een aantal gevallen vooral zijn bedoeld om de beoogde richting aan te geven.

Een tweede beperking raakt aan de verhouding tussen de grote steden en andere gemeenten. In de analyse, conclusies en aanbevelingen komen wel vaak elementen naar voren die impliciet of expliciet verwijzen naar deze verhouding, maar een systematische studie hiernaar is niet ondernomen. 
Het zijn steeds de grote steden zelf, c.q. de grootstedelijke gebieden, die het centrale onderwerp vormen, overigens wel geplaatst in hun relatieve positie ten opzichte van andere gebieden. De raad pretendeert derhalve niet tot uitspraken te komen over voornoemde verhouding, maar onderkent uiteraard dat deze een belangrijke rol zal spelen bij de discussie over en implementatie van voorstellen in dit rapport.

Een soortgelijke beperking geldt voor de voorstellen die bij realisatie niet slechts consequenties hebben voor de grote steden, c.q. grootstedelijke gebieden, maar ook voor andere gemeenten, zoals het geval is bij de financiële en bestuurlijke verhoudingen. Ook hier komt het rapport tot de desbetreffende conclusies en aanbevelingen vanuit het hoofdonderwerp, de grote stad/het grootstedelijk gebied, al is het besef dat in sommige gevallen de aanbevelingen alleen bij algemene gemeentelijke aanpassingen te realiseren zijn, wel in de beschouwing en onderbouwing van de voorstellen betrokken geweest. Hierbij is overigens te bedenken dat de problemen die de aanleiding vormen tot dit rapport, zich doorgaans wel intensiever voordoen in de grote steden, maar toch in veel opzichten een 'verdichting' zijn van zaken die elders ook aan de orde zijn, zij het in minder geconcentreerde en gecumuleerde mate.

Tegenover deze beperkingen staat, naar de raad meent, het voordeel dat het hoofdthema van het rapport op alle onderdelen kon worden gespecificeerd en geconcretiseerd. Dit hoofdthema is het beste te omschrijven als de bestudering van de condities voor stedelijke vernieuwing. Hierbij is bijzondere aandacht gewijd aan de vraag of de institutionele structuur waarin de stedelijke ontwikkeling is gesitueerd, toereikend is en voldoende zelfregulerende prikkels bevat om op adequate wijze het hoofd te bieden aan de internationale uitdagingen op het gebied van de economie, de sociale structuur en de stedelijke voorzieningen.

Om deze vraag te kunnen beantwoorden dienen de specifieke kenmerken te worden onderkend van de hedendaagse verstedelijking en stedelijkheid. Kort samengevat komen deze kenmerken neer op het volgende:

a) internationalisatie; de grootstedelijke gebieden worden steeds meer de strategische schakelpunten tussen landen, over nationale grenzen heen. Hierbij is sprake van een toenemende betrokkenheid van grootstedelijke centra op elkaar en van rechtstreekse concurrentie tussen deze gebieden;

b) regionalisatie; regio's, en meer in het bijzonder de grootstedelijke regio's, treden meer rechtstreeks en onafhankelijk op en gaan, als onderdeel van nationale staten, binnen en buiten de nationale grenzen hun eigen relaties en bindingen aan;

c) een zwaartepuntverschuiving treedt op in de rangorde en verstrengeling van de grootstedelijke gebieden, in nauwe samenhang met a) en b). De rangorde en de functionele verbanden die zich sinds de industrialisatie in de Verenigde Staten en Noordwest-Europa redelijk stabiel hebben ontwikkeld, veranderen voor het eerst weer. De desbetreffende verschuivingen doen zich voor binnen landen, tussen landen en tussen werelddelen;

d) uitwaaiering van verstedelijking spreidt zich over een steeds groter gebied. Dit betekent in eerste instantie dat de grote steden en hun directe omgeving onverbrekelijk met elkaar verbonden zijn en samen het wezen bepalen van de grootstedelijke gebieden, 'metropolitan areas', waarin de grote stad het meer of minder krachtige centrum vormt. In tweede instantie leidt deze spreiding ertoe dat meer dan voorheen de grote steden een proces doormaken van ruimtelijke en functionele differentiatie, waarin de concurrentie met de directe omgeving, de verder verwijderde omgeving, middelgrote steden en landelijke regio's, maar ook de samenhang van deze gebieden, steeds scherper wordt; 
e) de grote steden zijn meer dan ooit object van migratiestromen door de toenemende 'verhuisbewegingen' in internationaal verband. De maatschappelijke en culturele differentiatie neemt hierdoor toe. Veel migranten zijn evenwel slecht gekwalificeerd voor de mogelijkheden op de plaatselijke arbeidsmarkten, waardoor vraagstukken van armoede en werkloosheid toenemen in omvang.

Deze kenmerken geven een indruk van de externe invloeden op de sociale en economische ontwikkeling van de grote steden. Zij geven aan dat de mogelijkheden voor grootstedelijk beleid vooral gelegen zijn in een weloverwogen positie innemen in externe ontwikkelingen. De toets voor de institutionele veerkracht ligt derhalve hierin dat zij toereikend moet zijn om de grote steden aansluiting te bieden op de internationale bewegingen, mede in het belang van de nationale samenleving.

Aan dit hoofdthema wordt hierna als volgt uitwerking gegeven. Hoofdstuk 2 bevat een internationale plaatsbepaling van de grootstedelijke gebieden en het hieruit resulterend referentiekader. Hiermee wordt niet alleen beoogd de relatieve positie weer te geven van de verschillende grootstedelijke gebieden, maar ook lering te trekken uit beleidsstrategieën die elders werden uitgeprobeerd in reactie op de druk van de externe omstandigheden.

Daarna volgen vier hoofdstukken die betrekking hebben op respectievelijk de grootstedelijke economie, sociale problemen in de grote steden, de maatschappelijke voorzieningen en de financieel/bestuurlijke verhoudingen. Deze vier beleidsgebieden worden alle gekenmerkt door een eigen dynamiek. De betekenis van het sociale hoofdstuk is derhalve niet te herleiden tot de economische ontwikkeling, of andersom, maar wel wordt ook aandacht besteed aan de onderlinge wisselwerking tussen deze thema's, die soms erg intensief blijkt te zijn.

Tenslotte worden in hoofdstuk 7 de analyses op de vier genoemde gebieden gerecapituleerd en in onderlinge samenhang afgerond met een aantal beleidsaanbevelingen.

Het rapport 'Van de stad en de rand' is voorbereid door een interne projectgroep van de WRR. Voorzitter was prof. dr. A.M.J. Kreukels, lid van de raad, projectsecretaris drs. W.G.M. Salet, stafmedewerker. Bij de voltooiing van het rapport maakten voorts deel uit van de projectgroep: het raadslid prof. dr. B.M.S. van Praag en de stafmedewerkers mr. J.C.F. Bletz, drs. P. Haighton, drs. P. den Hoed, M.G. van der Hulst, drs. G.J. Kronjee, dr. C.W.A.M. van Paridon en mr.drs. J.C.I. de Pree.

Ten behoeve van het rapport is een aantal studies verricht. In de WRR-reeks 'Voorstudies en achtergronden', is reeds verschenen:

- H.F.L. Garretsen en H. Raat, Gezondheid in de vier grote steden; V65, 1989;

- W.H. Leeuwenburgh en P. van den Eeden, Onderwijs in de vier grote steden; V68, 1990.

- M.W. de Jong en P.A. de Ruijter (red.), Logistiek, infrastructuur en de grote stad; V69, 1990;

- C.P.A. Bartels en E.J.J. Roos, Sociaal-economische vernieuwing in grootstedelijke gebieden; V70, 1990;

In de reeks Werkdocumenten van de WRR zijn verschenen:

- A. van den Berg, Th. van Eijk, P. Misdorp, Non-activiteit in de grootstedelijke gebieden in kaart gebracht; 1988 (W37);

- I. Boogaarts, Kunst en cultuur in Amsterdam; een inventarisatie van de financiële ontwikkelingen; 1989 (W38);

- J.G.B.M. van de Goor, Binnengemeentelijke decentralisatie en deconcentratie in Amsterdam, Rotterdam, Den Haag en Utrecht; 1989 (W39);

- W.J. Dercksen, P. den Hoed en E.W. van Luijk, Werkloosheidsbestrijding in Amsterdam, Rotterdam, Den Haag en Utrecht; 1990 (W50). 
In de reeks Werkdocumenten zullen binnenkort verschijnen:

- D. Hanemaaijer, Kansen en bedreigingen voor de grote steden in een aantal bedrijfstakken;

- H.J.Th. Wilmer, Naar een nieuwe structuur voor het grootstedelijk verkeersen vervoersbeleid;

- P. den Hoed (eindred.), Gebundelde pre-adviezen maatschappelijk werk in de stedelijke gebieden. Hierin zijn de volgende pre-adviezen opgenomen:

- P. den Hoed, Maatschappelijk werk in historisch perspectief;

- A. Brand, Zorg op maat;

- W.A. Fransen, De institutionele traditie van het maatschappelijk werk in Nederland;

- E. Hueting en R. Ney, plaats en betekenis van de sociale zorg in de grootstedelijke gebieden;

- W.B.A.M. Melief, Functie en plaats van het maatschappelijk werk in het geheel van voorzieningen in de grote stad.

Tenslotte zijn de volgende niet door de WRR gepubliceerde bijdragen geleverd:

- Bureau voor Economische Argumentatie (BEA), Financiën van de vier grote steden, Eigen uitgave van het Bureau voor Economische Argumentatie, Lisse 1987;

- P. Jansen, Intergemeentelijke samenwerking, interne publikatie WRR 1987;

- Economisch Technologisch Adviesbureau Strankinga (ETAS), Investeren in de grote steden (met deel bijlagen), Eigen uitgave ETAS, Hilversum 1989;

- G.J Kronjee en M. van Wietingen, Statistisch overzicht sociale problemen in de steden: tabellen en grafieken, interne notitie WRR, februari 1989. 


\section{Internationale plaatsbepaling en referentiekader}

\section{I Inleiding}

Om inzicht te krijgen in de relatieve positie van de Nederlandse grote steden, zowel wat betreft de inhoudelijke stand van de sociale en economische ontwikkeling als wat betreft de institutionele drijfveren, wordt in dit hoofdstuk een globale internationale plaatsbepaling ondernomen (paragraaf 2.2). Het doel hiervan is het karakter en de reikwijdte te verduidelijken van de inhoudelijke en institutionele opgaven waarvoor de grote steden in Nederland gesteld zijn. Deze plaatsbepaling is bovendien van belang omdat in de stedelijke cultuur sprake is van een sterke internationale voorbeeldwerking: zowel in de sfeer van de problemen als van de oplossingen plegen bepaalde basismechanismen in meer steden min of meer tegelijkertijd op te treden. Hierdoor worden de mogelijkheden die elders reeds werden beproefd, vaak als uitgangspunten beschouwd voor nieuwe stedelijke ontwikkelingen.

In paragraaf 2.3 worden de uitdagingen voor het grootstedelijk beleid vanuit de internationale typering in algemene zin aangegeven. De specifieke opgaven voor de Nederlandse steden worden in de volgende hoofdstukken per deelgebied nader gepreciseerd. Paragraaf 2.4 bevat het samenhangend geheel van uitgangspunten dat ten grondslag ligt aan de beleidsanalyses in dit rapport.

De evolutie van steden is niet los te denken van de algemene maatschappelijke ontwikkelingen. Tot in de vorige eeuw golden de steden nog als zelfstandige entiteiten, de centrale zenuwcentra van het vroege handelsverkeer en van de zich industrialiserende westerse samenleving. Dit verschijnsel van de autonome stad is sedertdien vrijwel geheel teloor gegaan. De stedelijke centra zijn nog altijd knooppunten van economische en culturele activiteit, maar een van de opvallendste kenmerken is nu juist hun toenemende inbedding in nationale en internationale verbanden. Wel treft men hier doorgaans grotere concentraties aan van sociale problemen en in vele opzichten tonen zij een bijzondere verdichting van de algemeen maatschappelijke ontwikkelingen.

Het stedelijk leven heeft ruim baan genomen buiten het oorspronkelijke territoir. De ruimtelijke schaal van stedelijke activiteiten is opgegaan in veel hogere schaalniveaus. Diverse stedelijke bezigheden hebben een nieuw zwaartepunt gevonden op regionaal niveau, zoals op het gebied van de ruimtelijke ordening, de arbeidsmarkt, de volkshuisvesting en het verkeer en vervoer het geval is. De actieradius van de gespreide economische bedrijvigheid is nog ruimer. Zij bestrijkt binnen het Nederlandse grondgebied uitgestrekte ontwikkelingsassen vanuit het westen. In cultureel opzicht zou men zelfs de waarden en normen van de Nederlandse samenleving in haar geheel kunnen typeren als een stedelijke cultuur.

Maar niet alleen is het stadsleven in de loop van de tijd buiten zijn grenzen gegroeid. Omgekeerd drukken ook invloeden uit de - zeer wijde - omgeving hun gewicht op de stedelijke ontwikkeling. De demografische ontwikkelingen in de grote steden worden al enige tijd gedomineerd door de migratiefactor (met name de invloed van de buitenlandse migratie op de samenstelling van de bevolking is groot). In economisch opzicht neemt de afhankelijkheid van de steden vanwege de internationalisering van de economie en de infrastructuur in snel tempo verder toe. De ontwikkeling van verschillende soorten van stedelijke bedrijvigheid is nog slechts voor een deel op stedelijk niveau te beïnvloeden. Een groot deel van de traditionele 'home-entrepreneurs' is verdwenen en veel stedelijke bedrijven zijn onderdeel geworden van concerns die opereren op 
internationale markten, met eigen netwerken en logistieke ketens. Er ontstaan functionele relaties van gespecialiseerde activiteit tussen de grote metropolen. Bekend zijn de netwerken van Tokio, Londen en New York als de 'aanvoerders' van respectievelijk het Zuidoost-Aziatische blok, het Europese en het Noordamerikaanse blok. Bij nadere verkenning zijn vele dergelijke netwerken aan te wijzen op het terrein van het financieel verkeer, handel en transport, produktie, dienstverlening, wetenschap en cultuur enzovoort. De sterkte c.q. de zwakte van de stedelijke economie als 'motor' van de nationale economie wordt in toenemende mate beïnvloed door de positie in deze internationale netwerken.

Ook in bestuurlijk opzicht tenslotte, is een groot deel van de beleidsbepaling verschoven naar een hoger schaalniveau. Na de oorlog zijn de zwaartepunten van het overheidsbeleid - in ons land nog meer dan elders in vergelijkbare landen - verplaatst naar het nationale niveau. De zeggenschap van de stedelijke besturen is ook in dit opzicht betrekkelijk gering geworden. In de jaren ' 80 heeft het centralistische kenmerk van het Nederlandse overheidsbeleid zich internationaal gezien nog wat scherper afgetekend, doordat in het noorden van Europa (de Scandinavische landen) en in het zuiden (Frankrijk, Spanje, Italië, Portugal) een aanzienlijke decentralisatie heeft plaatsgevonden naar de lokale en regionale bestuursniveaus. In veel gevallen betreft het financiële decentralisatie, die een doorwerking kreeg in de decentralisatie van inhoudelijke beleidsgebieden ${ }^{1}$.

Gegeven de vele interdependenties tussen de grote steden en de wijde omgeving, worden de ontwikkelingen van de grootstedelijke activiteiten in dit rapport uitdrukkelijk verkend vanuit het krachtenveld waarin zij zijn gesitueerd en vanuit de verschuivingen die in dit krachtenveld optreden. Er is dus geen premisse van stedelijke autonomie. Integendeel, de verantwoordelijkheid voor het grootstedelijk beleid kan geen exclusieve aangelegenheid zijn van de lokale (publieke en particuliere) instanties, maar nationale en zelfs internationale partijen nemen hier een eigen positie in en de toekomstperspectieven van de steden liggen juist in het vermogen van alle betrokken partijen om hun krachten in goed samenspel te optimaliseren ${ }^{2}$. De vraag of, in het licht van de sociale en de economische uitdagingen van de steden, de gegroeide institutionele verhoudingen in Nederland een dergelijke optimalisering mogelijk maken, raakt de kern van het rapport.

Ondanks de overweldigende invloeden van de exogene factoren is de loop van de stedelijke ontwikkeling geenszins gedetermineerd. Zowel met betrekking tot de rolverdeling tussen de verschillende partijen die bij het grootstedelijk beleid betrokken zijn, als met betrekking tot de inhoudelijke richting van het beleid, doen zich op de vier hierna te onderscheiden hoofdkenmerken van stedelijke ontwikkeling fundamentele beleidsdilemma's voor. De internationale plaatsbepaling van de grootstedelijke gebieden maakt het mogelijk om meer zicht te krijgen op de keuzen die hier moeten worden gemaakt.

\subsection{Hoofdkenmerken van de internationale plaatsbepaling}

De vier hoofdkenmerken van deze internationale plaatsbepaling hebben betrekking op:

- de positie van de economische bedrijvigheid;

- de sociale stedelijke structuur;

- de maatschappelijke voorzieningen in de grote steden;

- de financieel/bestuurlijke infrastructuur.

'] M. Goldsmith, 'Social, economic and political trends and their impact on British cities'; in: Regenerating the cities; M. Parkinson, B. Foley and D. Judd (eds.), Manchester, Manchester University Press, 1988, blz. 28-38.

2] P.E. Peterson, City Limits; Chicago, The University of Chicago Press, 1981. 


\subsubsection{Positie van de economische bedrijvigheid}

De economische bedrijvigheid in de stedelijke gebieden wordt diepgaand beïnvloed door de mondiale herstructurering van de economie. Technologische vernieuwingen, de verplaatsing van industriële bedrijvigheid naar goedkope produktielanden en de daaropvolgende modernisering van de economie in een aantal van die landen, hebben geleid tot geopolitieke verschuivingen van economische zwaartepunten en hebben het tempo versneld van de structurele veranderingen in de traditionele stedelijke industriecentra van het westen. Deze grote verschuivingen in ruimtelijke zwaartepunten hebben recentelijk meer aandacht gekregen. Het betreft verschuivingen op wereldschaal, met name de trend van Atlantische concentraties naar de Pacific Rim. Het betreft ook verschuivingen binnen continenten, zoals de verschuiving van de noordoostelijke Frost Belt naar de zuidelijke Sunbelt in Noord-Amerika en de aanvulling van de noordelijke industriegebieden in Europa met het middenAlpengebied (München, Zürich, Milaan) met zijn uitstraling langs verschillende ruimtelijke assen.

Bij de aanduiding van dergelijke globale ruimtelijke bewegingen past de kanttekening dat processen slechts op de langere duur structuren plegen te veranderen en dat de nieuwe ruimtelijke formaties vaak labiel blijken te zijn. Stedelijke gebieden die op grond van een traditionele industriële concentratie een motorfunctie hebben verworven voor de groei van nationale economieën, behouden door hun massieve gewicht vaak nog een belangrijke economische betekenis, ook al voltrekt de groei zich daar minder snel dan in andere gebieden. Bepalend is uiteindelijk of de traditionele centra in een periode van economische transitie na verloop van tijd een nieuwe stuwende positie weten te verwerven. Over een langere periode geeft de dynamiek van de ruimtelijke spreiding derhalve vaak geheel andere inzichten dan dwarsdoorsneden op een bepaald moment. 'Verouderde' stedelijke gebieden kunnen na modernisering een nieuwe aantrekkingskracht gaan uitoefenen, zoals New York en zelfs Pittsburg in de Frost Belt, Düsseldorf in de nabijheid van het Ruhrgebied en de miraculeuze opleving van Glasgow in de zuid-westelijke periferie van Schotland hebben aangetoond. Excentrische ligging ten opzichte van nieuwe ruimtelijke en infrastructurele formaties determineert de stedelijke ontwikkeling kennelijk niet, al stelt zij hieraan wel extra opgaven.

Hoewel de exogene invloeden op de stedelijke economieën (de globale veranderingen van de wereldeconomie) niet vatbaar zijn voor grootstedelijk beleid, kunnen ten aanzien hiervan zeer verschillende beleidsconsequenties worden getrokken, die de ontwikkeling van de stedelijke gebieden in hoge mate beïnvloeden. In dit opzicht zijn de internationale verschillen zeer leerzaam. Zo hebben diverse verouderde stedelijke industriegebieden in de Verenigde Staten en in Groot-Brittannië gedurende de jaren ' 80 een versnelde economische transitie ondergaan. In de Bondsrepubliek daarentegen is de economische vernieuwing in de opkomende stedelijke gebieden in het zuiden enorm versneld, maar hier werden de traditionele industriegebieden - met name het Ruhrgebied met kolossale steun van de overheid op de been gehouden zonder voldoende vernieuwing van de economische structuur.

In Groot-Brittannië bestaan grote regionale verschillen in economische ontwikkeling, globaal gezien opnieuw tussen noord en zuid. Maar de gecombineerde beleidsstrategie van versterkte marktwerking enerzijds en een actief economisch ontwikkelingsbeleid voor de stedelijke gebieden anderzijds heeft er wel toe geleid dat daar zelfs in de perifere industriegebieden (zuid-west Schotland, noord-oost Engeland, de Midlands, Wales) een groot deel van de verouderde industrie nu is gesaneerd en dat geavanceerde industrie (variërend van high-tech tot offshore) en zakelijke dienstverlening daar in opkomst zijn. Merseyside (met Liverpool) is vanuit een oogpunt van economisch herstel nog altijd de grote achterblijver. In het welvarende Duitsland daarentegen werd de 
traditionele bedrijvigheid in de achterblijvende regio's juist beschermd. Zo heeft het Ruhrgebied te maken met een sanering van vooral de mijnbedrijvigheid. Daar was het federale, het regionale en het lokale beleid er een lange tijd op gericht om de verouderde industrieën af te schermen. In een rapport van de Sachverständigenrat werd onlangs geconcludeerd dat alleen al de steenkoolen staalbedrijvigheid tussen 1978 en 1986 met 50 miljard DM werd 'gepäppelt' ${ }^{3}$. Desondanks werkte de gestadige achteruitgang door in een aantal andere bedrijfstakken. De economische vernieuwing van de stedelijke koploper in dit gebied (Essen) steekt mager af bij de veel grotere dynamiek van Britse steden die vroeger een vergelijkbaar profiel hadden. De manier waarop in het grootstedelijk economisch beleid wordt ingespeeld op exogene ontwikkelingen, is dus bepaald niet indifferent.

Het veranderende karakter van de westerse economie heeft vooral in de stedelijke gebieden diepe sporen getrokken, omdat daar de concentraties van de traditionele industrieën waren gesitueerd. De betekenis van de industrie is in deze gebieden gedurende de afgelopen vijfentwintig jaar aanzienlijk gereduceerd. Hierbij waren ook geografische bewegingen van grote invloed. Afgezien van de nodige variaties en lokale verschillen was het algemene patroon in de westerse stedelijke gebieden eerst een opvallende terugval van de bevolking (met name in de middenklassen) door de suburbanisatie van het wonen. Deze selectieve bevolkingsmigratie werd al spoedig gevolgd door een breder verlies aan economische functies en werkgelegenheid: bedrijven, diensten en instellingen trokken de stad uit naar het suburbane gebied, waarbij de straal van dit ommeland steeds wijder werd. Uiteindelijk werden in dit proces de relaties tussen de grootstedelijke kernen en hun omliggend gebied intensiever en belangrijker ten aanzien van wonen, werken en voorzieningen.

Deze dynamiek en de hiermee gepaard gaande aderlating van de grote steden aan hun ommeland is voor het eerst systematisch en indringend geanalyseerd door Hoover en Vernon ${ }^{4}$. Zij toonden aan dat woon-werkforensisme over een steeds wijder gebied plaatsvindt en dat deze dubbele suburbanisatie in verband staat met de hergroepering van de economische functies in de grootstedelijke centra en in de suburbane gebieden. Het diffuser worden van verstedelijking zet nog steeds door in de westerse landen. Hierbij kunnen in principe hele nationale grondgebieden betrokken raken. De suburbanisatie rondom de grootstedelijke kernen strekt zich steeds meer uit tot diep in het landelijk gebied.

In Europa werd de neiging naar ontstedelijking voor het eerst gesignaleerd in de oude industriegebieden van Groot-Brittannië en West-Duitsland ${ }^{5}$. Uit vervolgonderzoek in 1988 blijkt dat de trek uit de steden en de stedelijke gebieden (naar de 'half-way areas') na een korte stabilisatie opnieuw doorzet en zich nu ook in andere Europese landen begint af te tekenen. De bevolking van een aantal oude industriesteden is gedurende enkele decennia nagenoeg gehalveerd. Er zijn uitzonderingen op deze algemene trend. Daartoe behoren allereerst de grote metropolen, zoals London en Parijs, die een sterke aantrekkingskracht blijven uitoefenen. Daarnaast zijn er stedelijke gebieden die vanwege bijzondere achtergronden een eigen ontwikkeling doormaken. Naar zal blijken, behoren de Nederlandse steden tot deze tweede categorie.

'] Sachverständigenrat, Arbeitsplätze im Wettbewerb, Viertes Kopitel, Wirtschoftliche Erneuerung oltindustrieller Problemregionen: Dos Beispiel Ruhrgebiet, Jahresgutachten 1988/1989; Stuttgart, Kohlhammer, 1989, blz. 183-211.

4] E.M. Hoover en R. Vernon, Anatomy of a Metropolis, the changing distribution of people and jobs within the New York Metrapolitan Region; Cambridge (Mass.), Harvard University Press, 1959.

5] P. Hall en D. Hay, Growth Centres in the European Urbon System; London, Heinemann Educational Books, 1980. Nieuw onderzoek in 1988 van P. Cheshire, D. Hay e.a. in Urban problems ond regionol policy in the European Community; Luxembourg, Office for Official Publications of the European Communities, 1988. 
In het algemeen zoeken de steden vooral expansie in de dienstverlening, terwijl de modernisering van de industrie verspreid raakt tot diep in het landelijk gebied. Hierbij geldt echter opnieuw dat de ontwikkeling van de steden niet is voorbestemd: sommige steden houden industriële bedrijvigheid vast, andere weten moderniserende industrieën aan zich te binden. Voor de nieuwe clusters op het grensvlak van industrie en dienstverlening zijn de steden, althans in beginsel, zelfs zeer kansrijk. Sommige steden slagen er meer in dan andere om nieuwe resultaten te boeken op het gebied van de diensteneconomie. Duidelijk is wel overal dat de onderlinge betrokkenheid tussen stedelijke en niet-stedelijke gebieden meer gewicht krijgt en dat de steden in dit competitieve (en tegelijkertijd coöperatieve!) krachtenveld een nieuwe economische positie moeten zien te verwerven. In een dergelijk 'urban field' (Friedmann, Miller), 'urban realm' (Webber), of 'metroplex' (Meltzer) ${ }^{6}$ blijken veel meer culturele en morfologische varianten te ontstaan dan in de tamelijk hiërarchisch geordende patronen van weleer.

In ons land beperkte de suburbanisatie zich vanaf de jaren '60 relatief lang vooral tot het wonen. (In het afgelopen decennium neemt de stedelijke bevolking overigens weer in omvang toe.) Pas vanaf de tweede helft van de jaren '70 zette in ons land de trek naar buiten door van de economische functies. Dit proces is thans volop gaande en de schaal van de gebieden die erbij betrokken raken, wordt steeds groter. De Randstad is om deze reden niet meer een afgebakend stedelijk gebied. De economische hergroepering leidt ertoe dat de omvang van de industrie in Amsterdam en Rotterdam relatief ver is teruggezakt (in Den Haag en Utrecht was dit niveau traditioneel al laag). De nieuwe impulsen voor de bedrijvigheid liggen in de steden op het vlak van de zakelijke dienstverlening, met een uitschieter naar boven voor de nieuwe bedrijvigheid rondom de luchthaven Schiphol. De modernisering en vernieuwing van de industrie zijn daarentegen geconcentreerd op de oost- en zuidwaartse ontwikkelingsassen buiten de Randstad. Ook de nieuwe dienstverlening begint zich nu echter geleidelijk te spreiden over deze ontwikkelingsassen. Deze ontwikkelingen zijn niet onverdeeld gunstig te noemen voor de economische positie van de grote steden.

Internationale waarnemers, zoals Peter Hall, wijzen erop dat pogingen van de overheid om de tendensen van ruimtelijke suburbanisatie te bedwingen via concepties van 'urban containment' tot mislukken gedoemd zijn. De diffusie van stedelijke activiteiten over een wijd gebied is een feit en laat zich niet dwingen in kunstmatige 'containers' ? De verspreide ontwikkeling van de bedrijvigheid hoeft niet bedreigend te zijn voor de grote steden, maar dan moeten deze wel een eigen markante positie weten te behouden. Er mag wel spreiding, maar geen erosie van de stedelijke economie optreden. Het eerste is, zo blijkt uit de internationale voorbeelden, slechts beperkt vatbaar voor beïnvloeding, maar het laatstgenoemde leent zich daarvoor zeer wel.

\subsubsection{Sociale structuur}

In de steden doen zich veel verschillende sociale problemen naast elkaar voor, veelal in onderlinge combinatie bij bepaalde bevolkingsgroepen en in bepaalde stadsdelen. In dit rapport zijn bij de analyse van deze stedelijke problemen enige keuzes gemaakt. Over sommige vraagstukken met een onmiskenbaar stedelijk karakter heeft de raad nog onlangs gerapporteerd. In het rapport 'Rechtshandhaving' is uitvoerig ingegaan op vraagstukken inzake veiligheid

6] J. Friedmann, J. Miller, 'The urban field as human habitat'; Journal of the American Institute of Planners, november 1965, jaargang 31. nr. 4, blz. 312-320. M.M. Webber, 'The urban place and the non-place urban realm'; in: Explorations into urban structure; door M.M. Webber e.a., Philadelphia, University of Pennsylvania Press, 1964, blz. 79-90; J. Meltzer, Metropolis to metroplex, the social and spotial planning of cities; Baltimore and London, Johns Hopkins University Press, 1984.

'] P. Hall, R. Thomas, H. Gracey en R. Drewett. The Containment of Urbon Englond; Vol. I and Vol. áll; London, Allen and Unwin, 1973. 
en drugsbeleid en in het rapport 'Allochtonenbeleid' werd de positie geanalyseerd van de migranten, die bij uitstek in de steden zijn gehuisvest. In dit rapport wordt de analyse van de sociale stadsproblematiek geconcentreerd op twee centrale vraagstukken, die ook internationaal gedurende de jaren ' 80 een belangrijke beleidsprioriteit hebben gekregen, de werkloosheid en de armoede in de steden. Het gaat hier om centrale problemen die niet noodzakelijkerwijze maar wel feitelijk vaak gepaard gaan met andere vraagstukken of achterstandsindicatoren (zoals het niveau van opleiding, gezondheid, werkervaring). Ook de mogelijkheden om deze vraagstukken beleidsmatig te beïnvloeden zijn geschakeerd over een reeks van beleidsgebieden.

De positionering van de steden op het sociale vlak houdt nauw verband met de bovengenoemde economische trends. De omvangrijke en veelal schoksgewijze uitstoot van industriële arbeid heeft werkloosheidsproblemen van kwalitatieve en structurele aard gecreëerd. Het hoge tempo van de economische transformatie en de concentratie daarvan in stedelijke gebieden heeft hier tot een opeenstapeling van problemen gevoerd waarop de steden onvoldoende waren geprepareerd. Bovendien is door de eenzijdige samenstelling van de huishoudens die uit de steden wegtrekken, en vanwege de eenzijdige samenstelling van de binnenstromers het arbeidsmarktprofiel van de stedelijke bevolking verslechterd. Zelfs de steden die met succes het tijdperk van de diensteneconomie hebben betreden, kampen met structurele aansluitingsproblemen op de arbeidsmarkt.

Tegen deze achtergrond werd juist in de economisch succesvolle Amerikaanse steden in de eerste helft van de jaren ' 70 het begrip van de 'duale economie' geïntroduceerd (de combinatie van een groeiende economie met een verscherping van de werkloosheid). Inmiddels hebben de meeste Amerikaanse steden het probleem van de structurele werkloosheid overwonnen. Maar veel steden kampen daar wel met een nieuw structureel armoedevraagstuk. In de Europese steden is dit beeld in de verschillende landen meer gedifferentieerd. In het algemeen volgen deze steden (de Nederlandse voorop) de ontwikkeling van massale en geconcentreerde werkloosheid, maar vanwege het naar verhouding hoge voorzieningenniveau is het armoedevraagstuk minder nijpend. De Nederlandse steden laten tevens een opvallende segmentatie van de arbeidsmarkt zien. Zo bestaat in de Amsterdamse regio op het vlak van de arbeidsmarkt geen structurele relatie tussen de werkzoekenden in de hoofdstad en de enige echte groeipool in het gebied: de bedrijvigheid rondom Schiphol.

De sociale problematiek in de grote steden reikt dieper dan de gevolgen van de economische schokbewegingen alleen. De sociale problematiek kent een eigen dynamiek, die op haar beurt ongunstige condities schept voor economische ontwikkeling. Het is opnieuw de internationale typering die - hoe globaal en gedifferentieerd ook - aantoont hoe ingrijpend de sociale structuur en de hiermee samenhangende typisch grootstedelijke problematiek gedurende de laatste twee decennia van karakter zijn veranderd. De Amerikaanse 'war against poverty' in de jaren ' 60 was gericht op de bestrijding van algemene achterstandssituaties van grote delen van de stedelijke bevolking, die weliswaar in armoede verkeerden, maar voor het overige leefden in betrekkelijk geïntegreerde sociale structuren en in naar verhouding coherente stadswijken. De sociale structuur van de stedelijke bevolking (bezien naar demografische samenstelling en naar kenmerken als inkomen en opleiding) was daar in de jaren ' 60 opvallend evenwichtig.

De huidige sociale structuur wijkt opvallend af van dit evenwichtige beeld. Illustratief is het voorbeeld van Boston: er is nauwelijks werkloosheid, maar niettemin verkeert 40 procent van de bevolking onder de armoedegrens. In Massachussets kan 40 procent van de werklozen lezen noch schrijven; in deze 'best educated state in America' heeft 30 procent van de volwassenen de lagere 
school niet voltooid ${ }^{8}$. Dergelijke problemen zijn geconcentreerd in de steden en zijn in deze scherpte en intensiteit nieuw. Het kenmerk van de ruimtelijke concentratie hangt samen met jarenlang voortdurende eenzijdige selecties in de verhuisbewegingen naar en vanuit de steden. Op het schaalniveau van de stad is de bevolkingssamenstelling ontwricht en in de Verenigde Staten is dit soms een kenmerk van gehele stedelijke gebieden.

De typische grootstedelijke problematiek van de jaren ' 80 is in het algemeen minder breed - al zijn de lokale verschillen in dit opzicht groot - maar dieper; de problemen dragen steeds meer een structureel karakter. Achterstanden raakten geconcentreerd bij bijzondere groepen (bejaarden, werklozen, minderheidsgroepen, éénoudergezinnen) en zij raakten ruimtelijk gesegmenteerd ${ }^{9}$. De probleemwijken zijn niet meer de sobere volksbuurten van weleer met hun integratiemechanismen en met de kenmerkende sociale controle. De sociale banden zijn er vaak verbroken of herschikken zich in kleine geisoleerde subculturen. De mogelijkheden om daar bovenuit te stijgen zijn in dergelijke stadswijken klein.

Deze versmalling en verscherping van de stadsproblematiek zijn in de Amerikaanse en (reeds in veel mindere mate) de Britse steden meer manifest dan in de Nederlandse steden. In Europa en in Nederland in het bijzonder zijn het peil en vooral ook de toegankelijkheid van de voorzieningen hoger en deze zijn tot dusverre minder ingeschrompeld. De veranderingen in de onderliggende sociale structuur zijn minder diepgaand en treden ook minder zichtbaar naar buiten dan in de bovengenoemde steden. In de Nederlandse grote steden kan preventief ingrijpen een verdere uitholling van de sociale structuur nog effectief tegengaan. Dit stadium is in sommige stadswijken van Amerikaanse en ook Britse steden reeds gepasseerd.

Het overeind blijven van de sociale en maatschappelijke voorzieningen maakt echter niet ongedaan dat de onderliggende sociale structuur van de stedelijke bevolking ook in ons land aanzienlijk is veranderd. De stadsbevolking in Nederland is naar de aard van haar samenstelling en naar de aard van de voortgaande selectieve verhuisbewegingen een grotendeels non-actieve bevolking geworden met kenmerken van geblokkeerde sociale mobiliteit. In die zin zijn de bovengenoemde internationale ontwikkelingen ook in de Nederlandse grote steden opgetreden. Vooral de samenstelling van de bevolking in Amsterdam en in mindere mate Rotterdam wordt gekenmerkt door grote eenzijdigheden. Hierbij dient onmiddellijk de kanttekening te worden gemaakt dat de verschillen tussen de stad en de nabije stedelijke omgeving bijzonder groot zijn. Op stadsregionaal niveau wordt hierdoor alweer de gemiddelde doorsnee van de Nederlandse bevolking gemeten.

\subsubsection{Maatschappelijke voorzieningen}

De arrangementen van de westerse verzorgingsstaten zijn gedurende het afgelopen decennium vrijwel overal herzien. In politiek en inhoudelijk opzicht worden nieuwe prioriteiten gesteld, mede ter beteugeling van de collectieve uitgaven. In dit verband is opvallend dat, in aanvulling op de fysieke stedelijke vernieuwing gedurende de afgelopen vijftien jaar, thans nieuwe strategische zwaartepunten worden gelegd in de sfeer van de stedelijke voorzieningen. Met name in de Canadese, de Amerikaanse en de Britse steden is de programmatuur van het grootstedelijk beleid vaak grondig vernieuwd. Zo wordt het traditionele voorzieningenbeleid (met zijn nadruk op de fysieke stadsstructuur) in een aantal steden van deze landen verrijkt door nieuw zwaartepunten van beleid op het gebied van onderwijs en gezondheid, veelal geïnitieerd vanuit de

8] P. Dommergues, 'Unanswered questions'; in: Mecanisms for job creation, Paris, OECD, 1989, blz. 32.

'] D.E. Shalala and J. Vitullo-Martin, 'Rethinking the urban crisis'; Journal of the Americon Planning Association, Winter 1989, jaargang 55, nr. I, blz. 3-13. 
particuliere sector. Hiertoe worden plaatselijk nieuwe organisatieverbanden opgericht tussen particuliere en publieke sectoren. Ook tussen steden ontstaan op dergelijke gebieden netwerken voor de uitwisseling van informatie. Op het Europese continent volgen de netwerken van nieuwe stedelijke voorzieningen op enige afstand. In Nederland wordt hiermee momenteel een eerste begin gemaakt (onderwijs in Rotterdam, gezondheid in Eindhoven). In vergelijking met de inzet van internationale steden kan echter nog niet van een echt strategische heroriëntatie worden gesproken.

Van structurele betekenis is de herijking van de institutionele verhoudingen in het voorzieningenbeleid, dat vrijwel overal na de oorlog werd overvleugeld door de nationale overheden. Het gaat hier om het brede gebied van de voorzieningen, variërend van gezondheidszorg tot onderwijs of volkshuisvesting. Kenmerkend voor deze omslag in de institutionele verhoudingen is dat hier twee bewegingen in elkaar grijpen. In de eerste plaats zijn de verhoudingen tussen de nationale en de lokaal/regionale centra van besluitvorming aan het verschuiven (mede te plaatsen tegen de achtergrond van de toenemende internationalisatie). Op het brede terrein van de voorzieningen moeten de nationale machtscentra - niet alleen de centrale overheden, maar wellicht nog meer de centraal georganiseerde particuliere sector - meer ruimte laten aan de lokale instanties, die efficiënter kunnen inspelen op bijzondere lokale omstandigheden.

In de tweede plaats is de rolverdeling tussen de overheid en de particuliere sector in beweging. De overheid ziet zich steeds meer genoopt de uitvoering van taken af te stoten. De rol van de lagere overheden - de steden voorop - komt hierdoor op het snijvlak van twee structurele bewegingen te liggen: ten eerste de verschuiving van de hogere naar de lagere schaalniveaus van besluitvorming en ten tweede de overheveling van taken van de publieke naar de particuliere sector. Wanneer wordt gekozen voor het model van decentralisatie in economische zin, dan valt aan de betrokken overheden de nieuwe verantwoordelijkheid toe om de condities te bepalen voor de marktwerking en om de voorwaarden te bepalen waaronder eventuele financiële faciliteiten worden verstrekt. Wordt daarentegen gekozen voor decentralisatie in functionele zin, dan zijn de condities voor economische mededinging doorgaans niet van toepassing en is de regulering verbonden met overheidstoezicht.

Zo verandert de institutionele context aanzienlijk waarin het grootstedelijk beleid tot stand komt. Het initiatief voor deze veranderingen ligt doorgaans niet bij de lokale instanties, maar bij de centrale overheden, die het overbelaste centrale besturingsapparaat willen verlichten. De condities waaronder taken worden overgeheveld en de condities waaronder naar nieuwe vormen van decentralisatie (territoriaal, functioneel of anderszins) wordt gestreefd, blijven centraal bepaald. Vrijwel overal waar deze centraal geleide decentralisatie van de arrangementen van de verzorgingsstaat plaatsvindt, rijst de vraag of de decentrale instanties nu subject of object worden in de nieuwe verhoudingen. Zeker is wel dat de rol van de lokale instanties, de instanties in de steden voorop, een nieuwe inhoud gaat krijgen. Nolens volens komen de steden in de frontlinie te liggen van de verschuivingen in de institutionele verhoudingen van de verzorgingsstaat.

Deze ingrijpende ontwikkeling is nog overal volop gaande en nog vrijwel nergens uitgekristalliseerd in nieuwe duurzame verhoudingen. De publieke en private partijen in de Nederlandse steden moeten in deze transformatie een extra afstand overbruggen. Zij zijn, meer dan vergelijkbare steden in het buitenland, gedurende de opbouw van de verzorgingsstaat in een positie van afhankelijkheid geraakt ten opzichte van de nationale machtscentra. $\mathrm{Nu}$ de institutionele condities beginnen te verschuiven, kunnen hier de eerste kenmerken van ontwenningsverschijnselen worden waargenomen. 


\subsubsection{Financieel/bestuurlijke infrastructuur}

De structuur van de inkomsten en uitgaven van de Nederlandse gemeenten is uniek in de internationale vergelijking. Er bestaan nauwelijks voorbeelden van landen waar de financiële verhouding tussen de verschillende overheidslagen zo is gecentraliseerd als bij ons. Een van de achtergronden van deze uitzonderingspositie is dat in een klein land lokale verschillen in het peil van de voorzieningen en verschillen in lokale belastingen of heffingen minder snel geaccepteerd plegen te worden dan in landen met een grote schaal. De Europese eenwording zwakt geleidelijk de ratio af van deze extreme uniformiteit en centralisatie.

Overigens zijn de uitgaven van de Nederlandse gemeenten internationaal gezien relatief hoog. Maar de combinatie van beleidsmatige en financiële centralisatie beperkt de eigen gemeentelijke zeggenschap over het omvangrijke uitgavenpatroon en het rijk geschakeerd lokaal beleid. Voor de steden die in toenemende mate op internationale markten concurreren, levert dit institutionele patroon aanzienlijke knelpunten op. De mate waarin het mogelijk is om door financiële herschikkingen in het economisch ontwikkelingsbeleid, het sociaal beleid en het voorzieningenbeleid een sterk lokaal profiel te ontwikkelen in het internationale krachtenveld, is hierdoor zeer beperkt.

De centralisatie van de financiële verhoudingen heeft niet alleen tot gevolg dat de lokale zeggenschap wordt ingesnoerd. Voor dat probleem is in Nederland al vaker aandacht gevraagd. Tenminste zo ernstig is de tot dusverre onderbelicht gebleven consequentie, dat door de financiële centralisatie de prikkels worden ontnomen aan de lokale politieke cultuur om een verband te leggen tussen de bronnen van gemeentelijke inkomsten en de soorten van gemeentelijke uitgaven. De kosten van het hoge verzorgingsniveau van de stedelijke bevolking worden immers grotendeels door het Rijk vergoed. Aan de andere kant vloeien de terugkerende inkomsten voor de overheid uit investeringen in een sterke sociale en economische plaatselijke structuur ook grotendeels naar het Rijk. Dit is een structuurbepalend gegeven voor de het functioneren van de plaatselijke politieke cultuur, die inderdaad zeer afwijkt van steden in andere landen, die zelf meer financiële risico's en verantwoordelijkheden dragen.

Op het gebied van de bestuurlijke organisatie hebben in internationaal verband nagenoeg alle grootstedelijke gebieden met problemen te kampen. Over een breed internationaal front zijn gedurende de laatste decennia nieuwe bestuurlijke vormen uitgeprobeerd voor de interbestuurlijke verhoudingen in het grootstedelijk gebied. De meeste experimenten zijn niet duurzaam gebleken; zij evolueren met de maatschappelijke dynamiek die tot voortdurende aanpassingen noopt. In een aantal gevallen werden ze weer ingetrokken, maar ontstaat na verloop van tijd weer een nieuwe variant. Zo ontstond in veel landen een traditie van bestuurlijke differentiatie voor het grootstedelijk gebied, die in ons land nooit overtuigend tot ontwikkeling is gekomen.

In de Angelsaksische landen is de golf van regionale verbanden uit de jaren '70 voor een groot deel weggeëbd, maar wordt het bestuurlijk vacuüm als een probleem ervaren (veel stadsregionale verbanden in de Amerikaanse steden lijden een kwijnend bestaan, in het Verenigd Koninkrijk werden de 'metropolitan counties' ingetrokken, zoals ook de roemruchte Greater London Council). Veelal wordt het 'regionale gat' opgevuld met nieuwe functionele verbanden (onze 'schappen'). Het interbestuurlijk verkeer is er zeer beweeglijk. Slechts uit Toronto komen berichten over een duurzame, effectieve organisatie op stadsregionaal niveau, waarbij voor strategische beleidsfuncties de beslissingsbevoegdheden zijn voorbehouden aan een federatief regionaal verband.

In Europa treft men verspreid over de diverse landen wel meer experimenten aan die met succes werden doorgezet. De bekende hoofdstadsraad Kopenhagen 
heeft het uiteindelijk niet gered. In de Bondsrepubliek bestaat een reeks van varianten. Er zijn nieuwe initiatieven in België (Brussel) en Frankrijk. Met name het Franse experiment is boeiend omdat de regionalisering hier gepaard ging met een omvangrijke overdracht van specifieke naar algemene geldstromen, waarvan de besteding niet vooraf door het Rijk wordt bepaald.

De twee grootstedelijke experimenten van het vorige decennium in Nederland (de lichte 'pre-gewesten' Eindhoven en Rijnmond) zijn verdwenen. Het vraagstuk van de bestuurlijke organisatie is uiteindelijk weer onder het regime gebracht van de Wet op de gemeenschappelijke regelingen. Daarin wordt vertrouwd op de bereidheid van gemeenten om met elkaar samen te werken. Tot dusverre is deze samenwerking in de stedelijke gebieden met hun kenmerkende verschillen tussen de stad en de omliggende kernen, gebrekkig gebleken. Om deze reden heeft de Commissie Montijn het bestuurlijke debat voor deze gebieden onlangs weer open gebroken met haar rapport 'Grote steden, grote kansen'. Aan dat debat worden in dit rapport enige nieuwe suggesties toegevoegd.

\subsection{Onderdelen van grootstedelijk beleid}

Reeds uit de vluchtige internationale positiebepaling op de vier onderscheiden stedelijke hoofdkenmerken wordt de omvang zichtbaar van de opgaven waarvoor de betrokken maatschappelijke en publieke instanties zijn gesteld. Het gaat hier om:

- versterking van de economische concurrentiepositie;

- versterking van de sociale structuur;

- een bijbehorende specialisatie van het voorzieningenbeleid;

- institutionele hervorming.

\subsubsection{Versterking van de economische concurrentiepositie}

Een van de belangrijkste opgaven voor het grootstedelijk beleid in een periode van economische transitie heeft betrekking op de versterking van de economische concurrentiepositie. Het betreft niet alleen de verhouding met de concurrerende internationale centra, de steden zullen zich ook moeten waarmaken in de directe regionale en landelijke omgeving. De economische afhankelijkheid van de stedelijke economie van krachten die buiten de directe invloedssfeer liggen van de eerstbetrokken stedelijke instanties, is groot. De benutting van de stedelijke potenties vergt daarom bundeling van krachten. Een inbreng van het nationale overheidsbeleid is zowel nodig om de kansen in de internationale concurrentie te vergroten, als voor de noodzakelijke profilering van de stedelijke economie in de nationale context.

De nationale beleidsinstanties hebben belang bij de economische toekomst van de stedelijke gebieden omdat de vooruitzichten van deze economische kerngebieden rechtstreeks bepalend zijn voor het lot van de nationale economieën zelf. De achterblijvende groeicijfers van de grootstedelijke economie maken deze structurele interdependentie niet ongedaan. De afhankelijkheid tussen stedelijke en nationale groeiperspectieven is wederzijds. Dit is niet alleen het geval in landen met de kleine schaal van Nederland. In landen als Frankrijk, Groot-Brittannië en de Bondsrepubliek wordt deze relatie zelfs veel explicieter onderkend en maakt de centrale bemoeienis om de stedelijke gebieden als 'nationale activa' te behouden of te ontwikkelen prominent deel uit van het nationaal economisch beleid. In de Verenigde Staten gebeurt dit evenzeer, zij het doorgaans implicieter (vooral in de vorm van omvangrijke militaire orders voor het stedelijk bedrijfsleven, zoals de 'urban-impact' studies hebben uitgewezen) ${ }^{10}$.

\footnotetext{
10] N.J. Glickman, The urban impocts of federal politics; Baltimore, Johns Hopkins University Press, 1980.
} 
De betrokkenheid van de nationale overheid bij het economisch grootstedelijk beleid vergt een nadere rechtvaardiging omdat Nederland, behalve vanuit de sfeer van de ruimtelijke ordening, in dit opzicht geen expliciete beleidstraditie kent. In de Verenigde Staten bestaat een dergelijke traditie wel, vooral op het niveau van de staten. Op federaal niveau vinden veel schommelingen in dit beleid plaats. In het begin van de jaren ' 80 overheerste de gedachte dat de beste economische politiek voor de steden was om de markt zoveel mogelijk haar loop te laten hebben. De verouderde industriële steden zouden vanzelf neergaan, wat mensen zou aanmoedigen om naar meer kansrijke plaatsen te verhuizen. Vanuit een oogpunt van nationale economische groei zou geen belang bestaan bij een fixatie op bepaalde plaatsen. Medio ' $80 \mathrm{kwam}$ de National Research Council on National Urban Policy na een reeks van rapportages echter tot de omgekeerde conclusie. De nationale groei van de economie ware niet te beschouwen als een zero-sum game waarbij sommige gebieden alleen ten koste van andere kunnen groeien. Het negeren van ruimtelijke zwaartepunten zou de duur van de economische aanpassingsprocessen alleen maar verlengen en uiteindelijk een politieke terugslag teweeg brengen die de beoogde economische transitie slechts zou vertragen. De sociale en economische kosten van achterblijvende gebieden zouden zo op den duur een blok aan het been worden van de nationale economie ${ }^{11}$.

In Groot-Brittannië ontstond in het midden van de jaren '70 een spanning tussen het traditionele regionaal economisch beleid en het nieuwe stedelijk beleid dat met het White Paper 'Policy for the Inner Cities' in 1977 een belangrijke injectie kreeg ${ }^{12}$. De achtergrond van het nieuwe stedelijk beleid lag in de toenemende problemen van de steden (immigratiedebatten) en de grote ongelijkheden tussen de steden en de geürbaniseerde regio's. Gedurende de jaren ' 80 werd het nationale beleid inzake de 'regeneration' van de steden geactiveerd via een reeks van beleidsinitiatieven, verspreid over de verschillende departementen. De achtereenvolgende regeringen-Thatcher streefden expliciet naar een versnelde economische transitie in de steden (sanering van verouderde bedrijvigheid en actieve ontwikkeling van kansrijke mogelijkheden) met bovenal het oogmerk de steden te ontwikkelen tot de trekkers van de nationale economie.

Aansluitend bij de bovenstaande motieven worden de economische groeipotenties van de grootstedelijke bedrijvigheid in dit rapport niet primair geanalyseerd vanuit de lokale invalshoek maar vanuit hun mogelijke bijdrage aan de groei van de nationale economie. De uitdagingen voor de nationale overheid om de stedelijke groei-impulsen een optimale kans te geven, liggen vooral in de sfeer van het voorwaardenscheppend beleid inzake infrastructuur en onderwijs en in een versterking van het economisch klimaat door technologische vernieuwing. Voorts is de bevordering van ondernemerschap in het midden- en kleinbedrijf van belang.

\subsubsection{Versterking van de sociale structuur}

Vanuit de invalshoek van de specifieke stadsproblematiek wordt in dit rapport de versterking van de sociale structuur als de belangrijkste opgave beschouwd voor het grootstedelijk beleid zelve. Uit de internationale plaatsbepaling is duidelijk gebleken dat de combinatie van het hoge zorgniveau met een steeds verder afkalvende sociale structuur onhoudbaar is. De steden zullen op het vlak van stedebouw, ruimtelijke inrichting, woningbouw en voorzieningen in het dagelijks leefmilieu hun sociale concurrentiepositie dermate moeten verstevigen dat op den duur meer evenwicht zal ontstaan in de samenstelling van de bevolking. De eenzijdige vertekeningen in de bevolkingsopbouw, zowel

\footnotetext{
1'] R. Hanson, 'US cities in transformation'; Futures, June 1985, jaargang 17, nr. 3, blz. 232-242.

12] M. Stewart. 'Ten years of inner city policy'; Town Planning Review, 1987, jaargang 58, nr. 2, blz. 129-145.
} 
van de steden als in omgekeerde zin van de kernen in de omgeving, kunnen niet als een 'natuurlijke' verdeling worden beschouwd. Hoewel het stedelijk wonen reeds lang de traditionele gemeentegrenzen heeft overstegen, zullen de steden in deze wijdere omgeving toch een zelfstandige positie van voldoende sterkte moeten kunnen ontwikkelen.

De versterking van de sociale structuur kan verder inhoud krijgen door de verschillende belemmeringen weg te nemen voor de sociale mobiliteit van stedelijke bevolkingsgroepen. Deze sociale opgaven voor het grootstedelijk beleid zullen langs verschillende beleidssporen uitgewerkt worden. Voor sommigen, zonder reëel uitzicht op de arbeidsmarkt, moeten materiële voorzieningen een voldoende sociale bewegingsruimte blijven garanderen. Voor veel stedelijke 'non-actieven' zullen echter via arbeid, opleiding en onderneming nieuwe mogelijkheden moeten groeien om in hun eigen bestaan te kunnen voorzien. Daarbij staan de eigen verantwoordelijkheden en initiatieven van de betrokkenen en de eigen mogelijkheden van het lokale bedrijfsleven voorop. In aansluiting hierop is een intensief overheidsbeleid onontbeerlijk.

Op het vlak van het sociale-zekerheidsbeleid is de betrokkenheid van de nationale overheid en van de sociale partners dominant. De bekostiging en de beleidsbepaling van de sociale uitkeringen zijn vanwege hun aandeel in het macro-economisch beleid en vanwege de effecten op de inkomensverdeling nagenoeg volledig gecentraliseerd. Toch bestaat ook hier weer die wederzijdse afhankelijkheid. De uitkeringsgerechtigden in de steden zijn afhankelijk van de nationale beslissingen over de sociale uitkeringen. Omgekeerd is echter ook het nationale beleid - alleen al uit financiële overwegingen - rechtstreeks afhankelijk van de sociale ontwikkeling in de dichtbevolkte steden.

De noodzaak tot beheersing van de collectieve uitgaven in de achterliggende jaren, heeft het centrale karakter van dit beleid nog verder aangescherpt. De nationale richtlijnen werden strakker getrokken. Tegelijkertijd ontstond bij het Rijk het voornemen om de gemeenten een groter deel van de bijstandsuitkeringen uit de algemene inkomsten te laten betalen. Het oogmerk van deze beperkte financiële decentralisatie is om de gemeenten enig direct financieel belang te geven bij de beheersing van de uitgaven voor de sociale uitkeringen. Voor de gemeenten is deze combinatie van geslonken beleidsvrijheid met het vooruitzicht van een toenemende financiële verantwoordelijkheid weinig aantrekkelijk. Reeds de eigen gemeentelijke bijdrage van 10 procent aan de bijstandsuitkeringen bracht een aantal gemeenten (de grote steden met hun omvangrijke bijstandsbestanden voorop) in grote verlegenheid. Het is een verontrustend signaal dat kennelijk de sociale structuur van de grootste gemeenten in het land te zwak is om voor dit cruciale beleid meer financiële verantwoordelijkheid te nemen of toegekend te krijgen. Op zich houdt dit gegeven reeds de prikkel voor de steden in om meer te investeren in hun sociale structuur. De - ook in de internationale vergelijking - nog altijd vergaande centralisatie van deze materiële voorzieningen schermt het lokaal bestuur af van zowel de mogelijkheid als de noodzaak eigen verantwoordelijkheden te nemen.

De behoefte aan inhoudelijke decentralisatie vloeit vooral voort uit de structurele uitdaging om de sociale uitkeringen mede te benutten ten einde de sociale mobiliteit te vergroten. De uitkeringen zullen meer aangewend moeten worden als sociale investering dan als louter inkomensbron. De recente beleidsinitiatieven in deze richting bieden goede vooruitzichten. Om dit mogelijk te maken is echter aanvullend beleid op micro-niveau onvermijdelijk. Slechts bij een decentraal en gedifferentieerd beleid zal voldoende maatwerk verricht kunnen worden, dat recht doet aan de individuele sociale problematiek.

De consequenties van deze beleidsstrategie voor de herziening van de functionele structuur van het sociaal beleid kunnen worden getypeerd aan de hand 
van de drie beleidsfuncties in de sfeer van de openbare financiën: de distributieve functie heeft betrekking op de herverdelende rol van de overheid. Gebruikelijk is dat deze functie, die directe inkomenseffecten ten gevolge heeft, op het centrale overheidsniveau wordt uitgeoefend (mede in verband met de rechtszekerheid en de rechtsgelijkheid van de inkomensgevolgen); de functie van macro-economische beheersing is vooral van toepassing op uitgaven die, als daarover niet in hoofdlijnen op centraal niveau zou worden beslist, mogelijk tot onberekenbare macro-economische effecten kunnen leiden; de allocatieve functie heeft betrekking op de toedeling van specifieke middelen of impulsen om een doelmatige voortbrenging van produkten of diensten te verzekeren. In tegenstelling tot de eerste twee functies dient de allocatie juist decentraal te geschieden vanwege kostenbeheersing van het bestuurlijk apparaat en om verzekerd te zijn van een doeltreffende beleidsvoering die aansluit op de bijzondere lokale omstandigheden. Hiervoor is een vrije beleidsruimte vereist om op decentraal niveau de benodigde afwegingen te kunnen maken.

Op het gebied van de sociale uitkeringen hebben de eerste twee motieven (de distributieve en de macro-economische functies) gedurende de afgelopen periode tot een gedetailleerde centralisatie geleid, waardoor de allocatieve functie - die in de oorsprong van de sociale wetgeving is verankerd - stelselmatig werd uitgehold. De bovengenoemde opgave voor het beleid dat de uitkeringen meer als sociale investering aangewend moeten worden dan als louter inkomensbron, betekent dat wat gaandeweg is beschouwd als louter distributief beleid daarnaast steeds meer een allocatief karakter zal gaan dragen. De behoefte om allocatief beleid 'op maat' te kunnen voeren, zal het centralistische kenmerk van het huidige beleid steeds meer op de proef gaan stellen.

\subsubsection{Specialisatie in het voorzieningenbeleid}

De inhoudelijke samenhang tussen het sociaal en economisch beleid enerzijds en het stedelijk voorzieningenbeleid anderzijds kan het best worden verduidelijkt aan de hand van de algemene ontwikkeling die de Amerikaanse steden recentelijk hebben doorgemaakt. Kenmerkend voor de eerste fase van de 'wederopstanding' na de bijna-faillissementen van New York, Cleveland, Detroit, Chicago, Newark en al die andere grote industriesteden in het begin van de jaren '70, was de eenzijdige en onverbloemde beleidskeuze voor de bevordering van economische groei. De economisch succesvolle steden hebben in deze eerste fase het sociaal beleid veelal naar het tweede plan verplaatst. Toen werd de 'duale' ontwikkeling van de steden gesignaleerd. De prioriteit voor de economische basis bleek noodzakelijk in de Amerikaanse verhoudingen, maar niet voldoende. Zij bleek niet alleen inadequaat voor de scherp toenemende sociale problematiek, maar ook onvoldoende voor een duurzaam herstel van de stedelijke economie. Slechts voor enkele wereldsteden zoals New York en Los Angeles - hoewel ook niet zonder fluctuaties - bleek de nieuwe hiërarchie in de internationale diensteneconomie voldoende perspectieven te bieden om te kunnen spreken van een structureel herstel.

Bij de grote middenmoot van steden werd spoedig duidelijk dat de nieuwe economische successen in de diensteneconomie kwetsbaar zijn vanwege de afhankelijkheid van internationale netwerken, vanwege de toegenomen flexibiliteit van de dienstenhuishouding, vanwege de toenemende 'footlooseness' van standplaatsfactoren door de nieuwe (tele)communicatiesystemen, vanwege de nieuwe bedreigingen van ruimtelijke deconcentratie, enzovoort. Niet alleen de eenzijdige 'boom-cities' in Texas zoals Denver, Houston of Dallas (die met het ritme van de olieconjunctuur op en neer lijken te deinen) hebben zulke fluctuaties ondervonden, maar ook de 'intelligente' steden zoals Boston of San Francisco. De nieuwe formaties zijn gevoelig, zowel voor regionale als voor internationale stoorzenders. In de tweede fase van de 'urban renaissance' kwam het erop aan om een breder sociaal en cultureel draagvlak te vinden voor een duurzaam stedelijk herstel. 
Het boeiende van het Noordamerikaanse voorbeeld is dat de particuliere sector (inclusief het bedrijfsleven) in een aantal steden een belangrijk aandeel heeft gehad in de sociale en culturele verbreding van het stedelijk herstel. Slechts door kwaliteit en evenwicht van de stedelijke voorzieningen wordt een duurzame basis voor herstel gecreëerd. De steden profileren zich door een specifiek patroon van bedrijvigheid. Sommige steden kwalificeren zich als gediversificeerde dienstencentra, andere doen diepte-investeringen in gespecialiseerde vormen van dienstverlening. Weer andere ontwikkelen zich als moderne produktiecentra of juist als consumentgerichte centra ${ }^{13}$.

Doordat de verbijzondering van functies van de bedrijvigheid mogelijk wordt gemaakt door een profilering van het voorzieningenbeleid, vindt de concurrentie tussen de steden in de Verenigde Staten vaak plaats op het vlak van de 'amenities', de typische stedelijke voorzieningen. De ene stad profileert zich door extra investeringen in het onderwijs, de andere manifesteert zich als de cultuurstad, weer een andere als de stad voor veiligheid en het gezonde leefmilieu. De differentiatie van deze stedelijke profielen hangt nauw samen met de bijzondere omstandigheden waarin elk stedelijk gebied verkeert. Deze selectieve profilering is in de loop van de jaren ' 80 overgenomen door de Britse steden. Hier werpt de vroegere autostad Birmingham zich op als een nieuw internationaal zakencentrum door doelbewuste investeringen in congres-, beurs- en tentoonstellingscentra en een uiterst ambitieuze cultuurpolitiek. Bristol buit de gespecialiseerde onderwijs- en kennisprofielen uit voor specialisaties in de medische industrie en de luchtvaart. In de Schotse steden wordt de technische kennis van onderwijs- en researchcentra optimaal benut voor versterking van de high-tech industrie. Newcastle profileert zich met het gespecialiseerde technische arbeidspotentieel in de ingenieursbedrijvigheid (groeiend aandeel in de offshore industrie).

Aldus blijkt de inzet van de stedelijke voorzieningen van strategisch belang, niet alleen om te voorzien in de behoeften van de stedelijke bevolking, maar ook voor de versterking van een duurzaam economisch herstel. De belangrijke constatering van dit betoog, die ook als cruciale uitdaging voor het voorzieningenbeleid in de Nederlandse steden beschouwd kan worden, is dat de specificiteit van de economische en sociale ontwikkeling in sterke mate kan worden beïnvloed door de keuze voor en het benutten van inhoudelijke zwaartepunten in het voorzieningenbeleid.

\subsubsection{Institutionele hervorming}

De vraag of in het stedelijk beleid in de Nederlandse context met een zelfde reikwijdte beslissingen genomen kunnen worden over de strategische samenhangen in het economisch en het sociaal beleid en het voorzieningenbeleid, is een vraag naar de institutionele structuur van het stedelijk beleid. De Nederlandse steden kunnen in dit opzicht niet op één lijn gezet worden met vergelijkbare Amerikaanse steden of zelfs maar met de Europese zustersteden waarmee zij zich na 1992 in één interne markt zullen bevinden. Daarvoor zijn de institutionele verhoudingen waarin het Nederlandse stadsleven is gesitueerd, te zeer afwijkend. De beleidsinhoudelijke samenhangen tussen economisch beleid, sociaal beleid en voorzieningenbeleid, zoals die in de Amerikaanse en Britse steden (en sinds kort zelfs in het voorheen zo gecentraliseerde Frankrijk) voortdurend op de agenda staan en die daar steeds aanleiding geven tot nieuwe politieke definities en coalities, worden in het Nederlandse stedelijk beleid ook wel beredeneerd en tot inzet van doeleindennota's gemaakt. Maar in Nederland is het veel moeilijker om er op dit beleidsniveau materiële consequenties aan te verbinden, omdat de financiële en beleidsmatige verhoudingen zo sterk gecentraliseerd zijn. 
Net als in de andere open economieën zijn ook in Nederland de verhoudingen tussen economisch en sociaal beleid en het voorzieningenbeleid gedurende het afgelopen decennium aanzienlijk bijgesteld. In dit opzicht kan Nederland zich niet onttrekken aan algemene internationale trends. Maar doordat de beslissingen omtrent de herallocaties van de uitgaven van de overheid grotendeels gecentraliseerd zijn, heeft het grootstedelijk beleid hier niet de specificiteit kunnen ontwikkelen die in vergelijkbare internationale steden wel bestaat. De institutionele structuur van het grootstedelijk beleid is niet geschikt om op de vele uitdagingen met een specifiek karakter specifieke antwoorden te vinden. Als dat wel wordt geambieerd is een ingrijpende herstructurering van de beleidsmatige en financiële verhoudingen tussen het Rijk en de steden onontbeerlijk.

Wat betreft de inhoudelijke beleidskeuzen, hebben de Nederlandse steden geheel in de internationale lijn in het begin van de jaren ' 80 de koers omgegooid. De exclusieve aandacht voor het sociaal-fysieke stadsvernieuwingsbeleid werd afgezworen. Naast de sociale oriëntatie moesten nu ook het economisch beleid en het produktieve voorzieningenbeleid met kracht ter hand worden genomen. Maar deze nieuwe beleidsprioriteit kon nauwelijks in financiële maatregelen vertaald worden. Het bleek veel moeilijker om herallocaties van de gemeente-uitgaven in deze nieuwe beleidsrichting tot stand te brengen (hoewel het beeld in de grote steden in dit opzicht nog gunstiger is dan in de gemiddelde gemeenten, die juist in deze periode een naoorlogs dieptepunt van economische investeringen bereikten). Voor de recente verbreding van het stedelijk herstelbeleid naar sociale vernieuwing is het niet anders. Wat betreft de financiering, gaat het primair om herschikkingen binnen de rijksbegroting. Ook herallocaties tussen verschillende stedelijke voorzieningen, of zelfs binnen kokers van voorzieningen, zijn in de huidige verhoudingen moeilijk tot stand te brengen. Er vinden wel ombuigingen van uitgaven plaats - in de afgelopen jaren zelfs intensief - maar de richting hiervan wordt slechts in beperkte mate op lokaal niveau beïnvloed. Bovendien blijken die herallocaties vaak dwars tegen de nieuwe beleidsprioriteiten in te druisen.

Het probleem van de Nederlandse gemeenten in de internationale vergelijking is niet dat zij over te weinig financiële middelen zouden beschikken, maar dat zij de geldstromen die via hun begroting lopen, zowel aan de zijde van de inkomsten als via de uitgaven te weinig kunnen beïnvloeden en zo onvoldoende verantwoordelijkheid dragen om in de internationale concurrentie een eigen profiel te kiezen. Het tweede kernprobleem hangt nauw met het voorgaande samen: doordat het grootstedelijk bestuur voor zijn inkomsten- en uitgavenpatroon zo is gebonden aan het hoger bestuur, is het voor een groot deel afgeschermd van de sociale en economische ontwikkelingen van de stad en van de mogelijkheden en risico's die daarmee verbonden zijn. De kosten voor het sociaal beleid en de mogelijkheden die uit een succesvolle economische ontwikkeling voortvloeien, worden grotendeels op een ander bestuursniveau afgewikkeld. De partijen in de stad zijn niet 'tot elkaar veroordeeld' en kunnen bijgevolg naast elkaar blijven lopen. In de internationale voorbeelden is veel vaker sprake van een actieve inzet van maatschappelijke instanties en bedrijfsorganisaties om aan de versterking van de economische en sociale structuur een nieuwe richting te geven. De overheidsorganisaties kunnen daar op die initiatieven inhaken - hebben daartoe een logische dwang - zonder deze zelf te willen organiseren. De veelgeroemde 'civic culture' in de Angelsaksische traditie berust niet op een ideaaltypische gedachtenconstructie, maar is diep geworteld in een financiële en bestuurlijke infrastructuur waarin partijen op elkaar zijn aangewezen. Om deze redenen biedt de uitdaging van de bestuurlijk/financiële infrastructuur een essentiële 'grondslag' voor de beleidsinhoudelijke perspectieven die hierboven werden aangeduid. 


\subsection{Beleidsvisie}

\subsection{Inhoudelijke beleidsthema's}

Uit de internationale typering blijkt dat de Nederlandse steden voor forse uitdagingen staan. Wat betreft de economische ontwikkeling, hebben de steden inmiddels het accent gelegd op de plannen voor grootse ruimtelijke projecten. Van Amsterdam tot Arnhem en van Groningen tot Maastricht liggen de plannen klaar voor de ambitieuze 'waterfront'-projecten waarmee Boston, Baltimore en San Diego enige tijd geleden de toon hebben gezet. Het zijn de grote blikvangers voor de stedelijke vernieuwing. Voor architecten en stedebouwkundigen liggen hier de kansen waarvan zij enige decennia verstoken zijn gebleven. Maar hoe inspirerend straks de resultaten ook mogen zijn, het zou niet juist zijn om de mate van de economische en sociale vernieuwing aan de uitstraling van deze ruimtelijke artefacten af te meten. Dat bleek reeds bij een aantal internationale voorbeeldprojecten die vaak na de totstandkoming kwetsbaar bleken en in de moeilijkste fase belandden. Zelfs in de opvallende London Docklands, in Route 128 Boston en in Sillicon Valley zijn sporen van vluchtigheid opgetreden.

Voor een versteviging van de stedelijke economie zal een breed draagvlak gevonden moeten worden in nauwe samenhang met de condities voor de nationale groei van de economie enerzijds en met een geprofileerd aanbod van lokale voorzieningen anderzijds. De steden hebben de kansen om de industriële bedrijvigheid te moderniseren meer laten liggen dan volgens de theoretische mogelijkheden had kunnen worden verwacht. $\mathrm{Nu}$ vindt deze vernieuwing elders plaats. De steden zullen de achterstand moeten inlopen. De belangrijke impulsen zijn momenteel gelegen in de sfeer van de diensteneconomie. Maar ook hier ligt volgens de internationale trends het gevaar van verdergaande trek uit de steden op de loer en ook hier doen zich mogelijkheden voor die slechts benut kunnen worden indien de stedelijke en nationale krachten hierop eensgezind worden afgestemd. Een belangrijke test-case op dit moment is de vraag of de kansen van de nationale groeipool Schiphol (die nu voor de tweesprong 'mainport' ofwel 'regionale functie' staat) optimaal zullen worden benut.

Wat betreft de investeringen in de sociale structuur van de steden, doen zich grosso modo twee beleidsstrategieën voor die naar het oordeel van de raad naast elkaar beproefd dienen te worden. De ene strategie - prominent verwoord door de Amerikaan Kasarda ${ }^{14}$ - is erop gericht om de eenzijdigheden in de samenstelling van de stedelijke bevolking te veranderen (geografische mobiliteit). Via stedelijke inrichting, huisvestingsbeleid en aanbod van adequate voorzieningen kan de demografische en sociale opbouw van de stedelijke bevolking op de langere duur aanzienlijk evenwichtiger worden. Percentages van sociale woningbouw die in de grote steden hoog oplopen, weerspiegelen niet een evenwichtige opbouw van de bevolking. Ook al is de samenstelling van de sociale woningsector in Nederland zeer gemengd (deze wordt hierom internationaal benijd), het staat vast dat de steden in het aanbod van woonruimte en in de ruimtelijke inrichting en de sociale voorzieningen eenzijdige steken hebben laten vallen. Hierdoor zijn de huishoudens met een bovenmodaal inkomen en de kinderrijke gezinnen in groter getale uit de steden verdwenen dan voor een evenwichtige sociale structuur wenselijk is. De steden hebben nog slechts schoorvoetend een begin gemaakt met een aangepaste beleidsstrategie. De belangrijke vraag is hoe binnen het stadsregionale niveau de scheef gegroeide verhoudingen kunnen worden rechtgetrokken.

14] New urban policies for new urban realities'; opgenomen in de congresbundel van het Bundesforschungsanstalt für Landeskunde und Raumordnung, Proceedings of the European meeting on applied urbon research (in Essen 1981); J.D. Kasarda, G.M. Hellstern, F. Spreer en H. Wollmann (eds.); Bonn, 1982, blz. 5-15. 
De tweede beleidsstrategie (in Amerika verwoord door de stroming van Marcuse ${ }^{15}$ bepleit meer investeringen in een gedifferentieerd sociaal beleid. Omdat de samenstelling van de stedelijke bevolking altijd selectieve trekken zal behouden, zullen voor de afhankelijke bevolkingsgroepen meer kansen gecreëerd moeten worden ter bevordering van de sociale mobiliteit. Uitgaande van de eigen verantwoordelijkheden en mogelijkheden van de non-actieve stadsbewoners en van particuliere organisaties, zal de overheid aanvullende initiatieven moeten ontplooien om de mogelijkheden voor zelfredzaamheid te vergroten. Deze premisse is niet onbetekenend. Uit vele internationale invalshoeken, zelfs vanuit het lage verzorgingsniveau in de Amerikaanse steden, komen immers de signalen dat het automatisch aanreiken van sociale en maatschappelijke voorzieningen tot averechtse gevolgen leidt ${ }^{16}$.

In dit rapport worden diverse mogelijkheden nagegaan om aan beide strategieën uitvoering te geven.

Het voorzieningenbeleid is van strategische betekenis voor de conditionering van het economische èn van het sociale spoor. Door culturele voorzieningen, infrastructuur, onderwijs, gezondheid en huisvesting worden specifieke condities gecreëerd voor economische en sociale ontwikkeling. De betekenis van het voorzieningenbeleid is zo strategisch omdat de internationale economische en sociale processen doorgaans veel moeilijker rechtstreeks beïnvloed kunnen worden, zeker in het kader van een grootstedelijk beleid. Als het erop aankomt de loop van de economische en sociale ontwikkelingen in de steden te beïnvloeden, biedt het voorzieningenbeleid hiertoe doorgaans de primaire en de meest hanteerbare aangrijpingspunten, omdat langs deze weg de specifieke condities worden gecreëerd. Hoewel het niveau van de algemene voorzieningen in Nederland vanuit internationaal gezichtspunt hoog genoemd kan worden, worden de mogelijkheden van een gerichte profilering van de voorzieningen in het kader van het grootstedelijk beleid onvoldoende benut.

\subsubsection{Institutionele beleidsthema's}

De institutionele beperkingen waaraan de Nederlandse steden zijn gebonden, kunnen het best worden getypeerd door de reacties te bezien van de partijen in het grootstedelijk beleid op de bedreigende omstandigheden waarmee veel westerse steden werden geconfronteerd tussen 1975 en 1985. Op het eerste gezicht is het onze steden niet opvallend slecht vergaan. Het niveau van de centraal georganiseerde sociale voorzieningen daalde, maar het peil bleef - zeker naar internationale maatstaven bezien - relatief hoog. Ook in economisch opzicht ligt er in de internationale vergelijking geen doem op de Nederlandse steden. Dit hangt direct samen met de relatieve welvaart van het hele land. In de direct omliggende landen scoren de Duitse steden in het algemeen wat beter (hoewel daar grote verschillen bestaan), de Belgische steden verkeren echter in grotere problemen en voor de Britse steden waren de jaren ' 80 zeer moeizaam.

Niettemin gaan achter deze globale typeringen zeer verschillende praktijken schuil. Kenmerkend voor de Nederlandse steden is de relatief geringe eigen dynamiek. De afhankelijke condities van het grootstedelijk beleid in Nederland beperken het vermogen tot aanpassing onder de sterk veranderende omstandigheden. In dit opzicht wordt de positie van onze steden niet gekenmerkt door een grote slagvaardigheid. Bijvoorbeeld de bovengenoemde Britse steden hadden (afgezien van Londen) weliswaar grotere tegenvallers te verduren,

15] P. Marcuse, 'The decline of cities in the United States'; in: Proceedings of the Europeon meeting on applied urban research op. cit.), b|z. 23-31.

16] Bijvoorbeeld Ch. Murray, Losing ground, American social policy 1950-1980; New York, Basic Books, 1985; W.j. Wilson, The truly disadvantaged, the inner city, the underclass and public policy; Chicago, University of Chicago Press, 1987; N. Glaser, 'A kinder and gentler America'; Journal of the American Planning Association, Autumn 1989, jaargang 55, nr. 4, blz. 41 1-416. 
maar daar zijn inmiddels de institutionele condities voor het stedelijk beleid ingrijpend herzien. Vertrokken vanuit een lager welvaartsniveau is een groot deel van die steden in vergelijking met de Nederlandse steden inmiddels goed geëquipeerd om aan de internationale uitdagingen het hoofd te bieden. De reactiesnelheid van het nationale en lokale grootstedelijk beleid op het sociale en het economische vlak ligt daar enige slagen hoger.

Opvallend voor de Britse formule voor het grootstedelijk beleid van de jaren ' 80 is, dat aanvankelijk de centrale regering in directe samenwerking met het bedrijfsleven de bevordering van het economisch herstel in handen heeft genomen. Met voorbijgaan aan de overwegend sociaal georiënteerde lokale partijen - in het bijzonder het grootstedelijk bestuur - werd een reeks van instrumenten ingezet om de steden een trekkersfunctie te geven in het herstel van de nationale economie. Het centrale beleid was eenzijdig gericht op een versterking van het economische proces via marktwerking (leidend tot versnelde sanering van het verouderde bedrijfsleven) enerzijds en een actieve stimulering van kansrijke ontwikkelingen anderzijds (via het creëren van vrijhavens, zoals 'free enterprise zones', 'dereguleringszones' en zelfs letterlijk 'free ports'; via de instelling van zelfstandige bestuursorganen met aanzienlijke competenties, zoals de 'urban development corporations' bijvoorbeeld in de London Docklands; via rechtstreekse ontwikkelingssubsidies aan het bedrijfsleven zoals de 'city grants'; enzovoort). Na verloop van tijd is de eenzijdige centrale structurering van deze programma's verbreed naar de andere partijen. Op stedelijk niveau bestaat daar inmiddels een actieve wisselwerking tussen lokale partijen. De Britse weg naar 'urban regeneration' is niet onomstreden, maar het effect is wel dat de stedelijke economie daar inmiddels een vooraanstaande positie inneemt in de landelijke ontwikkelingen.

In Nederland bestaat op rijksniveau - buiten de sfeer van de ruimtelijke ordening - relatief weinig bijzondere bemoeienis met de grootstedelijke ontwikkeling. Niettemin is het stedelijk beleid dat plaatselijk tot ontwikkeling komt, in hoge mate gebonden aan de condities die centraal worden bepaald, aangezien meer in het algemeen de verhoudingen in het Nederlandse bestel een centraal kenmerk dragen. Vanaf enige afstand bezien moet het wel bevreemding wekken dat de Nederlandse steden, hoewel vanaf 1980 zichtbaar bewogen door een nieuw elan, doch juist ook op dat moment - zoals elders - getroffen door economische en sociale tegenslagen, de verscherping van de sociale en economische problemen zo lijdzaam hebben ondergaan. Niemand had kunnen verwachten dat hier binnen enkele jaren een kwart van de actieve beroepsbevolking zonder werk zou raken (met een harde duurzame kern die in de grootste steden niet kleiner zou worden, in tegenstelling tot de rest van het land). Achteraf gezien was dit een internationale tendens waarmee veel steden te maken kregen. Het opvallende en zorgwekkende van het grootstedelijk beleid in Nederland is het trage reactiepatroon, behalve van de eerdergenoemde rijksoverheid ook van de andere betrokken partijen.

De tekortkoming van het grootstedelijk beleid was niet dat bij de plotselinge tegenslagen niet onmiddellijk de juiste antwoorden voorhanden waren. De kern van het probleem is dat de reacties van de eerstbetrokken partijen lang uitbleven. Inmiddels is hierin verbetering gekomen, maar de resultaten (inzake vernieuwing van bedrijvigheid, versterking van het ondernemingsklimaat, arbeidsbemiddeling, uitstroom van werklozen en bijstandsgerechtigden) zijn in de steden nog altijd bescheiden. Het reactiepatroon weerspiegelde het patroon van onderlinge afhankelijkheden. Waar een verscherpte lokale dynamiek van particuliere en publieke partijen met bijzondere ondersteuning van rijkswege nodig was onder de bedreigende omstandigheden, overheerste de vertrouwdheid met het centraal gealloceerde beleid. Het relaas van de banenplannen die na verloop van tijd onder centrale regie tot stand kwamen en die dan met zoveel centrale voorwaarden werden omkleed dat zij niet op de 
lokale omstandigheden pasten, is typerend voor dit reactiepatroon. Eerst sinds kort wordt deze vicieuze cirkel op enige plaatsen doorbroken. Maar de structuur van afhankelijkheden is nog niet wezenlijk aangetast. In de reacties op de nieuwe stedelijke vraagstukken kwamen de mechanismen van de verzorgingsstaat op onrustbarende wijze bloot te liggen.

Gegeven de inhoudelijke uitdagingen voor het grootstedelijk beleid en gegeven de verschuivingen in het institutionele krachtenveld, adviseert de raad gericht af te stevenen op een nieuwe, minder receptieve bestuurscultuur. Deze moet gestalte krijgen door op twee manieren in te spelen op de in gang zijnde herordening van de arrangementen van de verzorgingsstaat. In de eerste plaats moet het grootstedelijk beleid op een nieuwe wijze gepositioneerd worden in de verschuivingen tussen de centrale en de lokale organisatieniveaus. Hiertoe werden in het voorgaande stapsgewijs vier uitgangspunten ontwikkeld.

Dit institutionele schema wordt hier nog eens beknopt samengevat.

a. Voor de versterking van de economische concurrentiepositie worden in dit rapport twee algemene uitgangspunten voor beleid geanalyseerd. In de eerste plaats is het de verantwoordelijkheid van de lokale gemeenschap zelf (het bedrijfsleven, de gemeenten, overige lokale instanties) om een gunstig economisch klimaat te creëren. In de tweede plaats worden vanwege het gewicht van de grootstedelijke economie in de nationale economie en de hieruit voortvloeiende interdependenties en vooral ook met het oog op de internationale concurrentiepositie de mogelijkheden onderzocht voor een inschakeling van de nationale overheid via voorwaardenscheppend beleid voor de versterking van de grootstedelijke economie.

b. Voor de verbetering van de sociale structuur is het institutionele uitgangspunt van de analyse eerder omgekeerd. Het sociale-zekerheidsbeleid en het arbeidsmarktbeleid raakten gedurende de laatste decennia steeds meer gecentraliseerd. Onlangs is hierin via nieuwe decentralisatievoorstellen beweging gekomen. Op deze gebieden zal worden nagegaan op welke wijze het toenemend belang van de allocatieve beleidstaken decentraal kan worden recht gedaan.

De verantwoordelijkheid voor de bevordering van de geografische mobiliteit ter versterking van de sociale stedelijke structuur ligt primair bij de lokale instanties. Bij deze vraagstukken manifesteert zich de noodzaak om oplossingen te vinden op het regionaal niveau.

c. Voor het voorzieningenbeleid zal eveneens worden nagegaan of de allocatieve beleidsonderdelen adequaat op decentraal niveau kunnen worden bepaald. Een belangrijk uitgangspunt bij deze analyses is dat de verschillende modellen van decentralisatie (functionele, territoriale en economische decentralisatie) nauwgezet onderscheiden moeten worden, omdat de nieuw te creëren verhouding tussen de particuliere instanties en de betrokken overheden bij elk voorzieningenstelsel steeds anders ligt.

d. De financieel/bestuurlijke verhouding zal in nauwe wisselwerking met de drie bovengenoemde materiële gebieden moeten worden aangepast in decentrale richting. Het gaat hier primair om de vergroting van de verantwoordelijkheid voor de lokale inkomsten. Op lokaal niveau moet een grotere uitwisseling mogelijk worden tussen uitgaven voor verschillende beleidssporen. De steden moeten niet worden afgeschermd voor de eigen verantwoordelijkheden en de daarmee verbonden risico's. De huidige financiële verhouding prikkelt de steden niet vanzelf tot economische en sociaal-produktieve investeringen maar straft deze eerder af.

In nauwe samenhang met deze eerste plaatsbepaling (verschuivingen in de schaalniveaus van besluitvorming) moet voor het grootstedelijk beleid tegelijkertijd een nieuwe positie worden bepaald in de tweede institutionele omwenteling van de naoorlogse verhoudingen: de veranderende rolverdeling en taakuitoefening in de verhoudingen tussen de particuliere en de publieke sector. De institutionele condities voor het grootstedelijk beleid worden niet 
automatisch verbeterd wanneer centrale taken zonder meer worden overgeheveld van het centrale naar het lokale niveau. Daarvoor is de institutionele context van het huidige grootstedelijk beleid te zeer geblokkeerd geraakt. Deze blokkades kunnen eerst verdwijnen wanneer het beleid meer gestoeld is op de primaire verantwoordelijkheden in het maatschappelijk verkeer. Dit betekent niet dat de overheid hierin geen rol meer zou hebben, maar wel dat het vertrekpunt van beleid ligt in het verkeer tussen burgers en maatschappelijke organisaties en dat de lokale en uiteindelijk ook de centrale overheden hierin geroepen kunnen worden.

\subsubsection{Naar een responsief grootstedelijk beleid}

De verklaring voor de vertraagde en nog steeds ontoereikende reacties op de nieuwe sociale en economische uitdagingen voor het grootstedelijk beleid ligt, als gezegd, voor een belangrijk deel in de receptieve bestuurscultuur, die samenhangt met de wijze waarop de verantwoordelijkheden en de hieruit voortvloeiende afhankelijkheden zijn georganiseerd. Terwijl de lokale partijen, daarin gesteund en zonodig beperkt door een direct intermediërend lokaal bestuur, tot diep in het interbellum de voortrekkers waren van het grootstedelijk beleid en van het lokaal beleid in het algemeen, zijn gedurende de naoorlogse expansie van de collectieve sector de betrokkenen, de bestuurlijke methoden en administratieve routines, alsmede de verantwoordelijkheden voor het grootstedelijk beleid geleidelijk afgestemd op de centrale beleidsvoerders. Eerst onlangs worden in de steden meer eigen initiatieven ontwikkeld voor een economisch ontwikkelingsbeleid, voor banenplannen, voor de profilering van voorzieningen, maar men stuit hierbij dikwijls op institutionele barrières.

Aan de optiek die in dit raadsadvies over het grootstedelijk beleid wordt ontwikkeld, ligt het uitgangspunt ten grondslag dat-niet eens in de eerste plaats het grootstedelijk bestuur - maar vooreerst de partijen in de stad eigen verantwoordelijkheid dragen voor de ontwikkelingen in hun gemeenschap. Dit uitgangspunt van stedelijke burgercultuur en ondernemingscultuur biedt een normatief houvast om de ontwikkelingen in de stad en de regels inzake de verhoudingen tussen partijen, die hierop in hun werkzaamheid gericht zijn, te analyseren, ook als deze ontwikkelingen op zeker moment minder voortvarend zijn. Deze verantwoordelijkheid van partijen duidt niet alleen op zeggenschap, maar ook op de risico's die hiermee gepaard gaan en de aanspreekbaarheid voor derde partijen. Vanuit deze optiek gezien draagt de stedelijke samenleving het kenmerk van een risico-samenleving. De positie van het lokaal bestuur dient zich in dit krachtenveld te ontwikkelen.

Met bovengenoemd uitgangspunt van 'weerbare partijen' in de stad wordt de verantwoordelijkheid voor de stedelijke ontwikkeling niet volledig afgebakend. De stad en de partijen die hierin werkzaam zijn, zijn niet autonoom. Er zijn velerlei begrenzingen aan dit uitgangspunt, zeker in de egalitaire bestuurstraditie van Nederland. Ook in de culturele, de economische en meer in het algemeen de maatschappelijk sfeer is de stedelijke ontwikkeling in velerlei verbanden opgenomen die niet eenzijdig tot de verantwoordelijkheid van lokale partijen gereduceerd kan worden. Hieraan wordt in dit rapport dan ook steeds aandacht geschonken. Maar het is wel nodig om steeds het voornoemde uitgangspunt voor ogen te houden. Wanneer de responsiviteit van de partijen in de stad niet meer naar behoren functioneert, ontbreekt in het stelsel van verantwoordelijkheden de essentiële schakel voor stedelijke revival.

Het is in dit opzicht dat de typisch Angelsaksische burgercultuur en ondernemingscultuur inspiratie kan bieden voor het grootstedelijk beleid in Nederland. Niet de uitkomsten daarvan, die van plaats tot plaats verschillen en die bezien vanuit de Nederlandse traditie in sommige gevallen zelfs teleurstellen, maar de mechanismen die hierin werkzaam zijn, kunnen tot voorbeeld dienen voor het grootstedelijk beleid in Nederland. Kennelijk is het mogelijk om in de 
stad tot een rechtstreekse uitwisseling te komen van partijen en belangen, die in de Nederlandse context veeleer gescheiden optrekken, ook in de richting van de overheid en hooguit via de overheid kunnen worden geaccommodeerd. De typische 'public-private partnerships' die in de Amerikaanse en Britse steden een veel bredere toepassing vinden dan in de Europese afgietsels daarvan (waar het voornamelijk gaat om horizontale contracten tussen overheden en de wereld van het vastgoed), leiden daar tot een directe uitwisseling van belangen tussen zeer verschillende maatschappelijke groeperingen. Het gaat daar niet alleen om de relatie tussen de overheid en de grote investeerders, maar ook om die tussen het huurderscomité en de vastgoedbelegger, de milieu-organisatie en de oliemaatschappij, de minderheidsorganisatie en de werkgeversassociatie, de buurtorganisatie en de investeringsbank.

Het ligt niet in de lijn van dit advies om dergelijke relaties te idealiseren. Maar het zijn wel uitingen van stedelijke responsiviteit, voorbeelden van een directe uitwisseling van belangen die in de Nederlandse stedelijke cultuur veel minder tot wasdom komt, omdat de noodzaak daartoe ontbreekt. De partijen zijn bij ons veel minder tot elkaar veroordeeld. Het zou een vergissing zijn om de Angelsaksische 'civic culture' te herleiden tot een morele categorie. In de financiële en beleidsmatige structuur van het grootstedelijk beleid zijn uiteenlopende partijen daar zozeer op elkaar aangewezen dat zij elkaar (moeten) tegenkomen - inmiddels volgens een zekere traditie - in het platform voor grootstedelijke ontwikkeling.

Een van de belangrijke voorwaarden voor de totstandkoming van een dergelijke stedelijke bestuurscultuur is dat voldoende financiële prikkels bestaan die de partijen aan elkaar binden. Voor groeperingen in de stad die op steun van het stedelijk bestuur zijn aangewezen, moet het evident zijn dat de overheid deze middelen tenminste voor een deel uit lokale inkomstenbronnen put. Deze directe relatie leidt ertoe dat alle partijen in de stad belang hebben bij het hooghouden van de lokale belastingcapaciteit. Hieruit vloeit de noodzaak voort om deze krachten aan de stad te binden. Anderzijds mag deze relatie niet zozeer gaan domineren dat de stadspolitiek eenzijdig wordt bepaald door de afhankelijkheid van de economisch dragende krachten. Een dergelijke eenzijdige afhankelijkheid heeft van het 'public entrepreneurship' in een aantal Amerikaanse steden een syndroom gemaakt. Via het electorale mechanisme moet verzekerd worden dat een bredere afweging van belangen plaatsvindt, opdat de partijen met de sterkste belastingcapaciteit op hun beurt afhankelijk zijn van de kracht van de politieke organisatie van de andere partijen in de stad. Het precaire evenwicht tussen deze twee mechanismen creëert een voedingsbodem voor een weerbare bestuurscultuur van partijen in de stad.

In Nederland bestaat een dergelijk evenwicht slechts op nationaal niveau. In de stad is het bij de gegroeide verhoudingen grondig verstoord. In de Nederlandse stad bestaat wel een levendige politieke articulatie via het electorale mechanisme, maar er bestaat onvoldoende noodzaak om de eigen inkomstenbronnen hoog te houden. Het merendeel van de stedelijke voorzieningen zowel als van de inkomsten wordt van rijkswege verschaft. In deze inmiddels zeer vertrouwde - maar internationaal gezien hoogst uitzonderlijke - bestuurlijke context heeft zich in Nederland een stedelijke bestuurscultuur ontwikkeld die men het best zou kunnen typeren als de 'cultuur van de verwachtingen'. Hierin verandering te brengen is het primaire oogmerk van dit rapport. 


\section{De grootstedelijke economie}

\section{I Inleiding}

Voortrekkers en achterblijvers zijn in een economie op velerlei niveaus te onderscheiden. Als men naar personen op de arbeidsmarkt kijkt, naar afzonderlijke bedrijven binnen bepaalde sectoren of bedrijfstakken, naar regio's binnen nationale entiteiten of zelfs naar nationale economieën binnen de context van de wereldeconomie, is het steeds mogelijk een onderscheid te maken naar voortrekkers en achterblijvers, waarbij in een dynamische omgeving de samenstelling van deze twee groepen voortdurend verandert.

Historisch gezien zijn de steden er tot voor kort altijd in geslaagd met verve een voortrekkersrol te vervullen. Dit gold niet alleen voor allerlei maatschappelijk-culturele aspecten, maar zeker ook voor de economische ontwikkeling. Arbeidsdeling, handel, financiële transacties, internationale contacten, markten en beurzen, technologische doorbraken, op al deze terreinen hebben de steden van oudsher een voortrekkersrol vervuld. Hun concurrentiepositie was daarmee ook van grote invloed op het welbevinden van de hele regio.

In de laatste decennia echter lijken de steden in economisch opzicht van voortrekker tot achterblijver getransformeerd te zijn $\mathbf{1}$. Factoren als toenemend ruimtegebrek, afgenomen bereikbaarheid, relatief slechter woningaanbod en arbeidsaanbod kunnen beschouwd worden als even zovele aanduidingen dat de steden niet meer bij machte lijken een competitief milieu aan te bieden voor rendabele economische activiteiten die passen in een moderne economie.

Dit hoofdstuk richt zich eerst op een beschrijving van dit proces van relatieve achteruitgang van de grote steden, met aandacht voor de kenmerken en oorzaken in het recente verleden en heden. Deze beschrijving mondt uit in een plaatsbepaling, waarin de positie van de steden afgezet wordt tegenover de omringende regio's èn - cruciaal - in de steeds verder internationaliserende economie, tegenover steden in de ons omringende landen.

Uitgaande van de nu bestaande situatie wordt vervolgens, ter verscherping van het zicht op mogelijke ontwikkelingen, voor de komende periode een scenario van maximale economische groei geschetst. Aansluitend wordt ingegaan op de ontwikkelingskansen en bedreigingen voor een aantal bedrijfstakken in de vier grootstedelijke gebieden.

Het laatste deel van het hoofdstuk is, aansluitend bij de analyse van het recente verleden, heden en toekomst, geconcentreerd op een beleidsinhoudelijke plaatsbepaling voor de komende periode. Deze plaatsbepaling wordt tenslotte geconcretiseerd voor twee beleidsterreinen: economisch ontwikkelingsbeleid en infrastructuurbeleid. Bij dit beleidsgedeelte wordt overigens geen omvattende beleidsagenda gepresenteerd, maar ligt conform de opzet van dit rapport het accent op ontwikkelingscondities, die op onderdelen exemplarisch worden uitgewerkt.

\subsection{Het recente verleden en het heden}

\subsubsection{Data en de gebiedsindeling}

Voor de analyse in de volgende paragrafen 3.2.2 tot en met 3.2.4 is gebruik gemaakt van data van het CBS, gepubliceerd in diverse afleveringen van Regionale Economische Jaarcijfers en voor 1970 van de Regionale Economische Indicatoren. Hierbij dient te worden opgemerkt dat de gegevens zoals die

'] Die terugloop komt ook tot uiting in het aandeel van de bevolking dat in de drie grote steden woont. In I 930 was dit aandeel op zijn hoogtepunt, met 22,8 procent. Daarna was er sprake van een geleidelijke daling tot 19,3 procent in 1960. Vervolgens verliep de daling veel sneller, via 12,4 procent in 1980 tot 11,7 procent in 1988. Eerst sinds 1984 doet zich weer enige groei voor. 
in paragraaf 3.2.3 en verder worden gepresenteerd, niet precies op elkaar aansluiten, onder meer vanwege een ingrijpende revisie van de Nationale Rekeningen door het CBS met ingang van 1977. De resultaten van de periode 19701977 zijn daarom niet helemaal vergelijkbaar met die van de periode 1977 1986. Omdat de gegevens betrekking hebben op een vrij geaggregeerd niveau en de aandacht zich vooral richt op groeipercentages en niet op niveaus, is het toch mogelijk beide reeksen naast elkaar te gebruiken. Weliswaar reiken deze gegevens niet verder dan 1986, maar in paragraaf 3.2.5 en 3.2.6 worden recentere data gepresenteerd, die over het algemeen de gesignaleerde trends in paragraaf 3.2.2 tot en met 3.2.4 bevestigen.

In voornoemde publikaties komen data voor betreffende produktie, verbruik, toegevoegde waarde, export en arbeidsvolume werknemers, voor Nederland, voor landsdelen, provincies en voor COROP-regio's (CBS-indeling van Nederland in 40 regio's) ${ }^{2}$. Per onderscheiden gebied is een verdere onderverdeling gemaakt naar bedrijfsklassen, op basis van de Standaard Bedrijfstak Indeling van het CBS.

De COROP-indeling staat weliswaar een zekere regionalisatie van gegevens toe, maar niet in die mate dat er een strak onderscheid gemaakt kan worden tussen (grote) steden en randgemeenten. Dit is alleen mogelijk voor Amsterdam. Bij Den Haag zijn de omringende plaatsen meegeteld, Rotterdam is terug te vinden in Rijnmond en bij Utrecht wordt geen onderscheid gemaakt tussen stad en provincie. Dit maakt het moeilijk om eventuele divergerende ontwikkelingen tussen steden en omliggende gebieden adequaat in kaart te brengen. Om hier toch enig zicht op te krijgen, is in het vervolg de indeling toegepast zoals vermeld in overzicht 3.1. Op basis van deze indeling is het mogelijk eventuele verschillen tussen de grote steden en het omliggend gebied èn tussen West- en overig Nederland te traceren ${ }^{3}$.

\subsubsection{Een algemene terugblik}

De jaren van economische wederopbouw na de Tweede Wereldoorlog kenmerkten zich door een snel groeiende bevolkingsomvang, een naar arbeidsplaatsen gemeten kleiner wordende landbouwsector, een groeiende industrie en een zich snel ontwikkelende dienstensector. De toenemende produktiviteit in de landbouw had vergaande negatieve gevolgen voor de werkgelegenheidsontwikkeling met name buiten de Randstad. Dit leidde tot migratie naar het westen van Nederland, waar de groeiende industrie en dienstensectoren aanvankelijk zorgden voor voldoende werkgelegenheidsgroei.

In deze jaren was het beleid niet alleen gericht op migratie naar het westen, maar werd ook gepoogd de industriële ontwikkeling te bevorderen in die regio's

${ }^{2}$ ] COROP staat voor Coördinatiecommissie Regionaal Onderzoekprogramma. Deze commissie heeft Nederland in 40 gebieden ingedeeld, de zogenaamde COROP-regio's. Voor de exacte indeling wordt verwezen naar CBS, Regionale Economische joorcijfers 1986; 's-Gravenhage, Staatsuitgeverij, 1989, aanhangsels 3, 4 en 5.

3] Het arbeidsvolume, uitgedrukt in mensjaren, bij deze cijfers heeft alleen betrekking op werknemers. Dit betekent dat zelfstandigen en directeuren niet in de berekeningen zijn opgenomen. In bepaalde sectoren, zoals de landbouw en, in mindere mate, de handel en zakelijke dienstverlening, kan dit tot enige vertekening van de feitelijke ontwikkeling leiden. In de Arbeidskrachtentelling AKT 1985 en de Enquête Beroepsbevolking EBB 1987 worden ook gegevens per provincie gepresenteerd. Daaruit valt op te maken dat het aantal zelfstandigen en meewerkende gezinsleden uiteenloopt van ongeveer 15 procent (Friesland) tot 9 procent (Utrecht). Over het algemeen liggen de cijfers in de Randstad en het zuiden lager dan in het noorden en oosten.

Ook moet worden opgemerkt dat de gegevens betreffende de toegevoegde waarde alleen beschikbaar zijn in lopende prijzen. Op regionaal niveau zijn er geen gegevens bekend betreffende de prijsontwikkeling, waardoor het niet mogelijk is de toeneming van de toegevoegde waarde uit te splitsen in een volume- en een prijssrijgingsdeel. Aangezien het hier echter gaat om een vergelijking van regio's, waarin op sectorniveau door de bank genomen vergelijkbare prijsontwikkelingen plaatsvinden, hoeft dit niet tot belangrijke verstoringen in het beeld van de economische ontwikkeling te leiden. Een uitzondering hierop wordt gevormd door de zeer forse prijsstijgingen en -dalingen binnen de bedrijfsklasse delfstoffenwinning. Deze prijsstijgingen vertekenen enigszins de resultaten voor Groningen en, in recente jaren, voor de Kop van Noord-Holland (aanvoer van olie en gas uit de Noordzee). 
Drie grote steden:

Vier grote steden:

Randstad Midden:

West-Nederland:

Overig Nederland:
De COROP-gebieden: Amsterdam (bestaande uit de stad Amsterdam). Rotterdam (officiële COROP aanduiding: Rijnmond), bestaande uit Rotterdam en de randgemeenten en het COROP-gebied: 's-Gravenhage (officiële COROP-aanduiding: agglomeratie 's-Gravenhage), bestaande uit Den Haag en de randgemeenten

Idem als hierboven, maar aangevuld met het COROP-gebied Utrecht, gelijk aan het gebied van de provincie Utrecht

Het COROP-gebied: Schiphol (officiële COROP-aanduiding: Overig Groot-

Amsterdam) en de COROP-gebieden: Leiden-Bollenstreek/Delft-Westland/ Oostelijk Zuid-Holland

De voorgaande COROP-gebieden, aangevuld met de COROP gebieden: Kop van Noord-Holland, Alkmaar en omgeving, IJmond, Agglomeratie Haarlem, Zaanstreek, Gooi- en Vechtstreek, Overig Groot-Rijnmond en ZuidOost-Zuid-Holland (gelijk aan de provincies Utrecht, Noord- en Zuid-Holland)

Noord-, Oost- en Zuid-Nederland.

waar door werkgelegenheidsverlies in de landbouw sociaal-economische problemen ontstonden. Vooral door middel van verbetering van de infrastructuur probeerde de overheid de economische ontwikkeling buiten het westen te stimuleren.

In de jaren 60 , toen de economie een ongekende groei doormaakte, stak de ontwikkeling van het westen nog steeds boven het landelijk gemiddelde uit. Dit was met name te danken aan de groei van de dienstensectoren, de gunstige ligging van het westen en de daar bestaande agglomeratievoordelen. In deze jaren werden vooral de bedrijfsklassen van de industrie die buiten de Randstad lagen, geconfronteerd met de noodzaak tot herstructurering. De neergang van de textielindustrie, de problemen in de veenkoloniale industrie en de mijnsluitingen zijn hiervan sprekende voorbeelden.

Het westen fungeerde als locomotief van de Nederlandse economie. Het patroon van vier grootstedelijke agglomeraties met een open middengebied, de Randstad, werd in de nationale ruimtelijke ordening een richtsnoer voor verdere ontwikkeling. De stedelijke concentratie resulteerde echter uiteindelijk niet alleen in positieve uitkomsten. Men kreeg er steeds meer te maken met de negatieve effecten: vervuiling, congestie in het verkeer, woningnood die moeilijk was weg te werken, ruimtegebrek in het algemeen. Geleidelijk reageerde in de jaren ' 60 het overheidsbeleid hierop door middel van een versterking van zwakke regio's. De infrastructuur werd verbeterd en er werden gerichte investeringspremies gegeven. In het begin van de jaren '70 kwam hier nog het actieve deconcentratiebeleid bij, zoals het beleid gericht op de spreiding van rijksdiensten en de Selectieve Investeringsregeling.

Door de congestieverschijnselen in de Randstad, de toegenomen welvaart en het omvangrijk geworden autobezit was de autonome uitstroom van de bevolking uit het westen reeds op gang gekomen. Tot ver in de jaren ' $80 \mathrm{zou}$ de bevolkingsgroei in Noord- en Zuid-Holland fors achterblijven bij die van de rest van Nederland en hadden deze provincies te maken met omvangrijke uitgaande migratiestromen. In het midden van de jaren ' 80 komt hier een eind aan en laten ook de grote steden eindelijk weer een groei van de bevolking zien. Het overheidsbeleid is dan niet meer gericht op deconcentratie van de bevolking. Bovendien kan een autonome trek terug naar de stad worden waargenomen.

Maar de grote steden lieten niet alleen een achteruitgang zien in hun bevolkingsomvang. In de onderhavige periode moesten zij ook een terugloop incas- 
seren bij de bedrijven, soms door herstructurering/opheffing maar niet zelden ook door verplaatsing naar elders. Nederland volgt hiermee met een zekere vertraging de suburbanisatie van bedrijvigheid, die in de Verenigde Staten reeds in de jaren ' 50 de suburbanisatie van de bevolking op de voet volgde. De langdurige recessie van de jaren '70 en de hiermee verbonden oliecrises van 1973 en 1979 leidden ook in het westen van Nederland tot een langdurige stagnatie. De terugval van de economie was echter in dit deel van Nederland groter dan elders. Vooral de grote steden Amsterdam en Rotterdam en in iets mindere mate Den Haag en Utrecht maakten een moeilijke periode door, waarbij zij met de diepgaande gevolgen te maken kregen van industriële herstructurering, met name in de metaalsectoren (vooral de scheepsbouw), de chemie en de aardolieverwerkende industrie, sectoren geconcentreerd in Amsterdam en Rotterdam. Deze herstructurering ging gepaard met massaal verlies van werkgelegenheid. De problemen voor de grote steden werden nog vergroot door de verplaatsing van bedrijven naar vestigingsplaatsen buiten de stad. De verkeersproblematiek en het ruimtegebrek, samen met de bezwaren in die tijd tegen grootschalige en mogelijk overlast veroorzakende vestigingen en de onverschillige houding ten opzichte van knelpunten van kleinschalige bedrijvigheid, kenmerkend voor het toenmalige grootstedelijke beleid, kunnen worden gezien als de belangrijkste oorzaken daarvan.

$\mathrm{Na}$ lange jaren van groei kwam in de jaren '70 de klap in de grote steden hard aan; harder dan waar ook in Nederland. In de volgende paragrafen zal de economische ontwikkeling van de laatste twintig jaar meer in detail onder de loep worden genomen.

\subsubsection{De ontwikkeling van West-Nederland: 1970-1986}

De afnemende groei in de jaren ' 70 , de stagnatie in het begin van de jaren ' 80 en het hieropvolgende herstel, zijn goed af te lezen uit tabel 3.1. Hierin staan de groei van de toegevoegde waarde en van de werkgelegenheid voor Nederland als geheel vermeld, alsmede voor West- en overig Nederland en voor de drie grote steden. Grosso modo tonen de cijfers dat West-Nederland in de groei van toegevoegde waarde en werkgelegenheid achterblijft bij de rest van Nederland en dat binnen West-Nederland de drie grote steden hier weer sterk bij achterblijven. Weliswaar wordt de achterstand in groei op de rest van Nederland wel geringer, maar de daling in de werkgelegenheid heeft men in de steden pas recent kunnen stoppen en dan nog in zeer beperkte mate. Indicaties uit de recente jaren komen in de volgende paragraaf aan de orde.

Tabel 3.1 laat voor de periode vanaf 1983, na de crisis van 1980-1983, een fors herstel zien. Ten tijde van die crisis daalde de reële toegevoegde waarde in Nederland totaal met 0,3 procent per jaar, en in de Randstad zelfs met ruim 1 procent. Ook in de werkgelegenheidsontwikkeling laat deze crisisperiode zich gemakkelijk herkennen. In 1986 was de helft van de groei van de toegevoegde waarde en van de werkgelegenheid afkomstig uit de provincies Utrecht, Noord- en Zuid-Holland. Voor de drie grote steden lag het aandeel op ruim 20 procent.

De onderscheiden groeipercentages voor West-Nederland en de drie grote steden geven al aan dat de relatieve achteruitgang van West-Nederland niet voor het gehele gebied geldt. Naast gebieden die achterbleven, zijn er ook regio's die een sterke ontwikkeling te zien hebben gegeven.

Op een soortgelijke manier kan de ontwikkeling worden geschetst van de grote steden afzonderlijk alsmede van de omliggende regio's ${ }^{4}$. Ten opzichte van het nationaal gemiddelde laten de COROP-gebieden Rotterdam en vooral Amster-

1] Nogmaals wordt benadrukt dat de hier gehanteerde regiogrenzen alleen in het geval van Amsterdam overeenstemmen met de gemeentegrenzen. 
Tabel 3.1 Gemiddelde jaarlijkse groei van de toegevoegde waarde en van de werkgelegenheid, 1970-1986

$\begin{array}{llllll}\text { Aandeel } & 70-77 & 77-86 & 77-80 & 90-83 & 93-86\end{array}$

a. Groei toegevoegde waarde

$\begin{array}{lrrrrrr}\text { Nederland nominaal } & 100,0 & 12,5 & 5,1 & 7,1 & 4,2 & 4,1 \\ \text { Nederland reëel a) } & & 3,7 & 1,5 & 2,1 & -0,3 & 2,7 \\ \text { West-Nederland nominaal } & 48,0 & 11,5 & 5,0 & 6,9 & 4,0 & 4,1 \\ \text { Drie grote steden nominaal } & 21,0 & 10,3 & 4,2 & 6,0 & 3,3 & 3,2 \\ \text { Vier grote steden nominaal } & 27,4 & 10,9 & 4,4 & 6,3 & 3,4 & 3,6 \\ \text { Overig Nederland nominaal } & 52,0 & 13,5 & 5,2 & 7,2 & 4,4 & 4,1\end{array}$

b. Groei werkgelegenheid

$\begin{array}{lrrrrrr}\text { Nederland } & 100,0 & 0,23 & 0,12 & 1,18 & -2,10 & 1,30 \\ \text { West-Nederland } & 49,3 & 0,01 & -0,04 & 0,84 & -1,81 & 0,88 \\ \text { Drie grote steden } & 21,7 & -1,15 & -0,67 & 0,53 & -2,91 & 0,42 \\ \text { Vier grotesteden } & 29,1 & -0,57 & -0,34 & 0,79 & -2,52 & 0,74 \\ \text { Overig Nederland } & 50,7 & 0,45 & 0,27 & 1,52 & -2,38 & 1,72\end{array}$

c. Absolute verandering werkgelegenheid (*1000 arbeidsjaren)

\begin{tabular}{lrrrrr} 
Nederland & 63 & 42 & 144 & -257 & 155 \\
West-Nederland & -2 & -7 & 51 & -110 & 52 \\
Drie grote steden & -80 & -55 & 15 & -81 & 11 \\
Vier grote steden & -50 & -37 & 29 & -92 & 26 \\
Overig Nederland & 61 & 49 & 93 & -147 & 10 \\
\hline
\end{tabular}

Bron: CBS, Regionale economische indicatoren 1970;'s-Gravenhage, Staatsuitgeverij, en CBS, Regionale economische jaarcijfers; 's-Gravenhage, Staatsuitgeverij, diverse jaren.

a) Hierbij zijn de prijzen gedefinieerd met de prijsindex voor de binnenlandse produktie, als te vinden tabel $\mathrm{H} 4$ in CBS, Nationale Rekeningen 1988; 's-Gravenhage, SDU uitgeverij, 1989.

dam slechte uitkomsten zien. Utrecht en in mindere mate Den Haag wijken juist positief af. Bij drie onderscheiden COROP-gebieden kan worden vastgesteld dat de kerngebieden over het algemeen lagere resultaten behalen dan het aangrenzende randgebied, zowel bij de toegevoegde waarde als bij de werkgelegenheid. De grote steden waren niet bij machte om tegenover het verlies van verouderde sectoren nieuwe groeisectoren aan te boren die voor een hernieuwde groei van de toegevoegde waarde en de werkgelegenheid zouden kunnen zorgen. Terwijl zo het grootstedelijk kerngebied over het algemeen door een voortdurend dalende werkgelegenheid is gekenmerkt, steeg de werkgelegenheid juist in de nabije, maar ook in de verder afgelegen randgebieden, ook ten opzichte van het nationaal gemiddelde. Zo vormt het middengebied van de Randstad, de regio Schiphol, Leiden-Bollenstreek, Delft-Westland en Oostelijk Zuid-Holland, een belangrijke trekker van de regionale economie. De uitstraling van de nationale luchthaven is hierin herkenbaar. De groei van Schiphol leidde tot een versterking van economische activiteiten op het gebied van handel, overslag, transport en de daarmee samenhangende zakelijke dienstverlening. Ook groeide de industriële bedrijvigheid in het hele middengebied van de Randstad. De congestie, de vervuiling en het ruimtegebrek in de grote steden waren aan deze groei mede debet. De regio Schiphol liet zelfs in de crisisperiode nog een zeer forse groei zien, ook van de werkgelegenheid. 
De groei van dit middengebied, inclusief de provincie Utrecht, zette zich vervolgens met kracht voort in de jaren van herstel sinds 1983. De gegevens duiden op een groei die beduidend boven het landelijk gemiddelde ligt, al lijkt de ontwikkeling in de regio Schiphol nu wat afgeremd te zijn.

De figuren 3.1, 3.2 en 3.3 geven dit weer, maar dan als afwijking van het Nederlands gemiddelde.

Figuur 3.1 Regionale groeidifferentiatie;

afwijking t.o.v. Nederlands gemiddelde

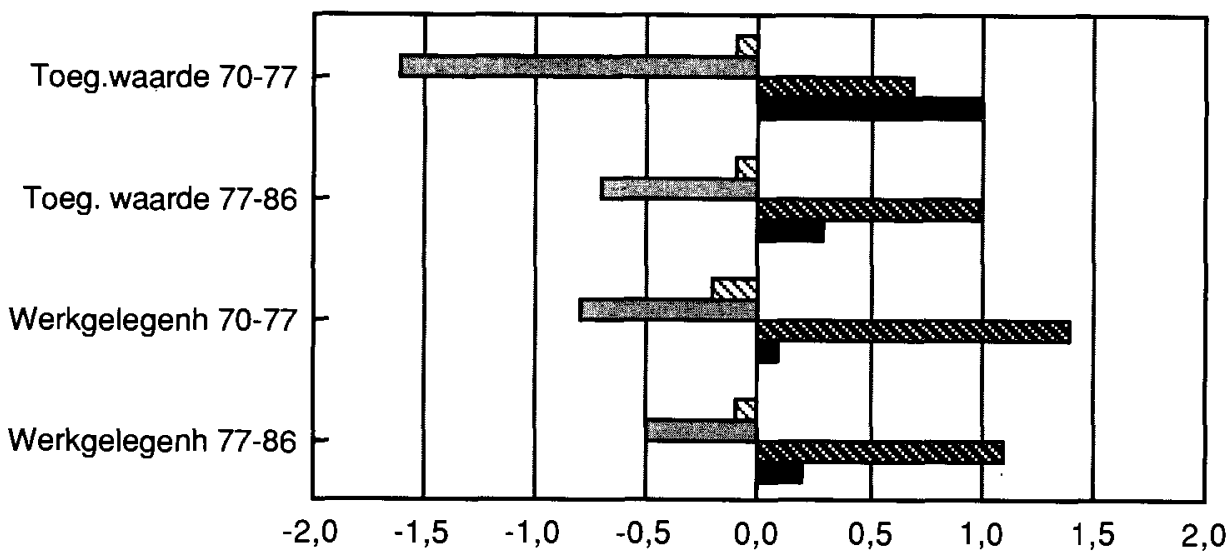

West Nederland Vier grote steden

Randstad midden $\square$ Overig Nederland

Bron: CBS

Figuur 3.2 Regionale groeidifferentiatie;

afwijking t.o.v. Nederlands gemiddelde

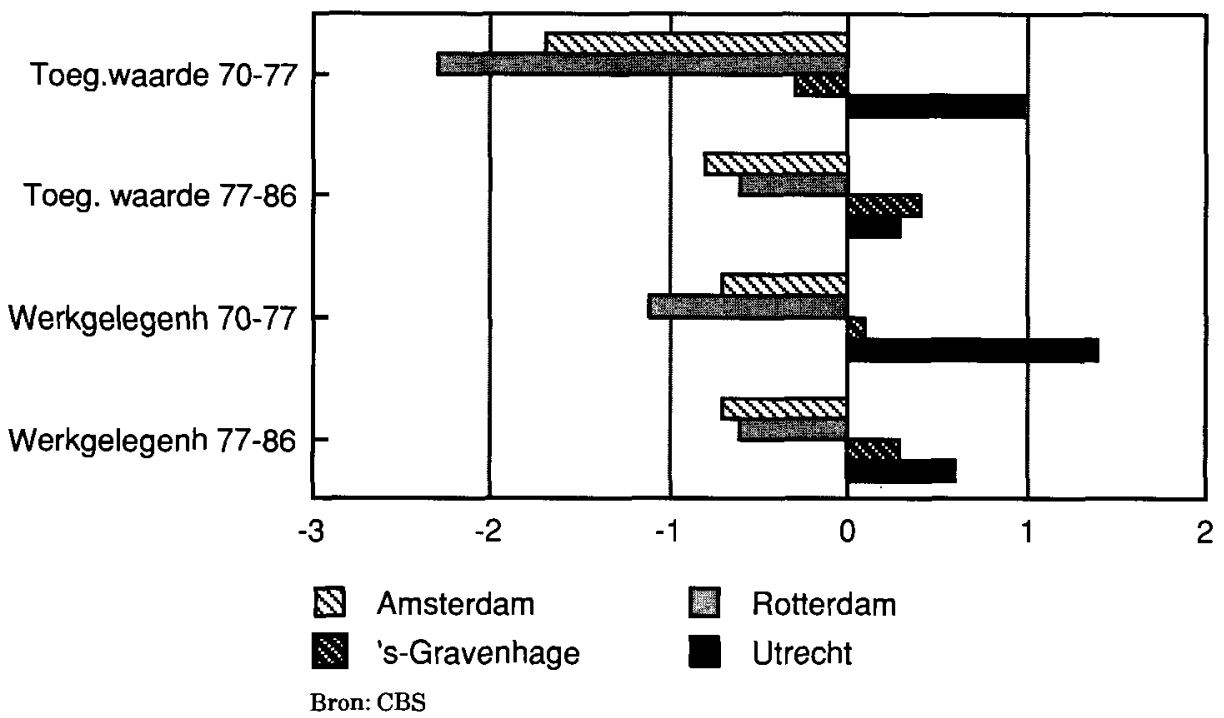


Figuur 3.3 Regionale groeidifferentiatie:

afwijking to.v. Nederlands gemiddelde



Bron: CBS.

Samenvattend kan worden gesteld dat de ruimtelijk economische ontwikkeling vanaf 1970 gekenmerkt wordt door een achterblijven van de grote steden, een sterke groei van de omringende regio's in West-Nederland en een ontwikkeling van overig Nederland die over het algemeen net iets gunstiger was dan die van West-Nederland in totaliteit ${ }^{5}$. Het proces van economische herstructurering heeft naast enige gebieden in overig Nederland, zoals ZuidLimburg, Oost-Groningen, Twente en Nijmegen, vooral Amsterdam, Rotterdam en in mindere mate Den Haag getroffen. Vooralsnog is het herstel (wat economische groei betreft) van deze drie grote steden, gerekend vanaf 1983 , ook geringer dan elders. Blijkbaar waren en zijn de voorwaarden in de grote steden niet zodanig dat nieuwe activiteiten op dezelfde wijze tot bloei kunnen komen als in bijvoorbeeld het middengebied van West-Nederland. Natuurlijk, de Nederlandse economie heeft als geheel zeker tot 1985 slecht gepresteerd, vooral waar het ging om de werkgelegenheid. De meeste oorzaken die hiervoor worden aangereikt, hoge loonkosten, sterke munt, concurrentie van de nieuwe industrialiserende landen (NIC's) enzovoort, zijn echter in principe voor alle regio's van toepassing. Als de grote steden dan toch duidelijk achterlopen in hun economische performance, moet de conclusie wel luiden dat de vestigingsfactoren zich daar ongunstig hebben ontwikkeld ten opzichte van andere regio's.

\subsubsection{De ontwikkeling van de sectorstructuur}

De voorafgaande beschrijving behandelde alleen de ontwikkelingen op het geaggregeerde niveau. De vraag rijst of het daar geschetste beeld ook opgaat voor de afzonderlijke sectoren en of er verschillen tussen de sectoren waarneembaar zijn. Om deze vraag te kunnen beantwoorden, is de economische structuur ingedeeld in negen groepen van bedrijfsklassen (zie overzicht 3.2).

5] Deze verschuivingen zijn ook terug te vinden in een recente publikatie van het CBS, Regionale Economische Jaarcijfers, 1970-1985; Voorburg, CBS, 1990, waar gegevens op provincieniveau zijn geanalyseerd. 
1. Landbouw, visserij en delfstofwinning

2. Voeding, textiel, papier/graf. en bouwmat.

3. Aardolie/gas en chemische industrie

4. Metaal en elektro

5. Bouwnijverheid

6. Openb. nut, handel, horeca en reparatie

7. Transport en communicatie

8. Banken en zakelijke diensten

9. Overheid en quartaire sector

$\begin{array}{ll}\text { Afkorting } & \text { SBI klasse } \\ \text { LD } & 1-3 \\ V T & 4-12+15 \\ \text { AC } & 13+14 \\ \text { ME } & 16-20 \\ \text { BN } & 22 \\ \text { OR } & 21+23-25 \\ \text { TC } & 26-28 \\ \text { BZ } & 29-32 \\ \text { OQ } & 33-36\end{array}$

Op basis van deze sectorstructuur worden gegevens over de toegevoegde waarde en de werkgelegenheid gepresenteerd voor een aantal relevante regio's ${ }^{6}$. Op basis van beide grootheden over de 9 sectoren in 1986, alsmede de groeipercentages over de perioden 1970-1977 en 1977-1986, ontstaat het volgende beeld. Niet onverwacht blijkt West-Nederland relatief sterker georiënteerd op de diensten, terwijl overig Nederland relatief hogere aandelen laat zien bij de industrie. Dit geldt zowel voor de toegevoegde waarde als voor de werkgelegenheid. Binnen West-Nederland zijn de drie grote steden meer geconcentreerd op de sectoren transport en communicatie, alsmede op banken en zakelijke diensten. Het middengebied van de Randstad is eveneens geconcentreerd op transport en communicatie, maar daarnaast ook op de groep openbaar nut, handel en horeca en op de landbouw. De sectoren bouwnijverheid en overheid/quartaire sector zijn vrij gelijkmatig over de verschillende onderscheiden regio's verspreid.

De verschillen tussen de regio's worden pregnanter als gekeken wordt naar de groeipercentages over de periodes 1970-1977 en 1977-1986. De ontwikkeling van de drie grote steden ten aanzien van de toegevoegde waarde en de werkgelegenheid wijkt in nagenoeg alle gevallen negatief af van die van Nederland. Dit geldt zowel voor de industrie als voor de tertiaire en quartaire diensten, hoewel juist voor de dienstensectoren wordt verondersteld dat grote steden een aantrekkelijke vestigingsplaats vormen. De drie grote steden hebben in de periode 1970-1986 blijkbaar niet het vereiste vestigingsprofiel gehad. In het Randstad-middengebied zijn de ontwikkelingen over het algemeen positief afwijkend geweest van die van Nederland, maar dit was toch niet voldoende om voor West-Nederland als totaal een relatief gunstige ontwikkeling mogelijk te maken. De figuren 3.4 en 3.5 laten die sectorale verschillen in groei van de drie grote steden en de Randstad met het Nederlands gemiddelde duidelijk uitkomen (alleen afwijkingen van het landelijk gemiddelde zijn opgenomen). Overig Nederland laat wel voor nagenoeg alle sectoren een positieve ontwikkeling zien.

Als men dezelfde gegevens voor de vier grootstedelijke gebieden afzonderlijk vergelijkt met die van Nederland, ontstaat het volgende beeld. In de sectorstructuur van de regio Amsterdam valt het hoge aandeel op van de bedrijfsklassen: voeding, textiel, kleding, papier, grafisch en bouwmaterialen. Ook banken/zakelijke diensten en transport/communicatie springen eruit. In de regio Rotterdam ligt het accent op olie/chemie en op transport/communicatie, terwijl de overheid/quartaire sector zich onderscheidt in de regio Den Haag. In de regio Utrecht scoren relatief sterk openbaar nut/handel/horeca, banken/ zakelijke diensten en overheid/quartaire sector.

6] Voor de regio-indeling met betrekking tot West-Nederland en overig Nederland wordt verwezen naar overzicht 1. Onder Randstad-midden worden begrepen de COROP-gebieden Overig Amsterdam, Leiden-Bollenstreek, Delft en Westland en Oostelijk Zuid-Holland. Voor de goede orde, Randstad-midden en de drie grote steden tellen niet op tot West-Nederland. 
Waar het de ontwikkeling in de tijd betreft, doen de provincie Utrecht en in mindere mate de agglomeratie Den Haag het beter dan de twee andere grootstedelijke regio's. Groot-Amsterdam en Rijnmond vertonen nagenoeg over de hele linie groeicijfers, die onder het Nederlands gemiddelde liggen. Dit geldt niet alleen voor de industrie. Ook bij de diensten blijkt de groei van de toegevoegde waarde en de werkgelegenheid in deze grootstedelijke regio's achtergebleven te zijn bij de gemiddelde Nederlandse groei.

De hier gepresenteerde gegevens beslaan een relatief lange periode, van 1977 tot 1986. Een nadere onderverdeling van deze periode maakt het mogelijk na te gaan of deze negatieve ontwikkeling zich aanhoudend heeft voorgedaan of dat sprake is geweest van een zeker herstel in de latere jaren. Ook al is het moeilijk om hieruit een globaal patroon te destilleren, er kan niet gesteld worden dat er na 1983 van een duidelijke opleving voor de grote steden sprake is. Weliswaar liggen de groeicijfers hoger dan daarvoor, maar ten opzichte van het Nederlands gemiddelde is de reeds bestaande achterstand alleen maar toegenomen. In de periode 1980-1983, de echte crisisperiode, behaalden de grootstedelijke gebieden, met uitzondering van Utrecht, nog relatief de beste resultaten van de hele periode 1977-1986. Wellicht is dit terug te voeren op het grote aandeel van diensten, die over het algemeen iets minder gevoelig zijn voor conjuncturele schommelingen.

De resultaten van de grootstedelijke gebieden vallen derhalve tegen. Hierbij moet worden bedacht dat deze resultaten nog enigszins werden opgekrikt door de aangrenzende randgebieden. In de grote steden zelf was de ontwikkeling nog negatiever. Zowel bij de toegevoegde waarde als bij de werkgelegenheid lag de gemiddelde jaarlijkse groei in de periode $1977-1986$ bijna 1 procent onder het landelijk gemiddelde. Deze achterstand doet zich bij bijna alle sectoren voor, al is de achteruitgang in de industrie wel sterker dan bij de diensten. Het moge duidelijk zijn dat een dergelijke ontwikkeling vooral ten aanzien van de grote steden de aandacht vraagt en - gelet op de al lang aanwezige trend, naast de constatering dat nagenoeg alle sectoren hierdoor getroffen worden - een over een langere periode volgehouden gerichte beleidsinspanning vereist.

Figuur 3.4 Sectorale groeidifferentiatie voor toegevoegde warde; afwijking t.o.v. Nederlands gemiddelde

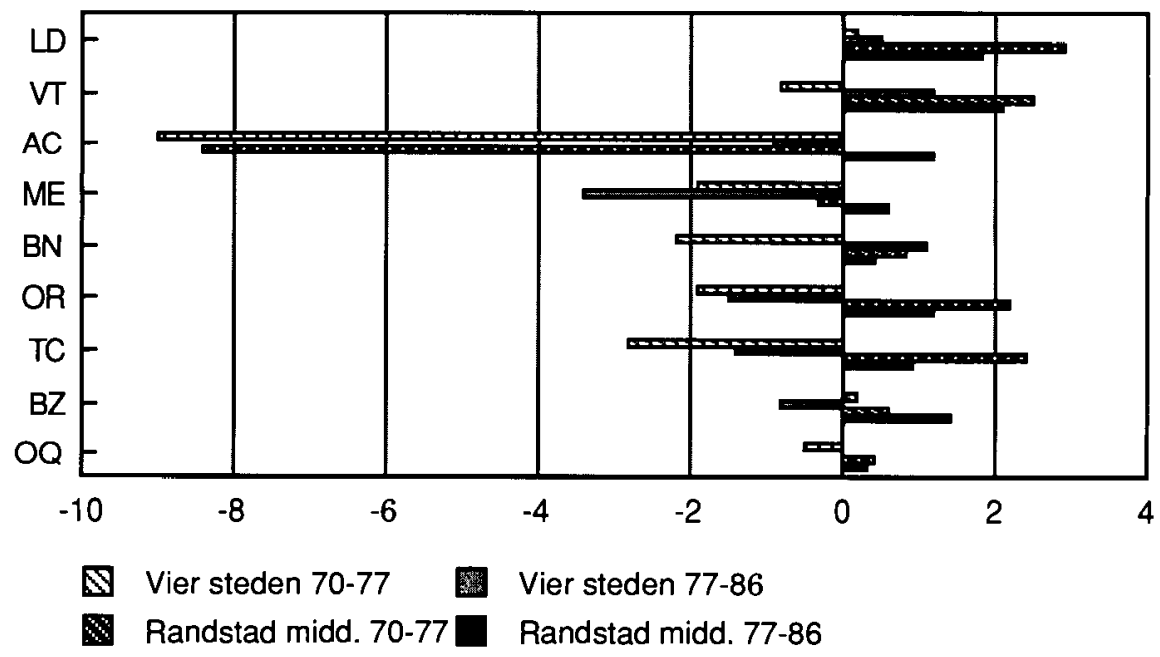

Bron: CBS. 
Figuur 3.5 Sectorale groeidifferentiatie voor werkgelegenheid; afwijking t.o.v. Nederlands gemiddelde

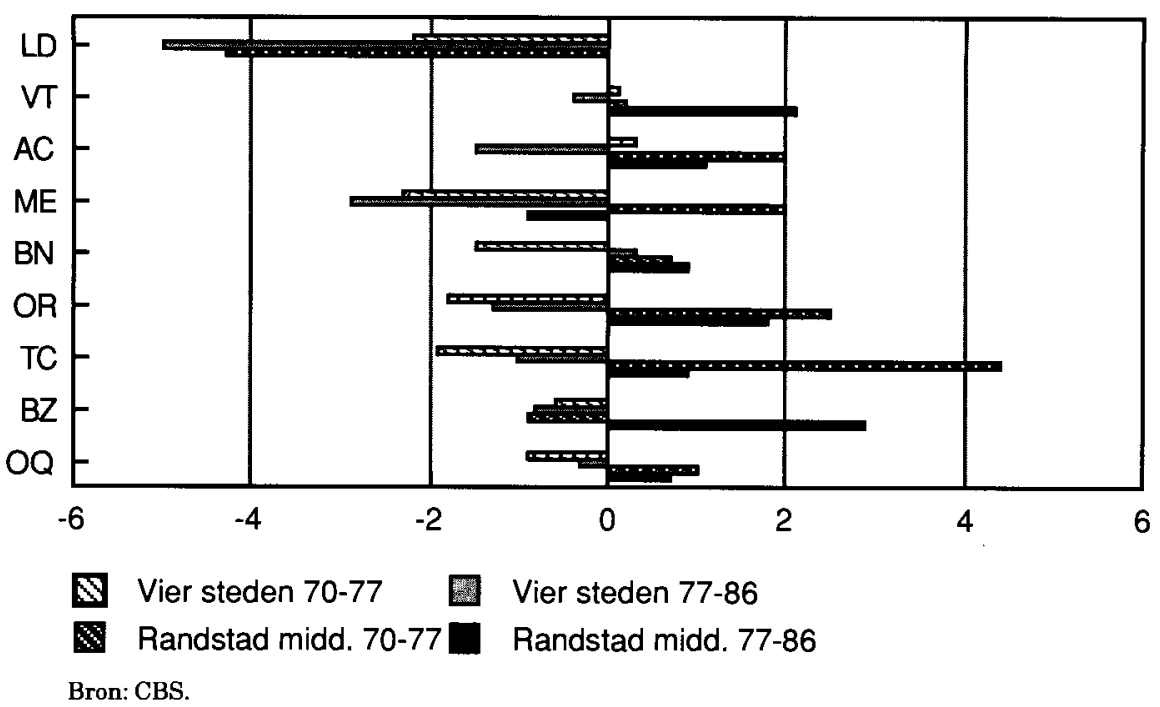

De conclusie moet luiden dat de grote steden sinds 1970 een aanhoudend relatief neergaande ontwikkeling hebben doorgemaakt. Binnen West-Nederland vond er een verschuiving plaats van activiteiten en daarmee ook van werkgelegenheid vanuit de grote steden naar de omliggende gebieden. Daarnaast heeft overig Nederland zijn positie tegenover West-Nederland weten te verbeteren. Deze ontwikkelingen zijn, met gradaties, in alle onderscheiden sectoren waarneembaar. Het roept de vraag op wat de oorzaken zijn van deze afkalving.

\subsubsection{Export}

Sinds 1981 publiceert het CBS gegevens over de export naar provincie van herkomst. Deze gegevens maken het mogelijk om voor de drie Randstadprovincies, uitgesplitst naar de al eerder toegepaste indeling met 9 sectoren, de ontwikkeling hiervan in kaart te brengen. De resultaten zijn terug te vinden in tabel 3.2. Er zijn hier slechts 8 sectoren opgenomen, daar de bouwnijverheid geen export kent.

De totale Nederlandse export bestaat globaal uit 75 procent industrieprodukten, 20 procent diensten en 6 procent landbouwprodukten. De export van diensten is geconcentreerd bij handel en transport/communicatie. Het aandeel van banken/zakelijke diensten bedraagt ongeveer 1,5 procent. Het indirecte belang van deze bedrijfstakken als accommoderend voor de exportontwikkeling in het algemeen is echter wel groot. Bovendien zijn deze sectoren van groot belang voor de werkgelegenheid.

De totale bijdrage van de drie Randstadprovincies in de Nederlandse export is overeenkomstig het aandeel van dit deel van Nederland in de nationale werkgelegenheid en de toegevoegde waarde. Het aandeel van de Randstad in de totale export van industriële produkten (exclusief gas en petrochemie) is beperkt tot ongeveer 30 procent.

Wanneer regionale verschillen in ogenschouw worden genomen, valt in de eerste plaats de overheersende positie op van het Rijnmondse petrochemische complex. Dit blijkt ook uit het grote aandeel van de export van deze sector in en vanuit de provincie Zuid-Holland. Hetzelfde geldt voor de sector transport, waarin Amsterdam met Schiphol en Rotterdam met de haven samen goed zijn voor bijna driekwart van de nationale export van transportdiensten. De export 
Tabel 3.2 De exportpositie in 1986 en exportontwikkeling tussen 1981 en 1986, per provincie voor 8 sectoren

\begin{tabular}{|c|c|c|c|c|c|c|c|c|c|c|}
\hline & \multicolumn{2}{|l|}{ Nederland } & \multicolumn{2}{|l|}{ Randstad } & \multicolumn{2}{|c|}{ Overig Nederland } & \multicolumn{2}{|c|}{ Noord-Holland } & \multicolumn{2}{|c|}{ Zuid-Holland } \\
\hline & Aandeel & Groei & Aandeel & Groei & Aandeel & Groei & Aandeel & Groei & Aandeel & Groei \\
\hline & 1986 & $81-86$ & 1986 & $81-86$ & 1986 & $81-86$ & 1986 & 81.86 & 1986 & $81-86$ \\
\hline \multicolumn{11}{|l|}{ Sector } \\
\hline LD & 5,8 & 6,3 & 5,8 & 6.4 & 5,9 & 6,3 & 4,7 & 6,6 & 6,8 & 6,5 \\
\hline $\mathbf{V T}$ & 21.1 & 4,7 & 13,0 & 3.4 & 27,9 & 5,2 & 17,5 & 3,6 & 9,0 & 2,4 \\
\hline$A C$ & 28,2 & $-2,3$ & 32,5 & $-3,6$ & 24,7 & $-0,7$ & 14,1 & -4.1 & 45,0 & $-3,9$ \\
\hline ME & 24,8 & 4,2 & 19,2 & 1,2 & 29,4 & 6,0 & 31,0 & 3,1 & 12,0 & $-1,5$ \\
\hline OR & 9,5 & 6,2 & 11,3 & 4.5 & 8,1 & 8,3 & 12,7 & 4,5 & 9,0 & 4,2 \\
\hline TC & 8,3 & 1.6 & 14,0 & 0,1 & 3,6 & 7,7 & 15,8 & 2,5 & 14,1 & $-1,5$ \\
\hline BZ & 1,3 & 1.6 & 2,4 & 2,9 & 0.4 & $-3,5$ & 2,2 & 1,2 & 2,3 & 6,4 \\
\hline OQ & 0.9 & 5,6 & 1,8 & 6,9 & 0,2 & $-3,5$ & 2,1 & 2,9 & 1,9 & 10,8 \\
\hline Totaal & 100,0 & 2,2 & 100,0 & 0,3 & 100,0 & 4,0 & 100,0 & 2,1 & 100,0 & $-1,2$ \\
\hline Absoluut ${ }^{a}$ & $200.943(100)$ & & $90.682(45)$ & & $109.811(55)$ & & $30.894(15)$ & & $53.188(27)$ & \\
\hline
\end{tabular}

Bron: CBS, Regionale Economische Jaarcijfers; 's-Gravenhage, Staatsuitgeve-

rij, diverse jaren.

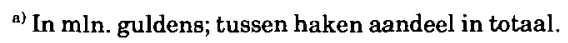

van financiële en zakelijke diensten vindt vooral plaats vanuit Den Haag en Amsterdam. Overigens vindt bijna de gehele nationale export van deze diensten zijn oorsprong in de Randstad.

De ontwikkeling van de export vormt eens te meer een bevestiging van de ontwikkelingen die eerder al waren geschetst. De Randstad is een belangrijke exporteur, maar het groeiproces is trager dan in de rest van het land. Terwijl voor het laatstgenoemde deel van ons land de export gemiddeld toenam met 4 procent, was dit voor de Randstad slechts 0,3 procent. Dit laatste cijfer is sterk beinvloed door prijsveranderingen voor olie en gas. Als naar de ontwikkelingen op sectoraal niveau wordt gekeken, blijkt echter dat voor 5 van de 8 sectoren, met een aandeel in de totale export van meer dan 90 procent, de groei in overig Nederland hoger was dan in de Randstad. Bij de afzonderlijke provincies laat Utrecht (niet opgenomen in tabel 3.2) goede uitkomsten zien. ZuidHolland scoort slecht over nagenoeg de hele linie.

3.2.4.2 Regionale investeringen

De tendenties uit de voorafgaande paragrafen roepen de vraag op naar de determinanten van dit proces. Waardoor is het in de Randstad en meer in het bijzonder in de grote steden minder goed gegaan dan elders in Nederland? én van de belangrijkste groeibepalende factoren is de mate van investeringen. Investeringen betekenen werkgelegenheid, met name in de bouwnijverheid en de constructie en in de machine-industrie. Particuliere investeringen, eenmaal gerealiseerd, zorgen voor nieuwe arbeidsplaatsen. Investeringen zorgen er ook voor dat het produktieproces efficiënter kan verlopen en dat nieuwe of verbeterde produkten kunnen worden gefabriceerd, allemaal factoren die van invloed zijn op de concurrentiepositie en daarmee op de groei en de werkgelegenheid. Publieke investeringen, in infrastructuur, in onderwijs, enzovoort, oefenen niet alleen een vraag-effect uit, maar, belangrijker, ze versterken de concurrentiekracht van een economie op langere termijn. Kortom, de omvang van de investeringen vormt een eerste bruikbare indicator voor de ontwikkelingskansen van een regio. De cijfers in deze paragraaf hebben betrekking op de periode 1977-1986. Om te voorkomen dat conjuncturele uitschieters de resul- 
Tabel 3.3 Bruto-investeringsontwikkeling in de grootstedelijke gebieden, 19771986

\begin{tabular}{|c|c|c|c|c|c|c|c|c|c|}
\hline & \multicolumn{3}{|c|}{ Eind ' 70} & \multicolumn{3}{|c|}{ Begin ' 80} & \multicolumn{3}{|c|}{ Midden ' 80} \\
\hline & $\begin{array}{l}\text { Omvang } \\
\text { Absoluut }\end{array}$ & $\begin{array}{l}\text { Aandeel } \\
\text { in perc, }\end{array}$ & $\begin{array}{r}\text { volume } \\
1980=100\end{array}$ & $\begin{array}{l}\text { Omvang } \\
\text { Absoluut }\end{array}$ & $\begin{array}{l}\text { Aandeel } \\
\text { in perc, }\end{array}$ & $\begin{array}{r}\text { volume } \\
1980=100\end{array}$ & $\begin{array}{l}\text { Omvang } \\
\text { Absoluut }\end{array}$ & $\begin{array}{l}\text { Aandeel } \\
\text { in perc, }\end{array}$ & $\begin{array}{r}\text { volume } \\
1980=100\end{array}$ \\
\hline Utrecht & 3,8 & 6,1 & 92,2 & 4,2 & 6,1 & 100,0 & 4,7 & 6,0 & 112,7 \\
\hline IJmond/Zaanstad & 2.6 & 4,1 & 85,1 & 3,0 & 4,4 & 100,0 & 3,8 & 4,9 & 125,6 \\
\hline Amsterdarn & 2,7 & 4,4 & 87,2 & 3,1 & 4,6 & 100,0 & 3,9 & 5,0 & 124,0 \\
\hline Ov. Amsterdam & 1,7 & 2,7 & 77,3 & 2,2 & 3,2 & 100,0 & 2,8 & 3,6 & 127,3 \\
\hline Leiden/Alphen & 2,6 & 4,1 & 95,3 & 2,7 & 3,9 & 100.0 & 3,0 & 3,8 & 111,2 \\
\hline 's-Gravenhage & 2,7 & 4,2 & 78,5 & 3,4 & 4,9 & 100.0 & 3,9 & 5,1 & 116,3 \\
\hline Delft & 1,2 & 1,9 & 104,4 & 1,2 & 1,7 & 100,0 & 1,3 & 1,7 & 115,2 \\
\hline Rijnmond & 5,5 & 8,8 & 79,5 & 7,0 & 10,2 & 100,0 & 8,5 & 10,0 & 122,7 \\
\hline Or.Rijnm $/ Z O-Z H$ & 2,2 & 3,5 & 79,3 & 2,8 & 4,1 & 100,0 & 2,8 & 3,5 & 99,1 \\
\hline Drie grote steden & 10,9 & 17,5 & 81,0 & 13,5 & 19,7 & 100,0 & 16,3 & 21,0 & 121,4 \\
\hline Vier grote steden & 14,7 & 23,6 & 83.1 & 17,7 & 25,8 & 100,0 & 21,0 & 27.1 & 118,6 \\
\hline Randstad midden & 5,5 & 8,7 & 90,5 & 6.0 & 8,8 & 100,0 & 7,1 & 9,2 & 117,8 \\
\hline West Nederland & 27,6 & 44,1 & 87,1 & 31,7 & 46,4 & 100,0 & 37,1 & 47,8 & 117,1 \\
\hline Overig Nederland & 34.9 & 55,9 & 95,4 & 36,6 & 53,6 & 100,0 & 40,5 & 52,2 & 110,7 \\
\hline Nederland & 62,5 & 100,0 & 91.5 & 68,3 & 100,0 & 100,0 & 77,6 & 100,0 & 113,6 \\
\hline
\end{tabular}

Bron:CBS, Regionale Economische Jaarcijfers; 's-Gravenhage, Staatsuitgeverij, diverse jaren.

Men zou nu verwachten dat de investeringsontwikkeling in de Randstad en vooral in de grote steden is achtergebleven bij die van andere regio's. Onverwachts blijkt dit echter niet het geval te zijn. Tabel 3.3 bevat het verloop van de totale investeringen. De bruto investeringen zijn in de drie westelijke provincies sterker toegenomen dan in overig Nederland en deze toename was voor de drie grote steden zelfs hoger dan voor de regio Randstad-midden. De sterke investeringsgroei deed zich in Amsterdam, Den Haag en Rijnmond voor. Vooral Amsterdam springt eruit. De investeringstoename was hier nauwelijks geringer dan in het COROP-gebied Schiphol (Overig Groot-Amsterdam).

Er bestaan gegevens over de sectorale verdeling van de investeringen, alsmede over de verdeling van de investeringen naar vaste activa. In het eerste geval worden onderscheiden landbouw, nijverheid, vervoer (= transport-, opslag- en communicatiebedrijven), overige bedrijven, woningen en overheid. In het tweede geval gaat het om bruto investeringen in gebouwen, grond-, weg- en waterbouw, vervoer, machines, toename veestapel en woningen.

In nagenoeg alle sectoren blijkt de stijging van de bruto investeringen in WestNederland sterker dan in overig Nederland en in de drie grote steden is deze weer sterker dan in het middengebied van de Randstad. Dit geldt zowel voor bedrijfs- als voor overheidsinvesteringen. (Terzijde zij opgemerkt dat het aandeel van de overheid in de totale investeringen ook in deze periode blijft teruglopen, van 15,4 procent naar 13,8 procent.) Nog opvallender is dat de drie grote

7] Daarbij is van de volgende periodisering uitgegaan:

* eind 70: gemiddelde van de jaren 1977 tot 1980

* begin ' 80 : gemiddelde van de jaren 1980 tot 1983

* midden '80: gemiddelde van de jaren 1983 tot 1986. 
steden juist bij de nijverheid zeer hoge groeicijfers voor de investeringen laat zien (en bij de landbouw, maar deze sector is qua omvang te verwaarlozen). Randstad-midden kent alleen bij transport, opslag en communicatie relatief gunstige groeicijfers. Nadere, hier niet weergegeven berekeningen, laten zien dat deze onderlinge verschuivingen zich over de hele periode hebben voorgedaan, zowel voor als na de crisis van begin jaren ' 80 . Deze resultaten maken niet helderder waarom West-Nederland en daarbinnen vooral de drie grote steden het ook in de periode 1977-1986 zoveel slechter gedaan hebben.

De groei van de bruto investeringen in de drie grote steden is relatief hoog bij gebouwen en bij machines. Bij vervoersmiddelen is de toename juist opvallend laag. Randstad-midden scoort nog hoger bij machines, hoog bij vervoer, maar zeer laag bij gebouwen en grond-, weg- en waterbouw. Overig Nederland scoort alleen relatief gunstig bij vervoer.

Al met al moet worden geconstateerd dat de redenen waarom de sterke toename van de investeringen in de Randstad en daarbinnen vooral in de drie grote steden (nog) niet terug te vinden zijn in groei- en werkgelegenheidscijfers, vooralsnog niet scherp zijn te traceren. Opmerkelijk is de tegenstelling zeker. Mogelijkerwijs ligt de verklaring in een afwijkende sectorstructuur, een meer uitgesproken herstructurering van de grote steden in de betreffende periode dan elders in het land en - vrij plausibel - een versneld afschrijvingsbeleid aldaar, omdat in de stad eerder sprake is van het beproeven van vernieuwingen.

\subsubsection{Plaatsbepaling in de nationale context}

Sinds 1988 wordt in een samenwerkingsverband tussen de NMB, de Vereniging van Kamers van Koophandel en het Instituut voor Ruimtelijke Organisatie van TNO een publikatie uitgebracht waarin de economische ontwikkeling van bedrijfstakken en regio's in kaart wordt gebracht, aan de hand van een viertal indicatoren ${ }^{8}$. Dit onderzoek is gebaseerd op een enquête onder meer dan 60.000 Nederlandse ondernemingen. In deze Enquête Regionale Bedrijfsontwikkeling (ERBO) zijn voor een viertal indicatoren, namelijk ontwikkeling netto bedrijfsresultaat, omzetontwikkeling, investeringsscores in vaste activa en een gewogen gemiddelde van deze drie (de ERIN-indicator) gegevens verzameld over 24 bedrijfsklassen en 14 regio's $^{9}$. De gegevens bieden de mogelijkheid om ook recente ontwikkelingen in kaart te brengen, ook al zijn ze onvolledig en zijn er vraagtekens te plaatsen bij de betrouwbaarheid.

Tabel 3.4 geeft de kerngegevens weer voor Nederland, de vier grootstedelijke gebieden en de rest van de drie westelijke provincies ${ }^{10}$. De conclusie is in lijn met de hoofdtrend van de voorafgaande paragrafen: de grootstedelijke gebieden blijven achter. In nagenoeg alle gevallen komen de resultaten uit onder het landelijk gemiddelde. In 13 van de 16 gevallen is de afwijking ten opzichte van het landelijk gemiddelde van 1988 op 1989 in negatieve zin toegenomen. De rest van het westen daarentegen ziet zijn positie tegenover de rest van Nederland ook licht negatief afwijken. De gevolgtrekking moet zijn dat de rest van Nederland beter dan gemiddeld heeft gepresteerd. Ook dit is in lijn met de bevindingen in de vorige paragraaf.

Als gekeken wordt naar de ERIN-indicator, vertoont Nederland een lichte stijging van 3,3 naar 3,5. Amsterdam en Rotterdam stijgen weliswaar ook, maar in mindere mate en zij zien hierdoor hun achterstand toenemen. Den Haag daalt naar het niveau van Rotterdam en ook Utrecht bevindt zich nu onder de

${ }^{8}$ ] Het valt te betreuren dat er geen indicator is berekend betreffende de werkgelegenheidsontwikkeling.

'] Zie NMB/VVKINRO-TNO, De vitaliteit van het Nederlandse bedrijfsleven; vergelijking van de economische ontwikkeling in bedrijfsklassen en stedelijke knooppunten in 1988; Amsterdam, 1989, en NMB/VVKINRO-TNO, De vitaliteit van het Nederlands bedrijfsleven, Editie 1990; z.pl., z.uitg., 1990.

${ }^{10}$ ] Deze gebieden wijken af van de COROP-indeling van het CBS. 
streep. De rest van West Nederland loopt in de pas met Nederland. Bij de afzonderlijkerindicatoren valt de relatief sterke daling op van de omzetgroei, vooral in Amsterdam en Rotterdam. Bij het netto bedrijfsresultaat en bij de investeringsgroei verkleint Rotterdam zijn achterstand op Nederland iets.

Tabel 3.4 Ontwikkeling indicatoren ERBO-enquête voor Nederland en de grootstedelijke gebieden, 1988 en 1989

\begin{tabular}{|c|c|c|c|c|c|c|c|}
\hline & & Nederland & Amsterdam & Rotterdam & 's-Gravenhage & Utrecht & Overig Westen \\
\hline \multirow[t]{2}{*}{ ERIN } & 1988 & 3,3 & 3,1 & 3,0 & 3,2 & 3,6 & 3,3 \\
\hline & 1989 & 3,5 & 3,2 & 3,1 & 3,1 & 3,4 & 3,4 \\
\hline \multirow[t]{2}{*}{ NBR } & 1988 & 6,5 & 6,4 & 6,2 & 6,5 & 6,5 & 6,5 \\
\hline & 1989 & 6,6 & 6,6 & 6,5 & 6,5 & 6,4 & 6,6 \\
\hline \multirow[t]{2}{*}{ OMZ } & 1988 & 5,4 & 5,5 & 4,2 & 5,0 & 6,9 & 4,7 \\
\hline & 1989 & 4,9 & 4,1 & 2,8 & 3,8 & 6,1 & 4,6 \\
\hline \multirow[t]{2}{*}{ INY } & 1988 & 3,6 & 3,5 & 3,2 & 3,3 & 3,7 & 3,5 \\
\hline & 1989 & 3,6 & 3,4 & 3,3 & 3,1 & 3,5 & 3,5 \\
\hline
\end{tabular}

Tbelichting:

ERIN $=$ ERbo-INdicator (gewogen indicator voor onderstaande variabelen)

NBR = groei netto bedrijfsresultaat

$\mathrm{OMZ}=$ groei jaaromzet

INV = groei investeringen in vaste activa

Bron: NMB/VVK/NRO-TNO, De vitaliteit van het Nederlandse bedrijfsleven; vergelijking van de economische ontwikkeling in bedrijfsklassen en stedelijke knooppunten in 1988, Amsterdam, 1989, en NMB/VVK/NRO-TNO, De vitaliteit van het Nederlands bedrijfsleven, Editie 1990; z.pl., z.uitg., 1990.

Deze resultaten worden nogmaals bevestigd in twee publikaties van de Kamers van Koophandel omtrent de economische positie van de vier grote steden ${ }^{11}$. Zowel voor 1987 als 1988 moest worden geconstateerd dat de omzetontwikkeling van de vier steden achterbleef bij het landelijk gemiddelde. Hierbij is de ontwikkeling voor Utrecht nog het minst slecht. Voor 1987 wordt gemeld dat deze relatief ongunstige omzetontwikkeling in belangrijke mate samenhangt met de slechte nominale exportontwikkeling, veroorzaakt door onzekerheid over valuta en grondstofprijzen. In 1988 wordt de oorzaak gelegd bij de grote bedrijven, met 50 of meer werkzame personen, die achterbleven, maar een duidelijke oorzaak wordt niet gegeven.

De grote steden lopen sterk uiteen waar het gaat om hun exportgerichtheid. Amsterdam en Rotterdam zijn in sterke mate georiënteerd op het buitenland, terwijl Den Haag en vooral Utrecht veel meer afzetten in de rest van Nederland. De verschillen naar regio van herkomst zijn geringer bij de inkoop. Wordt gekeken naar het aantal bedrijven dat in hoofdzaak georiënteerd is op respectievelijk de lokale, de Nederlandse of de buitenlandse markt, dan telt Amsterdam relatief veel lokale bedrijven en Utrecht en Den Haag juist veel nationale bedrijven. Rotterdamse bedrijven zijn sterk internationaal georiënteerd. Op het internationale vlak scoren Amsterdam en Rotterdam goed, maar blijft Den Haag ver achter.

II] Zie Werkgroep Grote Steden van de Kamers van Koophandel en Fabrieken, De economische positie van de vier grote steden in Nederland in 1987, Amsterdam enz., 1988, en idem, De economische positie van de vier grote steden in Nederland in 1988, Amsterdam/Den Haag/Rotterdam/Utrecht, 1989. Zie ook: H. Knol, J.G. Lambooy, W.J.J. Manshanden en M. de Smidt, 'Functionele samenhang in de Noordvleugel van de Randstad'; Economisch Statistische Berichten, 14 maart 1990, jaargang 75, nr. 3749, blz. 252-255. 
De arbeidsproduktiviteit, hier gedefinieerd als omzet per werknemer, is in de grote steden beduidend ( $30 \%)$ hoger dan landelijk. Dit geldt zowel voor de industrie als voor de groothandel. De verschillen tussen de vier grote steden zijn echter aanzienlijk. De arbeidsproduktiviteit ligt in Rotterdam in veel sectoren zeer hoog (in totaal $150 \%$ van het landelijk niveau), waarna Amsterdam (115\%), Utrecht (94\%) en Den Haag (74\%) volgen. Bij het lage aandeel van Den Haag moet in aanmerking worden genomen dat de produktiviteit van ambtenaren (die in deze stad zijn oververtegenwoordigd) statistisch gelijk wordt gesteld aan het salaris. De combinatie van een matige omzetontwikkeling en een hoge arbeidsproduktiviteit resulteert in een werkgelegenheidstoename die achterblijft bij het landelijk gemiddelde. Ook hier is de ontwikkeling in Utrecht nog het gunstigst.

De winst- en rendementspositie van de grote steden is weliswaar niet ongunstig, maar wijkt toch in toenemende mate negatief af van het landelijk resultaat. De verschillen tussen de vier grote steden zijn beperkt, al doet Rotterdam het minder dan de rest. Desondanks is de investeringsontwikkeling van de grote steden in 1988 veel positiever dan die voor Nederland $(+10,8 \%$ tegenover $0 \%$ ). Dat is vooral te danken aan de grote bedrijven, de kleine ondernemingen investeerden juist minder.

Tenslotte komt naar voren dat bij het thema 'nieuwe ontwikkeling' de vier grote steden er niet echt uitspringen. De meeste aandacht gaat uit naar automatisering van de administratie, gevolgd door kwaliteitszorg. Nieuwe technologische ontwikkelingen worden in de praktijk slechts op zeer bescheiden schaal toegepast. Hierbij gaat het vooral om de informatietechnologie. De mogelijkheid om beschikbare kennis van wetenschappelijke instellingen te benutten bijvoorbeeld via transferpunten wordt slechts beperkt benut. Wat betreft de consequenties van Europa '92, zijn bedrijven vooralsnog alleen actief bij het verzamelen van informatie.

Over het algemeen blijken de vier steden nauwelijks van elkaar af te wijken waar het de 'nieuwe ontwikkelingen' betreft. Dit duidt op factoren die in alle sectoren van belang zijn. Een mogelijke verklaring zou gevonden kunnen worden in het bestaan van 'vernieuwende' en 'stagnerende' bedrijven, waarbij de laatste categorie in de grote steden is oververtegenwoordigd. Een dergelijke tweedeling is recentelijk toegepast in een onderzoek van de Nationale Investeringsbank, waarbij in 21 branches een onderscheid werd gemaakt tussen een relatief succesvolle en een relatief tegenvallende onderneming ${ }^{12}$. Ongeacht de ontwikkeling van de branche, die van groei tot neergang uiteenliep, bleken de succesvolle bedrijven overal betere resultaten te hebben behaald. Dit was gerealiseerd door een marktgerichter en energieker beleid, gericht op uitbreiding van marktsegmenten, een sterkere exportinspanning en aanpassingen in het produktassortiment.

\subsubsection{Plaatsbepaling in de internationale context}

De concurrentiepositie van de vier grootstedelijke gebieden wordt bepaald door de ontwikkelingen van aanbod en vraag. Aan de aanbodkant betreft dit de vestigingsvoorwaarden, waarmee grootstedelijke gebieden bestaande bedrijvigheid kunnen vasthouden, respectievelijk nieuwe bedrijvigheid kunnen aantrekken. De vraagkant heeft betrekking op veranderende eisen aan de kant van de ondernemingen als gevolg van marktverschuivingen en technologische processen. De hieruit resulterende concurrentiepositie bepaalt de economische ontwikkeling van grootstedelijke gebieden.

In de ontwikkeling van alle nationale economieën in de geïndustrialiseerde wereld is waarneembaar geweest hoe het aandeel van de landbouw in toege-

12] Zie Nationale Investeringsbank, Overwinnen bij broncheproblemen, 's-Gravenhage, NIB, 1989. 
voegde waarde en werkgelegenheid sterk is gedaald, hoe de industrie aanvankelijk groeide maar later ook haar aandeel zag dalen en hoe in de na-oorlogse periode het aandeel van de diensten steeds meer toenam. In de meeste landen van de OECD is het aandeel van de diensten nu op of boven de 60 procent gekomen. De grootstedelijke gebieden in deze landen hebben aanvankelijk een sterke groei laten zien, als gevolg van de uitstoot van arbeid door de landbouw en de vraag naar arbeid door industrie en later diensten. Later ontstond echter een proces van suburbanisatie. De ontwikkeling van het openbaar vervoer en later het autobezit bood steeds meer mensen - eerst de beter betaalden maar later ook anderen - de mogelijkheid om steeds verder van de werkplaats te gaan wonen. Van den Berg maakt in dit verband een onderscheid tussen migratie naar de randgemeenten en - in een latere fase - migratie die zich richt op gebieden buiten de agglomeratie ${ }^{13}$. Dit laatste wordt nog versterkt doordat de werkgelegenheid zich ook verplaatst naar de rand van de agglomeratie. Deze ontwikkeling lijkt ook in de nabije toekomst niet echt te veranderen. De opkomst van nieuwe op kennis georiënteerde bedrijfstakken schept weliswaar nieuwe kansen voor grootstedelijke gebieden, maar vooralsnog is het werk-en leefmilieu in veel gevallen zoveel minder dat een herstel van de concurrentiepositie pas op langere termijn mogelijk lijkt.

De suburbanisatie van bewoners is later gevolgd door die van bedrijven. De industrie zag zich genoodzaakt, vanwege de toenemende congestie, het gebrek aan adequate uitbreidingsmogelijkheden en de hogere kosten, naar vestigingsplaatsen elders uit te kijken. Aanvankelijk was dit nog aan de rand van grootstedelijke gebieden, maar geleidelijk is dit overgegaan van suburbanisatie - bij nog verdergaande spreiding - naar de- of exurbanisatie. De ontwikkeling van transport- en communicatietechnologieën, de uitbreiding van de infrastructuur en de opkomst van niet-grondstof gebonden industrieën hebben deze ontwikkeling versneld. Ook voor ondernemingen die diensten produceren, is deze trend steeds duidelijker waarneembaar. Deze ontwikkelingen bleven niet tot het nationale niveau beperkt. Multinationaal opererende ondernemingen, met hoofdkantoren in stedelijke gebieden en produktiedivisies regionaal gespreid, komen steeds vaker voor. Men kan stellen dat deze trends zich grosso modo in heel West-Europa voordoen, maar dat de uitkomsten voor de verschillende grootstedelijke gebieden nogal uiteenlopen ${ }^{14}$. Nederland liep hierbij niet voorop, maar haalt nu de sub- en zelfs de de-urbanisatie van bedrijfsvestigingen versneld in.

Zoals het bedrijfsleven steeds sterker geïnternationaliseerd is geraakt, zo zijn ook grootstedelijke gebieden steeds sterker doordrongen geraakt van de invloed van buitenlandse steden. Voor steeds meer bedrijfstakken geldt dat ondernemingen in beginsel hun vestigingsplaats in verschillende landen kunnen kiezen, of het nu gaat om het hoofdkantoor, om produktie, distributie of om R\&D-activiteiten. Voor nagenoeg iedere activiteit kan aldus een beredeneerde afweging van verschillende vestigingsplaatsen gemaakt worden. Het Nederlands Economisch Instituut (NEI) heeft in opdracht van de Rijksplanologische Dienst een onderzoek uitgevoerd naar het vestigingsplaatsmilieu in de Randstad in internationaal perspectief ${ }^{15}$. In dit onderzoek is voor 5 typen van bedrijvigheid, hoofdkantoren, R\&D-vestigingen, high-tech produktievestigingen, distributie-activiteiten en zakelijke dienstverlening nagegaan hoe de Randstad, hier als één grootstedelijk gebied beschouwd, zich verhield tot 6 andere

13] Een uitgebreide internationale vergelijking is terug te vinden in L. van den Berg, Urban Systems in a Dynamic Society; Aldershor, Gower, 1987.

14] Zie bijvoorbeeld Nederlands Economisch Instituut, Verschuiving van economische zwaortepunten in Noord-West-Europa: Fictie of realiteit? Onderzoek ten behoeve van de Rijksplanologische Dienst; Rotterdam, NEI, 1989.

15] Zie Nederlands Economisch Instituut, Plaots en functie van de Randstad in de Nederiandse economie; onderzoek uitgevoerd in opdracht von de Rijksplonologische Dienst; Rotterdam, NEI, 1987. 
grootstedelijke gebieden, te weten Brussel/Antwerpen, Londen, Parijs, Frankfort, Hamburg en München. Het NEI heeft in dit onderzoek een groot aantal vestigingsplaatsfactoren onderscheiden, op het terrein van wetgeving/overheid, infrastructuur en bereikbaarheid, agglomeratievoordelen, arbeidsmarkt, kwaliteit van de omgeving en kwaliteit van de accommodatie. Op grond hiervan vond vervolgens een rangordening plaats van de onderscheiden grootstedelijke gebieden. Over het algemeen kwam de Randstad er niet ongunstig af.

Dit beeld wordt ook bevestigd en gespecificeerd in het Franse onderzoek van Brunet en anderen (1989) naar de rangorde van 220 West-Europese steden met een inwonertal boven de 200.000. Amsterdam komt als enige Nederlandse stad in de sub-top voor, onder Londen, Parijs en Milaan. De andere drie grote steden zitten in de klasse onder de sub-top. Ook als men zich realiseert dat een dergelijke rangorde een betrekkelijke betekenis heeft, dan is deze uitkomst voor de vier grote steden gunstig. Dit krijgt extra reliëf als men de deelscores in beschouwing betrekt. Dan blijkt een stad als Utrecht het internationaal gezien in de $R \& D$ goed te doen en nemen Amsterdam en Rotterdam een solide positie in tussen de steden die hoog scoren op internationaal verkeer in relatie met economische betekenis. Den Haag scoort dan goed op een combinatie van R\&D én internationaal bestuurlijke en culturele uitwisseling ${ }^{16}$.

Zowel bij de distributie-activiteiten als bij de high-tech produktievestigingen staat de Randstad bovenaan. De vooraanstaande positie bij de distributie-activiteiten, vanouds een sterk punt voor Nederland, is te danken aan de relatief gunstige ligging op het Europees continent, de uitstekende vervoersinfrastructuur, de handelsgeest, het arbeidsklimaat en de faciliteiten op fiscaal gebied en het douane-vrij entrepot. Desondanks wordt deze positie op sommige punten bedreigd. Aandachtspunten in dit verband zijn de noodzaak tot verdergaande efficiëntie en kostprijsverbetering, vooral via een verbetering van de infrastructuur, de beschikbaarheid van bedrijfsruimte tegen concurrerende prijzen en de ontwikkeling van goede informatiesystemen. Bij de high-tech produktievestigingen is de gunstige positie vooral te danken aan de arbeidsrust, de politieke stabiliteit, de hoogte van de arbeidsproduktiviteit, de beschikbaarheid van geschoolde arbeidskrachten en de nabijheid tot de Europese markt. De verschillen met de Bondsrepubliek Duitsland zijn hier zeer beperkt. Andere landen, vooral Groot-Brittannië en België, trachten via investeringspremies hun positie te versterken. Gelet op de hiermee behaalde resultaten, dient ook Nederland op dit instrument alert te zijn.

Bij de zakelijke dienstverlening, alsmede bij de lokatie van hoofdkantoren, neemt de Randstad in het algemeen een gemiddelde positie in. Naast de aanwezigheid van een florerende handels- en transportsector, wordt het vigerende fiscale systeem als zeer gunstig beoordeeld voor met name ondernemingen met een holding-structuur. $\mathrm{Bij}$ nieuwe vestigingen van hoofdkantoren, vooral vanuit de Verenigde Staten en Japan, komt de Randstad echter steeds meer naar voren als een magneet voor verkoop en diensten (gerelateerd aan de 'mainports'), terwijl het zuiden van het land steeds meer betekenis krijgt voor produktie in relatie met de Europese markt. Amsterdam neemt vervolgens binnen de Randstad voor de vestiging van hoofdkantoren een bijzondere positie in voor die bedrijven die zich vanwege de fiscale voordelen in Nederland vestigen ${ }^{17}$.

16] Les villes 'Europeennes'; Ropport pour lo DATAR, R. Brunet (ed.), Paris, RECLUS, 1989. Voor de samenvatting van de bevindingen werd geput uit: M. de Smidt, De Randstad in internationaal perspectief; Werkstukken Stedelijke Netwerken nr. 2I, Faculteit der Ruimtelijke Wetenschappen, Rijksuniversiteit Utrecht, 's-Gravenhage, SDU uitgeverij, 1990, blz. 12 - 16.

17] R. Buck, 'Marktpositie en marktattractiviteit van Nederland voor nieuwe investeerders'; in: Nieuwe buitenlondse bedrijven in Nederland; werving in perspectief von 1992; R. Buck en M. van Nieuwkerk (red.), Nijmegen, Buck Consultants International BV. 1988, blz. II-30. 
Aangetekend moet worden dat dergelijke ondernemingen ook veel gewicht hechten aan een factor waarop de Randstad beduidend lager scoort, namelijk 'internationale allure'. Londen, Parijs en in mindere mate steden als Brussel, Rome, Genève en Wenen springen er wat deze factor betreft veel gunstiger uit. Voor een deel wordt deze factor beïnvloed door de grootte van het stedelijk gebied. Het is niet te verwachten dat de Randstad in de nabije toekomst in staat is om op dat vlak Londen en Parijs te overtreffen. Ook gegevenheden als de aanwezigheid van EG- of $\mathrm{VN}$-zetels zijn moeilijk te veranderen. Wel zijn er mogelijkheden om het voorzieningenniveau te verbeteren en woonvoorzieningen en kantoorlokaties te creëren die door deze groep van ondernemingen gewenst wordt. Het vastgoedniveau - tot uitdrukking komend in het lage huurprijsniveau, de geringe dynamiek in de prijzen (prijsstijging), de geringe prijsverschillen tussen de toplokaties en de overige lokaties en het ontbreken van echte complexvorming binnen de grote stad - is een teken aan de wand ${ }^{18}$. Daarnaast dient dan ook de kwaliteit van de (telecommunicatie-)infrastructuur van hoog niveau te zijn.

De Randstad scoort ongunstig bij de lokatie van R\&D-vestigingen. Ook hier geldt dat in andere landen gebruik wordt gemaakt van het instrument van de investeringsbevorderende maatregelen, maar ook wordt gewezen op de soms geringe beschikbaarheid van voldoende hoog gekwalificeerde onderzoekers in ons land. Daarnaast blijkt de communicatie tussen bedrijfsleven en universiteiten vooralsnog minder te zijn dan in de ons omringende landen, waardoor enerzijds potentieel beschikbare kennis niet vlot genoeg doorstroomt naar het bedrijfsleven en anderzijds eventuele aanpassingen in het onderwijs- en/of onderzoekprogramma niet snel genoeg worden gerealiseerd. Dit geldt overigens niet alleen voor de Randstad, maar ook voor de rest van Nederland. Sterker dan tot nu toe wellicht al is gebeurd, dienen stedelijke gebieden de mogelijkheden van de universiteiten en andere hoogwaardige onderzoeksinstituten te benutten voor het verwerven van dergelijke vestigingen.

Ervan uitgaande dat de concurrentiepositie van stedelijke gebieden in toenemende mate bepaald wordt door de mate waarin men als knooppunt in diverse netwerken is opgenomen, is de lokatie van Nederland in de Europese en intercontinentale distributie te beschouwen als een belangrijk en kostbaar 'asset'. Toch lijkt er in Nederland en daarbinnen in de grootstedelijke gebieden in het algemeen geen sprake van intermediaire diensten, die vanuit een kernpositie in Nederland bijvoorbeeld het Europese territorium beheersen. Eerder tekent zich een patroon af waarin de vestiging in de Randstad ofwel slechts een schakel is in het internationale netwerk ofwel - nog minder - een lokatie voor de bediening van overwegend de Nederlandse markt ${ }^{19}$. Toch zijn er hiervan afgeleid mogelijkheden voor vestigingen van internationaal georiënteerde activiteiten in Nederland en daarbinnen speciaal in de Randstad.

Hier komt echter opnieuw naar voren dat, waar Nederland en de Randstad voor deze potenties in het internationale economische verkeer zich onderscheiden op basis van ligging, infrastructuur en economisch profiel, dit voor de grote steden zelf (Amsterdam en Rotterdam in eerste instantie en Den Haag en Utrecht in tweede instantie) meer zou kunnen gelden dan nu het geval is. Intussen kunnen in andere Westerse landen voorbeelden worden aangewezen van grote steden die economisch versterkt opnieuw een sterke positie innemen in het grootstedelijke gebied en de ruimere omgeving. Dit kan in een aantal gevallen zelfs worden teruggevoerd op de vernieuwing van de industriële bedrijvigheid (in een aantal Noord-Amerikaanse steden, in Westduitse steden, zoals Stuttgart en Britse steden, zoals Newcastle upon Tyne en Glasgow).

${ }^{18}$ ] M. de Smidt, op. cit., blz. 35-4l en blz. 44-45.

19] Ibid., blz. 43-44. 
In andere gevallen komt dit neer op een profilering, waarbij (zakelijke) dienstverlening een belangrijk segment vormt (in Franse steden, zoals Montpellier, Grenoble en Westduitse steden, zoals Düsseldorf en Frankfort). Op het vlak van het structurele economisch herstel scoren derhalve onze vier grote steden zelf (nog) niet gunstig.

Welke ontwikkelingen zijn er gaande aan de vraagkant, aan de kant van de ondernemingen? Hier wordt onderscheid gemaakt tussen marktverschuivingen en technologische ontwikkelingen. De Europese Gemeenschap wordt sinds 1985 gekenmerkt door een hernieuwd elan en als (in 1993 of later) een volledig vrije markt werkelijkheid wordt, lijkt de afstand tot de belangrijkste markten een nog belangrijker criterium te worden dan nu.

Onlangs is een publikatie verschenen bij het Centraal Planbureau, waaruit naar voren komt dat bij de huidige bevolkings- en welvaartsverdeling het gebied rond Luxemburg het meest centraal ligt in de Europese Gemeenschap ${ }^{20}$. Naast Luxemburg scoren ook België, Nederland, Frankrijk en de Bondsrepubliek relatief gunstig. De andere landen laten veel ongunstiger uitkomsten zien. Er blijkt sprake te zijn van een positieve samenhang tussen centrale ligging en loonhoogte. Simulaties laten vervolgens zien dat een gelijk inkomensniveau in de hele Europese Gemeenschap evenmin als de opening van de Kanaaltunnel een verschuiving teweegbrengen in het zwaartepunt ${ }^{21}$.

Meer veranderingen zijn te verwachten op het vlak van de technologie. Nog meer dan in het verleden lijkt technologie een doorslaggevende factor te zijn in de concurrentiepositie van ondernemingen en daarmee van nationale economieën. Enerzijds gaat het hierbij om (de creatie van) technologische kennis, anderzijds om de mogelijkheden deze kennis snel en adequaat om te zetten in produkten waar vraag naar bestaat. De economische crisis van het begin van de jaren ' 80 wordt niet zelden geïnterpreteerd als de fase van overgang naar nieuwe sleuteltechnologieën. Elke langere fase van groei wordt gekenmerkt door de opbloei van nieuwe technologieën en/of sectoren. Die fase kan pas intreden als alle relevante actoren, ondernemers, aanbieders van arbeid, afnemers van produkten en de overheid als institutioneel vormgever zich bewust zijn geworden van de nieuw gecreëerde mogelijkheden. Die ondernemingen en die landen, die zich het beste weten aan te passen, laten over het algemeen de beste resultaten zien. Na verloop van tijd echter raken de toepassingsmogelijkheden uitgeput. Er ontstaat dan een periode van onzekerheid, waarin afgetast wordt welke nieuwe sleuteltechnologieën eventueel als opvolger kunnen worden aangemerkt. De veronderstelling is dat ooit dat moment aanbreekt, waarna een nieuwe groeifase van start kan gaan ${ }^{22}$.

Over het algemeen worden momenteel de volgende technologieën aangeduid als potentiële sleuteltechnologie: micro-elektronica, flexibele automatisering, informatietechnologie, nieuwe materialen en biotechnologie. De vraag is nu in welke mate deze sleuteltechnologieën worden toegepast in Nederlandse ondernemingen. Daarvoor heeft het Instituut voor Ruimtelijke Organisatie (INROTNO) een onderzoek verricht naar de geografische spreiding van bedrijven die in dit opzicht innovatief zijn, dat wil zeggen die deze sleuteltechnologieën toepassen $^{23}$.

${ }^{20}$ ] Zie H.J. Roodenburg, Central Locations in the European Common Market, CPB Onderzoeksmemorandum no. 59, 's-Gravenhage, CPB, 1989.

21] Men mag verwachten dat de economische integratie van Oost-Europa in de wereldeconomie een verschuiving van het $\mathbf{z w a a r t e -}$ punt naar het Oosten zal betekenen, wat vooral de Bondsrepubliek ten goede zal komen.

${ }^{22}$ ] Zie voor een veel uitgebreidere beschrijving bijvoorbeeld C. Freeman, J. Clark en L. Soete, Unemployment and Technical Innovation; A Study of Long Woves and Economic Development; London, Frances Pinter, 1982.

${ }^{23}$ ] C. Machielse, P.A. de Ruijter e.a., Economisch-technologische vernieuwing en ruimtelijke orgonisatie; Delft, Instituut voor Ruimtelijke Organisatie-TNO, Delft, 1988. 
De grootstedelijke gebieden blijken in de industriële innovatie nauwelijks vertegenwoordigd. Vooral voor Groot-Rijnmond is de score zorgelijk laag. Daartegenover zijn de waarden bij de innovatieve kennisdiensten en overige goederenbehandeling juist zeer hoog, met name in Amsterdam. Op basis van deze uitkomsten en van andere studies is de conclusie van INRO-TNO dat het beste algemene groeiprofiel aanwezig is in zuid-oost Noord-Brabant en in sommige Randstadgebieden zoals de regio Delft-Westland en Het Gooi/Vecht. Daarnaast laten grote gedeeltes van de Randstàd een meer dan gemiddeld groeiprofiel zien. Men concludeert dat de beste vooruitzichten zijn te verwachten in die regio's die zich aan de rand van grootstedelijke gebieden bevinden.

Samenvattend kan worden geconcludeerd dat, voorzover de gegevens dit toelaten, ook in de recente jaren de trend waarneembaar is waarbij het westen van Nederland licht achterblijft bij overig Nederland, waarbij binnen de Randstad de grootstedelijke gebieden achterblijven bij de omringende regio's en de grote steden er negatief uitspringen ten aanzien van het economisch herstel en hun relatieve positie ten opzichte van hun directe en verder verwijderde omgeving. Hiertegenover lijken de grootstedelijke gebieden als geheel in Europees perspectief potenties te behouden, die overigens - wil men deze benutten in de komende periode van meer geprononceerde internationale concurrentie - een investering vereisen op internationale maat. De redelijk centrale ligging in Europa, in de nabijheid van de belangrijkste afzetmarkten, en de vooraanstaande positie bij de distributie-activiteiten in Europa zijn voorname 'assets', die ook in de toekomst - overigens met de nodige inspanning - van betekenis zijn en blijven. In de volgende paragraaf zullen de ontwikkelingen in de komende periode worden belicht, waarbij de 'internationale maat' en de kwetsbare sectorstructuur van de grootstedelijke gebieden opnieuw als referentiepunt dienen.

\subsection{De komende periode}

\subsection{Inleiding}

De analyse tot nu toe in dit hoofdstuk heeft duidelijk gemaakt dat de grootstedelijke gebieden in Nederland het in de afgelopen periode niet gemakkelijk hebben gehad en het ook niet gemakkelijk zullen krijgen. De toenemende internationalisering, technologisering en flexibilisering zijn evenzeer bedreigingen als uitdagingen.

In paragraaf 3.3.2 wordt in de vorm van een scenario stilgestaan bij datgene wat technisch-economisch in de komende periode mogelijk is. Uitgaande van de regionaal- en sectoraal-economische structuur, zoals in 1985 aanwezig, wordt geschetst welke uiterste groeimogelijkheden zich aftekenen voor de vier grootstedelijke gebieden. Hierbij wordt gebruik gemaakt van de methodiek die door de raad eerder werd toegepast in het rapport 'Ruimte voor groei'. Met deze op de input-output-analyse gebaseerde benadering wordt een sectoraal en regionaal gedifferentieerd groeipad geschetst tot het jaar 2000 .

Of en in welke mate deze groeimogelijkheden ook daadwerkelijk gerealiseerd worden, hangt echter niet zozeer af van de technisch-economische structuur zoals die in 1985 bestond of van de doorwerking van exogeen veronderstelde groeipercentages voor consumptie en export. Het heeft veel meer te maken met de bereidheid van ondernemers om te investeren, van andere actoren in de maatschappij om veranderingen mogelijk te maken op allerlei niveaus. Nauw hiermee samen hangen de vestigingsvoorwaarden die overheden weten te ontwikkelen om ondernemers over te halen om in een bepaalde regio te investeren.

Waar de 'Ruimte voor groei'-methodiek wel een duidelijke indicatie geeft van de mogelijke beleidsruimte, schiet ze tekort waar het gaat om gedrags- en beleidsreacties. De verkenning van de economische ontwikkeling in een aantal bedrijfstakken in paragraaf 3.3.3, die aansluit bij deze scenario-analyse, refereert juist wel aan deze feitelijke, mogelijke en wenselijke reacties. Als zodanig vormt ze het complement van de scenario-analyse. Aan de hand van 
een aantal bedrijfstakken wordt voor de vier grootstedelijke gebieden exemplarisch aangegeven welke kansen en bedreigingen zich in de komende periode voordoen en welke beleidsinzet daarbij wordt gevraagd.

In paragraaf 3.3.4 volgt tenslotte - aansluitend bij de analyse van recente verleden en heden - een samenvatting van de in de komende periode te verwachten ontwikkelingen en condities.

\subsubsection{Een scenario van maximale groei}

In het rapport 'Ruimte voor groei' heeft de raad een poging gedaan een antwoord te vinden op de vraag aan welke voorwaarden zou moeten worden voldaan opdat er in de periode 1985-1995 sprake zou zijn van een duurzame welvaartsgroei, waaronder ook begrepen werd realisering van doelstellingen op het terrein van werkgelegenheid, milieu en produktiviteit. In dat rapport werd gebruik gemaakt van een optimaliseringsmodel, waarmee nagegaan werd of, op grond van de aanwezige technisch-economische structuur en de te verwachten ontwikkelingen voor consumptie en export, het mogelijk zou zijn bepaalde doelstellingen, geformuleerd als minimumrestricties, ook daadwerkelijk te realiseren. Het ging hierbij met name om het schetsen van de voorwaarden waaronder welvaartsgroei in stand kon worden gehouden.

In deze paragraaf wordt dezelfde benadering gebruikt, maar nu om de mogelijkheden voor groei van de grootstedelijke gebieden in kaart te brengen ${ }^{24}$. Op basis van regionale input-output-tabellen zijn berekeningen gemaakt van de groeimogelijkheden van de grootstedelijke economieën. Onder erkenning van de beperkingen van input-output-analyse, zoals de veronderstelde vaste produktietechnologie en de constant gehouden prijzen, is getracht een beeld te schetsen van de groeimogelijkheden van de toegevoegde waarde en de werkgelegenheid, op basis van een jaarlijkse groei-impuls overeenkomstig het maximale-groeiscenario van 'Ruimte voor groei' 25 .

Deze gevolgen voor de produktiegroei en werkgelegenheidsontwikkeling worden in deze paragraaf uitgewerkt op grootstedelijk regionaal en sectoraal niveau. De regio-indeling die hier wordt aangehouden is overeenkomstig die in de vorige paragrafen. Regionale input-output tabellen voor 1985 zijn vastgesteld voor de regio's West-Nederland (Zuid- en Noord-Holland plus Utrecht), de stad Amsterdam, het COROP-gebied Rijnmond, de agglomeratie Den Haag en de provincie Utrecht. De sectorale indeling is wat minder ver uitgewerkt dan in paragraaf 3.2.4. Hier worden onderscheiden landbouw, nijverheid, vervoer, overige bedrijven en overheid.

Het model werkt als volgt. De groei in een economie wordt vorm gegeven door middel van jaarlijkse groei-impulsen van de finale vraag, die volgens de bekende Leontief-formule van het input-output-model doorwerken in de groei van de produktie en in de daarmee - lineair - samenhangende werkgelegenheid. De werkgelegenheid wordt achteraf sectoraal gecorrigeerd voor de ontwikkeling van de arbeidsproduktiviteit. Hoewel de exogene groei-impulsen van de finale vraag per regio en per sector gelijk zijn, is de uitkomst van deze modelberekeningen per regio natuurlijk verschillend, daar de sectorstructuur en de samenstelling van de finale vraag (sectoraal en verdeeld naar consumptie, investeringen en export) per regio verschilt. Per sector is nagegaan wat de mogelijk geachte maximale groei is van de consumptie, de investeringen, de export en de leveringen aan de rest van Nederland ${ }^{26}$. Gezien het verkennende

24] De inhoud van deze paragraaf is gebaseerd op een onderzoek van het bureau ETAS, verricht in opdracht van de WRR. Zie Economisch Technologisch Bureau Strankinga, Investeren in de grote steden; Hilversum, 1989.

25] Zie voor een uitgebreide beschrijving van de gevolgde methodiek WRR, Ruimte voor groei; Kansen en bedreigingen voor de Nederlondse economie in de komende tien joor; Rapporten aan de Regering 29; 's-Gravenhage, Staatsuitgeverij, 1987.

26] Alle gegevens zijn afkomstig uit WRR, Ruimte voor groei, op. cit., alsmede uit sectorverkenningen voor 'Ruimte voor groei'. Deze cijfers komen over het algemeen goed overeen met die van het CPB, De Nederlondse economie op langere termijn; Drie groeiscenario's voor de periode 1985-2010; Werkdocument no. I; 's-Gravenhage, 1985. 
karakter van deze analyse is ervan uitgegaan dat elke economische sector onafhankelijk van de regionale plaatsing met dezelfde groeimogelijkheden van de finale vraag kan worden geconfronteerd. De jaarlijkse maximale groeiimpulsen kunnen als volgt worden samengevat. Voor de consumptie is er een beperkte groei van produkten uit de landbouw- en voedingsmiddelensector (3,5\% per jaar). Voor industrieprodukten is rekening gehouden met een groei van zo'n 6 tot 9 procent per jaar. De consumptiegroei van diensten is eveneens royaal ingeschat, variërend van zo'n 4 procent voor gezondheidszorg tot 5 à 6 procent voor handel en horeca en 9 procent voor diverse zakelijke diensten. De sectoraal opgebouwde groei-impuls door investeringen is berekend op een jaarlijks totaal van gemiddeld ruim 7 procent en die van de export op bijna 5 procent. De uitvoer vanuit de stedelijke economieën naar overig Nederland bedraagt in totaal - gemiddeld sectoraal gewogen -4 procent per jaar, overeenkomstig de verwachte produktiegroei van Nederland als geheel. Vooral in de landbouw en in de industrie alsmede in sommige diensten is sprake van een zeer snelle groei van de arbeidsproduktiviteit ${ }^{27}$.

De gebruikte groeicijfers, geëxtrapoleerd tot het jaar 2000, representeren een maximale-groeiscenario. Ze moeten dan ook als hoog worden gekwalificeerd. In de afgelopen twee jaar zijn weliswaar in diverse sectoren, zowel voor consumptie-, investerings- als exportgroei hogere cijfers gescoord, maar onder invloed van een waarschijnlijke conjuncturele terugval van kortere of langere duur zullen naar verwachting de gemiddelde groeicijfers over de lange termijn weer afvlakken.

De modelberekeningen op dit niveau bieden inzicht in de regionale effecten van de per sector als maximaal haalbare ingeschatte groei. Natuurlijk zullen de groeimogelijkheden per sector in elke regio verschillen en kan een sector in een regio sneller of langzamer groeien dan het landelijke gemiddelde. De intentie is om aan te geven hoe de grootstedelijke gebieden zich op basis van de economische structuur van 1985 kunnen ontwikkelen in een scenario, waarbij op nationaal niveau relatief gunstige uitkomsten kunnen worden gerealiseerd.

De uitkomsten van de scenario-berekening zijn weergegeven in tabel 3.5. Hieruit komt naar voren dat ook voor de nabije toekomst de economische ontwikkeling van de grootstedelijke gebieden zal achterblijven bij die van de rest van het land. Dit geldt zowel de toegevoegde waarde als voor de werkgelegenheid. Vooral Den Haag en Amsterdam laten een relatief grote achterstand zien ten opzichte van het nationale niveau. Rotterdam en vooral Utrecht springen er gunstiger uit.

Tabel 3.5 laat tevens zien dat de grootstedelijke gebieden in alle sectoren slechter scoren, met uitzondering van de overheid en woningbezit. Bij de sector vervoer en overige bedrijven zijn de negatieve afwijkingen opvallend. Deze tertiaire activiteiten worden juist voor de grootstedelijke gebieden van zeer groot belang geacht.

Nogmaals, deze berekeningen zijn gebaseerd op de uitgangssituatie van 1985 en op veronderstellingen omtrent de groei van de finale vraag en de arbeidsproduktiviteit. Alternatieve scenario's, die hier niet gepresenteerd worden, tonen aan dat bij een minder gunstige afzetontwikkeling van de op export georiënteerde bedrijfsklassen, met name terug te vinden in de industrie, de nationale economie veel slechtere uitkomsten oplevert, maar dat de grootstedelijke gebieden dan wel op het nationale niveau uitkomen. Met andere woorden, de economische structuur van de grootstedelijke gebieden is met een accent op de

${ }^{27}$ ] Een groei van de arbeidsproduktiviteit met jaarlijks 8 procent betekent, bij constante produktie, dat de werkgelegenheid in 15 jaar met bijna 70 procent terugloopt. Bij een jaarlijkse stiiging met 5 procent bedraagt die terugloop, bij constante produktie, nog altijd ruim 50 procent. 
Tabel 3.5 Gemiddelde jaarlijkse groei van de toegevoegde waarde en van de werkgelegenheid voor Nederland en de vier grootstedelijke gebieden, volgens het maximale-groeiscenario

LAND* NIJV VERV OBDR WONI OVHD TOTAAL

a. Gemiddeld jaarlijkse groei toegevoegde waarde

$\begin{array}{llllllll}\text { Amsterdam } & 0,7 & 4,5 & 3,8 & 3,8 & 2,3 & 1,6 & 3,6 \\ \text { Rotterdam } & 0,6 & 4,6 & 5,7 & 4,0 & 2,3 & 1,5 & 4,3 \\ \text { Den Haag } & 0,6 & 4,6 & 2,9 & 3,9 & 2,3 & 1,5 & 3,3 \\ \text { Utrecht } & 0,5 & 5,4 & 5,2 & 4,4 & 2,3 & 1,7 & 4,1 \\ \text { West-Nederland } & 1,0 & 4,9 & 5,4 & 4,4 & 2,3 & 1,6 & 4,1 \\ \text { Nederland } & 1,8 & 5,1 & 5,6 & 4,7 & 2,3 & 1,6 & 4,3\end{array}$

b. Gemiddeld jaarlijkse groei werkgelegenheid

\begin{tabular}{lrrrrrrr} 
Amsterdam & $-4,5$ & 1,8 & 0,0 & 2,1 & 0,0 & 1,6 & 1,8 \\
Rotterdam & $-4,7$ & 1,7 & 1,5 & 2,4 & 0,0 & 1,5 & 1,9 \\
Den Haag & $-4,8$ & 2,1 & $-0,8$ & 2,3 & 0,0 & 1,5 & 1,8 \\
Utrecht & $-4,8$ & 2,4 & 1,5 & 2,8 & 0,0 & 1,7 & 2,3 \\
West-Nederland & $-4,3$ & 2,1 & 1,2 & 2,6 & 0,0 & 1,6 & 2,0 \\
Nederland & $-3,5$ & 2,0 & 1,4 & 3,0 & 0,0 & 1,6 & 2,1 \\
\hline
\end{tabular}

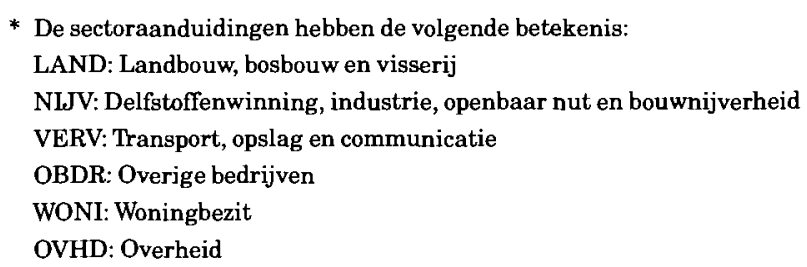

Bron: ETAS, Investeren in de grote steden, Hilversum, 1989.

diensteneconomie en niet op de industriële bedrijvigheid minder afhankelijk van de afzetmogelijkheden elders dan andere regio's in ons land, maar ze kan ook minder profiteren van een eventuele gunstige ontwikkeling.

\subsubsection{Kansen en bedreigingen in een aantal bedrijfstakken}

\subsubsection{Inleiding}

Het zojuist beschreven scenario veronderstelt een lijdzame houding van de kant van het bedrijfsleven en de overheid. Er zijn geen mogelijkheden aanwezig om de invloed van beleidsaanpassingen op de grootstedelijk economische structuur in de uitkomsten te verdisconteren. Het is duidelijk dat dit de waarde van deze uitkomsten beperkt. Het scenario biedt niet meer dan een eerste indruk van de ontwikkelingsruimte van de grootstedelijke gebieden, uitgaande van de structuur van 1985 . In tegenstelling tot dit algemene groeiscenario wordt in deze paragraaf het beleidsveld van de grootstedelijke economie nader verkend aan de hand van ontwikkelingen, kansen en bedreigingen, alsmede uitdagingen en opgaven, in een aantal geselecteerde bedrijfstakken. Hierbij vormen derhalve, beleid, reactie, interventie e.d. wèl een referentiepunt. De hier volgende uiteenzetting beperkt zich tot algemene bevindingen en conclusies ${ }^{28}$,

${ }^{28}$ ] Dit overzicht is gebaseerd op D. Haanemaayer, Kansen en bedreigingen voor de grote steden in een aantal bedrijfstakken; Werkdocumenten WRR, 's-Gravenhage, (nog te verschijnen). 


\subsubsection{Algemene karakteristiek en ontwikkelingsperspectief}

De volgende bedrijfstakken werden geselecteerd: de grafische industrie (inclusief uitgeverijen), de metaal-elektro-industrie, uiteenvallend in basismetaal, metaalprodukten, machinebouw, elektrotechniek en transportmiddelen), het toerisme, de transportsector, het bankwezen en de zakelijke dienstverlening, uiteenvallend in de ingenieurs- en architectenbureaus, accountancy en computerdienstverlening. Bij deze selectie heeft de potentiële betekenis voor de economie van de grote stad, c.q. het grootstedelijk gebied, vooropgestaan. Volledigheid wordt niet gepretendeerd. Zo zijn de voor de grote stad belangrijke branches als de voedingsector, de petrochemie en het verzekeringswezen buiten beschouwing gebleven. De selectie moet dan ook voor alles als exemplarisch worden beschouwd

Bij de geselecteerde branches kunnen meer in het algemeen ten aanzien van de basiskenmerken en ontwikkelingen de volgende conclusies worden getrokken.

De grafische industrie is een bedrijfstak met goede economische vooruitzichten, die in belangrijke mate geconcentreerd blijkt in de grote steden. Dit is in elk van de grote steden het geval, al scoren vooral Amsterdam en in iets mindere mate Den Haag extra hoog. Juist in de koppeling met reclamebureaus, uiteenlopende culturele en onderwijsinstellingen, uitgeverijen en dergelijke is deze branche bijna natuurlijkerwijs aan de grote stad gebonden. Het ontwikkelingsperspectief van de branche als geheel is gunstig. Omzetstijging is vooral te verwachten in de zakelijke markt. Dit gaat voor een belangrijk deel samen met een hoog investeringsniveau en een meer gemarkeerde positie in export en in internationaal verband. De Europese marktintegratie leidt hier tot schaalvergroting en stelt ook toenemende eisen aan de flexibiliteit van bedrijven.

De grafische industrie in de grote steden doet het echter minder goed dan de bedrijfstak als geheel. Vooral de export blijft achter. Bovendien is er sprake van een aantal bedrijfsverplaatsingen van de grote stad naar de onmiddellijke omgeving, vanwege ruimtegebrek en grondkosten. Bij deze verplaatsing speelt ook schaalvergroting een rol, al blijven kleine en gespecialiseerde bedrijven hun positie behouden. Bij de toekomstige ontwikkeling moet er rekening mee worden gehouden dat de milieu-aspecten een belangrijker rol spelen.

De metaal-elektro-industrie is van belang vanwege de werkgelegenheid en het vernieuwingspotentieel. Ten aanzien van de geboden werkgelegenheid zijn de verschillen tussen de grote steden gering. Ten onrechte zouden de in het algemeen lage werkgelegenheidsaandelen ten opzichte van het landelijk gemiddelde de indruk kunnen wekken, dat deze branche een onbelangrijke positie inneemt in de grootstedelijke economie. Circa 50 procent van de industriële werkgelegenheid in de gemeente Den Haag wordt bijvoorbeeld in 1988 in deze bedrijfstak aangetroffen. Opvallend is dat de bedrijven in de grote steden - met de nodige verschillen tussen de steden en per deelsector (basismetaal, metaalproduktie, machinebouw, elektrotechniek en transportmiddelen) - in het algemeen achterblijven bij het landelijk gemiddelde, vooral in omzet en export. De grote steden hebben juist in die deelsectoren die nog de beste vooruitzichten hebben, de basismetaal en elektrotechnische industrie, geen gunstige positie qua werkgelegenheidsaandeel. In de gemeente Den Haag speelt in de elektrotechnische industrie het volgende een negatieve rol: het onvoldoende aanbod van gekwalificeerde arbeidskrachten (overigens een landelijk probleem), gebrek aan goede woonruimte en onvoldoende aanbod van bedrijfshuisvesting voor kleine vestigingen (tot $100 \mathrm{~m}^{2}$ ). De Europese economische eenwording heeft belangrijke consequenties voor deze branche. Schaalvergroting, specialisatie en flexibele reactie op de marktontwikkeling zijn hierbij doorslaggevend voor succes.

Het toerisme verwijst naar de horeca en daaraan gelieerde prestaties. Bezien we de horeca alleen, dan springt Amsterdam er qua aantal werkzame personen 
zeer duidelijk uit, zowel ten opzichte van de andere grote steden als ten opzichte van het landelijk gemiddelde. De ontwikkeling van de horecasector in bedrijfseconomisch opzicht is landelijk matig, waarbij de restaurantbedrijven overigens een iets gunstiger ontwikkeling laten zien dan de hotel- en cafébedrijven. Het ondernemerschap is hier doorslaggevend.

De vier grote steden blijven in de landelijk al niet gunstige ontwikkeling nog eens extra achter. Dit betreft vooral de omzetontwikkeling. Alleen Rotterdam doet het op dit punt beter.

In een breder genomen toeristisch profiel neemt Amsterdam eveneens een vooraanstaande plaats in ten opzichte van de andere drie grote steden en ten opzichte van het landelijk gemiddelde. Dit valt af te lezen uit het aantal overnachtingen en uit de bezoekersaantallen van attracties. Maar Amsterdam blijft achter bij ontwikkelingen in andere Westeuropese metropolen, vermoedelijk mede vanwege het negatieve imago van vervuiling, onveiligheid. Ook de kwaliteit van het winkelaanbod zou te wensen over laten en er zou onvoldoende aanbod zijn in de sfeer van het nachtelijke uitgaansleven. Ten aanzien van de ontwikkelingen van de ruimer genomen toeristische bedrijvigheid wordt landelijk gerekend met een groei van ongeveer 3 procent. De groeiverwachting voor het grootstedelijk toerisme ligt daarbinnen echter lager. Het toerisme in de vier grote steden levert minder op dan mogelijk is. Voor een toename van deze deelmarkt zijn, naast de binnenlandse dagtoeristen, de buitenlandse toeristen die Nederland als nevenbestemming hebben, de belangrijkste doelgroep. De laatste jaren wordt hier door de grote steden met de nodige initiatieven op ingespeeld, waarbij het 'zakelijk toerisme' (congressen en beurzen) een bijzonder aandachtspunt is. Amsterdam richt zich hier nadrukkelijk op, met enig succes.

De transportsector omvat weg-, rail-, water- en luchttransport en de hierbij aansluitende hulpbedrijven. Als men de twee 'mainports' Schiphol en de Rotterdamse haven erbij betrekt, blijkt het aantal werkzame personen in de grootstedelijk gebieden van Amsterdam en Rotterdam ver boven het landelijk gemiddelde uit te gaan. Op Schiphol groeit de werkgelegenheid door. De werkgelegenheid in de zeevaart in Rotterdam daalt echter vanaf 1983 geleidelijk. Wel blijft in deze stad de omvang van de werkgelegenheid stabiel in andere sectoren van transport. Het COROP-gebied Utrecht komt qua werkgelegenheid uit op het landelijk gemiddelde en het COROP-gebied Den Haag ligt daaronder.

De transportbranche heeft in bedrijfseconomisch opzicht redelijke vooruitzichten. De omzetontwikkeling bleef in 1988 echter achter bij die van het Nederlandse bedrijfsleven in het algemeen. De deelsector van het wegtransport heeft de beste vooruitzichten. Van de vier grote steden bleef Rotterdam achter in de omzetontwikkeling en Den Haag in de omzet- en investeringsontwikkeling. Amsterdam (omzet en investeringsniveau) en Utrecht (gemiddeld bedrijfsresultaat) scoren hier beter. Alle vier de grote steden vertonen een positief beeld ten aanzien van het exportaandeel in de omzet.

Nederland heeft in deze branche internationaal gezien bijzondere mogelijkheden en kansen. In het algemeen wordt aangenomen dat ons land met zijn huidig potentieel na 1992 zijn sterke positie behoudt in de geïntegreerde Europese markt en deze verder kan ontwikkelen. Naast de marktintegratie kan ook de milieuproblematiek leiden tot belangrijke verschuivingen in de transportsector. Een deel van het goederenvervoer over de weg zou kunnen doorschuiven naar het rail- en watervervoer. Dit zou vooral grote gevolgen hebben voor het binnenlands goederenvervoer ( $80 \%$ wegtransport). Meer in het algemeen zal door veranderingen in produktie- en distributieprocessen het goederentransport blijven groeien, waarbij de taak van het transportwezen in het totale produktieproces meer geschakeerd zal worden. Het gaat steeds minder om transport sec en steeds meer om een groeiend aanbod van een totaal pakket van logistieke dienstverlening, zoals opslag, distributie, voorraadbeheer en 
verpakking. De informatiestromen die met deze distributie en transportstromen verbonden zijn, worden steeds belangrijker. De telematica-infrastructuur wordt een noodzakelijk faciliteit ter beheersing van goederenstromen en de optimale inzet van transportmateriaal. Gesteld wordt dat op dit ogenblik in de telematica-infrastructuur - een strategisch facet van de transportsector de ontwikkelingen in Nederland ongunstig afsteken tegen die elders in Europa. De organisatie van de transportsector zal zich nationaal en internationaal aan deze veranderingen aanpassen. De internationalisering van de goederenstromen kan leiden tot samenwerkingsvormen, deels fusies en deels overnames.

Het bankwezen is qua aantal werkzame personen in Nederland sterk geconcentreerd in het COROP-gebied Amsterdam. Bijna een kwart van de landelijke werkgelegenheid bevindt zich daar. De drie andere grote steden blijven in de buurt van het landelijk gemiddelde. Internationaal gezien is de omvang van de Nederlandse banksector bescheiden, niet alleen afgemeten aan de topsteden Londen en Frankfort. In deze branche zijn belangrijke verschuivingen aan de gang: 'globalisering' van de financiële dienstverlening, leidend tot een verminderde betekenis en afhankelijkheid van lokale markten; 'institutionalisering van besparingen', leidend tot concentraties van vermogens bij een klein aantal beleggingsinstellingen die hoge kwaliteitseisen stellen aan het financiële systeem; liberalisering van het kapitaalverkeer en van de financiële dienstverlening. Mede door 'Europa 1992' zullen de verschillende financiële centra onderling uitwisselbaar zijn vanuit de optiek van de gebruikers. De toenemende concurrentie werpt hier zijn schaduw vooruit in fusies die een afspiegeling zijn van de veranderingen in de organisatiestructuur, de arbeidsontwikkeling en het kantorennet. Vooral door de automatisering zal de werkgelegenheid afnemen in het gehele land (voor de komende drie jaar is landelijk sprake van 7000 tot 12.000 minder arbeidsplaatsen). Amsterdam rekent echter voor de komende periode voor deze branche, inclusief het verzekeringswezen, per saldo op een stabiliteit in de werkgelegenheid tot het jaar 2000. Naast deze schattingen van de verandering in de omvang van het personeelsbestand is van belang dat de vereiste kwalificaties veranderen. Er moet in relatie tot de automatisering worden gerekend met een toename van het aandeel technisch en commercieel personeel. Ten aanzien van de kantoorvestigingen in het bankwezen zijn er in de Nederlandse bankwereld tenslotte nog geen aanwijzingen voor drastische veranderingen, terwijl dit in andere landen wel het geval is.

De zakelijke dienstverlening komt in de grote steden uit op een percentage werkzame personen dat duidelijk boven het landelijk gemiddelde ligt. Den Haag scoort hier het hoogst. In elk van de vier grote steden is de werkgelegenheid in de afgelopen jaren gegroeid. In het algemeen geldt dat, anders dan in het bank- en verzekeringswezen, in de zakelijke dienstverlening geen teruggang van de werkgelegenheid wordt verwacht door de grootschalige toepassing van informatietechnologie.

De zakelijke dienstverlening is van oudsher in de grote steden geconcentreerd geweest. De laatste jaren trad een verplaatsing van deze dienstverlening naar buiten op, maar deze trend lijkt sinds kort weer om te buigen. Er komen ook weer meer vestigingen in de grote stad zelf. Echter, de vestigingen die zich op de (inter)nationale markt richten, blijven overwegend buiten de grote stad. (Hier staat tegenover dat vestigingen van buitenlandse bedrijven meer dan de Nederlandse bedrijven op de grote steden georiënteerd blijven). Bij vestigingen in de grote stad blijkt de nabijheid tot het centrum en de bereikbaarheid voor de klant doorslaggevend, bij de vestiging buiten de grote stad de bereikbaarheid met de auto ${ }^{29}$. Er is ook sprake van verplaatsingen over grotere afstand (Utrecht, Noord-Brabant) op grond van markttechnische overwegingen, vooral in de computerdienstverlening.

$\left.{ }^{29}\right]$ M. Hessels, Zakelijke diensten en stadsgewestelijke differentiatie; Economisch Statistische Berichten, 18 juli 1990, jaargang 75 , nr. 3766 , blz. $660-663$ en blz. 668 . 
Stedelijke specialisaties weerspiegelen zich in de vestigingen. De Rotterdamse zakelijke dienstverlening is in belangrijke mate gelieerd aan de haven- en havengebonden bedrijvigheid. In Den Haag vormen de hoofdkantoren van petrochemische bedrijven een belangrijk oriëntatiepunt.

In bedrijfseconomisch opzicht zijn de vooruitzichten voor de zakelijke dienstverlening vrij gunstig. Vooral de explosieve omzetontwikkeling is opvallend. In Utrecht, Amsterdam en Rotterdam ligt deze ook nog eens boven het landelijk gemiddelde. De investeringsontwikkeling daarentegen was in 1988 aan de lage kant, al lag het investeringsniveau in Amsterdam, Rotterdam en Den Haag wel boven het landelijk gemiddelde.

De ontwikkelingen in deze branche kunnen worden onderscheiden naar ingenieurs- en architectenbureaus, de accountancy en de computerdienstverlening.

\section{Ingenieurs- en architectenbureaus}

Deze bureaus hebben een moeilijke tijd doorgemaakt in de eerste helft van de jaren ' 80 . Het aantal arbeidsplaatsen daalde tot beneden de 50.000, maar is sindsdien weer gestegen. In deze ontwikkeling speelt het investerings- en privatiseringsbeleid van de overheid een belangrijke rol, aangezien circa 50 procent van de omzet uit overheidsopdrachten komt. Er wordt voor de nabije toekomst van uitgegaan dat het personeelsbestand geen ingrijpende wijzigingen zal ondergaan.

De branche is in het vestigingsgedrag sterk cliënt-volgend, leidend tot een concentratie in Den Haag en omgeving (georiënteerd op departementen en petrochemische bedrijven) en Rotterdam en omgeving (georiënteerd op de haven- en havengebonden industrie). De verwachting is dat hierin geen ingrijpende verandering zal komen. Voor de meeste bureaus zijn er geen redenen om de activiteiten naar elders te verplaatsen, ook niet in samenhang met geavanceerde mogelijkheden van informatietechnologie.

Het personeelsbestand van de bureaus zal naar verwachting in de nabije toekomst geen ingrijpende wijzigingen ondergaan. Verschuivingen in werkterreinen - bijvoorbeeld door de toename van milieutechnologie - zullen in de volumesfeer beperkte gevolgen hebben. Een kleinschalig fusieproces wordt niet uitgesloten, in verband met de benutting van kostbare automatiseringssystemen die voor kleine bureaus niet rendabel zijn.

Temidden van de totale zakelijke dienstverlening is deze branche vrij sterk op de export georiënteerd: circa 20 procent van de omzet komt uit export. Dit geldt vooral voor de onderdelen scheepsbouw, offshore en werktuigbouw. De internationale markt wordt overwegend vanuit Nederlandse vestigingen bestreken. Slechts een enkel bureau heeft buitenlandse vestigingen. In enkele sectoren wordt toename van de export voorzien: landbouw, procestechnologie, werktuigbouwkunde en elektrotechniek. De sterkte van Nederlandse bureaus is vooral gelegen in de 'know how', kwaliteit van geleverde diensten, internationale reputatie en service. Een minpunt is het prijsniveau van de geleverde diensten. Men ontmoet voorts nogal wat belemmeringen in de internationale handel, zoals protectionistische bepalingen, problemen rond vrij verkeer van werknemers en problemen rond transfers van winsten.

\section{Accountancy}

In de accountancy zijn de afgelopen jaren opvallend veel samenwerkingsverbanden tot stand gekomen. Dit houdt deels verband met de internationalisering van vele ondernemingen die opdrachtgever zijn van accountantskantoren en deels met de verbreding van het werkterrein, namelijk van controle naar advisering over organisatie, financiële aangelegenheden en automatisering. Internationalisering komt in hoofdzaak voor bij de grote kantoren, aanvankelijk in de vorm van buitenlandse vestigingen, later vooral in de vorm van samenwerkingsverbanden. De middelgrote en kleine kantoren zijn over- 
wegend nationaal of regionaal georiënteerd. Er wordt wel gesteld dat ook de middelgrote kantoren genoodzaakt zullen zijn in de nabije toekomst internationale contacten aan te knopen, gelet op de trends bij opdrachtgevers. Een en ander ging gepaard met een voortdurende werkgelegenheidsgroei tot boven de 60.000 arbeidsplaatsen in 1984.

Deze trends hebben ook in ruimtelijk opzicht effecten gehad in de vorm van een aantal nieuwe vestigingen buiten de stadscentra (bijvoorbeeld Utrecht-Rijnsweerd, station Rotterdam-Alexanderpolder en een groot aantal vestigingen in Amstelveen).

De verwachting is dat de rust in deze branche nog niet op korte termijn zal terugkeren. Verdere ontwikkeling van het werkveld, voortgaande internationalisering en informatisering worden verwacht. De positie van de grote steden is, zeker als men uitgaat van de grootstedelijke agglomeraties, niet in het geding. Ze kunnen in sterke mate profiteren van de genoemde ontwikkelingen. Aangezien internationale activiteiten in samenwerkingsverbanden geschieden, is de omvang van de export marginaal: 0,2 procent van de totale omzet in de branche. Binnen de branche wordt de internationale concurrentiepositie zeer positief beoordeeld. Dat hangt vooral samen met reputatie, prijsstelling, 'know how' en kwaliteit.

\section{Computerdienstverlening}

De snelle groei van de computerdienstverlening kwam ook tot uiting in het daaraan doorgaans inherente snelle verloop van bedrijven. In 1986 werd in ons land het aantal werkzame personen geraamd op ongeveer 20.000. In 1988 is ongeveer fl. 4,5 miljard omgezet met een groeicijfer ten opzichte van 1987 van ruim 20 procent. De groei is vooral gerealiseerd in de software-dienstverlening, de verkoop van standaardprogrammatuur (handel) en opleidingen.

Verwacht wordt dat deze markt voorlopig nog blijft groeien, maar veel bedrijven krijgen te maken met een herpositionering. In de eerste plaats zal er meer aandacht komen voor het internationale niveau. Het Nederlandse bedrijfsleven exporteert zeer weinig - slechts enkele procenten van de omzet. De Europese eenwording zal een aanzienlijke invloed hebben op de concurrentieverhoudingen. Verder zal in de nabije toekomst het verschil tussen leveranciers (van hardware) en dienstverleners gaan vervagen. Tenslotte doet zich steeds meer de noodzaak voor - mede onder invloed van internationale concurrentie - nieuwe markten tot ontwikkeling te brengen, zoals telematica en onderhoud en beheer van systemen. Dit vergt omvangrijke investeringen in $R \& D$. Onderzoeken binnen de branche wijzen op groeimogelijkheden voor de export in de sfeer van hardware-leveringen, maatwerk van software en systeemontwikkeling. Internationale handel in hardware ondervindt nogal wat belemmeringen. Wat betreft de internationale concurrentiepositie, worden reputatie, prijs en levertijd als minpunten opgevoerd, terwijl kwaliteit en persoonlijk contact als sterke punten worden beschouwd. Slechts een beperkt deel van de branche was voornemens, blijkens onderzoek uit 1986, de blik over de grenzen te richten. De personele situatie in de bedrijven, verwachte financieringsproblemen en gebrek aan ervaring op buitenlandse markten vormen hier een hindernis.

Op grond van bovengeschetste algemene trends is thans de verwachting dat de totale informatica-branche, waarvan de computerdienstverlening deel uitmaakt, in de komende jaren een heroriëntatie te wachten staat in de vorm van fusies en concentraties op nationaal en internationaal niveau.

De opmerkelijke ontwikkeling in deze branche in de afgelopen jaren heeft aanleiding gegeven tot een bescheiden stammenoorlog onder een aantal Nederlandse steden over de vraag welke stad de meeste aantrekkingskracht heeft op de telematica-sector, waaronder de computerdienstverlening ressorteert. $\mathrm{Nu}$ een reorganisatie in de branche in het verschiet ligt, kan langzamerhand een balans worden opgemaakt. Ook de computerdienstverlening blijkt een sector die de cliënten volgt. Men treft deze sector relatief veelvuldig aan in het middengebied van Zuid-Holland. Het gaat hier om bedrijven met waarschijn- 
lijk een oriëntatie op alle vier grote steden. Bij de lokatie in en rondom de stad Utrecht gaat het waarschijnlijk om bedrijven met een randstedelijke en landelijke oriëntatie. Of de voorspelde structuurwijzigingen in de branche zullen leiden tot wijzigingen in dit lokatiepatroon, is nu niet te voorzien.

\subsubsection{Beleidsopgaven}

De grafische industrie is in potentie een belangrijke sector in de grootstedelijke economie van de toekomst, niet alleen in Amsterdam maar ook in de andere steden. De ontwikkelingen binnen de branche zijn voorspoedig; de internationale concurrentiepositie wordt als gunstig beoordeeld. Het vestigingspatroon is in grote lijnen afgestemd op ruimtelijke concentratie van opdrachtgevers. De recente minder gunstige ontwikkeling van de branche in de drie grote steden is echter een punt van aandacht. Het is niet zonder meer duidelijk wat hiervan de oorzaken zijn.

$\mathrm{Bij}$ ongewijzigd beleid is het aannemelijk dat economisch sterkere bedrijven uit de steden zich zullen vestigen in gebieden met gunstigere vestigingsvoorwaarden. Daarom zijn op dit gebied maatregelen nodig, bijvoorbeeld ten aanzien van de beschikbaarheid van bedrijfsterreinen, van aanvaardbare grondkosten en van bereikbaarheid. Waar gebleken is dat de exportpositie van de grafische industrie in de drie grootste steden achterblijft, verdient het voorts overweging om exportbevordering hoog op de agenda te zetten. In de derde plaats is de personeelsvoorziening een rem op de bedrijfsontwikkeling. Wellicht is de grafische sector bij uitstek een sector waar sprake is van 'verborgen vacatures'. Bij gebrek aan voldoende arbeidsaanbod doen ondernemers ook geen pogingen personeel te werven. Ook de arbeidsvoorziening dient daarom hoog op de beleidsagenda te (blijven) staan.

De uitgangspositie van de metaal-elektro-industrie in de vier grote steden is ongunstig. De twee deelsectoren die geacht worden de gunstigste concurrentiepositie te hebben - de basismetaal en de elektrotechnische industrie - zijn zwak vertegenwoordigd (gemeten in werkgelegenheidscijfers) en de bedrijven zijn verhoudingsgewijs weinig gericht op de export. Dit levert in een Europa zonder binnengrenzen een achterstand op.

Over de kenmerken van de metaal-elektro-industrie in de grote steden is niet voldoende bekend om haar toekomstperspectief goed te kunnen schetsen. Vanuit de algemene analyse kunnen de volgende agendapunten voor beleid in grootstedelijke gebieden worden genoemd. In de eerste plaats exportbevordering; het exportaandeel in de grote steden ligt immers te laag. Een tweede agendapunt is de management-ondersteuning, inzetbaar in (interne en externe) ontwikkelingsprocessen van primair ambachtelijke bedrijven naar professionele organisaties binnen een Europese markt. Ten derde zullen de vestigingscondities (zoals het aanbod van bedrijfsruimte) moeten worden geoptimaliseerd. Tenslotte zal de scholing - in termen van intensivering van de samenwerking tussen bedrijven, universiteiten en hogescholen - voldoende aandacht moeten krijgen.

Bij het toerisme zal een forse inspanning vereist zijn, willen de vier grote steden kunnen profiteren van de groei. Tot de kernpunten in het stedelijk toeristisch beleid van de jaren ' 90 behoren - blijkens onder andere onderzoek van het Nederlands Bureau voor het Tberisme - marketing, produktvernieuwing, kwaliteitsverbetering, scholing en bedrijfstakorganisatie. Zoals vermeld, zijn er in de vier steden initiatieven ten aanzien van produktvernieuwing en kwaliteitsverbetering. Het verdient echter aanbeveling om parallel aan de vernieuwing van het fysieke aanbod aandacht te besteden aan organisatorische vernieuwing binnen de bedrijfstak. Te denken valt aan professionalisering van de marktanalyse van het toeristisch produkt, scholing van personeel in de toeristische industrie (zo wijst de gemeente Amsterdam op de behoefte aan scholing van gidsen) en een actievere rol (ook in financieel opzicht) van de verschillende geledingen van het stedelijk bedrijfsleven die baat hebben bij het toerisme. 
Het strategisch belang van de transportsector voor de grote steden is groter dan afgeleid zou kunnen worden uit de werkgelegenheidscijfers. Bedacht moet worden dat de transportsector - op grond van het doorgaans ruimte-intensieve karakter van de bedrijven en op grond van bereikbaarheidsoverwegingen niet eenvoudig inpasbaar is binnen het stedelijk gebied. Transportbedrijven zoeken dan ook al snel een lokatie in aangrenzende gemeenten, of verder weg, bijvoorbeeld in het open middengebied van de Randstad of in de provincies Utrecht en Brabant.

Voor wat betreft de positie van grootstedelijke gebieden vormen congestieproblemen op de hoofdverkeerswegen (en op de aan- en afvoerwegen) en de schaarste aan ruimte voor bedrijfsvestigingen duidelijke bedreigingen. Dit probleem klemt temeer daar de twee internationale 'mainports' - Schiphol en de Rotterdamse haven - deel uitmaken van het grootstedelijk gebied.

Vermoedelijk zal - meer in algemene zin - de toekomst van de transportsector direct samenhangen met de mate waarin de fysieke infrastructuur en informatiesystemen ter begeleiding en beheersing van goederenstromen worden ontwikkeld. Tot nog toe is het niet gelukt de internationale ontwikkeling te volgen en de institutionele schotten tussen verschillende vervoerswijzen, gebieden en bedrijven te slechten.

Om de toekomstige positie van het bankwezen en andere financiële dienstverlening internationaal veilig te stellen en te verbeteren, is de Initiatiefgroep 'Amsterdam als Internationaal Financieel Centrum' in het leven geroepen, waarin kennis van de internationale markten en tot op zekere hoogte 'commitment' vanuit de leidende ondernemingen zijn geconcentreerd. Ook internationaal gezien is dit initiatief opmerkelijk, wanneer men zich realiseert dat het in enkele andere Westeuropese landen vooral de nationale overheden zijn die de verantwoordelijkheid op zich nemen voor behoud en uitbouw van de internationale positie van de financiële centra daar.

De groep heeft, op basis van een analyse van internationale ontwikkelingen en van de kansen van Amsterdam, voorstellen gedaan om de internationale positie van de stad als financieel centrum te versterken. Aanbevelingen hebben betrekking op zowel de vestigingsplaatsaspecten van Amsterdam als het functioneren van de financiële markten in Nederland.

Bij de zakelijke dienstverlening zijn er thans, als men de grootstedelijke agglomeraties als uitgangspunt neemt, geen manifeste problemen. Zo wordt in een branche als de accountancy een versterking verwacht van de positie van de Randstad. Op niveau van de stedelijke kernen zijn de verwachtingen echter wisselend. Zo voorziet Utrecht een stabilisatie van de werkgelegenheidsomvang op het huidige peil. Amsterdam daarentegen rekent op een stijging van de totale werkgelegenheid tussen 1985 en 2000 van 1 tot 2 procent jaarlijks. Voor de kansen van de vier grote steden als vestigingsplaats van buitenlandse ondernemingen is de verwerkelijking van één interne markt in de Europese Gemeenschap een belangrijk gegeven. Het verkleint een van de belangrijkste nadelen van Nederland - de kleine thuismarkt. Volgens een enkele bron doet zich reeds op zekere schaal een proces voor waarbij ondernemingen in de zakelijke dienstverlening van buitenlandse origine zich in Nederland vestigen. Dit gaat overigens in eerste instantie ten koste van het Nederlandse bedrijfsleven in deze sector. Er is hier behoefte aan een actievere opstelling van de brancheorganisaties, het Rijk en andere overheden, aansluitend bij de werkafspraken die de Commissie Buitenlandse Investeringen van het ministerie van Economische Zaken, afgestemd op Amsterdam Financieel Centrum, heeft gemaakt. Naast acquisitie en promotie in het buitenland kan gedacht worden aan begeleiding van buitenlandse bedrijven binnen het gehele traject naar de realisatie van een vestigingsbeslissing. Banken, accountantskantoren en dergelijke hebben een belangrijk aandeel in de bedrijfsacquisitie, aangezien blijkt dat dit type instellingen een belangrijke rol speelt in de vestigingsbeslissing van 
buitenlandse bedrijven. In de acquisitie zal de nadruk onder andere gelegd moeten worden op een aantal traditioneel sterke punten, zoals de kwaliteit van het arbeidspotentieel in ons land in de dienstensector.

\subsubsection{Samenvatting van de ontwikkelingen met het oog op de toekomst}

Uit het macro-economisch scenario blijkt dat bij een beleid voor de grootstedelijke economie in de toekomst de ontwikkelingen tot nu toe, ondanks een recent herstel, geen onverdeeld gunstig en wenkend perspectief inhouden. Van de andere kant is er blijkens de verkenning in een aantal bedrijfsklassen volop potentieel aanwezig in de grootstedelijke economie. $\mathrm{Bij}$ de exemplarische excursie komt naar voren dat in de afzonderlijke bedrijfstakken naast bedreigingen veel kansen aanwezig zijn. Nog belangrijker is dat het succes in de ene bedrijfstak in de grootstedelijke economie in veel gevallen extra mogelijkheden en uitdagingen in andere bedrijfstakken inhoudt. Dit vereist een alerte en dynamische economie in de grote steden, c.q. de grootstedelijke gebieden en een beleid dat daaraan impulsen geeft, maar vooral ondersteunend en accommoderend is. Over die alerte en dynamische economie èn het daarbij aansluitende beleid gaat de volgende paragraaf.

\subsection{Beleidsinhoudelijke plaatsbepaling en beleidsperspectief}

\subsubsection{Inleiding}

In paragraaf 3.4.2 wordt eerst, aansluitend bij de gedeelten in hoofdstuk 2 die over economie gaan, een beschouwing gegeven over de betekenis en strekking van de grootstedelijke economie in de komende periode, in het bijzonder vanuit de invalshoek van de verhoudingen tussen grootstedelijke gebieden in internationaal verband en in de nationale economie.

Daarna zal in paragraaf 3.4.3 het vereiste beleid in hoofdlijnen worden geschetst. Dit beleidsgedeelte wordt in paragraaf 3.4.4 afgerond met een uiteenzetting en aanbevelingen voor beleid op meer operationeel niveau, uiteengelegd in twee beleidssporen: economisch ontwikkelingsbeleid en infrastructuurbeleid.

\subsubsection{Plaatsbepaling}

In hoofdstuk 2 is gewezen op de verschuivingen en hergroepering van economische zwaartepunten en verbanden op internationaal niveau. Een en ander komt neer op een zwaartepuntverschuiving tussen grootstedelijke gebieden op mondiaal niveau, binnen werelddelen (onder andere de noord-zuid verschuivingen) en binnen landen (in een aantal landen eveneens noord-zuid verschuivingen). Deze hergroepering staat in relatie met de toenemende internationalisering en met de toenemende dynamiek, omloopsnelheid en -intensiteit in de economie in het algemeen en de grootstedelijke economie in het bijzonder. Deze hergroepering - zo werd in hoofdstuk 2 geconcludeerd - is geen gedetermineerd proces. Integendeel: er is sprake van afwijkingen van de algemene patronen en er doen zich in de loop van de tijd steeds nieuwe verschuivingen voor. Een treffend voorbeeld hiervan vormt de Bondsrepubliek Duitsland, waar de recent ingezette 'Süd-Nord-Gefälle' met een verschuiving naar de Zuidduitse steden, nu weer meer omgebogen wordt naar het midden-gebied onder invloed van de eenwording van Duitsland. De koppeling met Oost-Duitsland en Berlijn geeft nieuwe impulsen aan de Westduitse havensteden Hamburg en Bremen. Deze steden hebben in hun ontwikkelingsbeleid al hun oog laten vallen op het Oostduitse stedelijk complex Berlijn - Leipzig. Zo valt ook sinds enige jaren in Frankrijk een politiek waar te nemen, waarbij men in een gericht nationaal verstedelijkingsbeleid onder andere mikkend op een versterking van steden met een high tech-of dienstenspecialisatie (zoals Montpellier) of met een functie in het internationaal verkeer (Straatsburg) en de havensteden ('Action Le Port et La Ville') op zijn minst een eigen knooppuntpositie ten opzichte van Noord-West-Europa tracht te realiseren, nu het Europese middengebied en Zuid-Europa, met Italiaanse en Spaanse steden als Milaan 
en Barcelona, in belang toenemen. Samengevat komt het erop neer dat de verstedelijkingspatronen onder steeds weer nieuwe condities wijzigingen ondergaan. Ze worden in ruime mate bepaald door de dynamiek van nationale en internationale economische markten en komen tot stand mede door een gericht ontwikkelingsbeleid binnen en ten aanzien van de onderscheiden grootstedelijke regio's.

Bij de plaatsbepaling van onze grote steden en grootstedelijke gebieden gaat het enerzijds om de relatieve positie van die steden in het eigen land en anderzijds - en dat wordt steeds belangrijker - om de relatieve positie ten opzichte van grote steden en grootstedelijke gebieden in andere landen, bijvoorbeeld Brussel en Frankfort. Vanuit het oogpunt van de ontwikkelingsdynamiek moet na de analyse van de grootstedelijke economie in het recente verleden en het heden de conclusie luiden, dat deze in de loop der tijd verzwakt is geraakt, zich weliswaar enigszins heeft hersteld onder het gunstige gesternte van de nationale economische opleving vanaf medio jaren ' 80 , maar dat ze over het geheel genomen nog kwetsbaar blijft en op dit ogenblik nog weinig extra reserves lijkt te hebben. Dit beeld wordt voor de komende periode in de scenarioanalyse eerder bevestigd dan afgezwakt.

Alvorens in te gaan op de opgaven en uitdagingen in de komende periode, wordt hier opnieuw, zoals in hoofdstuk 2 , de vraag gesteld of in de nationale economie de grootstedelijke economie überhaupt nog een relevant concept en uitgangspunt is. Immers, alom is nu in West-Europa en in ons land, zoals eerder in de Verenigde Staten, sprake van een spreiding en deconcentratie niet alleen van bewoners, maar ook in toenemende mate van bedrijvigheid. Is bij een dergelijke ruimtelijke diffusie van grootstedelijke functies een grootstedelijke economie nog wel een graadmeter? Doet een grootstedelijke economie er zelfs nog toe? Aansluitend bij het gestelde in hoofdstuk 2 is het antwoord dat de grootstedelijke economie van essentieel belang is en blijft in het kader van de nationale economie.

Dit heeft in eerste instantie te maken met het gegeven uit de voorgaande analyse dat ongeveer de helft van de bruto toegevoegde waarde (zie tabel 3.1) van het binnenlands produkt daar verdiend wordt. Direct daarbij sluit de overweging aan dat als nu - gegeven nog steeds dit aandeel - de groei in de grote steden relatief achterblijft, het een nationaal economisch belang van de eerste orde is, deze groeiverzwakking om te buigen. Belangrijker is echter, zoals uit een wetenschappelijke discussie over dit onderwerp in de Verenigde Staten naar voren komt, dat de spreiding en concentratie van economie nationaal gezien geen zero-sum aangelegenheid is, waarbij het niets uitmaakt waar de economische activiteiten plaats vinden en waar de afzet is gelokaliseerd. Integendeel, de concentratie en vooral de verstrengeling van economische activiteiten en ook van de afzet blijken een doorslaggevende factor in de kwaliteitsbepaling van de nationale economie. Tenslotte gaan - zoals uit de uiteenzetting verderop naar voren komt - ook van de moderne logistiek, naast extra mogelijkheden voor spreiding en 'footloose' lokatie, ook belangrijke impulsen uit voor grootstedelijke concentratie en verstrengeling. De grootstedelijke gebieden blijven daarmee - ook bij de huidige spreiding van economische bedrijvigheid over meer steden en streken - als het ware over het gehele nationale grondgebied strategische gegevenheden voor de ontwikkeling en het functioneren van de nationale economie.

In deze zin blijven de grootstedelijke gebieden Amsterdam, Rotterdam, Den Haag en Utrecht doorslaggevend voor de nationale economie. In alle westerse landen komt een soortgelijke betekenis voor de nationale economie tot uiting van grootstedelijke knooppunten, zoals Brussel, Frankfort, Genève, Milaan en dergelijke, om de eerste-ordemetropolen, zoals Londen, Parijs, New York en Tokio maar niet te noemen. 
Een dergelijke grootstedelijke economische profilering vergt - dat kan uit de uiteenzetting hiervóór worden afgeleid - in tegenstelling tot wat tot nu toe gebruikelijk was een sterkere oriëntatie op de relatieve positie in internationaal verband. Het houdt ook, vanwege de stedelijke diffusie, meer dan voorheen de noodzaak in van concurrentie, naast samenhang en complementariteit, tussen de grote stad en de randgemeenten en tussen de grootstedelijke gebieden, de Randstad-formatie en de rest van verstedelijkt Nederland.

Hierbij dient men, zoals eerder werd gesteld, niet te mikken op rigide concentratie in grote steden. 'Urban containment' is geen reële optie. Anderzijds is het zaak te voorkomen dat de economie van de grote steden nog meer erodeert dan in het recente verleden, blijkens de analyse in dit hoofdstuk, het geval was. De enige geëigende formule voor het beleid is derhalve niet zich uitsluitend en alleen op de grote stad te richten, maar die grote stad en het omliggende grootstedelijke gebied te benaderen als een complementair geheel, waarin de kernstad en de randgemeenten een eigen aandeel hebben en eigen eisen stellen. Concurrentie en samenhang van deze deelgebieden is kenmerkend voor elk grootstedelijk gebied in de westerse wereld en bepalend voor de kwaliteit van de grote stad zelf en het omliggend grootstedelijk gebied in zijn geheel. Zoals een vertegenwoordiger van een multinational het formuleerde: "We zijn in een Elzasser dorpje onder de rook van Straatsburg neergestreken vanwege de aantrekkelijkheid van die stad als internationaal knooppunt”.

Bij een nadere specificatie van de betekenis van de grote steden voor de nationale economie is van belang dat deze steden nu voor de meeste economische functies geen algemene en natuurlijke incubatiecentra meer zijn. Recente inzichten wijzen uit dat de theorie, die wil doen geloven dat de meeste vernieuwingsprocessen nog steeds in de grote steden opkomen en zich van daaruit spreiden over het land, niet houdbaar is ${ }^{30}$. De incubatiefunctie van grote steden is daarmee niet verdwenen of van geringere betekenis, maar zij is wel specifieker en meer toegespitst dan voorheen. De grote steden vormen voor bepaalde 'external economy industries', zoals de modegevoelige industrie, de media, de informatica en ook het opkomend subcultureel (etnisch en anderszins) ondernemerschap nog steeds en wellicht zelfs meer dan voorheen een doorslaggevend milieu. Die grootstedelijke incubatie-achtergrond vindt men meer in het algemeen terug in alle bedrijvigheid, handel en dienstverlening waar een accent ligt op snelle directe contacten en informatie-uitwisseling: 'transactionele activiteiten'. De specifieke incubatiefunctie van de grote steden is dan ook nauw verbonden met het brandpunt zijn en blijven van de grote steden in de transport- en communicatieketens. Grote steden behouden hun karakteristiek als knooppunten van transport en communicatie, waar internationale en nationale verbindingen in elkaar overlopen. Daarmee blijven ze transferpunten van de eerste orde, zoals ze altijd in de geschiedenis van het westen centrale marktplaatsen geweest zijn. Dit verklaart bij voorbeeld waarom vooral (inter)nationale hoofdkantoren in de grote steden of de Randstad geconcentreerd blijven.

Met deze transport- en communicatie- en met de incubatiefunctie in de meer specifieke betekenis is vervolgens nauw verbonden de strategische betekenis van de grote steden op het vlak van kennisfuncties. Het gaat hier om zakelijke diensten die gedeeltelijk betrekking hebben op kennisintensieve intermediaire diensten. De concentratie van universiteiten en hogescholen, andere

${ }^{30}$ ] P.A. de Ruijter, 'De bruikbaarheid van het begrip "incubatiemilieu" '; Geogrofisch Tijdschrift, jaargang 17, nr. 2, 1983, blz. $106-110$. Hierin wordt de stedelijke incubatiethese vastgehouden. In de twee volgende publikaties wordt deze in zijn algemeenheid verworpen: M.W. de Jong, New economic activities and regional dynamics; Amsterdam, Koninklijk Aardrijkskundig Genootschap, Economisch Geografisch Instituut, Universiteit van Amsterdam, 1987. E. Wever, Nieuwe ondernemingen in Nederland; Assen, Van Gorcum, 1984. 
onderwijsvoorzieningen, media en cultuur in de grote steden speelt hierbij een belangrijke rol.

Ook al zijn de schaalvoordelen, die tot voor kort kenmerkend waren voor de grote steden en grootstedelijke gebieden, sterk afgenomen vanwege de door de technologie toegenomen transport- en communicatiemogelijkheden, de grote steden blijven toch - overigens in een complementair verband met hun randgemeenten - knooppunten van verzorging in de ruimste zin, zowel in commerciële vormen: handel en geldwezen, als in niet-commerciële vormen: gezondheidszorg, maatschappelijke dienstverlening, culturele accommodaties en hoogwaardig onderwijs.

Deze relatieve positie van de grote steden in nationaal verband raakt steeds meer verbonden met die in internationaal verband. Uit onderzoek in de Verenigde Staten blijkt dat steden en gebieden brandpunten van economische vernieuwing en modernisering zijn, als ze functioneren als knooppunten van wereldwijde processen van produktie, distributie en consumptie. Kortom, die steden tellen mee, waar een verband bestaat tussen de lokale, nationale en internationale economie. Knight noemt dit de 'global city' ${ }^{31}$.

"the primary role that the global city plays in global society is the governance of technology, i.e. the advancement and management of industrial and cultural know how. In order to do this, the city must assimilate technological culture and build a society that is learning based and multi-cultural".

Deze mondiale grootstedelijke 'stepping stones' zijn juist door de interne en externe druk op het functioneren tegelijkertijd de lokaties van economische, maatschappelijke en culturele ontwikkelingsverschillen en -spanningen. Dualiteit is kenmerkend voor deze grote steden: er zijn winnaars en verliezers in de economie en in de samenleving. Niet voor iedereen staan de voorzieningen open. Door de hoge initiële investeringen en de vereiste know-how kan niet zo maar elke actor direct beschikken over of toegang hebben tot de geavanceerde infrastructuur. Extreme vormen van competitie, concurrentie naast samenwerking, complementariteit en maatschappelijke netwerken zijn onlosmakelijk met deze steden en gebieden verbonden. Men kan zelfs stellen dat, waar deze kenmerken vanuit maatschappelijke of politieke overwegingen worden geneutraliseerd of afgezwakt, ook de vooraanstaande functies van deze gebieden in de kern worden aangetast. Tenslotte brengen de dynamiek en flexibiliteit in de economie/technologie en het daarmee verbonden aanpassingsvermogen in deze stedelijke gebieden noodzakelijkerwijs een differentiatie in 'boom-', transitie- en achterstandsgebieden met zich mee ${ }^{32}$.

De diensteneconomie vormt voor de grootstedelijke gebieden het front, waar hun extra kansen liggen. De verstrengeling van die diensteneconomie met de produktiecentra in en vooral ook buiten de grootstedelijke gebieden dient daarbij in acht te worden genomen. Voor de positionering van de economie van de grote steden, c.q. grootstedelijke gebieden, in de komende periode is de functionele differentiatie tussen de grote steden en gebieden van belang. Uit onderzoek in de Verenigde Staten - het land dat in deze ontwikkeling nog steeds voorop loopt - blijkt dat die differentiatie voor een belangrijk deel, maar niet uitsluitend door de diensteneconomie wordt bepaald. Het heeft in dat land geleid tot een vierdeling van: a) gediversifieerde dienstencentra; b) gespeciali-

3'] City in a global society; R.V. Knight, G. Gappert (eds.), Series: Urban Affairs Annual Reviews, Vol. 35; Newbury Park, London, New-Delhi, Sage Publications, 1989.

32] Dit gedeelte is gebaseerd op de in het kader van dit WRR-rapport verrichte studie: Logistiek, infrostructuur en de grote stod; M.W. de Jong en P.A. de Ruijter (red.); WRR voorstudies en achtergronden V69; 's-Gravenhage, SDU uitgeverij, 1990. 
seerde dienstencentra; c) produktiecentra en d) consumentgerichte centra ${ }^{33}$.

De ontwikkeling is in ons land nog te pril om een dergelijk nieuwe functionele differentiatie te kunnen aanwijzen. Wel is er in de loop der tijd tussen de vier grootstedelijke gebieden een differentiatie van de economische profielen ontstaan, die hier nog eens wordt samengevat. In Groot-Amsterdam is het transportcomplex van de luchthaven Schiphol met aanverwante bedrijvigheid en dienstverlening in belangrijke mate met Amsterdam verbonden. Daarmee is Amsterdam het nationaal/internationaal distributie- en transportknooppunt van de eerste orde. Daarnaast zijn er in Amsterdam als nationale hoofdstad veel activiteiten, instellingen en organisaties met een nationale strekking gelokaliseerd. In het bijzonder de financiële sector is in Amsterdam geconcentreerd. In Groot-Rijnmond zijn de zeehavenactiviteiten van de Rotterdamse havens, met een eerste plaats in de mondiale rangorde van zeehavens, de daarmee verbonden handel en transport, de in de havens gelokaliseerde procesindustrie (petrochemie), installatietechniek en scheepsbouw, beeldbepalend. In de agglomeratie Den Haag is aansluitend bij de landelijke bestuursfuncties een specialisatie in (tele)communicatie-bedrijven typerend voor het economisch profiel (Siemens, Philips, PTT). Ook is er een aantal (inter)nationale hoofdvestigingen met kantoren of bedrijfsonderdelen gevestigd, met name in Rijswijk. In Utrecht is de landelijke openbaar-vervoersfunctie (hoofdzetel van de NS en nationaal spoorwegknooppunt) bepalend. Dit leidde ook tot de vestiging van een groot aantal nationale instellingen en organisaties en van tentoonstellingen en beurzen (Jaarbeurs). In dit grootstedelijke gebied is tenslotte de computerdienstverlening en de metaalnijverheid van belang ${ }^{34}$.

In een op vernieuwing gerichte ontwikkeling scoren de vier grootstedelijke gebieden vooral met een oververtegenwoordiging van de kennisdiensten. Net als in andere landen zijn deze diensten nog steeds een grootstedelijk verschijnsel. De dominantie van de grote steden was op dit vlak overigens vroeger meer uitgesproken. De middelgrote steden in de halfwegzone tussen de Randstad en de perifere regio's in het noorden, oosten en zuid-oosten van ons land zijn sterk in opkomst ${ }^{35}$. De grote steden lijken hun voorsprong echter te behouden op een aantal strategische segmenten van dienstverlening, zoals de financiële dienstverlening, de reclame en de internationaal georiënteerde zakelijke diensten.

De industriële bedrijvigheid met een sterk vernieuwend karakter daarentegen is relatief sterk vertegenwoordigd in de regio's: zuid-oost Noord-Brabant, Arnhem/Nijmegen, Twente en delen van het noorden. Er zijn twee groepen te onderscheiden. Perifeer gelegen regio's, waar kennisdiensten ontbreken en regio's in de halfwegzone (vooral in Noord-Brabant en Gelderland), waar de kennisdiensten in toenemende mate aanwezig zijn. De vernieuwingsgerichte produktie is in de grote steden ondervertegenwoordigd, hoewel er in absolute aantallen nog wel vernieuwingsgerichte bedrijven zijn gevestigd. In Rijnmond zijn deze bedrijven zelfs in absolute aantallen beperkt aanwezig. Binnen de Randstad zijn vernieuwingsgerichte bedrijven vooral te vinden in een schil rond de vier grote steden: in het Gooi en de Vechtstreek, de Zaanstreek, in Delft en het Westland, en in de 'open gebieden' van Groot-Amsterdam, zoals de Haarlemmermeer. Betwijfeld moet worden of de grote steden voor de flexibele en vernieuwende produktie in het algemeen perspectieven hebben. Het argument voor deze veronderstelde perspectieven is dat weliswaar de arbeidskosten bij

33] Th. Noyelle, Th. Stanback, The economic tronsformotion of American Cities; Ottawa, Rowman and Allanheld, 1984, aangehaald in: Technology Assessment in Stad en Regio; J.J. Broekhuis (red.), Groningen, Wolters-Noordhoff, 1988, blz. 27.

34] Deze typering is ontleend aan: Logistiek, infrostructuur en de grote stod, op. cit., blz 24.

${ }^{35}$ ] J.H.j. van Dinteren, Zakelijke diensten en middelgrote steden; Amsterdam: Koninklijk Nederlands Aardrijkskundig Genootschap, Nijmegen: Katholieke Universiteit Nijmegen, Geografisch Instituut, 1989. 
flexibele specialisatie sterk aan belang inboeten, maar dat de arbeid zelf flexibiliseert (qua kennis, kunde en inzet). Het gediversificeerde arbeidsaanbod in de grote steden zou dan een positieve vestigingsfactor zijn. Dit gaat in het buitenland bijvoorbeeld op voor Noord-Italië, bij netwerken van kleine en middelgrote bedrijven zonder beheersing of dominantie door grote bedrijven. Ons land is gekenmerkt door een industriële structuur met netwerken van flexibele produktie waarin grote ondernemingen juist een dominerende, organiserende rol vervullen. Men denke aan Philips, Akzo, DSM, DAF of Rank Xerox (overigens zijn grote ondernemingen, zoals Shell en Unilever wel gevestigd in de grootstedelijke zuidvleugel van de Randstad). Het is weinig aannemelijk dat deze ondernemingen hun produktienetwerken naar de grote steden verplaatsen. De middelgrote steden en het verstedelijkte platteland in de halfwegzone bieden meer voordelen dan de grootstedelijke milieus, waar de competitie om vestigingsplaatsen groter is en er bijkomende problemen zijn met congestie, (veronderstelde) arbeidsmotivatie enzovoort ${ }^{36}$.

De goederenbehandeling (handel, transport en distributie) is in sterke mate geconcentreerd aan de binnenzijde van de Randstad, aanvullend op de concentraties in de 'mainports' van Amsterdam en Rotterdam. Deze concentratie zet zich voort langs de hoofdvervoersassen in zuidelijke en zuidoostelijke richting.

De toenemende verstrengeling van produktiebedrijven, goederenbehandelende diensten en kennisdiensten bepaalt het toekomstige landschap van economische bedrijvigheid in ons verstedelijkt land. De grote steden en de grootstedelijke gebieden blijven een relatief sterke positie innemen ten aanzien van de 'mainports' (goederenbehandelende diensten: handel, transport en distributie) en ten aanzien van kennisdiensten. Deze specifieke profilering van de grote steden gaat samen met een toenemende diffusie van industrie en goederenbehandeling over geheel Nederland. De economische bedrijvigheid in de grote steden en de rest van het land raakt hiermee steeds meer aan elkaar gerelateerd. Hiermee tendeert ons land met name in economisch opzicht steeds meer naar één 'urban field' of 'metroplex'. Aangenomen mag worden dat een goed functioneren van de onderdelen (de grootstedelijke concentraties en de overige gebieden) van het 'urban field' of 'metroplex' op zich en in onderlinge samenhang bepalend is voor het economisch-technologisch concurrentievermogen van Nederland in een internationale context.

Deze profilering tussen de grote steden, grootstedelijke gebieden, de middelgrote steden, het verstedelijkte platteland in de halfwegzone en de perifere regio's valt intussen af te lezen uit de lokatiekeuze van buitenlandse ondernemingen. Produktie- en distributiebedrijven vestigen zich voornamelijk in Noord-Brabant, Gelderland en Limburg. Voorbeelden zijn Fuji in Tilburg, General Electric in Bergen op Zoom, Digital in Nijmegen. Europese of regionale hoofdkantoren van buitenlandse ondernemingen zijn nagenoeg alle geconcentreerd in de grote steden, Amsterdam voorop. De (inter)nationale distributie- en produktie-activiteiten die aan de 'mainports' Amsterdam of Rotterdam gebonden zijn, tenderen tenslotte naar een vestiging in de onmiddellijke omgeving daarvan. De recente vestiging van het Europese distributiecentrum van Nissan in Amsterdam is hiervan een voorbeeld.

In het volgende gedeelte wordt nader aangegeven wat er vanuit deze context meer in het bijzonder ten aanzien van de economie van de grote stad zelf aan beleidsinzet in de komende periode vereist is.

${ }^{36}$ ] H.P. Krolis, C. Machielse, P.A. de Ruijter, Kiemen van vernieuwing: economisch-technologische ontwikkelingen en ruimtelijke gevolgen voor Twente; Delft, Instituut voor Ruimtelijke Organisatie-TNO. 1989. 


\subsubsection{Hoofdelementen van de algemene beleidsstrategie}

De Vierde Nota over de Ruimtelijke Ordening en de hierbij aansluitende WestEuropa studie, alsmede het Tweede Structuurschema Verkeer en Vervoer bieden voor de nationale en internationale positie van de grote steden een eerste nuttig beleidskader. In deze nota's wordt voor het eerst weer onderkend dat de grootstedelijke gebieden belangrijke voorposten zijn in de internationale concurrentiestrijd.

Hierbij sluit een verschuiving aan van een beleidsoriëntatie op problemen en zwakten naar een beleidsinspanning gericht op sterkten en potenties. Het accent ligt hier echter primair op de ruimtelijke ordening en het verkeer en vervoer. Dat is niet voldoende, want de positionering in internationaal verband impliceert ook een specifiek grootstedelijk economisch ontwikkelingsen infrastructuurbeleid. Een dergelijk beleid is in Nederland na de jaren '50 nauwelijks van de grond gekomen, laat staan dat het is uitgemond in gerichte beleidsprogrammma's.

Deze beleidsmatige onderbelichting en onderinvestering in ons land werd nog eens extra versterkt door het spreidingsbeleid, dat vanaf de jaren '60 tot in de jaren ' 80 kenmerkend was voor de nationale ruimtelijke ordening. In vergelijking met andere landen was en is in ons land de oriëntatie op de grote steden als essentiële schakels van de nationale economie zwak tot afwezig, zowel binnen de steden zelf als bij het Rijk. In de VS, Frankrijk, West-Duitsland en Groot-Brittannië vindt men vele en uiteenlopende voorbeelden van een grootstedelijk stimuleringsbeleid. In een enkel geval neemt daar de nationale overheid zelf het heft in handen als de besturen van de grote steden niet meedoen of tegenstribbelen, zoals in het Verenigd Koninkrijk. Waar de nationale overheid en de grootstedelijke overheid elkaar vinden en complementair gestalte geven aan een dergelijk strategisch beleid, zoals in Frankrijk, ontstaan extra kansen en perspectieven. De recente en komende ontwikkelingen in Parijs en in de grootstedelijke regio rondom Parijs, en ook in Montpellier, Grenoble, Lyon en Lille, illustreren dit.

In Nederland is dan ook een beleidsombuiging vereist, wanneer men de inhoudelijke plaatsbepaling, zoals hierboven geschetst, serieus neemt. Eerste impulsen voor een dergelijke omslag zijn het advies van de Commissie Andriessen aan het eind van de jaren ' $70 /$ begin jaren ' 80 over de noodzakelijke versterking van de Amsterdamse economie en daarna het rapport van de Commissie Albeda in 1987 dat gevarieerde impulsen voor de sociaal-economische ontwikkeling van Rotterdam in kaart bracht en tenslotte het advies aan de regering in 1989 van de Commissie Montijn over de versterking van de grote steden in ons land in het algemeen. Op deze aanzetten wordt in het nu volgende gedeelte voortgebouwd.

Aansluitend bij het gestelde in hoofdstuk 2, komt deze beleidsstrategie neer op een gezamenlijke krachtsinspanning van het nationale en lokaal-regionale bestuur in nauwe relatie met de bedrijfssector in de brede zin van het woord. Het moge duidelijk zijn dat de ontwikkeling van een dergelijke strategie een majeure inspanning zal vergen. Het vergt zowel de inbreng van individuele ondernemers, het bedrijfsleven in ruimere zin, als van beleidmakers op nationaal en stedelijk niveau en van toeleveraars van onderzoek en statistische gegevens. Het vereist de keuze en invulling van doelstellingen die in een dergelijke strategie zouden moeten worden gerealiseerd. De raad onthoudt zich, conform de opzet van dit rapport, van het invullen van een dergelijke strategie in concrete projecten en programma's voor elk van de vier grootstedelijke gebieden. Nog eens wordt herhaald dat in dit advies vooral de vereiste beleidsbenadering en condities worden aangegeven waarmee de grootstedelijke economie het profiel verkrijgt dat, gelet op de in dit advies gehanteerde uitgangspunten, vereist is.

Wat zijn nu de hoofdelementen van een algemene beleidsstrategie voor de economie van de grootstedelijke gebieden? 
Op nationaal niveau komt dit voor het Rijk neer op een nieuw grootstedelijk accommoderend beleid. Zoals in de jaren ' 50 , onder minister Van den Brink, door secretaris-generaal Winsemius het regionaal stimuleringsbeleid voor perifere regio's werd ontwikkeld en vervolgens tot vast beleid werd, zo dringt zich nu in de jaren ' 90 de noodzaak op van een grootstedelijk accommoderend beleid. Dit accommoderend beleid is gekenmerkt door het volgen (niet het sturen) van de dynamiek en de daaruit naar voren komende profilering in de economie en vervolgens het daarbij aansluitend versterken van de geprofileerde onderdelen via facilitaire bijdragen (niet alleen en niet in de eerste plaats door middel van financiële middelen, maar ook door middel van expertise, acquisitie, promotie, lobbies in internationale circuits enz.). Een dergelijk nationaal grootstedelijk stimuleringsbeleid verschilt in twee opzichten wezenlijk van het tot voor kort gebruikelijke beleid. In de eerste plaats onderscheidt het zich van het steunbeleid waarbij achtergebleven regio's het richtpunt vormen, zoals lange tijd het geval was in het regionaal sociaal-economisch beleid. Terwijl daarbij het nagestreefde doel was om regionale verschillen te reduceren en achterstandsregio's op te trekken naar het landelijk gemiddelde, gaat het er bij het nationale grootstedelijke accommoderend beleid juist om in de grootstedelijke gebieden extra voorzieningen veilig te stellen, zodat ze hun positie kunnen blijven waarmaken in de internationale concurrentieslag in de komende periode. Het komt derhalve neer op een regionale differentiatie, waarin de bijzondere positie van de grootstedelijke gebieden in de nationale economie op dezelfde manier wordt gehonoreerd als dit steeds binnen de industrie het geval is geweest bij voor ons land strategische bedrijvigheid.

In de tweede plaats verschilt dit grootstedelijk accommoderend beleid van het gebruikelijke stimuleringsbeleid doordat het niet in de plaats treedt van de eigen inspanningen in deze gebieden zelf. Het gaat hierbij - anders dan men zou verwachten - niet om een hulpbeleid van de nationale overheid, dat in de vorm van extra middelen ten goede komt aan de grote steden en daarmee de eigen inzet verzwakt in de lokale en regionale economische markt en van het openbaar bestuur op dat niveau. Het gaat om een aanvulling bovenop die inzet, waardoor een kwaliteitsontwikkeling mogelijk wordt gemaakt die zonder die aanvulling onmogelijk gerealiseerd had kunnen worden. Hierbij is de internationale positionering van de grote steden en de grootstedelijke gebieden het doorslaggevende criterium.

Voor een dergelijk accommoderend beleid behoort eerst het regionaal-economisch beleid in voornoemde zin te worden aangepast en vervolgens expliciet op de grootstedelijke gebieden te worden gericht. Een eerste - zij het nog bescheiden - begin lijkt hiervoor gemaakt in de nieuwe nota van het regionaal economisch beleid voor de periode 1991-1994: 'Regio's zonder grenzen'. Voor de grootstedelijke gebieden wordt daarin, evenals voor de overige regio's, een voorwaardenscheppende beleid nieuwe stijl ingevoerd dat primair als structuurversterkend is bedoeld. Hierbij is de internationale concurrentiepositie een belangrijk ijkpunt. In de projectmatige ondersteuning staan de bedrijfsterreinen en de bedrijfsomgeving voorop ${ }^{37}$. Dit nieuwe beleid kan worden beschouwd als de eigentijdse opvolger van het voorwaardenscheppend beleid in de periode 1981-1988, dat in 1988 voor de grote steden werd opgeheven en waarvan de betreffende gelden werden overgebracht naar de algemene uitkering van het Gemeentefonds. Voor een verdere versterking van dit structureel regionaal stimuleringsbeleid voor de grote steden en de grootstedelijke gebieden, met vooral effecten op de middellange en lange termijn, kan overigens veel geleerd worden van het Westduitse regiobeleid, dat in een recente OECD-studie juist 
vanuit het oogpunt van deze structuurversterking ten voorbeeld wordt gesteld $^{38}$.

Naast het spoor van specifiek regionaal-economisch beleid voor de grootstedelijke gebieden dient ook het spoor van het economisch structuurbeleid te worden benut. Dit komt erop neer dat, als binnen economische sectoren in de grootstedelijke gebieden de behoefte kenbaar wordt gemaakt aan ondersteunende infrastructuur, deze als een nationaal economisch belang voor nationale verantwoordelijkheid en rekening wordt genomen, voorzover de betrokkenen zelf deze infrastructuur niet kunnen realiseren.

Dat een dergelijke inzet een zwaardere betrokkenheid van het Rijk met zich meebrengt dan tot nu toe in het officiële beleid het geval is, wordt door de raad als onontkoombaar beschouwd tegen de achtergrond van het belang dat hier aan de orde is. Deze betrokkenheid van het Rijk heeft consequenties voor de relaties met de grote steden, in die zin dat, onverlet het complementaire karakter van die relaties, het Rijk meer dan voorheen zijn eigen herkenbare inbreng en verantwoordelijkheid heeft. Het gaat bij deze nieuwe zichtbare betrokkenheid primair om accommoderend beleid, waarbij het Rijk die strategische voorzieningen voor zijn rekening en verantwoordelijkheid neemt, die in de internationale verhoudingen tussen grootstedelijke gebieden essentieel blijken en die niet door marktpartijen en grootstedelijke besturen (alleen) gedragen kunnen worden.

Een belangrijk aandachtspunt bij de ontwikkeling van een dergelijk beleid is dat in het kader van de Europese Gemeenschap aan zowel het regionaal sociaal-economisch als aan het structuurbeleid strakke grenzen zijn gesteld om oneigenlijke concurrentieverhoudingen te voorkomen, zeker als vanaf 1993 binnen één Europese markt moet worden geopereerd. Al op dit ogenblik treedt de Europese Gemeenschap harder op, zoals onlangs bleek bij haar reactie op steunbeleid van de deelstaat Baden-Württemberg bij een vestiging van Mercedes-Benz. Van de andere kant lijkt het niet reëel er van uit te gaan dat binnen de ene markt van de Europese Gemeenschap de onderscheiden nationale staten niet in hun eigen grootstedelijk 'kapitaal' zullen blijven investeren, zoals ze nu al bedekt of openlijk en op veel manieren doen.

De nu vereiste lokaal/regionale beleidsinzet komt neer op een duidelijke ombuiging ten opzichte van de huidige aanpak. Sinds een aantal jaren zijn de grote steden zich beter bewust geworden van de mogelijkheden om via een gericht beleid te werken aan de verbetering van de economische structuur van hun stad. De crisis aan het begin van de jaren ' 80 , die juist ook de grote steden zo zwaar trof, ging gepaard met een veel terughoudender opstelling van de kant van de nationale overheid. Deze houding was terug te voeren op financiële - er moest stevig bezuinigd worden - en op ideologische argumenten - Keynesiaans-geïnspireerd beleid werkte niet, deregulering was veelbelovend en van industriepolitiek wilde men ook niets meer weten. De steden werden aldus gedwongen om voor de snel groeiende sociale problematiek, stagnerende groei en hoge werkloosheid, zelf een oplossing te vinden. Dit heeft geresulteerd in de ontwikkeling van een aantal initiatieven, waarbij de steden zelf poogden deze negatieve trend te keren, overwegend via relatief grootschalige projecten, zoals de nieuwbouw van het stadhuis en de renovatie van de binnenstad in Den Haag, de plannen Kop van Zuid en Noordrand voor Rotterdam, het plan IJrand voor Amsterdam enzovoort. In al deze plannen werd uitgegaan van een gecombineerd optrekken van de particuliere en de private sector. Beide partijen

\footnotetext{
38] Het Westduitse regionaal-economisch beleid beantwoordt het meest aan een lange termijn ontwikkelingsbeleid, niet alleen voor landelijke maar ook voor stedelijke regio's. Zie: Organisation for Economic Cooperation and Development, Regional policies in Germony; Paris, OECD, 1989.
} 
zouden zich verplichten bepaalde investeringsprojecten te realiseren. Al deze plannen waren er uiteindelijk op gericht de vestigingsvoorwaarden in de grootstedelijke gebieden te verbeteren, om aldus andere bedrijven er toe over te halen ook hier te gaan investeren. Hoe waardevol en relevant ook - ze waren bij het herstel een belangrijke indirecte impuls -, dergelijke plannen betroffen meestal slechts een bepaald gebied of bepaalde bedrijfsklassen, zonder dat duidelijk was dat juist daar de grootste problemen waren, respectievelijk dat de meest gunstige uitkomsten daar te verwachten zouden zijn.

Het gaat meer in het algemeen in het grootstedelijk economisch beleid om een benadering waarin het economisch potentieel zelf centraal staat, maar dan niet vanuit een korte-termijnopbrengst maar vanuit een ontwikkelingsperspectief op langere termijn. Een dergelijke benadering zal in de eerste plaats recht moeten doen aan: a) de dynamiek van nieuwe grootstedelijke zwaartepunten en formaties in een open en zich internationaliserende economie, hetgeen een steeds opnieuw snel, flexibel en alert reageren impliceert vanuit de grootstedelijke regio's in nauwe relatie met de nationale economie en b) het steeds meer verbonden zijn van de grootstedelijke economie met de randgemeenten binnen de grootstedelijke regio's en met de omliggende regio's en steden; dit laatste noopt tot een open grootstedelijk regionaal beleid, opnieuw in nauwe relatie met de nationale economie.

Het economisch beleid in de meer rechtstreekse betekenis, zowel vanuit nationaal als vanuit lokaal/regionaal niveau, is geschakeerd en gedifferentieerd: stimulering van investeringen, exportbevordering, impulsen voor innovatie en voor technologie-ontwikkeling/toepassing, bevordering van ondernemerschap, maar ook het beschikbaar stellen van de benodigde infrastructuur (fysieke infrastructuur: bedrijfshuisvesting, verkeersverbindingen, de kwaliteit van het woon-, werk-en leefmilieu in de ruimste zin) en minder materiële varianten: hoog gekwalificeerde beroepsbevolking, hoogwaardige voorzieningen enz.). In de nu volgende uiteenzetting over het grootstedelijk economisch beleid wordt dit economisch ontwikkelingsbeleid als uitgangspunt genomen, met dien verstande dat de verkeers- en vervoersinfrastructuur samen met de telecommunicatie (logistiek) als afzonderlijk beleidsspoor aandacht krijgt; dit omdat deze laatste onderdelen een eigen plaats innemen en één geheel vormen.

Een dergelijk beleid vereist een beleidsinfrastructuur die op dit ogenblik, wat het onderzoek en de voorbereiding betreft, in Nederland voor een belangrijk deel nog zal moeten worden ontwikkeld, voorzover het gaat om een gebundelde inzet in de grote stad en de grootstedelijke agglomeratie. In de Noordamerikaanse steden is een dergelijke gebundelde inzet vanaf het begin van de jaren ' 80 kenmerkend. In een aantal gevallen verkrijgt dat zelfs de vorm van strategische stadsplannen, waaraan bedrijven, instellingen en stadsbestuur gezamenlijk vorm geven op basis van het nodige onderzoek, expertise, meningsvorming en afspraken. De economische herprofilering vormt het centrale richtpunt van deze plannen. Dit geldt bij voorbeeld voor Philadelphia, Chicago en San Francisco. Bepalend in deze plannen zijn de afweging en de keuzes ten aanzien van gevoelige verhoudingen tussen economische bedrijvigheid, verkeer, stedelijk en landschappelijk schoon, milieubelasting en sociale problemen vanuit een perspectief van de sterkten en zwakten van de betreffende grote stad in internationaal verband. Een dergelijke aanpak is tot bepaalde hoogte terug te vinden in de onlangs geïnstalleerde Rotterdamse ontwikkelingsraad ROTOR.

Dit economisch beleid vergt voor alles een versterking van de relaties en bindingen in de grote stad, c.q. het grootstedelijk gebied in uiteenlopende beleidssectoren. Voorzover dit de financiële verhoudingen raakt tussen overheidsniveau, respectievelijk de financiële huishouding van de grote steden, worden 
hiervoor in hoofdstuk 6 voorstellen ontwikkeld die erop neerkomen dat op dit lokaal/regionaal niveau risico's en verantwoordelijkheden van de bedrijfssector en lokale overheid meer op elkaar moeten worden betrokken dan nu het geval is. Vervolgens zullen ook meer dan tot nu toe de relaties tussen sociale problemen en economische ontwikkelingen recht moeten worden gedaan dan in het huidige beleidsklimaat, gekenmerkt door een geprononceerde bestuurlijke kloof tussen de twee 'werelden' van sociale problemen en economische ontwikkelingen, mogelijk blijkt. In dit hoofdstuk werd er al op geattendeerd dat de economische ontwikkeling steeds opnieuw tegenstellingen en achterstanden bewerkstelligt, maar anderzijds ook de middelen genereert voor 'transfers' tussen economische ontwikkelingen en sociale problemen. In hoofdstuk 4 wordt vanuit de invalshoek van sociale problemen op deze samenhang teruggekomen. Over de financiële 'transfers' ter zake bevat hoofdstuk 6 de nodige uiteenzettingen en aanbevelingen. Tenslotte hebben ten aanzien van het economisch ontwikkelingspotentieel meer dan vroeger een aantal grootstedelijke voorzieningen grote betekenis, zoals onderwijs, arbeidsvoorziening en gezondheidszorg, c.q. maatschappelijke dienstverlening. Hierop wordt ingegaan in hoofdstuk 5 .

\subsection{Beleidsopgaven: economisch ontwikkelingsbeleid en infrastructuur-} beleid

\subsection{Institutionele verhoudingen}

Het bedrijfsleven is het uitgangspunt voor de vernieuwing en ontwikkeling van de economie van de grote stad. Het bestuur van de grote stad dient in deze visie aan te sluiten bij datgene wat in het bedrijfsleven tot ontwikkeling komt, zonder hiervoor in de plaats te treden of te trachten de centrale regisseur te zijn. Wel is dit bestuur een onmisbare betrokkene vanuit de verantwoordelijkheid voor de economie van de grote stad, maar ook vanuit de verantwoordelijkheid voor het algemeen belang. Als men deze eigen beleidsaandacht voor de grootstedelijke economie recht doet, kan vervolgens de afweging met andere belangen (sociale problemen, milieubelasting, congestie) het volle pond krijgen, zodat ook de bijdragen van de economie aan deze belangen uitgebuit kunnen worden. Het economisch motor zijn van de grote steden zal echter eerst en voor alles op eigen titel in de institutionele verhoudingen moeten worden vertaald.

Ook al zijn in de loop van de jaren ' 80 de grote steden meer dan daarvoor in deze richting geëvolueerd, er is nog steeds geen sprake van een gemakkelijke en soepele directe interactie van het bedrijfsleven en de grote stad, c.q. het bestuur van de grote stad. Een dergelijke interactie en een soortgelijke interactie met het Rijk waar het gaat om grootstedelijke belangen die de stad en de onmiddellijke omgeving te boven gaan, vragen om een Nederlands equivalent van de 'Civic Culture', die men in de grote steden in Noord-Amerika aantreft als een cultuur van oriëntatie op de eigen stad. Deze 'Civic Culture' is te beschouwen als een belangrijke 'omgevingsfactor' voor de bedrijvigheid en maatschappelijke activiteiten. Een dergelijke oriëntatie resulteert dan vanzelf in de nodige verbanden en strategische coalities, noodzakelijk voor het economisch ontwikkelingsbeleid en het infrastructuurbeleid. Zo treft men in Noordamerikaanse grote steden de 'Civic Societies' aan. Deze 'stedelijke genootschappen' blijken daar van eminent belang voor de wisselwerking tussen bedrijfsleven en stad. Dergelijke basisverhoudingen maken het mogelijk om naar tijd en plaats met de nodige variatie en differentiatie een eigen invulling te realiseren. Amsterdam, Rotterdam, Den Haag en Utrecht kunnen niet alleen, maar moeten in de economische sector hun eigen 'cultuur' en verhoudingen vinden.

Doorslaggevend om op dit vlak tot verdere netwerkvorming te komen, en tevens een verklaring voor de beperkte voortgang tot nu toe, lijkt vóór alles te 
zijn dat door de financiële en bestuurlijke afhankelijkheden de grote stad nu te weinig partij is voor de bedrijfssector. Wanneer men dan ook een dergelijke wisselwerking tussen bedrijfssector en grote stad in het economische beleid essentieel acht, zal voor alles deze grotere financiële en bestuurlijke aansprakelijkheid gestalte moeten krijgen. Dan kan ook het grootstedelijke bestuur met meer kracht en minder vrijblijvendheid samenwerking in de particuliere sector en samenwerking tussen de particuliere sector en het openbaar bestuur versterken en benutten. De grotere betrokkenheid op lokaal en regionaal niveau op het vlak van het grootstedelijke ontwikkelingsbeleid bindt ook meer dan voorheen op stadsgewestelijk niveau het bedrijfsleven en de onderscheiden grootstedelijke gemeenten met elkaar. Ook hier ligt een opgave, waarin met name de Kamer van Koophandel een belangrijke katalyserende werking kan hebben, zoals de stadsgewestelijke draai die de Rotterdamse Ontwikkelingsraad (ROTOR) heeft gemaakt, illustreert.

Een dergelijke binding van bedrijfsleven en lokaal/regionaal bestuur heeft als noodzakelijk complement een betrokkenheid van het Rijk, dat vanuit de economische ontwikkelingsoptiek van het bedrijfsleven in de grote steden, met infrastructuur en andere accommodaties de grote steden internationaal op niveau brengt en houdt. Dit betekent een grotere betrokkenheid van het ministerie van Economische Zaken bij de economie van de grote steden, door middel van een strategische 'support' van de economie van elke grote stad. Daarnaast zal het Rijk in de verkeers- en verbindingeninfrastructuur opnieuw de grote stad, het grootstedelijke gebied, 'apart' moeten durven bedienen, wanneer dit nodig is vanuit het nationale en internationale economische ontwikkelingsperspectief. Ook dit vraagt om een voortgezette profilering van de rijksinzet, die met het bereikbaarheidsplan voor de Randstad een goede start heeft gekregen vanuit het ministerie van Verkeer en Waterstaat.

In het volgende gedeelte zullen de twee sporen, het beleid ten aanzien ván de verkeers- en verbindingeninfrastructuur en het economisch ontwikkelingsbeleid onderdeelsgewijs worden uitgewerkt.

\subsubsection{Infrastructuur en logistiek}

De economisch-technologische ontwikkeling leidt tot een toenemende verstrengeling en afhankelijkheid van produktie en dienstverlening onderling. De logistiek (organisatie, planning, invoering en beheer van alle activiteiten rond bewerking, transport en opslag van produkten, vanaf de eerste winning als grondstof tot en met het leveren als eindprodukt aan de klant) speelt een belangrijke rol in deze netwerkvorming. De hiermee samenhangende complexiteit in de bedrijfsvoering uit zich onder meer in een groei van het transport en de zakelijke relaties, een sterke onderlinge betrokkenheid van uiteenlopende relaties en een expansie van de schaal waarop de relaties plaats vinden: een transactionele economie. Dit leidt tot een steeds grotere mobiliteitsbehoefte en een toenemend beslag op de infrastructuur. Het is van het grootste belang dat dit maatschappelijk wordt geaccepteerd en dat de consequenties hiervan worden aanvaard ${ }^{39}$.

De milieuproblematiek, maar ook de toenemende congestie staan in het centrum van de belangstelling. Terecht is er grote zorg voor het behoud en de verbetering van het woon- en leefklimaat. Juist in de grootstedelijke gebieden doet zich meer dan elders een spanning voor tussen het gegeven van mobiliteit en concentratie, verbonden met de nationale en internationale dynamiek in die gebieden en het belang van een bereikbaar, aantrekkelijk en vanuit milieuoogpunt zo min mogelijk belast gebied. Die grootstedelijke gebieden die het juiste evenwicht weten te vinden in deze spanning of die deze spanning voor een deel weten te af te leiden of te neutraliseren door terug te vallen op een

39] Dit gedeelte is gebaseerd op een in opdracht van de WRR verricht onderzoek: Logistiek, infrastructuur en de grote stad, op. cit. 
ruimer ommeland, scoren zeker internationaal gezien in de komende periode het hoogst. Dit komt ook naar voren in een studie die onlangs werd verricht in opdracht van het ministerie van Economische Zaken ${ }^{40}$.

Voorkomen moet echter worden dat de actuele intensivering van de publieke aandacht voor milieubelasting en congestie het lange-termijnbelang van de vereiste infrastructuur zodanig overstemt dat de noodzakelijke verbeteringen en investeringen achterblijven, waardoor onnodig schade wordt gedaan aan de toekomstige economische ontwikkeling. Noodzakelijke investeringen in de grootstedelijke infrastructuur dienen zoveel mogelijk te worden afgestemd op de door het milieu gestelde eisen. In een beleidsbenadering waarin de trade-off tussen deze eisen en die ten aanzien van de grootstedelijke infrastructuur voorop staat, zal het belang van de laatst genoemde tot zijn recht kunnen komen.

Dit is te meer van belang omdat, na een periode van onrustbarend achterblijvende investeringen in de Nederlandse infrastructuur, juist met het verschijnen van het Tweede Structuurschema voor Verkeer en Vervoer en de Vierde Nota over de Ruimtelijke Ordening aanzetten voor een inhaalbeweging zijn gegeven. In vergelijking met de ons omringende landen zijn zelfs de daarin aangekondigde inspanningen echter nog steeds als bescheiden te kenschetsen. Met het oog op de cruciale functie van de infrastructuur dient de centrale overheid de investeringen hierin nog sterker op te voeren dan tot nu toe het geval is, zowel in de vier grootstedelijke gebieden als op het niveau van de Randstad als geheel.

Op zich vormen investeringen in de infrastructuur al een belangrijke randvoorwaarde voor een optimale logistieke ontwikkeling in de moderne westerse economieën. In de kruispunteconomie van Nederland, met zijn functie als toegangs- en vertrekpoort van het Europese vasteland, is een dergelijke kwaliteit van de infrastructuur van nog groter gewicht. Daarenboven stelt het gespreide karakter van het economisch kerngebied, de Randstad, speciale eisen. De uitgangspositie van de grote steden in Nederland is derhalve gunstig, maar de ruimtelijke structuur stelt tevens bijzondere eisen aan de infrastructuur.

Toegankelijkheid voor het zakelijk verkeer is van wezenlijk belang voor de concurrentiepositie van de grote steden, internationaal en nationaal. Dit vereist in de eerste plaats een goede infrastructuur. Naar de mening van de raad zou de rijksoverheid zich verantwoordelijk dienen te stellen voor een infrastructuur in de grote steden en de Randstad die zich kan meten met de fysieke voorzieningen in andere westerse landen en zou zij - waar nodig - bereid moeten zijn tot additionele financiering, zoals dit elders ook geschiedt. Daarnaast kan voornoemde toegankelijkheid een nadere regulering vereisen. Maatregelen als tolheffing, spitsvignetten, rekeningrijden enzovoort beogen het particuliere woon-werkverkeer terug te dringen, ten gunste van het zakelijk verkeer. Hierbij dreigt evenwel het gevaar dat zulke maatregelen de concurrentiepositie van de grote steden ten opzichte van andere lokaties zullen schaden. Zeker in het geenszins denkbeeldige geval dat de verhoopte uitdunning van de verkeersstroom uitblijft, resulteren slechts kostenverhogingen die als het ware een extra barrière opwerpen rondom de grote steden. Dit is een potentieel bijeffect dat naar de mening van de raad in de afweging dient te worden betrokken alvorens tot maatregelen van dit type over te gaan.

De relatie tussen ontwikkelingen in de logistiek, de infrastructuur en de positie van de grote steden is een gecompliceerde. Terwijl voorheen de grote steden zelf unieke transportknooppunten waren, is dit al lang niet meer het geval.

${ }^{40}$ ] Stichting het Nederlands Economisch Instituut, Economisch-technologische ontwikkelingen en veranderende eisen in de bedrijfsomgeving; Onderzoek ten behoeve van het Ministerie van Economische Zaken; Rotterdam, NEI, 1990. 
Produktie- en transportfuncties zijn in een veel groter gebied te vinden. De grote steden domineren daarentegen in delen van de (logistieke) dienstverlening en bezetten de bovenste sport van de knooppunten-hiërarchie (de grote zee- en luchthavens). De grote steden zijn vanuit het oogpunt van de ontwikkelingen in de logistiek en infrastructuur cruciaal voor het concurrentievermogen van de Nederlandse economie ten aanzien van de 'mainports', de 'human resources' en het financieel-organisatorisch draagvlak. Dit komt er op neer dat de grote stad vooral een indirecte functionele betekenis heeft. De grote stad moet dan ook mede worden beschouwd in het perspectief van de samenhang van activiteiten over het gehele nationale territoor en zelfs in nog ruimer geografisch verband: 'mainport' èn achterland vormen samen het 'urban field' en het metroplex. Dat komt in termen van infrastructuur neer op aandacht voor de hoofdtransportassen van de Randstad naar het zuiden en naar het oosten. Daarnaast zal aan de fijnmaziger infrastructuurbehoeften binnen de grootstedelijke gebieden en tussen de grootstedelijke gebieden onderling recht moeten worden gedaan.

Ten aanzien van de huidige en de gewenste infrastructuur staan in principe drie opties open, te weten: een kwalitatieve verbetering van het rendement (hetzelfde beter aanwenden), een kwantitatieve verbetering (meer van hetzelfde) en een gedeeltelijke of algehele vernieuwing (bij voorbeeld de hoge-snelheidstrein). Veel meer dan nu het geval is, moet worden getracht de bestaande infrastructuur efficiënter te benutten. Dit vormt de eerste optie.

Behalve efficiënter gebruik binnen de bestaande kaders, moet ook substitutie met kracht worden gestimuleerd. In het bijzonder dienen telematica (thuiswerk en teleconferenties) en railvervoer te worden gestimuleerd. Dit komt nu nog onvoldoende van de grond vanwege de zwakke representatie van deze belangen in het geheel van de huidige institutionele verhoudingen, al begint voor het railvervoer, door externe druk, de situatie zich te wijzigen. Ten aanzien van telematica is er nu al veel potentieel in het bedrijfsleven, dat in de vorm van dienstverlening veel breder in te zetten zou zijn.

Op dit ogenblik domineert in de op moderne logistieke principes gebaseerde bedrijfsyoering de combinatie lucht-en wegverkeer. Voor andersoortig gebruik (woon-werkverkeer, sommige vormen van Europees vliegverkeer) zou substitutie moeten plaatsvinden naar andere vervoerssoorten. Door versterking van aantrekkelijke alternatieven in de vorm van de versterking van de rail-, telematica- en waterinfrastructuur kan de bestaande en nog te ontwikkelen luchten weginfrastructuur beter worden benut voor het door de logistiek opgelegde noodzakelijke gebruik in de moderne bedrijfsvoering. Intussen zal er in Nederland voor gewaakt moeten worden dat de vooraanstaande plaats die Schiphol als luchthaven in het internationale verkeer inneemt, behouden blijft en verder versterkt wordt als één van de Europese 'mainports' voor het intercontinentale passagiers- en goederenvervoer. Hier dient in het thans voorbereide Plan van Aanpak Schiphol en omgeving, een in dit licht aanvaardbaar compromis te worden gevonden met andere belangen, zoals milieuwaarden en concurrerende ruimtebehoeften. Iets soortgelijks geldt voor de andere 'mainport': de Rotterdamse haven. De eerste positie van wereldhaven is voor de nationale en grootstedelijke economie een strategische factor van de eerste orde. Conflicterende belangen zijn hier echter tot nu toe minder remmend voor de investeringsplannen en de vernieuwing van de haveninfrastructuur.

De 'mainports' zijn de knooppunten van het hoogste niveau, die een schaarse, derhalve unieke en onvervangbare rol spelen in de Nederlandse economie. Door de logistieke ontwikkelingen wordt de multinodaliteit, dat wil zeggen de overstap naar en het gekoppeld zijn van deze knooppunten aan andere vervoerssoorten, juist hier belangrijk. Het gaat dan om aansluiting tussen uiteenlopende vervoerssoorten als lucht-, rail-, weg-, en water- en telematica-infra- 
structuur. De aansluiting en afstemming van uiteenlopende vervoerssoorten in de 'mainports' dienen te worden gestimuleerd; in het bijzonder zullen hierbij de energie- en milieubesparende transportvormen (rail, water, telematica) moeten worden gestimuleerd. Nauw verbonden met deze infrastructuurvereisten is de ruimtelijke inrichting van het ruimere gebied om de luchthaven Schiphol, c.q. de Rotterdamse zeehaven, waar het gaat om economische activiteiten die rechtstreeks aan deze 'mainports' gekoppeld zijn. Dit betekent een inrichting en infrastructuur waarbij rekening wordt gehouden met het strategisch belang van vooral het Schiphol-centrumgebied op zich, los van het grootstedelijk gebied Amsterdam, maar wel met duidelijke bindingen en relaties met dat grootstedelijk centrum. Dit Schipholgebied dient met het oog op toekomstige ontwikkelingen, congestie en milieubelasting ruimer te worden genomen dan $\mathrm{nu}$, al zullen bedrijfsvestigingen nabij de hoofdverkeerswegen moeten worden geconcentreerd. Een dergelijke benadering is overigens in overeenstemming met ontwikkelingen bij een aantal grote luchthavens in het buitenland.

Vervolgens is er behoefte aan de opzet van een goede organisatie van en een strategische visie op de netwerkstructuur (assen en knooppunten) voor het goederenvervoer in Nederland, in het bijzonder het goederenvervoer per spoor. Dit laatste wordt steeds meer van belang in de nieuwe Europese vervoersstructuur. Dit noopt tot maatregelen om de vereiste railinfrastructuur op de kortst mogelijke termijn te realiseren (de Betuwelijn). Scheiding van de kosten van infrastructuur en exploitatie lijkt een voorwaarde voor een efficiënte organisatie van het goederenrailvervoer, met name voor de internationale verbindingen.

Een goede aansluiting van de vier grootstedelijke gebieden en van geheel verstedelijkt Nederland over de weg met het Europees achterland is zowel voor het goederenverkeer als voor het zakelijk verkeer van groot belang. De huidige verbindingen, plus de projecten opgenomen in het Tweede Structuurschema voor Verkeer en Vervoer, zijn - gegeven de noodzakelijke afweging met milieubelasting en verkeerscongestie - hiervoor een toereikende voorziening.

In vergelijking met de ons omringende landen is de railinfrastructuur binnen de grote steden (metro en stadsspoor) traditioneel zwak ontwikkeld. Relatief laat is, met name in Amsterdam en Rotterdam, een begin gemaakt met de aanleg van een bescheiden netwerk. Het succes hiervan heeft aanleiding gegeven tot uitbreiding c.q. aanleg van snelspoorlijnen. In het bijzonder is de discussie actueel in Den Haag en Utrecht. Geleidelijk wordt ook in stadsgewestelijk verband over nieuwe snelspoorlijnen gesproken, bijvoorbeeld voor het gebied tussen Den Haag en Rotterdam en voor het gebied met als as PurmerendAmsterdam-Schiphol en de as IJmond-Schiphol-Gooi. Deze schaalvergroting in de railinfrastructuur van steden naar stadsgewesten is in veel westerse grootstedelijke agglomeraties manifest. De koplopers, zoals het beroemde Bay Area Rapid Transit (BART) in San Francisco, de Parijse railinfrastructuur van metro en railverbindingen met de banlieue en de villes nouvelles rondom Parijs, tonen aan dat een investering hierin - ook daar waar deze investeringen op basis van de huidige reizigerstoestroom te hoog gegrepen lijken - op termijn een geweldige voorsprong levert in de grootstedelijke ontwikkeling.

Tegen deze achtergrond dient te worden overwogen of, aansluitend op de huidige plannen, een Randstad-rail met als zodanig herkenbaar materieel kan worden bevorderd met snelle verbindingen tussen de vier grootstedelijke gebieden en de luchthaven Schiphol. Daarvoor kan het huidige net de basisinfrastructuur bieden. Hierbij kan de geleding in een noordelijke en zuidelijke Randstadvleugel mede richtinggevend zijn. Deze railinfrastructuur dient dan tevens een optimale aansluiting op de nationale en internationale verbindingen te garanderen, ten einde dubbelinvesteringen binnen en tussen de grootstedelijke gebieden te voorkomen. Voor alles verschaft het grootstedelijk 
milieu in ons land in internationaal perspectief een bijzondere voordeelsfactor bij de ontwikkelingen in de komende periode. Een afgeleid voordeel is dat deze in eerste instantie dure infrastructuur een probaat middel is tegen de randstedelijke congestie en milieu-aantasting. De eerste verantwoordelijkheid voor een dergelijke accommodatie ligt bij de rijksoverheid, die als enige deze ingrijpende infrastructuur bestuurlijk veilig kan stellen. Voor een vlotte voorbereiding, financiering en exploitatie zou een eigen maatschappij kunnen worden opgezet, bijvoorbeeld als zelfstandig onderdeel van de NS. Een dergelijke randstedelijke railinfrastructuur brengt bovendien met zich mee dat kan worden volstaan met een beperkt aantal TGV-stations (in elk geval bij de luchthaven Schiphol). Dit resulteert dan op zijn beurt in een hoge-snelheidstreinverbinding zonder veel onderbrekingen op de tracés vanuit Frankrijk en WestDuitsland.

In de grootstedelijke gebieden zelf zal in de komende periode het accent moeten komen te liggen op het openbaar vervoer in ruimere zin. Hierbij zullen - zoals buitenlandse voorbeelden aantonen - in toenemende mate, naast de radiaalverbindingen van de centrale stad naar de randgebieden en de nevencentra, de tangentiële verbindingen (dat zijn verbindingen tussen de nevencentra en de randgebieden onderling) meer gewicht moeten krijgen. Het rapport van McKinsey \& Company uit 1989 dat hiertoe een eerste aanzet geeft is in dit opzicht nog steeds behartenswaardig, maar de eerste aandacht dient uit te gaan naar de bestuurlijke organisatie van deze stadsregionale vervoersinfrastructuur ${ }^{41}$. De grootstedelijke gebieden hebben een voldoende financieelorganisatorisch draagvlak om de noodzakelijke afstemming van de infrastructuur binnen deze stadsgewestelijke concentraties te realiseren. $\mathrm{Er}$ zal meer speelruimte moeten zijn voor een gerichte ontwikkeling en exploitatie van de gedifferentieerde vervoerssituatie en infrastructuur binnen de vier grootstedelijke gebieden. In hoofdstuk $6 \mathrm{zal}$ op de bestuurlijke vormgeving hiervan nader worden ingegaan.

Telematicavoorzieningen, opgevat als de telematica-infrastructuur en de daarbij aansluitende organisatorische en bedrijfsmatige aanpassingen, vormen een belangrijke troef voor de grote steden in de Randstad, mits zij - voortbouwend op de specifieke aard van de betrokken economische activiteiten projectmatig worden versterkt. Sommigen spreken hun bezorgdheid uit over de huidige stand van zaken in deze grootstedelijke infrastructuur en het ontwikkelingsperspectief. Anderen noemen vanuit internationaal vergelijkend oogpunt de uitrusting als geheel bevredigend. Wel blijkt uit internationaal vergelijkend onderzoek dat bij de verdere ontwikkeling een continue inzet op hoog niveau, die over een lange tijd wordt volgehouden, een eerste vereiste is, wil men althans in de pas blijven met de ontwikkelingen elders. Hiervoor is een grote mate van samenwerking vereist tussen lokale autoriteiten, projectontwikkelaars, hard- en softwareleveranciers en de PTT, zodat bedrijven die een hoogwaardige voorziening zoeken, snel en efficiënt kunnen worden bediend. Naast de teleportactiviteiten zouden ook de informaticaplatforms (RIT, ARIT in Amsterdam, PIT in Rotterdam, Infokey in Den Haag en knooppuntsystemen (INTIS) daarin een rol kunnen spelen. In aansluiting op deze institutionele basis dient de rijksoverheid binnen het technologiebeleid ruimte vrij te maken om te investeren in enkele proefprojecten die het karakter dragen van 'telematica-modelgebieden'. 


\subsubsection{Economisch ontwikkelingsbeleid}

a. Onderwijs

Onderwijs is een belangrijk strategisch mechanisme voor de ontwikkeling van de economie. In hoofdstuk 5 zal worden aangetoond dat met name in NoordAmerika, maar ook in het Verenigd Koninkrijk juist onderwijs en scholing, meer in het bijzonder het beroepsonderwijs, worden ingezet voor de economische ontwikkeling van de grote steden. Het gaat hier onder andere om de bekende 'Compact' programma's van Boston, Londen en Newcastle upon Tyne, waarin het bedrijfsleven en de scholen rechtstreeks contracten sluiten voor uitwisseling en ondersteuning, via bijscholing van leraren in het bedrijfsleven, stages voor leerlingen, garanties voor banen na scholing in curricula waarin ook het bedrijfsleven zijn inbreng heeft, enzovoort.

In ons land is Rotterdam de eerste stad die een dergelijke inzet van het onderwijs voor de economie heeft onderkend en hiervoor beleid heeft ontwikkeld. Daarbij blijkt overigens dat ons centralistisch onderwijsbestel nogal wat hindernissen en beperkingen oplevert. In hoofdstuk 5 worden aanbevelingen gedaan om de directe relaties tussen onderwijs en economie in de grote steden te versterken en daarvoor in de sfeer van differentiatie van curricula, salarissen en arbeidsvoorwaarden van het onderwijzend personeel meer ruimte te geven. Het beroepsonderwijs en in het bijzonder het lager beroepsonderwijs zouden - gelet op de problematisch lage instroom in de grote steden - een afzonderlijk vernieuwingsprogramma in nauwe samenwerking met het bedrijfsleven rechtvaardigen. Met name de vicieuze cirkel van negatieve beeldvorming en feitelijke geringe profilering van het beroepsonderwijs in de grote steden zou zo snel mogelijk moeten worden doorbroken.

Tenslotte brengen de hoogwaardige beroepskwalificaties die steeds meer vereist worden en die doorslaggevend zijn voor de kwaliteit van de grootstedelijke economie, met zich mee dat ook de positie en betekenis van het hoger en universitair onderwijs in de grote steden van steeds groter belang wordt. In hoofdstuk 5 wordt tegen deze achtergrond gesuggereerd de banden tussen de instellingen van hoger onderwijs en stad vooral bestuurlijk te versterken. Dit zou een extra impuls krijgen, als die instellingen meer ruimte wordt gegeven voor differentiatie en eigen profilering.

b. Innovatie, export, acquisitie en netwerkvorming

Uit een eerste internationale vergelijking, waarbij in het bijzonder naar WestBerlijn en Londen is gekeken, komen de volgende aspecten naar voren:

- het geheel van betrokken organisaties verschilt aanzienlijk. Zo is er in Nederland een relatief groot aantal instellingen actief met deeltaken, terwijl bijvoorbeeld in West-Berlijn de Technologie Vermittlungsagentur (TVA) voor een sterkere coördinatie lijkt te zorgen;

- in het algemeen zijn de Nederlandse grote steden minder actief op dit vlak dan de buitenlandse grote steden. Overigens blijkt dat in Nederland in andere regio's en in een aantal middelgrote steden meer activiteiten worden ontwikkeld; ${ }^{42}$

- een interessante en zeer effectieve vorm van kennistransfer is die via personen. In West-Berlijn doet men veel aan het plaatsen van hoger opgeleiden bij het midden- en kleinbedrijf;

- voor de kosten van extern advies aan bedrijven bestaan in West-Berlijn en Londen subsidieregelingen met een stedelijke component. In West-Berlijn wordt daarnaast het instrument loonkostensubsidie voor managementondersteu-

42] Dit wordt ook bevestigd in het recente onderzoeksrapport van A.H. Kleinknecht en A.P. Boot, De regionole dimensie in de Nederlandse industrie en dienstverlening; Amsterdam, Stichting voor Economisch Onderzoek, 1990. 
ning gehanteerd. In Nederland zijn op dit vlak slechts in sommige gevallen beperkte subsidies mogelijk ${ }^{43}$.

In de eerste plaats kan hier een aantal thema's worden genoemd: a) internationalisering verdient meer aandacht; kennisdiffusie en managementondersteuning zouden moeten worden ingezet om de samenwerking van bedrijven in de grote steden in Europees verband te stimuleren; b) innovatie verdient meer aandacht in die zin dat het accent in de grote steden minder op de industriële technologie ligt en meer op markt- of organisatorische innovatie betrekking heeft. Met name de innovatie in de zakelijke dienstverlening zou extern ondersteund moeten worden. Dit vergt waarschijnlijk een aanzienlijke uitbreiding van de capaciteit van de Innovatie Centra (IC's).

In de tweede plaats is in de grote steden nog meer dan elders in het land de institutionele vormgeving van kennisdiffusie en managementondersteuning aan de orde. Er is een wildgroei van intermediaire organisaties ontstaan. Elk nieuw programma leidt weer tot nieuwe verbanden. De bestaande organisaties zoals de Kamers van Koophandel, de Innovatie Centra en de Instituten voor het Midden en Klein Bedrijf (IMK) zouden de kern moeten vormen. Als deze drie onder één dak en op één adres in een ondernemershuis bij de $\mathrm{KvK}_{\mathbf{L}}$ gaan opereren wordt de overzichtelijkheid sterk verbeterd.

In de derde plaats zou gedacht kunnen worden aan de toepassing van vraagsubsidies voor kennistransfer. Te vaak wordt bij beleidsintensivering gekozen voor de aanbodkant, die dan met overheidssteun wordt uitgebouwd. In veel gevallen zijn er reeds commercieel opererende organisaties actief die in principe goed in staat zijn een bijdrage te leveren aan de gestelde doelen. Door overheidssteun de vorm van vraagsubsidie te geven kan de inschakeling van commerciële kennisbronnen worden gestimuleerd. Dit gebeurt al bij de Instiren SMO-regelingen en bij andere recente subsidiestromen voor kennisdiffusie, technologie en managementsondersteuning vanuit het ministerie van Economische Zaken.

Er is sprake van een toenemende belangstelling voor netwerkvorming tussen de betrokken organisaties en de bedrijfssector. Algemeen wordt ingezien dat goede netwerkstructuren en een effectief opereren van de relevante actoren in dit geheel een belangrijke invloed hebben op het functioneren van bedrijven en instellingen. De regionale ontwikkeling kan zodoende in de grootstedelijke gebieden in belangrijke mate worden gestuurd. De inventarisatie verwijst naar de volgende aspecten:

- West-Berlijn komt uit de vergelijking naar voren als de regio waar de structuur naar de uiteenlopende doelgroepen toe het meest overzichtelijk is;

- intergemeentelijke samenwerking blijkt zowel in de Nederlandse grootstedelijke gebieden als in de Londense regio voornamelijk neer te komen op overleg. Gezamenlijke besluitvorming, zoals die bij voorbeeld in regio's in Gelderland en Noord-Brabant voorkomt, is in de Randstad nauwelijks aan de orde;

- in Londen is men het verst met het ontplooien van ontwikkelingsacties op wijkniveau, onder andere gevoed door de wens een scherpere 'targeting' van de beleidsinspanningen te bereiken. In de Nederlandse steden neemt deze vorm van decentralisatie in belang toe. Amsterdam gaat hierin het verst met de binnengemeentelijke decentralisatie. Vertegenwoordigers van de groepen waarop het beleid zich richt, zijn echter in het algemeen niet positief over deze opzet;

- zowel in Nederland als in het buitenland streeft men er steeds meer naar het bedrijfsleven zelf een belangrijker rol te laten spelen in de ontwikkelingsacties. De indruk is dat deze betrokkenheid in West-Berlijn en Londen al groter is dan in de Nederlandse steden;

13] Dit en de volgende gedeelten zijn gebaseerd op een in opdracht van de WRR verrichte studie: C.P.A. Bartels en E.J.J. Roos, Sociaal-economische vernieuwing in grootstedelijke gebieden; WRR Voorstudies en achtergronden V70; 's-Gravenhage, SDU uitgeverij, 1990.

WETENSCHAPPELIJKE RAAD VOOR HET REGERINGSBELEID 
- beleidsintensivering komt nog te vaak neer op uitbreiding van bestaande ambtelijke organisaties en intermediaire instellingen of het opzetten van nieuwe organisaties. Hierdoor is het aantal actoren dat zich vanuit diverse posities voor ontwikkelingsacties inzet, erg uitgedijd. Vraagtekens kunnen worden gezet bij de efficiency en effectiviteit van dit bestel.

Het economisch ontwikkelingsbeleid in de Nederlandse grootstedelijke gebieden kan in de komende periode aan effectiviteit winnen als het organiserend vermogen nieuwe impulsen krijgt. Deze hebben vooral betrekking op de regionale samenwerking en de betrokkenheid van het bedrijfsleven.

Het bedrijfsleven zal een belangrijke rol moeten spelen bij de diverse onderdelen van het grootstedelijk ontwikkelingsbeleid. Hiervoor zijn al de nodige suggesties gedaan: particuliere financiering van bepaalde infrastructurele voorzieningen; grotere betrokkenheid bij de ontwikkeling, revitalisering en beheer van bedrijventerreinen; een belangrijker rol in scholings- en onderwijsvoorzieningen; een belangrijker stem en aandeel in activiteiten gericht op de bestrijding van werkloosheid. Met deze betrokkenheid wordt niet in eerste instantie gedoeld op overlegstructuren waarin het georganiseerd bedrijfsleven is vertegenwoordigd. Het gaat vooral om het betrokken zijn van individuele bedrijven bij de ontwikkelingsactiviteiten.

De directe en actieve betrokkenheid (ook in financieel opzicht) van de rijksoverheid bij dit economisch ontwikkelingsbeleid van de grootstedelijke gebieden zal zorgvuldig moeten worden bepaald. Dit om te voorkomen dat de structuurversterkende fondsen en programma's vanuit het ministerie van Economische Zaken de inzet en verantwoordelijkheden tussen bedrijfsleven en lokale/ regionale overheid op lokaal en regionaal niveau verzwakken of zelfs vervangen. De ervaringen met de structuurversterkende programma's voor de regio's Midden-Gelderland, Twente, Noord-Brabant, Zuid-Limburg (PNL) en de noordelijke provincies (ISP) bieden hiervoor het nodige lesmateriaal in positieve en negatieve zin.

\section{c. Bedrijfshuisvesting}

Uit de eerder genoemde eerste internationale vergelijking blijkt dat:

- in Groot-Brittannië een effectieve aanpak voor het ontwikkelen van nieuwe lokaties wordt gehanteerd, terwijl in Nederland wel veel plannen bestaan, maar de realisering traag verloopt;

- in elk van de vier grote steden wordt gewerkt aan het realiseren van nieuwe toplokaties. Door deze versnippering van inspanningen is het de vraag of op deze wijze een aanbod kan worden ontwikkeld dat werkelijk concurrerend kan zijn op de internationale markt;

- in Nederland minder wordt gedaan aan renovatie en sanering van verouderde gebouwen en terreinen, onder andere vanwege het ontbreken van aparte financieringsinstrumenten hiervoor;

- het instrument van het bedrijfsverzamelgebouw in de andere landen intensief wordt gehanteerd, terwijl in Nederland nog geen maximale inspanning op dit gebied bereikt lijkt te zijn.

De volgende aanbevelingen worden van deze constateringen afgeleid. In de eerste plaats zou er een duidelijker uitvoeringsstrategie voor grootschalige nieuwe lokaties moeten komen, met een expliciete aanduiding van de planning. Aansluiten bij de behoeften van specifieke marktsegmenten zal in een aantal gevallen planologisch pijnlijke keuzen ten gunste van het economisch belang vereisen. In dit verband is ook aandacht gewenst voor het ontwikkelen van bedrijvenparken met een zodanige status dat ze een positief element kunnen vormen bij acquisitiepogingen op de internationale markt. Bedrijfsterreinen met de allure van bij voorbeeld Sofia Antipolis in Zuid-Frankrijk kent de Randstad momenteel niet. Voor het handhaven van de nagestreefde 
status zal het Grondbedrijf zich bij verkopen van grond nadrukkelijk moeten laten leiden door van die status afgeleide criteria. In de huidige praktijk gebeurt dit soms te weinig. De rijksoverheid zou voor haar betrokkenheid een duidelijker prioriteitsstelling moeten hanteren. Deze zou kunnen aansluiten bij de visie die men ontwikkelt ten aanzien van het belang van de verschillende grootstedelijke gebieden vanuit het oogpunt van de internationale concurrentiepositie van Nederland.

In de tweede plaats zal er meer dan nu al gebeurt aandacht moeten zijn voor vestigingsmogelijkheden in de steden zelf. In het beleid van de betreffende gemeenten vraagt dit een duidelijke prioriteitsstelling ten koste van alternatieven als met name de woningbouw.

In de derde plaats valt er in Nederland meer te doen aan het revitaliseren van verouderde gebouwen en terreinen. De gevolgen van economische herstructureringsprocessen zullen zich immers juist bij de bedrijfshuisvesting manifesteren. Steden zullen in de toekomst meer te maken krijgen met bedrijfspanden die minder courant worden geacht en met bedrijfsterreinen die verloederen door afbraak van bestaande bedrijvigheid. Een alert optreden, door tijdig een organisatie op te zetten voor het opkopen van vrijkomende panden en deze te renoveren, is een eerste vereiste. Aanzetten hiervoor kunnen in onze grote steden gevonden worden. $\mathrm{Er}$ is echter een grotere inspanning vereist binnen de huidige financiële mogelijkheden. Naast het meer structureel aanwenden van stadsvernieuwingsgelden hiervoor, zoals in Amsterdam gebeurt, zou ook de private sector meer aandeel kunnen hebben in de financiering van renovatie en herstructurering. Buitenlandse steden, maar ook het N.V. Zeedijkproject in Amsterdam, tonen aan dat dit een reële optie is. In het kader van de herziening van het rijksbeleid ten aanzien van de stadsvernieuwing zou aansluitend moeten worden nagegaan hoe het ministerie van Economische Zaken met een eigen financiële inbreng de economische revitalisatie meer gewicht kan geven in relatie met een nieuwe opzet van stadsvernieuwing. In de Britse praktijk is er nu al een veel intensievere financiële bemoeienis van de rijksoverheid met de economische revitalisatie van de grote steden.

In de vierde plaats moet de specifieke incubatiefunctie van de stad meer in het oog worden gehouden. Dat houdt in een aantal gevallen voldoende eenvoudige en goedkope huisvesting in. Ook flexibel te huren ruimten in bedrijfsverzamelgebouwen vervullen hier een essentiële functie. Een uitbreiding en vooral spreiding over het stedelijk gebied is hier vereist, evenals een meer thematische benadering, zoals in West-Berlijn wordt aangetroffen (bijvoorbeeld het opzetten van bedrijfscentra die zich specialiseren in milieutechnologie). 


\section{Sociale problemen in de grote steden}

\section{I Inleiding}

In de grote steden hebben zich in de jaren ' 80 internationaal twee kernproblemen ontwikkeld, de concentraties van armoede en werkloosheid. In dit hoofdstuk wordt nagegaan hoe het de grote steden in Nederland in deze opzichten is vergaan, welke achtergronden hierbij een rol spelen en welke opgaven hieruit voortvloeien voor van het grootstedelijk beleid, in het bijzonder voor de institutionele context. De globale internationale trends die in hoofdstuk 2 werden aangegeven, zullen hierbij als achtergrond dienen.

In paragraaf 4.2 wordt de ontwikkeling van de inkomens en de werkloosheid geanalyseerd over een periode van dertig jaar tegen de achtergrond van demografische processen. Hierbij wordt een onderscheid gemaakt tussen de schaalniveaus van het stedelijk gebied en van Nederland. Uit deze kwantitatieve tijdreeksen komt een groeiende onevenwichtigheid naar voren van de sociale structuur in de steden gedurende de laatste vijftien jaar.

In paragraaf 4.3 wordt deze stedelijke problematiek geanalyseerd. Het gaat hier steeds om verschillende soorten belemmeringen van mobiliteit. Het betreft allereerst de ruimtelijke selecties van de sociale problemen. Er zijn grote verschillen tussen de centrale steden en de gemeenten in de stedelijke omgeving. Vervolgens wordt de sociale mobiliteit onderzocht. Hierbij gaat de aandacht naar de kwalitatieve aspecten van de stedelijke werkloosheid, naar de materiële problemen en tenslotte naar typisch stedelijke immateriële problemen. Paragraaf 4.4 rondt de analyses af met een samenvattend overzicht van opgaven voor de versterking van de sociale structuur. Hierin komt naar voren dat het sociale profiel van de Nederlandse steden internationaal gezien a-typisch is en worden de beleidsdilemma's zichtbaar waarvoor het grootstedelijk beleid in Nederland is gesteld.

In paragraaf 4.5 wordt onderzocht welke beleidsmogelijkheden er zijn. Hiertoe worden eerst de beleidsconsequenties belicht van de financiële en bestuurlijke verhoudingen, alsmede de mogelijkheden op het gebied van het ruimtelijk en het sociaal beleid. Als beleidsuitdagingen die voortvloeien uit ruimtelijke en sociale belemmeringen van de mobiliteit, komen vervolgens aan de orde: de perspectieven voor het omgevingsbeleid, het beleid inzake de huishoudens met een minimum inkomen, de beleidsmogelijkheden met betrekking tot immateriële problemen, toegespitst op het maatschappelijk werk, het beleid inzake de bestrijding van werkloosheid en tenslotte de mogelijkheden voor activering van het ondernemerschap.

\subsection{Ontwikkeling en ruimtelijke spreiding van inkomen en werkloosheid}

Zowel de omvang als de demografische samenstelling van de bevolking zijn belangrijke verklarende achtergronden voor de ontwikkelingen in de stedelijke problematiek. In deze paragraaf worden de inkomensontwikkelingen en de werkloosheidsproblemen van de stedelijke bevolking geanalyseerd tegen de achtergrond van de demografische ontwikkelingen ${ }^{1}$.

'] Bij de analyse van sociale problemen in de eerstvolgende paragrafen is herhaaldelijk gebruik gemaakt van een statistisch bronnenonderzoek dat binnen de WRR is verricht: G.J. Kronjee en M. van Wietingen, Statistisch overzicht sociale problemen in steden: tabellen en grafieken; interne notitie WRR, februari 1989.

In dit onderzoek worden de sociale ontwikkelingen over een periode van 30 jaar geanalyseerd op de volgende schaalniveaus: de grote stad, het stadsgewest (COROP-niveau), het stadsgewest exclusief de grote stad, de provincie en Nederland. In de voorliggende rapporttekst wordt de analyse grotendeels beperkt tot de centrale steden en de stadsgewesten in vergelijking tot de gemiddelde ontwikkelingen in Nederland en wordt slechts af en toe ingegaan op de overige twee schaalniveaus. 


\subsection{I.I Omvang bevolking}

De bevolking van Nederland als geheel en ook de bevolking van NoordHolland, Zuid-Holland en Utrecht laten vanaf 1960 een vrij constante groei zien. In de grootstedelijke gebieden is het beeld echter diffuus. Na een aanvankelijke vermindering groeit de bevolking van Groot-Amsterdam weer na 1984. GrootRijnmond vertoont tussen 1975 en 1988 een vrij constante groei, terwijl het bevolkingsaantal van de (in ruimtenood verkerende) agglomeratie Den Haag in deze periode ongeveer gelijk blijft. In de provincie Utrecht neemt de bevolking voortdurend toe.

Het beeld wordt duidelijker als de grootstedelijke gebieden worden gesplitst in de centrale stad en het omliggende gebied. In de loop van de jaren '60 beginnen de stedelijke centra inwoners te verliezen, Den Haag het eerst en Utrecht het laatst. Rond 1985 is er een kentering; de bevolking in de grote steden stabiliseert zich en begint zelfs, vooral in Amsterdam, weer toe te nemen. De randgebieden hebben, in tegenstelling tot de centrale steden, tussen 1975 en 1988 een constant groeiende bevolking.

De omvang van een bevolking is afhankelijk van de geboorten- en migratiesaldi. Op landelijk niveau is een geboortenoverschot de belangrijkste oorzaak van de bevolkingsgroei. In de verstedelijkte provincies en vooral in de stedelijke randgebieden draagt het geboortensaldo ook substantieel bij aan de bevolkingsomvang, met uitzondering van het randgebied van Den Haag dat een relatief oude bevolking heeft. Op stedelijk niveau is het geboortensaldo van ondergeschikt belang. Hier houden geboorte en sterfte elkaar min of meer in evenwicht en is het migratiesaldo de bepalende factor.

Wat betreft het migratiesaldo, is het nuttig onderscheid te maken tussen binnenlandse en buitenlandse migratie.

Het binnenlands migratiesaldo is in de vier grote steden al geruime tijd negatief. De grootste uitstroom heeft plaatsgevonden in het tweede deel van de jaren ' 60 en in de jaren '70. Deze massale uittocht is weliswaar in de jaren ' 80 tot stilstand gekomen, maar in alle vier grote steden blijft toch het aantal binnenlandse migranten dat vertrekt dat van de komenden overtreffen. De migratiestroom uit de grote steden lijkt zich voor een deel te richten op de directe omgeving, waar gedurende de gehele periode een positief binnenlands migratiesaldo te zien is. Veel mensen hebben zich echter nog verder gevestigd en men kan in dit opzicht misschien al spreken van één stedelijk gebied in het westen met één rand (de halfwegzone: Veluwe en Brabant).

De buitenlandse migratie vertoont over de gehele periode '73-'87 een positief saldo op alle niveaus, een enkele uitzondering daargelaten. De migrantenstroom richt zich voor een belangrijk deel op de grote steden (vooral Amsterdam) en is de afgelopen jaren zo omvangrijk dat de bevolkingsomvang van deze steden er sterk door wordt bepaald. Vanaf 1985 (Utrecht 1987) slaat door de buitenlandse migratie het negatieve migratiesaldo van de steden om naar positief. Gezien het eerder genoemde relatief geringe belang van het geboortensaldo, betekent dit in alle gevallen een omslag van een krimpende naar een groeiende bevolking, welke zich in Amsterdam het sterkst manifesteert. Voor de randgebieden is de buitenlandse migratie van ondergeschikt belang. Hier is de bevolkingsontwikkeling nagenoeg geheel afhankelijk van geboorte, sterfte en binnenlandse migratie.

\subsubsection{Bevolkingsopbouw}

\section{a. Leeftijdsopbouw}

In de periode 1961-1988 is er sprake van een ontgroening van de Nederlandse bevolking. Het aandeel van de groep 0-14-jarigen neemt in deze periode af van 30 procent van de totale bevolking tot 18,5 procent. Het aandeel van de poten- 
tiële beroepsbevolking neemt toe van 60,4 procent naar 69 procent, terwijl het aandeel van 65 jaar en ouder stijgt van 9,6 procent naar 12,5 procent. Deze ontwikkelingen in de leeftijdsopbouw zien we op alle onderzochte niveaus, zij het dat er aanzienlijke verschillen zijn. Het aandeel 0-14-jarigen ligt in de hele periode in de stedelijke gemeenten lager dan het landelijk gemiddelde. Op COROP-en provincieniveau is dit aandeel over het algemeen ook lager maar de verschillen met het landelijk gemiddelde zijn kleiner. De randgemeenten in het stedelijk gebied laten met betrekking tot deze leeftijdsgroep een verschillend beeld zien, maar in geen enkel geval wijkt het percentage 0-14-jarigen sterk af van het gemiddelde.

In 1961 heeft de potentiële beroepsbevolking (15-64 jaar) in alle vier grote steden een groter aandeel dan het landelijk gemiddelde. De relatieve groei van deze groep heeft alleen in Utrecht gelijke tred gehouden met de landelijke groei. In alle andere steden is de groei duidelijk lager. In 1988 hebben alleen Amsterdam en Utrecht nog een groter aandeel van deze leeftijdsgroep dan het landelijk gemiddelde. De stedelijke randgebieden en de provincies volgen de ontwikkelingen van de centrale steden zonder noemenswaardige afwijkingen. $\mathrm{Er}$ is in de centrale steden weliswaar sprake van een relatieve toename van de potentiële beroepsbevolking, iets wat in het kader van de werkloosheid van belang is, maar deze toename is minder dan het landelijk gemiddelde.

Het aandeel 65-jarigen en ouder is in de steden over de hele periode hoger dan het landelijk gemiddelde, met uitzondering van Utrecht over de periode 19611965. De relatieve groei van deze groep is in de steden ook hoger, waarbij met name Rotterdam en Den Haag opvallen. De randgebieden hebben een aandeel 65-jarigen en ouder dat lager ligt dan het landelijk gemiddelde. Uitzondering hierop is het randgebied van Den Haag, waar vanaf 1982 dit aandeel hoger is. Demografen verwachten een verdere veroudering van de Nederlandse bevolking. Van de bevolking van de vier grote steden verwacht men echter dat deze minder sterk zal verouderen dan de Nederlandse bevolking als geheel ${ }^{2}$. Wat dit betreft, zou de afwijking van de bevolkingssamenstelling van de steden ten opzichte van het landelijk gemiddelde dus kunnen verminderen.

\section{b. Huishoudenssamenstelling}

Wat betreft de verdeling van de stedelijke bevolking over de verschillende huishoudenscategorieën, is de situatie in de grote steden ongunstig voor het welvaartsniveau ${ }^{3}$. Mede door het hoge aandeel ouderen wonen in de steden relatief veel alleenstaanden, ruim anderhalf keer zo veel als het landelijk gemiddelde. De stijging van hun aandeel is hier groter dan het landelijk gemiddelde. Het aandeel alleenstaanden is gestegen door de veroudering van de bevolking en door echtscheidingen (die overigens sinds 1985 weer dalen). De tweedeling centrale stad-stedelijke rand is ook hier opvallend. Het aandeel alleenstaanden is in de stedelijke randgebieden in de hele periode lager dan het landelijk gemiddelde.

Het aandeel (echt)paren zonder kinderen ligt in de grote steden (met uitzondering van Utrecht) in 1977 hoger, maar in 1985 lager dan het landelijk gemiddelde. Het aantal (echt)paren mèt kinderen is over de hele periode beduidend lager dan landelijk het geval is. In de randgemeenten van het stedelijk gebied is het aandeel (echt)paren - precies omgekeerd - gelijk aan of hoger dan het landelijk gemiddelde. In de randgemeenten van Den Haag wonen echter relatief weinig (echt)paren met kinderen. Dit is een gevolg van de oudere leeftijdsopbouw van de bevolking in dit gebied.

${ }^{2}$ ] D. Op 't Veld, W. Relou en J. Starmans, 'Vergrijzing vanuit een ruimtelijk perspektief'; Beleidsanalyse, 1989, jaargang 18, nr. 2, blz. 12-21.

3] F. Knol. Bevolking en voorzieningen in de 4 grote steden; SCP-cahier, nr. 53; Rijswijk, Sociaal en Cultureel Planbur eau, 1986, blz. 85. 
Tabel 4.1 Huishoudens in de vier grote gemeenten, naar soort, 1977/1978 - 1985 (in procenten)

\begin{tabular}{|c|c|c|c|c|c|c|c|c|}
\hline Gemeente & & Jaar & $\begin{array}{r}\text { Een-pers. } \\
\text { hh. }\end{array}$ & $\begin{array}{r}\text { Niet-gez. } \\
\text { hh. }\end{array}$ & $\begin{array}{r}\text { Echtpaar } \\
\text { zonder } \\
\text { kinderen }\end{array}$ & $\begin{array}{r}\text { Echtpaar } \\
\text { met } \\
\text { kinderen }\end{array}$ & $\begin{array}{r}\text { Eénouder- } \\
\text { gezin }\end{array}$ & $\begin{array}{r}\text { Totaal } \\
\text { (abs) }\end{array}$ \\
\hline \multirow[t]{6}{*}{ Amsterdam } & Gemeente & $\mid 977 / 78$ & 28,2 & 8,4 & 24,9 & 30,9 & 7,6 & 300.000 \\
\hline & & 1981 & 39,0 & 10,4 & 19,3 & 23,2 & 7,9 & 336.800 \\
\hline & & 1985 & 49,8 & 7,8 & 15,6 & 17,4 & 9,4 & 356.500 \\
\hline & COROP exc. & 1977/78 & 16,8 & 3,0 & 23,9 & 51,6 & 4,7 & 105.700 \\
\hline & & $198 \mid$ & 19,1 & 4,7 & 21,4 & 49,4 & 5,3 & 111.800 \\
\hline & & 1985 & 25,4 & 5,4 & 22,6 & 40,9 & 5,8 & \\
\hline \multirow[t]{6}{*}{ Rotterdam } & Gemeente & $1977 / 78$ & 23,3 & 5,5 & 29,5 & 36,2 & 5,5 & 220.100 \\
\hline & & 1981 & 31,2 & 6,4 & 25,0 & 29,8 & 7,3 & 240.900 \\
\hline & & 1985 & 39,0 & 5,8 & 20,9 & 24,4 & 9,6 & 260.500 \\
\hline & COROP exc. & $1977 / 78$ & 15,3 & 2,1 & 27,2 & 51,9 & 3,6 & 202.300 \\
\hline & & 1981 & 17,6 & 4,2 & 25,0 & 46,5 & 6,8 & 226.700 \\
\hline & & 1985 & 20,8 & 5,4 & 24,5 & 43,6 & 5,7 & 248.100 \\
\hline \multirow[t]{6}{*}{ Den Haag } & Gemeente & $1977 / 78$ & 27,3 & 5,2 & 25,7 & 35,8 & 6,0 & 182.600 \\
\hline & & $198 \mid$ & 35,2 & 7,9 & 21,8 & 28,6 & 6.3 & 199.400 \\
\hline & & 1985 & 41,9 & 6,7 & 19,7 & 23,4 & 8,0 & 206.200 \\
\hline & COROP exc. & $1977 / 78$ & 17,2 & 4,0 & 25,8 & 45,0 & 7,8 & 75.500 \\
\hline & & 1981 & 19,5 & 7,0 & 23,4 & 43,2 & 7,0 & 84.200 \\
\hline & & 1985 & 25,9 & 6,9 & 25,8 & 34,9 & 6,3 & 91.900 \\
\hline \multirow[t]{6}{*}{ Utrecht } & Gemeente & 1977/'78 & 31,0 & 7,8 & 20,9 & 36,9 & 3,4 & 92.000 \\
\hline & & 1981 & 40,3 & 5,7 & 20,5 & 28,8 & 4,4 & 100.100 \\
\hline & & 1985 & 44,3 & 7,9 & 17,4 & 23,2 & 7,2 & 107.500 \\
\hline & COROP exc. & $1977 / 78$ & 16,4 & 4,3 & 25,4 & 49,7 & 4,2 & 204.000 \\
\hline & & 1981 & 18,9 & 5,3 & 23,1 & 47.5 & 5,1 & 226.500 \\
\hline & & 1985 & 25,4 & 4,7 & 21,3 & 41,8 & 6,7 & 263.900 \\
\hline \multirow[t]{3}{*}{ Nederland } & & $1977 / 78$ & 17,9 & 4,4 & 24,9 & 47,7 & 5,1 & 4.718 .700 \\
\hline & & 1981 & 22,1 & 5,6 & 22,7 & 43,3 & 6,0 & 5.111 .100 \\
\hline & & 1985 & 27,5 & 5,3 & 21,6 & 38,7 & 6,8 & 5.565 .300 \\
\hline
\end{tabular}

Bron: CBS, Woningbehoeftenonderzoek 1977/1978; Deel $1 \mathrm{t} / \mathrm{m} \mathrm{4B}$, 's-Gravenhage, Staatsuitgeverij, $1980 \mathrm{t} / \mathrm{m} 1982$.

CBS, Huishoudens 1981; 's-Gravenhage, Staatsuitgeverij, 1985.

CBS, Huishoudens 1985;'s-Gravenhage, Staatsuitgeverij, 1988.

Het aantal éénoudergezinnen neemt in de bestudeerde periode met meer dan de helft toe. De éénoudergezinnen zijn in de steden sterk vertegenwoordigd. In de hele periode (Utrecht alleen in 1985) is hun aandeel in de steden hoger dan het landelijk gemiddelde. Recentelijk neemt deze groep in de steden zelfs sterk toe. De randgemeenten van het stedelijk gebied laten een sterk wisselend beeld zien ten aanzien van het aandeel éénoudergezinnen. De provincies nemen een tussenpositie in. De concentratie van éénoudergezinnen in stedelijke kernen is een internationaal verschijnsel ${ }^{4}$. Het aandeel éénoudergezinnen zal vermoe-

4] A. Alexandre \& L. Macfarlane, 'The city reborn'; The OECD Observer, augustus/september 1988, nr. 153, blz. 26-29. 
delijk in de naaste toekomst niet verder groeien. Het aantal echtscheidingen daalt, als gezegd, sinds 1985. Dit neemt niet weg dat door migratie de concentratie van éénoudergezinnen in steden wel kan toenemen.

Eénoudergezinnen hebben een relatief laag welvaartsniveau. Ruim een derde leeft op, of beneden, het minimumniveau en vijf-zesde van alle hoofden van éénoudergezinnen heeft geen inkomen uit betaalde arbeid. In veel landen concentreert de armoede zich steeds meer bij vrouwen en kinderen, mede als gevolg van het gestegen aantal éénoudergezinnen. Het financiële probleem is in éénoudergezinnen niet het enige. De huisvesting is dikwijls beneden de maat en jongeren uit deze gezinnen leveren relatief slechtere schoolprestaties en zijn langer werkloos ${ }^{5}$. Hoofden van éénoudergezinnen hebben weinig kans op verbetering van hun positie. Uit een onderzoek onder twaalf sociale diensten blijkt dat 30 procent van de bijstandscliënten die langer dan twee jaar een uitkering ontvangen, vrouwen zijn die aan het hoofd staan van een éénoudergezin ${ }^{6}$.

c. Allochtonen/autochtonen

Een belangrijk demografisch gegeven in verband met het ontstaan van sociale problemen in de steden is het aandeel personen uit etnische minderheden. Hun aandeel stijgt licht in Nederland, maar sterk in de grote steden. Amsterdam spant hierbij de kroon. Een vijfde van de Amsterdamse bevolking kan nu tot de allochtonen worden gerekend, terwijl dit verhoudingscijfer voor geheel Nederland een twintigste is.

Als de andere geografische niveaus in de analyse worden opgenomen, komt een patroon naar voren dat ook bij andere gegevens te herkennen is. Het aandeel allochtonen is in de grote gemeenten zonder uitzondering hoger dan het landelijk gemiddelde. In de randgebieden daarentegen is hun aandeel beduidend lager, met uitzondering van het aandeel Turken in Groot-Rijnmond. In de grootstedelijke gebieden als geheel en in de verstedelijkte provincies ligt het aandeel allochtonen over het algemeen wat boven het landelijk gemiddelde.

Nederland zal naar verwachting in de nabije toekomst blijvend een immigratieland zijn, waarbij het aandeel van mensen met minder kansen op de arbeidsmarkt aanzienlijk zal zijn (WRR, 'Allochtonenbeleid', 1989). Dit heeft uiteraard vooral gevolgen voor de grote steden, waar immers de buitenlandse immigratie is geconcentreerd. Deze verwachting is in het bijzonder van belang voor de gemeente Amsterdam, die tot nu toe de grootste aantrekkingskracht voor immigratie uit het buitenland blijkt te hebben.

\subsubsection{Inkomens}

Uit een analyse van de inkomensstatistieken over de periode 1960-1984 blijkt dat de gemiddelde inkomens, zowel per inkomenstrekker als per inwoner, eerst zijn gestegen en vervolgens zijn gedaald. Tussen de verschillende regionale niveaus en tussen de steden onderling zijn er echter aanzienlijke verschillen. Tabel 4.2 bevat de meest recente gegevens van de inkomenstrekkers. Het CBS heeft in 1989 een nieuw - voortaan vijfjaarlijks - onderzoek gedaan, waarvan de resultaten naar verwachting in 1992 worden gepubliceerd.

In 1960 hebben de inkomenstrekkers in de vier grote steden een gemiddeld inkomen dat in de buurt ligt van het landelijk gemiddelde. In Utrecht is het inkomen iets lager, in de andere drie gemeenten is het zelfs hoger. Het pro-

5] J.J. Latten, 'Jongeren in éénoudergezinnen'; Bevolking en gezin, 1984, nr. I, blz. 25-41.

6] I. Schoemakers-Salkinoja e.a., De Gemeentelijke Sociole Dienst in perspectief; Stukwerk, nr. 48; Rijswijk, Sociaal en Cultureel Planbureau, 1988, blz 41 . 
Tabel 4.2 Gemiddelde inkomens per inkomenstrekker in de vier grote gemeenten, in de COROPgebieden exclusief de grote gemeenten en in Nederland, 1960 - 1984 (in guldens)

\begin{tabular}{|c|c|c|c|c|c|c|c|c|c|}
\hline Jaar a) & Nederland & Amsterdam & $\begin{array}{c}\text { COROP } \\
\text { exc. }\end{array}$ & Rotterdam b) & $\begin{array}{c}\text { COROP } \\
\text { exc. }\end{array}$ & Den Haag & $\begin{array}{c}\text { COROP } \\
\text { exc. }\end{array}$ & Utrecht & $\begin{array}{c}\text { COROP } \\
\text { exc. }\end{array}$ \\
\hline 1960 & 5.764 & 5.971 & - & 6.211 & . & 6.339 & - & 5.508 & 6.266 \\
\hline 1965 & 8.407 & 8.401 & - & 8.715 & - & 9.095 & - & 7.517 & 9.506 \\
\hline 1969 & 11.830 & 11.167 & 14.350 & 11.704 & 13.162 & 12.469 & 17.371 & 11.560 & 13.335 \\
\hline 1974 & 20.570 & 19.286 & 24.261 & 19.854 & 22.537 & 20.754 & 27.521 & 20.040 & 23.096 \\
\hline 1976 & 25.154 & 22.959 & 29.490 & 22.774 & 27.762 & 25.208 & 32.898 & 23.502 & 28.407 \\
\hline 1978 & 28.420 & 25.764 & 33.106 & 26.107 & 30.997 & 28.260 & 36.644 & 28.367 & 32.141 \\
\hline 1982 & 27.280 & 24.780 & 32.207 & 24.790 & 29.379 & 26.350 & 32.353 & 25.301 & 29.621 \\
\hline 1984 & 26.800 & 23.590 & 29.993 & 24.000 & 29.308 & 25.680 & 31.583 & 23.930 & 29.178 \\
\hline
\end{tabular}

Bron: WRR, op basis van CBS.

a) 1960 - 1976: totaal-inkomen inclusief belasting; 1978 - 1984: besteedbaar inkomen.

b) 1974 - 1978: exclusief Hoek van Holland.

bleem van de 'arme' steden is anders dan veelal wordt verondersteld tamelijk recent. Pas na 1974 ontstaan er opvallende verschillen tussen de gemiddelde inkomens in de steden en het landelijk gemiddelde en beginnen de demografische ontwikkelingen van de bevolkingsopbouw duidelijk door te werken in de spreiding van de inkomens. In 1984 hebben de vier grote steden een gemiddeld inkomen per inkomenstrekker dat aanzienlijk onder het landelijk gemiddelde ligt. De gemeente Den Haag heeft het hoogste gemiddelde, de gemeente Amsterdam het laagste. Opvallend zijn de uitkomsten voor de stedelijke rand: de COROP-gebieden zonder de kern van de grote gemeenten. Zonder uitzondering is het gemiddeld inkomen hier aanzienlijk hoger dan op de andere niveaus, en dat geldt voor de gehele periode. Er is in de inkomensstatistiek duidelijk een 'arme' centrale stad met een 'rijke' rand zichtbaar. Uit nadere analyse van de statistieken blijkt dat het gemiddeld inkomen van de steden en de meer welvarende randen tezamen ongeveer overeen komt met het landelijk gemiddelde. Op het stadsgewestelijk schaalniveau worden gedurende de laatste dertig jaar geen opvallende afwijkingen van het landelijk gemiddelde waargenomen.

Het gemiddeld inkomen per inwoner (inclusief kinderen) verschilt sterk met het gemiddeld inkomen per inkomenstrekker. In alle vier grote gemeenten ligt dit inkomen zelfs hoger dan het landelijk gemiddelde. Met name in Amsterdam en Den Haag is het verschil aanzienlijk. De mogelijke veronderstelling dat de hogere inkomens per inwoner in de steden verklaard zouden kunnen worden door een meer dan gemiddeld aandeel van de 'tweeverdieners' blijkt niet op te gaan. Er wonen hier zelfs relatief minder tweeverdieners ${ }^{7}$ ! De paradox van relatief arme inkomenstrekkers in de steden en toch hoge inkomens per stedelijke inwoner wordt verklaard doordat de grootstedelijke inkomenstrekker door de kleinere omvang van de huishoudens het inkomen met minder mensen hoeft te delen.

De statistische gegevens over de inkomensverdeling per verschillende klasse bevestigen de voorgaande bevindingen. In de centrale steden zijn de laagste inkomensklassen duidelijk oververtegenwoordigd, terwijl de hoogste klassen een lager aandeel dan het landelijk gemiddelde hebben. Uitzondering is Den Haag, waar de laagste klasse ondervertegenwoordigd is, terwijl de hoogste klassen een aandeel hebben dat te vergelijken is met het landelijk aandeel. In de stedelijke randgebieden is het beeld weer omgekeerd. Hier zijn de laagste

'] H.M. Kruythof, Homogenisering en diversicotie in de randstod, ontwikkelingen in woonmilieus 1981-1986; Stedelijke Netwerken, Werkstukken 15; Delft, Onderzoeksinstituut voor Technische Bestuurskunde, Technische Universiteit Delft, 1989, blz. 70. 
klassen onder- en de hoogste klassen oververtegenwoordigd. Ook hier dus weer een bevestiging van het beeld van verstedelijkte gebieden die het als geheel niet zo slecht doen, maar waarin tussen centrale stad en randgebied zeer grote verschillen bestaan.

\subsubsection{Werkloosheid}

Uit statistische gegevens over de algemene ontwikkeling van de werkloosheid tussen 1960 en 1987 blijkt dat deze tot 1970 tot de ook bij volledige werkgelegenheid normale frictiewerkloosheid is beperkt. Van 1970 tot 1980 stijgt de werkloosheid licht en ontstaan er duidelijke verschillen tussen de stad en de andere gebiedsafbakeningen. Na 1980 schiet de werkloosheid omhoog met een piek rondom 1983/1984. Daarna zet in het algemeen een herstelperiode in, maar nemen de verschillen tussen de schaalniveaus niet af.

Evenals bij de inkomens is er bij de werkloosheid een aanzienlijk verschil tussen de centrale stad en het randgebied. Werkloosheid is nog recenter dan de concentratie van de lage inkomens een stedelijk probleem geworden. Tot 1980 zijn er geen belangrijke verschillen tussen de stad en de andere gebiedsafbakeningen, maar na 1980 verslechtert de positie van de grote steden zeer snel. Bij nadere analyse blijkt dat de grootstedelijke gebieden (grote gemeenten, inclusief randgemeenten) tussen 1978 en 1983 een ontwikkeling laten zien die min of meer gelijk is aan de landelijke ontwikkeling. Daarna ligt zelfs op dit schaalniveau de werkloosheid hoger dan het landelijk gemiddelde. Uitzondering is de provincie Utrecht, waar de werkloosheid de gehele periode lager ligt dan het landelijk gemiddelde.

Tabel 4.3 Werkloosheid in de vier grote steden als percentage van de beroepsbevolking van 15-64 jaar (de potentiële beroepsbevolking), $1960-1987$

\begin{tabular}{lrrrrrrrrr}
\hline Jaar & Nederland Amsterdam & $\begin{array}{c}\text { COROP } \\
\text { exc. }\end{array}$ & & Rotterdam & $\begin{array}{c}\text { COROP } \\
\text { exc. }\end{array}$ & $\begin{array}{r}\text { Den Haag } \\
\text { COROP } \\
\text { exc. }\end{array}$ & $\begin{array}{r}\text { Utrecht } \\
\text { COROP } \\
\text { exc. }\end{array}$ \\
\hline 1960 & 0,49 & 0,58 & - & 0,28 & - & 0,79 & - & 0,60 & 0,27 \\
1965 & 0,37 & 0,49 & - & 0,21 & - & 0,47 & - & 0,39 & 0,18 \\
1970 & 0,45 & 0,73 & - & 0,43 & - & 0,75 & - & 0,41 & 0,26 \\
1975 & 2,27 & 3,08 & - & 2,07 & - & 2,46 & - & 1,74 & 1,05 \\
1977 & 2,29 & 2,92 & - & 2,92 & - & 2,85 & - & 1,87 & 1,03 \\
1979 & 2,31 & 3,02 & 0,75 & 3,47 & 1,27 & 2,71 & 0,88 & 2,14 & 1,16 \\
1981 & 4,20 & 5,37 & 1,49 & 6,09 & 2,42 & 3,78 & 1,46 & 4,10 & 2,35 \\
1983 & 8,40 & 11,82 & 3,82 & 12,46 & 5,74 & 9,85 & 4,05 & 10,37 & 5,48 \\
1985 & 7,71 & 14,33 & 3,44 & 11,66 & 5,04 & 10,79 & 3,76 & 10,60 & 4,85 \\
1987 & 6,88 & 14,44 & 3,31 & 12,14 & 4,66 & 10,49 & 3,60 & 10,66 & 4,43 \\
1989 & 3,81 & 7,68 & 1,51 & 8,27 & 2,92 & 6,14 & 1,78 & 6,02 & 2,06 \\
\hline
\end{tabular}

Bron: CBS.

a De gegevens over werkloosheid in dit jaar berusten niet meer op een registratie bij de arbeidsbureaus, maar op een CBS-steekproefonderzoek: de Enquête Beroepsbevolking.

Werklozen in grotere steden hebben een kleinere kans weer aan het werk te komen dan werk lozen in andere gebieden. Hun uitstroomkans, de kans binnen een jaar werk te vinden, is kleiner ${ }^{8}$. Dit hangt nauw samen met de persoonsgegevens van de werklozen aan de ene kant en met ontwikkelingen op de arbeidsmarkt aan de andere kant. In paragraaf 4.3 .2 wordt de kloof op de stedelijke arbeidsmarkt nader bestudeerd. 


\subsubsection{Concentratie en cumulatie van sociale problemen}

Vanouds wordt het profiel van de stedelijke bevolking gekenmerkt door afwijkingen van het landelijk gemiddelde en dit geldt zeker ook voor sociale problemen. De grotere sociale problematiek, onder andere doordat de stad minder welvarende migranten aantrekt uit landelijke gebieden of het buitenland, is niet per se verontrustend, gemeten aan de ook in het verleden gevonden patronen. Evenwel blijken de concentratie en cumulatie van sociale problemen in de grote steden toe te nemen. Wilson signaleerde soortgelijke processen in het buitenland ${ }^{9}$.

$\mathrm{Na}$ de welvaart van de jaren '60 is de economische teruggang in de jaren '70 gepaard gegaan met een onevenredige toename van de sociale problematiek in de grote steden. Nu het landelijk economisch beter gaat, is het herstel in de steden traag. De verschillen in bevolkingsopbouw van stad en rand nemen verder toe, waarbij de grootstedelijke woonomgeving kennelijk weinig aantrekkelijk wordt gevonden door bevolkingsgroepen met een gunstige arbeidsmarktpositie, waarvan velen relatief mobiel zijn en op een grotere arbeidsmarkt georiënteerd. In de grote steden stijgt het aandeel van bevolkingsgroepen met minder kansen op de arbeids- en woningmarkt. Zij zijn weinig mobiel en zoeken dicht bij huis werk, dat er daar minder is.

Binnen de grote steden neemt de tendens naar ruimtelijke segregatie en wijksgewijze concentratie van bevolkingscategorieën toe. De beperkte kansen op sociale mobiliteit in achterstandswijken leiden ertoe dat de eenzijdigheid in de bevolkingsopbouw blijft bestaan en omgekeerd kunnen door de eenzijdige bevolkingsopbouw extra belemmeringen ontstaan voor de sociale mobiliteit van de inwoners. De sociale cohesie in deze wijken is ver te zoeken. Men voelt zich niet met elkaar verbonden en van onderlinge solidariteit is nauwelijks sprake ${ }^{10}$.

Een opvallend positief punt in vergelijking met veel buitenlandse steden is wel dat de achterstandswiiken in de Nederlandse steden veelal worden gekenmerkt door een betrekkelijk gemengde bevolkingssamenstelling van autochtone en allochtone bewoners. Niettemin zijn ook hier recent indicaties die op een verschil wijzen in toegankelijkheid van het onderwijs voor allochtonen en autochtonen. Er blijkt nu in scholen in sommige stadswijken een toenemende, hoge concentratie allochtone leerlingen voor te komen. Tegelijkertijd ontwikkelt de doorstroming van allochtonen naar hoger onderwijs zich ongunstig.

Naast de ruimtelijke concentratie van problemen treedt vaak een cumulatie van verschillende soorten problemen op, waartussen meestal geen noodzakelijk maar wel een feitelijk, statistisch significant verband bestaat. In dit opzicht gaat in dit hoofdstuk de eerste aandacht uit naar de inkomenspositie en naar problemen van werk loosheid. In hoofdstuk 5 worden verbanden gesignaleerd op het vlak van onderwijs, gezondheid en de beroepskwalificatie.

\subsection{Selectieve ontwikkeling van geografische en sociale mobiliteit}

Hiervoor werd aan de hand van cijfermatige tijdreeksen vastgesteld dat de sociale structuur van de grote steden gedurende de laatste vijftien jaar in toenemende mate wordt gekenmerkt door onevenwichtigheden (ontwikkeling en samenstelling van de bevolking, het inkomenspatroon en de duurzame werkloosheid). In deze paragraaf worden nadere achtergronden van deze ontwikkeling onderzocht, waarbij de analyse wordt gericht op de selecties die optreden in de geografische en sociale mobiliteit van de stedelijke bevolking.

9] W.J. Wilson, The truly disadvantoged. The Inner City, the Underclass and Public Policy; Chicago, University of Chicago Press, 1987.

10] G. Engbersen, R. van der Veen en K. Schuyt. Moderne Armoede, Overleven op het sociaal minimum; Leiden/Antwerpen, Stenfert Kroese, 1987, blz. 144 e.v. 
Kenmerkend voor de selecties in de geografische mobiliteit zijn de grote verschillen tussen de ontwikkelingen in de sociale structuur van de steden en die van de randgemeenten in het stedelijk gebied (par. 4.3.1). Met name de kenmerken van de woningmarkt en de inrichting van de ruimtelijke omgeving worden als strategische toedelingsmechanismen beschouwd voor de selecties in de geografische mobiliteit.

De selectieve ontwikkelingen van de sociale mobiliteit hebben in de eerste plaats betrekking op de gebrekkige kwalificaties van delen van de stedelijke bevolking voor opleiding, arbeid en ondernemerschap. In paragraaf 4.3.2 worden deze beperkingen onderzocht. In paragraaf 4.3.3 komen de materiële beperkingen aan de orde van degenen die om uiteenlopende redenen niet op de arbeidsmarkt werkzaam zijn. In paragraaf 4.3.4 gaat de aandacht uit naar immateriële problemen die de kansen op maatschappelijk functioneren belemmeren.

\subsubsection{Selecties in de geografische mobiliteit}

Gedurende de laatste decennia is het beslag op de ruimte door stedelijke functies (wonen, werken, vrijetijdsbesteding, verkeer en vervoer) sterk toegenomen. Alleen al door deze groeiende ruimteconsumptie heeft een uitwaartse verplaatsing van stedelijke activiteiten plaats gevonden. In de statistieken van het bodemgebruik is duidelijk zichtbaar hoezeer de natuurlijke en agrarische bestemmingen van de ruimte - zelfs tot ver buiten de stedelijke gebieden - werden verdrongen door het urbane grondgebruik. Hierbij komt dat de oorspronkelijke stedelijke centrumfuncties door de aantrekkelijkheid van verdergelegen lokaties worden leeggezogen.

De hier geschetste ontwikkeling is al geruime tijd gaande. Deze valt als volgt nader te specificeren:

- deconcentratie: spreiding van activiteiten en bouwwerken over een groter gebied;

- verdunning: vermindering van de intensiteit van het grondgebruik;

- ontmenging: toenemende ruimtelijke scheiding van functies ${ }^{11}$.

Volgens Ottens zijn deze verschillende vormen van extensivering te herleiden tot de voortgaande bevolkingsgroei, de toenemende mobiliteit en de voortdurende verhoging van normen van ruimtegebruik ${ }^{12}$.

Als gevolg hiervan is een ontwikkeling gaande naar een circulaire in plaats van een centrische verdichting van functies. De stad is niet meer vanzelfsprekend en niet meer in alle opzichten het centrum van een groter gebied, ook al blijft de bevolking van de randgemeenten vooralsnog de voorzieningen in de stadskernen gebruiken ${ }^{13}$. Deze ontwikkeling van ruimtelijke deconcentratie is een internationaal verschijnsel, waarop plaatselijk zeer verschillende beleidsreacties volgen. De meest extreme trends treft men aan in de Verenigde Staten, waar de centrumvliedende krachten in sommige stedelijke gebieden (zoals Detroit) zich ongehinderd hebben kunnen doorzetten. Daar wordt het verschijnsel wel aangeduid als het 'doughnut-complex' - zoet aan de rand en een gat in het centrum ${ }^{14}$. Overigens laat de hevige concurrentieslag tussen de plaatselijke gemeenschappen in de VS ook voorbeelden zien van de omgekeerde ontwikkeling (bijvoorbeeld in Los Angeles).

Internationaal gezien is in de Nederlandse grootstedelijke gebieden geen sprake van extreme ruimtelijke mobiliteit. Maar het proces van ruimtelijke

"] H.F.L. Ottens, Verstedelijking en Stodsontwikkeling, een geografische analyse van aktuele problemen, tendensen en beleidsoverwegingen; Proefschrift Utrecht; Assen/Maastricht, Van Gorcum, 1989, blz. 9-10.

12] Ibid., blz. 158.

13] F. Knol, op. cit., blz. 59.

14] Visions of the modern city; Ed. by W. Sharpe and L. Vallock; Baltimore/London, Johns Hopkins University Press, 1987, blz. IS. 
extensivering en deconcentratie zet wel gestadig door, met een toenemende mate van segregatie (een ruimtelijk 'uitsorteren' van groepen en functies over het stedelijk gebied). In kringen van planologen staat de gewenste mate van spreiding en concentratie van ruimtelijke activiteiten op verschillende schaalniveaus ter discussie. Een theoretisch optimum bestaat hiervoor niet. Ook het model van geconcentreerde stedelijkheid kent zijn beperkingen. Hier komt bij dat in de praktijk de ruimtelijke ontwikkeling een eigen loop neemt, niet gestuurd maar op zijn best begeleid door het ruimtelijk overheidsbeleid.

In het licht van het voorgaande is de verwachting gewettigd dat de trend van ruimtelijke schaalvergroting van het stedelijk gebied zich zal doorzetten en dat binnen deze grotere schaal verder gedifferentieerde patronen van spreiding en concentratie zullen ontstaan. Het valt te betwijfelen of de zogeheten groene bufferzones, die kunstmatig zijn opgeworpen tegen de uitdijende stedelijke ruimte, zullen standhouden. Kansrijker is op den duur de inrichting van de echte recreatiegebieden en de bescherming van gebieden met natuurwaarde. De ruimtelijke spreiding van de woonmilieus heeft voor een deel reeds plaatsgevonden. De tendens naar de ontwikkeling van nieuwe nevencentra aan de rand van het stedelijk gebied - die in Nederland minder ver om zich heen heeft gegrepen dan in diverse andere landen, omdat de grootstedelijke gebieden hier reeds historisch uit verschillende kernen zijn opgebouwd - zal vermoedelijk eveneens doorgaan. In Nederland is deze deconcentratie van centrumfuncties vooralsnog beperkt gebleven tot de ontwikkeling van distributiecentra en diverse nieuwe centra voor de bedrijvigheid.

De uitdaging voor het ruimtelijk beleid is niet zozeer om dit diffusieproces te stoppen, maar om het - vooral in het belang van het milieu - in zo goed mogelijke banen te leiden. Bepalend voor het lot van de grote steden is hierbij vooral de kwaliteit van de selecties die zullen optreden als gevolg van de ruimtelijke verdringingsprocessen. De kernvraag is of de stad een voldoende concurrerend vestigingsmilieu biedt, dat wervend genoeg is voor de instandhouding en de mogelijke verbetering van een solide sociale en economische structuur. De kwaliteit van de ruimtelijke omgeving biedt hiertoe geen voldoende maar wel een noodzakelijke voorwaarde.

De interessante achtergrond van deze vraag is dat de steden niet dezelfde middelen kunnen inzetten voor het creëren van een aantrekkelijk vestigingsklimaat als de kleinere gemeenschappen in de rand van of buiten het stedelijk gebied. In de steden is de ruimte niet alleen schaarser, maar de grond is er doorgaans ook duurder, zeker voor de woonomgeving. In de steden bestaat meer overlast van de geconcentreerde activiteiten, de bevolking ondervindt er meer hinder van het verkeer, de milieulasten zijn er groter. De mogelijkheden beschutte woonmilieus te creëren waarin kinderen kunnen opgroeien, worden in de stad vaker bedreigd door aanspraken van andere ruimtegebruikers. Hier staat tegenover dat de steden - zowel in de directe woonomgeving als in het complete stadsbeeld - andere kwaliteiten kunnen bieden die in de wijdere omgeving niet eenvoudig zijn te realiseren. Voor een deel liggen die mogelijkheden op het vlak van het omgevingsbeleid: de directe nabijheid van de dagelijkse bestemmingen (werk, recreatie, diverse voorzieningen) en de optimale verplaatsingsmogelijkheden (fiets en openbaar vervoer) besparen tijd en geld. De kwaliteit van de stedelijke openbare ruimten, de menging en grote variëteit van functies en het mogelijke aanbod van zeer uiteenlopende woonmilieus kunnen in beginsel aan de stedelijke vestigingsmogelijkheden bijzondere kansen geven.

In de afgelopen periode zijn de kansen die het typische stedelijk milieu biedt voor het creëren van een concurrerend vestigingsklimaat, niet altijd optimaal benut. Een sterke troef, vooral internationaal gezien, is de stadsvernieuwing. Een van de grote winstpunten van de intensieve stadsvernieuwing in de Neder- 
landse steden is ongetwijfeld dat hierdoor de eenzijdige concentraties van minderheden in bepaalde stadsdelen vermeden konden worden ${ }^{15}$. Overigens varieert de kwaliteit van de vernieuwde woonmilieus van verbeeldingsrijke woonbuurten die internationaal de aandacht trekken tot te haastig gereconstrueerde buurten die niet duurzaam zijn verbeterd. Een algemene tekortkoming van de stadsvernieuwingsprojecten (die inmiddels wel wordt onderkend) betreft de eenzijdige fixatie op de woonfunctie, waardoor juist de typisch stedelijke kansen voor een gevarieerd en aantrekkelijk vestigingsmilieu werden onderbenut.

De grootste tekortkomingen in de wervingskracht van het stedelijk leefmilieu liggen echter in de stadscentra en in de naoorlogse stedelijke buitenwijken. De omgevingskwaliteit en de aantrekkingskracht van de stadscentra is in sommige steden sterk achteruit gegaan, in andere juist verbeterd. De kwaliteit van de hoofdwinkelgebieden is in Amsterdam en Den Haag zienderogen verslechterd, in Utrecht daarentegen - zoals ook in een groot aantal middelgrote steden - enorm verbeterd. De kwaliteit en de belevingswaarden van de openbare ruimten zijn door onzorgvuldig beheer en commerciële exploitatie van pleinactiviteiten achteruit gegaan in Amsterdam en in mindere mate in Den Haag. Overigens heeft Den Haag recentelijk in dit opzicht wel opmerkelijke initiatieven ontplooid ${ }^{16}$. Architectonische vernieuwingen zijn zeldzaam in de centra van Amsterdam ${ }^{17}$ en Utrecht, maar hebben daarentegen een nieuwe identiteit gegeven aan het stadshart van Rotterdam. Overigens hebben alle grote steden min of meer grootse plannen ontwikkeld voor een functionele verbetering van hun centrum.

De snelle achteruitgang van een aantal naoorlogse, 'relatief luxe' buitenwijken van de steden, zoals de Bijlmermeer in Amsterdam en het Kanaleneiland in Utrecht, vormt een extra tegenslag omdat juist hier de eenzijdigheden van de binnenstedelijke bevolkingssamenstelling voor een deel gecorrigeerd hadden moeten worden. Weliswaar worden de oude stadswijken rond de binnensteden gekenmerkt door een grote dynamiek - zo is binnen de grachtengordels af en toe sprake van 'gentrification' - in het algemeen bestaan in deze stadsdelen toch veel minder mogelijkheden om gedifferentieerde woonmilieus te ontwikkelen ${ }^{18}$. Dat is bij de renovatie van deze wijken genoegzaam gebleken. In de naoorlogse buitenwijken van de steden kon dit wel, maar de hiertoe welhaast ideale marktcondities zijn onvoldoende benut. Mede hierdoor zijn de verschillen tussen de stad en de randgemeenten scherp toegenomen.

Indicatief voor de eenzijdige relaties tussen de grote steden en de randgemeenten is de ontwikkeling van de verhouding tussen huur-en koopwoningen. Al moet worden bedacht dat in Nederland relatief veel huishoudens met een bovenmodaal inkomen in woningen in de sociale huursector zitten, de verhoudingen tussen huur- en koopwoningen zijn in de steden dermate afwijkend (vooral in Amsterdam en Rotterdam) dat deze de gegroeide eenzijdigheden treffend illustreren. In 1978 bedroeg het aandeel huurwoningen in Amsterdam 92,6 procent(!). In Rotterdam bedroeg het ruim 88 procent, terwijl landelijk toen nog 60 procent van de woningen in de huurcategorie viel. In het algemeen is er een verschuiving binnen de woningvoorraad te zien van huur- naar koopwoningen. In de centrale steden loopt deze verschuiving trager dan in de rand-

15] G. de Kleijn, Maatschappelijke effecten van stadsvernieuwing in Rotterdam; Inleiding VROM studiedag 26-10-1989.

16] Gemeente 's-Gravenhage, Noto De kern gezond; Plan voor de herinrichting van de openbare ruimte in de Haogse binnenstad; 's-Gravenhage, Gemeentedrukkerij, 1989.

17] Nieuwjaarstoespraak van de Directeur Openbare Werken en Ruimtelijke Ordening van Amsterdam Oskam, januari 1989 , Gemeente Amsterdam.

18] Amsterdom onder en boven de streep; stadsdeelcijfers op sociaal-economisch gebied rond het stedelijk gemiddelde, deel I $/ \mathrm{m}$ deel 3. Gemeente Amsterdam, Bestuursinformatie, af́deling onderzoek en statistiek, 1987 en 1988. 
gebieden. Een grote groep uit de middencategorieën in de inkomensklassen heeft hierdoor de stad verlaten.

Het aandeel kleine woningen ligt in de vier grote steden beduidend boven het landelijk gemiddelde. Dit is in mindere mate terug te zien op regionaal niveau met uitzondering van de provincie Utrecht, waar de verdeling van de grootteklassen globaal overeenkomt met het landelijk gemiddelde. In de periode 1981-1986 blijkt de woningvoorraad in de grote steden beter en duurder te worden (effect van de stadsvernieuwing). Tegelijkertijd neemt de concentratie van sociaal zwakkere bevolkingsgroepen toe. De woningvoorraad in de stedelijke randgebieden maakt ongeveer dezelfde ontwikkeling door, maar daar stijgt het sociaal-economische niveau van de bevolking ${ }^{19}$.

Tabel 4.4 Woningvoorraad in de vier grote gemeenten, de grootstedelijke agglomeraties en Nederland, $1977 / 78$ en $1985 / 86$

\begin{tabular}{|c|c|c|c|c|}
\hline Gemeente/regio & Jaar & $\begin{array}{c}\text { Abs. } \\
\text { Aantal won. } \\
(\times 1.000)\end{array}$ & $\begin{array}{c}\% \\
\text { Waarvan } \\
\text { huur }\end{array}$ & $\begin{array}{l}\text { Waarvan } \\
\text { eig.bew. }\end{array}$ \\
\hline \multirow[t]{2}{*}{ Amsterdam } & $1977 / 78$ & 274,1 & 92,6 & 7,4 \\
\hline & 1985/86 & 328,0 & 90,1 & 9,9 \\
\hline \multirow[t]{2}{*}{ Groot Amsterdam } & $1977 / 78$ & 366,9 & 83,3 & 16,7 \\
\hline & $1985 / 86$ & 453,2 & 79,1 & 20,9 \\
\hline \multirow[t]{2}{*}{ Rotterdam } & $1977 / 78$ & 208,2 & 88,6 & 11,4 \\
\hline & 1985/86 & 250.1 & 83.6 & 16.4 \\
\hline \multirow[t]{2}{*}{ Rijnmond } & $1977 / 78$ & 400,5 & 76,3 & 23,7 \\
\hline & $1985 / 86$ & 495,1 & 70,3 & 29,7 \\
\hline \multirow[t]{2}{*}{ 's-Gravenhage } & $1977 / 78$ & 168,9 & 76,4 . & 23,6 \\
\hline & 1985/86 & 185,6 & $72,6^{\circ}$ & 27,4 \\
\hline \multirow[t]{2}{*}{ Agglomeratie 's-Gravenhage } & $1977 / 78$ & 241,2 & 74,5 & 25,5 \\
\hline & $1985 / 86$ & 274,5 & 69,5 & 30,5 \\
\hline \multirow[t]{2}{*}{ Gemeente Utrecht } & $1977 / 78$ & 78,5 & 71,2 & 28,8 \\
\hline & 1985/86 & 87,2 & 70,0 & 30.0 \\
\hline \multirow[t]{2}{*}{ Provincie Utrecht } & $1977 / 78$ & 260,8 & 56,9 & 43.1 \\
\hline & $1985 / 86$ & 341,1 & 53,9 & 46,1 \\
\hline \multirow[t]{2}{*}{ Nederland } & $1977 / 78$ & $4.251,3$ & 60,8 & 29,2 \\
\hline & $1985 / 86$ & $5.283,5$ & 56,8 & 43,2 \\
\hline
\end{tabular}

Bron: WRR.

Het huisvestingsaanbod in de steden past bij de waargenomen samenstelling van de bevolking naar huishoudensstructuur en naar welvaartsniveau. Doordat de hoeveelheid woningen en het soort aanbod (eigendomsverhouding, grootte woningen) de bevolkingsopbouw beïnvloeden, dreigt hier echter een zichzelf versterkend proces. Afstemming van nieuwe woningen op de behoeften van de zittende bevolking zal de eenzijdigheden in de samenstelling van de 
bevolking nog bevorderen. In de grote steden kent de woningmarkt te weinig doorstromingsmogelijkheden. Een 'wooncarrière' binnen de steden wordt geblokkeerd door het beperkte aanbod van koopwoningen en eengezinswoningen. Zo functioneren de betere buitenwijken in Amsterdam (Bos en Lommer, de Westelijke Tuinsteden, Buitenveldert en Watergraafsmeer) veelal als 'tussenstation' op weg naar buiten voor relatiefjonge huishoudens die nog niet hun top op de woningmarkt hebben bereikt, maar die voor Amsterdamse begrippen wel op het maximale niveau zitten ${ }^{20}$.

\subsubsection{De kloof op de stedelijke arbeidsmarkt}

\subsubsection{De arbeidsmarktparadox}

De geregistreerde werkloosheid is in Nederland sterk gestegen in het begin van de jaren ' 80 en vervolgens vanaf 1984 weer gedaald, tot 14 procent aan het eind van 1988. De werkloosheid in de vier grote steden bleef in Amsterdam en Rotterdam na 1984 geleidelijk toenemen, tegen de landelijke trend in; in Den Haag fluctueerde het beeld, maar daar was uiteindelijk ook sprake van een verdere toename van werkloosheid. Alleen Utrecht volgde de landelijke daling. Eind 1988 bedraagt het aandeel van de werklozen als onderdeel van de totale beroepsbevolking in Amsterdam 23,8 procent (ruim 70.000 personen); in Rotterdam is dit 22,2 procent (ruim 50.000 personen) in Den Haag 16,5 procent (ruim 30.000 mensen) en in Utrecht 16 procent (ruim 20.000 personen). In de vier grote steden samen woont dan ruim een kwart van de geregistreerde werklozen van Nederland (27 procent). Volgens de Rapportage arbeidsmarkt waaruit deze gegevens zijn geput, heeft in Amsterdam en Rotterdam ongeveer 40 procent van de werklozen de kans om weer aan het werk te komen. In de andere twee steden ligt die kans in de buurt van het landelijk gemiddelde van 50 procent $^{21}$. Cijfers volgens deze methode worden vanaf 1989 nog slechts in absolute aantallen verstrekt. Hieruit blijkt dat recentelijk de werkloosheid in Amsterdam en Rotterdam is gedaald tot respectievelijk 68.500 personen en 48.700 personen. In Den Haag vond een stijging plaats naar 34.800 personen en in Utrecht naar 20.900 personen ${ }^{22}$.

Onder meer vanwege de bestandsvervuiling van de bovengenoemde cijfers wordt de werkloosheid inmiddels op een andere manier geregistreerd door het CBS. Voortaan worden alleen volledig baanloze, bij het arbeidsbureau ingeschreven werklozen meegeteld, die onmiddellijk beschikbaar zijn en een baan zoeken van tenminste 20 uur per week. Dan komen de cijfers veel lager uit. Dit komt neer op een aandeel werklozen in de beroepsbevolking van 11,7 procent in Amsterdam, 13,3 procent in Rotterdam, 9,1 procent in Den Haag en 8,8 procent in Utrecht ${ }^{23}$. Hierbij moet bedacht worden dat binnen de steden een grote differentiatie bestaat van de werkloosheid in de verschillende wijken.

Aan de andere kant is de ontwikkeling van de werkgelegenheid sedert de recessie begin jaren ' 80 in drie van de vier grote steden niet achtergebleven bij de landelijke ontwikkeling. De gegevens in tabel 4.5 wijzen op de 'arbeidsmarktparadox' van de grote steden (de gelijktijdige toename van zowel de werkloosheid als het aantal banen), vooral in Amsterdam.

Naast de 'officiële' werkloosheid bestaat ook een grote categorie van 'verborgen' werklozen, personen die niet bij het arbeidsbureau zijn ingeschreven. De

${ }^{20}$ ] Zie A. Buys en C. Cortie, Doorstroming en wooncarrières op de Amsterdamse woningmarkt, het continu migratieonderzoek Amsterdam; Amsterdam, Universiteit van Amsterdam en Gemeente Amsterdam, 1988.

21] Ministerie van Sociale Zaken en Werkgelegenheid, Ropportoge arbeidsmarkt 1988; 's-Gravenhage, Staatsuitgeverij, 1988, blz. 55.

22] Ministerie van Sociale Zaken en Werkgelegenheid, Kwortaalberichten Arbeidsmarkt; le kwartaal 1990, 's-Gravenhage, SDU uitgeverij, 1990, blz. 20.

${ }^{23]}$ CBS, Sociaal-Economische Moandstatistiek; maart 1990, blz. 15-17. 
Tabel 4.5 Ontwikkeling van het aantal banen in de vier grote steden en Nederland als percentage van het eerst genoemde jaar

\begin{tabular}{lrr}
\hline & $1979-1983$ & $1983-1987$ \\
\hline Amsterdam & $-5,8$ & $+7,2$ \\
Rotterdam & $-3,5$ & $+7,3$ \\
Den Haag & $-4,4$ & $-0,6$ \\
Utrecht & $-2,4$ & $+9,3$ \\
Nederland & & $+7,1$ \\
\hline
\end{tabular}

Bron: Rapportage arbeidsmarkt 1986; 's-Gravenhage, Ministerie van Sociale Zaken en Werkgelegenheid, 1986, blz. 103.

Rapportage arbeidsmarkt 1989; 's-Gravenhage, Ministerie van Sociale Zaken en Werkgelegenheid', 1989.

CBS, Statistiek Werkzame Personen; Voorburg, CBS, 1986.

inschrijving bij het arbeidsbureau is voor veel werklozen uitsluitend de sleutel voor het verkrijgen van een uitkering. Andere werklozen, bijvoorbeeld de categorie ouder dan 57,5 jaar en een deel van de herintredende vrouwen, schrijven zich in veel mindere mate in, omdat hun inkomen er niet van afhankelijk is. Daarnaast bestaat een categorie part-time werklozen die evenmin afhankelijk is van een uitkering en die sterk is ondervertegenwoordigd in de registratie van het arbeidsbureau. Tenslotte is een deel van de werkloosheid te vinden onder arbeidsongeschikten. De WAO-percentages in de grote steden liggen hoger dan elders, met een extra uitschieter naar boven voor Amsterdam.

Vanwege de gebrekkige registratie van de verschillende categorieën werklozen zou kunnen worden uitgegaan van volledige economische non-activiteit: de totale bevolkingsgroep tussen 15 en 64 jaar die nog niet of niet meer actief is op de reguliere arbeidsmarkt. Een volledig en systematisch overzicht van deze non-activiteit wordt officieel echter niet bijgehouden. Ten behoeve van dit rapport is een dergelijk overzicht gemaakt op het samengestelde schaalniveau van de vier stedelijke arbeidsmarktregio's ${ }^{24}$. Tabel 4.6 is hierop gebaseerd.

In de periode 1981-1985 is de economische non-activiteit sterk toegenomen, tot nagenoeg 50 procent van de beroepsbevolking. De percentages verwijzen naar omvangrijke bevolkingsgroepen: meer dan een half miljoen personen in de regio Amsterdam, ruim 440.000 personen in de regio Rotterdam, ruim 250.000 personen in de regio Den Haag en tenslotte ruim 300.000 personen in de regio Utrecht.

Tabel 4.6 Economische non-activiteit als percentage van de potentiële beroepshevolking, 1981 en 1985; vier grote steden

\begin{tabular}{lccr}
\hline & 1981 & 1985 & \% groei \\
\hline Amsterdam & 41.1 & 47.9 & +6.8 \\
Rotterdam & 45.0 & 48.1 & +3.1 \\
Den Haag & 42.5 & 44.8 & +2.3 \\
Utrecht & 44.8 & 48.1 & +3.3 \\
\hline
\end{tabular}

Bron: A. van den Berg, Th. van Eijk en R. Misdorp, Non-activiteit in de grootstedelijke gebieden in kaart gebracht; Werkdocumenten, W37; 's-Gravenhage, WRR, 1988, bijlage 44, tabel 3.

24] A. van den Berg, Th. van Eijk en P. Misdorp, Non-activiteit in de grootstedelijke gebieden in kaart gebracht; Werkdocumenten, W37; 's-Gravenhage, WRR, 1988. 
De totale economische non-activiteit omvat een groot aantal groepen. De grootste groep (van 11 procent in Rotterdam tot 15 procent in Utrecht) is (dag)onderwijs volgend; tussen 1981 en 1985 is de relatieve omvang van deze groep met 1 procent toegenomen. De volgende groep, het aandeel personen in de $A A W /$ WAO (80-100 procent), bedraagt 4,5 tot 7 procent. Over de periode 1981-1985 blijft het aandeel per arbeidsmarktregio redelijk constant (met uitzondering van de regio Amsterdam). Het aandeel full-time werkzoekenden steeg met 3 tot 4 procent, tot een niveau van 6 procent in Utrecht tot 8 procent in Amsterdam. Het aandeel part-time werkenden (minder dan 15 uur) steeg het minst in Amsterdam ( 0,3 procent) en het meest in Utrecht (meer dan 1 procent). Nadat enkele kleinere groepen onderscheiden zijn (zoals dienstplichtige militairen en vervroegde uittreders) resteert een grote groep overigen: 11 tot 19 procent van de totale economische non-activiteit. In absolute aantallen gaat het om aantallen tussen krap 100.000 personen in regio Den Haag en ruim 170.000 in regio Rotterdam. Waarschijnlijk betreft deze groep overwegend huisvrouwen die geen betaalde arbeid verrichten en die niet via de arbeidsbureaus werk zoeken (minder dan 10 procent van de niet-werkzame vrouwen tussen 15 en 64 jaar zoekt actief werk). De omvang van de groep overigen is - uitgezonderd Amsterdam - in de beschouwde periode overigens aanmerkelijk afgenomen (met 10 tot 20 procent).

Aan de vraagkant bestaat ook 'verborgen werkgelegenheid'. In de eerste plaats de informele werkgelegenheid, waarvan mag worden aangenomen dat $\mathrm{zij}$ vooral in de grote steden een niet verwaarloosbaar deel uitmaakt van de totale werkgelegenheid. In de tweede plaats zijn er 'verborgen vacatures'. Bij veel werkgevers bestaat een latente vraag, die om uiteenlopende redenen niet manifest is (bijvoorbeeld moeilijk vervulbare vacatures die een tijdje zijn opgeschort, of structureel overwerk door zittend personeel, of niet goed gearticuleerde vraag, of vacatures als gevolg van onvoldoende aandacht van de kant van het management voor de personeelsvoorziening).

\subsubsection{Scholing}

Tabel 4.7 Opleidingsniveau beroepsbevolking (per 1.1. 1988; in \% naar hoogst behaald diploma)

\begin{tabular}{lrrrrrrr}
\hline & $\begin{array}{r}\text { lager } \\
\text { onderwijs }\end{array}$ & $\begin{array}{r}\text { le fase } \\
\text { avo }\end{array}$ & bo & $\begin{array}{r}\text { 2e fase } \\
\text { avo }\end{array}$ & bo & $\begin{array}{r}\text { hoger } \\
\text { onderwijs }\end{array}$ & $\begin{array}{r}\text { niveau } \\
\text { onbekend }\end{array}$ \\
\hline Amsterdam & 15.8 & 9.0 & 13.9 & 7.7 & 22.5 & 23.7 & 4.9 \\
Rotterdam & 25.1 & 7.1 & 21.1 & 4.8 & 24.5 & 13.0 & 2.6 \\
Den Haag & 19.6 & 12.5 & 17.3 & 6.7 & 22.6 & 18.5 & 1.0 \\
Utrecht & 21.8 & 9.0 & 14.8 & 5.5 & 21.3 & 21.4 & 6.1 \\
Nederland & 15.6 & 7.5 & 20.5 & 4.5 & 31.2 & 16.6 & 2.1 \\
\hline
\end{tabular}

$\begin{array}{ll}\text { avo: } & \text { Algemeen vormend onderwijs } \\ \text { bo: } & \text { Beroepsonderwijs }\end{array}$

Bron: Externe Commissie Grote Stedenbeleid, Grote steden grote kansen; 's-Gravenhage, Ministerie van Binnenlandse Zaken, 1989, blz 17.

Een belangrijke achtergrond van de arbeidsmarktparadox van de grote steden wordt gevormd door onvoldoende of verkeerde scholing van de beroepsbevolking. In tabel 4.7 vindt men dit weergegeven. Het naar Nederlandse verhoudingen hoge aantal personen met uitsluitend lagere opleiding in de vier steden steekt uit boven de vraag op de stedelijke arbeidsmarkten. Opvallend is het hoge aandeel laag- en ongeschoolden in Rotterdam. Amsterdam daarentegen ligt dicht bij het landelijk gemiddelde. De vier steden hebben naar verhouding 
zeer weinig mensen met een beroepsopleiding. Vooral het tekort aan geschoolden met de tweede fase beroepsopleiding is opvallend. Tenslotte valt het profiel van de hooggeschoolde beroepsbevolking op. Terwijl Rotterdam hier bescheiden scoort, tellen Utrecht en vooral Amsterdam uitzonderlijk veel hooggeschoolden (in Amsterdam bijna een kwart van de totale beroepsbevolking).

De aanbodoverschotten op de arbeidsmarkt lopen sterk uiteen naar opleidingsniveau. Naarmate het opleidingsniveau stijgt, pleegt het aanbodoverschot lager te worden. Dit gegeven wordt grotendeels weerspiegeld in de cijfers over opleidingsniveaus van geregistreerde werkzoekenden in de grote steden. In Rotterdam heeft meer dan de helft van deze groep uitsluitend lager onderwijs gevolgd en bijna 30 procent MAVO of lager beroepsonderwijs. In Utrecht heeft 40 procent maximaal lager onderwijs (bij de groep die langer dan twee jaar werkloos is, stijgt dit aandeel tot de helft) en 20 procent lager beroepsonderwijs. In alle steden neemt de vraag naar arbeidskrachten met alleen lager onderwijs af en het aantal werklozen met uitsluitend lager onderwijs toe. De helft van alle jeugdige werklozen heeft niet meer dan lager onderwijs, en wordt daarmee als ongeschoold beschouwd. Opvallend is dat in 1987 het aandeel ingeschreven werkzoekenden met een tweede fase beroepsopleiding zeer laag was.

Afwijkend van het bovenomschreven patroon is het aandeel van de hooggeschoolde werklozen. Rotterdam volgt de tendens wel. Het relatief kleine aantal hooggeschoolden komt hier snel aan de slag. In Utrecht daarentegen is 29 procent van de geregistreerde werklozen hooggeschoold. Ook in Amsterdam is nog altijd een op elke vijf werklozen hooggeschoold. Gedeeltelijk betreft het langdurig werklozen: 8,5 procent van de langdurig werklozen in Utrecht (twee jaar en meer) heeft een academische opleiding. In de groep tot twee jaar is dit aandeel 12,5 procent. De percentages voor personen met een hogere beroepsopleiding of een halve universitaire studie liggen nog iets hoger, namelijk op respectievelijk 11,5 procent en 13,5 procent. Werkloosheid onder hooggeschoolden betreft vooral personen met opleidingen waarnaar minder vraag bestaat en die na afloop van de studie in de grote steden blijven wonen.

\subsubsection{Openstaande vraag en moeilijk vervulbare vacatures}

De kwalitatieve discrepanties tussen vraag en aanbod op de arbeidsmarkt worden nog scherper wanneer de omvangrijke pendel en de toenemende moeilijk vervulbare vacatures worden bezien ${ }^{25}$. Vanouds werken in de stad meer personen van buiten dan dat stadsbewoners buiten de stad werkzaam zijn, en dit pendelsaldo werd in de afgelopen decennia sterk beïnvloed door de uittocht van de sociale middenklassen naar de omgeving. In de vier grote steden bedraagt het pendelsaldo gemiddeld ongeveer 40 procent van het aantal personen dat in de stad werkzaam is. In Amsterdam betreft het bijna 100.000 personen, in Rotterdam 50.000 personen en in de twee overige steden ruim 40.000 personen ${ }^{26}$. Dit is een verdere aanwijzing dat werkzoekenden in de steden hun ruimtelijk voordeel, de nabijheid tot arbeidsplaatsen, kennelijk onvoldoende kunnen benutten bij gebrek aan arbeidskwalificatie.

Het aantal werklozen is vooralsnog een veelvoud van het aantal openstaande vacatures, hoewel dit aantal vacatures recentelijk snel toeneemt. Hierbij moet rekening worden gehouden wordt met het verschijnsel verborgen vacatures, waarvan het aantal bijvoorbeeld in Utrecht wordt geschat op het drievoudige van wat bij het arbeidsbureau is aangemeld. Tabel 4.8 geeft inzicht in de aantallen van beide categorieën voor de steden en voor Nederland.

25] W.J. Dercksen, P. den Hoed en E.W. van Luijk, Werkloosheidsbestrijding in Amsterdom, Rotterdom, Den Hoog en Utrecht; Werkdocumenten, W50, 's-Gravenhage, WRR, 1990.

26] CBS, Regionaal Statistisch Zakboek 1989; 's-Gravenhage, SDU uitgeverij, 1989, blz. 344. 
Uit de tabel blijkt dat ondanks de omvangrijke werkloosheid toch een aantal vacatures moeilijk kan worden vervuld. Het moeilijkst te vervullen blijken de vacatures voor hooggeschoolden, maar ook op de andere opleidingsniveaus staan vacatures open. Het gaat niet om grote aantallen, de omvang varieert van enige tientallen tot enige honderden plaatsen per opleidingsniveau, maar het bestaan hiervan verdient aandacht, niet alleen omdat hier toch kansen liggen voor werklozen, maar ook omdat onvervulbare plaatsen een signaal zijn voor een niet-optimaal functioneren van de arbeidsmarkt. De tabel bevat de meest recente gegevens toegespitst naar onderwijsniveau. Hierbij dient echter in aanmerking genomen worden dat het totale aantal vacatures sedertdien enorm is toegenomen (een stijging met ongeveer 50.000 in het laatste jaar) tot 133.800 in 1990 . Hoeveel hiervan moeilijk vervulbaar zijn, is niet bekend ${ }^{27}$.

Tabel 4.8 Vacatures ${ }^{\text {a) }}$ en moeilijk vervulbare vacatures ${ }^{\text {b) }}$ naar opleiding ${ }^{\text {c) }}$ per 31 januari 1988

\begin{tabular}{|c|c|c|c|c|c|c|c|c|}
\hline & \multicolumn{8}{|c|}{ Onderwijsniveau } \\
\hline & \multicolumn{2}{|c|}{ Basisonderwijs } & \multicolumn{2}{|c|}{ LBO/MAVO } & \multicolumn{2}{|c|}{ HAVO/NWO/MBO } & \multicolumn{2}{|c|}{ HBONO } \\
\hline & Vacat. & $\mathrm{mvv}$ & Vacat. & $\mathrm{mvv}$ & Vacat. & $\mathrm{mw}$ & Vacat. & $\mathrm{mwv}$ \\
\hline Amsterdam & 366 & $39 \%$ & 1.024 & $32 \%$ & 1.896 & $34 \%$ & 1.323 & $51 \%$ \\
\hline Rotterdam & 292 & $29 \%$ & 759 & $36 \%$ & 1.463 & $22 \%$ & 569 & $55 \%$ \\
\hline 's-Gravenhage & 291 & $43 \%$ & 372 & $27 \%$ & 978 & $46 \%$ & 549 & $51 \%$ \\
\hline Utrecht & 92 & $39 \%$ & 283 & $39 \%$ & 607 & $43 \%$ & 683 & $72 \%$ \\
\hline Nederland & 9.600 & $40 \%$ & 19.100 & $42 \%$ & 21.800 & $39 \%$ & 13.700 & $50 \%$ \\
\hline
\end{tabular}

Bron: CBS.

a) Exclusief vacatures bij de overheid, onderwijs, sociale werkplaatsen, uitzendbureaus en uitleenbedrijven.

b) Moeilijk vervulbare vacatures (mvv) als percentage van het desbetreffende aantal vacatures.

c) Indeling volgens de Standaard Onderwijs Indeling 1978.

Tenslotte is ook het wervingsgedrag van betekenis. Werkgevers beperken zich bij de werving uiteraard niet tot het lokale aanbod; in de vier grote steden negeren zij soms zelf dit lokale aanbod, vanwege het uitgesproken negatief imago van het stedelijk werklozenbestand. Onderzoek heeft uitgewezen dat bijvoorbeeld Amsterdamse bouwbedrijven al snel geneigd zijn buiten de stad personeel te recruteren ${ }^{28}$. Sprekende voorbeelden van onwillige werklozen, waarvan iedereen er wel een paar kent, overheersen het beeld van het grootstedelijke aanbod zodanig dat het 'normale' aanbod er onzichtbaar door wordt. Deze beeldvorming heeft de arbeidsbureaus in de afgelopen periode steeds meer tot een vraaggericht beleid uitgenodigd.

De verhoudingen tussen vraag en aanbod op de stedelijke arbeidsmarkten worden voorts in hoge mate beïnvloed door de regelgeving inzake sociale zekerheid en arbeidsmarkt, alsmede door het beleid dat terzake door de betrokken instanties wordt gevoerd. Deze institutionele vraagstukken komen later in dit hoofdstuk en in hoofdstuk 5 aan de orde.

$\left.{ }^{27}\right]$ CBS, Statistisch Bulletin; 12 juli 1990, blz. 2.

${ }^{28}$ ] NSS Beleidsonderzoek en Beerenschot, Van werkloosheidsbestrijding naar activerend arbeidsmarktbeleid; 's-Gravenhage, NSS Beleidsonderzoek, 1990, blz. 21 en 22. 


\subsubsection{Materiële beperkingen van de mobiliteit}

De sociale wetgeving gaat ervan uit dat mensen in beginsel in hun eigen onderhoud voorzien; slechts voorzover dit niet mogelijk is, worden materiële voorzieningen geboden voor een minimaal bestaan. Voor een aantal stedelingen zijn er echter nauwelijks mogelijkheden (weer) aan de slag te komen, ofwel omdat zij vanwege hun leeftijd, gezondheid of bijzondere maatschappelijke omstandigheden niet voor arbeid gekwalificeerd zijn, ofwel omdat in hun bijzondere geval de drempels voor toetreding tot de arbeidsmarkt te hoog zijn. Het aandeel van deze immobiele, duurzaam sociaal-afhankelijke bewoners in de grootstedelijke bevolking is in de afgelopen periode zo gestegen dat sprake is van een typisch stedelijk verschijnsel.

Zo verdubbelde het cliëntenbestand van de GSD in Rotterdam tussen 1981 en 1985 van ruim 33.000 naar 66.000 . Op dit moment is een zeer groot deel van de mensen die toen uit het arbeidsproces werden gestoten, nog steeds zonder werk. Meer dan de helft van de mensen die in Rotterdam een RWW-uitkering ontvangen, was in 1989 al circa drie jaar onafgebroken cliënt van de GSD ${ }^{29}$.

Blijkens een recent onderzoek op initiatief van de Gemeentelijke Sociale Diensten onder mensen met een minimuminkomen in 30 gemeenten, neemt de immobiliteit onder deze mensen toe. Er ontstaat een omvangrijke 'harde kern' van huishoudens met een dubbele afhankelijkheid van de overheid: voor het verkrijgen van inkomen, maar ook voor positieverbetering ${ }^{30}$.

Het ontstaan van immobiliteit blijkt ook uit een onderzoek onder de categorie 'echte minima' (huishoudens waarvan het inkomen niet meer bedraagt dan het voor het desbetreffende huishoudenstype geldende sociaal minimum). Deze inkomenscategorie is in de periode 1981 tot 1987 geregistreerd in verband met de verstrekking van een zogenoemde eenmalige uitkering. Uit dit onderzoek blijkt dat tussen 1982 en 1985 het percentage dat er in slaagt de categorie echte minima te verlaten, is afgenomen. Deze afname komt vooral voor onder éénoudergezinnen, bijstandsontvangers en de leeftijdscategorie $35-64$ jaar $^{31}$.

In verband met de toenemende immobiliteit van personen in de laagste inkomenscategorieën is het niet verwonderlijk dat zij een groeiend beroep doen op de Gemeentelijke Sociale Diensten ${ }^{32}$. In de vier grote gemeenten nemen in de korte periode 1980-1984 de aantallen uitkeringsgerechtigden in het kader van groepsregelingen (RWW- en WWV-regelingen) toe met ongeveer 200 procent. In deze gemeenten blijkt ongeveer een zevende deel van de inwoners te leven van een uitkering in het kader van de ABW, RWW, WWV, AAW of WAO. Overigens worden zulke proporties ook in een aantal kleinere steden in Nederland waargenomen. Deze kern van blijvend afhankelijken omvat verschillende categorie-en: éénoudergezinnen, allochtone bevolkingsgroepen, ouderen en werklozen waaronder ook een zeer groot deel van de arbeidsongeschikten valt. De categorie werklozen en arbeidsongeschikten overlapt de andere categorieen. Binnen deze statistische categorieën zijn er weer belangrijke individuele verschillen; niet iedereen die tot een dergelijke statistische categorie behoort, verkeert in problematische omstandigheden.

De hoogte van de uitkeringen wordt nationaal bepaald; op lokaal niveau bestaat weinig ruimte voor differentiatie. Het niveau van de uitkeringen is in Nederland relatief hoog en staat de minimaal vereiste sociale bewegingsruimte toe. De meeste gemeenten voeren in de marge van de sociale zekerheid een eigen aanvullend 'minimabeleid' dat in bijzondere noden moet voorzien.

29] A. Brand, Zorg op moot, preadvies voor de WRR, 1990 (nog te verschijnen).

${ }^{30}$ ] Gemeentelijke Sociale Dienst Rotterdam, Minimo zonder morge; Rotterdam, GSD, 1984.

$\left.{ }^{31}\right]$ M. Huizing en $H$. Erkens, 'Echte minima en de eenmalige uitkering'; in: Supplement bij de Sociaal-Economische Maondstatistiek, 1989, nr. 2, biz. 10-16.

${ }^{32}$ ] VNG. Steden vergeleken; Verslog tweede fose studie grootstedelijke problematiek; VNG-studies nr. 7, 's-Gravenhage, VNG, 1986. 
Met name bij langdurige minima kunnen relatief kleine achterstanden zich ophopen tot grotere tekorten. Bij grote inkomensafhankelijke gezinnen ontstaan vaak knelpunten en bij bejaarden die uitsluitend van de AOW moeten rondkomen, tekorten.

De bestedingsmogelijkheden op het minimale bestaansniveau worden echter slechts ten dele bepaald door het inkomen. De mate waarin zij de stedelijke voorzieningen kunnen gebruiken, hangt ook af van de kosten die hiervoor in rekening worden gebracht. Voor verschillende voorzieningen gelden inkomensprijzen (bijvoorbeeld voor maatschappelijke dienstverlening of voor kinderdagverblijven) inkomenssubsidies (zoals de subjectsubsidies in de volkshuisvesting) of inkomensheffingen (zoals de premies voor gezondheidszorg). De combinatie van deze gegevens voert tot de zogenaamde 'poverty trap': bij een inkomensverbetering moet voor sommige voorzieningen meer worden betaald, de subsidies voor andere voorzieningen dalen en heffingen moeten worden voldaan, zodat het netto-inkomen per saldo niet vooruitgaat.

Deze afroming doet zich echter vooral voor bij de actieven en vooral bij de zojuist geactiveerden. Voor de duurzaam afhankelijken is de 'poverty trap' nauwelijks van toepassing; hun inkomen stijgt niet.

Woonlasten vormen veruit de belangrijkste bestedingscategorie voor de duurzaam afhankelijke bevolkingsgroepen. Hier doet zich het probleem voor dat een groot deel van de inkomensafhankelijke stedelijke bevolking (bejaarden, éénoudergezinnen, duurzaam werklozen) huizen bewoont die erg duur zijn geworden in verhouding tot hun inkomen. Weliswaar wordt de sociale huisvesting nog steeds gesubsidieerd: via het subject (de bewoner), via het object (langlopende subsidie op de woning) en via de plaats (lokatiesubsidies en stadsvernieuwingsgelden). Maar alle subsidiestromen (nog het minst de plaatsgebonden subsidies) zijn beknot onder druk van de budgettaire problemen van de overheid. Een van de weinige manieren om de objectsubsidies te verminderen is een jaarlijkse extra verhoging van de huren. Dit is dan ook telkens gebeurd gedurende de jaren ' 80 - elk jaar een stapje, maar bij elkaar en sprong. Compensatie van deze verhogingen via de subjectsubsidies werd afgegrendeld. Ook langs andere wegen werden de woonlasten voor de subjecten met een minimuminkomen verhoogd onder druk van de sanering van de rijksfinanciën. Als gevolg hiervan bewonen vele van deze huurders huizen die ooit wel werden gebouwd voor de 'doelgroepen' waartoe zij behoren, maar die nu feitelijk te 'luxe' voor hen zijn geworden. In alle stilte is zo in de steden een ouderwets woonlastenvraagstuk gegroeid dat zijn schaduw vooruit werpt op de voltooiing van de tweede helft van de stadsvernieuwingsoperaties.

In een herhalingsonderzoek naar de ontwikkeling van de positie van de 'minima zonder marge' is becijferd dat de woonlastenquoten van groepen met het minimuminkomen van 1983 tot 1986 gemiddeld zijn gestegen van 30 procent tot 40 procent. Deze huishoudens geven nu dus 40 procent van hun maandinkomen uit aan de woonlasten. Van de onderzochte huishoudens heeft 18 procent zelfs een woonlastenquote van meer dan 50 procent. Bijna 30 procent scoort een quote tussen de 41 en $50 ; 44$ procent van de huishoudens heeft een quote van 40 of minder. Slechts 10 procent geeft minder dan een kwart uit aan woonlasten ${ }^{33}$. Het gaat hierbij om de totale woonlasten, waarin zowel de huur als de energieprijzen zijn begrepen. In de tweede helft van de jaren ' 80 verliep de ontwikkeling van de woonlastenquote veel geleidelijker, doordat weliswaar de huurlasten extra bleven stijgen, maar tegelijkertijd de energieprijzen daalden. In 1988 kwam de huurstijging voor huishoudens met een minimuminkomen gemiddeld uit op 4,4 procent. De energieprijzen daalden in dat jaar echter nog 
sterker, namelijk met 5,2 procent ${ }^{34}$. Thans bewegen de energieprijzen zich in opwaartse richting.

Een stringente beperking van de mobiliteit ligt in de vrijwel-onmogelijkheid de woonlasten te drukken door te verhuizen naar een goedkopere woning. Zulke woningen zijn in de grote steden nauwelijks beschikbaar, aangezien de vraag hiernaar het aanbod ver overtreft.

\subsubsection{Immateriële beperkingen van de mobiliteit}

De belemmeringen van de sociale mobiliteit liggen steeds vaker ook op immaterieel gebied. Eerder werd gesignaleerd dat in onze steden een groeiende categorie ontstaat die blijvend afhankelijk is van sociale zekerheid. Ook in andere landen doet dit verschijnsel zich voor. In Amerikaans onderzoek is bijvoorbeeld onder éénoudergezinnen al een derde generatie afhankelijken van bijstandsvoorzieningen aangetroffen ${ }^{35}$. Er zijn dus al kleindochters die net als hun grootmoeders permanent afhankelijk zijn van bijstand. Ook in studies over steden in het Verenigd Koninkrijk wordt gewezen op de intergenerationele afhankelijkheid waardoor een onderklasse ontstaat met een cumulatie van problemen: een laag scholingsniveau, analfabetisme, gebrek aan continuiteit in de huishoudenssamenstelling, slechte huisvesting.

In analyses van dit vraagstuk wordt echter ook vaak gewaarschuwd niet op basis van statistische vergelijkingen te besluiten tot het onvermijdelijk bestaan van armoede en van een sociale onderklasse ${ }^{36}$. Wanneer het sociaal beleid zich hierbij neerlegt en te eenzijdig de nadruk legt op het verstrekken van uitkeringen, bestaat het risico dat als neveneffect een duurzame afhankelijkheid ontstaat met alle psychische mechanismen vandien ${ }^{37}$. Er ontstaat dan een verlies aan geloof in eigen kunnen, een psychische belemmering voor toetreding tot de arbeidsmarkt, die vaak niet meer overwonnen kan worden door financiële prikkels of verplichtingen tot deelname aan het arbeidsproces ${ }^{38}$. Het lijkt wellicht humaan om aan de groepen onderaan in de orde minder eisen te stellen, maar het heeft onbedoeld negatieve maatschappelijke gevolgen, zoals de voorbeeldwerking voor anderen, en het versterkt de afhankelijkheid. Uit de internationale onderzoekstraditie komen veel signalen over deze nadelige gevolgen, niet alleen voor de samenleving maar primair ook voor de betrokkenen zelf.

Voor deze divers samengestelde categorie van mensen zal het reguliere arbeidsmarktbeleid geen uitkomst bieden. Integendeel, naarmate dit beleid zich meer richt op de bemiddeling van de relatief kansrijke cliënten, om zo de uitstroom uit de bijstand en de toestroom naar de arbeidsmarkt te bevorderen, nemen hun kansen, naar te verwachten is, verder af. Hoewel recentelijk nieuwe beleidsinitiatieven zijn genomen met het oog op de minder kansrijke cliënten tekent zich in ons land nog steeds deze verdringing af binnen het sociaal beleid en het arbeidsmarktbeleid. Niet alleen vinden hierin selecties plaats (leeftijdsgrenzen, arbeidservaring, enz.) en zijn nieuwe faciliteiten slechts bereikbaar voor een deel van de cliënten (zelfs van het nieuwe arbeidsmarktinstrument bij uitstek voor de duurzaam afhankelijken - de banenpool zal in de praktijk nog moeten blijken in hoeverre het bereikbaar wordt voor de

34] Inkomensbeleid 1990; Tweede Kamer, Vergade rjaar 1989-1990, 21 307, nrs. I-2, blz. 43-44.

35] R. Segalman, The Swiss Woy of Welfore, Lessons for the Western World; Westport, Connecticut, Praeger, 1986.

${ }^{36}$ ] - P. Townsend, 'Deprivation'; in: Journal of Social Policy, 1987, jaargang 16, nr. 2, blz. 125-146.

- M.A. Hughes, 'Concentrated Deviance and the 'Underclass' Hypothesis'; in: Journal of Policy Analysis and Management, 1989, jaargang 8, nr. 2, blz. 274-282.

${ }^{37}$ ] R.H. Haveman, 'New Policy for the New Poverty'; Challenge, september/oktober 1988, jaargang 31, nr. S, blz. 27-36.

${ }^{38}$ ] T.J. Kane, 'Giving Back Control: Long-Term Poverty and Motivation'; in: Sociol Service Review, september 1987, jaargang 61, nr. 3 , blz. 405-419. 
beoogde categorie), maar ook worden de moeilijk bereikbare groeperingen niet meer aangesproken op het normatieve vereiste om in het eigen bestaan te kunnen voorzien. $\mathrm{Zo}_{0}$ ontstaat een piramidevormige orde in het sociaal beleid. Bovenaan staan de jonge veelbelovende autochtonen, voor wie de meeste beleidsinstrumenten bestaan en aan wie ook eisen worden gesteld. Onderaan staan de onbemiddelbaren, de oudere werklozen en arbeidsongeschikten, vrouwelijke hoofden van éénoudergezinnen en de eerste generatie allochtone werklozen. Het zijn met name deze categorieën die de vraag naar individuele hulpverlening doen toenemen. $\mathrm{Zij}$ zoeken hulp voor alle soorten problemen variërend van huis-, tuin- en keukennoden, zoals gebrekkige huisvesting en het maken van schulden tot aan moeilijk oplosbare problemen in de psycho-sociale sfeer, zoals eenzaamheid en labiele identiteit ${ }^{39}$.

Deze individuele hulpverlening is meestal in handen van het particulier initiatief, weliswaar gesubsidieerd door de overheid, maar traditioneel ondergebracht bij instanties met een zelfstandige verantwoordelijkheid ${ }^{40}$. Vooral de kerken spelen een dominante rol in de geschiedenis van de hulp. Hoewel ze ook altijd de armoede benaderd hebben als een materieel vraagstuk, hebben ze toch meestal het gewicht gelegd bij de morele kant van dit verschijnsel. Het gedrag van de armen was een moreel vraagstuk en de plicht om je ermee in te laten was een christelijke plicht. Het lijkt erop dat de hulpzoekenden de kerken in de grote steden weer hebben gevonden, getuige de ervaringen van enkele centrumkerken. (Pauluskerk in Rotterdam o.a.).

\subsection{Samenvatting van opgaven voor de sociale problematiek}

$\mathrm{Na}$ de voorgaande analyses is het mogelijk om de balans op te maken van de sociale problemen in de Nederlandse steden. Als globaal ijkpunt dienen hierbij de internationale trends uit hoofdstuk 2 . De welvaart en de sociale voorzieningen zijn in Nederland zo hoog dat men een internationale vergelijking van de stedelijke problemen met een zeker vertrouwen tegemoet zou kunnen zien. Toch moet nu worden vastgesteld dat de sociale ontwikkelingen in de steden een zeer gedifferentieerd beeld opleveren.

Wat betreft de twee grote sociale vraagstukken in de jaren ' 80 - de werkloosheid en de armoede - hebben de sociale voorzieningen in de Nederlandse steden beter stand gehouden dan in de meeste vergelijkbare landen. De verzorgingsarrangementen die voor deze problemen onder gunstiger omstandigheden in het leven waren geroepen, bleken in dit opzicht solide.

De oorzaken van de problemen namen echter in scherpte toe. De sociale structuur van de steden is in deze periode verzwakt. Dit is een groot verschil met vergelijkbare steden in landen die al eerder stuitten op de grenzen van het gangbare beleid en die derhalve eerder mogelijkheden moesten zoeken om de sociale structuur te versterken.

De economische non-activiteit van de Nederlandse beroepsbevolking is traditioneel hoog. Vanaf het midden van de jaren '70 ontstond echter in de grote steden een nieuwe concentratie van afhankelijke huishoudens en de toename van de werkloosheid is, in tegenstelling tot de landelijke situatie, na 1984 niet of nauwelijks afgezwakt.

De concentratie en cumulatie van sociale problemen hebben hier een eigen dynamiek, die een soepele aanpassing aan de veranderende economische eisen

${ }^{39}$ ] E. Hueting en R. Ney, Plaats en betekenis van de sociale zorg in de grootstedelijke gebieden in historisch en beleidsmatig perspectief, Preadvies voor de WRR, 1989 (nog te verschijnen) en W.B.A.M. Melief, Functie en plaats van het maatschappelijk werk in het geheel van de grote stad, Preadvies voor de WRR, 1990 (nog te verschijnen).

40] W.A. Fransen, De institutionele traditie van het maatschappelijk werk in Nederland; preadvies voor de WRR, 1990 (nog te verschijnen). 
bemoeilijkt. Ook bij de verzwakking van de sociale structuur door demografische ontwikkelingen en selecties in de ruimtelijke en sociale mobiliteit nemen de Nederlandse steden internationaal een eigen plaats in.

De afname van de stedelijke bevolking duidt al geruime tijd op een algemene ontwikkeling van de Westerse steden - de grote metropolen, zoals Parijs en Londen, uitgezonderd. De stabilisatie en zelfs lichte aanwas van de bevolking in de Nederlandse steden na 1985 is tegen deze achtergrond zeer opvallend. De omvangrijke bouwprocessen hebben hierop een belangrijke invloed uitgeoefend, maar deze kunnen niet onbeperkt doorgaan. Vanuit demografisch oogpunt is de omvang van de buitenlandse migraties de doorslaggevende factor voor de ommekeer naar een groeiende stadsbevolking. In de stedelijke randgebieden heeft in het algemeen gedurende de laatste dertig jaar wel een voortdurende groei van de bevolking plaats gevonden, maar internationaal gezien is de deconcentratie van de stedelijke bevolking in ons land vooralsnog geografisch beperkt gebleven.

Qua samenstelling van huishoudens is in de centrale steden een eenzijdigheid gegroeid die het spiegelbeeld vormt van de eenzijdigheden in de randgemeenten. In de stad domineren de éénpersoonshuishoudens (50 procent in Amsterdam); echtparen zonder en vooral met kinderen zijn er naar verhouding te weinig, terwijl de éénoudergezinnen oververtegenwoordigd zijn. In de stedelijke rand overheersen de gezinnen met (en zelfs de meerpersoonshuishoudens zonder) kinderen.

De tegenstellingen in de sociale structuur van de 'arme stad en de rijke rand' zijn welhaast ideaaltypisch. Zij worden gesignaleerd op het gebied van inkomen, arbeid en (met enige nuancering voor de typische universiteitssteden) opleiding en gezondheid. Tevens blijken migranten in de steden over-en in de randgemeenten ondervertegenwoordigd te zijn. Opvallend is dat veel stedelijke problemen op het landelijk gemiddelde uitkomen, wanneer zij worden gemeten op het schaalniveau van het grootstedelijk gebied.

Bij de ontwikkelingen in de samenstelling van de bevolking in de stedelijke gebieden moet men het schaalniveau goed voor ogen houden. Op het schaalniveau van het stedelijk gebied (COROP) is de bevolkingssamenstelling in Nederland opmerkelijk evenwichtig (alleen de allochtonen zijn hier oververtegenwoordigd). Voor veel kenmerken bestaan overeenkomsten met het landelijke gemiddelde. Internationaal zijn er voorbeelden van hele stedelijke regio's die door eenzijdigheden wordt gekenmerkt. Op dit schaalniveau is de sociale structuur van de Nederlandse stedelijke gebieden vooralsnog intact.

Daarentegen is binnen dit schaalniveau het contrast tussen de stad en de nabije omgeving erg groot. Vrijwel nergens kent de sociale structuur van de centrumsteden zulke grote afhankelijkheden als in Nederland.

Ook op het gebied van de sociale mobiliteit is de dynamiek van de Nederlandse steden gering. De sociale afhankelijkheid wordt in hoge mate gekenmerkt door haar duurzaamheid. België, Nederland en Spanje - hierbinnen vooral de stedelijke gebieden - behoren in dit opzicht internationaal tot de achterblijvers ${ }^{41}$.

Hiermee zijn de contouren geschetst voor de selecties in de ruimtelijke en sociale mobiliteit. De extensivering van het ruimtegebruik, de schaalvergroting en de 'overloop' van stedelijke activiteiten zullen in de komende periode zeker doorzetten. In dit opzicht zijn de internationale signalen universeel. Maar de selecties die hierin optreden, staan niet bij voorbaat vast en zij zijn bepalend voor het lot van de steden. De steden hebben eigen kansen in het stadscentrum, in de oude en deels reeds aanzienlijk vernieuwde stadswijken en in de buitenwijken.

41] Zie onder andere Labour Force Statistics 1966-1986; Paris, OECD, 1988; Quarterly Labour Force Statistics, Paris, OECD; Employment Outlook, Paris, OECD, september 1987. 
Geconstateerd werd dat deze kansen vooral in de stedelijke centra (de kwaliteit van de winkelcentra, de openbare ruimten en de stadsarchitectuur) en in de buitenwijken (achteruitgang van relatief nieuwe naoorlogse wijken) niet steeds optimaal werden benut. Op het vlak van de huisvesting tekent zich een bijzonder probleem af in het contrast tussen de steden en de randgebieden met betrekking tot de verhouding tussen huur- en koopwoningen. De omvang van een sociale huursector - hoe gemengd van samenstelling ook - die in Amsterdam en Rotterdam ongeveer 90 procent van de totale woningvoorraad beslaat, is een internationaal curiosum.

De werkloosheid is in Nederland in sterke mate een grootstedelijk vraagstuk geworden. De kwalitatieve discrepantie tussen vraag- en aanbodontwikkelingen op de arbeidsmarkt is zeer groot. Aan beide zijden werden belemmeringen gesignaleerd die tot een krachtsinspanning van alle betrokken partijen nopen. Via beroepsgerichte opleidingen, activeringsprogramma's, het creëren van werkervaringsplaatsen en aanvullende arbeidsplaatsen zal de kloof op de stedelijke arbeidsmarkten zoveel mogelijk moeten worden versmald. De aanwezigheid van een gevarieerd arbeidsaanbod in de steden is een van de klassieke vestigingsfactoren voor het aantrekken en ontwikkelen van bedrijvigheid.

Degenen die geen perspectief hebben op de arbeidsmarkt krijgen weliswaar relatief hoge uitkeringen (in de internationale vergelijking), maar dit betekent niet dat de betreffende huishoudens een grote sociale bewegingsruimte hebben. Het sociale zekerheidsstelsel verkeert in de buurt van het maximaal mogelijke. Binnen de bestedingsmogelijkheden van de minima zullen de extra woonlastenverhogingen steeds zwaarder gaan drukken, ook al wordt er in het volkshuisvestingsbeleid voor de jaren ' 90 vanuit gegaan dat deze negatieve koopkrachteffecten in het algemeen opgevangen kunnen worden door de ruimte uit hoofde van de economische groei en door de voor lastenverlichting beschikbaar komende ruimte. De verhoging van de woonkwaliteit, inclusief de omvangrijke stadsvernieuwing die in de grote steden nu ongeveer voor de helft is voltooid, legt aldus - achteraf - een steeds zwaardere financiële last op de primaire doelgroepen.

Tenslotte werd de aandacht gevestigd op de toenemende betekenis van de immateriële belemmeringen en selecties in de sociale mobiliteit. Vanwege de groei van het aantal blijvend afhankelijken van sociale zekerheid ontstaan steeds meer sociale en psychische problemen en hindernissen voor toetreding op de arbeidsmarkt. Naast het materiële sociaal beleid en het arbeidsmarktbeleid zal hierom een nieuwe aandacht moeten komen voor het individueel gerichte sociaal beleid.

\subsection{Beleidsopgaven ter versterking van de sociale structuur}

In deze afsluitende paragraaf wordt nagegaan of de institutionele context van het grootstedelijk beleid adequate reacties mogelijk maakt op de ruimtelijke concentratie van de sociale problemen in de steden en in hoeverre hier nieuwe beleidsrichtingen zijn aan te bevelen. Hiertoe wordt in eerste instantie gekeken naar het verband tussen de financiële en bestuurlijke verhoudingen met de ontwikkeling van de sociale structuur. Hoewel institutionele vraagstukken eerst in hoofdstuk 6 integraal worden uitgewerkt, is het nodig er hier al aandacht aan te schenken, omdat zij een richtinggevende betekenis hebben voor de beleidsmogelijkheden die in dit hoofdstuk worden behandeld.

\subsection{De financiële en bestuurlijke mechanismen}

De afhankelijke positie van de Nederlandse steden ten opzichte van het Rijk leidt er toe dat de vanzelfsprekende noodzaak om te investeren in de sociale en economische krachten ontbreekt. Feitelijk wordt hierin door de grote steden sinds kort weer meer geïnvesteerd, maar dit gebeurt niet omdat de institutio- 
nele verhoudingen een dergelijk gedrag logisch zouden afdwingen. Het werd vijftien jaar lang niet gedaan en de stedelijke gemeenschappen lopen hierin nog niet in alle opzichten voorop. Anders dan in vergelijkbare steden in het buitenland, bestaat in de Nederlandse steden geen existentiële drang om de dragende huishoudens en bedrijven aan zich te binden. Wat betreft de ontwikkeling van de sociale structuur, werd al opgemerkt dat de voorzieningen voor de toenemende afhankelijkheid van de stedelijke bevolking van rijkswege worden betaald. Wat betreft de samenstelling van de bevolking, bestaat in de steden geen grote geneigdheid om de gegroeide onevenwichtigheid in huisvesting en ruimtelijke omgeving te verminderen.

De beleidsdilemma's naar aanleiding van de concentratie van sociale problemen in de steden liggen daarom niet alleen bij het ruimtelijk en het sociaal beleid. Zij hangen nauw samen met de financiële en bestuurlijke verhoudingen. De lokale financiële verantwoordelijkheden en risico's zullen vergroot moeten worden, opdat de plaatselijke gemeenschappen uit noodzaak in hun eigen krachten investeren. Bij de weg naar een grotere lokale rekenschap doet zich het probleem voor dat de gegroeide afhankelijkheid eerst moet worden overwonnen. Dit is voor gemeenten met een zwakke sociale structuur - zoals hier vooral voor Amsterdam en Rotterdam werd vastgesteld - geen sinecure. Het hoge niveau van de sociale voorzieningen (voor de bijstand, voor de sociale huisvesting, enz.) wordt grotendeels door het Rijk gesubsidieerd. Ook wanneer de lokale gemeenschappen voor een klein deel van deze geldstromen medeverantwoordelijk worden gemaakt (bijvoorbeeld door een deel van de specifieke uitkeringen voor bijstand of individuele huursubsidie via de algemene uitkeringen aan de gemeenten te verstrekken), nemen de kosten voor de gemeenten met een zwakke sociale structuur toe. De weg naar een vergroting van de lokale verantwoordelijkheid houdt in het bijzonder voor de grote steden risico's in; bij voorstellen in deze richting zullen de gegroeide ongelijkheden in aanmerking genomen moeten worden. Voor lokale gemeenschappen met een zwakke sociale structuur zullen daarom flankerende maatregelen nodig zijn om de sprong naar een grotere eigen verantwoordelijkheid te kunnen maken. Deze conditie is richtinggevend voor de nadere verkenning van beleidsmogelijkheden in deze paragraaf en wordt tevens in hoofdstuk 6 verder uitgewerkt.

Het tweede beleidsvraagstuk dat zich hier voordoet, heeft betrekking op de bestuurlijke schaal. Een van de opvallende bevindingen in de analyse van de stedelijke problemen is dat de 'arme stad en de rijke rand' tezamen geen problematisch beeld opleveren. Voor de meeste aspecten komt de score, gemiddeld over de stedelijke regio, overeen met het landelijk gemiddelde. Men zou zich kunnen afvragen of dan eigenlijk niet sprake is van een 'natuurlijke' verdeling tussen de stad als woonplaats van de minder vermogende bevolking en de stedelijke rand voor de middenklassen en de beter gesitueerden, waarbij de kernen in de 'stedelijke rand', gezien de pendel naar het centrum slechts 'verlengde' stadswijken zijn. Hierbij zouden door een 'verlenging' van de schaal van de bestuurlijke organisatie tot het gewestelijk niveau de stedelijke tekorten kunnen worden verevend met de overschotten van 'op de stad parasiterende' voorsteden.

Een dergelijke benadering wordt in dit rapport niet gevolgd. Er is geen 'natuurlijke' verdeling tussen een arme stad en een rijke rand. De suburbs zijn geen veredelde buitenwijken van de stad. En de ongelijkheden tussen stad en rand zijn geen uitgangspunt voor bestuurlijke schaalvergroting, maar vormen waarschijnlijk de grootste belemmering ervoor. Hiermee is de gedachtenvorming over nieuwe bestuurlijke vormen in het stedelijk gebied niet van tafel in hoofdstuk 6 komt deze aan de orde - maar wel wordt afstand genomen van vereveningsvoorstellen die uitgaan van de bestaande ongelijkheden als een vast gegeven.

In dit rapport wordt een lans gebroken voor de weerbaarheid van lokale 
gemeenschappen met de hieruit voortvloeiende concurrentieverhoudingen, niet uitsluitend maar terdege ook binnen de stedelijke regio. Meer eigen zorg voor het behoud van krachten in de stad zal de Nederlandse steden geen kwaad doen. Dit wil niet zeggen dat de stad en de kernen binnen en buiten de stedelijke regio elkaar in alle opzichten de loef moeten afsteken; in een aantal opzichten vergen gemeenschappelijke belangen een gezamenlijk zakelijk opereren. Een grotere eigen verantwoordelijkheid biedt meer kansen voor onderlinge samenwerking. Aan de versterking van het weerbaarheidsmotief zijn diverse grenzen gesteld: het lokaal bestuur blijft in veel opzichten gebonden aan hoger bestuur, er mag geen ondoelmatig beleidsvacuüm ontstaan voor de voortbrenging van voorzieningen en het hoger bestuur moet voorkomen dat negatieve externe effecten worden afgewenteld. Deze uitgangspunten en voorwaarden zijn richtinggevend voor de navolgende analyses van beleidsmogelijkheden inzake het ruimtelijk en sociaal beleid.

\subsubsection{Het ruimtelijk perspectief}

Het ruimtelijk beleid hoort tot de gebieden waar het zwaartepunt op lokaal niveau is blijven liggen. Het probleem ligt hier dan ook niet zozeer in tekortschietende plaatselijke bevoegdheden, maar in het gebruik dat hiervan door de steden - zij het onderling met aanzienlijke verschillen - wordt gemaakt.

Een vraag is hoe ver de mogelijkheden in de praktijk kunnen reiken, wanneer men de gegroeide onevenwichtigheden in aanmerking neemt en de traagheden in verandering van eenmaal gegroeide patronen (bijv. in de gebouwde omgeving). Zo is in recente beleidsnota's inzake de ruimtelijke ordening en inzake de volkshuisvesting de overheersende trend weliswaar om in de centrale steden de totstandkoming te bevorderen van gedifferentieerde woonmilieus, maar in de praktijk bevatten de recente uitbreidingswijken van de grote steden nog altijd een groot aandeel sociale huurwoningen. De koerswijziging komt slechts schoorvoetend op gang.

Het beleidsstreven om de onevenwichtige samenstelling van de bevolking in de steden te verminderen door ontwikkeling van gedifferentieerde woonmilieus is al oud en resulteerde aan het eind van de vorige eeuw en in de jaren'20 en ' 30 in stedelijke uitbreidingen voor het middenkader. Ook na de Tweede Wereldoorlog hebben nog diverse uitbreidingen in deze sfeer plaatsgevonden. Maar uiteindelijk is dit beleidsstreven toch stuk gelopen op de overheersende oriëntatie op sociale woningbouw, die nog steeds tot uitdrukking komt in de stedelijke woningbehoefte-onderzoekingen, in de wachtlijsten en in politieke pressie $^{42}$. De reëel bestaande behoefte die hier ligt, moet worden onderkend. Anders loopt de huidige, aarzelende koerswijziging in de grote steden opnieuw stuk.

De consequentie hiervan is dat voor het nijpender wordende verdelingsvraagstuk (vanwege de teruglopende bouwprogramma's in de sociale sector) een zware prioriteit moet worden gelegd bij de toewijzing van nieuwe huurwoningen in de omgeving van de steden.

Bij de huidige ruimtelijke beleidsvoornemens voor de inrichting van de Randstad wordt deze consequentie vooralsnog niet gewogen. In de Vierde Nota inzake de Ruimtelijke Ordening werd nog gerekend met de mogelijke noodzaak van 1 miljoen nieuwe woningen voor de Randstad. Deze globale raming was wellicht aan de hoge kant, maar nodigde wel uit tot principiële keuzen over de ruimtelijke spreiding. In recente beleidsnota's van de eerstbetrokken provincies en van de Rijksplanologische Dienst wordt de aanvankelijke raming van het aantal te bouwen woningen sterk gerelativeerd en wordt voor

${ }^{42}$ ] Een historisch overzicht in J.B. Kok, Sleutelen aan de stedelijke bevolkingssamenstelling; Amsterdam, Planologisch Demografisch Instituut, Universiteit van Amsterdam, $198 \mathrm{I}$. 
de mogelijke lokatie van de benodigde woningen (de cijfers lopen nu van 650.000 tot 700.000 ) zoveel mogelijk aangesloten op de bestaande ruimtelijke structuur, alsmede op uitbreiding van de centrale steden. In de laatstgenoemde nota worden tevens mogelijkheden verkend voor uitbreiding van de 'stedelijke ring' onder behoud van het groene hart van de Randstad ${ }^{43}$.

Voor het huidige betoog blijft echter de vraag waar het aandeel van de sociale huurwoningen moet komen. In het ruimtelijk beleid van de afgelopen twintig jaar konden huurwoningen buiten de centrale steden slech ts in grotere aantallen worden gerealiseerd in de grotere bouwlokaties (groeikernen). In zo'n regionale opvang van stedelijke woningzoekenden in de huursector, als complement op de koerswijziging in de centrale steden, is vooralsnog niet voorzien. Dit punt speelt in de huidige beleidsvoorbereiding geen rol van betekenis.

Omdat bij de keuzen in het ruimtelijk beleid veel overwegingen spelen die in dit rapport niet worden behandeld, kan hier geen complete afweging worden gemaakt. Maar het is wel van belang dat het uitgangspunt van de bestrijding van de eenzijdige ruimtelijke selecties -ázowel in de steden als in de stedelijke omgeving - in het ruimtelijk beleid voor de toekomst de volle aandacht krijgt.

Voor het volkshuisvestingsbeleid geldt dezelfde overweging. Vermindering van de onevenwichtigheden in de grootstedelijke woningvoorraad veronderstelt een effectieve regionalisering van het beleid inzake de woningdistributie, de doorstroming en de programmering van nieuwe woningen. In de samenwerkingsregelingen volgens de Wet Gemeenschappelijke Regelingen bestaat op de bovengenoemde punten in de praktijk vaak een beleidsvacuüm ${ }^{44}$. Om deze reden is een provinciale richtlijn- en aanwijzingsbevoegdheid gecreëerd, die echter met grote terughoudendheid dient te worden gehanteerd. De praktijk moet zich op dit punt nog gaan vormen.

Het gaat bij deze vermindering van onevenwichtigheden om verantwoordelijkheden van hoger bestuur; uit de rivaliteit tussen plaatselijke gemeenschappen valt geen herverdeling van gegroeide ongelijkheden te verwachten. De regionalisering van de volkshuisvesting zou een belangrijke impuls kunnen krijgen door het op regionale of hogere schaal laten opereren van de woningcorporaties, die nu veelal in een beperkt (stedelijk of juist stedelijk omgevings-) gebied werkzaam zijn. Men kan hierbij denken aan de verruiming van werkgebieden, aan samenwerkingsverbanden of fusies tussen stedelijke en 'groeikerncorporaties' en dergelijke. Deze functionele weg biedt goede mogelijkheden, nu de beleidsverantwoordelijkheden van de woningcorporaties in een aantal opzichten zijn verruimd. Voor het gangbare relatiesysteem (huurders, toezichthoudende gemeenten, enz.) zou deze optie bijzondere aanpassingen inhouden, die hier niet zijn onderzocht. Hier is vooral de constatering van belang dat het ondoelmatige regionale beleidsvacuüm een belangrijke belemmering vormt voor een succesvolle ombuiging van de onevenwichtigheid in het woningbestand van de steden en dat het uiteenlopen van de diverse lokale belangen bij dit herverdelingsvraagstuk tot een nauwe betrokkenheid noopt van hoger bestuur.

\subsubsection{De minimuminkomens}

Hiervoor werd geconstateerd dat in de steden steeds meer huishoudens afhankelijk zijn geworden van een minimuminkomen, in veel gevallen een periodieke bijstandsuitkering. Ook als dit niet het geval is, kan de Algemene Bijstandswet $(\mathrm{ABW})$ via de bijzondere bijstand voor de betrokkenen van belang

43] De Randstad maakt zich op; Interprovinciole Verstedelijkingsvisie op de Randstad; uitg. van het Randstad Overleg Ruimtelijke Ordening; z.pl., z.n., 1990; De Randstad op weg naar 2015; Studienota Verstedelijking Randstad 1995-2015; Rapport van een ambtelijke stuurgroep van de Rijksplanologische Dienst en het Ministerie van Verkeer en Waterstaat; 's-Gravenhage, RPD, 1990.

44] Memorie van Toelichting bij het ontwerp voor de Huisvestingswet, Tweede Kamer, Vergaderjaar 1987-1988, 20 520, nr. 3. blz. 1 . 
zijn. Hieronder wordt nagegaan hoe de uitgangspunten van deze wet zich in de afgelopen periode hebben ontwikkeld en of zich mogelijk nieuwe richtingen aandienen voor het stedelijk beleid inzake de minima.

Sinds haar invoering in 1965 bepaalt de ABW dat aan iedere burger die niet in het eigen levensonderhoud kan voorzien, bijstand wordt verleend, naar gelang van de omstandigheden en mogelijkheden van persoon en gezin, alsmede van het betoonde besef van verantwoordelijkheid voor de voorziening in het bestaan; de wet beoogt de persoon in staat te stellen voor zichzelf te zorgen. Aan bijstand worden derhalve voorwaarden verbonden die strekken tot inschakeling in de arbeid, tenzij redenen van medische, sociale of andere aard zich hiertegen verzetten. Een aantal belangrijke uitgangspunten is hiermee gegeven: een individuele benadering, het aanvullend karakter van de voorziening, de tijdelijkheid, de gerichtheid op uitstroom naar werk en de eigen verantwoordelijkheid van de uitkeringsgerechtigde. Bijstand wordt uitgekeerd door de gemeente, het gemeentebestuur speelt bij de uitvoering van de wet een centrale rol.

Hoewel de ABW sinds 1965 niet fundamenteel is gewijzigd, hebben de betekenis en het karakter van de bijstand sindsdien wel ingrijpende veranderingen ondergaan. De gemeentelijke vrijheid bij de vaststelling van de hoogte van de uitkeringen is beperkt door het Bijstandsbesluit landelijke normering (1974), dat vergroting van de rechtszekerheid en rechtsgelijkheid beoogde. Tevoren, in 1972 , was de aanvankelijke 100 procent-financiering uit de algemene gemeentelijke middelen al vervangen door een regeling waarbij de gemeenten 50 procent van de kosten - afgezien van de uitvoeringskosten - bij het Rijk konden declareren, een percentage dat een jaar later tot 90 werd verhoogd. De laatste wijziging uit het begin van de jaren '70 betrof een aanscherping van het toezicht.

In 1979 werd in de wet de verplichting opgenomen de bijstand voor een echtpaar te bepalen op het bedrag van het netto-minimumloon. Bijstand werd hiermee gekoppeld aan het landelijk inkomensbeleid. Een jaar later werd ook de mogelijkheid tot verlening van bijstand voor bijzondere bestaanskosten landelijk genormeerd.

Sinds $1980 \mathrm{kwam}$ de ABW onder grote druk te staan. Toenemende aanvragen in combinatie met de beperking van de stijgende overheidsuitgaven - hebben geleid tot een eenmalige verlaging en een langdurige bevriezing van de hoogte van de normbijstand. Ook heeft de herziening van het sociale zekerheidsstelsel rond 1987 de bijstand voor nieuwe categorieën, zoals gedeeltelijk arbeidsongeschikten, in beeld gebracht. Voorts is de centrale regelgeving in sterke mate verfijnd en verdicht. De vergoeding van steeds meer kosten is landelijk bepaald, er worden meer groepen bijstandsgerechtigden onderscheiden aan de hand van diverse leefvormen en het gemeentelijke voorwaarden- en sanctiebeleid wordt meer dan voorheen door rijksregels gestuurd.

Het beslag dat de uitvoering van de $\mathrm{ABW}$ legt op de algemene inkomsten van de gemeenten (via het gemeentelijke aandeel van 10 procent en vooral ook via de apparaatskosten) is de laatste jaren enorm toegenomen. De 'verfijningsfactor sociale zorg' en een aanvullende compensatieregeling voor stijgende bijstandskosten geven de grote gemeenten slechts een beperkte tegemoetkoming. Bezuinigingen op het uitvoerend apparaat, de Gemeentelijke Sociale Dienst (GSD), zijn onder dergelijke omstandigheden moeilijk te vermijden. Afname van de aandacht die kan worden besteed aan maatschappelijke begeleiding en aan maatregelen ter bevordering van de zelfstandige bestaansvoorziening van bijstandsgerechtigden, is een logisch gevolg. De sociale diensten ontwikkelen zich steeds meer tot louter administratieve uitvoeringsorganen.

Bij vele bijstandsgerechtigden die toestroomden in de jaren ' 80 , groeide een VAN DE STAD EN DE RAND 
duurzame afhankelijkheid van de bijstand, zonder dat hierop door de eerstverantwoordelijke partijen adequaat werd gereageerd. Afwachtendheid kenmerkte het gedrag van deze partijen gedurende een groot deel van de jaren ' 80 . Als gevolg hiervan ontstond bij vele uitkeringsgerechtigden, net als bij de gemeenten, een eenzijdige gerichtheid op de financiële kant van de bijstand. Als deze houding de overhand krijgt, verliezen de normatieve grondslagen van de Algemene Bijstandswet (de eigen verantwoordelijkheid, het aanvullend karakter, de tijdelijkheid, de gerichtheid op uitstroom en de individualisering van de uitvoering) hun betekenis.

Voorzover het doel van de ABW is waar nodig te voorzien in bestaansmiddelen op een minimumniveau, is dit niet in gevaar gekomen ${ }^{45}$. Weliswaar zijn de uitkeringen bevroren, maar bij verdere ingrepen heeft men de nadelige gevolgen vooral trachten te beperken door meer rekening te houden met de leefvorm, de leeftijd en dergelijke van de aanvragers. Doordat het minimumloon dezelfde ingrepen heeft ondergaan, is de koppeling in stand gehouden. De principiële uitgangspunten van de wet zijn echter veel minder tot hun recht gekomen en de uitstroom naar werk is te weinig bevorderd.

Het gemeentelijke 'minimabeleid', dat vanaf het begin van de jaren ' 80 in veel plaatsen is ontwikkeld, beoogt in genoemde tekortkomingen te voorzien. Deels gaat het om individueel gerichte hulp (schuldregeling, nood- en waarborgfondsen, enz.), deels om generieke maatregelen zoals vrijstelling of verlaging van belastingen, het hanteren van inkomensprijzen, kortingspasjes voor sportieve en culturele activiteiten en dergelijke. Steeds gaat het om voorzieningen buiten de ABW om. Reeds in 1985 heeft de rijksoverheid, op grond van het uitgangspunt dat inkomensbeleid landelijk beleid is, aangekondigd dat algemene gemeentelijke besluiten van inkomenspolitieke aard niet langer getolereerd zouden worden; steunfondsen werden wel toegestaan, mits elke aanvrage individueel zou worden beoordeeld ${ }^{46}$. Niet alle algemene ondersteunende maatregelen zijn inmiddels verdwenen; er is nog steeds een grote variëteit aan zowel bijzondere als algemene voorzieningen aanwezig ${ }^{4}$.

Toch wordt de gemeenten ook wel verweten dat zij te weinig doen op het punt van aanvulling van minimuminkomens en dat zij te weinig bekendheid geven aan wat zij doen ${ }^{48}$.

In april 1989 heeft de regering de SER advies gevraagd inzake de herinrichting van de $A B W$, waarin een belangrijke plaats wordt toegekend aan decentralisatie en deregulering ${ }^{49}$. Om het individualiseringsbeginsel beter tot zijn recht te laten komen, wordt onder andere voorgesteld het passend maken van de uitkering in het individuele geval tot een gemeentelijke verantwoordelijkheid te maken ${ }^{50}$.

Door verruiming van de bijzondere bijstand zou een afzonderlijk gemeentelijk minimabeleid grotendeels overbodig worden, met uitzondering van de hulp bij schuldsanering door gemeentelijke waarborgfondsen ${ }^{51}$.

45] De discussie over de verhouding tussen inkomens-, zorg- en herintredingsvoorzieningen is mede geëntameerd door de HRWB. HRWB, 'Op eigen krocht, een bodempakket ols bestaanszekerheidsvoorziening' 's-Gravenhage, HRWB advies nr. 49, 1987. Voorts: HRWB, Bedreigde zekerheid; 's-Gravenhage, Signalement nr. 22, 1986. HRWB, Welzijn en bestoanszekerheid; 's-Gravenhage, Dwarskijken nr. 9, 1986.

46] Circulaire van de stoatssecretaris van Binnenlandse Zaken van I maart 1985, no. BT/U231 ('Gedoogcirculaire').

$\left.{ }^{47}\right]$ Vereniging van Nederlandse Gemeenten, Gemeentelijk minimabeleid; 's-Gravenhage, VNG, 1989.

${ }^{48}$ ] Konsumentenkontakt, Hoe bijzonder is bijzandere bijstand?, een onderzoek noar het niet-gebruik; 's-Gravenhage, KK, september 1989.

49] Herinrichting van de Algemene Bijstandswet, Tweede Kamer, Vergaderjaar 1988-1989, 21á 84, nr. 2. Onlangs (17 juli 1990) is een wetsontwerp ingediend dat op het punt van de bijzondere bijstand tot wijziging van de ABW moet leiden; op hier relevante onderdelen wijkt het niet wezenlijk af van de herinrichtingsnota, Tweede Kamer, Vergaderjaar 1989-1990, 21 644, nrs. I-3.

50] Herinrichting Algemene Bijstandswet (op. cit.), blz. 14.

51] Ibid., blz. 16. 
De vergroting van de beleidsruimte zou gepaard moeten gaan met een verhoging van het aandeel van de gemeenten in de kosten van de bijstand. In plaats van 10 procent zouden zij in de toekomst 20 procent voor hun rekening moeten nemen van de algemene bijstand en 100 procent van de bijzondere bijstand, die de vorm van een toeslag zou krijgen. Hiermee wordt beoogd gemeenten een actiever lokaal bijstandsbeleid te laten voeren, dat leidt tot meer maatwerk en een grotere uitstroom uit de $\mathrm{ABW}{ }^{52}$. Aanvankelijk leek het kabinet voornemens het gemeentelijk bijstandsaandeel te verhogen tot 20 procent, maar inmiddels is hier van afgezien.

In de discussie over deze plannen is tegengeworpen dat de voorgestelde decentralisatie geenszins de aangekondigde vergroting van de gemeentelijke financiële verantwoordelijkheid zou rechtvaardigen; vanuit gemeentelijke kring werd zelfs een volledige vergoeding door de centrale overheid passend genoemd, zozeer wordt deze uitkering door rijksnormen bepaald ${ }^{53}$.

Met name voor de grote steden ligt hier een teer punt. De toestroom naar en de uitstroom uit de bijstand worden weliswaar voor een groot deel veroorzaakt door macro-processen op de arbeidsmarkt, maar de lokale gemeenschappen beschikken, zoals eerder opgemerkt, wel over diverse mogelijkheden om de uitwerking van deze processen te beïnvloeden (ruimtelijk beleid, economisch beleid, onderwijs, enz.). Een vergroting van de lokale financiële medeverantwoordelijkheid is daarom voor ook de grote steden best te verdedigen, ook al worden de condities voor de bijstandsuitkeringen grotendeels nationaal bepaald. Wat deze beleidsoptie op de korte termijn echter belemmert, is dat bij de huidige hoge aantallen uitkeringsgerechtigden reeds het 10-procentaandeel een groot deel van de financiële bewegingsruimte opslorpt. Binnen de huidige financiële verhouding kunnen de gemeenten niet zonder meer financieel aansprakelijk worden gemaakt, omdat zij de hiermee gemoeide overschrijdingsrisico's binnen hun beperkte vrije bewegingsruimte niet kunnen dragen. In het financieel/bestuurlijke hoofdstuk 6 wordt een voorstel ter vergroting van de lokale financiële verantwoordelijkheid uitgewerkt, waarin met de gegroeide ongelijkheden rekening wordt gehouden.

Het uitgangspunt om aan de ene kant (in het kader van de inkomenspolitiek) op centraal niveau de algemene bestaanskosten verder te objectiveren en aan de andere kant de aanvullende differentiatie te doen plaatsvinden waar dit het beste kan - op lokaal niveau - biedt een goed raamwerk voor beleidsaanpassingen. Een mogelijke bedreiging van de rechtsgelijkheid kan worden voorkomen door de opstelling van beleidsregels ter invulling van lokale vrijheden, waaraan het gemeentebestuur wordt gebonden. Een opvallend gemis in de herinrichtingsplannen is wel dat nauwelijks aandacht wordt besteed aan het feit dat individualisering, zeker waar deze mede op uitstroom is gericht, hogere uitvoeringskosten veroorzaakt, die in de beginfase, waarin nog geen sprake kan zijn van inverdieneffecten, zwaar kunnen drukken.

Ook de bijzondere bijstand vereist een arbeidsintensieve, individuele beoordeling.

De al genoemde stijging van de woonlastenquoten en de daarop volgende stabilisering op een hoog niveau in de tweede helft van de jaren '80 (stabiliserend vanwege de stijgende huurlasten en de dalende energiekosten) raken uiteraard de huishoudens met een laag inkomen het hardst. De energieprijzen bewegen thans in opwaartse richting. Krachtens de recente beleidsnota 'Volkshuisvesting in de jaren negentig' ${ }^{54}$ worden de jaarlijkse extra huurprijsverhogingen

52] Ibid., blz. I5.

53] Raad voor de Gemeentefinanciēn, Advies von 12 juli 1989, nr. 44655 RGF 16/71. Sociaal-Economische Raad, Commissie Sociale Voorzieningen, Interimadvies hoofdlijnen herinrichting Algemene Bijstandswet; 's-Gravenhage, SER, Publikatie nr. 15, 1989.

54] Volkshuisvesting in de jaren negentig; Tweede Kamer, Vergaderjaar 1988-1989, 20691, nrs. 2-3. 
binnen bepaalde voorwaarden gecontinueerd. Tegelijkertijd wordt uit hoofde van sociale beleidsdoelstellingen vastgehouden aan het uitgangspunt dat nieuwe - en dus normaal gesproken dure - woningen in de sociale huur-en koopsector rechtstreeks ten goede zouden moeten komen aan de sociale doelgroepen met een laag inkomen. Dit is mogelijk, mits de subsidie hiertoe strekt. Het beleid is thans dat de kosten vervolgens achteraf (door jaarlijkse extra huurverhogingen) in rekening worden gebracht bij de desbetreffende huishoudens. Hier is sprake van een 'ingroeiproces'. Deze werkwijze is echter problematisch voor dat deel van de huishoudens dat geen inkomensverbetering doormaakt.

\subsubsection{Individuele hulpverlening}

In 1979 hebben Van Dijck c.s. in een bekend rapport kritiek uitgeoefend op gemeentebesturen die de GSD slechts zagen als een uitkeringskantoor en niet als een element in het lokale pakket van welzijnsvoorzieningen ${ }^{55}$. De GSD zou in de toekomst zijn cliënten tijdens en soms ook na de aanvraagbehandeling moeten begeleiden. Voorts zou de GSD meer informatie moeten verzamelen over aard en omstandigheden van zijn cliënten en zou hij projecten moeten bevorderen die gericht zijn op de verbetering in de toestand van probleemgroepen. Het zogeheten Bijstands Maatschappelijk Werk zou de kernfunctie van de GSD moeten worden.

Deze aanbevelingen zijn, hoewel populair in het jaar van publikatie, niet uitgevoerd. Een belangrijke reden hiervoor lag uiteraard in de explosieve groei van het aantal uitkeringsgerechtigden in de jaren ' 80 . Het personeel had en heeft nog steeds zijn handen vol aan de behandeling van de aanvragen om materiële hulp. Maar er zijn ook andere en meer principiële factoren waarom het maatschappelijk werk in de context van de GSD een marginale positie heeft ${ }^{56}$. Ten eerste bevat de $A B W$ geen rechtsplicht tot het verstrekken van immateriële hulpverlening, terwijl die wel is vastgelegd voor de materiële bijstand. Ten tweede is de GSD een ambtelijk-juridische organisatie die sterk gericht is op inpassing van cliënten in het wettelijk systeem (een ander soort organisatie dan van een hulpverlener die het voor zijn cliënt soms ook moet opnemen tegen overheidsdiensten). Ten derde verwachten de cliënten van de GSD snelle en correcte afhandeling van hun aanvragen en zijn ze veelal niet geïnteresseerd in immateriële bijstand.

De immateriële hulpverlening, in dit geval het maatschappelijk werk, kan derhalve beter als algemene hulpverlening op zich zelf blijven staan dan bij de GSD's te worden ondergebracht. In de praktijk is het maatschappelijk werk vaak samengebracht met de gezinszorg. Daar sluit het ook historisch gezien het best op aan.

Bij individuele hulpverlening, zoals algemeen maatschappelijk werk, zal een gegeven blijven dat de uitvoering hiervan deels los staat van de gemeentebesturen. Dit vloeit voort uit de aard van de vertrouwensfunctie en uit het feit dat vaak ver binnen de privésfeer wordt getreden; bovendien wordt de hulp vaak ingeroepen door mensen die deel uitmaken van minderheden binnen de gemeenten, en die als zodanig in beginsel dienen te worden beschermd tegen het bestuur van de meerderheid. Voor dergelijke gevallen blijft de volgende institutionele oplossing het meest geëigend. Het gemeentebestuur zorgt voor een regeling van de positie van de betreffende uitvoerende instelling, waarbij een organisatorische zelfstandigheid wordt gegarandeerd. Voorts regelt het de financiering ervan. Tenslotte ziet het erop toe dat het uitvoerend werk onder toezicht komt van een bestuur dat is samengesteld uit burgers zonder direct belang bij de activiteiten van de instelling.

35] J.J.J. van Dijck e.a., Noor een gemeentelijke sociale dienst nieuwe stijl; Tilburg, IVA, 1979.

56] A. Brand, op. cit. 
De financiering van de instellingen kan blijven geschieden uit verschillende bronnen, zoals de AWBZ, het Gemeentefonds, de verschillende sociale wetten en de rijkssubsidieregelingen die gemaakt zijn voor hulp aan verschillende bevolkingsgroepen (minderheden, langdurig werklozen, thuislozen enz.), waarbij instellingen, naast een basissubsidie, de behandelingskosten van cliënten kunnen verhalen. Door de Welzijnswet is een organiek kader geschapen, waarin de bestuurlijke bevoegdheden op welzijnsgebied aan de gemeenten zijn toegewezen. Juist door de fondsen en de subsidiëring kan binnen dit kader door het Rijk worden gestuurd en kan door de veelzijdigheid van het financiële regime een eenzijdige afhankelijkheid van overheidsorganen worden tegengegaan.

\subsubsection{Bestrijding van werkloosheid}

\subsubsection{Vertraagde reacties op de werkloosheid}

De samenstelling van het werklozenbestand in de grote steden verklaart waarom zij minder dan overig Nederland in de tweede helft van de jaren ' 80 hebben geprofiteerd van het gunstig economisch tij. Vele van deze werklozen zullen voor deelname aan de arbeidsmarkt een grote sprong moeten maken. In de afgelopen tien jaren is het antwoord op dit kwalitatieve aspect van de werkloosheid lang uitgebleven. Het is nuttig om de rol van de betrokken partijen te bezien, omdat slechts door een gezamenlijke beleidsinspanning in de komende periode vooruitgang kan worden geboekt.

De rol van de uitkerende instanties - de bedrijfsverenigingen en de sociale diensten - was en is voor een deel nog steeds zeer terughoudend in de actieve bevordering van nieuwe mogelijkheden van hun cliënten op de arbeidsmarkt. Zij hebben wel belang bij een vermindering van de werkloosheidsuitkeringen, maar zij beschouwen het niet als hun taak hierin een actief beleid te voeren.

De sociale diensten hebben de mogelijkheden die de ABW biedt om (her)inschakeling in het arbeidsproces te bevorderen, niet optimaal benut, ook vanwege de toenemende druk op het werkapparaat. De wettelijke mogelijkheden om cliënten te bewegen zich actiever op de toetreding tot de arbeidsmarkt in te stellen, werden evenmin voldoende benut.

De traditionele arbeidsvoorzieningsorganisatie, het gewestelijk arbeidsbureau, was in 1985 nog pas kort overgeschakeld op een vraaggerichte benadering, die weliswaar door werkgevers werd toegejuicht maar die tevens met zich meebracht dat de categorie der zeer moeilijk bemiddelbaren minder aandacht kreeg. De aanbodgerichte bemiddeling is - nog altijd - nagenoeg non-existent. Hierdoor wordt met name de groep werklozen die al langer in het bestand zit, moeilijk bereikt. Via speciaal in het leven geroepen instanties (Baanvak, Werkraat, SRW) wordt hier recentelijk wel wat aan gedaan, maar het effect hiervan is toch relatief gering ten opzichte van de totale omvang van de problemen. Mede tegen deze achtergrond kwamen in toenemende mate de gemeentelijke overheden tot eigen activiteiten. Niet alleen was er sprake van een eigen personeelsbeleid dat kansarme groepen beoogde te bevoordelen en van een sterkere gerichtheid van het sociaal-cultureel werk op vergroting van de arbeidskansen bij zijn cliënten. Ook werden tal van initiatieven ondersteund en zelf genomen op het vlak van scholing, werkervaring en werkverschaffing. Voor een deel werden en worden deze activiteiten uit de algemene gemeentelijke middelen gefinancierd. Bijdragen van de rijksoverheid gaan echter een steeds belangrijker rol spelen (PCG-gelden, art. $36 \mathrm{WWV-middelen).} \mathrm{Ook} \mathrm{overigens} \mathrm{is} \mathrm{het}$ Rijk zich meer met de langdurige werkloosheid gaan bezighouden, onder andere door speciale financiële voorzieningen zoals de wet Vermeend/Moor en de jeugdwerkgarantiemaatregelen. De gemeenten hebben hier een uitvoerende functie maar dit geldt eveneens voor de arbeidsbureaus. Een groot probleem van de specifieke rijksregelingen is dat deze randvoorwaarden bevatten, die de lokale uitvoering sterk bemoeilijken, zoals de beperkingen van de 
arbeidsduur in het Jeugdwerkgarantieplan en de Kaderregeling Arbeidsinpassing en de detacheringsformule van deze laatste regeling.

Het geheel overziend kan vastgesteld worden dat de nauw betrokken organisaties gedurende de jaren ' 80 niet waren voorbereid op de abrupte toeneming van de werkloosheid tussen 1981 en 1983. In het algemeen kwamen de reacties vertraagd op gang. Ook bij de betrokken partijen, de werklozen zelf en het bedrijfsleven, zijn de inspanningen niet altijd optimaal.

$\mathrm{Nu}$ langzamerhand het geheel van mogelijkheden is uitgebreid, wordt bij een aantal werklozen een beperkte bereidheid gesignaleerd om scholing te volgen, werkervaring op te doen of bepaalde vormen van arbeid te aanvaarden ${ }^{57}$. Hoewel de meerderheid van de werklozen wèl is georiënteerd op een plaats op de arbeidsmarkt, maar er kennelijk niet in slaagt hiertoe geschikte mogelijkheden te vinden, is het frappant dat het bij gegeven mogelijkheden soms niet lukt gegadigden hiervoor te interesseren. Hiervoor is geen eenduidige verklaring te geven, maar wel is een feit dat blijkens recent onderzoek onder langdurig werklozen 19 procent van de onderzoeksgroep bleek te behoren tot de 'ondernemende en calculerende' werklozen - actief op de zwarte arbeidsmarkt en een onjuist gebruik makend van verzorgingsarrangementen - en 10 procent tot de 'autonomen', die hun uitkering als een basisinkomen beschouwen ${ }^{58}$.

Ook de inzet van het bedrijfsleven is vaak beperkt. De afspraken die de laatste jaren op centraal niveau tot stand zijn gekomen, hebben er nog niet toe geleid dat daadwerkelijk in redelijke mate werkervaringsplaatsen of andere entrees voor (langdurig) werklozen worden geboden. Ook afspraken in cao's - in 1989 een dozijn - over het scheppen van werkervaringsplaatsen of het in dienst nemen van langdurig werklozen hebben nog weinig concrete resultaten opgeleverd. De deelname van vertegenwoordigers van het bedrijfsleven in lokale en regionale commissies en besturen die zich (mede) op werkloosheidsbestrijding richten, en meer nog het maken van afspraken over baangaranties na voltooiing van een opleiding of het creëren van ervaringsplaatsen op lokaal niveau, zijn uitzonderingen. Het enige tripartite werkgelegenheidsconvenant dat in een der grote steden is gesloten, in Rotterdam, bevat nauwelijks concrete afspraken die tot (her)intreding van werklozen kunnen leiden. De resultaten van het Utrechtse Jaarprogramma 1990, waarbij de overheid en het bedrijfsleven ter plaatse afspraken hebben gemaakt, moeten worden afgewacht. Na de invoering van de Arbeidsvoorzieningswet komt wellicht meer vaart in deze ontwikkeling.

\subsubsection{Mogelijkheden voor bestrijding van werkloosheid}

Veel beleidssferen bieden mogelijkheden om het probleem van de werkloosheid op de een of andere manier aan te pakken (het economisch beleid, de arbeidsvoorziening, de sociale zekerheid, het onderwijsbeleid, sociaal-cultureel beleid). Voor al deze beleidssferen is het algemene argument van dit rapport van toepassing, dat de allocatieve beleidstaken bij voorkeur op decentraal niveau uitgeoefend dienen te worden door de lokale partijen (in de meeste gevallen primair door de lokale marktpartijen en in aanvulling hierop door de gemeentelijke overheid). Alleen zo kan het beleid adequaat inspelen op de lokale bijzonderheden en alleen zo wordt voor de eerstbetrokken lokale

\footnotetext{
${ }^{57}$ ] J. de Koning en J.H. Gravesteijn-Ligthelm, De JOB-maatregel: Ploatsingseffecten en knelpunten; 's-Gravenhage, Ministerie van Sociale Zaken en Werkgelegenheid, 1989.

R.Hoffius, Een laatste kans; Eindrapport evaluatie heroriënteringsgesprekken; 's-Gravenhage. Ministerie van Sociale Zaken en Werkgelegenheid, 1989.

W. Dercksen c.s., op. cit.

${ }^{58}$ ] H. Kroft e.a., Een tijd zonder werk; Leiden/Antwerpen, Stenfert Kroese, 1989.
} 
partijen responsiviteit mogelijk. Langs deze weg kunnen bovendien plaatselijk verbanden worden gelegd tussen de verschillende beleidssferen en kan meer onderlinge afstemming van beleid ontstaan dan bij de rijksregelingen mogelijk is.

Tegen deze achtergrond worden de uitgangspunten van de recente herinrichtingsplannen voor de bijstandswet (waarin een duidelijk onderscheid wordt aangehouden tussen centrale distributie via de bijstandsnorm en decentrale allocatie via de uitgebreide bijzondere bijstand) en de voornemens tot decentralisatie van de arbeidsvoorziening onderschreven. Deze voeren tot een grotere lokale verantwoordelijkheid en aanspreekbaarheid. Meer in het algemeen wordt in dit rapport bepleit om via herordening van financiële verhoudingen bij alle partijen financiële prikkels te leggen.

Met het oog op de vele mogelijke verbindingen tussen verschillende soorten van lokaal beleid is vooral voor het stedelijk bedrijfsleven en voor de gemeenten een belangrijke rol weggelegd in de bestrijding van de plaatselijke werkloosheid. Deze partijen krijgen bovendien een nieuwe beleidsverantwoordelijkheid, doordat de bureaus voor de arbeidsvoorziening op regionaal niveau komen te staan onder een tripartite samengesteld bestuur (RBA). Voor de gemeenten en het lokale bedrijfsleven bieden de RBA's een belangrijke aanvulling op hun eigen aanbod van voorzieningen. De gemeenten moeten een eigen economisch en sociaal beleid voeren - bij voorkeur in aansluiting op initiatieven vanuit het plaatselijk bedrijfsleven, zoals die sinds kort in de Rotterdamse convenant en het Utrechtse jaarprogramma op gang komen - waarbij vanuit de lokale oriëntatie op de sociale en economische infrastructuur van de grote stad het aanbod wordt benut van de regionaal georganiseerde arbeidsvoorziening.

Uit het voorgaande blijkt reeds dat de bestrijding van de stedelijke werkloosheid in dit rapport niet wordt bezien vanuit een eenzijdige organisatie-optiek. Hoe belangrijk de ontwikkeling naar de regionale arbeidsvoorziening ook is, zij is niet het exclusieve of overheersende stramien voor de bestrijding van de werkloosheid. De verschillende beleidssferen die raken aan de bestrijding van de stedelijke werkloosheid, zijn elk op eigen wijze maatschappelijk opgebouwd. $\mathrm{Zij}$ hebben een eigen mogelijke bijdrage, waarvan de potenties niet optimaal benut zouden worden, wanneer zij vanuit een exclusieve organisatorische invalshoek gerangschikt zouden worden. Overigens brengt de invoering van de RBA's natuurlijk wel mee dat de gemeenten de publieke arbeidsbemiddeling, die zij gedurende de afgelopen jaren noodgedwongen op eigen titel zijn gaan verrichten, voor een deel hierin kunnen inbrengen.

Een strategische rol is weggelegd voor de gemeentebesturen, die vanuit hun publieke en generieke invalshoek in vrijwel alle beleidssferen op een of andere wijze zijn betrokken. De rol van de gemeenten in het achterstandsbeleid wordt hier in vele gedaanten opgevoerd, variërend van een direct sturende rol via het eigen personeelsbeleid, de beleidsuitvoerende rol in het zekerheidsbeleid, de conditionerende rol in het ondernemingsbeleid, de participerende rol in de arbeidsvoorziening en de stimulerende rol in het onderwijs tot de meer afstandelijke, faciliterende rol met betrekking tot het sociaal-cultureel werk. De overstijging van de functionele afbakening tussen de verschillende betrokken beleidsgebieden stelt de gemeenten in staat de noodzakelijke 'transfers' tussen de verschillende takken van beleid inzake de bestrijding van werkloosheid te bevorderen. Wezenlijk in nagenoeg alle bovengenoemde gemeentelijke rollen is dat de lokale overheid zich niet in de positie van de stuurman laat manoeuvreren, omdat deze dan zou voorbijgaan aan de kracht van elke beleidssfeer die vanuit een eigen maatschappelijke achtergrond is opgebouwd.

Met het oog op de bestrijding van de stedelijke werkloosheid worden in het ver- 
volg van dit hoofdstuk verschillende beleidssferen uitgewerkt. Het betreft allereerst het nauwverwante gebied van de arbeidsvoorziening en de sociale zekerheid. De bespreking hiervan vangt aan met de recente samenwerkingsinitiatieven via de heroriënteringsgesprekken. Tenslotte wordt de afwijkende institutionele setting voor de bevordering van het ondernemerschap als een apart beleidsgebied uitgewerkt.

\section{a. Heroriënteringsgesprekken}

De heroriënteringsgesprekken van de samenwerkingsverbanden tussen de sociale diensten en de arbeidsbureaus, die naar het voorbeeld van het Haagse 'Werkraat' in 1988 landelijk werden ingevoerd, behoren tot de weinige beleidsinitiatieven die rechtstreeks zijn gericht op de 'vergeten groep' van langdurig werklozen. De arbeidsbureaus raakten langs deze weg weer betrokken bij de moeilijkst bemiddelbare groepen, terwijl deze initiatieven (die nu door het Rijk apart worden bekostigd) aan de sociale diensten de mogelijkheid boden voor een soort inhaaloperatie, nadat de wettelijk veronderstelde individuele begeleiding jarenlang op een laag pitje was gezet. De gesprekken zullen in een proefperiode van drie jaar worden gevoerd met alle langdurig werklozen (langer dan drie jaar werkloos). Het doel is te komen tot een individueel actieplan, dat kan bestaan uit zulke uiteenlopende zaken als (verwijzing naar) een opleiding of cursus, arbeidsbemiddeling door het GAB of START, een beroepskeuzeadvies, een werkervarings-, oriëntatie- of stageplaats, enzovoort.

Een tussentijdse evaluatie van de heroriënteringsoperatie geeft geen doorslaand succes te zien. Het programma werd gestart zonder dat een stelsel van werkervaringsplaatsen was gerealiseerd, zonder dat de toegankelijkheid van bedrijfsopleidingen was vergroot en zonder voldoende mogelijkheden om de langdurig werklozen regelmatig te begeleiden op een vaak jarenlang traject naar herintreding. Een en ander heeft de tendens versterkt dat de uitvoerende instanties hun aandacht toch weer zijn gaan concentreren op de meest kansrijke groepen, onder meer door een leeftijdsgrens (naar boven) te hanteren van 40 of 45 jaar. Het is onduidelijk in hoeverre de heroriënteringsgesprekken werkelijk tot meer herintreding leiden. Evaluatie-onderzoek uit 1989 toont aan dat 13,5 procent van degenen met wie een dergelijk gesprek gevoerd is, hierna in een baan is geplaatst, maar laat de rol van de heroriëntering hierbij in het midden.

Niettemin is het zeker positief dat hiermee samenwerkingsverbanden tot stand zijn gekomen tussen verschillende organisatieculturen. Ook hebben de verbanden in sommige steden zelfs een ruimer takenpakket gekregen. De mogelijkheden om serieuze kansen te bieden, zijn inmiddels toegenomen door een uitbreiding van het instrumentarium. De praktijk heeft afdoende uitgewezen dat individuele begeleiding een conditio sine qua non is voor herintreding van een groot deel van de langdurig werklozen. Veelal zal hiervoor zelfs meer nodig zijn dan een (her)oriënterend gesprek en de opstelling van een actieplan; bij langere trajecten zouden ook periodieke herbesprekingen gewenst zijn, die in veel gevallen gekoppeld kunnen worden aan de heronderzoeken in het kader van de uitvoering van de $A B W$. De uitstroommogelijkheden van de $A B W$ en de arbeidsbemiddeling door de arbeidsbureaus dienen in combinatie ten volle benut te worden. De raad beveelt daarom aan, vanuit het oogpunt van het grootstedelijk beleid, de herori-enteringsgesprekken niet alleen te continueren maar ook, zo mogelijk versterkt door een regelmatige follow up, tot de algemene basis te maken voor herintreding van langdurig werklozen.

\section{b. Uitstroom Algemene Bijstandswet}

Wat betreft de naleving van de verplichtingen van de bijstandsgerechtigden, werd al eerder opgemerkt dat bij de sociale diensten in de praktijk een grote 
terughoudendheid bestaat in het opleggen van sancties aan werkloze uitkeringsgerechtigden die onvoldoende meewerken aan hun herintreding in het arbeidsproces. Als motieven voor deze opstelling werden genoemd het ontbreken van een duidelijk perspectief op passend werk en de arbeidsintensieve (en dus dure) controle die nodig zou zijn.

$\mathrm{Nu}$ de arbeidsmarkt voor een aantal cliënten nieuwe mogelijkheden biedt en ook via het geïntensiveerde arbeidsmarktbeleid geleidelijk nieuwe plaatsen ontstaan, ligt het in de lijn dat sancties zonodig wèl worden toegepast. Het recht op bijstand is geen onvoorwaardelijk recht, de bijstand biedt niet een basisinkomen, waarvoor vrijelijk kan worden gekozen.

Hierbij moet wel in aanmerking worden genomen dat sancties in de regel geen instrumenten van het arbeidsmarktbeleid zijn; zij maken deel uit van het normatieve kader van de sociale-zekerheidswetgeving. De toepassing van de sanctie moet met inachtneming van richtlijnen berusten op individuele afweging, waarin met de achtergronden van de betrokkene rekening wordt gehouden.

Wat betreft de inspanningsverplichting voor het uitvoerend bestuur om uitstroom uit de bijstand naar arbeid te bevorderen, voorzien de herinrichtingsplannen van de bijstandswet in enige nieuwe mogelijkheden. Hierbij wordt uitgegaan van een nauwe samenwerking met de arbeidsbureaus. De meeste mogelijkheden worden door actieve sociale diensten overigens reeds in praktijk gebracht. Nieuw is de uitgebreide mogelijkheid om bijstand te verlenen in specifieke kosten met het oog op de zelfstandige bestaansvoorziening: niet alleen voor kosten van om- en bijscholing, maar ook voor die van kinderopvang en voor verwervingskosten zal bijstand mogelijk worden, voorzover hierin niet op andere wijze kan worden voorzien. Voorts krijgen gemeentebesturen de bevoegdheid aanvullende voorwaarden aan de bijstand te verbinden met het oog op de arbeidsinschakeling, om zo een betere afstemming mogelijk te maken op specifieke kenmerken van de lokale of regionale arbeidsmarktsituatie, alsmede een betere aansluiting op de dienstverlening van het arbeidsbureau.

De aanvullende rol van de bijstand, ook waar het gaat om het treffen van voorzieningen, blijft gehandhaafd en wordt in de verhouding met het arbeidsbureau zelfs aangescherpt. Men heeft kennelijk de arbeidsvoorzieningsorganisatie niet het gras voor de voeten weg willen maaien door het gemeentebestuur deels dezelfde taken toe te delen bij de uitvoering van de ABW. In grote lijnen volgen de herinrichtingsplannen het SER-advies over de verhouding tussen uitvoeringsinstanties van sociale-zekerheidsregelingen en de arbeidsvoorzieningsorganisatie ${ }^{59}$. De SER zag hierin voor de uitvoeringsorganen vooral een rol bij het toestaan en eventueel bevorderen van deelname aan activiteiten met behoud van uitkering ('passief of facilitair' beleid). Positieve stimulansen, bijvoorbeeld premiëring van geslaagde scholing, werden afgewezen, maar financiële drempels tot het volgen van scholing dienden wel te worden versoepeld. Overigens werd het gemeentebestuur een iets minder passieve functie toegedacht dan de bedrijfsverenigingen: de creatie van werkervaringsprojecten of specifieke werkgelegenheidsprojecten in de quartaire sector, (mede) uitvoering van het Jeugdwerkgarantieplan en het treffen van voorzieningen op het gebied van de basiseducatie werden als (aanvullende) gemeentelijke taken genoemd ${ }^{60}$.

Bovengenoemde maatregelen gericht op creatie van nieuwe arbeidsplaatsen, komen voort uit initiatieven van de overheid en hebben betrekking op werk in de collectieve sector. De algemene gedachte achter deze maatregelen is dat uit-

$\left.{ }^{59}\right]$ Sociaal-Economische Raad, Advies voorzieningenbeleid werklozen; Publikatie nr. 7; 's-Gravenhage, SER, 1989.

${ }^{60}$ In het interim- advies dat de commissie sociale voorzieningen van de SER op 8 september 1989 uitbracht over de herinrichtingsplannen, wordt in grote lijnen hetzelfde standpunt ingenomen. 
keringsgelden beter kunnen worden besteed aan het scheppen van werkgelegenheid die de kwaliteit van het stedelijk leven verhoogt. In dit brede kader passen ook het Arbeidsmarkt- en Opleidingsfonds (A+O-fonds) voor de overheid en een soortgelijk fonds voor welzijn. Het gaat hier om de creatie van tijdelijke arbeidsplaatsen van 2 tot 4 jaar bij de overheid voor personen die jonger zijn dan 27 jaar en die langer dan 1 jaar werkloos zijn. Het $\mathrm{A}+\mathrm{O}$-fonds voor de overheid berust op een subsidie die ontstaan is door verlaging van de jeugdsalarissen bij de overheid. In 1989 zijn 1600 mensen via deze regeling aan de slag gekomen ${ }^{61}$. Bovendien worden in sommige steden ook PCG-gelden ingezet voor loonkostensubsidies van soms 100 procent en dus in feite voor het creëren van arbeidsplaatsen. In West-Duitsland bestaat een langere traditie op dit terrein ${ }^{62}$. Dit soort regelingen van werkcreatie in de collectieve sector door de overheid samen met het lokaal bedrijfsleven blijkt daar te worden uitgevoerd in een coöperatieve en gedepolitiseerde sfeer. Het initiatief tot dergelijke regelingen ligt in handen van de stadsbesturen, die hiermee kunnen voorzien in publieke behoeften op het terrein van onder meer veiligheid, milieuzorg en sociaal beleid. Deze voorbeelden verdienen ook voor Nederland de aandacht.

\section{c. Banenpools}

Ter bevordering van een directe uitstroom van de sociale uitkeringen naar arbeid werd in het jongste regeerakkoord de invoering op ruime schaal aangekondigd van een figuur die het direct scheppen van werk met behulp van uitkeringsgeld zoveel mogelijk benadert, de arbeidspools, in het onlangs gepubliceerde Sociale vernieuwingsplan omgedoopt tot banenpools.

Hiermee wordt beoogd zeer moeilijk bemiddelbare werklozen, die met het huidige arbeidsvoorzieningsinstrumentarium niet worden bereikt, werk te bieden, vooralsnog uitsluitend in de collectieve sector.

De vormgeving van de banenpools is een gezamenlijke verantwoordelijkheid van de RBA's en de gemeenten, die een overeenkomst moeten sluiten om de desbetreffende rijksbijdragen te ontvangen. De gemeenten zijn verantwoordelijk voor de oprichting en instandhouding van de pools. De stimulans in de vorm van extra besparing op de bijstandsuitgaven is niet van de baan, zij het dat nu sprake is van een extra prikkel van bijvoorbeeld 10 of 20 procent, waardoor het gemeentelijk belang bij een effectieve daling van de lokale werkloosheid zou worden verdubbeld c.q. verdrievoudigd.

De banenpools kunnen een belangrijk middel worden om de sociale mobiliteit te vergroten van groepen die overigens weinig perspectief hebben. Verkleining van dit effect door een mogelijk stigmatiserende werking van het instrument zal zoveel mogelijk vermeden moeten worden. Ook hierom is het te betreuren dat alle plaatsen vooralsnog in de quartaire sector gevonden zullen moeten worden. Nagegaan zou dienen te worden of op termijn een uitbreiding naar de particuliere sector in aanmerking komt, zeker in de steden met een structurele achterstand. Maar het instrument bestaat nog maar pas, het kan op verschillende manieren verder worden ontwikkeld, ook in de financieringswijze (inzet van uitkeringsgelden). Hierbij valt bijvoorbeeld te denken aan een constructie waarbij de gemeente wordt toegestaan om, uiteraard zonder verlies van de mogelijkheid bijstandsuitgaven bij het Rijk te declareren, een grotendeels met bijstandsgeld te financieren arbeidsplaats voor drie of vier jaar te 'kopen', onder voorwaarde dat de betrokken uitkeringsgerechtigde vervolgens in vaste dienst genomen wordt. Zo'n figuur kan in het begin een aanvulling op de arbeidspools vormen. Het waken voor concurrentievervalsing kan men overlaten aan het overleg tussen de RBA-partijen binnen het grootstedelijk gebied.

${ }^{61}$ ] C. den Ouden, 'Voorzieningen voor werklozen'; in: Hondboek lokaol werkgelegenheidsbeleid; R. de Boer, R. van Bekkum, Th.H.E.M. Keune e.a. (red.), 's-Gravenhage, VUGA, 1988 e.v., blz. A 4-1-38.

${ }^{62}$ ] G. Morsinkhof, Arbeidsvoorzieningenbeleid in de BRD; Interne notitie Utrecht; Rijksuniversiteit Utrecht, 1989. 
Al geruime tijd wordt, in veel verdergaande mate dan dit binnen de $\mathrm{ABW}$ het geval is, geld uit werkloosheidsfondsen ingezet ter bestrijding van werkloosheid. De arbeidspool voor havenwerknemers en de Regeling werktijdverkorting zijn de duidelijkste voorbeelden, maar ook VUT-afspraken en overeenkomsten ter bestrijding van jeugdwerkloosheid zijn hier van betekenis. Een recent voorbeeld vormt de financiering van premievrijstelling voor in dienst genomen zeer langdurig werklozen (Wet Vermeend/Moor en opvolgers).

Een en ander heeft een zodanige omvang genomen dat in toenemende mate kritiek valt te horen, onder meer vanuit kringen van fondsbestuurders, op deze 'inbreuken op de verzekeringsgedachte', die bovendien concurrentievervalsend kunnen werken ${ }^{63}$. Dit gevaar is uiteraard aanwezig. De verbinding die de genoemde en andere maatregelen kunnen leggen tussen het werkloosheidsbestrijdingsbeleid en het sociale-zekerheidsbeleid is evenwel te waardevol om er van af te zien. Wel kan men zich voorstellen dat voor de financiering van verdere arbeidsvoorzieningsmaatregelen een beroep zal worden gedaan op de mogelijkheid van afzonderlijke geldelijke bijdragen uit toeslagen op de premies, bedoeld in artikel 79 van de werkloosheidswet. Een dergelijke mogelijkheid zou de band tussen arbeidsvoorziening en sociale verzekeringen formaliseren op een manier die in meer landen is gehanteerd.

Binnen het kader van het facilitaire beleid ten aanzien van de arbeidsvoorziening hebben de bedrijfsverenigingen nog niet alle mogelijkheden benut. Ze kunnen zich als platform voor de regeling van sociale voorzieningen binnen hun bedrijfstakken toeleggen op het voorkomen van werkloosheid. De regering heeft meermalen de verwachting uitgesproken dat preventieve taken aan belang winnen, gezien de toenemende complexiteit van de arbeidsmarkt en de noodzaak om binnen de bedrijfstak te zorgen voor (om)scholingsfaciliteiten, voldoende functiedifferentiatie en een dynamisch personeelsbeleid, gericht op vergroting van (interne) mobiliteit. In dit verband kan ook worden verwezen naar de verwachting dat de fricties tussen vraag en aanbod van arbeid door de technologische ontwikkelingen zullen toenemen ${ }^{64}$. In sommige bedrijfstakken wordt ook geëxperimenteerd met een soort personeelsdiensten voor de bedrijfstak; vooral de detailhandel heeft behoefte aan inzet van personeel op onregelmatige tijden, waarbij men een beroep kan doen op een personeelsdienst van de bedrijfstak.

Ook voor de actieve werkloosheidsbestrijding bestaat echter reden om (met het oog op de langere termijn) de positie van de bedrijfsverenigingen serieus te nemen. Zo wordt onder de nieuwe werkloosheidswet de duur van de werkloosheidsuitkering gekoppeld aan het arbeidsverleden van de werknemer. Hierdoor zullen in de toekomst ook langdurig werklozen blijven vallen onder de Werkloosheidswet. Ze hebben dan te maken met de bedrijfsverenigingen als uitvoerders van de wet en niet met de GSD's zoals thans het geval is. In dit verband ligt samenwerking tussen arbeidsvoorzieningsorganisatie en bedrijfsvereniging (c.q. GAK) evenzeer voor de hand als nu tussen arbeidsbureaus en GSD.

De noodzaak van samenwerking tussen bedrijfsvereniging en arbeidsvoorzieningsorganisatie zou uiteraard ook toenemen als er op den duur, zoals in andere landen, een beleid zou worden gevoerd waarbij de bijstandswet weer

${ }^{63}$ ] W. van Voorden, 'Is sociale vernieuwing ook verbetering?'; Socioal Moandblad Arbeid, januari 1990, jaargang 45, nr. I, blz. 3-6. H.F.Heijmans, 'Inbreuken op de verzekeringsgedachte - de kleren van de keizer?'; Sociaal Maandblad Arbeid, februari 1990, jaargang $45, \mathrm{nr} .2$, blz. $71 \mathrm{t} / \mathrm{m} 76$.

${ }^{64}$ ] G.R. de Wet en P.A. Hovestadt, Technologie en werkgelegenheid; 's-Gravenhage, Organisatie voor strategisch marktonderzoek, 1990, blz. 33. 
meer haar beperkte positie zou krijgen en de betekenis van de aan arbeid gekoppelde sociale-zekerheidswetten weer zou toenemen. Dit gebeurt in WestDuitsland. Zodra men aan een werkverschaffingsproject deelneemt, wordt er bijvoorbeeld weer werkloosheidspremie betaald en valt men weer onder de werking van de werkloosheidswet.

Een afzonderlijk punt in het contact tussen arbeidsvoorzienings- en socialezekerheidsorganisatie betreft de meldingen van niet-adequaat gedrag van uitkeringsgerechtigden aan de GSD's en aan de bedrijfsverenigingen. Uit onderzoek komt naar voren dat slechts een beperkt deel van de gevallen van verwijtbaar gedrag wordt doorgegeven aan de uitkeringsinstanties ${ }^{65}$. Er moet daarom ook naar middelen worden gezocht waardoor de meldingsplicht serieuzer wordt genomen. Deze plicht zou kunnen worden uitgebreid tot een preventieve informatieplicht wanneer de arbeidsbureaus zich (volgens plan) meer gaan toeleggen op trajectbemiddeling en individuele begeleiding. Het is dan zaak dat de uitkeringsinstanties op de hoogte worden gehouden van de voortgang van de individuele cliënt door het circuit van (om)scholings- en arbeidsvoorzieningsinstrumenten. Dit vereist afzonderlijke afspraken tussen arbeidsbureau en uitkeringsinstantie.

\section{e. Bevordering van aanbodsgericht arbeidsvoorzieningsbeleid}

De arbeidsvoorziening is traditioneel afgestemd op de behartiging van het algemeen belang, wat tot uiting komt in de dwang die het arbeidsbureau mag uitoefenen om mensen aan het werk te helpen en in de inzet van extra middelen om werkloosheid als sociaal probleem te bestrijden. De ervaring leert dat uitzendbureaus weliswaar zeer goed in staat zijn om capabele, gemotiveerde en tot scholing bereid zijnde werklozen aan arbeid te helpen, maar dat zij met andere werklozen nauwelijks succes hebben. Bij die categorie ligt de hoofdtaak van de publieke arbeidsvoorziening.

$\mathrm{Na}$ het beleid van werkverruimende maatregelen vooral in de sociaal-culturele sfeer van het begin van de jaren ' 80 en na de vraaggerichte benadering uit de tweede helft van die periode wijzen, lijkt het moment nu aangebroken voor een offensieve aanbodgerichte politiek. De methode die hierbij gevolgd wordt, moet aansluiten op de kenmerken van het aanbod van werklozen die al lange tijd ingeschreven staan, met name hun lage scholing.

In steden als Helmond en Enschede is hiervoor een op het individuele geval gerichte methode van bemiddeling ontwikkeld, die past in de Angelsaksische traditie van het 'casework'.

De kern van de methode is dat een bemiddelaar die de lokale werkgelegenheidssituatie goed kent, optreedt als vertrouwensman tussen vragers en aanbieders van arbeid. Er wordt niet gewacht totdat vacatures worden gemeld of totdat een werkloze zich aandient bij het arbeidsbureau, maar de bemiddelaar zoekt beide partijen afzonderlijk op en tracht die vervolgens met elkaar in contact te brengen. De methode blijkt werkgelegenheid aan het licht te brengen die (nog) niet de vorm van vacatures had gekregen. $\mathrm{Zij}$ is vooral succesvol voor het midden- en kleinbedrijf.

In enkele wijken van de grote steden is het voorbeeld van Helmond en Enschede overgenomen. Het zou echter op veel groter schaal nagevolgd moeten worden in het kader van een offensief aanbodgericht beleid.

In het kader van het aanbodgerichte beleid past ook een kwalificatie-offensief. Regering en arbeidsvoorzieningsorganisatie streven ernaar ongeschoolde en laaggeschoolde werklozen aan bepaalde (scholings)kwalificaties te helpen.

65] R. Hoffius, op. cit., blz. 37. 
Een bijkomend voordeel is dat de werklozen zo ook voor de vragers herkenbaar worden. Voorafgaand aan de beroepsgerichte kwalificatiecursussen worden meestal ook weer allerlei toegangscursussen georganiseerd in de sfeer van basiseducatie (bijv. leren van de Nederlandse taal) en van beroepsoriëntatie en primaire beroepsoefening. Zo ontstaan de scholings- annex bemiddelingstrajecten, die soms enkele jaren in beslag nemen en vaak een hoge uitval kennen. Tegen die achtergrond is een nader onderzoek van belang naar de toelatingseisen van het leerlingwezen en de centra voor vakopleiding, de instituten die zorgen voor de kwalificaties. Het idee om voor bepaalde categorieën uitzonderingen te maken op de algemeen geldende toelatingseisen (de klantgerichte scholing waarmee de Task Forces in Engeland enige furore hebben gemaakt), dient ondersteund te worden. Ook zou de eindverantwoordelijkheid voor de individuele begeleiding van de werkloze door het scholings- en bemiddelingscircuit primair in handen moeten liggen van functionarissen die zorgen voor de arbeidsinpassing. Zo worden voorwaarden geschapen om te voorkomen dat de scholingskwalificaties een doel op zich zelf gaan worden.

Een laatste element van een offensief aanbodbeleid van de arbeidsvoorziening is een actief portefeuillebeheer. De grote steden gelden als plaatsen waar men niet precies weet wie er allemaal staan ingeschreven. Er bestaat een zekere sociaal-culturele anonimiteit van de ingeschrevenen. Door de heroriënteringsgesprekken is deze anonimiteit al deels opgeheven. Op dit pad moet verder worden gegaan door een behandeling van de werkloze uitkeringsgerechtigde op een manier waarop bijvoorbeeld een schadeverzekeringsbedrijf in principe zijn schadegevallen beheert, dat wil zeggen met zorgvuldigheid, elk individueel geval afzonderlijk behandelend en met inzet van middelen om de schade (in dit geval ook voor de samenleving) weg te nemen.

\subsubsection{Bevordering van ondernemerschap}

In veel landen zijn lokale initiatieven ontwikkeld ter bevordering van het zelfstandig ondernemerschap. Het gaat hierbij niet alleen om de ontwikkeling van hoog gespecialiseerde toeleveringsbedrijven die een belangrijke rol vervullen in de groeiende en zich vernieuwende economie, maar ook om de bevordering van een zelfstandige bestaansvoorziening van betrekkelijk laaggeschoolden, die al dan niet in het arbeidsproces opgenomen zijn.

In deze paragraaf worden enige internationale ervaringen weergegeven met het bevorderen van de zelfstandige vestiging van werklozen en/of reeds werkenden.

In het Verenigd Koninkrijk heeft, sinds de Anglo-American Conference on Community Involvement in 1980, in kringen van het bedrijfsleven, de wetenschap en de overheid een intensieve verwerking van Amerikaanse ervaringen plaatsgevonden ${ }^{66}$. De OECD startte in 1982, eveneens geinspireerd door Amerikaanse voorbeelden, een internationaal vergelijkend onderzoekprogramma naar lokale werkgelegenheidsinitiatieven, dat een katalyserende rol heeft vervuld ${ }^{67}$.

De resultaten die in de Verenigde Staten zijn geboekt met het terugdringen van de werkloosheid, trekken al enige tijd de aandacht. Gedurende de laatste vijftien jaar is daar 80 procent van de nieuwe banen gerealiseerd in het kleinbedrijf. Kwantitatief gezien, betreft het vooral verbijzonderingen van de laag-

66] Een voortreffelijk overzicht in de stroom van uitwisselingsrelaties kan worden gevonden in Regeneroting the cities; The UK crisis and the US experience; Ed. M. Parkinson, B. Foley and D. Judd; Manchester, Manchester University Press, 1988.

${ }^{67}$ ] OECD. Mechanisms for job creation; lessons from the United States; Paris, OECD, 1989. Andere publikaties van het langlopend onderzoekprogramma 'local initiatives for employment creation' betreffen: OECD, Creating jobs ot the local level; Paris, OECD, 1985; OECD, New roles for cities and towns; Paris, OECD, 1987; OECD, Implementing change: entrepreneurship and local initiotives; Paris, OECD, 1990. Tenslotte de jaarlijkse uitgave OECD, Innovation/Employment; Paris. 
geschoolde dienstverlening. Tussen 1979 en 1985 verviervoudigde het aantal kleine zelfstandigen. De groei voltrekt zich vooral in de sfeer van de 'convenience-industry' (letterlijk op te vatten als het leveren van gemakken) op het gebied van onderwijs, kinderopvang, voeding, auto-onderhoud, winkelvoorziening, enzovoort ${ }^{68}$. Het zijn de bekende voorbeelden van laagniveau-specialisaties van dienstverlening die in de macro-economische en institutionele context van de Verenigde Staten veel eenvoudiger kunnen ontstaan dan in de context van de Europese landen.

Toch zijn door bescheiden financiële prikkels ook reeds in Europese landen op deze gebieden opvallende successen geboekt. Een voorbeeld dat voor minder selectieve toepassing ook in Nederland aandacht verdient, betreft het gebruik van uitkeringsgelden als startkapitaal voor bedrijfjes (de 'Irish enterprise allowance', de 'chômeurs/entrepreneurs' in Frankrijk, vergelijkbare initiatieven in Zweden ${ }^{69}$. In het Verenigd Koninkrijk geldt de 'enterprise allowance' als succesvol. Volgens dit programma kunnen werklozen die over $£ 1000$ eigen startkapitaal beschikken, wanneer zij zich zelfstandig vestigen een jaar lang aanspraak maken op een toelage van $£ 40$ per week (hetgeen minder is dan de bijstandsuitkering). Het programma begon in 1983; vijf jaar later hadden reeds 350.000 personen gebruik gemaakt van de regeling en sindsdien komen er jaarlijks ongeveer 90.000 starters bij. Volgens een evaluatie in 1988 bleek tweederde van deze starters na twee jaar nog in bedrijf.

Overigens wordt dit succes recentelijk enigszins gerelativeerd: veel starters zouden ook zonder de toelage wel begonnen zijn; na verloop van tijd treedt een zekere verdringing op van de meest gewilde initiatieven; de gesubsidieerde nieuwkomers drukken de niet meer gesubsidieerden uit de markt, enzovoort ${ }^{70}$. Onlangs rapporteerde de Britse Rekenkamer dat van de starters na drie jaar nog slechts 57 procent in bedrijf zou zijn ${ }^{71}$. Niettemin wordt het programma als succesvol beschouwd en ontwikkelen zich uit de grote groep van nieuwe neringdoenden af en toe ook ondernemingen die aan anderen werk bieden.

In Nederland geldt voor starters het Bijstandsbesluit Zelfstandigen, de BZregeling. In vergelijking met de bovengenoemde buitenlandse regelingen is deze regeling royaal, maar vanwege de toelatingseisen (opleiding, levensvatbaarheid van het bedrijf) werkt zij veel selectiever. De regeling maakt het mogelijk starters een lening te verstrekken met een maximum van $f$ 25.000,bij de oprichting van een bedrijf. (In het jongste regeerakkoord is besloten de lening voor zelfstandigen die recht hebben op een bijstandsuitkering, te laten verlopen via het bancaire kanaal. Voor starters bestond aanvankelijk hetzelfde voornemen. Mede op grond van verzet van de grote steden is de oude regeling voor de starters althans voorlopig gehandhaafd in afwachting van nader onderzoek van de mogelijkheden tot bankleningen aan starters.) Hoewel aanvankelijk veel werd verwacht van het in de jaren ' 80 begonnen startersbeleid, vallen de resultaten in de grote steden tegen. Het gaat meestal om niet veel meer dan enkele honderden deelnemers per stad. De startersregeling in Nederland kent een uitgebreide voorbereidingsfase, waarin de starters plannen moeten overleggen, die vervolgens worden getoetst op levensvatbaarheid. Ook bestaat in Nederland de neiging om het startersbeleid 'uit te breiden naar ondernemers die te lang bezig zijn geweest om nog starter te heten, maar nog niet lang genoeg om alle kinderziektes achter zich te hebben' (ook wel doorstarters genoemd ${ }^{72}$. De indruk bestaat dat het Nederlandse startersbeleid in vergelijking met andere landen meer op zekerheid vooraf is gericht, selectiever is en

${ }^{68}$ ] P. Domergues, 'The American job machine'; in: Mechanisms for job creation; (op. cit.), blz. 27.

${ }^{69}$ ] OECD, Creating jobs at the local level; (op. cit.), blz. II.

${ }^{70}$ ] J. Hirst, 'Mediocre, to say the least; New Statesman and Society, 12 augustus 1988, jaargang I, blz. 25.

7] Enterprise culture; New Statesmon and Society; 1990, jaargang 3, nr. 84, blz. 27.

72] Handboek lokoal werkgelegenheidsbeleid; (op. cit.), blz, A2-3-52. 
meer is gericht op diegenen die al in het systeem van het startersbeleid zitten dan op het in de volle breedte mobiliseren van werklozen. In vergelijking met andere landen krijgt de startersregeling in Nederland ook relatief weinig aandacht in het beleid ter bestrijding van de werkloosheid.

Voor een meer gestructureerde ontwikkeling van het ondernemerschap is in de eerder genoemde Europese landen lering getrokken uit de Amerikaanse voorbeelden. Kenmerkend was daar dat het ondernemerschap zich van complete stadsdelen had afgekeerd. Dit heeft aantal Amerikaanse steden ertoe bewogen de ondernemingscultuur daar opnieuw te organiseren, in samenwerking met het bedrijfsleven, de gemeenten, onderwijsinstellingen en andere lokale organisaties. Het bedrijfsleven nam veelal het voortouw in deze 'public-privatepartnerships', maar ook de lokale overheden (die op het gebied van de sociale voorzieningen veelal terughoudender zijn dan in Europa) legden op dit gebied een grote voortvarendheid aan de dag. In het Verenigd Koninkrijk was het in eerste instantie de regering die - met diep wantrouwen jegens de sociale programma's van de gemeenten en de sociale plaatselijke instellingen - het vrije ondernemerschap 'in partnership with the people' in de steden lanceerde. Inmiddels is het zwaartepunt van deze activiteiten overigens ook daar naar het lokale niveau verschoven, niet alleen omdat de gemeenten inmiddels voor deze doelstelling ontvankelijker zijn geworden, maar vooral ook doordat vanuit het lokale bedrijfsleven in toenemende mate een beroep wordt gedaan op een actieve opstelling van de plaatselijke overheden.

Het organiseren van een ondernemingsklimaat waarin veel kleine bedrijven kunnen opbloeien, is in de Angelsaksische voorbeelden niet primair afhankelijk van langdurige belasting- of subsidiefaciliteiten. Zeker bestaat daar op lokaal niveau een variëteit van financiële tegemoetkomingen, maar het zijn vooral aanvullende stimulansen, investeringen die op den duur voor de overheden zelf tot nieuwe inkomsten moeten leiden. Soms getuigen dergelijke prikkels van een grote inventiviteit, zoals het gebruik van publieke aanbestedingen als hefboom voor de ontwikkeling van het midden- en kleinbedrijf, het fiscaal aantrekkelijk maken van de investering van particuliere spaargelden in nieuw op te richten bedrijven ('the limited partnership') of het gebruik van overhevelingsmechanismen die ertoe strekken dat publieke middelen door particuliere middelen worden aangevuld, zoals bij investeringsmaatschappijen voor het kleinbedrijf ${ }^{73}$. De variëteit van dergelijke prikkels is zeer groot.

Naast financiële prikkels spelen veel andere factoren een rol bij de stimulering van de lokale ondernemingscultuur, zoals ruimtelijke ordening, grondbeleid, onderwijs enzovoort. Een van de rapporteurs van het bovengenoemde OECDproject concludeert dat in de meeste lidstaten:

- lokaal nog te weinig wordt gedaan aan scholing in bedrijfsmanagement voor aspirant-ondernemers;

- de samenwerking of de mogelijke koppelingen tussen bedrijven onvoldoende worden aangemoedigd (subcontracting!);

- institutionele investeerders onvoldoende worden betrokken bij het oprichten van ondernemingen;

- de bedrijfsontwikkeling en het creëren van banen meer moeten worden gericht op de ruimtelijke lokaties waar zij nodig zijn ${ }^{74}$.

Alle genoemde factoren zijn ook in Nederland relevant. De lokale ondernemingscultuur kan hier op veel aanvullende manieren worden bevorderd, als zij tot inzet zou worden gemaakt van een geïntensiveerd beleid zoals sinds kort gebeurt in de sfeer van het arbeidsmarktbeleid. De rol van de verschillende

73] H. Sibille, 'Job creation in the United States'; in: Mechanisms for job creation, (op. cit.), blz. 22.

${ }^{74}$ ] J.P. Pellegrin, 'Local initiatives for enterprise'; The OECD Observer; June-July 1989, nr. I58, blz. II. 
overheden is hierin een voorwaardenscheppende en - op lokaal niveau - vooral ook een bemiddelende, in die zin dat de gemeenten vanuit een generieke invalshoek partijen bij elkaar kunnen brengen en initiatieven kunnen combineren die anders langs elkaar heen zouden lopen. Maar de primaire verantwoordelijkheid voor de ontplooiing van de lokale ondernemingscultuur ligt bij het bedrijfsleven zelf. Op deze grondslag is het succes van de Amerikaanse 'partnerships' gebaseerd.

In het Verenigd Koninkrijk heeft het bedrijfsleven, als een direct uitvloeisel van de eerdergenoemde Anglo-American Conference in 1980, een overkoepelende organisatie opgericht, 'Business in the Community' (BIC), ter bevordering van de ondernemingscultuur in de steden. Door de ondersteuning en oprichting van 250 lokale 'agencies' kon deze organisatie lokaal rechtstreeks samenwerkingsverbanden aangaan met de betrokken overheden en andere partijen. Onder andere via deze samenwerkingsverbanden heeft de nieuwe infrastructuur van de particuliere sector een eigen dynamiek gegeven aan het Britse grootstedelijk beleid in de jaren ' 80 .

BIC speelt een belangrijke rol in de concretisering van de collectieve verantwoordelijkheid van het bedrijfsleven door individuele bedrijven hierop aan te spreken en in concrete beleidsinitiatieven te betrekken. Hiertoe worden op nationaal en lokaal niveau veel zogenoemde 'vlaggeschipprojecten' ontwikkeld. Op nationaal niveau zijn acht teams ingesteld, die initiatieven bevorderen met betrekking tot de volgende thema's:

- recrutering van jonge werklozen door de aangesloten bedrijven;

- bevordering van startende ondernemingen;

- scholingsprogramma's voor vastgoed-ontwikkeling;

- bevordering van directe banden tussen bedrijfsleven en onderwijsinstellingen;

- kredietgaranties voor startende ondernemingen;

- ondersteuning van het midden- en kleinbedrijf door het stimuleren van lokale aankopen. Op plaatselijk niveau gaat dit zover dat grote bedrijven gespecialiseerd personeel uitlenen aan plaatselijke toeleveringsbedrijven om het gewenste kwaliteitsniveau van de produkten te bevorderen en de just-in-time leveringen te organiseren;

- contacten tussen bedrijven en vrijwilligersorganisaties (de typisch Britse 'voluntary sector');

- demonstratie aan bedrijven van de betekenis en bijzondere achtergronden van de vrijwilligersorganisaties ${ }^{75}$.

Een aantal particuliere organisaties ter stimulering van de plaatselijke werkgelegenheidsinitiatieven is met BIC geassocieerd.

- De 'Industrial Society' ( 400 werknemers, verspreid door het land) bevordert de kwaliteit van het ondernemerschap. Een van de opvallendste activiteiten betreft de ondersteuning van jongeren op de weg naar het ondernemerschap ('Headstart'). Na een intensieve cursus van twee maanden wordt de aspirantondernemer bijgestaan door een plaatselijk ondernemer die opereert als 'business mate'. Dit programma heeft enige furore gemaakt nadat de regering voor haar eigen 'frontlijn-initiatieven' een contract sloot met Headstart voor de begeleiding van 4500 jonge bewoners in achterstandsgebieden op weg naar het ondernemerschap.

- In het project 'Fullemploy' werken overheid en bedrijfsleven met gedeelde beurs samen om jaarlijks 3000 jongeren uit minderheidsgroeperingen te bekwamen in commerciële vaardigheden en zelfstandig ondernemerschap.

- 'Young Enterprise' betreft een zeer opmerkelijk experiment in 1500 scholen en buurtcentra om groepen van tien tot vijftien jongeren van $15-19$ jaar voor enige tijd zelf een (van een groot concern afgezonderde) onderneming te laten

75] Action for cities; London, HMSO, z.j. 
runnen. Zij worden hierbij geadviseerd door plaatselijke bedrijven. Het experiment wordt uitgebreid tot een deelname van 60.000 jongeren per jaar.

- De 'Prince's youth business trust' is het omvangrijkste particuliere initiatief voor ondersteuning van jonge starters. Er worden beurzen en leningen verstrekt om een eigen bedrijf te starten. Het ligt voorts in de bedoeling iedereen die een beurs of lening ontvangt een scholingscursus aan te bieden op het gebied van marketing.

De lokale 'agentschappen' trachten op soortgelijke wijze op lokaal niveau het ondernemerschap op tal van manieren te bevorderen ${ }^{76}$.

De combinatie van de particuliere initiatieven met de overheidsplannen voor de 'regeneration' van de steden heeft de ondernemingscultuur in een groot aantal Britse steden gedurende de afgelopen tien jaar enorm versterkt. In dit opzicht heeft het Britse model een grotere voorbeeldwaarde voor de stedelijke ontwikkeling dan in Nederland soms wordt beseft. Toch is het in zijn opzet om achterstandsgroepen en achterstandsgebieden te betrekken in de 'culture of enterprise' maar ten dele geslaagd. Vooral de sociale revitalisering langs deze weg blijkt moeilijk. Om nieuwe bruggen te slaan tussen de sociale doelgroepen en de economische ontwikkelingsprogramma's zijn in 1985 de City Action Teams (Cat's) ingesteld. Deze teams kregen de bevoegdheid om de geldstromen van de verschillende departementen naar de steden op regionaal niveau te coördineren. Een jaar later werden in acht steden City Task Forces ingesteld die de sociale doelgroepen meer moesten betrekken bij de centrale beleidsprogramma's ter bevordering van de stedelijke ondernemingscultuur (in Liverpool was hiermee al eerder ervaring opgedaan ${ }^{77}$. De Task Forces waren tijdelijk bedoeld, maar reeds in 1987 werd hun aantal verdubbeld.

Deze Task Forces ressorteren onder het Department of Trade and Industry. Het zijn betrekkelijk kleine teams, gelokaliseerd in de achterstandswijken, gedeconcentreerd vanuit de centrale regering, met directe verbindingslijnen naar de ambtelijke toppen van de diverse departementen. De Task Forces hebben een katalyserende taak, met grote bevoegdheden om slagvaardig verbindingen tussen verschillende partijen en verschillende beleidsprogramma's te kunnen leggen. Volgens de opzet zouden deze verbindingen betrekking moeten hebben op de centrale overheid, het lokale bedrijfsleven en de sociale doelgroepen, maar in de praktijk bleek al snel dat de sociale doelgroepen voornamelijk via de gemeenten en de lokale vrijwilligersorganisaties konden worden bereikt. Om duurzame economische ontwikkelingen te bevorderen werden door de Task Forces professionele instellingen gecontracteerd (zoals de eerdergenoemde 'Industrial Society') en werd via opleidingen de veelal tekortschietende management-bekwaamheid van de lokale vrijwilligersorganisaties vergroot.

Beleidsexperimenten van de Task Forces hebben geleid tot veel 'modelprogramma's' en beleidsvernieuwingen, bijvoorbeeld in de sfeer van klantgerichte scholing en recrutering (door 'topping-up' en 'rule-bending': het naar boven en beneden aanpassen van de reguliere kwaliteitsniveaus). Een beroemd voorbeeld dat inmiddels in het hele land succesvolle navolging heeft gekregen, betreft het Copthorne-programma, genoemd naar een hotelketen in Birmingham die 50 langdurig werklozen in dienst nam, nadat deze gedurende twee weken intensief waren geschoold in presentatie- en gesprekstechnieken. Het belangrijkste effect van deze cursus was dat zowel bij de werkgevers als bij de

76] A. Pike, 'Business in the community, Co-ordinating a sharper focus and stronger voice'; Finoncial Times, July 17, 1987, Section 3, blz. 2.

77] Na de rellen in Toxteth (Liverpool) in het begin van de jaren '80, werd door de toenmalige minister Heseltine de eerste Inner City Task Force ingesteld waarbij het lokaal bestuur nadrukkelijk werd gepasseerd. 
potentiële werknemers zelf het beeld van onbekwaamheid van betrokkenen werd doorgeprikt ${ }^{78}$. Vergelijkbare initiatieven werden op het gebied van de textielindustrie ontwikkeld in Glasgow.

De Britse Task Forces streven specifiek naar een katalyserende rol ter bevordering van een ondernemingscultuur bij bevolkingsgroepen en in stadsdelen waar deze cultuur traditioneel ontbreekt of inmiddels is wegge-ebd. Hun relatieve successen blijven vooralsnog afhankelijk van initiatieven van de Task Forces. Het zo snel mogelijk doorgeven hiervan aan de lokale organisaties stuit nog vaak op het probleem dat in de taakgebieden de capaciteit van de organisaties en de betrokkenheid van het bedrijfsleven te gering is ${ }^{79}$. Het (weer) opbouwen van lokale capaciteiten is een langdurig proces. In de Amerikaanse steden waar al langer volgens de bovengenoemde werkwijze wordt geïnvesteerd in de sociale structuur van de steden, werden de resultaten soms pas goed zichtbaar na vijftien jaar!

Het gaat hier om andere doelstellingen en voor een deel ook om andere partijen dan in het eigenlijke arbeidsmarktbeleid. Het is raadzaam om beide sferen naast elkaar tot ontwikkeling te laten komen. Ook voor de Nederlandse grote steden kan een dergelijke mobilisering van krachten ter bevordering van de ondernemerscultuur een belangrijk spoor worden in het werkgelegenheidsbeleid. Voorwaarde is dan wel dat binnen de algemene bevordering van het ondernemerschap - die in Nederland reeds actief wordt toegelegd op de kansrijke starters - uitdrukkelijk aandacht wordt besteed aan de mogelijkheden voor de werklozen. In dit verband is de Britse aanpak bestudering waard (met name de aanwijzing van 'taakgebieden' in de steden en de toespitsing op sociale doelgroepen). Anders dan in veel van onze landelijke gebieden - waar het betrekkelijk normaal wordt gevonden wanneer jonge mensen, ook zonder veel vooropleiding, voor zich zelf beginnen - is de 'natuurlijke inbedding' van startende en reeds bedrijvige ondernemers in de grote steden zeker niet optimaal. Een beleid van economische stadsvernieuwing, gezamenlijk gedragen door de lokale bedrijven, de gemeenten, het ministerie van Economische Zaken en de diverse organisaties voor het midden- en kleinbedrijf, zou hierin de noodzakelijke verbetering kunnen brengen. 


\section{Allocatie van stedelijke voorzieningen}

\section{I Inleiding}

De stedelijke voorzieningen verrijken niet alleen de stedelijke cultuur, maar scheppen condities voor de sociale en economische ontwikkelingen en voeden ook in sterke mate de specialisaties van de stedelijke bedrijvigheid en de kenmerken van de stedelijke bevolking. Omgekeerd wordt ook het aanbod van voorzieningen sterk gekleurd door de specifieke eisen van de bedrijvigheid en van de stedelijke bevolking. De voorzieningen bevinden zich zo in het hart van de grootstedelijke politiek, reden waarom er in dit rapport een belangrijke plaats voor wordt ingeruimd. Voorts geldt dat de stedelijke voorzieningen soms vatbaarder zijn voor directe beleidsbeïnvloeding dan de sociale en economische ontwikkelingen zelf.

De stedelijke voorzieningen bestrijken een gebied dat zich uitstrekt van fysieke voorzieningen, zoals de ruimtelijke inrichting, de infrastructuur en de volkshuisvesting, tot diverse culturele en maatschappelijke voorzieningen. Op onderdelen komen zij verspreid in het hele rapport aan de orde. Echter om een intensievere analyse mogelijk te maken wordt in dit hoofdstuk de aandacht geconcentreerd op drie clusters van stedelijke voorzieningen. Het betreft achtereenvolgens: onderwijs, arbeidsvoorziening en gezondheid en maatschappelijke dienstverlening.

Met deze selectie wordt geen nieuwe rangorde beoogd voor het stedelijk voorzieningenbeleid. Hoewel de centrale financiële en distributieve kaders in elk stedelijk gebied een gemeenschappelijke basis voor de voorzieningen zullen blijven garanderen, kunnen plaatselijk zeer verschillende beleidscombinaties en -accenten worden gelegd. Zo kunnen verschillende stedelijke profielen ontstaan, waarbij de ene stad zich sterk maakt voor de ontwikkeling van de culturele voorzieningen, terwijl in de andere een zwaartepunt komt te liggen bij onderwijsprogramma's of bij de fysieke stadsvernieuwing.

Bij de analyse van de drie voorzieningenclusters staat de vraag centraal of de institutionele context waarin het grootstedelijk voorzieningenbeleid tot stand komt, voldoende ruimte biedt om binnen het nationale financiële en het nationale distributieve kader een zelfstandig stedelijk beleid te ontwikkelen. Deze vraag krijgt extra reliëf nu zich vrijwel over de gehele linie van het voorzieningenbeleid ingrijpende institutionele veranderingen aftekenen. Ondanks de bijzondere achtergronden van elk afzonderlijk voorzieningencluster zijn er veel overeenkomsten in de institutionele ontwikkelingen op de drie geselecteerde beleidsgebieden. Deze overeenkomsten zullen hier in een wat ruimer tijdsperspectief kortweg worden getypeerd.

In de periode tussen de oorlogen lag het initiatief voor het voorzieningenbeleid nog grotendeels bij de lokale marktpartijen. De plaatselijke besturen speelden hierop in en vulden zonodig de lacunes in de voorziening zelf op. Met name de grote steden hadden in deze ontwikkeling een voortrekkersrol, bijvoorbeeld op het gebied van de zorg en dienstverlening, de sociale zekerheid, de volkshuisvesting en de arbeidsvoorziening. De centrale wetgever beperkte de eigen betrokkenheid bij dit beleid in hoge mate. Na de oorlog veranderde dit institutionele patroon. De omvang en de kwaliteit van de voorzieningen expandeerden in korte tijd. Kenmerkend voor de nieuwe verhoudingen was in de eerste plaats dat de rijksoverheid veel meer rechtstreeks geïnvolveerd raakte in de programmering van de voorzieningen. In de tweede plaats ontpopte het Rijk zich binnen de sfeer van de overheid als de grote initiator. 
Zo ontstond het nationale 'instellingenbeleid', waarvan de hoofdlijnen op de meeste gebieden in gemeen overleg tussen de centrale marktpartijen en de rijksoverheid werden bepaald. Kenmerkend voor dit instellingenbeleid is dat het, ondersteund door geldmiddelen van de rijksoverheid en omkleed met centrale voorwaarden, wordt uitgevoerd door particuliere, overwegend noncommerciële instellingen. Voorts is het instellingenbeleid gericht op het aanbod van voorzieningen. De positie van de gebruikers is in het instellingenbeleid nauwelijks tot wasdom gekomen. De beleidsvoorwaarden inzake de toegankelijkheid, de kwaliteit, het volume en zelfs de prijsvorming werden doorgaans centraal bepaald. De lokale partijen - zowel de gemeenten als de instellingen en in het bijzonder de uiteindelijke gebruikers - raakten in de uitvoering van hun beleid steeds meer gebonden aan de centrale voorwaarden van het Rijk en in een aantal gevallen van centrale maatschappelijke organisaties, de zogeheten koepels. Vanwege deze opzet kon het voorzieningenbeleid niet optimaal aansluiten op lokale en regionale omstandigheden.

Vanaf de jaren ' 70 heeft de kritiek op het functioneren van de topzware bureaucratieën geleid tot een decentralisatie van beleidstaken naar lagere overheden of naar functionele organisaties. Ook de begrotingstekorten droegen hiertoe bij. Kenmerkend voor de operaties in Nederland is echter dat de rijksoverheid als initiatiefnemer toch steeds de regie in eigen hand heeft gehouden. Dit is bepalender voor de kansen van het grootstedelijk beleid dan de vraag of de overheveling van taken langs territoriale dan wel functionele lijn dient te geschieden. De decentralisatiemodellen van de jaren ' 70 en ' 80 werden gedacht vanuit de top in de rijksdienst en eindigden bij de ontvangende burger, en wel via de hiërarchisch georganiseerde planstructuren in de jaren '70 en via de gebudgetteerde beleidsoverdrachten onder gedetailleerde centrale voorschriften in de jaren ' 80 . Deze modellen van decentralisatie waren meer geboren uit het motief om het rijksapparaat te ontlasten dan om de lokale aansprakelijkheden te vergroten.

In de tweede helft van de jaren ' 80 kantelde het institutionele patroon een slag verder als gevolg van de beleidsvoornemens om op verschillende gebieden de markt als vertrekpunt te nemen voor de uitvoering van het voorzieningenbeleid. Zulke ingrijpende operaties zijn thans ophanden in de gezondheidszorg en maatschappelijke dienstverlening, de volkshuisvesting en ten dele in de getripartiseerde arbeidsvoorziening. Voor het onderwijs is een dereguleringsoperatie begonnen waarbij de afzonderlijke onderwijsinstellingen meer zeggenschap krijgen (de 'autonome school'). Hiernaast zijn er op dit terrein inmiddels veel commerciële initiatieven en begeven ook de 'gewone' onderwijsinstellingen zich steeds meer op dubbele markten.

Het overheersende patroon van deze recente plannen voor stelselherziening is dat enerzijds lokale marktpartijen het voortouw krijgen in de uitvoering van het beleid en dat anderzijds de rijksoverheid de condities voor de marktwerking vaststelt. Zo gaan nieuwe vormen van maatschappelijke en statelijke invloed hand in hand. De lagere overheden, vooral de zwaarder geëquipeerde gemeentebesturen in de grote steden, bevinden zich op het kruispunt van deze twee structurele invloeden. Maar het pikante van hun positie is dat zij door de stelselherzieningen ogenschijnlijk langs beide kanten worden gepasseerd. Aan de ene kant verliezen de stadsbesturen hier en daar zelfs beleidsprogrammerende en -uitvoerende taken aan de marktpartijen. Aan de andere kant wordt de conditionering van de marktwerking gecentraliseerd.

Bezien vanuit de ratio van de stelsels zal derhalve in het algemeen de directe betrokkenheid van de lagere overheden in het voorzieningenbeleid betrekkelijk gering zijn. De nieuwe stelsels definiëren echter niet de maatschappelijke praktijk van het grootstedelijk beleid. $\mathrm{Zij}$ creëren hiervoor slechts nieuwe condities die in de praktijk van het beleid een eigen werking gaan krijgen. 
In het grootstedelijk beleid is het voor alle betrokkenen van primair belang dat de allocatieve beleidstaken zo optimaal mogelijk worden vervuld. De eerste verantwoordelijkheid hiervoor ligt in het plaatselijk verkeer tussen burgers en maatschappelijke organisaties. De lagere overheden zijn op diverse manieren in deze lokale netwerken betrokken (stimulerend, corrigerend, aanvullend), niet alleen vanuit hun rol binnen de desbetreffende voorzieningensector, maar ook en vooral vanwege hun generieke verantwoordelijkheid voor de stedelijke ontwikkeling.

Bezien vanuit deze optiek bieden de stelselherzieningen wel degelijk aanknopingspunten voor een verrijking van de stedelijke politieke cultuur, mits de uitvoering van de nieuwe stelsels met voldoende kracht wordt doorgevoerd. Kenmerkend voor de stelselherzieningen is immers dat de verantwoordelijkheden van de lokale instellingen worden vergroot. Scholen, woningbouwverenigingen, ziekenfondsen en arbeidsbureaus, die gedurende de laatste decennia voor vrijwel alle beleidsafwegingen waren gebonden aan centrale richtlijnen, kunnen zich nu ontpoppen als competente beleidspartijen. Het ontluikende 'sociale ondernemerschap' houdt op zijn minst de mogelijkheid in van een betere allocatie van voorzieningen, maar biedt hiertoe op zich nog onvoldoende garanties. Bepalend is het spel met de andere partijen (de beoogde marktwerking), in het bijzonder met de relatief ondergeorganiseerde partijen aan de vraagzijde. Bepalend is ook de wijze waarop het geheel van nieuwe voorwaarden zal uitwerken in de lokale praktijk van het grootstedelijk beleid. De rol van het grootstedelijk bestuur zal in reactie op deze ontwikkelingen van gedaante verwisselen en geactiveerd worden.

In de volgende drie paragrafen worden de nieuwe mogelijkheden van het grootstedelijk beleid voor elk van de drie geselecteerde clusters verkend met inachtneming van de bijzondere achtergronden op de drie beleidsterreinen. De paragrafen 5.2 tot en met 5.4 bevatten analyses inzake respectievelijk onderwijs, arbeidsvoorziening en gezondheid en maatschappelijke dienstverlening. In eerste instantie wordt voor elke voorziening onderzocht welke grootstedelijke kenmerken onderscheiden kunnen worden. Vervolgens wordt, mede in verband met hun mogelijke betekenis voor de sociale en de economische ontwikkelingen in het grootstedelijk gebied, de kwaliteit van de desbetreffende voorzieningen getypeerd. En tenslotte wordt nagegaan of de institutionele context waarin de voorzieningen tot stand komen, adequaat is of aanpassing behoeft.

\subsection{Onderwijs}

\subsection{Inhoudelijke plaatsbepaling}

Tussen de grote steden en het onderwijs bestaat van oudsher een bijzondere relatie. Niet alleen zijn onderwijsvoorzieningen, met name waar het gaat om het voortgezet, hoger en gespecialiseerd onderwijs, geconcentreerd in de steden, ook de vernieuwingen van het onderwijs hebben veelal een grootstedelijke achtergrond. Dit zal naar verwachting zo blijven en zelfs toenemen. Het grootstedelijk onderwijs heeft hiermee ook vanuit een nationaal oogpunt een meer dan gemiddelde betekenis.

De eerste van de hierboven bedoelde vernieuwingen, die uit de jaren ' 60 dateert, vindt haar oorsprong in het gegeven dat de grote steden concentratiepunten zijn van groepen met lagere scholings- en beroepskwalificaties. Centraal staan, in het kielzog van het algemene politieke en maatschappelijke klimaat in die tijd, het aanpassen van het onderwijs aan deze concentraties en het inzetten van het onderwijs bij de bestrijding van achterstanden. Grandria in Rotterdam en Van Calcar in Amsterdam zijn de belangrijke exponenten van 
dit 'onderwijs en sociaal milieu'-beleid (OSM), dat in de grote steden de vorm kreeg van zogenoemde compensatieprogramma's ${ }^{1}$.

De tweede vernieuwing kwam geleidelijk naar voren in de tweede helft van de jaren ' 70 (eerst in de Verenigde Staten en later - geïnspireerd door dat land ook in het Verenigd Koninkrijk): het grootstedelijk onderwijs als schakel in de economisch dynamische en hoogtechnische samenleving met een gedifferentieerd cultuurpatroon ${ }^{2}$. In eerste aanleg heeft dit perspectief vooral betrekking op de aansluiting tussen onderwijs en economische en technologische vernieuwing. Later komt daar in de Angelsaksische landen ook een toenemende aandacht bij voor persoonlijke vorming en cultuuroverdracht. Die verbindt zich dan met de oriëntatie op economie en technologie.

In Nederland beperkt de aansluiting bij deze tweede vernieuwing zich tot nu toe hoofdzakelijk tot een accentverschuiving in de richting van economie en technologie. In het bijzonder werden in de beleidsprogramma's voor de werkloosheidsbestrijding in de afgelopen periode de mogelijkheden voor bij-, her-en omscholing versterkt. De wettelijke en beleidsmatige voorzieningen hiervoor worden intussen geactualiseerd en bijgesteld ${ }^{3}$. Vooral in de grote steden zijn de voorzieningen in deze richting duidelijk in ontwikkeling, zoals blijkt uit een inventariserende studie ten behoeve van dit rapport ${ }^{4}$. Toch ligt het accent niet in eerste instantie op de versterking van economie en technologie. In de eindfase van het tweede kabinet-Lubbers wordt de oriëntatie van het onderwijs op economie en technologie zelf voor het eerst manifest in een aantal nota's, waarin de daarvoor vereiste aanpassing van het onderwijsbestel aan de orde wordt gesteld ${ }^{5}$. De huidige minister van Onderwijs en Wetenschappen bracht bij zijn eerste begrotingsbehandeling de beoogde kwaliteitsverbetering en -versterking opnieuw krachtig onder woorden. De Commissie Onderwijs-

'] Van Calcar begon met zijn programma in Enschede: C. van Calcar, Leren lezen, Enschedese onderzoekingen; Groningen, J.B. Wolters, 1967. Daarna zette hij zijn werk voort met een aantal projecten in Amsterdam. Grandria startte in 1969 in Rotterdam. Zie ook J. Slavenburg, Het project onderwijs en sociaal milieu; Rotterdam, Schooladviesdienst, 1978. In een evaluatie die in het najaar 1989 ter discussie stond op een congres te Rotterdam, werden de resultaten van het Onderwijs en Sociaal Milieu (OSM) programma tegenvallend genoemd.

2] In de Verenigde Staten ging een belangrijke impuls uit van: 'A Nation at Risk'. Dit invloedrijke rapport gaf in 1983 een onthutsend beeld van de toekomst van de Verenigde Staten, als het onderwijs niet verbeterd werd. Vanaf toen kwamen het bedrijfsleven en de zakenwereld in beweging voor het onderwijs. Voor een actuele benadering van het onderwijs in dit land: J.E. Chubb en Terry M. Moe, What prices democracy? Politics, morkets, ond Americon schools; Washington D.C., The Brookings Institute, 1990. Voor de nieuwe aanpak in het Verenigd Koninkrijk: The London Compact, London educotion business partnership; London, London Enterprise Agency, z.j.; 'Working classes, Business and schools'; in: The Economist, October 22, 1988, jaargang 309, no. 7573, blz. 33-34.

3] Een overzicht en profilering van een dergelijk beleid vindt men in: WRR. Activerend arbeidsmarktbeleid; Rapporten aan de Regering nr. 33, 's-Gravenhage, Staatsuitgeverij, 1987, in het bijzonder hoofdstuk 7 Scholing (blz. 96-110).

4] W. Dercksen, E.W. van Luijk en P. den Hoed, Werkloosheidsbestrijding in Amsterdam, Rotterdam, Den Haog en Utrecht; Werkdocumenten W50, 's-Gravenhage, WRR, 1990.

5] De school op weg noor 2000, een besturingsfilosofie voor de negentiger joren; 's-Gravenhage, Ministerie van Onderwijs en Wetenschappen, SDU uitgeverij, 1988. Welke haken en ogen vastzitten aan de hier geïmpliceerde regionalisering, waarbij Rijk en nationale onderwijsorganisaties aan de touwtjes blijven trekken, komt naar voren in de studie van J. van Kesteren, S. Boef-Van der Meulen en N. Cachet-Oost, Regionolisotie in het onderwijs; de Ropo-regeling; Rijswijk, Sociaal en Cultureel Planbureau, 1987 (Cahier, nr. 58).

Zie verder voor recente beschouwingen:

* W.C.M. Lieshout e.a., Rijkdom van het onvoltooide, Uitdogingen voor het Nederlandse onderwijs; (rapport in opdracht van de minister van Onderwijs en Wetenschappen en bestemd voor de Organisatie voor Economische Samenwerking (OESO)), 's-Gravenhage, SDU uitgeverij, 1989.

* De bedrijvige school, Een visie op het onderwijs von de toekomst; Amsterdam, ABOP en Meulenhoff Edinfo, 1989.

* In de Staatscourant van 16 oktober 1989 (blz. 5) wordt verwezen naar het advies dat de Centraal Economische Commissie over onderwijs en economie/arbeidsmarkt aan de informateur bij de laatste kabinetsformatie uitbracht. In de Stootscouront van 30 mei 1990 wordt vermeld dat de intussen in het regeerakkoord in het vooruitzicht gestelde Commissie Onderwijs en Arbeidsmarkt haar eindrapport op die dag uitbracht onder de titel 'Onderwijs en Arbeidsmarkt: naar een werkzaam traject'. 
Arbeidsmarkt (de Commissie Rauwenhoff) kan gezien worden als de meest uitgesproken representant van deze heroriëntatie. In het op 30 mei 1990 uitgebrachte rapport van deze commissie worden een groot aantal concrete aanbevelingen gedaan die neerkomen op het versterken van de onderlinge afstemming tussen onderwijs en beroepswereld, zoals dat in de Angelsaksische landen al langer gemeengoed was. Deze verandering verkeert niettemin nog in een pril stadium. Enerzijds wordt onderwijs nog niet algemeen beschouwd als strategisch vernieuwingsmechanisme voor economie en technologie. Anderzijds is het onderwijsveld de afgelopen jaren geconfronteerd met omvangrijke bezuinigingen, inkrimping, ingrijpende reorganisaties, fusies enzovoort. Dit laatste is gepaard gegaan met een verlies aan status en motivatie van de direct betrokkenen en met een afzwakken van creativiteit en innovatie-gerichtheid in het onderwijs.

De in verhouding late aandacht voor de betekenis van het onderwijs in sociaaleconomisch en ook in sociaal-cultureel opzicht in de Nederlandse grote steden hangt voor een deel samen met de kenmerken van het Nederlandse onderwijsbeleid. In Nederland wordt dit beleid in het algemeen op nationaal niveau bepaald in een samenspel tussen het Rijk en de landelijke onderwijsorganisaties. De speelruimte van de direct betrokkenen in de onderwijssector zelf en op plaatselijk en regionaal niveau wordt hierdoor ingeperkt. De gemeenten hebben dan ook vergeleken met het rijksaandeel in de onderwijsbegroting een relatief klein budget. De vrijheid om daarmee vervolgens beleid te voeren, is overigens onbeperkt. Dit levert voorbeelden op, zoals de eerder genoemde compensatieprogramma's in het programma 'onderwijs en sociaal milieu' (OSM) en later in het onderwijs voor allochtonen waar de grote steden eerder met beleidsnota's en maatregelen kwamen dan de rijksoverheid. In een latere fase ontstaat dan vaak onder druk van dit lokaal initiatief aandacht op rijksniveau. De per saldo beperkte speelruimte voor een grootstedelijk onderwijsbeleid, gedragen door de grote stad zelf, blijft intussen zeker in internationaal perspectief opvallend. Dat geldt zeker in vergelijking met de Angelsaksische, maar ook met de Westduitse traditie ${ }^{6}$. De institutionele verhoudingen in het Nederlandse onderwijs gaan terug op de grondwettelijk verankerde vrijheid van onderwijs. De gemeenten mogen niet treden in de onderwijsvrijheid van het bijzonder onderwijs en dienen in het kader van de financiële gelijkheid tussen bijzonder en openbaar onderwijs een evenredig deel van de gelden aan het bijzonder onderwijs toe te kennen.

Een invulling van de tweede vernieuwing in de grote steden zoals men die nu aantreft in de Verenigde Staten en in iets mindere mate in Groot-Brittannië, bevindt zich nog in een beginfase. Er is een aantal belangrijke hindernissen voor een dergelijke versterking op lokaal en regionaal niveau. Rotterdam, dat al enkele jaren uitgesproken ambities in die richting heeft, illustreert dit. In het bijzonder komt daar naar voren hoe tegendraads ons nationaal onderwijsbestel met zijn verkokerde en centraal bepaalde beleid uitpakt voor initiatieven van een op economische en technologische vernieuwing inspelend onderwijs in grootstedelijk verband. De eerder vermelde aanbevelingen van de Commissie Rauwenhoff beogen hierin verandering te brengen. Ze impliceren meer eigen initiatieven van de direct betrokkenen, met name in lokaal en regionaal verband.

6] Overigens is er in het Verenigd Koninkrijk op dit ogenblik sprake van een verschuiving. De nieuwe Education Act van minister Kenneth Baker in 1988 zwakt de relaties tussen de Local Education Authorities en het lokale bestuur en politiek af. Tegelijkertijd krijgt qua curricula en basisvereisten het nationale overheidsniveau meer greep op het onderwijs. 
In tweede helft van de jaren ' 80 tekent zich in het grootstedelijk onderwijsbeleid in de Verenigde Staten opnieuw een verschuiving af, waarbij - althans in de beleidsfilosofie, krachtig gesteund en inhoud gegeven door onderwijskundige specialisten aldaar - in een aantal grote steden de aandacht voor een hoogwaardig en gedifferentieerd onderwijs meer gewicht krijgt. Een nieuw element is dan dat onderwijs als centrale grootstedelijk 'asset' voor de cultuur en het economisch functioneren wordt gekoppeld aan onderwijs als mobiliseringsmechanisme bij sociale achterstand. Hierbij krijgen op het breukvlak van de economische en de sociale functie van het onderwijs de persoonlijke vorming en cultuuroverdracht als op zich staande waarden geleidelijk weer meer gewicht. Deze wisselwerking tussen beide beleidstradities in relatie met cultuuroverdracht en persoonlijke vorming vormt in de VS de grondslag van de meest recente onderwijsinitiatieven in de grote steden vanuit instellingen en bedrijven in de particuliere sector. Het stadsbestuur verleent hierbij hand- en spandiensten. Het gaat zodoende om een in de particuliere sfeer en in de overheid vertakt streven, waarbij het onderwijs zelf en de institutionele structuur worden aangepast en afgestemd op de uitwisseling en kruisbestuiving tussen wat tot dan toe ook in de Noordamerikaanse steden twee aparte werelden en culturen waren ? Terwijl in ons land de heroriëntatie in onderwijs op economie en technologie net gestart is en dan nog voornamelijk als nationaal uitgedragen strategie, is in de optiek van dit rapport deze in de VS beproefde combinatie een aantrekkelijk perspectief voor de langere termijn. Het tegelijkertijd nastreven van economische, sociale en culturele doeleinden is in grootstedelijk verband een uitdaging, omdat juist daar veel mogelijkheden liggen. Deze combinatie van oriëntaties zal dan ook verderop als referentiekader dienen voor de aanbevelingen ten aanzien van het onderwijs in de grootstedelijke gebieden.

De uitgangssituatie kan nu als volgt worden samengevat. Het strategische belang van het onderwijs voor de grote steden, dat is afgeleid van de betekenis van de steden als schakels in regionaal en nationaal verband enerzijds en in het internationale verkeer anderzijds, is duidelijk ${ }^{8}$.

De grote steden in Nederland, dat in vergelijking met andere landen over een voortreffelijke infrastructuur van onderwijs beschikt, blijven echter ondanks een aantal recente initiatieven in deze richting achter op het brede front van ondersteuning van economische en technologische vernieuwing, van persoonlijke vorming en cultuuroverdracht en van sociale mobilisering. A fortiori geldt dit voor de wisselwerking op dit brede front. De afhankelijkheid en de geringe speelruimte ten opzichte van het centraal bepaalde onderwijsbeleid vormen hierbij een belangrijke beperkende factor. Onder verwijzing naar de wet van de remmende voorsprong kan echter de huidige achterstand bij een investering over een langere periode in de grote steden in de komende jaren in een voorsprong worden omgebogen, mits een aantal aanpassingen worden doorgevoerd in de institutionele structuur in de grote steden en tussen de grote steden enerzijds en het Rijk en het nationaal onderwijsbestel anderzijds. Voordat hierop wordt ingegaan, volgt eerst een uiteenzetting over de huidige grootstedelijke onderwijssituatie.

'] 'Education, Bossy businessmen (American Survey)'; in: The Economist, August 26, 1989, jaargang 312, no. 7617, blz. 39-40.

8] S. Maclure, 'Editorial': 'The condition of education in Europe's great cities will be one of the measures by which the present phase of European civilisation is assessed'; in: Europeon journal of Educotion, jaargang 19, no. 4, 1984, blz. 357-363.

Zie verder: J. Baumert en H. Koehler, 'Trends and perspectives of secondary education in West-Berlin'; in: Europeon Journal of Educotion, no. 4, 1984, blz. 365-384; H. van Daele en J. van Puke, 'Urban education in Belgium'; in: Eurapeon Journal of Education, jaargang 19, no. 4, 1984, blz. 385-395; R. Mark. 'The education of adults in inner-city Britain: Findings based on a study of an inner area of Glasgow'; in: International Journal of Longlife Education, jaargang 6, no. 3, July/Sept., 1987, blz. 199-213; E.M. Beck en G.S. Coclough, 'Schooling and capitalism: the effect of urban economic structure on the value of education'; in: Industries, firms and jobs: sociological and economic approaches; G. Farkas en P. England (eds.), New York, Plenum, 1988; Centre for Educational Research and Innovation (CERI), Education, urban development and local initiatives; Paris, OECD, 1983. 


\subsubsection{Het onderwijsprofiel van de steden ${ }^{9}$}

Vanuit het oogpunt van sociale ongelijkheid en van het mobiliseren van jongeren die in achterstandssituaties verkeren, werkt een aantal essentiële kenmerken van de stad in onderlinge samenhang in op het onderwijs. Het eerste kenmerk is de bevolkingsomvang en -dichtheid. Van de totale schoolgaande populatie in ons land is ongeveer een derde in de vier grote steden geconcentreerd. Door de afname van het aantal geboorten kreeg men landelijk te maken met een afnemende vraag naar onderwijs. In de Nederlandse grote steden, evenals in andere Europese steden, daalden de leerlingenaantallen relatief sterker door de trek uit de stad. In de grote steden leidde dit meer dan elders tot ontslagen van leerkrachten en tot sluiting, samenvoeging of concentratie van scholen. Deze aanpassing aan de lagere aantallen leerlingen in de grote steden is in het basisonderwijs nog steeds aan de gang en zal in de jaren '90 doorgaan ${ }^{10}$. Ook in het algemeen voortgezet onderwijs (AVO) en het voortgezet beroepsonderwijs is, naast het streven naar schaalvergroting op gronden van doelmatigheid en kostenbeheersing, de verminderde instroom een belangrijke impuls voor de huidige concentraties ${ }^{11}$.

De forse toename van het aantal allochtone leerlingen vanaf de tweede helft van de jaren ' 70 vormde een rem op deze teruggang in de leerlingenaantallen. Het aandeel leerlingen tot 9 jaar van niet-Nederlandse afkomst is intussen (in 1989) in Amsterdam 47 procent, in Rotterdam 35 procent, en in Utrecht 30 procent. In Den Haag is dit voor de groep tot 14 jaar 22 procent ${ }^{12}$. Het cijfer voor Den Haag werd later van gemeentezijde gecorrigeerd tot 37 procent. Voor de komende periode wordt een zekere stabilisatie van deze instroom voorspeld, maar een abrupt einde ligt niet in de rede. De teruggang in leerlingenaantal wordt ook afgezwakt doordat de grote steden jongeren blijven aantrekken van buiten de stad. Zowel onder allochtonen als onder jongeren van buiten de grote stad blijken lage inkomens en laagwaardige scholings- en beroepskwalificaties te overwegen ${ }^{13}$. Tenslotte wordt de teruggang verzacht doordat steeds meer leerlingen steeds langer na de leerplichtige leeftijd onderwijs blijven volgen. Op grond van de demografische gegevens wijkt de onderwijsvraag in de grote steden zodoende in belangrijke mate af van die in de rest van het land. Er wordt hier voor de komende periode zelfs rekening gehouden met een toename van het leerlingenaantal, onder andere vanwege het hoge geboorteniveau van allochtonen, de neveninstroom van allochtone leerlingen en ook de bouw van nieuwe woningen in de stad. Die toename wordt tot 2000 geschat op ongeveer 15 procent.

Het tweede kenmerk is de structurele heterogeniteit. De grotere verscheidenheid in bevolkingsgroepen in de steden leidt er toe dat die verschillen zich hier in sterkere mate manifesteren dan in de rest van het land. Bovendien vormen zich groepen. De heterogeniteit is zodoende ook een groepsfenomeen. Het aantal mensen per groep maakt het mogelijk het groepseigene en de daarmee verbonden belangen te profileren. Dit vindt men terug in de organisatiegraad

9] Deze paragraaf steunt in belangrijke mate op de voor de WRR verrichte studie naar het onderwijs in de grote steden: W.H. Leeuwenburgh en P. van den Eeden, Onderwijs in de vier grote steden; Voorstudies en achtergronden V68, 's-Gravenhage, SDU uitgeverij, 1990.

${ }^{10}$ ] In Rotterdam bijvoorbeeld hebben ongeveer 100 van de 300 basisscholen minder dan het voor overheidsfinanciering vereiste aantal leerlingen.

1'] Na de fusie-operatie in het hoger beroepsonderwijs, die in de direct achter ons liggende periode in de vier grote steden tot opvallende reorganisaties leidde, is onlangs de reorganisatie van het middelbaar beroepsonderwijs onder de naam Sectorvorming en Vernieuwing Middelbaar Beroepsonderwijs (SVMB) gestart.

12] Rapport van de Externe Commissie Grote Stedenbeleid, Grote steden, grote kansen; 's-Gravenhage. Ministerie van Binnenlandse Zaken, 1989, blz. 16.

${ }^{13}$ ] Zie: H. Kruythoff, Social differences between inmigrants, outmigrants and populations of the four big cities; Paper voor het International Seminar on European Gentrification, Stedelijke Netwerken, Utrecht, January 26, 1990. 
van de onderscheiden groepen. Die organisatiegraad is nu bij onder andere etnische groepen in een aantal gevallen nog beperkt en in de gevallen waarin deze groepen zich laten horen, is dit vaak in los of ad hoc georganiseerd verband en informeel van aard. Landen met een langer verleden als multi-etnische samenleving laten zien dat na verloop van tijd hierin belangrijke veranderingen kunnen optreden.

Het derde kenmerk is de grootstedelijke cultuur. Die wordt voor een belangrijk deel gevoed door de structurele heterogeniteit. Ze heeft ook te maken met de anonimiteit en de grote aantallen mensen in de stad, met de uiteenlopendheid van voorzieningen en functies, met de verbindingen van juist de grote steden met datgene wat zich in nationaal en internationaal opzicht aan nieuwe ontwikkelingen en oriëntaties voordoet. Deze grootstedelijke cultuur kenmerkt zich ook in negatieve zin: isolatie, vereenzaming, onveiligheid, verloedering, drukte en lawaai. Problematisch geachte verschijnselen, zoals criminaliteit, druggebruik, AIDS, gezins- en jeugdproblematiek en slechte woon- en leefomstandigheden, behoren hier ook toe.

De bevolkingsomvang en -dichtheid leiden tezamen met de heterogeniteit van de leerlingen tot een uitgesproken heterogeniteit van het onderwijsaanbod in de stad. Hier komt bij dat de grote stad zich ook als gevolg van de onderwijsdichtheid onderscheidt door het aantal en de schakering van onderwijsondersteunende instanties, inclusief de hiermee verbonden deskundigheid.

De structurele heterogeniteit brengt met zich mee dat de leerlingen worden geconfronteerd met uiteenlopende sociale milieus. Met name de leerlingen uit de lagere milieus (vooral allochtonen) ervaren de afstand en spanning tussen hun milieu en dat van andere leeftijdsgenoten. De effecten van de gevarieerde samenstelling van de schoolpopulatie zijn niet eenduidig. De ene studie concludeert dat de betere leerlingen niet ontvankelijk zijn voor de klassesamenstelling, de andere dat ze daarvan juist de meeste profijt trekken. Door de een wordt geconstateerd dat het leerproces van de sociaal gedepriveerde leerlingen beter verloopt in een gemengd samengestelde klas, door de ander dat dit proces daar juist slechter verloopt ${ }^{14}$. Als deze laatste constatering klopt, zouden de scholen in de grote stad met hoge concentraties allochtone jongeren niet zonder meer negatief hoeven te zijn voor het leerproces ${ }^{15}$.

De grootstedelijke cultuur heeft grote invloed op het onderwijs. Veel leerlingen staan bloot aan remmende invloeden op hun studiebekwaamheden. Dit uit zich in problemen met studiemotivatie en -concentratie, in taalachterstanden, in een hoge verzuimfrequentie en dergelijke. De leerstof sluit vaker minder aan op de belevingswereld van de leerlingen; confrontaties met het docerend personeel zijn talrijk en hevig. Aan de andere kant ondervinden leerlingen in de stad ook veel stimulerende invloeden: een groot aantal culturele voorzieningen en instellingen, de mogelijkheid om aan allerlei manifestaties, evenementen en bijeenkomsten deel te nemen, een rijke schakering aan leefstijlen enzovoort. De beschikbaarheid van en het open staan voor dit educatief potentieel is echter weer sterk aan het sociale milieu gebonden. Ook heeft de stedelijke leefstijl een effect op de leersituatie en het schoolklimaat, leraren worden minder met égards benaderd, leerlingen zijn in het algemeen kritischer en staan vaak vrijblijvender tegenover hun leerstof.

De kenmerken van de grote stad hebben niet alleen invloed op het onderwijs, het onderwijs blijkt omgekeerd een afzonderlijk en versterkend effect te

14] Y. Dar en N. Resh, 'Classroom intellectual composition and academic achievement'; American Educational Research journal, jaargang 23, no. 3, 1986, blz. 357-374.

15] Zie: Wetenschappelijke Raad voor het Regeringsbeleid, Allochtonenbeleid; Rapporten aan de Regering, nr. 36; 's-Gravenhage, SDU uitgeverij, 1989. 
hebben op de in de grote stad aanwezige sociale ongelijkheid in de betekenis van ongelijke leef- en ontwikkelingskansen. Dit blijkt uit het traject van in-, door-en uitstroom van leerlingen.

Wat betreft de instroom kan worden gewezen op de oververtegenwoordiging van lage inkomens, werkloosheid en lager opgeleiden. De volgende cijfers, ontleend aan de situatie in Amsterdam, zijn illustratief. Van de vaders van de leerlingen uit het voortgezet onderwijs heeft 41 procent alleen lager onderwijs genoten (landelijk 36,4\%), 4,1 procent heeft een HAVO-opleiding (landelijk $8,0 \%$ ). Van de moeders heeft 61,6 procent (landelijk 50,3\%) alleen lager onderwijs gevolgd. Ook de verschillen in sociale milieus zijn aanzienlijk: 22,8 procent heeft een werkkring als lager employé en 15,9 procent als middelbaar employé (landelijk resp. $12,9 \%$ en $20,4 \%)^{16}$. De achtergrondcondities van de Amsterdamse leerlingen steken bij de instroom in het voortgezet onderwijs ongunstig af bij die in de rest van het land.

De gang door het onderwijs blijkt de verschillen te versterken en daarmee een extra bijdrage te leveren aan het verschil in leef- en ontwikkelingskansen. De schoolloopbaan is in hoge mate afhankelijk van de achtergrond van de leerling: status van de ouders, etniciteit, sekse en dergelijke. Dit soort factoren, waarop een leerling zelf geen invloed heeft, blijkt medebepalend voor het al dan niet vertraagd verlaten van de lagere school en de keuze van de schooltypen in het voortgezet onderwijs. In combinatie met het meritocratisch principe dat aan het selectie- en keuzeproces in het onderwijs ten grondslag ligt, leidt de interne werking van het onderwijs tot een verdere uitwaaiering van de maatschappelijke kansen die bij de start al ongelijk verdeeld waren. Bovendien zullen leerlingen in de grote steden gemakkelijker en sneller van schooltype wisselen, omdat de differentiatie daarvan groter is en de scholen beter bereikbaar zijn.

Tenslotte is het bij de uitstroom uit het onderwijs de vraag of er in vergelijking met de rest van Nederland verschillen in arbeidskansen zijn. Ook al is de arbeidsmarkt in de grote stad en de omgeving van de grote stad gedifferentieerd, de werkloosheidscijfers in de grote steden zijn hoger dan die in de rest van het land. De kansen om direct na het verlaten van de school een baan te vinden, zijn blijkens een recent onderzoek voor leerlingen uit de vier grote steden beduidend kleiner dan voor die in de rest van het land ${ }^{17}$.

De geschetste relatie tussen onderwijs en sociale ongelijkheid in grootstedelijk verband wordt bevestigd in empirisch onderzoek. Zo zijn schoolloopbanen onderzocht van leerlingen die in 1977 in Amsterdam het voortgezet onderwijs zijn gaan volgen. De vergelijking was gericht op het niveau van het gekozen type voortgezet onderwijs (LBO, MAVO, HAVO, VWO). De algemene conclusie is dat de schoolloopbanen in Amsterdam duidelijk anders verlopen dan elders. De initiële keuze van het schooltype, de verandering daarin op een later tijdstip, het aantal jaren dat men onderwijs genoot en de afsluitende examens wijken af van datgene wat in de rest van het land gebruikelijk is. Verder hangen deze specifieke schoolloopbanen samen met het sociale milieu, de sekse en de schoolvorderingen aan het eind van het basisonderwijs (gemeten via de CITO-toets en via het advies van het hoofd van de school) ${ }^{18}$.

16] A. Rozendaal, U. de Jong en P. van den Eeden, Vergelijking von de schoolloopbonen van leerlingen in het voortgezet onderwijs in Amsterdam en in de rest von Nederlond; Amsterdam, Vrije Universiteit, Vakgroep Methoden en Technieken, 1987.

17] F. van de Pol en M. Meesters. Een 'Event-history'-onolyse met een toepossing op de orbeidsmorktpositie von schoolverloters; Voorburg, CBS, Hoofdafdeling Statistische methoden, 1988. Uit deze studie blijkt ook dat de kans op werkloosheid na de eerste baan in de vier grote steden aanzienlijk groter is dan in de rest van het land.

${ }^{18}$ ] A. Rozendaal, U. de Jong en P. van den Eeden, op. cit Er is intussen een handelseditie van het eindrapport van dit onderzoek: J. Roeleveld, P. Koopman, U. de Jong en P. van den Eeden, Schoolloopbonen in Amsterdom, Leerlingen op Amsterdomse scholen voor olgemeen voortgezet onderwijs in de joren zeventig; Lisse, Swets en Zeitlinger, 1989. 
Meer in het bijzonder brengt dit onderzoek aan het licht dat in Amsterdam bij de beginkeuze naar verhouding meer gekozen wordt voor hogere typen voortgezet onderwijs (HAVO- en VWO-brugklas) en minder voor categoriaal LBO. $\mathrm{Na}$ de eventuele brugperiode ligt de vervolgkeuze ook gemiddeld op een hoger niveau. Een relatief groter aantal leerlingen komt in het VWO terecht; LBO en MAVO zijn ondervertegenwoordigd. Bovendien krijgen de leerlingen die het Amsterdamse voortgezet onderwijs instromen, gemiddeld een hoger advies mee dan de leerlingen in de rest van het land (40\% een HAVO- of VWO-advies, $30 \%$ in de rest van Nederland).

De prestaties, gemeten in de bij de aanvang van het voortgezet onderwijs in 1977 afgenomen CITO-toets, laten voor Amsterdam een lager gemiddelde zien dan voor overig Nederland. Dit komt overeen met de bevindingen van het CBS van de lagere CITO-prestaties bij leerlingen in de grotere steden in Noord- en Midden-Nederland ${ }^{19}$. Het verschil is terug te voeren op de lagere scores voor rekenen.

De leerlingen die in 1977 in Amsterdam in het voortgezet onderwijs starten, zijn gemiddeld ouder dan hun landgenoten. Ook de spreiding van de leeftijd is in deze stad groter. Deze verschillen zijn deels een gevolg van meer doublures in het basisonderwijs. Een tweede groep oudere leerlingen wordt gevormd door de kinderen van allochtonen die halverwege hun schoolloopbaan naar Nederland zijn gekomen.

De gemiddeld hogere start van leerlingen in het voortgezet onderwijs in Amsterdam leidt niet tot gemiddeld hogere eindposities. Jaarlijks loopt de positie van deze stad ten opzichte van de rest van Nederland terug. In het vierde schooljaar vindt een omslag plaats en verandert de aanvankelijke voorsprong op de rest van Nederland in een achterstand.

De grootste verschillen tussen Amsterdam en overig Nederland zijn te vinden in het schooltype waarin zowel in Amsterdam als in de rest van Nederland de slechtste resultaten worden behaald: het HAVO. Hier is het rendement in Amsterdam de helft kleiner! In deze stad is voor dit schooltype de verhouding vertrokkenen-geslaagden zeer ongunstig. Ook bij de andere schooltypen is het rendement in Amsterdam lager. Bovendien is de verblijfsduur van de vertrekkers in deze typen beduidend groter. Er slagen dus niet alleen minder leerlingen, degenen die het onderwijs verlaten, doen dit ook korter voor het eindexamen. Het is vervolgens opmerkelijk dat in het VWO de verschillen relatief klein zijn ${ }^{20}$.

In het LBO blijken de meisjes in Amsterdam vergeleken met de meisjes in de rest van Nederland in sterke mate een homogene groep met ongunstige achtergrondkenmerken en ongunstige resultaten. Van de schoolverlaters in het HAVO (40\% van de leerlingen volgt in Amsterdam na vijf jaar nog dit onderwijs) stroomt een veel grotere groep dan landelijk naar MAVO en LBO. Uitgaande van de verschillen in de percentages leerlingen met het VWO als definitieve keuze (Amsterdam 21\%, Nederland 14,6\%) komt voor Nederland 7,7 procent en voor Amsterdam 9 procent van het cohort dat in 1977 begon aan het voortgezet onderwijs, in de eindexamenklas. Dit is nog steeds een groter aandeel in Amsterdam, maar de relatief gunstige beginsituatie is vrijwel geheel verdwenen.

19] CBS, SMVO, 1982, Staten 3.8, 3.18 en 3.21 .

${ }^{20}$ ] Ook in Noordamerikaanse steden, zoals Los Angeles, New York, Chicago en Detroit, is de uitval op de high schools extreem. Deze varieert van 1/3 tot 3/5 van de leerlingen. Zie: 'Education, Bossy Businessmen (American Survey)', op. cit., blz. 30. 
Het voortijdig schoolverlaten is in Amsterdam voor alle schooltypen veel omvangrijker dan in de rest van het land. Het betekent hier ook vaker dat men het onderwijs definitief de rug toekeert. Zoals gezegd vindt het voortijdig verlaten van de school in Amsterdam ook meestal in een later stadium plaats. Het aantal doublures in het voortgezet onderwijs is, evenals bij het lager onderwijs, groter dan landelijk. Ook dat geeft een grotere kans op uitval dan in de rest van Nederland. De kans om te zakken voor het eindexamen is, behalve bij het LBO en de MAVO, het grootst in Amsterdam.

De Groot en Kole (1987) deden in het kader van het onderwijsvoorrangsbeleid een onderzoek naar elf scholen in Rotterdam. Het betrof acht LBO- en drie MAVO-scholen. Bij de scores aan de hand van een aangepaste versie van de CITO-Eindtoets Basisonderwijs komt naar voren dat de autochtone leerlingen over het geheel genomen zowel voor rekenen als voor taal bijzonder laag scoren. De allochtone leerlingen scoren nog lager en blijven eveneens beneden een te verwachten minimumniveau. Uit de vergelijking van de prestaties met de landelijke groep leerlingen die in 1985 dezelfde toets hebben afgelegd, blijkt dat de Rotterdamse leerlingen op alle scholen ver achterblijven. De achterstand manifesteert zich vooral bij leerlingen in het $\mathrm{LBO}^{21}$.

De constatering dat de patronen van de schoolloopbanen in Amsterdam en Rotterdam opvallend anders zijn dan die in de rest van Nederland roept vanzelf de vraag op waarom deze verschillen zich voordoen. Uit een reeks onderzoeken in diverse landen, in het kielzog van het intussen vermaarde onderzoek van Coleman c.s. naar verschillen in de Verenigde Staten tussen het katholieke onderwijs en het openbare onderwijs, komt naar voren dat de kenmerken van de school er terdege toe doen bij het verklaren van output-verschillen. Zelfs wanneer wordt gecorrigeerd voor kenmerken van de instroom van leerlingen en voor de samenstelling van de leerlingenpopulatie, blijven de kenmerken van het schoolbeleid van doorslaggevend belang. Deze bevindingen maken de conclusie dat de scholen in Amsterdam een lager rendement hebben, minder uitzonderlijk dan men in eerste instantie zou denken ${ }^{22}$.

Van Laarhoven en Dronkers geven de verschillen weer tussen openbaar en bijzonder onderwijs voor heel Nederland en voor Amsterdam, aan de hand van de eindexamens $1984^{23}$. Ook in Nederland blijken uitgesproken verschillen tussen scholen van uiteenlopende richting (zoals door Coleman c.s. vastgesteld). Bovendien - en dit vormt een aanvullende ondersteuning van de bevinding dat de rendementen van de scholen er lager zijn - zijn in Amsterdam de verschillen nog eens extra groot (zie tabel 5.1). Het afwijkende patroon van slagen voor examens geldt overigens voor alle vier de grote steden, zoals tabel 5.2 aangeeft. Bovendien blijkt ook hier dat Amsterdam het bijzonder slecht doet en dat de verschillen tussen jongens en meisjes (met uitzondering van Den Haag)

21] H.L. de Groot en S.C.A. Kole, 'Onderwijsstimulering in de gemeente Rotterdam'; in: Gemeenten en onderwijs; onder red. van A.M.L. van Wieringen, S. Karsten en J. Ax; Lisse, Swets \& Zeitlinger, 1988, blz. 363-380; H.L. de Groot en S.C.A. Kole. Onderwijsstimulering, Eindverslag van een onderzoek naar het functioneren van elf Ratterdamse scholen voor voortgezet anderwijs; Rotrerdam, 1987.

${ }^{22}$ ] J.S. Coleman, Th. Hoffer en S. Kilgore, 'Cognitive outcomes in public and private schools'; Sociology of Education, jaargang 55 , 1982, blz. 65-76; J.S. Coleman, Th. Hoffer en S. Kilgore, High school achievement; Public, Catholic, and private schools compared; New York, Basic Books, 1982; Th. Hoffer, A.M. Greeley en J.S. Coleman, 'Achievement growth in public and catholic schools'; in: Sociology of Educotion, jaargang 58, 1985, blz. 74-97; P. van Laarhoven en J. Dronkers, 'Verschillen de onderwijsresultaten in openbaar en bijzonder onderwijs?" in: Gemeenten en onderwijs (op. cit.), blz. 75-88.

23] Zie: P. van Laarhoven en J. Dronkers, op. cit. De auteurs stellen overigens dat een volwaardige replicerende analyse in het verlengde van Coleman c.s. bij gebrek aan de nodige gegevens in Nederland onmogelijk was.

Over deze verschillen in Amsterdam is ook gerapporteerd door U. de Jong en J. Roeleveld, Openbaar en bijzonder onderwijs: een constant verschil?, Effectiviteit en selectiviteit van Amsterdamse scholen voor voortgezet onderwijs in de zeventiger joren; Paper gepresenteerd op de Vlaams-Nederlandse Studiedagen voor sociologen en antropologen, Antwerpen, 7 en 8 april 1988. 
miniem zijn. Het onderwijs in de grote steden blijkt minder effectief dan dat in de rest van het land en de sociale ongelijkheid, die tot uiting komt in een grotere instroom van leerlingen met ongunstige achtergrondcondities, wordt uiteindelijk door het onderwijs extra versterkt.

Tabel 5.1 Percentages gezakten voor het eindexamen 1984, per richting en schoolsoort in het AVO, zowel voor heel Nederland als voor Amsterdam

\begin{tabular}{|c|c|c|c|c|c|}
\hline \multirow[t]{2}{*}{ Schoolsoort } & Pichting a) & & & & \\
\hline & Openb. & PC & RK & BN & Gem. \\
\hline MAVONederland & 8 & 5 & 4 & 5 & 5 \\
\hline Amsterdam & 22 & 12 & 6 & 7 & 13 \\
\hline HAVONederland & 24 & 18 & 17 & 21 & 20 \\
\hline Amsterdam & 42 & 20 & 35 & 23 & 30 \\
\hline Vwo Nederland & 15 & 12 & 10 & 19 & 13 \\
\hline Amsterdam & 30 & 22 & 12 & 16 & 21 \\
\hline Totaal Nederland & 15 & 11 & 10 & 13 & 11 \\
\hline Amsterdam & 30 & 16 & 16 & 14 & 20 \\
\hline
\end{tabular}

a) Openb. = Openbaar onderwijs;

$\mathbf{P C}=$ Protestant-Christelijk onderwijs;

$\mathrm{RK}=$ Rooms-Katholiek onderwijs;

$\mathrm{BN}=$ Bijzonder Neutraal onderwijs.

Bron: P. van Laarhoven en J. Dronkers, "Verschillen de onderwijsresultaten in openbaar en bijzonder onderwijs?"; in: Gemeenten en onderwijs; onder red. van A.M.L. van Wieringen, S. Kărsten en J. Ax; Lisse, Swets \& Zeitlinger, 1988, blz. 76.

Tabel 5.2 Slaagpercentages in het MAVO, HAVO, VWO in de vier grote steden en in Nederland

\begin{tabular}{lccr}
\hline & mannen & vrouwen & totaal \\
\hline Amsterdam & 76,2 & 75,3 & 76,0 \\
Rotterdam & $\mathbf{8 4 , 1}$ & 83,5 & $\mathbf{8 3 , 8}$ \\
's-Gravenhage & 83,5 & 79,9 & 82,1 \\
Utrecht & 80,5 & 81,7 & $\mathbf{8 1 , 1}$ \\
Nederland & $\mathbf{8 7 , 8}$ & & $\mathbf{8 8 , 0}$ \\
\hline
\end{tabular}

Bron: CBS, Scholenlijst voor het voortgezet onderwijs (MAVO-HAVO-VWO), schooljaar 1982-1983; diverse tabellen, 1983.

Gegevens over de relatie tussen onderwijs en sociale ongelijkheid zijn ruimschoots voorhanden. In het algemeen ontbreken soortgelijke gegevens echter over de inzet van het onderwijs voor economische en technologische vernieuwing en voor persoonlijke vorming en cultuuroverdracht. Daarom wordt hier volstaan met een korte typering.

Zowel in economisch als in cultureel opzicht beschikken de steden over een rijk en geschakeerd geheel van scholen, in de reguliere en niet-reguliere onderwijssfeer, in part-time en volledig onderwijs, in door de overheid gefinancierd bijzonder en openbaar onderwijs en in commercieel opgezet onderwijs. In de grote stad vindt men een bijna complete reeks van onderwijstypen en -vormen: van basisonderwijs tot en met universitaire en post-universitaire opleidingen, van 
ad hoc seminars tot en met bijscholingscursussen, eerste- en tweede-kansonderwijs enzovoort. Het universitaire onderwijs, aangevuld met hoger beroepsonderwijs, is in belangrijke mate geconcentreerd in de vier grote steden of in de directe omgeving daarvan: in Amsterdam de Universiteit van Amsterdam en de Vrije Universiteit, in Rotterdam de Erasmus Universiteit, tussen Rotterdam en Den Haag de Technische Universiteit Delft, tussen Amsterdam en Den Haag de Rijksuniversiteit Leiden, in Utrecht tenslotte de Rijksuniversiteit Utrecht.

Dit geheel vormt een 'onderwijsmassa' die door de keuzemogelijkheden reliëf geeft aan een grootstedelijke markt van onderwijs. Ook al is de onderwijssector geen echte markt, toch neemt het marktelement in het onderwijs een belangrijke plaats in. Elke afzonderlijke onderwijsinstelling in de grootstedelijke gebieden zal het effect daarvan direct of indirect ondervinden. Zo kan men stellen dat in de grote steden niet alleen de vraag het onderwijsaanbod bepaalt, maar dat het onderwijsaanbod ook vraag naar zich toetrekt. Eveneens leidt de grotere keuze tussen scholen tot meer mogelijkheden voor tussentijdse wisseling van school.

Daar komt bij dat door de maatschappij, vooral bij het onderwijs aan de wat oudere leerlingen, een appèl wordt gedaan op het onderwijs voor het latere beroep. Het bedrijfsleven in al zijn geledingen heeft belang bij een geoefend werknemerspotentieel; het oefent daarom via de daarvoor beschikbare kana- . len invloed uit op de eindkwalificaties. Het onderwijs in grote steden is niet alleen heterogeen door de heterogeniteit van de leerlingenpopulatie, maar ook door de structuur van de grootstedelijke economie, die heel intensief en gevarieerd is. Het is juist dit rijk geschakeerde aanbod, nauw gerelateerd aan het profiel van economie, technologie en cultuur, dat de aanleiding vormde voor de eerder genoemde belangstelling voor onderwijs in de grote steden in de Verenigde Staten en het Verenigd Koninkrijk. Een eerste indicatie van een dergelijke benadering van het onderwijs op grootstedelijk niveau in ons land is te vinden in rapport van de Adviescommissie Sociaal-Economische Vernieuwing Rotterdam (Commissie Albeda) ${ }^{24}$.

Intussen zijn de grote steden er wel op uit om onderwijs binnen te halen of te versterken dat voor hun economie van strategisch belang kan zijn. Zo kan worden gewezen op Europastudies aan de Universiteit van Amsterdam, de Amerikaanse School en de Informatica-universiteit in Den Haag, Japankunde en de nieuwe opleiding in de logistiek in nauwe relatie met de Rotterdamse haven aan de Erasmus Universiteit te Rotterdam en op de commerciële opleidingen in de informatica in Utrecht, nauw gerelateerd ook aan computerbedrijven, die zich in Utrecht hebben gevestigd (IBM, VOLMAC)). De sterktezwakte-profielen van de grootstedelijke economie, zoals die naar voren kwamen in hoofdstuk 3, zijn hierbij een belangrijk aanknopingspunt: de financiële sector in Amsterdam, de bedrijvigheid rondom Schiphol, de Rotterdamse haven met handel, transport, vervoer en bijbehorende logistiek en met de petrochemische industrie, de biochemische industrie, tuinbouw en bloem-

${ }^{24}$ ] Rapport van de Adviescommissie Sociaal-economische vernieuwing Rotterdam, Nieuw Rotterdam, een opdracht voor alle Rotterdammers; Rotterdam, 1987. Hierin staat een pleidooi voor een grootschalige alfabetiseringscampagne, strikte handhaving leerplicht, instelling van huiswerkklassen, extra taallessen voor etnische minderheden, nieuwe didactische vormen voor kinderen uit non-verbale milieus, verplicht onderwijs voor voortijdige 'afhakers' in LBO en MBO, optimaliseren van doelstelling van minimaal diploma op het niveau van het primair leerlingwezen, meer in het algemeen niemand van school af zonder diploma. Daarnaast: instelling van een middelbare horecaschool, vergaande concentratie van het nautische onderwijs, inschakeling van docenten uit het bedrijfsleven, hechtere relatie tussen hbo/universiteit en bedrijfsleven, het centrum voor haven- en vervoerseconomie betrekken bij de logistieke concepties, instelling van programma-adviescommissies voor bijsturing van het hoger en universitair onderwijs, fondsvorming en risicodragend kapitaal voor aan het onderwijs gelieerde starters, uitbreiding van stageplaatsen bij het midden- en kleinbedrijf. 
bollenteelt in de Randstad, de administratieve, management- en bestuurlijke functies die kenmerkend zijn voor Den Haag en Utrecht.

Op de functie van het onderwijs voor de persoonlijke vorming en cultuuroverdracht wordt in Nederland, evenals in de meeste andere Westerse landen, alleen nog gepreludeerd in beschouwingen over de recente ontwikkelingen in Europa en in mondiaal verband. In het bijzonder wordt hierbij het belang van taalonderwijs beklemtoond. Deze functie is inderdaad essentieel wanneer de grote steden extern steeds meer als strategische schakels in regionaal, nationaal en internationaal verband gaan fungeren en wanneer zij intern een toenemende culturele en sociale differentiatie gaan vertonen.

\subsubsection{Kwaliteit van het aanbod van onderwijsvoorzieningen}

De kwaliteit van het hoger onderwijs en de wetenschap en de kwaliteit van de grote stad zijn op een bijzondere wijze met elkaar verbonden. De onderwijsinfrastructuur is - samen met de kwaliteit van stedelijke aantrekkelijkheid, cultuurvoorzieningen, hoogwaardig winkelbestand, internationale luchthavens, enzovoort - bepalend voor de plaats van de grootstedelijke regio's in de internationale rangorde ${ }^{25}$. Op dit punt zijn de grote steden in Nederland (afzonderlijk èn gezamenlijk) goed bedeeld. De laatste tijd wordt ook meer geïnvesteerd in de relaties tussen de hoger-onderwijsinstellingen en de grote stad (bijv. in de vorm van universitaire transferpunten). Extra reliëf krijgt deze relatie - en dan niet alleen op het vlak van economische en technologische vernieuwing - wanneer de universiteiten meer autonoom, meer gedifferentieerd en minder uniform zijn. Dit betekent een wijziging van het ongedifferentieerde universitaire bestel dat na de Tweede Wereldoorlog in Nederland is ontstaan. Een dergelijke institutionele ombuiging geeft meer kansen voor een geprononceerde nesteling - ook bestuurlijk - in de grootstedelijke regio. De Erasmus Universiteit Rotterdam biedt een goed voorbeeld hoe binnen de huidige mogelijkheden een dergelijke intensievere relatie uitgebuit kan worden in nauwe wisselwerking met het stadsbestuur en stedelijke instellingen. Een bijzonder aandachtspunt vormt in de Randstad de losse band van de Technische Universiteit Delft met zowel de Rotterdamse als de Haagse agglomeratie. Dit potentieel zou meer rechtstreeks dienen te worden betrokken bij de technologische en economische vernieuwingen in deze agglomeraties en in de Randstad in haar geheel.

In het hoger beroepsonderwijs heeft de afgelopen jaren een concentratie plaats gevonden die ook de grote steden sterk raakte. Dit geldt met name voor de technische opleidingen, de lerarenopleidingen, de kunstacademies enzovoort. Onlangs is een dergelijk concentratie- en fusieproces in het middelbaar beroepsonderwijs gestart. Dit proces zou, om de orde van grootte aan te geven, in Rotterdam (uitgaande van de huidige 35 onderwijsinstellingen) uitmonden in twee reusachtige regionale instellingen met in totaal 15.000 leerlingen. Er is nog discussie of de bundeling sectoraal (schoolcombinaties voor respectievelijk techniek, economie, dienstverlening enz., waarbij de voltijdse opleiding en het leerlingstelsel per schoolcombinatie bij elkaar gebracht zijn) of multisectoraal (de sectoren in éen school gebundeld) moet zijn. De betrokkenheid van de vier grote steden bij deze operaties verschilt per stad. Voor alles is het een aangelegenheid van het nationaal onderwijsbeleid geweest. Het ministerie van Onderwijs en Wetenschappen en de betreffende onderwijsinstellingen waren hierbij de belangrijkste partijen.

In de grootstedelijke onderwijsvernieuwing en het grootstedelijk onderwijsbeleid is de schijnwerper overwegend gericht op het initiële onderwijs (basis-

25] Cities in an global society; door R.V. Knight, G. Gappert (eds.), Series: Urban Affairs Annual Reviews, Newbury Park etc., Sage Publications, Vol. 35, 1989. 
school en voortgezet onderwijs in onderling verband). Basisvorming, opleidingskeuze en -traject in het verdere voortgezette onderwijs zijn daarbij belangrijke aandachtspunten. Het WRR-rapport 'Basisvorming in het onderwijs' (1986) zal naar verwachting binnenkort uitmonden in een nieuw wettelijk regime voor de basisvorming. In afwachting hiervan hebben de grote steden zich wel al over deze nieuwe structuur uitgesproken. Rotterdam streeft naar een meerjarige heterogene brugperiode voor alle openbare scholen. In Amsterdam kwamen de aanbevelingen van een daarop gericht onderzoek neer op de afwijzing van het onderscheid in twee eindniveaus van de basisvorming, omdat dit zou leiden tot een nog grotere segregatie tussen scholen en wijken. In het wetsontwerp is later de constructie van twee eindniveaus komen te vervallen ${ }^{26}$.

Het onderwijsvoorrangsbeleid (OVB) verschaft op dit ogenblik het kader en de middelen aan de grote steden bij het afstemmen van onderwijs op sociale achterstanden. Het OVB-schoolfaciliteitenbeleid is een pure rijksaangelegenheid. Het OVB-gebiedenbeleid, waarin afstemming plaats vindt tussen scholen en welzijnsinstellingen in de desbetreffende buurten, is overwegend gemeentelijk beleid. Het rijksaandeel van het OVB-beleid vindt zijn zwaartepunt in de zogenoemde 'concentratiescholen' in de grote steden, scholen met overwegend allochtone kinderen. In de steden en recentelijk ook bij het Rijk erkent men dat het OVB ten aanzien van de faciliteiten voor de scholen (instellingencomponent) en de schoolomgeving (de zogenaamde gebiedscomponent) minder resultaten oplevert dan in redelijkheid zou mogen worden verwacht ${ }^{2}$. In de grote steden probeert men intussen door middel van overeenkomsten met schoolbesturen een gerichtere aanpak te realiseren. In deze convenanten, die in het recente sociale-vernieuwingsprogramma een extra impuls krijgen, wordt vastgelegd om welke activiteiten voor welke doelstelling en met welke middelen het gaat ${ }^{28}$. Door het Rijk is recent een nieuwe Onderwijsvoorrangswet in het vooruitzicht gesteld, die een meer gericht voorrangsbeleid, afgestemd op de lokale situatie, mogelijk zou moeten maken ${ }^{29}$.

Een effectieve achterstandsbestrijding in het onderwijs vereist de betrokkenheid van het stedelijk bestuur. Deze is echter in het Nederlandse onderwijsbestel op dit ogenblik alleen mogelijk als alle bijzondere en openbare scholen op

${ }^{26}$ ] M. Alkan, C. Mullard en J.F. Vos, Basisvorming in een multiculturele stod: ontwikkelingen in Amsterdom; Amsterdam, Cres Publication Series, 1987.

27] Zie voor een evaluatie van het Onderwijsvoorrangsbeleid (OVB) in Rotterdam H.L. de Groot en S.C.A. Kole, op. cit. Zie voor Rotterdam ook C. van Orlé, Onderwijsvoorrang, Af en toe dreigt het echt te goon lukken; Utrecht, Rijksuniversiteit Utrecht. Vakgroep Grondslagen en Technieken en Methoden van Pedagogische en Andragogische Wetenschappen, 1988.

Voor een evaluatie van het OVB in 's-Gravenhage: Naor een effectieve bestrijding van onderwijsochterstonden, Notitie over evaluatie en bijstelling van het Haogse onderwijsvoorrangsbeleid, de verbetering van doorstroming van leerlingen en een projectvoorstel; Gemeente 's-Gravenhage, Afdeling Onderwijs, januari 1989.

Voor een evaluatie van het OVB in Utrecht: A. Kramer en $\mathrm{H}$. Slaats, Omgoan met verschillen, de somenwerking tussen onderwijs en weizijnswerk in de Utrechtse Voorrangs-Gebieden; Utrecht, School-Advies-Centrum en de Vakgroep Sociale en Organisatiepsychologie, Rijksuniversiteit Utrecht, 1988.

Voor een algemene notitie: J. Kloprogge, En toen was er OVB...?, notitie betreffende het onderwijsvoorrangsbeleid 1987; 's-Gravenhage, SVO, 1988; J. Kloprogge, Voorrang voor de gebieden?, notitie over het onderwijsvoorrongsbeleid in 1988; 's-Gravenhage, SVO, Landelijke Evaluatie Onderwijsvoorrangsbeleid, 1989.

Verder: A.J. Nijssen, Onderwijs en welzijn in onderwijsvoorrangsgebieden; een beschrijving van de start van de uitvoering van het onderwijsvoorrangsbeleid (gebiedenniveau); Leiden, Stichting Research voor Beleid, 1987. En: Th. Roelandt en J. Veenman, Minderheden in Nederland; positie in het onderwijs; Rotterdam, Instituut voor Sociologisch-Economisch Onderzoek, 1988. Voor een samenvattend overzicht: WRR, Allochtonenbeleid; (op. cit.), blz. ISB.

28] Dat gaat in de richting van het advies van de WRR over het Allochtonenbeleid. De inzet van middelen zou meer moeten worden gerelateerd aan de output van de achterstandsbestrijding; tevens zou een premie op een doelmatige aanpak gesteld kunnen worden.

29] Ministerie van Binnenlandse Zaken, Sociale vernieuwing, Opdracht en hondreiking; 's-Gravenhage, 1990, b1z. 43-44. 
vrijwillige basis tot afspraken komen. Wel is de bestrijding van schoolverzuim primair een gemeentelijke taak (gemeentelijke leerplichtambtenaren). Het Rijk probeert sinds enige tijd dit gemeentelijk beleid te stimuleren. Het Rijk richt zich met de voorgestelde maatregelen in het algemeen direct op de scholen en niet op de gemeenten. Dit geldt eveneens voor drop-outs en het op een te laag niveau blijven van veel leerlingen, verschijnselen die vooral in de grote steden geconcentreerd zijn ${ }^{30}$.

Meer in het algemeen is de kwaliteitsbevordering in het initiële onderwijs in de komende periode verbonden met de vernieuwingsbeweging van de 'effectieve school', afkomstig uit de Verenigde Staten en met name in Amsterdam en Rotterdam omhelsd, krachtig gestimuleerd door onderwijskundige centra in die steden. In Den Haag werd over hetzelfde onderwerp in 1987 door de gemeente een beleidsnota uitgebracht. Het bijzonder onderwijs in deze stad had echter geen boodschap aan dit beleid. Daardoor is in deze stad dit vernieuwingsbeleid alleen in het openbaar onderwijs tot uitgangspunt genomen. Het accent ligt op de kwaliteit van iedere afzonderlijke school en op haar vermogen elke leerling een optimale scholing te geven, afgestemd op zijn of haar vermogens. In de beleidsprogramma's gaat het vooral om een krachtig, inspirerend leiderschap op de scholen, een taakgericht leraarschap en een stimulerend schoolklimaat. Een dergelijk stimuleringsbeleid vraagt een zodanige beleidsvrijheid voor het grootstedelijk bestuur, dat enerzijds de elementaire onderwijsvrijheid en het primaat van de scholen onverlet blijft, maar dat anderzijds in grootstedelijk verband de onderwijsinzet en -kwaliteit door het bestuur van de grote stad beter kan worden gestimuleerd en bevorderd.

De kwaliteit van het onderwijs met het oog op de arbeidsmarkt wordt in Nederland voornamelijk vanuit een sociale invalshoek benaderd. Het WRR-rapport 'Activerend arbeidsmarktbeleid' (1987) heeft hiervoor een aantal lijnen getrokken die nu ook in het beleid van de grote steden kunnen worden teruggevonden ${ }^{31}$. Ook het dag- en avondonderwijs en de aanvullende beroepsopleiding, onderdelen van de nieuwe infrastructuur voor volwasseneneducatie, worden hierbij betrokken. Het basisidee om scholing, werkervaring en insluizing in het arbeidsbestel op elkaar te betrekken en in een individueel gerichte trajectbenadering tot kern te maken van een activerend arbeidsmarktbeleid, is hierbij de centrale leidraad. De regering heeft in haar recente beleidsvoornemens deze koppeling van onderwijs aan de bestrijding van werkloosheid bij jongeren en langdurig werklozen extra aangescherpt ${ }^{32}$. Daarbij speelt het nieuwe Regionale Bestuur Arbeidsvoorziening (RBA) een belangrijke rol. De koppe-

30] Zie voor een beschrijving van de ontwikkeling van het achterstandsbeleid over drie periodes: 1974-| 1980; 1980- 1985 en na 1985 , het tegenhouden van een centrale rol van de gemeenten hierbij, en de verwerping van de onderwijsvoorrangswet op 20 januari 1987 door de Eerste Kamer (deze vond de wet te ingewikkeld en was tegen de samenwerking tussen het onderwijs en welzijn en de gebiedsgewijze aanpak). J.J.G.M. Rutten, 'Onderwijsvoorrangsbeleid: terug naar de gemeente', in: Gemeenten en onderwijs (Op. cit.), blz. 38I-393. Intussen is er een tussentijdse regeling waarin de feitelijke OVB-projecten voortgang vinden tot 1990. Dan moet er een nieuwe wettelijke regeling komen. Er worden twee modellen gehanteerd. Het zogenaamde centraal georiënteerde Groningse model. Hierbij vindt overdracht plaats van bevoegdheden van de deelnemende scholen en instellingen aan een centrale projectorganisatie. Het zogenaamde decentrale Helmondse model. Hierbij vindt geen overdracht van bevoegdheden van scholen en instellingen plaats. Gemeenten hebben overigens steeds aanzienlijke bedragen besteed aan de bestrijding van achterstanden in het onderwijs. De gemeente Den Haag stopt bovenop het geld dat het van het Rijk ontvangt een ongeveer gelijk bedrag uit eigen middelen in het onderwijsvoorrangsbeleid. De vier grote steden dienden in 1988 een gezamenlijke projectaanvraag in bij het Rijk voor het versterken van het onderwijs in concentratiescholen. Dat zou verdere segmentering tussen 'witte' en 'zwarte' scholen moeten tegengegaan (Gezomenlijke projectoonvraog 'kwaliteitsverbetering vier grote steden'; Amsterdam, Den Haag, Rotterdam en Utrecht, september 1988).

31] Wetenschappelijke Raad voor het Regeringsbeleid, Activerend arbeidsmarktbeleid (op. cit.), in het bijzonder hoofdstuk 7 'Scholing' (blz. 96.1 10) en W.J. Dercksen, E.W. van Luijk en P. den Hoed, Werkloosheidsbestrijding in Amsterdam, Rotterdam, Den Haag en Utrecht; Werkdocumenten W50, 's-Gravenhage, WRR, 1990.

32] Sociole vernieuwing, Opdracht en handreiking (op. cit.), blz. 6-22. 
ling met het onderwijs moet echter nog worden uitgewerkt, nu het aanvankelijk overwogen Regionaal Educatief Overleg, dat aan het RBA gekoppeld zou worden, voor het huidige kabinet geen verplichte constructie meer is.

Hier vult de raad deze suggesties aan met de aanbeveling onderwijs en scholing in grootstedelijk verband op eigen merites te beoordelen. $\mathrm{Zij}$ moeten afzonderlijk aandacht krijgen in het kader van economische en technologische vernieuwing en in termen van persoonlijke vorming en cultuuroverdracht. Hier zal - aansluitend bij de ervaringen in de grote steden in de Angelsaksische wereld - het beleid de komende jaren zo goed als geheel tot ontwikkeling moeten worden gebracht. De pleidooien en initiatieven in deze richting in het bedrijfsleven, in de steden en de laatste tijd ook bij het Rijk nemen toe. Vooral de aanbevelingen van de Commissie Onderwijs - Arbeidsmarkt van de SER en het recente advies van de Commissie Rauwenhoff vormen hierbij een belangrijke leidraad ${ }^{33}$.

Dit pleidooi houdt in de eerste plaats een versterking in van beroepsopleidingen in het initieel en regulier onderwijs en in de bedrijfssector, waarbij de uitwisseling en samenwerking tussen beide in belangrijke mate wordt versterkt. Afzonderlijke scholingsinitiatieven en cursussen vanuit het particulier initiatief op commerciële of op non-profit grondslag kunnen dit geheel completeren en versterken zo deze gevarieerde en gedifferentieerde onderwijsmarkt en -infrastructuur. Ook de opzet en inrichting van het nieuwe stelsel van volwassenenonderwijs kan voor deze functies aangescherpt worden, zoals tot nu toe het geval was ten aanzien van de inzet voor de arbeidsvoorziening.

Een belangrijk thema is de afstemming van de curricula en cursussen in het beroepsonderwijs op de nieuwe economische en technologische ontwikkelingen. Zo is er in de Rotterdamse regio een grote behoefte aan een betere afstemming van MTS, MAVO en HAVO op de procestechnologie in de havens. Het brede veld van opleidingen is onvoldoende ingesteld op deze vernieuwing. Vooral ontbreekt de noodzakelijke dynamiek in aanpassing van cursussen, vakonderdelen en onderwijsprogramma's aan nieuwe omstandigheden. Tenslotte is een aanpassing van de huidige LTS vereist. Deze opleiding blijkt juist in de grote steden problematisch. De instroom is er miniem en het huidige opleidingsprogramma staat er meer dan elders ter discussie.

Ten aanzien van de relatie bedrijf en scholing erkennen de bedrijven, nadat zij de afgelopen jaren de scholing zelf ten tijde van de recessie hadden ingekrompen, dat hierbij niet meer volstaan kan worden met centraal vastgestelde CAO's. Ook vinden zij een relatie met het gemeentebestuur van de grote stad essentieel. Tegelijkertijd wordt vastgesteld dat deze contacten op dit ogenblik beperkt zijn. Bovendien tekent men hierbij aan dat regelingen en afspraken een regionaal en sectoraal karakter behoren te hebben. Niet uitsluitend de grote steden zijn dan uitgangspunt, maar de grote steden en de omliggende randgemeenten samen ${ }^{34}$.

Een belangrijk strijdpunt bij de beoogde aanpassingen is de component algemene vorming in de beroepsopleiding. De raad heeft in zijn rapport 'Basisvorming' het belang van die algemene vorming in relatie met het beroepsonderwijs beklemtoond. Hij heeft echter ook laten zien dat er gedifferentieerde oplossingen mogelijk zijn. In het algemeen wordt in Nederland

33] Zie naast de Commissie Onderwijs-Arbeidsmarkt en een aantal recente adviezen van de SER op dit vlak, de recente onderwijsnota van het VNO, de nieuwjaarsrede 1989 van de directeur van de Kamer van Koophandel van Amsterdam, De Vilder, en de toespraak van de directeur van de Nederlandsche Bank, Wellink, op 3 november 1988 bij gelegenheid van het tienjarig jubileum van de Gelderse Ontwikkelingsmaatschappij.

34] Gegevens, verkregen tijdens gesprekken met vertegenwoordigers van de bedrijfssector in de Rotterdamse havens. 
strak vastgehouden aan de algemene vorming als verplicht onderdeel. Ten gunste van de nodige variatie, flexibiliteit en dynamiek in de beroepsopleidingen zou dit principe zeker bij de concrete vormgeving losser moeten worden gehanteerd, zonder daarbij de begrenzing zoals aangegeven in 'Basisvorming', te laten schieten. Op deze manier wordt bereikt dat leerlingen die een vaardigheidstraining aankunnen, maar die onoverkomelijke drempels ervaren bij cognitieve leerprocessen, toch een kans hebben. Het potentieel van gespecialiseerde vakkrachten kan hiermee behoorlijk worden uitgebreid. Dit is een belangrijk aandachtspunt bij de invoering van de nieuwe wet op de basisvorming. De innovatie in het beroepsonderwijs moet aan dit genuanceerde beginsel verder uitwerking geven. Deze leidraad laat het belang van de twee afzonderlijke componenten - algemene vorming èn gerichte beroepstraining onverlet.

De relaties tussen de betrokkenen in grootstedelijk verband zijn op het vlak van economische/technologische vernieuwing en onderwijs tot nu toe weinig geprofileerd. Er komt echter schot in, nu ook het initiële en reguliere beroepsonderwijs, zoals in Rotterdam, zich inspant om zijn marktpositie te versterken door contractonderwijs aan te bieden op de niet-reguliere onderwijsmarkt. Dit heeft dan vooral betrekking op het midden- en kleinbedrijf, omdat de grote bedrijven hun eigen voorzieningen hebben. Ook beginnen in steeds meer gemeenten scholen en bedrijven samenwerkingsrelaties aan te gaan ${ }^{35}$.

Het uiteindelijk doel zou tenslotte een brede benadering moeten zijn, waarbij sociaal achterstandsbeleid, economisch-technologische vernieuwing alsmede persoonlijke vorming en cultuuroverdracht onderdelen zijn van een brede en geschakeerde onderwijsmarkt en een hierop inspelend grootstedelijk onderwijsbeleid ${ }^{36}$. Dit vereist echter een institutionele aanpassing, waarin de beleidsruimte én de marktwerking van onderwijs op lokaal/regionaal niveau meer gewicht heeft dan nu het geval is. Daarover gaan de volgende paragrafen.

\subsubsection{Ontwikkelingen in de institutionele verhoudingen}

Het Nederlandse onderwijsbestel kenmerkt zich door de tweedeling van openbaar en bijzonder onderwijs, waarbij de overheid garant staat voor de vrijheid van onderwijs voor de bijzondere scholen en daarnaast zelf openbaar onderwijs aanbiedt - onafhankelijk van het aanwezige bijzonder onderwijs. Het laatste is als het ware de tweede garantie in het systeem van onderwijsvrijheid. Dit alles gaat terug op de zogenaamde pacificatie: de beëindiging van de schoolstrijd en de grondwetsherziening van 1917. Artikel 23 van de Grondwet regelt het beginsel van de vrijheid van richting, de bevoegdheid van de overheid deugdelijkheidseisen te stellen en de verplichting aan de overheid om zich de zorg voor het onderwijs als publieke zaak aan te trekken. Hiermee is de gelijkberechtiging en financiële gelijkstelling van het bijzonder en openbaar onderwijs grondwettelijk verankerd. Deze constructie is een belangrijke bepalende factor voor het qua differentiatie beperkte Nederlandse onderwijsbestel.

Overigens wordt in recente studies geconcludeerd dat de hier samengevatte principes en regelingen van onderwijsvrijheid heel wel in een decentraal onderwijssysteem tot hun recht kunnen komen en daarmee in overeenstem-

35] Voor een overzicht en voor knelpunten en aandachtspunten: Scholen en bedrijven, Handreiking voor Samenwerking; samengesteld door F. Heere en A. Schoorl, Stichting Research voor Beleid, 's-Gravenhage, Sociaal-Economische Raad, 1989.

36] Ook in Nederland treft men al verdwaald pleidooien aan om persoonlijke vorming en cultuuroverdracht meer centraal te stellen als indirecte maar bepalende elementen in de kwaliteit van het onderwijs, die nauwelijks in overkoepelend overheidsbeleid manipuleerbaar zijn. Zie: W.K.B. Hofstee, 'De kwadratuur van de kwaliteit: reflecties over de kwaliteit van het voortgezet onderwijs'; in: De kwaliteit van het voortgezet onderwijs; Voordrachten gehouden op het symposium De kwaliteit van het voortgezet onderwijs, Utrecht 2 juni 1984, Amsterdam, Uitgave: Vereniging voor Onderwijs Kunst en Wetenschap in samenwerking met Elseviers Uitgeversmaatschappij, 1984, blz. 24-36. 
ming zijn te brengen. Daarbij wordt aangetekend dat in de discussies over de onderwijsvrijheid die de grondslag vormden van de regeling in 1917, dit centralistisch stelsel niet voorondersteld werd ${ }^{37}$.

Niet alleen zijn de structuur en de inhoud van het onderwijs wettelijk in vergaande mate vastgelegd. Ook de voorwaarden waaronder het onderwijs plaatsvindt en waaronder schoolbesturen moeten werken, zijn uitgebreid en gedetailleerd geregeld.

De positie van de gemeenten is door deze twee kenmerken ten principale bepaald. De gemeenten zijn primair schoolbestuur voor scholen van openbaar onderwijs. Daarnaast hebben de gemeentebesturen een verantwoordelijkheid voor het gehele onderwijs in hun bestuursgebied: 'zorg- of hoedsterfunctie'. Beide functies samen worden als gemeentelijke dubbelrol omschreven. De wet geeft echter voor de tweede functie nauwelijks een basis. Doorgaans geeft de functie van schoolbestuur van het openbaar onderwijs de doorslag. Het Rijk is de bepalende regelaar en beleidsvoorbereider bij uitnemendheid. Het verstaat zich hiervoor rechtstreeks met de schoolbesturen (van openbaar en bijzonder onderwijs). De gemeenten zijn aan deze regelingen gebonden en dienen voorts de financiële gelijkstelling van openbaar en bijzonder onderwijs te garanderen. Ook al heeft de gemeente een aantal bevoegdheden: (a) autonoom schoolbestuur (openbaar onderwijs); b) medebewindvoerder voor het Rijk en c) autonoom beleidsvoerder): haar betrokkenheid is uiteindelijk toch voor een belangrijk deel afhankelijk van en gebonden aan anderen. Zo wordt wel gesproken van mechanisch medebewind ${ }^{38}$. Hierbij kan worden aangetekend dat in de grote steden de tweedeling in openbaar en bijzonder onderwijs extra geprofileerd is vanwege het grote aantal openbare scholen naast het grote aantal bijzondere scholen met even zovele schoolbesturen. Er zijn wel overkoepelende verbanden in het bijzonder onderwijs, maar die missen de bevoegdheid van schoolbesturen. De gemeentelijke overheid heeft derhalve te maken met talloze schoolbesturen.

De discussie over een grotere betrokkenheid van de gemeente werd al gevoerd in de jaren '70. De toenmalige Raad voor de Territoriale Decentralisatie bracht het rapport 'Decentralisatie van rijkstaken Onderwijs' uit ${ }^{39}$. De discussie laaide opnieuw op ten tijde van de formatie van het tweede kabinet-Lubbers. In het desbetreffende regeerakkoord werd decentralisatie van regelgeving naar lagere overheden met het oog op de positie van het bijzonder onderwijs expliciet uitgesloten. Mentink heeft hierover opgemerkt dat bij het afwegen van de voor-en nadelen van een gedecentraliseerd onderwijsbeleid in ons land slechts in geringe mate een beroep wordt gedaan op argumenten in de sfeer van doelmatigheid en effectiviteit. Opvattingen over en interpretaties van het

${ }^{37}$ ] D. Mentink, Onderwijsbeleid en onderwijsvrijheid; 's-Gravenhage, Stichting voor Onderzoek van het Onderwijs, 1984 en D. Mentink, 'De smalle marges van de gemeentelijke onderwijshuishouding, een juridische oriëntatie'; in: Gemeenten en onderwijs (op. cit.), blz. 12I-136. Tenslotte van dezelfde auteur het recente proefschrift Orde in onderwijsbeleid; Deventer, Kluwer, 1989. Hier wordt onder meer gesteld dat uit niets blijkt dat de decentrale regelgeving op het gebied van de deugdelijkheidseisen volgens de grondwet uitgesloten zijn. Met decentrale regelgeving werd vanaf het begin gerekend.

Zie voor een algemeen historisch overzicht: S. Karsten, 'Lokaal onderwijsbeleid in historisch perspectief (1857-1920)'; in: Gemeenten en onderwijs (op. cit.), blz. 103-1 19. Deze auteur laat zien hoe ook van 'onderop', met name vanuit de onderwijsbonden en vanuit de gemeenten druk werd uitgeoefend in de richting van een centralistisch onderwijsbeleid in Nederland.

30] D. Mentink, 'De smalle marges van de gemeentelijke onderwijshuishouding, een juridische oriēntatie' (op. cit.).

39] Raad voor de Territoriale Decentralisatie, Decentralisatie van rijkstaken; 's-Gravenhage, Staatsuitgeverij, 1980. 
begrip vrijheid van onderwijs bepalen grotendeels de uitslag van het afwegingsproces" ${ }^{40}$.

Tijdens de laatste fase van het tweede kabinet-Lubbers startte men uiteindelijk ook op het ministerie van Onderwijs en Wetenschappen de lang uitgebleven deregulering. De omvangrijke bureaucratie en regelgeving, verbonden met het nationale onderwijsbeleid, zouden worden teruggedrongen ten gunste van eigen initiatief en inbreng van het onderwijsveld zelf. De oplossing werd gezocht in een grotere autonomie voor de schoolbesturen en scholen. In de dereguleringsnota 'De school op weg naar 2000' (1988) werd dit nieuwe bestuurlijke profiel tot uiting gebracht na een voorzet in de nota "Minder Regels, Meer Ruimte' (1986). De beoogde autonomie van de scholen vindt haar contrapunt in eindtermen, die door de minister van Onderwijs en Wetenschappen worden vastgesteld en waaraan de scholen vervolgens zijn gebonden. De grotere autonomie wordt geëffectueerd door de invoering van 'lump sum'financiering voor scholen. Deze voorstellen zijn gebaseerd op functionele decentralisatie, waarbij de autonomie uitsluitend invulling krijgt langs de lijn van scholen en schoolbesturen.

Hoe nauw deze nieuwe voorstellen luisteren in het Nederlandse onderwijsbestel, komt tot uiting in de reactie van de Commissie Hirsch Ballin op de dereguleringsnota. Voor het openbaar onderwijs is er geen bezwaar om de eindtermen in de publieke besluitvorming vast te stellen. Bij het bijzonder onderwijs is terughoudendheid op zijn plaats. Het zonder meer centraal vaststellen van de eindtermen acht de Commissie Hirsch Ballin in strijd met de Grondwet. De overheid zou dan greep krijgen op de aard en inhoud van het bijzonder onderwijs. Wel vindt de Commissie dat de bijzondere scholen zelf eindtermen moeten opstellen, die dan marginaal door de overheid kunnen worden getoetst. Het tweede element - het geven van een eigen budget aan de scholen - heeft in grote lijnen de instemming van de Commissie. Intussen is in het huidige kabinet een vergelijk getroffen over het strijdpunt van de eindtermen, waarin de eigen speelruimte van de schoolbesturen erkend wordt. De aanbevelingen van de Commissie Hirsch Ballin leidden er ook toe dat de constructie van Regionaal Educatief Overleg, gekoppeld aan de nieuwe Regionale Arbeidsbesturen, sinds het laatste regeerakkoord geen verplicht onderdeel meer is in de nieuwe structuur van de arbeidsvoorziening.

De recente vernieuwingsvoorstellen en de voorgestelde deregulering richten zich in eerste instantie terecht op de scholen en de schoolbesturen. De gemeentelijke rol blijft echter overwegend die van schoolbestuur in het openbaar onderwijs. Het gemeentelijk onderwijsbeleid kan alleen tot stand komen op basis van overeenstemming met de besturen van het bijzonder onderwijs. Ook in het regeerakkoord van het huidige kabinet wordt een principiële wijziging op dit vlak uitgesloten. De enige uitzondering op dit bestuurlijk patroon vormt het nieuwe stelsel van volwasseneneducatie. Hier is zowel in de beleidsvoorbereidende, als in de beleidsbepalende en -uitvoerende sfeer aan de gemeente een doorslaggevende positie toegekend.

40] D. Mentink, Onderwijsbeleid en onderwijsvrijheid (op. cit). Overigens is onlangs ook binnen het CDA de discussie over het bijzonder onderwijs heropend. Het Wetenschappelijk Instituut van het CDA heeft in september 1989 het rapport Ruimte voor kwoliteit uitgebracht. De grote invloed van de overheid is het hete hangijzer in dit rapport. Om die reden hebben de opstellers veel moeite met de nieuwe Wet op de Basisvorming, onder andere vanwege de centraal gestelde eindtermen. Ze pleiten voor een verschuiving van de centrale bemoeienis van de overheid naar de schoolbesturen. Om die verschuiving een reëel karakter te geven, dienen die besturen wel volgens de opstellers van dit rapport in regionaal verband te fuseren. Dan kunnen ze ook strategische beslissingen nemen. Dat impliceert, aldus het rapport, de noodzaak van het verlaten van het huidige declaratiestelsel en het omarmen van een budgetstelsel. Overigens werd juist het declaratiestelsel indertijd gekozen voor de betrokkenen als garantie bij de inrichting van het onderwijs. Zie ook: H. Wansink, 'Het einde van de schoolstrijd', in: Intermediair; jaargang 25, nr. 38, 22 september 1989, blz. 33, 35, 37 en 39. 
Gelet op de bestaande verhoudingen en de toch voortdurende druk op meer decentralisatie in het onderwijs, wordt door Van Wieringen (1988) bepleit de wederzijdse afhankelijkheids- en invloedsrelaties tussen rijksoverheid, nationale onderwijskoepels, plaatselijke schoolbesturen, leerkrachten, hun professionele achterban, schoolbegeleidingsdiensten en onderwijskundigen vanuit het belang van differentiatie te benutten ${ }^{41}$. Onderzoek wijst overigens uit dat de feitelijke bemoeienis en invloed van de gemeenten op het onderwijs (controlerend, dienstbaar, beleidsinnoverend) tot nu toe zeer beperkt is. Een verband met omvang en urbanisatiegraad van gemeenten wordt niet gevonden ${ }^{42}$. Eerder blijkt politisering en geprononceerde partijpolitieke cultuur van belang. De vier grote steden scoren om die reden ten aanzien van een uitgesproken onderwijsbeleid hoger dan gemiddeld.

Vooral zou de beleidsruimte in het vigerende stelsel zo optimaal mogelijk moeten worden benut: a) in zijn functie van schoolbestuur is het gemeentebestuur deels medebewindvoerder en deels autonoom bestuur; b) in zijn 'zorgfunctie' heeft het gemeentebestuur een beleidsgebied dat zo groot is als het gemeentebestuur dat zelf wil zien. Dit geldt zeker voor zaken die niet bij wet zijn uitgesloten. Concreet heeft de grote stad op dit ogenblik als gemeente een eigen beleidsruimte voor volwasseneneducatie, bij het gebiedsbeleid in het onderwijsvoorrangsprogramma, bij de schooladvies- en begeleidingsdiensten, bij de leerplichthandhaving en bij nog enkele andere onderdelen, zoals bij de zogenaamde boventalligenregeling en cumifaciliteiten.

Dit laatste wordt ook in de praktijk geillustreerd. Sommige gemeenten voeren in het huidige bestel veel meer een eigen beleid dan andere en drukken een stempel op het onderwijs. Amsterdam maakt van de bestaande beleidsruimte op een andere wijze gebruik dan bijvoorbeeld Rotterdam. In Utrecht valt op hoe daar over een lange periode - zeker in vergelijking met de andere drie grote steden - het verschijnsel van 'witte en zwarte scholen' ingedamd is. In dezelfde stad is de verhouding met het bijzonder onderwijs redelijk. Dit geldt tot op zekere hoogte ook voor Rotterdam. In Den Haag en Amsterdam is die verhouding aanzienlijk meer beladen.

In de optiek van dit rapport is evenwel een extra versterking van lokaal en regionaal onderwijsbeleid in de grote steden een vereiste ten gunste van een grootstedelijk onderwijsbeleid dat de nationale economische en technologische vernieuwing krachtig ondersteunt door hoogwaardige en zich steeds vernieuwende onderwijsvoorzieningen. Persoonlijke vorming en culturele overdracht dienen op zodanige wijze geboden te worden dat de geconcentreerde achterstand in stadsbuurten en bij bepaalde bevolkingsgroepen, met name allochtonen, effectief wordt teruggedrongen. Over die beleidsopgaven gaat de volgende paragraaf.

\subsubsection{Beleidsopgaven}

Goed onderwijs is nu en in de onmiddellijke toekomst bepalend voor de kwaliteit van de grote steden in sociaal, economisch/technologisch en cultureel opzicht. Die kwaliteit - zo is eerder betoogd - is mede van nationale betekenis. $\mathrm{Zij}$ wordt in belangrijke mate bevorderd door een onderwijsmarkt waarop vraag en aanbod elkaar snel en flexibel weten te vinden en waarop risico's en verantwoordelijkheden zo direct mogelijk met elkaar verbonden zijn. Hierbij behoort de overheid haar verantwoordelijkheid te nemen in termen van eisen voor een minimaal te garanderen kwaliteit en toegankelijkheid. Tevens dient ze de scherpe kanten van segmentering die door de selectie en niveaudifferentiatie in het onderwijs wordt versterkt, af te zwakken. Het grootstedelijk

41] A.M.L. van Wieringen, 'Gerneentelijk onderwijsbeleid en onderwijsbestuur'; in: Gemeenten en onderwijs (op. cit), blz. 8- 10.

42] P. Detering en W. Kalkman, Besturen met beleid; Amsterdam, Universiteit van Amsterdam, 1985. 
bestuur komen meer mogelijkheden toe, zowel als het gaat om prikkels te bieden voor de partijen in het onderwijs, als om een aantal condities te waarborgen vanuit het algemeen belang. Het decentrale en gedifferentieerde beleidsmodel van de Angelsaksische landen biedt hiervoor een aantrekkelijk referentiepunt. In een dergelijk model kan de nationale overheid haar eigen verantwoordelijkheid behouden. Deze verantwoordelijkheid is in het onderwijs verbonden met garanties voor basiskwaliteit, een gegarandeerde toegang en beschikbaarheid van onderwijs enzovoort. Die verantwoordelijkheid komt het lokaal en regionaal niveau niet toe. Integendeel, in een aantal gevallen zal die verantwoordelijkheid op nationaal niveau de komende periode zelfs aangescherpt worden bij een steeds meer toenemende internationale samenhang van onderwijs, economie, technologie en arbeidsmarkt.

Binnen een dergelijk nationaal bestel wordt voor de grote steden een versterking van een beleidsmatige betrokkenheid voorgesteld met een daarbij aansluitende beleidsruimte. Uitgangspunt hierbij is overigens dat de in de Grondwet verankerde onderwijsvrijheid en de garanties voor het bijzonder onderwijs niet mogen worden aangetast. Binnen deze randvoorwaarde zou echter een balansverschuiving dienen plaats te vinden van het huidige onderwijsbeleid vanuit het ministerie naar het lokaal en regionaal niveau. Zo kan de bijzondere situatie in Amsterdam, Rotterdam, Den Haag en Utrecht direct en krachtig in beleid worden omgezet, iets waarvoor nu veel hindernissen en obstakels bestaan, zoals het onderwijsvoorrangsbeleid treffend illustreert.

De uiteenlopende vormen van onderwijs moeten echter niet over één kam worden geschoren. Het nieuwe stelsel van volwasseneneducatie gaat het meest in de richting van een dynamiserend en gedifferentieerd grootstedelijk onderwijsbeleid. Dit biedt verrassenderwijs aan de gemeente - in het kader van de Wet Gemeenschappelijke Regelingen met andere gemeenten samen - in samenspraak met de betrokken scholen en de vertegenwoordigers van de onderwijsvraag een beleidsvoorbereidende en beleidsbepalende functie.

Het basisonderwijs, het algemeen vormend onderwijs en het lager en middelbaar beroepsonderwijs hebben op dit ogenblik nog met de meeste belemmeringen te kampen. Hier manifesteert zich de tweeslag openbaar en bijzonder onderwijs meer dan bij de andere onderwijssoorten. Deze belemmeringen worden niet weggenomen door de voorgestelde functionele decentralisatie. In die voorstellen blijven de scholen en schoolbesturen los staan van hun grootstedelijke omgeving. Gelet op enerzijds de strategische belangen voor de grote steden zelf en anderzijds de nationale onderwijsbelangen is ten aanzien van het basisonderwijs, het algemeen voortgezet onderwijs en het lager en middelbaar beroepsonderwijs naar de mening van de raad in de steden een bijstelling van de institutionele verhoudingen vereist. Daartoe dienen de volgende voorstellen ${ }^{43}$.

In de eerste plaats dienen de functies van het gemeentebestuur als bevoegd gezag voor het openbaar onderwijs te worden ontkoppeld van die als overheid die de algemene zorg voor het onderwijs op haar grondgebied heeft. De huidige koppeling van beide functies staat een vrije en ongebonden beleidsmatige betrokkenheid bij onderwijs in de meest brede zin (algemene zorg) in de weg. In de huidige situatie komt het gemeentebestuur zichzelf tegen als belanghebbende partij (bevoegd gezag van het openbaar onderwijs).

Doel van de hier voorgestelde ontkoppeling is het creëren van een situatie waarin de gemeente zich zonder extra handicap kan wijden aan het grootstede-

${ }^{43}$ ] De voorstellen zijn voor een belangrijk deel gebaseerd op: W.H. Leeuwenburgh en P. van den Eeden, Onderwijs in de vier grote steden (op. cit.) 
lijk onderwijsbeleid in brede zin. Bij deze ontkoppeling zal de gemeentelijke verantwoordelijkheid als bevoegd gezag in het openbaar onderwijs onaangetast moeten blijven en meer in het bijzonder de publieke beheersvorm op volwaardige wijze gestalte dienen te krijgen, zodat wordt gegarandeerd dat voor iedereen in het land onderwijs bereikbaar is (dit laatste is het centrale motief van het openbaar onderwijs). De huidige wetgeving biedt voor een apart regelen van deze publieke beheersvorm als mogelijkheden: a) een bestuurscommissie krachtens artikel 61 van de Gemeentewet in te stellen of b) het bevoegd gezag te delegeren aan een samenwerkingsorgaan tussen gemeenten ingevolge de Wet Gemeenschappelijke Regelingen. Deze laatste oplossing komt voor de grote steden wat betreft het basisonderwijs, het algemeen vormend onderwijs en het lager en middelbaar beroepsonderwijs niet in aanmerking, omdat deze overwegend een aangelegenheid van de stad zelf zijn. Voor de bestuurlijke vormgeving van de publieke beheersfunctie van deze vormen van openbaar onderwijs wordt voor de grote steden verwezen naar de binnengemeentelijke decentralisatie, die de gelegenheid creëert de publieke beheersfunctie apart te plaatsen bij de deelbesturen. Landelijk gezien hebben andere mogelijke oplossingen, zoals voorgesteld door de Raad voor het Openbaar Onderwijs en recentelijk de licentie-constructie, de aandacht gekregen ${ }^{44}$.

Als op deze wijze de weg is vrijgemaakt voor een actieve betrokkenheid in de hier bedoelde onderwijssectoren van de onderwijswereld zelf en voor beleidsmatige impulsen van het bestuur in de grote stad, dient het Rijk vervolgens de ruimte te geven voor differentiatie in de planning, inrichting, bekostiging en exploitatie van scholen. Hierbij is de differentiatie in personeelsbeleid in de vorm van aanstellings- en beloningsverschillen voor de grote steden een van de belangrijkste hefbomen voor een meer effectieve inzet bij de concentraties van achterstanden, maar ook voor verhoging van de kwaliteit en de effectiviteit van het onderwijs.

Bij een dergelijke bijstelling van de beleidsverantwoordelijkheid blijft de gelijkheidsregeling van het openbaar en bijzonder onderwijs ook op het decentrale niveau gegarandeerd. Tegelijkertijd bevordert ze de noodzakelijke beleidsdifferentiatie van de grootstedelijke context. Als men een dynamisch en wendbaar bestuur op decentraal grootstedelijk niveau essentieel acht, leidt het achterwege laten van deze bijstelling tot ondoorzichtige bestuurlijke verhoudingen. De strubbelingen rond de gebiedsautoriteiten, de samenwerkingsverbanden en een meer gerichte inzet van middelen en personeel in de regelingen en wetgeving ten aanzien van het onderwijsvoorrangsbeleid - laatst nog bij de parlementaire behandeling van het programma van sociale vernieuwing - zijn hiervan een sprekend voorbeeld.

Een commissie zou moeten nagaan hoe bij deze nieuwe beleidsbalans de bevoegdheden ten aanzien van bekostiging en personele formaties tussen het Rijk, de afzonderlijke onderwijsinstellingen en het grootstedelijk bestuur dienen te worden bijgesteld.

De stimulering en afstemming in bredere zin, waarbij ook andere onderwijssectoren dan de hiervoor genoemde betrokken zijn en waarbij de combinatie van de langer bestaande oriëntatie in het onderwijsbeleid ten aanzien van sociale achterstand en de meer recente oriëntatie op de economisch/technologische functie, annex persoonlijke vorming en cultuuroverdracht de leidraad vormt, verwijst haast vanzelf naar een grootstedelijk uitwisselingspunt.

44] J. Wallage, 'Naar een Raad voor het Openbaar Onderwijs'; in: Het bestuur van het openbaar onderwijs; R.W.C. Akkermans en J.M.C. Leune (red.), Den Bosch, Malmberg, 1983; C.A.M. Tetteroo, 'Het bestuur van het openbaar onderwijs; een andere gedachte'; in: Gemeentelijk onderwijsbeleid op weg noar het joar 2000; Leusden, YUGA advisering BV, 1989, blz.51-56. Hier wordt de licentieconstructie uiteengezet. 
Een grootstedelijke onderwijsraad of vergelijkbaar platform kan hierin voorzien. Een dergelijk open beraad zou adviezen kunnen uitbrengen aan het stadsbestuur, waarbij overigens de primaire rol van de gemeenteraad in de besluitvorming onaangetast blijft. Het gaat bij deze onderwijsraad om een grootstedelijk klankbord, waarin de geschakeerde belangen in het onderwijs zoveel mogelijk rechtstreeks tot zaakwaarneming leiden. Via het gemeentebestuur kunnen de vertegenwoordigde instellingen en instanties zich wenden tot welke relevante partij buiten hun bestel ook. Dit kan variëren van uiteenlopende overheidsinstanties, het georganiseerd bedrijfsleven, culturele instellingen tot landelijke onderwijsorganisaties of -bonden. Het gemeentebestuur kan op zijn beurt in de onderwijsraad de grootstedelijke onderwijswereld confronteren met vereisten en condities die de grootstedelijke omgeving aan haar oplegt. Hiermee wordt het mogelijk om door inschakeling van deskundigheid in en buiten het onderwijsveld aan innovaties, aanpassingen en oplossingen voor knelpunten snel en op grootstedelijke schaal een impuls te geven. Op dit grootstedelijk niveau kan ook het meest adequaat worden voorzien welke praktische problemen zich presenteren en welke oplossingen voorhanden zijn. Of een dergelijke grootstedelijke onderwijsraad een aangelegenheid is van de grote stad of van de grootstedelijke agglomeratie kan aan de onderscheiden steden overgelaten worden. In de stad Utrecht bestaat al over een langere periode een succesvol onderwijsoverleg op stadsniveau. Het onderwijsoverleg in het kader van de Rotterdamse Ontwikkelingsraad (ROTOR) is een voorbeeld van een initiatief in de richting van de agglomeratie-variant.

Een samenvattende schets van die bredere en geschakeerde betrokkenheid vormt de afsluiting van dit perspectief voor een grootstedelijk onderwijsbeleid. De volgende driedeling groepeert de verschillen in strategisch belang en de wijze van betrokkenheid bij de betreffende onderwijssoorten vanuit de grote stad.

Het eerste en meest strategische niveau ligt bij het hoogwaardig en specialistisch onderwijs (waaronder universiteiten en hoger onderwijs). Eerder werd hierover gesteld dat een meer gedifferentieerd en minder uniform universitair onderwijs meer kansen biedt voor optimalisering van de functie van dit onderwijs in grootstedelijk verband. Het vereist echter ook meer dan thans een visie van het grootstedelijk bestuur op de uiteenlopende andere specialistische opleidingen in de grote stad of in de grootstedelijke regio. De beleidsmatige vrijheid voor initiatieven en stimulering zijn op dit strategisch niveau het grootst. De competitie en dynamiek vragen hier echter meer dan elders een grote mate van creativiteit en bundeling van inzet in de grote stad, c.q. de grootstedelijke regio. Het bestuur van de grote stad heeft in dit verband een eigen verantwoordelijkheid, die in de komende periode alleen maar toeneemt als het gespecialiseerd en hoogwaardig onderwijs steeds meer één van de belangrijkste 'assets' wordt in de internationale rangorde van grote steden.

Het tweede strategische niveau is het geheel van beroepsonderwijs, de volwasseneneducatie daarbij inbegrepen. Op nationaal niveau zijn bij dit onderwijs de ministeries van Onderwijs en Wetenschappen, van Sociale Zaken en van Economische Zaken betrokken. Het beroepsonderwijs zal meer in regionaal perspectief moeten worden gezien dan tot nu toe vanuit de grote steden het geval is. De concentratieprogramma's in het HBO en recentelijk in het MBO vormen het uitgangskader. De grote steden zouden zich hierbij meer dan tot nu toe beleidsmatig betrokken moeten voelen en daarvoor met werkgevers en werknemers als eerste betrokkenen tot afspraken moeten komen. Gelet op de schaal van de relaties tussen vraag en aanbod in dit onderwijs, zou hierbij niet de grote stad zelf maar de grootstedelijke regio het uitgangspunt moeten zijn. Ook is een grotere inzet van onderwijs vereist voor economische en technologische ontwikkeling. De recente voorstellen van de Commissie OnderwijsArbeidsmarkt voor meer directe relaties tussen vraag en aanbod op plaatselijk en regionaal niveau vormen hiervoor een bruikbaar vertrekpunt. 
Het derde strategische niveau is het geheel van het basisonderwijs, inclusief het algemeen vormend onderwijs. In vergelijking met de vorige twee niveaus zijn op dit ogenblik de mogelijkheden binnen de grote stad gedifferentieerd beleid te voeren, hier het geringst. Reden waarom in dit rapport het uitgangspunt van de autonome school wordt onderschreven, maar wel wordt aangevuld met een meer geprononceerde beleidsmatige betrokkenheid van het stadsbestuur, binnen de strakke condities die ons Nederlands onderwijsbestel met zijn vrijheid van onderwijs hiervoor stelt. De voorgestelde balansverschuiving moet leiden tot een meer gedifferentieerd grootstedelijk onderwijsbeleid in relatie tot de achterstanden en specifieke knelpunten in vraag en aanbod, maar ook tot de bijzondere mogelijkheden die de grote stad ook op dit niveau biedt.

\subsection{Arbeidsvoorziening}

\subsubsection{Algemeen kader}

Op 1 januari 1991 zal de nieuwe Arbiedsvoorzieningswet in werking treden, waarmee de arbeidsvoorzieningsorganisatie wordt verzelfstandigd, getripartiseerd en geregionaliseerd ${ }^{45}$. De wet geldt zowel voor gebieden in en rondom grote steden als voor plattelandsregio's. Alvorens in de volgende paragrafen wordt ingegaan op vraag en aanbod van arbeidsvoorziening in de grote steden, wordt in deze paragraaf de arbeidsvoorziening(sdienst) in een historisch kader belicht.

Voor alle duidelijkheid vooraf: de bemiddeling door het arbeidsbureau is slechts een van de manieren waarop vraag en aanbod van arbeid elkaar ontmoeten. Naar schatting wordt eenvijfde van de vacatures vervuld door bemiddeling van het Gewestelijk Arbeidsbureau ${ }^{46}$. Een groot deel van de contacten tussen vragers en aanbieders komt rechtstreeks tot stand via personeelsadvertenties, via 'horen zeggen', en via informele netwerken die bestaan tussen bepaalde groepen van bedrijven en bepaalde categorieën van werknemers. Een ander deel ontstaat via de weg van uitzendarbeid en van free-lance contracten. De verschillende methodes van arbeidsvoorziening sluiten vaak op elkaar aan. Dit geldt ook voor de verschillende soorten van arbeidscontracten. Zo komen vaste arbeidsrelaties vaak voort uit flexibele.

De nieuwe wet op de arbeidsvoorziening bestrijkt bovendien een breed terrein. Tot voor kort was arbeidsbemiddeling de enige juridische aanduiding van de intermediaire activiteiten op de arbeidsmarkt, activiteiten die de staat de afgelopen eeuw als een onderdeel van het algemeen belang naar zich toegetrokken heeft. Aangezien deze intermediaire activiteiten echter niet alle binnen het juridisch afgebakende begrip arbeidsbemiddeling vielen, is het noodzakelijk geworden om in de nieuwe wetgeving te kiezen voor een opener en veelzijdiger begrip. Daarom spreekt de wetgever thans ook over arbeidsvoorziening. Onder arbeidsbemiddeling werd enige tijd een tweezijdige activiteit verstaan, namelijk de dienstverlening aan zowel werkzoekenden als werkgevers, maar de nieuwe wet omvat zowel de een-als de tweezijdige dienstverlening op de arbeidsmarkt. Het begrip arbeidsvoorziening houdt ook in die zin een verruiming in dat er nu ook dienstverlening onder valt ten behoeve van het tot stand komen van arbeidsverhoudingen, die niet een arbeidsovereenkomst zijn, zoals freelance arbeid en thuisarbeid ${ }^{47}$. Ook de gecombineerde leer-en arbeidsovereenkomsten vallen eronder, alsmede het ter beschikking stellen van arbeidskrachten door uitzendbureaus en de gemeentelijke 'banenpools'.

45] Arbeidsvoorzieningswet, Tweede Kamer, Vergaderjaar 1989-1990, 20569, nr. 101.

${ }^{46}$ ] C.G.S.H. Janssen, M. Wegerif, 'De marktpositie van de openbare arbeidsbemiddeling': Economisch Statistische Berichten, 24 januari 1990, jaargang $75, \mathrm{nr} .3742$, blz. 87.

47] R. van Bekkum, 'Gemeenten en arbeidsvoorziening', in: Hondboek lokaol werkgelegenheidsbeleid; R. de Boer e.a. (red.), 's-Gravenhage, Vuga, 1988 e.v., A 3-I-5. 
De arbeidsvoorziening heeft zich ontwikkeld tot een zelfstandige bedrijfstak met een ruim aanbod. Hierin kan in grote lijnen een aantal fasen worden onderscheiden.

In de eerste fase aan het einde van de $19 \mathrm{e}$ eeuw, de periode waarin de sociale kwestie centraal staat, maakt de publieke arbeidsbemiddeling enerzijds nog deel uit van de werkloosheidsverzekeringen en anderzijds van de armenzorg. Deze arbeidsbemiddeling wordt grotendeels uitgevoerd door verenigingen ${ }^{48}$. Zo doen vakverenigingen vanaf hun ontstaan bijna allemaal aan arbeidsbemiddeling. Sommige vakverenigingen hebben eigen arbeidsbureaus opgericht. De Staatscommissie over de Werkloosheid telde in 1911 bijvoorbeeld 71 van dergelijke bureaus. Van werkgeverszijde bestaan er dan slechts 15 . Ook armbesturen en soortgelijke instellingen doen aan het einde van de $19 \mathrm{e}$ eeuw in toenemende mate aan arbeidsbemiddeling. Een nieuw soort verenigingen van armenzorg ontstaat onder invloed van een nieuwe categorie van grootstedelijke ondernemers. Zij willen zich richten op een meer progressief beheer van de armenzorg. Het huidige Amsterdamse arbeidsbureau is uit zo'n soort vereniging voortgekomen.

In de tweede fase, vooral kort na de Eerste Wereldoorlog, staat het begin van een verzoening van het werkgevers- en werknemersbelang centraal. De openbare arbeidsvoorziening wordt uit de sfeer van de sociale strijd en uit die van de armenzorg gehaald. Zij dient volgens de dan heersende opvatting neutraal en professioneel te worden verricht ${ }^{49}$. Het initiatief tot de openbare arbeidsbemiddeling wordt daarom in handen gelegd van een derde partij: de gemeentelijke overheid. Op die manier wil men voorkomen dat deze arbeidsvoorziening een onderdeel wordt van de strijd tussen arbeid en kapitaal en wil men een professionelere arbeidsbemiddeling bevorderen. Vanaf omstreeks 1915 vindt een snelle groei plaats van gemeentelijke arbeidsbeurzen, meestal in de vorm van een ambtelijke dienst, onder toezicht van werkgevers-en werknemersorganisaties en soms in die van een op een gemeentelijke concessie gebaseerde particuliere stichting, eveneens beheerd door werknemers en werkgevers.

De derde fase begint al voor de Tweede Wereldoorlog, als de arbeidsbemiddeling in feite wordt benaderd als een zelfstandig instrument van sociaal-economische beheersing ${ }^{50}$. Met name de economische crisis van de jaren ' 30 en de nieuwe opvattingen over de beheersing van economische crises vormen de achtergrond hiervan. De Tweede Wereldoorlog, wanneer de arbeidsbemiddeling wordt ingezet als middel voor de Duitse industriepolitiek, en vervolgens de betekenis van de arbeidsbemiddeling voor de wederopbouw, versterken de identiteit van de arbeidsvoorziening als onderdeel van de economische organisatie van het land. Het is de fase waarin de openbare arbeidsbemiddeling algemene erkenning heeft gekregen als een staatstaak en het staatsmonopolie op de arbeidsbemiddeling vrijwel volledig is. De daarbij behorende organisatorische vorm wordt die van een rijksbureau met daaronder gewestelijke diensten. De minister van Sociale Zaken is de eerst verantwoordelijke.

De vierde fase begint aan het einde van de jaren ' 60 . Het is de fase van de actieve, dienstverlenende overheid. De arbeidsvoorziening wil men dan opzetten vanuit een beleid van aanbod van verschillende soorten van openbare voorzieningen die te maken hebben met arbeidsbemiddeling. Dit wordt met name

48] B. Gewin, Arbeidsbeurzen; Utrecht, A.J. van Huffel, 1898, blz. 308-34l.

49] Staatscommissie over de werkloosheid, ingesteld bij KB van 30 juli 1909, nr. 42, Eindverslag; 's-Gravenhage. Algemeene Landsdrukkerij, 1914, blz. 597-687.

50] W.L.P.M. de Kort, De arbeidsbemiddeling in Nederlond, verhandeling naor oorzaken, ontwikkeling en behoeften; Alphen aan den Rijn, Samsom NV, 1940, blz. 333 e.v. 
duidelijk in het SER-advies uit 1973 over het Arbeidsbureau Nieuwe Stijl (ANS) ${ }^{51}$. De centrale gedachte van dit rapport komt er kort gezegd op neer dat de arbeidsvoorziening meer service-instituut in plaats van een bureaucratisch-administratieve voorziening moet worden. Na enige herzieningen en experimenten is het idee van het arbeidsbureau nieuwe stijl vanaf 1979 ingevoerd. Er komen dan nieuwe voorzieningen, zoals jobcentra, vacaturebanken, sollicitantenbanken, enzovoort. Het arbeidsbureau brengt bijzondere voorzieningen voor scholing tot stand en krijgt een vrij te besteden budget voor bijzondere regionale projecten. Voorts krijgt het de beschikking over een aantal plaatsings- en scholingsbevorderende instrumenten. Er wordt een vorm van organisatorisch en begrotingstechnisch zelfbeheer ingevoerd, maar de uiteindelijke financiële verantwoordelijkheid blijft bij het Rijk berusten.

Belangrijk voor de ontwikkeling in deze fase waren de inbreuken die vanaf het midden van de jaren ' 60 werden gemaakt op het beginsel van het monopolie van de arbeidsvoorziening dat was ingevoerd bij de Arbeidsbemiddelingswet van 1930. De eerste inbreuk op het monopolie werd gemaakt door de uitzendbureaus, die tijdens de krapte op de arbeidsmarkt in de jaren ' 60 ontstonden. Het monopolie werd verder aangetast door bepalingen in collectieve arbeidsovereenkomsten waarin sectorale arbeidsbemiddeling door werkgevers en werknemers gezamenlijk was vastgelegd (bijv. in de metaal en in de bouw).

De laatste fase treedt in aan het eind van de jaren ' 70 , als algemeen erkend wordt dat de arbeidsbemiddeling bestaat uit een groot aantal verschillende voorzieningen dat aan zijn oorspronkelijke monopolistische kader is ontgroeid. De openbare arbeidsbemiddeling uit de jaren ' 30 is een economische sector geworden van publieke en particuliere diensten. De wetgever wil deze verzelfstandigde maar op elkaar betrokken bureaus en diensten in één besturingssysteem brengen. De centrale uitgangspunten van dit systeem zijn dat arbeidsvoorziening als produkt behalve door arbeidsbureaus ook door vele anderen wordt geleverd, zoals bedrijven, bedrijfstakken en gemeenten, voorts dat mede op regionale schaal met deze anderen afspraken moeten worden gemaakt over de voorzieningen en de voorwaarden voor levering van die voorzieningen, en tenslotte dat de financiering door de staat wordt gegarandeerd. Door al deze kenmerken moet de wet vooral worden geïnterpreteerd als een geheel eigen vorm van functionele decentralisatie.

Bij de voorbereiding van het wetsontwerp is vaak gewezen op de gelijkenis van het nieuwe Nederlandse model met het $Z$ weedse publieke arbeidsvoorzieningssysteem. Die gelijkenis is ook groot, maar gaat niet veel verder dan die tussen de Nederlandse traditie van functionele decentralisatie en het Zweedse bestuurssysteem: een publiekrechtelijk systeem van besturen die zijn samengesteld uit vertegenwoordigers (in Zweden parlementaire vertegenwoordigers) van de Kroon en van organisaties van het bedrijfsleven. Het verschil is dat men in Nederland niet, en in Zweden wel, een grondwettelijk onderscheid kent tussen regering (collectief verantwoordelijk en belast met wetgevende activiteiten) en directeuren van diensten (individueel verantwoordelijk en belast met bedrijfsactiviteiten) ${ }^{52}$. De Zweedse regering mag zich op straffe van schending van de grondwet niet bemoeien met het beleid van de diensten. De rechterlijke controle op het functioneren van de diensten is daar essentieel. De diensten worden opgevat als overheidsbedrijven en vallen onder een strikt juridisch regime aangevuld met een regeling voor de openbaarheid en zorgvuldigheid (ombudsman). Het Zweedse systeem is kortom formalistisch en bedrijfsmatig van opzet en kent een principiële en institutioneel verankerde

51] Raad voor de Arbeidsmarkt, Advies inzoke het Arbeidsbureau Nieuwe Stijl; 's-Gravenhage, Sociaal-Economische Raad, 1971.

52] Neil Elder, Government in Sweden, The executive at work; Oxford, Pergamon Press, 1970, blz. 63-97; Nils Andrèn, Modern Swedish Government; Stockholm, Almquist and Wicksell, 1961, blz. 99-121. 
scheiding tussen regering en bedrijfsvoering. Het Nederlandse systeem kent die institutionele zuiverheid niet. De minister van Sociale Zaken is individueel verantwoordelijk en kan zich via zijn vertegenwoordigers in het CBA bemoeien met het beleid van de arbeidsvoorzieningsorganisatie, sterker nog: hij moet zich ermee bemoeien. Het Nederlandse systeem van de arbeidsvoorziening bevat het typisch Nederlandse compromis dat, waar publieke en particuliere belangen elkaar raken, het aan een samenwerkingsverband van beide belangen moet worden overgelaten om te komen tot gezamenlijke afspraken. Niet voor niets wordt de Arbeidsvoorzieningswet dan ook soms aangeduid als een contract tussen overheid en georganiseerd bedrijfsleven ${ }^{53}$.

$\mathrm{Na}$ de fasen van de sociale kwestie, met als organisatievorm de vereniging, vervolgens de verzoening van de sociale strijd met de professionele (gemeentelijke) arbeidsbeurzen, de nationale industriepolitiek met als organisatie de rijksdienst, en tenslotte het actieve aanbodbeleid van de verzorgingsstaat met vormen van zelfbeheer, is de arbeidsvoorziening nu in de nieuwe wet verankerd in een vorm van functionele decentralisatie van een geheel eigen soort. Door de arbeidersbeweging en door de nieuwe armenzorg is de moderne arbeidsbemiddeling aan het eind van de vorige eeuw tegen weerstanden in tot stand gebracht, door de gemeenten is zij vervolgens geprofessionaliseerd, door het Rijk is zij gemonopoliseerd, door de verzorgingsstaat is zij geactiveerd en door het Rijk en sociale partners samen wordt zij nu, via functionele decentralisatie sui generis, getripartiseerd en geregionaliseerd.

Tenslotte worden hieronder nog enkele aanvullende opmerkingen gemaakt.

Vanaf vrijwel de eerste fase zijn twee dominante functies onderscheiden aan de arbeidsbemiddeling. De bevordering van de doelmatigheid van de arbeidsmarkt, de economische functie en daarnaast een sociale functie. Zo moet de arbeidsvoorziening de werkloosheid bestrijden en tegengaan dat individuen en groepen die recht hebben op een zelfstandige inkomensverwerving, worden uitgesloten van de arbeidsmarkt of van delen hiervan. Op grond van de sociale functie moeten individuele werkgevers en werknemers op hun rechten en plichten worden gewezen en moeten soms ook sancties tegen hen worden toegepast, bijvoorbeeld in een geval van ongerechtvaardigd ontslag of als er sprake is van discriminatie. De beide functies van de arbeidsbemiddeling staan niet los van elkaar. Er moet voor worden gezorgd dat vraag en aanbod van arbeid met elkaar geconfronteerd worden. Tegelijkertijd moet erop worden gelet dat de partijen zich houden aan bepaalde regels en ook vanuit hun posities bijdragen leveren aan de bestrijding van de werkloosheid. Juist om die combinatie van de economische en sociale functie gaat het.

In de ons omringende landen wordt de arbeidsvoorziening momenteel gezien als een belangrijk onderdeel in het grootstedelijk beleid. Zo wordt in enkele Duitse steden een actief arbeidsmark tbeleid gevoerd, dat gericht is op het voorkomen van een groot circuit van werklozen ${ }^{54}$. Steden met weinig werklozen en derhalve ook weinig uitkeringen voor werkloosheid en sociale hulp, bezitten in de regel meer middelen om te zorgen voor gedifferentieerde voorzieningen voor beroepsscholing en voor werkervaring, dan steden met veel werklozen. In die steden wordt ook getracht een zodanige samenstelling van de werkgelegenheid tot stand te laten komen dat zij plaats biedt aan de verschillende categorieën van werknemers binnen de stad. Daartoe betreden die steden soms onorthodoxe paden, zoals het samen met particuliere investeerders bevorderen

53] Bijvoorbeeld door Ronald van Bekkum. 'Tweede Kamer aanvaardt Arbeidsvoorzieningswet', Sociaal Bestek; nr. 2, februari 1990, jrg. 52, blz. I7; F.H.A.M. Kruse. ‘.. de Arbeidsvoorzieningenwet belangrijker als uitdrukking van een gezamenlijke verantwoordelijkheid dan als instrument van regelgeving...: in: Resumee Symposium van Overheidsregulering naor zelfregulering; georganiseerd door SDU/PAO, 's-Gravenhage, 21 december 1988, blz. 2.

54] G. Morsinkhof, Arbeidsvoorzieningenbeleid in de BRD; Interne notitie; Rijksuniversiteit Utrecht, 1989. 
van experimentele werkgelegenheid, voortgekomen uit sociale en ecologische motieven. Het doel van die stedelijke bemoeienis is een negatieve spiraalvorming van toenemende werkloosheid, toenemende uitkeringen, toenemende begrotingstekorten en afnemende beleidsmogelijkheden tegen te gaan en het circuit van de bijstand zo beperkt mogelijk te houden.

Ook in Nederland is gedurende de afgelopen jaren veel aandacht gevraagd voor de arbeidsvoorziening in de grote steden. Zo zijn er plannen ontwikkeld voor gemeentelijke 'banenpools' en voor fondsen ter bestrijding van de werkloosheid in de Randstad. De Arbeidsvoorzieningswet biedt de kans aan de partijen in de grote stad - zowel overheid als bedrijfsleven - om het systeem waarin voorzieningen worden aangeboden, mede te besturen. Elke regio mag dit binnen centraal vastgestelde hoofdlijnen op haar eigen manier doen.

Of het ook lukt om binnen de grote steden de arbeidsmarktproblemen op te lossen, hangt echter niet alleen van de wet af. Juist een activiteit als bemiddeling is afhankelijk van vraag en aanbod. Wil de arbeidsvoorziening binnen de grote steden werken, dan moet er meer zijn dan het wettelijk systeem van de arbeidsvoorziening alleen en moet op stedelijk niveau ook een sociaal-economische infrastructuur bestaan waarin de arbeidsbemiddeling kan gedijen. De ontwikkeling hiervan is vooral een taak van de sociaal-economische partijen in de grote stad; de lokale werknemers- en werkgeversorganisaties en het stadsbestuur.

\subsubsection{Profiel van de stedelijke arbeidsmarkt}

De arbeidsmarkt is bij uitstek regionaal van aard, waarbij de grote steden enkele bijzondere kenmerken vertonen. Zo verandert de werkgelegenheid in de steden meestal eerder en intensiever dan op het platteland. Ontwikkelingen in de economie komen vaak het eerst aan het licht in de grote steden. Door de nauwe wederzijdse betrekkingen tussen de economische sectoren in de grote stad, hebben ontwikkelingen in de ene bedrijfssector bovendien directe gevolgen voor de andere bedrijfssectoren. Voor de arbeidsvoorziening in de grote steden houdt dit in dat ze vaak direct moet reageren bij de eerste tekenen van verandering in de economische structuur.

Tussen 1979 en 1989 is, zoals bekend, het percentage werklozen in de grote steden met sprongen gestegen, vooral door de herstructurering van de economie (zie hierover ook hoofdstuk 4). Zoals bekend doet de werkloosheid zich vooral voor onder allochtonen en onder laaggeschoolden, twee categorieën die in de grote steden zijn oververtegenwoordigd. Een stad als Rotterdam kampt ook met een aanzienlijke jeugdwerkloosheid. In de nabije toekomst zal dit iets afnemen, maar dezelfde personen blijven werkloos en keren nu terug als werklozen in een hogere leeftijdscategorie ${ }^{55}$. Hierdoor begint de werkloosheid nu te stijgen in de leeftijdscategorie 25 tot $\mathbf{4 0}$ jaar. Steden zoals Amsterdam en Utrecht, die veel hoger onderwijsinstellingen in hun bestuursgebied hebben, worden bovendien geconfronteerd met een aanzienlijke werkloosheid onder hoogopgeleiden (autochtonen èn allochtonen).

De grootstedelijke gebieden verschillen ook van het landelijk gebied, doordat zij regionale micro-kosmossen van de nationale arbeidsmarkt vormen. Vrijwel alle arbeidsmarktsectoren zijn vertegenwoordigd, zij het niet in elk gebied in dezelfde verhouding als nationaal. De meeste steden hebben in het laatste decennium veel industriële werkgelegenheid verloren en ook bij de bouw- en installatiebedrijven zijn veel arbeidsplaatsen verdwenen. Groei in de werkgelegenheid doet zich voor in de quartaire sector, bestaande uit overheidsdiensten en gepremieerde en gesubsidieerde dienstverlening. Ook de zakelijke

ss] W. Dercksen e.a., op. cit., blz. 74. 
dienstverlening en de bedrijfstak transport, opslag en communicatie, weet zich in de grote steden goed te handhaven. De arbeidsmarkt van de grote stad kent ook een grotere mate van specialisatie dan die van het platteland, doordat bepaalde ondersteunende activiteiten gemakkelijker afgestoten kunnen worden. Er zijn bijvoorbeeld gespecialiseerde voorzieningen voor onderwijs, accountancy, advocatuur, marketing, automatisering, catering, enzovoort. Telkens ontstaan weer nieuwe afsplitsingen en combinaties op de grensvlakken, bijvoorbeeld op dat tussen accountancy en advocatuur. De arbeidsbemiddeling in de grote steden zal dus altijd een grote verscheidenheid van bedrijfssectoren moeten bedienen en zich telkens moeten aanpassen aan de dynamiek van de bedrijvigheid.

De stad biedt vooral nieuwe werkgelegenheid aan hooggeschoolden, maar de arbeidskrachten in de meeste steden zijn overwegend laaggeschoold ${ }^{56}$. Hierdoor ontstaan grote discrepanties op de stedelijke arbeidsmarkt. Kenmerkend voor de grote steden is ook de hoge inkomende pendel van arbeidskrachten. In Utrecht is bijvoorbeeld de helft van de arbeidskrachten afkomstig van buiten de stad. Nadat in een aantal steden de bedrijvigheid is gaan groeien, ontstaat langzamerhand het inzicht dat de economische groei in de steden op langere termijn geremd zal worden door het te lage niveau van een groot deel van het arbeidsaanbod. De steden staan dus voor de opgave om ervoor te zorgen dat het arbeidsaanbod beter geschikt zal zijn voor de zich ontwikkelende werkgelegenheid, maar zij moeten er ook op letten dat in de stad plaats blijft voor laagwaardige werkgelegenheid, vooral in de oude wijken.

De gemeenten zijn zelf grote werkgevers en zij trachten een deel van de werkloosheid op te vangen via het eigen personeelsbeleid en via tewerkstelling binnen het, door de overheid gesubsidieerde, sociaal-cultureel werk ${ }^{57}$. Dit laatste hangt mede samen met het feit dat uitkeringen uitbetaald worden door de Gemeentelijke Sociale Dienst. De grote gemeenten hebben er daarom ook als eerste op aangedrongen de uitkeringen van de Gemeentelijke Sociale Dienst in te zetten voor creatie van werk in de collectieve sector, en vooral in de 'eigen' sfeer van collectieve dienstverlening. Ook langs de weg van overheidsopdrachten willen enkele grote gemeenten invloed uitoefenen op de arbeidsmarkt, bijvoorbeeld door aanbesteding van opdrachten voor bedrijvigheid in de eigen stad en door eisen te stellen aan het personeelsbeleid van de bedrijven waaraan opdrachten worden verleend, de zogeheten contract compliance.

Een groot deel van de langdurige werkloosheid - tot 40 procent - is geconcentreerd in de oude stadscentra. Deze wijken hebben meestal een eigen problematiek van openbare-ordehandhaving en van sociale controle in het algemeen. Veelal doen zich hier concentraties voor van 'beroepswerklozen', drop-outs en drugverslaafden. Men treft er echter meer nog groepen werklozen aan die in een recent onderzoek zijn getypeerd als ondernemenden en calculerenden ${ }^{58}$. Zij maken gebruik van de mogelijkheden van de informele economie en misbruiken het stelsel van sociale zekerheid. Er is daar een eigen informele economie ontstaan. Terwijl de werkgelegenheid in de stad toeneemt, stijgt tegelijkertijd de langdurige werkloosheid in de oude stadswijken. Een verklaring hiervoor is dat daar huizen beschikbaar zijn voor mensen met een laag inkomen, zoals een sociale uitkering. Een andere verklaring is de grotere mogelijkheid om anoniem te blijven. Tenslotte ontbreekt soms voldoende controle door de politie en andere overheidsdiensten (met name de Sociale Dienst).

56] Ibid., blz. |3-18.

$\left.{ }^{57}\right]$ Ibid., blz. 50, 51, 81, 82, 118, 119, 149, 150.

${ }^{58}$ ] H. Kroft e.a., Een tijd zonder werk, een onderzoek naar de levenswereld van langdurig werklozen; 's-Gravenhage, SDU uitgeverij, 1989. 
De grote steden kennen tenslotte buurten met een relatief homogene samenstelling, die men vroeger bijvoorbeeld middenstandswijken noemde. Hier kunnen andere typen van langdurig werklozen oververtegenwoordigd zijn, in het voornoemde onderzoek aangeduid als conformisten, ritualisten en retraitisten. Zij maken niet of nauwelijks misbruik van de sociale voorzieningen. De mate waarin zij nog hoop hebben op de arbeidsmarkt terug te keren verschilt, conformisten hebben nog hoop, retraitisten hebben alle hoop opgegeven.

Uit de opsomming wordt duidelijk dat er niet één type langdurig werkloze is. De stedelijke arbeidsvoorziening zal dan ook moeten zijn afgestemd op die spreiding van verschillende soorten van langdurig werklozen over verschillende wijken, wil ze successen boeken.

\subsubsection{Arbeidsvoorzieningsaanbod}

De openbare arbeidsvoorziening beschikt inmiddels over een ruim assortiment aan diensten en middelen om de strijd aan te binden tegen de bovengenoemde eenzijdigheden in de stedelijke arbeidsmarkt. Zo bieden de arbeidsbureaus veel soorten van bemiddelende diensten aan (via vacaturebanken; sollicitantenbanken; jobcentra; afdelingen voor beroepskeuze-advisering; afdelingen die speciaal bemiddelen voor bepaalde sectoren van de arbeidsmarkt; en is er het publieke uitzendbureau START). Deze middelen worden in de regel kosteloos verstrekt en staan voor iedereen open.

De arbeidsvoorziening heeft naast dienstverlenende middelen ook juridische middelen ter beschikking, gericht op de handhaving van de sociale-verzekeringswetten. Zo moet een werkloze zich laten inschrijven bij het gewestelijk arbeidsbureau. Gebeurt dit niet, dan zal dit leiden tot een sanctie op basis van artikel 26 van de werkloosheidswet (NWW). De directeur van het arbeidsbureau heeft ook de plicht de uitkerende instanties, zoals de bedrijfsvereniging of de gemeente, uit eigen beweging in kennis te stellen van een vermoeden van verwijtbare werkloosheid, dat wil zeggen werkloosheid die niet-onvrijwillig is ${ }^{59}$. Bovendien mag een directeur van een arbeidsbureau maatregelen tegen een werkloze laten nemen als deze onvoldoende meewerkt aan GAB-activiteiten. Tenslotte is nog een onderdeel van het arbeidsrecht gekoppeld aan de arbeidsbemiddeling. Zo geeft de directeur van het arbeidsbureau ontslagvergunningen af.

Behalve soorten van diensten en juridische middelen kent de arbeidsvoorziening ook allerlei middelen die haar makelaarsfunctie ondersteunen. Zo kan zij werkzoekenden cursussen aanbieden voor bijvoorbeeld beroepsgerichte volwasseneneducatie en voor beroepsoriëntatie en -uitoefening. Allochtonen kunnen geholpen worden door het aanbieden van een cursus Nederlands. Voor diegenen die al bepaalde kwalificaties hebben, staan soms nog voorzieningen open van het leerlingwezen en de Centra Vakopleiding. Naast deze onderwijsen scholingsvoorzieningen zijn er ondersteunende middelen, gericht op de bevordering van werkervaring en arbeidsinpassing. Hiertoe behoren het Jeugdwerkgarantieplan, de Werkgelegenheidsverruimende Maatregel, de Kaderregeling Arbeidsinpassing, en de Banenpools.

De arbeidsvoorziening kent een groot aantal methoden van bemiddeling in ruime en enge zin. Bij de bemiddeling in ruime zin gaat het om uitzendarbeid, outplacement, headhunting, en poolen van banen voor werklozen; dit laatste gebeurt bijvoorbeeld door stichtingen, waaraan door de gemeente en anderen opdrachten kunnen worden verleend. Ook experimenteert een enkel arbeidsbureau met nieuwe methoden van personeelsvoorziening voor bedrijven die zelf geen personeelsdienst hebben, zoals veelal in het midden- en kleinbedrijf.

${ }^{59}$ ] Kluwer Schets van het sociaal zekerheidsrecht; Jaspers en Riphagen (red.), Deventer, Kluwer, 1987, blz. 117. 
Bij de arbeidsbemiddeling in enge zin - het zogeheten tweezijdige bemiddelen - zijn methodes van 'doe-het-zelf' bemiddeling ontstaan (bijv. het computernetwerk Job-link). Ook hebben de arbeidsbureaus in 1989 intensief gewerkt met de methode van heroriënteringsgesprekken (zie hierover ook par. 4.4) en wordt sinds kort in een aantal stadswijken de maatwerkmethode beproefd, waarbij de bemiddelaar tracht een vertrouwenspositie op te bouwen ten opzichte van individuele vragers en aanbieders van arbeid.

De bevoegdheid middelen toe te wijzen, berust in de regel bij het arbeidsbureau. Toch heeft het Rijk steeds meer uitzonderingen op deze regel gemaakt. Zo worden voorzieningen voor de primaire beroepsgerichte volwasseneneducatie (PBVE) vaak toebedeeld vanuit coördinatiepunten van het GAB en het ministerie van Onderwijs en Wetenschappen gezamenlijk. Middelen op grond van artikel 36 van de Wet werkloosheidsvoorzieningen (WWV) worden verstrekt door de gemeenten. Voorzieningen voor beeldend kunstenaars kunnen verstrekt worden door de Gemeentelijke Sociale Diensten. Kosteloze beroepskeuze-advisering kan men verkrijgen van zelfstandig dienstencentra. Middelen die ertoe moeten bijdragen dat langdurig werklozen weer in dienst treden, mogen ook worden gehanteerd door het uitzendbureau START en sinds kort in een enkel geval door particulier uitzendbureaus.

De arbeidsvoorziening wordt hoofdzakelijk gefinancierd uit de begroting van Sociale Zaken en Werkgelegenheid. Toch is ook hier sprake van een toenemende verscheidenheid. Banenpools en werkervaringsplaatsen moeten ten dele bekostigd worden uit de sociale-verzekeringsfondsen. Plaatsingsbevorderende voorzieningen die bestaan uit onderwijs en scholing, worden ten dele of geheel vergoed uit de begroting van Onderwijs en Wetenschappen. Verder worden middelen verkregen uit het Europees Sociaal Fonds, uit de fondsen ter bevordering van arbeidsmobiliteit en scholing van bepaalde bedrijfstakken, en zijn er mogelijkheden om werkloosheid te bestrijden met middelen uit liefdadigheidsfondsen, zoals het Koningin Julianafonds (KJF). Voorts zijn er de integrale financieringen uit meer begrotingen tegelijkertijd, zoals de Probleem Cumulatie Gebiedenregeling (onder andere de begroting van Binnenlandse Zaken). Het arbeidsbureau beschikt sinds kort over de bevoegdheid voor bepaalde aanvullende vormen van dienstverlening een vergoeding te vragen. In principe maakt de Arbeidsvoorzieningswet het mogelijk geldelijke bijdragen te verkrijgen van werkgevers en werknemers (toeslag op de premie werkloosheidswet) en retributies.

\subsubsection{Beleidsopgaven}

Hoewel het aanbod van voorzieningen van de arbeidsbemiddeling groot en gevarieerd is, blijkt de arbeidsvoorziening in de stedelijke omgeving niet zo te gedijen als men op grond van deze gegevens zou mogen verwachten. Zo moest in 1988 al worden geconstateerd dat de Maatregel Langdurig Werklozen door lang niet zoveel werklozen werd gebruikt als was verwacht. Hoewel al meteen duidelijk was dat het doel niet gehaald kon worden, viel het resultaat van 8.000 deelnemers in 1988 tegen ${ }^{60} \mathrm{Nu}$ is dit al een hoog getal als men het plaatst naast het aantal deelnemers aan allerlei andere voorzieningen, bijvoorbeeld de primaire beroepsgerichte volwasseneneducatie. Uit de eerder vermelde studie naar de werk loosheidsbestrijding in de grote steden, blijkt dat het bij veel van die voorzieningen gaat om slechts enkele honderden deelnemers ${ }^{61}$.

Kenmerkend voor de arbeidsbemiddeling is dat het maatwerk is. Elke vrager en elke aanbieder heeft zijn eigen kenmerken. Geconstateerd moet echter

${ }^{60}$ ] C. den Ouden, 'Voorzieningen voor werklozen', in: Handboek lokaal werkgelegenheidsbeleid (op. cit.), blz. A4-I-3I.

6'] W. Dercksen e.a., op. cit. 
worden dat het maatwerk op de arbeidsmarkt van de grote steden nog grotendeels op gang moet komen ${ }^{62}$.

Hiervoor zijn zeker ook oorzaken aan te wijzen zoals een bureaucratische attitude bij verschillende soorten van uitvoerders van het beleid ter bestrijding van de werkloosheid, een in zijn eigen personeelsontwikkeling te veel geremd arbeidsbureau, en onvoldoende toepassing van sancties bij misbruik van sociale voorzieningen. Maar daarnaast zoekt de raad in lijn met het centrale uitgangspunt van dit rapport de oorzaak in de neiging tot verzelfstandiging van de arbeidsbemiddeling in een omvattende beleidsstructuur, met uitgebreide voorbereidingsprocedures gericht op een grote mate van beleidszekerheid vooraf en achteraf, en in de factoren die het ontstaan van een dergelijke beleidsstructuur begunstigen.

Bij de neiging tot verzelfstandiging is het goed te bedenken dat de arbeidsbemiddeling alleen al door de aard van haar rol telkens het gevaar loopt dat zij buiten spel komt te staan. Als bemiddelaar is de arbeidsvoorziening de derde partij, de vragers en aanbieders van arbeid bepalen uiteindelijk zelf of zij een relatie aangaan en of er een arbeidscontract ontstaat.

De eerste begunstigende factor voor de neiging tot verzelfstandiging is de concentratie van beleidsaandacht voor de arbeidsvoorzieningsmaatregelen op het gebied van arbeidsinpassing, scholing en dergelijke. Dit soort maatregelen moet helpen om mogelijke weerstanden bij de ontmoeting tussen vraag en aanbod te overwinnen en is in dit opzicht ook belangrijk. Aan de werkgever kunnen bijvoorbeeld bepaalde subsidies worden gegeven, als deze een langdurig werkloze in dienst neemt. Aan werknemers kan scholing worden aangeboden, waardoor deze wellicht hun kans op het verkrijgen van een baan vergroten. Het zijn allemaal facilitaire instrumenten voor de arbeidsbemiddeling. Door een eenzijdige bestuurlijke aandacht voor de faciliteiten voor de bemiddeling ontstaat het gevaar dat deze hulpmiddelen - om zo te zeggen het 'handgeld' van de arbeidsbemiddeling - als het wezen van de arbeidsbemiddeling worden gezien.

Een tweede factor ligt in de lokale institutionele setting die onvoldoende noodzaak biedt voor de arbeidsbemiddeling om zich in haar meest wezenlijke taak, bemiddeling, te bewijzen. Zo is er in de steden een bestuurlijk vacuüm tussen het sociaal beleid enerzijds en het economische beleid anderzijds. Rechtstreekse confrontaties tussen beide blijven nog steeds grotendeels uit. Pas als binnen de grote stad de sociale sector de economische kan aanspreken voor de oplossing van zijn problemen, en omgekeerd, wordt arbeidsbemiddeling een doorslaggevende schakel in dit geheel.

De laatste factor is dat de arbeidsbemiddeling in de grote steden in de loop van haar geschiedenis steeds meer afhankelijk is geraakt van de omvang van de rijksmaatregelen en van het geld dat hiervoor wordt vrijgemaakt op centraal niveau. Men zou kunnen zeggen dat in de loop van de tijd het aantal financiële prikkels is verminderd die ertoe moeten bijdragen dat het arbeidsbureau zich primair toelegt op de mogelijke vraag om bemiddeling vanuit de stedelijke praktijk. Een van de mogelijke sleutels voor de verdeling door het CBA van de gelden over de arbeidsbureaus in de nieuwe wet op de arbeidsvoorziening is het aantal werklozen dat bij het arbeidsbureau staat ingeschreven. Hoe meer werklozen bij een arbeidsbureau staan ingeschreven, hoe ongunstiger hun situatie, des te meer middelen krijgt het op grond van deze verdeelsleutel. De toepassing van die sleutel houdt het gevaar in dat de grootstedelijke arbeidsvoorziening zich niet primair richt op een bijdrage tot versterking van het sociaal-economisch draagvlak van de stad.

${ }^{62}$ ] Inleidingen en perscommentaren; Symposium "Werk dat past"; 15 maart 1990, Helmond, gemeente Helmond, 1990. 
De Arbeidsvoorzieningswet behoeft niet per se te worden gewijzigd om de genoemde factoren weg te nemen. Zo biedt de wet in principe de ruimte om binnen landelijke kaders op regionaal niveau een beleid te voeren tot het instellen van eigen retributies. Of men in de beleidsaandacht de methode van bemiddeling weer centraal stelt in plaats van de ondersteunende instrumenten ten behoeve van de bemiddeling, hangt uiteindelijk niet af van de wet, maar van de houding van de partijen die haar toepassen. En tenslotte ligt het antwoord op de vraag of het institutionele vacuüm in het sociaal en economisch systeem van de stad wordt weggenomen, bij de actoren in de stad zelf.

Men zou kunnen tegenwerpen dat de neiging tot verzelfstandiging effectief wordt bestreden door de tripartisering van de arbeidsvoorziening, waardoor de partijen die de arbeidsmarkt bepalen, zelf zitting hebben in de RBA's. De tripartisering van arbeidsvoorziening bevat door haar decentrale uitwerking zeker een groot aantal voorwaarden voor een betere aansluiting van het aanbod van voorzieningen aan de situatie van de lokale arbeidsmarkt, maar het feit blijft dat de deelnemende partijen wel dezelfde kunnen zijn, maar hun positie niet per se. Een werkgever kan als lid van een RBA meehelpen een bepaalde voorziening tot stand te brengen. Dit houdt echter niet in dat dezelfde werkgever, maar nu in de rol van aanbieder van arbeid, ook van die voorziening gebruik zal maken. De context van de aanbieders van bemiddelingsdiensten verschilt wezenlijk met die van de concrete confrontatie tussen vragers en aanbieders van arbeid.

Men zou ook kunnen opperen dat een simpele manier om het aanbod van bemiddeling te binden aan het handelen van de partijen op de arbeidsmarkt, de wettelijke verplichting zou zijn voor zowel vragers als aanbieders van arbeid om zich te laten inschrijven bij het arbeidsbureau. Zolang de arbeidsbemiddeling bestaat, zijn dergelijke ideeën geopperd, maar ze zijn uiteindelijk nooit in de praktijk gebracht, mede omdat arbeidsbureaus op deze manier zouden verworden tot registratiekantoren.

Er zijn gegeven de uitgangspunten van dit rapport echter ook andere manieren te bedenken om de arbeidsbemiddeling in de grote steden beter te laten functioneren.

Zo valt te overwegen om op lokaal niveau de ruimte te benutten die wordt geboden door de sociale akkoorden tussen regering en sociale partners. Deze ontwikkelen zich steeds meer tot beleidskaders, dat wil zeggen een geheel van beginseluitspraken en algemene normen. Bij een beleidskader gaat men ervan uit dat de eigenlijke afspraken tussen werkgevers en werknemers tot stand komen in een systeem van bedrijfstakgewijze cao's. In een aantal landen bestaan echter ook regionale en grootstedelijke cao's, al dan niet onderverdeeld naar bedrijfstak. Aan deze mogelijkheid zou juist voor de grote steden in ons land meer aandacht moeten worden geschonken.

Ook zou het bestuur van de grote steden zich meer dienen te profileren in het arbeidsmarktbeleid en daarbij de beleidsconcurrentie moeten aangaan met andere steden en met hun eigen omliggend gebied. Een belangrijk onderdeel van het arbeidsmarktbeleid is het gebruik van de arbeidsbemiddeling. Het staat gemeenten in principe vrij om gebruik te maken van arbeidsbureaus in andere regio's. Als een arbeidsbureau van een andere regio voor een bepaald deel van de stedelijke bevolking beter is toegerust dan het 'eigen' arbeidsbureau, moet de betreffende gemeente het arbeidsbureau van de andere regio ook feitelijk kunnen benutten.

Het bestuur van de grote steden zou vervolgens het institutionele vacuüm tussen sociaal beleid (GSD) en economisch beleid (vestigingsbeleid en produktiemilieubeleid) moeten opvullen met een eigen sociaal-economisch beleid en dat laten doorspelen in de openbare arbeidsvoorziening door haar participatie aan 
het RBA. Het stadsbestuur zou hierbij vaste procedures van advies en overleg moeten afspreken met de belangrijkste organisaties van werkgevers en werknemers in de grote stad. De samenstelling van een stedelijk overlegorgaan voor sociaal-economisch beleid dient te zijn afgestemd op de karakteristiek van de economie van de betreffende stad. De steden maken daarbij zelf uit welke organisaties zij voor de werkgevers en werknemers in de stad representatief achten.

De individuele bemiddeling, waarbij getracht wordt tegelijkertijd het vertrouwen te winnen van zowel een vrager als een aanbieder van arbeid, zou bovendien veel prioriteit moeten krijgen. De (Helmondse) maatwerkmethode blijkt goed te werken en kan ook door de arbeidsbureaus in de grote steden worden toegepast. De uitvoering van andere activiteiten van het arbeidsbureau, zoals scholingsprojecten, poolprojecten, en dergelijke dienen organisatorisch zoveel mogelijk te worden onderscheiden van het maatwerk als individuele en tweezijdige bemiddeling. Dat wordt vergemakkelijkt als aan de andere activiteiten meer ruimte wordt gegeven voor verdere specialisatie en verzelfstandiging (bijv. in stichtingen).

De openbare arbeidsvoorziening in de grote steden zou verder meer gebruik moeten gaan maken van de diensten van het bedrijfsleven en de uitzendbureaus in de grote stad. Zo zouden RBA's in grootstedelijke gebieden de mogelijkheid kunnen onderzoeken om bevoegdheden tot het toewijzen van arbeidsvoorzieningsmiddelen te delegeren aan personeelsdiensten van bedrijven, bedrijfstakken of overheid. Het RBA stelt hierbij enkele basiscondities vast en legt zich voorts toe op tussentijdse controles, waarbij het zich het recht voorbehoudt om de delegatie te beëindigen op het moment dat het zijn vertrouwen verliest in de desbetreffende personeelsdienst. Door meer gebruik te gaan maken van de mogelijkheden van de particuliere uitzendbureaus doet de arbeidsvoorzieningsorganisatie zichzelf bovendien bewust concurrentie aan. Het is ook een goede methode om voeling te houden met een deel van de praktijken van de arbeidsmarkt, waarmee men anders niet zo gauw geconfronteerd wordt. Ook vanuit scholingsoogpunt is de markt van uitzendbureaus en van andere intermediërende instellingen (bijv. particuliere en publieke scholingsinstellingen) van veel belang. Als de openbare arbeidsvoorziening deze bureaus en (scholings)instellingen (meer) laat meedoen in bijvoorbeeld scholingsprojecten, ligt het voor de hand onderling kwaliteitsgaranties af te spreken en te verzekeren door middel van een code en keurmerk voor deze 'subcontracting'.

Tenslotte zou een intensiever gebruik moeten worden gemaakt van de mogelijkheden van terugkoppeling via beroeps- en ombudsmanprocedure. Tegen de concrete besluiten tot vergunningverlening is beroep mogelijk bij het College van Beroep voor het Bedrijfsleven. Op die manier heeft de wetgever een voorwaarde geschapen voor een confrontatie tussen het CBA en de markt van (particuliere) arbeidsvoorzieningsdiensten; iets dat ook van veel belang is, omdat het CBA zelf een medespeler is op die markt. Deze beroepsmogelijkheid bestaat niet ten aanzien van de bevoegdheid van het CBA om via regelgeving de condities vast te stellen waaronder vergunningen worden verstrekt en instanties aan de uitvoering van de arbeidsvoorziening kunnen deelnemen. Overigens zou men idealiter deze regelgevende bevoegdheid moeten leggen in de handen van een derde en onafhankelijke partij, bijvoorbeeld een regionale overheid. Maar er zijn geen politieke organen op het niveau van de RBAregio's, zodat deze bevoegdheid ook niet daaraan kan worden opgedragen. Dan blijft de mogelijkheid over deze bevoegdheid terug te geven aan het Rijk. Het is echter uit het politieke debat over deze bevoegdheid duidelijk geworden dat de wetgever de Arbeidsvoorzieningswet hiervoor juist niet bedoeld heeft. De enige mogelijkheid die dan nog open blijft, is om in de praktijk via de procedure van beroep tegen een concreet besluit ook de regels te laten toetsen waar dit besluit op is gebaseerd. De Arbeidsvoorzieningswet bevat bovendien centrale 
uitgangspunten die de rechter een houvast geven bij die toetsing. Hierop sluit ook de aanbeveling aan om de arbeidsvoorziening meer te confronteren met ervaringen die cliënten opdoen bij de bemiddeling door de arbeidsvoorzieningsorganisatie. De regionale besturen zouden het mogelijk moeten maken dat burgers zich met klachten over de kosteloze arbeidsbemiddeling kunnen wenden tot een gemeentelijke ombudsman of een soortgelijke regionale instantie.

Om, en dit als afrondende opmerking, te voorkomen dat individuele werknemers en werkgevers in de toenemende complexiteit van voorzieningen van het kastje naar de muur worden gestuurd, zou er in elke grote stad een centraal punt moeten komen waar informatie beschikbaar is over de aanwezige voorzieningen en uitvoerende instanties voor bemiddeling, scholing, enzovoort. In overleg tussen het RBA en de stad moet worden bepaald of men deze taak in handen legt van een onafhankelijk bureau van het RBA of van de gemeente.

\subsection{Gezondheid en maatschappelijke dienstverlening ${ }^{63}$}

\subsection{Stelselherziening}

Het ideaal van een 'gezonde stad' roept meer associaties op met de vitaliteit van de stedelijke economie dan met de lichamelijke of geestelijke toestand van de stedelijke bevolking. Weliswaar is het belang van gezondheid duidelijk voor iedereen, maar de bijzondere samenhang met het verschijnsel stad wordt nog wel eens onderschat, al groeit binnen de gezondheidssector recentelijk wel de aandacht voor de invloed van gezondheidsbevorderende omgevingscondities en sociale variabelen, zoals leefstijlen of voedingsgewoonten. Een belangrijke exponent van deze ontwikkeling is het gezondheidsbeleid van de Wereldgezondheidsorganisatie, dat op het niveau van de grootstedelijke gebieden een bijzondere uitwerking heeft gekregen in een internationaal netwerk van 'healthy cities'. De voorliggende tekst zoekt aansluiting bij deze initiatieven.

Het gezondheidsbeleid kan globaal worden onderscheiden in drie brede gebieden. Het betreft:

- de bevordering van de gezondheid (vooral via de preventieve zorg);

- de medische behandeling en genezing (de curatieve zorg);

- de verpleging en verzorging (de 'care', vooral via het beleid inzake de maatschappelijke dienstverlening).

Wat betreft deze drie onderdelen, ligt het zwaartepunt vanaf het begin van de eeuw bij de curatieve zorg. De moderne gezondheidszorg heeft zich in grote lijnen ontwikkeld vanuit de dominante positie van de artsen en de ziekenhuizen in de steden. De activiteiten ter bevordering van de gezondheid zijn overwegend gekanaliseerd in organisaties voor de preventieve zorg. De verzorging en verpleging heeft via de wereld van de instellingen en in de periode na de oorlog vooral ook via de overheid een eigen ontwikkeling doorgemaakt van 'mantelzorg' naar een professioneel georganiseerde dienstverlening. Veelal lag deze dienstverlening in het verlengde van de curatieve zorg. De overheersende aandacht voor de curatieve zorg begint nu geleidelijk af te nemen. Naast de recente profilering van de gezondheidsbevordering is vooral ook van belang dat de verpleging en verzorging voor langere duur meer aparte aandacht vragen, niet in de laatste plaats tegen de maatschappelijke achtergrond van de toenemende vergrijzing van de bevolking. Tegelijkertijd doet zich binnen de curatieve zorg de ontwikkeling voor naar kortere opnameduur, dagbehandeling en poliklinische behandeling. De ziekenhuizen ontwikkelen zich steeds meer tot centra van poliklinische zorg, terwijl hun oorspronkelijke verpleegtaken afnemen in

${ }^{63}$ ] In deze paragraaf wordt veelvuldig gerefereerd aan de voorstudie die in het kader van het stadsproject in opdracht van de WRR is verricht: H.F.L. Garretsen en H. Raat, Gezondheid in de vier grote steden; Voorstudies en achtergronden V65, 's-Gravenhage, SDU uitgeverij, 1989. 
betekenis. De bevordering van de thuiszorg speelt steeds meer in op de behoefte om de voor-en nabehandeling en meer in het algemeen de verzorging in de eigen omgeving te laten plaatsvinden. Tenslotte wordt de substitutie van medische zorg bevorderd door overwegingen van kostenbeheersing.

Het grootstedelijk gezondheidsbeleid zal op de bovengenoemde ontwikkelingen moeten inspelen. De centrale vraag van de voorliggende analyse is of de institutionele context waarin het gezondheidsbeleid tot stand komt, voldoende mogelijkheden biedt om op stedelijk niveau een eigen profiel te ontwikkelen. Deze vraag is des te dwingender nu als gevolg van structurele veranderingen in het systeem en de financiering van het gezondheidsbeleid op nationaal niveau ook het grootstedelijk beleid tot een aanzienlijke koerswijziging wordt gedwongen.

In het perspectief van dit rapport wordt de stelselherziening in de gezondheidszorg in beginsel als zeer kansrijk beschouwd voor een versterking van de grootstedelijke beleidsontwikkeling. Vanuit de hier gebezigde optiek komt voor het gehele voorzieningenbeleid in beginsel het uitgangspunt te liggen bij een directe afstemming tussen gebruikers en aanbieders van voorzieningen, waarbij de overheid een ordenende en zonodig bijsturende rol op zich neemt. De primaire coördinatie van het gezondheidsbeleid door ter plaatse opererende, maatschappelijke organisaties maakt op lokaal niveau nieuwe beleidscompetenties vrij bij partijen die voorheen in vrijwel alle opzichten aan centrale voorwaarden waren gebonden. Vanuit het oogpunt van een grootstedelijk beleid komen echter wel diverse achtergronden naar voren die nadere overweging nodig maken. De kernvraag in de analyse van het gezondheidsbeleid is dan ook welke aanvullingen op de stelselherziening nodig zijn om optimale kansen te creëren voor een grootstedelijk gezondheidsbeleid.

\subsubsection{Gezondheidsprofiel van de stedelijke bevolking}

Hoewel de gezondheidstoestand van de stedelijke bevolking veel overeenkomsten vertoont met de gemiddelde gezondheidssituatie in het land, zijn er toch ook opmerkelijke verschillen. Hiervoor zijn enige algemene oorzaken aanwijsbaar.

Het betreft in de eerste plaats de diverse bijzonderheden van de stadscultuur en de leefstijlen van de bevolkingsgroepen die het stedelijk leven niet alleen verrijken, maar die voor de gezondheid ook bijzondere risico's met zich meebrengen. De steden zijn ontmoetingsplaatsen voor verschillende culturen en leefstijlen, met hierbij behorende bijzondere aanpassingsproblemen en gezondheidsrisico's. Zo zijn diverse vormen van de jeugdproblematiek geconcentreerd in het stedelijk milieu. Voor anderen is juist het probleem dat het geïndividualiseerde stadsmilieu het maatschappelijk isolement versterkt.

In de tweede plaats wordt het gezondheidsprofiel van de stedelijke bevolking sterk gekleurd door demografische ontwikkelingen. In de vier grote steden is het aantal bejaarden $(65+)$ en vooral ook het aantal hoogbejaarden $(80+)$ oververtegenwoordigd; met name Den Haag steekt ver uit boven het landelijk gemiddelde, Amsterdam daarentegen zit daar niet meer zo ver boven. Voorts zijn er meer twintigers in de steden, terwijl de jongeren (20 -) juist ondervertegenwoordigd zijn. En tenslotte tellen de steden in verhouding tot het landelijke gemiddelde veel éénoudergezinnen en veel alleenstaanden.

In de derde plaats bestaat er een samenhang tussen sociaal-economische status en de mate van gezondheid ${ }^{64}$. De in de steden oververtegenwoordigde groepen

64] De ongelijke verdeling van gezondheid, Verslag van een conferentie gehouden op 16-17 maart 1987, Voorstudies en achtergronden V58, WRR, 's-Gravenhage, Staatsuitgeverij, 1987. 
met de laagste inkomens, opleidingen en beroepen zijn er ook qua gezondheid het slechtst aan toe. Deze ongelijkheidsfactor versterkt de bovengenoemde factoren. In Amsterdam en Rotterdam worden - mede in aansluiting op de eerder genoemde initiatieven van de Wereldgezondheidsorganisatie- sinds kort systematische onderzoekingen op buurtniveau verricht. Hieruit komen alarmerende gegevens naar voren over de verschillen in gezondheid tussen buurten, die blijkens de mortaliteitsstatistieken zelfs tot grote verschillen in levensverwachting blijken te leiden (de verschillen tussen buurten blijken ceteris paribus tot 5 jaar op te lopen). Uit analyses op buurtniveau in Rotterdam bleek dat vooral in de oudere centrumbuurten de sterftekans significant groter is dan gemiddeld in Rotterdam; dit geldt zowel voor de totale sterfte als voor specifieke doodsoorzaken als kanker en hart- en vaatziekten ${ }^{65}$.

De vele plaatselijke bijzonderheden dragen ertoe bij dat voor de aanzienlijke lokale verschillen in gebruik van gezondheidsvoorzieningen tot dusverre geen sluitende verklaringen zijn gevonden. Hier wreekt zich dat de beschikbaarheid van gegevens over de gezondheidssituatie op dit schaalniveau in menig opzicht tekort schiet. Een adequaat informatiesysteem is voor de stedelijke overheid van elementaire belang om de verschuivingen en problemen van de lokale gezondheidssituatie te kunnen signaleren en om op grond hiervan het gedrag van de andere betrokken partijen te kunnen beïnvloeden. In de ten behoeve van dit rapport gemaakte studie 'Gezondheid in de vier grote steden' worden diverse aanbevelingen gedaan om het informatiegehalte van het stedelijk kennisbestand te verhogen ${ }^{66}$.

In het voorgaande zijn drie algemene achtergronden geschetst voor de bijzonderheden in het gezondheidsprofiel van de stedelijke bevolking. Het is mede tegen de achtergrond van deze oorzaken dat het gebruik van medische voorzieningen en maatschappelijke dienstverlening in de grote steden - met een uitschieter voor Amsterdam en omgeving - ruim boven het landelijk gemiddelde ligt ${ }^{67}$. Ook wanneer rekening wordt gehouden met de specifieke bevolkingssamenstelling van de grote steden blijken de inwoners een ander consumptiepatroon te hebben dan die in de rest van Nederland.

Voorts vervullen veel voorzieningen in de grote steden een uitgesproken functie ten behoeve van de bevolking in de regio of in de provincie. Voor hooggespecialiseerde voorzieningen is zelfs sprake van een landelijke functie. Ook met deze bijzonderheid zal in het nieuwe stelsel rekening moeten worden gehouden.

\subsubsection{Globale typering van het voorzieningenaanbod}

Het volume van de zorgvoorzieningen in de grote steden staat in het algemeen op een hoog niveau. Gerelateerd aan het specifieke profiel van de bevolking is echter niet zonder meer sprake van een doelmatige voorzieningenstructuur. Dit wordt versterkt door het gegeven dat een aantal voorzieningen niet zozeer een functie heeft op het grootstedelijke schaalniveau, maar ook of veeleer op bovenlokaal niveau of op stadsdeelniveau.

${ }^{65}$ ] Buurtonderzoek in Amsterdam (GGD) en Rotterdam (REBUS). Zie: J.A.M. van Oers en J.H.M. Teeuwen, Sterfe en sociaal-economische status in Rotterdam; GGD Rotterdam e.0., rapport nr. 66, januari 1990, blz. 72-73.

${ }^{66}$ ] H.F.L. Garretsen en H. Raat, op. cit., blz. 214-219.

${ }^{67}$ ] In een onderzoek van het Instituut voor Onderzoek van Overheidsuitgaven worden verschillende kostenfactoren onderzocht. Naast enkele kenmerken van de bevolking is het bovenregionale karakter van de gespecialiseerde voorzieningen van invloed op het consumptieniveau. Voorts wordt gewezen op de verschillende regionale kosten van de accommodaties en op de wijze van afschrijving. Daarnaast zijn er nog veel witte plekken die door nader onderzoek verklaard moeten worden. Zie R. Gerritse, R.T.J.D. Janssen en J.D. Poelert, Noor een verdeelstelsel voor de centrole kas: verslog van een vooronderzoek; memorandum nr. 27; 's-Gravenhage, Instituut voor Onderzoek van Overheidsuitgaven (100), 1989. 
Op het vlak van de preventieve zorg (m.n. in de gezondheidszorg via basisgezondheidsdiensten, consultatiebureaus voor zuigelingen, bedrijfsgeneeskundige diensten enz.) hebben de steden van oudsher een voortrekkersrol. De basisgezondheidsdiensten van de grote steden hebben een aanzienlijk grotere omvang en een breder takenpakket dan de gezondheidsdiensten in de rest van het land. De effectiviteit van de preventieve zorg is moeilijk te beoordelen, omdat de diensten in het algemeen worden aangeboden zonder zekerheid of, en zo ja door wie, zij zullen worden afgenomen. Een eventuele verbetering in de gezondheidssituatie in de steden kan niet zonder meer worden gekoppeld aan preventieve programma's. Om toch adequaat te kunnen inspelen op de daadwerkelijke gezondheidssituatie hebben de grootstedelijke basisgezondheidsdiensten recentelijk (mede in het kader van het 'healthy cities'-beleid) de probleem- en wijkgerichtheid versterkt.

Bij voorzieningen gericht op behandeling en genezing is sprake van een grote capaciteit. Topklinische specialismen zijn ruimschoots voorradig; er is een relatief overschot aan ziekenhuisbedden; medische en therapeutische specialismen in de sfeer van de geestelijke gezondheidszorg zijn meer voorhanden dan gemiddeld in Nederland. De aanwezigheid van academische ziekenhuizen in drie van de vier grote steden is hier een wezenlijke factor. Uitzonderingen op dit algemene patroon kunnen onder andere worden gevonden in de capaciteitstekorten bij de revalidatiecentra, bij de fysiotherapeutische hulpverlening en bij de verloskundige hulp.

Een gemengd beeld bestaat bij de voorzieningen voor verzorging en verpleging. Een van de opvallende tekortkomingen betreft het grote beddentekort voor psycho-geriatrische patiënten; de behoefte aan deze plaatsen zal nog verder toenemen in het licht van de voorziene stijging van het aantal hoogbejaarden in de steden. Afgemeten aan de spreidingscriteria van de Wet op de bejaardenoorden zijn de grote steden wat betreft de verzorgingstehuizen voor bejaarden overbedeeld. Bij capaciteitsoverschotten van duurzame accommodaties moet wel rekening gehouden worden met rigiditeiten in de programmering van het aanbod. Waar nu overschotten bestaan, kunnen door veranderingen van de vraag binnen afzienbare termijn weer tekorten optreden. Tenslotte steekt ook het aanbod van de gezinsverzorging uit boven het landelijke gemiddelde.

Tegen de achtergrond van het specifieke bevolkings- en gezondheidsprofiel van de grote steden staat de doelmatigheid van de voorzieningenstructuur zowel kwantitatief als kwalitatief onder druk. $\mathrm{Z}_{0}$ is het hierboven als ruim gekenschetste aanbod van de gezinsverzorging in de steden niet voldoende om te voorzien in de bestaande behoeften, gezien de oververtegenwoordiging van bejaarden en van éénoudergezinnen. Door de bovenlokale functie van een groot aantal voorzieningen - bijvoorbeeld de ziekenhuizen en de medische specialismen - kan voorts het in verhouding grote volume niet rechtstreeks worden gerelateerd aan de grootstedelijke bevolking.

De druk op de voorzieningen komt in de eerste plaats tot uitdrukking in het bestaan van wachtlijsten, vooral in de sfeer van de verpleging en verzorging. Voor een deel wordt hiervoor een oplossing gevonden door een andere - meest lichtere - vorm van zorg te bieden of door langs andere weg zorg te organiseren en te financieren. Een tweede gevolg van de druk op het aanbod is het optreden van verdringingsprocessen in de taakuitoefening. Zo is de betekenis van de gezinszorg en het kruiswerk in de grote steden steeds meer identiek geworden aan hulpverlening aan bejaarden (meer dan $70 \%$ van de gevallen, landelijk is dit inmiddels ook al meer dan 50\%). De klassieke taak van tijdelijke huishoudelijke bijstand aan gezinnen in nood is in de grote steden nagenoeg volledig verdrongen. Ook de taakuitoefening van het algemeen maatschappelijk werk (amw) is in de stedelijke praktijk steeds meer van karakter veranderd; de oor- 
spronkelijke immateriële hulpverlening maakt in toenemende mate plaats voor hulp bij materiële problemen (vooral schuldsanering). Bij de bejaardenoorden heeft de relatieve toename van het aantal hoogbejaarde bewoners in combinatie met hun sterk verminderde validiteit tot gevolg dat deze zich van huisvestingsvoorziening met een verzorgend karakter hebben ontwikkeld tot zorgvoorziening sec. Mede hierdoor is momenteel de verhouding tussen verzorgings- en verpleegtehuis een belangrijk aandachtspunt geworden.

Op grond van deze globale typering kan met enig voorbehoud worden geconcludeerd dat het volume van de gezondheidsvoorzieningen in de grote steden in het algemeen adequaat genoemd kan worden wanneer men het aanbod relateert aan de landelijke gemiddelden. Meer problemen zijn er wanneer het voorzieningenaanbod wordt geplaatst tegen de achtergrond van het bijzondere gezondheidsprofiel van de stedelijke bevolking. Vooral op het gebied van de maatschappelijke dienstverlening en van de geestelijke gezondheidszorg bestaan knelpunten. De preventieve zorg en de medische specialismen en voorzieningen zijn in het algemeen goed voorzien (een belangrijke uitzondering betreft het psychiatrische beddentekort). Bij het aanbod van de gespecialiseerde voorzieningen moet wel in aanmerking worden genomen dat dit in belangrijke mate een bovenregionale functie heeft. Hierin is, zoals verderop zal blijken, een gevoelig probleem gelegen voor de overgang naar een nieuw stelsel van financiering van de gezondheidszorg.

\subsubsection{Vernieuwing van de institutionele context}

\subsubsection{De bevordering van de gezondheid}

Het stedelijk beleid ter bevordering van gezondheid heeft een belangrijke nieuwe impuls gekregen door het besluit van de Wereldgezondheidsorganisatie (WHO) om een centrale plaats toe te kennen aan de Health Promotion. Voor de uitwerking van dit beleid heeft de WHO een strategische positie ingeruimd voor een internationaal netwerk van steden ${ }^{68}$. Een van de opvallende uitgangspunten van deze internationale beleidsstrategie is de poging om de oude betekenis van gezondheid nieuw leven in te blazen in relatie tot de fysieke en sociale ontwikkelingen van de steden. De vrijwel overal dominerende aandacht voor de curatieve zorg vormt in deze gedachtengang slechts een onderdeel van het te voeren gezondheidsbeleid. Er zou weer meer accent moeten komen te liggen op preventie.

Deze beleidsstrategie werd op een tweetal conferenties in Canada toegespitst op het concept van de 'gezonde stad'. In Toronto werd een reeks van beleidsvoornemens ontvouwd om actief over de grenzen van de gezondheidszorg heen te kijken. Het gezondheidsbeleid werd hier een bestanddeel in het intersectorale grootstedelijk beleid ${ }^{69}$. Mede aan de hand van dit voorbeeld zou aan de ambitieuze voornemens voor het gezondheidsbeleid een nadere uitwerking worden gegeven via een internationaal netwerk van steden. Inmiddels heeft een groot aantal steden in Canada, de Verenigde Staten, Australië en Nieuw-Zeeland bij dit initiatief aangehaakt. In 1986 is het 'healthy cities'-project in Europa gestart op initiatief van de Europese sectie van de WHO (Lissabon 1986). In Europa nemen ongeveer 30 steden deel aan het initiatief. Volgens de opzet participeert de centrumstad van een nationaal netwerk in het internationale netwerk, waarin beleidsprogramma's en onderzoeksgegevens worden uitgewisseld. Op deze wijze ontstaat een intensieve internationale wisselwerking.

${ }^{69}$ ] M. Lalonde, A new perspective on the health of Conadians; 1974, Government of Canada, Ottawa. En: Ottawa charter for health promotion. An international conference on health promotion; the move towards a new public health, November 17-21, 1986, Ottawa (Ont.), Canada, 1986. In Nederland: Nota 2000, over de ontwikkeling van gezondheidsbeleid: feiten, beschouwingen en beleidsvoornemens; Tweede Kamer, Vergaderjaar 1985-1986, 19500, nrs. I en 2, blz. 19.

${ }^{69}$ ] Healthy Toronto 2000, A policy conference; City of Toronto, Department of Public Health, October 1984. 
Voorts wordt een reeks van onderzoeks- en beleidsinitiatieven op buurtniveau ontwikkeld teneinde zo exact mogelijk te kunnen aansluiten op de bijzondere achtergronden en behoeften van de stadsbevolking. In Rotterdam en Amsterdam zijn inmiddels intensieve onderzoeksprogramma's op wijkniveau gestart.

Ook voor de gemeenten in Nederland is een netwerk voor de bevordering van gezondheid opgericht, waarin een aantal grote en kleinere gemeenten is vertegenwoordigd. Eindhoven neemt voor het netwerk van de Nederlandse gemeenten de schakelpositie met het internationale netwerk in.

Nieuwe initiatieven ontstonden in Amsterdam en Den Haag (in het verlengde van de beleidsnota "Beter Gezond") en vooral ook in Rotterdam (Nota Gezonde Stad), dat zich in de richting van de tweede centrumstad ontwikkelt, met relaties naar het internationale netwerk van steden ${ }^{70}$.

\subsubsection{Curatieve zorg en maatschappelijke dienstverlening}

Een van de opvallende uitgangspunten van de beoogde stelselherziening is de financiële en beleidsmatige coördinatie van 'cure and care' via de weg van centraal geordende marktverhoudingen. De stelselherziening beoogt in hoofdlijnen de invoering van een basisverzekering voor iedereen in een marktgericht stelsel ${ }^{71}$. Aan deze globale opzet zullen gedurende het traject veel nieuwe inzichten worden toegevoegd, niet alleen van politieke maar ook van technische en administratieve aard. Maar het proces is op gang gekomen en zal voorlopig niet tot stilstand worden gebracht. Vanuit het oogpunt van bestuurlijke ordening worden tot dusverre alle tussentijdse beleidsvoornemens gedomineerd door twee institutionele zwaartepunten. In de eerste plaats is er sprake van een nieuw initiatief op centraal niveau: het verzekeringsstelsel en de marktvoorwaarden worden door de centrale wetgever vastgesteld. In de tweede plaats wordt voor de uitvoering van het nieuwe stelsel een cruciale betekenis toegekend aan de overeenkomsten tussen de verzekeraars en de aanbieders van zorg. De rol van de overige partijen is in de stelselherziening onderbelicht gebleven. Het streven naar territoriale decentralisatie uit de jaren '70 is beëindigd en de rol van de lagere overheden wordt gemarginaliseerd. De belangen van de uiteindelijke gebruiker van de voorzieningen - de patiënt moeten overwegend via de verzekeraars tot gelding komen.

Van de zijde van de steden is vanaf het begin van de stelselherziening, na het rapport van de Commissie Dekker, terughoudend gereageerd, niet alleen vanwege het verlies van een groot aantal beleidstaken maar ook vanwege het risico dat aan het afwijkende gezondheidsprofiel van de stedelijke bevolking met haar vele 'bijzondere' patiënten in een marktgericht stelsel te weinig recht zou worden gedaan ${ }^{72}$. Vanuit de optiek die in dit rapport wordt ontwikkeld, worden wel positieve mogelijkheden gesignaleerd voor de praktijk van het grootstedelijk gezondheidsbeleid om in aansluiting op het nieuwe bestel een eigen profiel te ontwikkelen. Voor een standpuntbepaling over de perspectieven voor een grootstedelijk gezondheidsbeleid is het echter nodig eerst in te gaan op de verschillende elementen. De analyse is gericht op drie onderdelen.

1. Verbijzondering van centrale voorwaarden

2. De decentrale uitvoering van het stelsel

3. Correcties van onvolkomenheden in de stelselherziening

${ }^{70}$ ] Zie bijvoorbeeld: Beter gezond, 's-Gravenhage, gemeente 's-Gravenhage, 1989; Het nieuwe Rotterdam, een gezonde stad; Rotterdam, GGD, oktober 1989.

11] Structuur en financiering gezondheidszorg, Nota Verandering Verzekerd; Tweede Kamer, Vergaderjaar 1987-1988, 19945 , nrs. 27 en 28. En de recente beleidsnota Werken aan zorgvernieuwing; actieprogramma van het beleid voor de zorgsector in de jaren negentig; Tweede Kamer, Vergaderjaar 1989-1990, 21 545, nrs I-2.

72] Gezondheidszorg en grootstedelijk bestuur; 's-Gravenhage, De gemeentebesturen van Amsterdam, Rotterdam, Den Haag en Utrecht, februari 1988. 
Ad 1. Verbijzondering van centrale voorwaarden

Voor de regeling van een nieuw verzekeringsstelsel en de nieuwe ordening van de marktverhoudingen op centraal niveau bestaan goede gronden. In de eerste plaats domineert het politieke motief van de redistributie. Door 'centrale organisatie van de solidariteit' worden de zorgvoorzieningen op een bepaald kwaliteitsniveau voor iedereen toegankelijk gemaakt. Op grond van dit motief wordt het doelmatig geacht de hoofdlijnen van de verzekeringsstelsels centraal vast te stellen. In de tweede plaats legt de gezondheidssector een dermate groot beslag op het nationale inkomen dat hiervan een relevante invloed uitgaat op de collectieve uitgaven en lasten.

Vanuit het oogpunt van een grootstedelijk gezondheidsbeleid moeten de bovengenoemde centrale voorwaarden als randvoorwaarden worden beschouwd. Hoe zij worden geformuleerd, laat het stedelijk beleid echter niet onverschillig. De distributieve en financiële voorwaarden slaan rechtstreeks terug op het decentrale beleid, bijvoorbeeld door de samenstelling van het basispakket en de centrale vergoedingen (de normuitkeringen) aan de verzekeraars. Het is daarom van groot belang om, voorzover het 'bijzondere' gezondheidsprofiel van de stedelijke bevolking systematisch van het 'normale' gezondheidsprofiel afwijkt, en voorzover het aanbod van voorzieningen bijzondere kenmerken vertoont (bijvoorbeeld de bovenregionale betekenis van gespecialiseerde voorzieningen), op centraal niveau differentiaties aan te brengen in de voorwaarden. Riskant in de opzet van het nieuwe stelsel is vooral het ontstaan van risicoselecties. De voorwaarden van acceptatieplicht en het verbod op premiedifferentiatie schermen de mogelijkheden voor het selecteren van de 'betere risico's' weliswaar voor een groot deel af, maar hierbij wordt wel verondersteld dat in de normuitkeringen een goede verevening tot stand komt van de verzekeringsrisico's.

De weg van differentiatie van de centrale voorwaarden is tot dusverre niet actief bewandeld, hoewel de opzet van de stelselherziening hiervoor in beginsel een reeks van mogelijkheden biedt.

- De verzekeringssystematiek van het beoogde stelsel staat uitzonderingen toe op de algemene uitkeringen uit de centrale kas aan de verzekeraars. Zo zijn 'bijzondere uitkeringen' mogelijk uit de centrale kas, buiten de normale verdeelsystematiek om. Hierbij wordt vooral gedacht aan de moeilijk verzekerbare risico's zoals zwakzinnigenzorg of zorg voor gehandicapten. Daarnaast bestaat de mogelijkheid van 'rechtstreekse bekostiging' aan de aanbieders. Het gaat hier om voorzieningen die slecht in de functionele omschrijving van het basispakket passen, of die typische kenmerken van collectieve goederen dragen. Voor diverse 'aparte' stedelijke voorzieningen geldt dat de vraag niet direct vanzelf zichtbaar is, maar het aanbod niettemin gegarandeerd dient te worden (preventie, geestelijke gezondheid). De bewijslast is aan de in het stedelijk gebied opererende partijen om aan de hand van de functie-omschrijving de noodzaak aan te tonen van dergelijke correctiemechanismen.

- Een belangrijk aangrijpingspunt betreft de verevening van de verzekeringsrisico's. In dit verband zijn vooral de consumptieverschillen voor de stedelijke gebieden van wezenlijk belang, omdat de consumptie van de medische voorzieningen daar structureel boven het landelijk gemiddelde ligt. Daarnaast is aparte aandacht nodig voor de regionale kostenverschillen die opnieuw in de steden (met name in Amsterdam) structureel afwijken van de landelijke gemiddelden. Voor dit laatste punt bestaat tot dusverre weinig aandacht, omdat de verzekeraars geacht worden te gaan concurreren op doelmatigheid.

- Een belangrijk aandachtspunt betreft tenslotte het aanbod van specialistische (met name intramurale) voorzieningen in de grote steden. Deze hebben vaak een bovenregionale functie en zijn als zodanig niet door de regionaal opererende verzekeraars op te brengen. 
Ad 2. De decentrale uitvoering van het stelsel

Terwijl het grootstedelijk gezondheidsbeleid met betrekking tot de centrale distributieve en financiële voorwaarden beperkt moet blijven tot mogelijke differentiatie op centraal niveau van de algemene voorwaarden, vervult het een hoofdrol bij de uitvoering van de verzekeringsstelsels. Hier gaat het om de allocatieve beleidsvraagstukken, die bij uitstek op het decentrale niveau doelmatig afgewikkeld kunnen worden. In de stelselherziening wordt het uitgangspunt consequent gelegd bij de vrije overeenkomsten tussen ter plaatse opererende marktpartijen. Hiertoe worden beleidsvoerende taken overgeheveld van de lagere overheden naar de marktpartijen. Deze keuze voor'primaire allocatie' houdt de belofte in van een directe versterking van de stedelijke democratie. Hoewel vanuit bestuurlijk oogpunt gezien de gemeenten van de grote steden veel beleidstaken verliezen, wordt vanuit maatschappelijk oogpunt de bewegingsruimte voor lokaal en regionaal beleid sterk verruimd.

Gedurende de laatste decennia is de beleidspositie van de marktpartijen, met name van de ziekenfondsen maar ook van een aantal aanbieders van de voorzieningen, structureel uitgehold door de toename van gedetailleerde, centrale richtlijnen inzake uiteenlopende beleidsonderdelen van allocatieve aard: prijzen, tarieven, honoraria, budgetten, spreiding van organisatie, organisatorische samenwerking tussen instellingen, functie-uitoefening, kwaliteit, enzovoort. Ook de territoriaal gedecentraliseerde dienstverlening bond de gemeentebesturen van de grote steden aan talrijke gedetailleerde richtlijnen die een doelmatige uitvoering van het beleid bemoeilijkten. Wanneer in een nieuw stelsel de ruimte wordt gecreëerd om over deze allocatieve zaken primair te laten beschikken, in het kader van de vrije overeenkomsten tussen decentrale marktpartijen, ontstaat een nieuwe ondernemingsgeest bij lokaal opererende instanties die tot administratiekantoren waren gedegradeerd. De overige lokale partijen, die niet rechtstreeks bij de overeenkomsten betrokken zijn, krijgen nu te maken met verzekeraars en zorgaanbieders die geëquipeerd zijn voor het voeren van een zelfstandig beleid. $\mathrm{Zij}$ kunnen hierop vanuit hun eigen verantwoordelijkheid inspelen. Het is daarom in het belang van de relatieve outsiders van het nieuwe stelsel (de lagere overheden en toch ook nog altijd de patiënten) dat de bovengenoemde allocatieve beleidszaken volgens plan in lokale en regionale overeenkomsten afgewikkeld kunnen worden en dat hieraan niet opnieuw een reeks van centrale richtlijnen zal worden opgelegd.

\section{Ad 3. Correcties van onvolkomenheden in het stelsel}

De constructie van een marktgericht stelsel in een marktvreemde sector brengt onvermijdelijk een 'mismatch' mee tussen het geconstrueerde stelsel en de meer gevarieerde werkelijkheid waarin het tot gelding moet komen. Bovendien wordt de beoogde marktwerking in hoge mate gecompliceerd doordat de vraag- en aanbodpartijen in de gezondheidszorg niet ondubbelzinnig bepaald kunnen worden. In feite is sprake van verschillende deelmarkten die elkaar overlappen via diverse dubbelrollen van de partijen. Zo wendt de verzekeraar zich met zijn verzekeringspak ket als aanbieder tot de verzekerden, maar wordt hij tegelijkertijd geacht in naam van de verzekerden als vragende partij de contracten met de aanbieders van zorg te sluiten. De verschillende deelmarkten zullen naadloos op elkaar moeten aansluiten om de beoogde marktwerking met zijn zelfregulerende prikkels tot haar volle recht te laten komen. Als de aansluitingspunten verstopt raken, hapert het hele stelsel.

Bij dergelijke complicaties zijn imperfecties en al dan niet systematische fouten niet te vermijden. Voor de organisatie van zulke complexe stelsels vormt echter niet zozeer het ontstaan van onvermijdelijke vertekeningen het grootste risico, maar het gebrekkige vermogen om vertekeningen te onderkennen, om ervan te leren en waar mogelijk te corrigeren. De structurering van dit aanpassingsvermogen biedt een van de boeiendste aanknopingspunten voor de aansluiting van het grootstedelijk gezondheidsbeleid op de stelselherziening. 
De betekenis van het aanpassingsvermogen kan reeds in het huidige embryonale stadium van de stelselherziening geïllustreerd worden door de verhoudingen tussen de deelmarkten te bezien ${ }^{73}$. Onvolkomenheden van het stelsel waren reeds op de tekentafel niet te vermijden. Idealiter is een marktstelsel opgebouwd rondom de primaire marktpartijen, in dit geval de dokter en de patiënt. Complicaties zijn hierbij dat de patiënt in menig opzicht geen echte marktpartij is, dat de financiering van de zorg via derden loopt en dat langs die weg de herverdeling tot stand komt. Het zwaartepunt van de beoogde marktwerking is tegen deze achtergrond gelegd bij de 'zaakwaarnemers' van de primaire marktpartijen, namelijk bij de verzekeraars en de georganiseerde aanbieders van zorg. De verhouding tussen de twee laatstgenoemde partijen vormt immers de kern van de beoogde marktwerking. Er zijn via de andere deelsystemen wel relaties met de primaire marktpartijen. Zo worden de verzekeraars geacht om in onderlinge concurrentie te dingen naar de gunst van de verzekerden. De verzekerde kan desgewenst een andere verzekeraar kiezen. De zorgverstrekkers op hun beurt worden geacht met elkaar te concurreren om de gunst van de verzekeraars. Deze kunnen desnoods kiezen voor andere aanbodpartijen. Aldus zijn de uitgangspunten sluitend. Maar door het zwaartepunt van de marktwerking te leggen bij de overeenkomsten tussen de verzekeraars en de georganiseerde aanbieders van zorg, is de verhouding van deze zaakwaarnemers met de verzekerden en de individuele zorgverstrekkers zeer kwetsbaar.

In de praktijk is deze kwetsbaarheid inmiddels groter geworden. Het Europa van 1992, maar vooral ook het vooruitzicht van de marktwerking heeft namelijk een groot aantal verzekeraars (vooral ziekenfondsen) in elkaars armen gedreven. Weliswaar bestaan nog steeds enige tientallen verzekeraars, maar er zijn op regionaal niveau duidelijke zwaartepunten ontstaan. Met de kennelijke bedoeling om hun marktpositie te verstevigen, is onder de verzekeraars een reeks van fusies en samenwerkingsverbanden opgetreden, die in sommige landsdelen trekken van een monopolie begint aan te nemen. In de grote steden is het ziekenfonds ook straks in zijn nieuwe vorm de natuurlijke marktleider. In drie van de vier grote steden bestaat slechts een ziekenfonds, in Den Haag is de voorgenomen fusie tussen de twee plaatselijke ziekenfondsen vooralsnog stuk gelopen. Overigens zijn de ziekenfondsen het vroegere monopolie van hun werkgebied kwijtgeraakt. In hoeverre hierdoor feitelijk meer mededinging zal ontstaan blijft een open vraag. Het gevaar van eenzijdige machtsconcentraties is allerminst denkbeeldig. Concurrentie tussen verzekeraars om de gunst van de verzekerden en de keuzevrijheid van de verzekerden krijgen zo een beperkte reikwijdte. Wel sluiten de verzekeraars in de toekomst onder zeer grote beleidsruimte de contracten met de aanbieders van zorg.

Niet alleen de gebruikers van de voorzieningen kunnen in het nauw raken als het front van de verzekeraars zich sluit, ook de aanbieders van zorg zullen reageren. Inmiddels zijn er voortekenen dat deze aanbieders hun krachten gaan bundelen, niet alleen vanwege het streven naar functionele zorgverbreding, maar vooral ook om door machtsconcentratie te voorkomen dat zij straks door de contracterende verzekeraars tegen elkaar worden uitgespeeld. De 'ketens en netwerken van zorg' hebben ook het doel vanuit de aanbodzijde georganiseerd tegenspel te bieden aan de verzekeraars. Ook hier dreigen weer aansluitingsproblemen tussen deelmarkten te ontstaan. Als de zorgverstrekkers hun belangen bundelen verliest het concurrentiemotief aan betekenis. En hoe verhouden zich dan de individuele aanbieders van zorg tot de organisaties van het aanbod? Dreigen daar op den duur dezelfde aansluitingsproblemen als nu tussen verzekeraars en verzekerden?

73] Zie ook A.P.W.P. van Montfort, 'Open-einderegelingen in de gezondheidszorg'; Openbare Uitgoven, februari 1990, jaargang 22, nr. 2, blz. 68-74. 
Afrondend kan worden geconcludeerd dat het stelsel in aanleg een preoccupatie heeft met de overeenkomsten tussen 'zaakwaarnemers': de verzekeraars en de georganiseerde zorgverstrekkers. Als gevolg hiervan zijn de schakelingen tussen de verschillende deelmarkten kwetsbaar voor verstoppingen. De eerste reacties in de praktijk hebben deze tendenties versterkt. Zo dreigt voor de primaire marktpartijen een nieuwe afhankelijkheid te ontstaan. De invoering van dit ingewikkelde stelsel kan derhalve niet onmiddellijk de graad van perfectie claimen. Het wordt dan ook slechts geleidelijk en met veel mogelijkheden voor tussentijdse aanpassingen ingevoerd. Niettemin is aan het ontstaan van eenzijdige machtsconcentraties tot dusverre te weinig tegenwicht geboden. Het georganiseerde aanpassingsvermogen van het stelsel is gebrekkig en dreigt de Achilleshiel van de operatie te worden.

In de beleidsvoornemens wordt terecht in eerste instantie vertrouwd op de mogelijkheden tot zelfcorrectie van de verzekeraars en de aanbieders van zorg. Men heeft de kansen op marktwerking niet bij voorbaat willen frustreren door van overheidswege reeds op voorhand een reeks van specifieke marktvoorwaarden aan de partijen op te leggen. In tweede instantie worden echter alle mogelijkheden voor signalering van en reactie op vertekeningen gesluisd via de centrale overheid. Voor mogelijke correcties van de patiënten, de lokale groeperingen en de lagere overheden wordt onvoldoende ruimte gecreëerd. Wat betreft de inbreng van de patiënten en hun organisaties, worden recentelijk reeds nieuwe mogelijkheden gezocht, maar deze zullen onvermijdelijk beperkt blijven. Met name de lagere overheden zouden meer ingeschakeld moeten worden om een kansrijke ontwikkeling van het stelsel mogelijk te maken.

De inbreng van de lagere overheden - in het bijzonder in de grote steden met hun bijzondere karakteristiek - is essentieel, omdat het stelsel veel ruimte laat voor gedifferentieerde lokale en regionale ontwikkelingen. Deze ontwikkelingen kunnen op centraal niveau niet doelmatig gesignaleerd en zonodig gecorrigeerd worden, omdat zich in elk gebied andere problemen gaan voordoen. Wat betreft de correctiemogelijkheden van de lagere overheden, is in de huidige beleidsvoornemens voor het nieuwe stelsel nog geen passende rol voorzien voor de lagere overheden om, in aanvulling op en binnen het kader van de centrale marktvoorwaarden, plaatselijk specifieke voorwaarden te stellen wanneer zich in een bepaald gebied eenzijdige machtsconcentraties gaan voordoen. Om deze rol te vervullen zullen de gemeenten het recht moeten hebben zelf de benodigde informatie te vergaren en gebruik te kunnen maken van de ten behoeve van het Rijk bestaande informatiestromen.

\subsubsection{Beleidsopgaven}

Bij de uitwerking van een perspectief voor het grootstedelijk gezondheidsbeleid moet een onderscheid worden gemaakt tussen de regels die de centrale wetgever stelt, en de maatschappelijke praktijk op een bepaald beleidsgebied. De praktijk rondom het stedelijk gezondheidsbeleid krijgt vorm door de partijen die hierin ieder met een eigen verantwoordelijkheid werkzaam zijn. De condities die van rijkswege aan deze partijen worden opgelegd en de veranderingen die hierin via stelselwijziging of anderszins optreden, krijgen geldingskracht in de praktijk. De betekenis van de maatschappelijke praktijk kan echter niet worden afgeleid uit de regels of stelsels die eraan worden opgelegd. De stelselwijziging leidt tot een nieuwe rolverdeling inzake financiering en beleidsproduktie, maar de concrete uitkomst hiervan zal worden bepaald door de wijze waarop de partijen zullen inspelen op de nieuwe condities. Door dit onderscheid te hanteren tussen centrale regels en maatschappelijke praktijk is het mogelijk de kansen van de structuurvernieuwing in een ruimer verband te plaatsen.

Een blik op de praktijk van het grootstedelijk gezondheidsbeleid leert dat de lokale overheden hierin een eigen verantwoordelijkheid dragen en dat de 
inbreng van de patiënten en hun organisaties een krachtige ontwikkeling doormaakt. Op deze waarneming is de verwachting gestoeld dat de wisselwerking tussen de gegroeide praktijk van het grootstedelijk gezondheidsbeleid en de nieuwe regels die hierin tot gelding moeten komen, de kansen voor een nieuw samenspel van de partijen eerder zal vergroten dan verkleinen. In het voorgaande werd beargumenteerd dat de rol van de lokale overheden en de patiënten zelfs krachtiger kan worden doordat zij te maken krijgen met meer competente verzekeraars en zorgverstrekkers. Voor een perspectief op het grootstedelijk gezondheidsbeleid is het van elementair belang dat deze partijen hun betrokkenheid blijven waarmaken vanuit een eigen verantwoordelijkheid.

Zo worden de contouren zichtbaar van de context waarin in het nieuwe bestel het grootstedelijk gezondheidsbeleid tot ontwikkeling kan komen. De centrale wetgever geeft het algemene kader aan voor de marktordening. Het belangrijkste kenmerk hiervan heeft betrekking op het karakter en de financieringsstructuur van een nieuw verzekeringsstelsel. Gezien het distributieve kenmerk van het verzekeringsstelsel en de macro-economische effecten, gaat het hier om zaken waarvan het inderdaad functioneel is dat deze centraal worden geregeld. De uitvoering van het verzekeringsstelsel met zijn vele allocatieve beleidsafwegingen wordt - weliswaar binnen algemene randvoorwaarden primair op lokaal en regionaal niveau bepaald, door overeenkomsten tussen verzekeraars en aanbieders van zorg. Speciale aandacht is hierbij nodig voor de vraag op welke wijze het belang van de patiënten hierin tot uitdrukking kan komen. De rol van de lagere overheden kan hier nader worden gespecificeerd.

In de eerste plaats dragen de gemeenten een algemene verantwoordelijkheid voor de gezondheid van de plaatselijke bevolking. Uit dien hoofde hebben zij een direct belang bij een optimaal verkeer tussen patiënten, verzekeraars, organisaties van het zorgaanbod en individuele zorgverstrekkers. Wanneer in dit toekomstige marktverkeer bepaalde onvolkomenheden ontstaan, zullen de lagere overheden hierop correcties moeten aanbrengen. Zo zullen de gemeenten voor de zaken van patiënten moeten opkomen, voorzover deze niet op eigen titel kunnen worden georganiseerd. Met name in de steden met hun bijzondere gezondheidsprofiel is dit een gevoelig aandachtspunt.

In de tweede plaats raakt de algemene beleidsverantwoordelijkheid van de gemeenten in de toekomst direct en indirect de ontwikkelingen in het gezondheidsbeleid veel ingrijpender dan tot dusverre. De mate waarin de algemene stadspolitiek van invloed is op het gezondheidsprofiel van de stedelijke bevolking en de mate waarin op het aangrenzende gebied van de gezondheidsvoorzieningen stedelijk beleid wordt gevoerd (speciale woonvoorzieningen voor ouderen, sociaalbeleid, enz.), zullen in de toekomst rechtstreeks gaan doorwerken in de rendementspositie van de verzekeraars. Weliswaar zullen in het toekomstige systeem van normuitkeringen aan de verzekeraars diverse bijzonderheden van de steden gecompenseerd moeten worden (anders kunnen zij het daar niet bolwerken), deze compensaties laten echter onverlet dat de partijen in de stad meer op elkaar aangewezen zullen zijn en dat zij met behoud van gescheiden verantwoordelijkheden tot een afstemming van het gezondheidsbeleid zullen geraken.

Het perspectief voor een grootstedelijk gezondheidsbeleid kan aan de hand van enige aandachtspunten nader worden uitgewerkt. Het betreft:

- de bevordering van gezondheid;

- thuiszorg;

- differentiatie van normuitkeringen;

- de lokale en regionale uitvoering van het stelsel. 


\subsubsection{De bevordering van gezondheid}

De actieve rol van het stedelijk bestuur bij de bevordering van gezondheid heeft zoals gezegd een nieuwe impuls gekregen door de initiatieven van de Wereldgezondheidsorganisatie. Door de gemeentelijke gezondheidsdiensten wordt nu veel systematische informatie vergaard over de ontwikkeling van het gezondheidsprofiel van de stedelijke bevolking. Hieruit vloeien programma's voort van preventieve zorg. Door gerichte beïnvloeding van omgevingscondities, leefstijlen en voedingsgewoonten kunnen de omstandigheden waaronder bepaalde concentraties van gezondheidsproblemen ontstaan, aanzienlijk worden verbeterd. Er zijn internationale voorbeelden te noemen van steden waar een dergelijke actieve gezondheidspolitiek - gedragen door maatschappelijke groeperingen - integraal deel uitmaakt van het stedelijk beleid. In de Nederlandse steden overheerst nog het beeld dat weliswaar bij de omvangrijke gemeentelijke gezondheidsdiensten veel kennis bestaat, maar dat toch de effectuering van deze inzichten zou kunnen worden versterkt. Het streven naar een 'gezonde stad' vormt nog vrijwel nergens een actief bestanddeel van de intersectorale stadspolitiek.

\subsubsection{Thuiszorg}

Een groot deel van de vroegere beleidstaken van het grootstedelijk bestuur op het gebied van de maatschappelijke dienstverlening (bejaardenoorden, gezinsverzorging, kruiswerk) zal volgens de voornemens van de stelselherziening geïntegreerd worden in het nieuwe bestel van de zorgsector. Op den duur zal de financiering dus via de verzekeraars gaan lopen. Langs deze weg kan met het oog op de gewenste substituties van de zorg een betere functionele samenhang tussen de voorzieningen ontstaan. Bovendien is van belang dat de afweging van allocatieve beleidsvraagstukken direct via de overeenkomsten van de marktpartijen kan plaats vinden. Voor verzekeraars en aanbodpartijen ontstaat meer ruimte om - ook in contact met andere plaatselijke partijen (gemeenten, woningbouwverenigingen, particuliere hulpdiensten) - een eigen beleid te voeren.

Niettemin is voor de bevordering van het zelfstandig bestaan in de eigen omgeving van hulpbehoevende ouderen of patiënten een bredere infrastructuur van thuiszorg nodig dan binnen het kader van het zorgstelsel gegarandeerd kan worden. Het betreft onder meer bijzondere woonvoorzieningen, de ruimtelijke inrichting van de woonomgeving, speciale vervoersmogelijkheden, de organisatie van hulp- en dienstverlening aan huis. Het grootstedelijk bestuur draagt ook in het toekomstig bestel een eigen algemene beleidsverantwoordelijkheid voor een adequate infrastructuur van de thuiszorg. Het hoeft hiervoor bij voorkeur niet de organisatie vañ de aangrenzende voorzieningen in eigen hand te nemen, maar het draagt wel verantwoordelijkheid voor het bestaan van een deugdelijke infrastructuur. Het zal deze moeten waarmaken zonder in de financiële en beleidsmatige competenties van de marktpartijen te treden. Dit kan door het aanbieden van aanvullende fysieke faciliteiten, zoals de dienstencentra die als organisatiebasis dienen voor hulp- en dienstverlening. Het kan ook door organisatorische middelen. Het afsluiten van overeenkomsten tussen het grootstedelijk bestuur en de marktparijen vormt bijvoorbeeld een belangrijk instrument om een doelmatige en adequate allocatie van de thuiszorg te bevorderen.

\subsubsection{Differentiatie van normuitkeringen}

Wat betreft de invulling van het verzekeringsstelsel en de financiële kaderstelling, is het grootstedelijk gezondheidsbeleid afhankelijk van de voorwaarden die op centraal niveau worden bepaald. Vanuit de optiek van het grootstedelijk beleid kunnen op deze voorwaarden slechts centraal vast te stellen differentiaties worden aangebracht op grond van de bijzonderheden van het stedelijk gezondheidsprofiel en op grond van de afwijkende betekenis van de voorzieningen in de steden. Gezien de opvallende afwijkingen van het gebruik van de 
zorgvoorzieningen door de stedelijke bevolking en gezien de bovenregionale betekenis van veel zorgvoorzieningen in de steden, is aanpassing van de centrale normuitkeringen inderdaad wenselijk. Op grond van de nieuwe functie-omschrijvingen van de basisverzekering zullen de in de steden opererende instanties moeten aantonen dat het gezondheidsprofiel van hun bevolking dermate afwijkend is van het 'normale' profiel dat op de centrale voorwaarden correcties worden aangebracht. De diverse mogelijkheden die hiertoe in de stelselherziening in beginsel zijn gecreëerd, worden tot dusverre onvoldoende benut. De volgende mogelijkheden dienen zich hiertoe aan.

- Voor moeilijk verzekerbare risico's zijn bijzondere uitkeringen mogelijk buiten de normale verdeelsystematiek om.

- Voor 'aparte' voorzieningen die slecht in de functionele omschrijving van het basispakket vallen, bestaat de mogelijkheid van rechtstreekse bekostiging aan de aanbieders.

- Voor het bovengemiddelde gebruik van voorzieningen zal verevening van de algemene normuitkeringen moeten plaatsvinden. De discussie over de wijze waarop dit moet gebeuren, is nog niet afgerond; het belang van de steden met hun afwijkende consumptieniveau zal verduidelijkt moeten worden. Tevens zal aan de regionale kostenverschillen aandacht moeten worden besteed, voorzover deze niet rechtstreeks tot de doelmatigheid van de bedrijfsvoering kunnen worden herleid.

- Het gegeven dat veel gespecialiseerde voorzieningen een bovenregionale functie hebben, zou in de uitkeringen verrekend kunnen worden. Nu gebeurt dit reeds bij de financiering van de RIAGG- en GGZ-voorzieningen; in het nieuwe stelsel zou deze systematiek verbreed kunnen worden (bijv. voor de intramurale voorzieningen).

\subsubsection{De lokale en regionale uitvoering van het stelsel}

Voor de uitvoering van de stelselherziening is een hoofdrol toebedacht aan de lokaal en regionaal opererende instanties. Veel meer dan nu het geval is, zullen prijs, kwaliteit, volume, spreiding enzovoort van de zorgvoorziening op decentraal niveau moeten worden vastgesteld. Voor alle partijen die in de praktijk van het grootstedelijk gezondheidsbeleid met een eigen verantwoordelijkheid werkzaam zijn, houdt deze vergaande decentralisatie nieuwe mogelijkheden in om tegen de achtergronden van de plaatselijke bijzonderheden een aangepast beleid te ontwikkelen.

Er zijn echter ook risico's aan deze operatie verbonden. De nieuwe verhoudingen moeten zich nog gaan vormen in een praktijk die hierop niet is ingesteld. De belangrijkste partij - de patiënt c.q. de verzekerde - is als marktpartij relatief zwak. Bovendien is het beoogde stelsel ingewikkeld, vooral ook omdat het berust op een verzameling van deelstelsels, die perfect op elkaar moeten aansluiten om de bedoelde concurrentie en marktprikkels effectief te kunnen laten werken. Onvolkomenheden van een dermate ingrijpende operatie zijn onvermijdelijk en zullen tijdig moeten worden gesignaleerd en zoveel mogelijk gecorrigeerd om te voorkomen dat deze de gehele structuur scheef zullen trekken. Tegen deze achtergrond werd het aanpassingsvermogen van het stelsel als de Achilleshiel beschouwd van de uitvoering van de operatie.

Het aanpassingsvermogen is te eenvoudig van structuur. Mogelijkheden voor aanpassing worden slechts voorzien voor de dominante marktpartijen en de centrale wetgever. De positie van de verzekerde zal voornamelijk via de verzekeraar tot uitdrukking moeten komen. De lagere overheden staan geheel buiten spel. Het risico van eenzijdige machtsconcentraties aan zowel vraag-als aanbodzijde onder een traag reagerende centrale marktordenaar is niet denkbeeldig.

Recentelijk zijn mogelijkheden gezocht voor een versterking van de positie van de gebruiker van de voorzieningen. Deze zullen uiteindelijk beperkt blijven. 
In veel gevallen zal de overheid de belangen van de gebruiker moeten waarborgen. De centrale overheid kan hiertoe de algemene voorwaarden creëren, maar zij is niet bij machte op alle lokale en regionale differentiaties adequaat te reageren. Niet alleen zullen zich van gebied tot gebied andere verhoudingen gaan vormen, maar ook zal de inhoud van de zorgvoorzieningen gaan verschillen. Alleen de lagere overheden kunnen op deze gedifferentieerde ontwikkelingen adequaat toezien. De positie van het grootstedelijk bestuur vormt een belangrijke testcase voor het aanpassingsvermogen van de stelselherziening.

De raad pleit voor een passende mogelijkheid voor de lagere overheden, met voorrang voor het grootstedelijk bestuur, om in aanvulling op de algemene marktordening van het Rijk nadere voorwaarden op te leggen aan de marktpartijen om de beoogde marktwerking te verbeteren. Tegelijkertijd moet voorkomen worden dat deze bijzondere bevoegdheid aan de lagere overheden de mogelijkheid zou bieden om de oude plannende en coördinerende taken weer op te pakken, die nu juist doelbewust werden ingetrokken. De lagere overheden moeten dus niet in de beleidsmatige verantwoordelijkheden van de marktpartijen treden, maar zij moeten wel de spelregels kunnen aanpassen wanneer deze bij de feitelijke ontwikkelingen in hun gebied niet meer adequaat blijken te zijn. Om deze bevoegdheid waar te maken moeten de lagere overheden het recht hebben zelf - bijvoorbeeld via de gemeentelijke gezondheidsdiensten - de benodigde informatie te vergaren en om gebruik te maken van de ten behoeve van het Rijk bestaande informatiestromen. 


\section{Financiële en bestuurlijke verhoudingen}

\section{I Inleiding}

De grootstedelijke gebieden ondergaan een ingrijpende gedaanteverwisseling. $\mathrm{Na}$ een langdurig proces van urbanisatie doet zich gedurende de laatste decennia internationaal een ontwikkeling voor van ruimtelijke deconcentratie en van economische en sociale herstructurering.

De grootstedelijke gebieden staan voor de noodzaak om in reactie op deze globale structuurveranderingen en in aansluiting op de internationale trends een nieuwe geprononceerde positie te ontwikkelen. In de voorgaande hoofdstukken werden de economische en sociale ontwikkelingen van de grootstedelijke gebieden geanalyseerd en werden de opgaven voor het grootstedelijk beleid gepreciseerd. Tevens werd nagegaan in hoeverre de grootstedelijke gebieden in aansluiting op de nationale regelgeving een eigen profiel kunnen ontwikkelen op het gebied van de maatschappelijke voorzieningen (inzake onderwijs, arbeid, gezondheid en maatschappelijke dienstverlening).

In dit hoofdstuk zal worden onderzocht of de financiële en bestuurlijke verhoudingen waarin de grootstedelijke ontwikkeling zich in Nederland voltrekt, voldoende prikkels bevatten om de vereiste aanpassingen tot stand te brengen.

Vanaf het midden van de jaren '70 wordt de economische en sociale structuur van de centrale steden gekenmerkt door een toenemende onevenwichtigheid, waaraan het grootstedelijk beleid tot dusverre onvoldoende tegenwicht heeft kunnen bieden. In dit opzicht bestaat een nauw verband met de onderliggende institutionele structuur van financiële en bestuurlijke verhoudingen. De institutionele achtergronden verklaren niet zozeer het ontstaan van de stedelijke problematiek, als wel het trage en ontoereikende reactievermogen van de bij de stedelijke ontwikkeling betrokken partijen (de burgers, de ter plaatse opererende instanties en bedrijven en de diverse overheden) om slagvaardig op nieuwe omstandigheden en problemen in te spelen.

In de voorgaande hoofdstukken werd reeds beargumenteerd dat naast een nationale, op de steden gerichte beleidsinzet vooral ook een vergroting nodig is van de competenties van de lokale partijen voor beleidstaken met een allocatief karakter. Hiermee wordt niet gedoeld op louter het overhevelen van rijksmiddelen naar lagere overheden. Louter vergroting van de financiële en bestuurlijke armslag van het stedelijk bestuur leidt niet vanzelfsprekend tot een versterking van de sociale en economische structuur van de stad. Geledingen in de stad zullen zelf meer verantwoordelijkheid moeten nemen voor het levensvatbaar houden van de stad en het stedelijk bestuur zal ernaar moeten streven deze maatschappelijke energie te versterken. Uiteraard speelt hierbij de kwaliteit van het lokale bestuur een belangrijke rol.

Vanuit deze invalshoek gaat het in dit hoofdstuk bovenal om de vraag of in eerste instantie burgers, lokale instanties en lagere overheden voldoende rekening houden met en verantwoording dragen voor de sociale en economische ontwikkeling van de steden. Een van de opvallende bevindingen in de voorgaande hoofdstukken is dat het krachtenveld waarin het stedelijk beleid tot stand komt, er niet automatisch toe neigt om de dragende sociale en economische krachten aan de stad te binden. Dat de centrale steden zulke beïnvloedbare mogelijkheden als de huisvesting, de ruimtelijke inrichting, het ondernemingsklimaat, de sociale mobiliteit, het onderwijs of de fysieke bereikbaarheid in veel gevallen slechts aarzelend konden mobiliseren om hun verzwakte positie te verstevigen, is in de voorgaande hoofdstukken genoegzaam aangetoond. 
Het gaat er nu om of in de structurering van de financiële en bestuurlijke verantwoordelijkheden mechanismen kunnen worden geactiveerd die meer vanzelfsprekend uitnodigen tot het benutten van dergelijke kansen. Het gaat hierbij vooral om het scheppen van de voorwaarden voor een bestuurscultuur waarin de maatschappelijke krachten zich bekommeren om de vitaliteit van de stad en waarin omgekeerd het stedelijk bestuur zich sterk maakt om deze krachten tot ontwikkeling te laten komen.

De navolgende analyse van de financiële en bestuurlijke verhoudingen bestrijkt onvermijdelijk een terrein dat niet exclusief aan de steden is voorbehouden. In het algemeen gelden deze verhoudingen ook voor de overige lokale gemeenschappen, ook al zijn voor de grote steden diverse bijzondere omstandigheden van toepassing. Wanneer in dit hoofdstuk mogelijkheden worden gezocht om in het belang van een krachtige stedelijke ontwikkeling de financiële en bestuurlijke verhoudingen aan te passen, zullen deze derhalve in het algemeen ook voor kleinere gemeenschappen van toepassing zijn. De consequenties daarvan worden in dit rapport niet nader onderzocht en brengen om deze reden een voorbehoud mee bij de aanbevelingen. Wel moet worden bedacht dat in de grote steden veelal de kansen en bedreigingen worden uitvergroot die zich ook elders zullen gaan voordoen. In deze zin nemen de grote steden, waar de noodzaak voor veranderingen van de algemene regelgeving het eerst zichtbaar wordt, een voortrekkerspositie in.

De opzet van dit hoofdstuk is als volgt. Eerst wordt de financiële verhouding geanalyseerd, uitmondend in enige richtinggevende aanbevelingen. Vervolgens komt de bestuurlijke verhouding aan de orde. Hierbij worden in eerste instantie de mogelijkheden voor beleidsmatige decentralisatie onderzocht en wordt vervolgens ingegaan op het vraagstuk van de bestuurlijke organisatie.

\subsection{De financiële verhouding}

\subsubsection{Particuliere en publieke uitgaven voor voorzieningen}

Stedelijke voorzieningen kunnen in het algemeen naar hun aard worden onderscheiden in particuliere en collectieve goederen en diensten. In het geval van de particuliere goederen en diensten bestaat een directe relatie tussen de koopkrachtige vraag en het aanbod. Voorbeelden treft men op het gebied van de winkelvoorziening, de cultuur, de gezondheidszorg, sport en recreatie. In het geval van de collectieve goederen en diensten kunnen de voorzieningen in beginsel niet doelmatig door de markt worden voortgebracht (er is geen sprake van uitsluitbaarheid) ${ }^{1}$. De klassieke voorbeelden treft men aan in de sfeer van de politiezorg en van de rechtshandhaving.

De wijze van bekostiging van de goederen en diensten via particuliere of publieke uitgaven valt niet samen met de aard van de voorzieningen. Collectieve voorzieningen komen niet altijd tot stand via publieke uitgaven. Er zijn voorbeelden van klassieke overheidstaken, zoals politietaken of infrastructurele voorzieningen, die voor een deel rechtstreeks via particuliere uitgaven worden bekostigd. Van sommige voorzieningen was de bekostiging voorheen gecollectiviseerd, maar wordt deze nu steeds meer door particulieren gedragen (huisvesting, onderwijs of maatschappelijke dienstverlening). Omgekeerd zijn er ook voorbeelden waar de kosten van typische marktvoorzieningen geheel of gedeeltelijk door publieke uitgaven worden gedekt.

Door de financiële tussenkomst van de overheid wordt de relatie tussen de vraag naar en het aanbod van de voorzieningen indirect, een effect dat nog eens

'] D.J. Wolfson, Publieke sector en economische orde; Groningen, Wolters-Noordhof, 1988, blz. 41-73. 
wordt versterkt door de gelede besluitvorming. De ontmoeting tussen vraag en aanbod wordt immers gefilterd door verschillende beleidscircuits tussen de verwerving van de middelen en de toedeling aan de uiteindelijke bestemming: de fiscus, de budgettaire verdeling over de uitgevende departementen, de toedeling aan lagere overheden of functioneel gedecentraliseerde organen, de maatschappelijke bestemming. Voor de toedeling van gelden aan publieke voorzieningen is meestal het politieke budgetmechanisme van toepassing. Slechts in een enkel geval, zoals bij een aantal door gemeentebedrijven geleverde goederen en diensten, speelt de directe afweging tussen kosten en baten een rol.

De verhouding tussen de publieke en de particuliere bekostiging van voorzieningen verandert in de loop van de tijd voortdurend, vooral onder invloed van de vigerende politieke verhoudingen, meer dan door enige economische of financiële stelselmatigheid. Zo kan het voorkomen dat de overheid aan de ene kant rechtstreeks participeert in het aanbod van particuliere goederen of diensten, terwijl zij aan de andere kant terugtrekkende bewegingen maakt op het gebied van de typische overheidstaken. Zowel op geaggregeerde niveaus als op het niveau van de individuele voorziening of voorzieningensoort kan het feitelijke verloop van deze veranderingen worden getraceerd.

Achter de veranderingen in uitgavencijfers per voorziening gaan echter verschillende praktijken schuil, terwijl ook het kwaliteitsniveau van de desbetreffende produkten en diensten aan wijzigingen onderhevig is. Daarom geeft het kwantitatieve overzicht slechts indicatieve informatie. Op geaggregeerd niveau bieden de veranderingen in het niveau van de collectieve uitgaven gedifferentieerd naar het bestedende overheidsorgaan - inzicht in de verschuivingen die zich voordoen.

Figuur 6.1 Jaarlijkse groei van het nationaal inkomen en van de collectieve uitgaven, 1971 - 1990

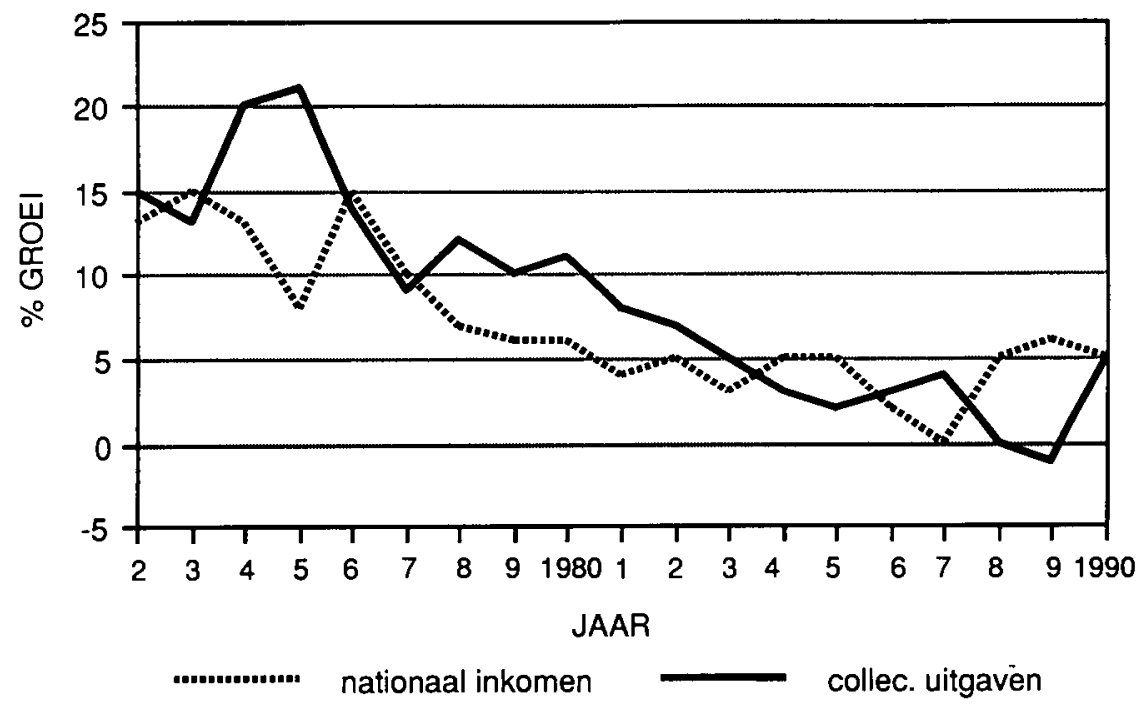


Tabel 6.1 Nationaal inkomen en overheidsuitgaven, 1971-1990, $x \mathrm{f}$ mld.

\begin{tabular}{|c|c|c|c|c|c|}
\hline Jaar & Nat. Ink. & Rijk & Or.Publr.L & Soc. Verz. & Coll. uitg \\
\hline 1971 & 125,1 & 17,6 & 24,0 & 21,0 & 62,6 \\
\hline 1972 & 141,7 & 19,1 & 28,0 & 24,9 & 72,0 \\
\hline 1973 & 162,6 & 20,1 & 32,1 & 29,0 & 81,2 \\
\hline 1974 & 184,2 & 25,0 & 37,5 & 34,8 & 97,3 \\
\hline 1975 & 199,9 & 31,6 & 44,7 & 41,7 & 118,0 \\
\hline 1976 & 229,6 & 35,5 & 50,9 & 47,7 & $134, \mid$ \\
\hline 1977 & 251,2 & 37,7 & 54,7 & 53,8 & 146,2 \\
\hline 1978 & 269,7 & 43,4 & 58,2 & 60,7 & 162,3 \\
\hline 1979 & 285,9 & 48,7 & 62,2 & 67,0 & 177,9 \\
\hline 1980 & 303,6 & 55,1 & 67,9 & 73,4 & 196,4 \\
\hline 1981 & 316,3 & 60,9 & 73,6 & 78,4 & 212,9 \\
\hline 1982 & 330,6 & 66,8 & 78,3 & 83,6 & 228,7 \\
\hline 1983 & 342,4 & 73,6 & 81,7 & 84,5 & 239,8 \\
\hline 1984 & 358,6 & 77,0 & 83,5 & 84,7 & 245,2 \\
\hline 1985 & 376,0 & 78,5 & 85,3 & 86,2 & 250,0 \\
\hline 1986 & 383,8 & 85,2 & 83,4 & 87,9 & 256,5 \\
\hline 1987 & 385,1 & 91,9 & 81,6 & 90,3 & 263,8 \\
\hline 1988 & 401,7 & 90,6 & 80,2 & 92,8 & 263,6 \\
\hline 1989 & 424,1 & 85,3 & 77,4 & 98,1 & 260,8 \\
\hline 1990 & 446,0 & 87,5 & 78,9 & 108,5 & 274,9 \\
\hline
\end{tabular}

Bron: Miljoenennota 1990, Tweede Kamer, Vergaderjaar 1989-1990, 21300 , nr. 1, blz. 368 (tabel 17.1)

Het aandeel van de collectieve uitgaven in het nationaal inkomen is na de Tweede Wereldoorlog sterk toegenomen (van ruim $37 \%$ in 1950 via $70,0 \%$ in 1983 naar $61,6 \%$ in 1990). Deze ontwikkeling kan worden verduidelijkt aan de hand van de verschillen in groei. Vanaf grofweg halverwege de jaren '70 stegen de collectieve uitgaven sterker dan het nationaal inkomen; vanaf 1983/1984 is de verhouding omgekeerd (zie figuur 6.1). In absolute cijfers is het nationaal inkomen in de laatste twee decennia verviervoudigd; in diezelfde periode zijn de collectieve uitgaven echter meer dan vervijfvoudigd. De uitgaven van het Rijk zijn in 1990 met een factor 5,5 gestegen ten opzichte van die in 1970; die van de sociale verzekeringen met een factor 6,2. De uitgaven van de lagere overheden zijn bijna verviervoudigd (zie tabel 6.1$)^{2}$. Men moet hierbij voor ogen houden dat de uitgaven worden toegerekend aan het publiekrechtelijk lichaam dat uiteindelijk de uitgaven verricht. Hieronder vallen veel rijkstaken met de uitvoering waarvan de gemeenten zijn belast. In de tweede helft van de jaren ' 80 werd het groeitempo teruggedrongen. Met name de daling van de uitgaven van de lagere overheden ('overige publiekrechtelijke lichamen'), waarvan de gemeentelijke uitgaven het grootste deel vormen, droeg hiertoe bij (zie tabel 6.2).

De vrijheid om de omvang en bestedingsrichting van hun uitgaven te bepalen, is voor de gemeenten echter sterker verminderd dan uit deze cijfers blijkt. $\mathrm{Na}$ de Tweede Wereldoorlog gingen zij immers steeds meer taken in opdracht van het Rijk behartigen.

2] De cijfers uit de Miljoenennota 1990 (Tweede Kamer, Vergaderjaar 1989-1990, 21 300, nr. I) zijn ontleend aan CBS- en CPB-gegevens. Deze rekenen de vitgaven toe aan het overheidsorgaan dat de gelden uiteindelijk besteedt. De cijfers kunnen zodoende niet eenduidig worden herleid tot die uit de Rijksbegroting. 
Tabel 6.2 Groei van het nationaal inkomen en van de collectieve uitgaven ten opzichte van het voorgaande jaar, 1972 - 1990, in procenten

\begin{tabular}{|c|c|c|c|c|c|}
\hline Jaar & Nat. Ink. & Rijk & Ov.Publr.L & Soc. Verz. & Coll. uitg. \\
\hline 1972 & 13,3 & 8,5 & 16,7 & 18,6 & 15,0 \\
\hline 1973 & 14,7 & 5,2 & 14,6 & 16,5 & 12,8 \\
\hline 1974 & 13,3 & 24,4 & 16,8 & 20,0 & 19,8 \\
\hline 1975 & 8,5 & 26,4 & 19,2 & 19,8 & 21,3 \\
\hline 1976 & 14,9 & 12,3 & 13,9 & 14,4 & 13,6 \\
\hline 1977 & 9,4 & 6,2 & 7,5 & 12,8 & 9,0 \\
\hline 1978 & 7,4 & 15.1 & 6,4 & 12,8 & 11,0 \\
\hline 1979 & 6,0 & 12,2 & 6,9 & 10,4 & 9,6 \\
\hline 1980 & 6,2 & 13.1 & 9,2 & 9,6 & 10,4 \\
\hline 1981 & 4,2 & 10,5 & 8.4 & 6.8 & 8.4 \\
\hline 1982 & 4,5 & 9,7 & 6,4 & 6,6 & 7.4 \\
\hline 1983 & 3,6 & 10,2 & 4,3 & 1,1 & 4,9 \\
\hline 1984 & 4,7 & 4,6 & 2,2 & 0,2 & 2,3 \\
\hline 1985 & 4,9 & 1,9 & 2,2 & 1,8 & 2.0 \\
\hline 1986 & 2,1 & 8,5 & $-2,2$ & 2,0 & 2,6 \\
\hline 1987 & 0,3 & 7.9 & $-2,2$ & 2,7 & 2,8 \\
\hline 1988 & 4,3 & $-1,4$ & $-1,7$ & 2,8 & $-0,1$ \\
\hline 1989 & 5,6 & $-5,8$ & $-3,5$ & 5,7 & $-1,1$ \\
\hline 1990 & 5,2 & 2,6 & 1.9 & 10,6 & 5,4 \\
\hline
\end{tabular}

Bron: Miljoenennota 1990, Tweede Kamer, Vergaderjaar 1989-1990, 21 300, nr. 1, blz. 368 (tabel 17.1).

De ombuiging van de collectieve uitgaven is - de voorziene stijging voor 1990 ten spijt - nog niet tot stilstand gekomen. Vrijwel alle relevante nationale en internationale taakstellingen wijzen op de noodzaak van een verdergaande beteugeling van de collectieve uitgaven in de komende periode ${ }^{3}$. Als gevolg van de ombuiging van het nationale macro-financiële beleidskader komen de gegroeide verhoudingen tussen het particuliere en het collectieve aandeel in de bekostiging van de lokale voorzieningen onder grote druk te staan ${ }^{4}$. Voor een deel vinden de veranderingen in de bekostiging van deze voorzieningen plaats buiten de invloedssfeer van het lokaal bestuur om, namelijk bij die voorzieningen waarvoor het Rijk een ongedeelde verantwoordelijkheid draagt, zoals in het geval van huursubsidies of bijstandsuitkeringen. Voor een ander deel werkt de macro-financiële ombuiging direct èn indirect door in de structuur van de gemeentelijke inkomsten, doordat het Rijk hier een zwaar stempel op drukt. In beide gevallen vormt de herijking van de verhouding tussen particuliere en publieke uitgaven in de komende periode een structureel vraagstuk voor de bekostiging van de stedelijke voorzieningen.

Terwijl dit structurele vraagstuk op nationaal niveau al geruime tijd centraal staat in de belangstelling, krijgt het in de sfeer van de gemeentefinanciën eigenlijk alleen aandacht voorzover de gevolgen van de macro-financiële ombuiging van collectieve naar particuliere uitgaven onevenredig op de gemeentefinanciën drukken. Ondanks hun aanzienlijke aandeel in de overheidsuitgaven dragen de gemeenten in dit structurele ombuigingsproces geen grote zelfstandige verantwoordelijkheid. In de praktijk gaat de overheersende

3] Deze trend tekende zich in de jaren ' 80 op internationaal niveau af. Zie voor een overzicht hiervan de Miljoenennota 1990 (op. cit.), blz. 370 .

4] Voorbeelden kunnen onder andere worden gevonden in de bekostiging van het basisonderwijs, in de aanpassing van de hoogte van de eigen bijdragen voor de gezinsverzorging, in de wijzigingen in de tabellen voor de individuele huursubsidie en in de verhoging van het huurwaardeforfait. 
aandacht uit naar de financiële verhoudingen binnen de publieke sector, en daarbinnen nog eens in enge zin toegespitst op de financiële verhoudingen tussen het Rijk en de gemeenten.

Deze blikvernauwing is mede te verklaren door een tweede lange-termijnontwikkeling die van structurele invloed is: de gemeenten zijn geleidelijk voor het grootste deel van hun inkomsten en uitgaven afhankelijk geworden van het Rijk. De centrale overheid heeft de gemeenten aan de ene kant voor steeds meer zaken in medebewind geroepen; aan de andere kant heeft zij gedurende de gehele eeuw de mogelijkheden voor de gemeenten beperkt om in eigen inkomsten te voorzien. De taakuitoefening van de gemeenten wordt grotendeels door het Rijk gesubsidieerd en de gemeentelijke uitgaven zijn - zoals het een subsidieverhouding betaamt - doorgaans aan nauwe condities onderworpen. In dit opzicht zijn de positie van gemeenten en de hiermee gepaard gaande bestuurscultuur vergelijkbaar met die van maatschappelijke groeperingen die van overheidswege worden gesubsidieerd. De afhankelijke financiële positie van de gemeenten ten opzichte van het Rijk vormt het tweede structurele vraagstuk dat moet worden bezien bij een analyse van de bekostiging van lokale voorzieningen.

De twee vraagstukken (de verhouding privaat - publiek en de verhouding publiek - publiek) zijn onderling nauw verweven. De financiële verhouding tussen het Rijk en de gemeenten vormt welbeschouwd een onderdeel van de verhouding tussen publieke en private financiering. Om de financiële positie van de steden (en die van het lokaal bestuur in het algemeen) te kunnen doorgronden is het nodig om de ontwikkelingen binnen de publieke financiële verhoudingen nader te bezien.

\subsubsection{De verhouding tussen het Rijk en de gemeenten}

Een financiële verhouding tussen publiekrechtelijke lichamen ontstaat wanneer verschillende overheidslagen zich met de produktie van diensten bezig houden en de fiscale bevoegdheden niet in dezelfde verhouding zijn verdeeld als de omvang van de budgetten ${ }^{5}$. Bij wet wordt bepaald welke belastingen door de besturen van provincies en gemeenten kunnen worden geheven en de wet regelt hun financiële verhouding tot het Rijk. Aldus zijn de gemeentelijke inkomsten door de Grondwet (art. 132, zesde lid) in een kader geplaatst. In het algemeen worden drie inkomstencategorieën van de gemeenten onderscheiden; in totaal ontvingen de gemeenten hieruit in 1989 ruim 48 miljard gulden ${ }^{6}$.

\section{a. Eigen inkomsten}

De eigen inkomsten vormden aanvankelijk de belangrijkste bron van de gemeentelijke inkomsten, maar zij zijn in de loop van deze eeuw stelselmatig teruggedrongen. Het laagste punt lag in 1970 . Sedertdien heeft weer enige verhoging plaats gevonden door de invoering van de onroerend-goedbelastingen (OGB) die thans het grootste deel van de eigen gemeentelijke inkomsten uitmaken. Door toedoen van de OGB is het aandeel van de eigen inkomsten in de totale inkomsten van de gemeenten weer wat gestegen tot bijna 10 procent in $1989^{?}$.

5] W. Bonnema en N.P. Mol, 'Financiële verhoudingen tussen overheden'; in: Macht en onmacht rond de rijksbegroting; Geschriften van de Vereniging voor Bestuurskunde; nr. 13, 's-Gravenhage, VUGA, 1990, blz. 95.

6] Bron: Miljoenennota 1990 (op. cit.), blz. 315 (tabel 8.2.1).

'] Berekend op grond van de Miljoenennota 1990 (op. cit.), blz. 315 (tabel 8.2.1). De 'eigen inkomsten' van de gemeenten bestaan uit het eigen belastinggebied (onroerend-goedbelastingen, hondenbelasting, woonforensenbelasting, toeristenbelasting, baaten aanlegbelasting en bouwgrondbelasting) en de heffingen en rechten (rioolrechten, reinigingsrechten, verontreinigingsheffing, leges, precariorechten, marktgelden, begraafrechten en parkeergelden). 
b. Algemene uitkering uit het Gemeentefonds

Het Gemeentefonds, dat in 1929 werd ingesteld, is van oorsprong een egalisatiefonds. Het beoogt de verschillende omvangs- en schaaleffecten, die gemeenten voor zeer verschillende structurele kosten kunnen plaatsen, te verevenen volgens objectieve grondslagen. De algemene uitkering uit het Gemeentefonds groeide de laatste decennia veel meer dan de eigen gemeentelijke inkomsten, maar minder hard dan de specifieke uitkeringen van het Rijk. Recentelijk neemt het relatieve aandeel van de algemene uitkering enigszins toe (ruim $27 \%$ in 1989 ).

\section{c. Specifieke uitkeringen}

Het kenmerkende van specifieke uitkeringen is dat het Rijk zowel de omvang als de bestedingsrichting van deze uitkeringen aan lagere overheden op voorhand heeft bepaald. Reeds in 1960, toen deze uitkeringen voor het eerst wat systematischer werden geregistreerd, vormden zij de belangrijkste inkomsten van de gemeenten ${ }^{8}$. Sindsdien is het relatieve aandeel gegroeid tot ruim 70 procent van de gemeentelijke inkomsten in 1984. Momenteel ligt hun aandeel in de gemeentelijke inkomsten op ongeveer 63 procent.

De functies van de drie inkomstencategorieën zijn zeer verschillend. Zij zijn door de wetgever in zijn toelichting op de ordening van de financiële verhouding tussen het Rijk en de lagere overheden verbonden met de gebruikelijke functionele indeling van de welvaartstheorie ${ }^{9}$. Daarin wordt een onderscheid gemaakt tussen de distributieve, de stabiliserende en de allocatieve functies van overheidsingrepen.

De distributieve functie betreft de herverdeling van inkomens en valt in hoofdzaak toe aan de centrale wetgever. Binnen de geldende verhoudingen mogen de gemeenten in ons land geen eigen inkomensbeleid voeren. De stabiliserende functie (de macro-economische beheersing) zal in verband met de mogelijke weglekeffecten eveneens voor een groot deel op centraal niveau gestalte moeten krijgen. De derde functie daarentegen - de allocatie van de produktiemiddelen - kan het best door de lagere overheden uitgeoefend worden, omdat op dit schaalniveau meer bekend is over de bijzonderheden van de vraagzijde van de voorzieningen en omdat zo de meest doelmatige uitvoering kan worden verkregen.

Wat betreft de motivering van de verhouding tussen de inkomstenbronnen van de gemeenten, heeft de wetgever zijn normatieve uitgangspunt nadrukkelijk bij de decentrale allocatieve functie gelegd, waarvoor de afweging van de risico's primair op lokaal niveau komt te liggen. Voorzover dit uitgangspunt niet expliciet wordt beperkt door de bovengenoemde kenmerken met betrekking tot de distributieve en macro-economische beheersingsfuncties van beleid, dient bij de voortbrenging van overheidsvoorzieningen de afweging tussen nut en offer zo direct mogelijk te kunnen plaatsvinden. Dit is het primaire beginsel in de ordening van de financiële verhouding tussen het Rijk en de gemeenten. De grenzen van de werking van dit uitgangspunt worden bepaald door het beleid dat de bovengenoemde distributieve en economisch stabiliserende functies dient.

\section{De eigen inkomsten}

Bezien we tegen deze normatieve achtergrond van de Financiële-Verhoudingswet 1984 (FVW) de drie inkomstenbronnen van de gemeenten, dan valt de eerste aandacht op de eigen gemeentelijke inkomsten. Het niveau hiervan kan

9] Een uitgebreide analyse is opgenomen in een publikatie van de Raad voor de Gemeentefinanciën, No een collier de misère: gelijkwoardigheid; 's-Gravenhage, VNG, 1986. Ook het verslag van het gelijknamige symposium van 5 november 1986 is hierin opgenomen.

9] Memorie van Toelichting bij de Financiële-Verhoudingswet 1984, Wet van 22 december 1983, Stb. 1983, 650. 
door de gemeenten binnen wettelijke beperkingen zelf worden bepaald, zodat het hieruit voortvloeiende aanbod van voorzieningen plaatselijk kan variëren. $\mathrm{Bij}$ de gemeentelijke heffingen - gering van omvang in ons land maar internationaal sterk in opmars - kan in beginsel een direct verband bestaan tussen het niveau van de voorziening en de kosten die hiervoor aan burgers en bedrijven in rekening worden gebracht. Bij lokale belastingen die naar de algemene gemeentebegroting toevloeien, is de directe afweging tussen nut en offer reeds geringer. Met name op de omvangrijke begrotingen van grote gemeenten bestaat geen rechtstreeks verband meer tussen de bekostiging van afzonderlijke additionele voorzieningen en de lokale belastingheffingen. Niettemin moet het plaatselijk bestuur ook in deze gevallen rekenschap geven voor eventuele aanvullende heffingen. Naast dit allocatieve kenmerk is van wezenlijk belang dat de categorie van de 'eigen inkomsten' aan het lokaal bestuur en aan de lokale partijen een direct belang geeft om de bronnen waaruit belasting kan worden geheven, op peil te houden.

\section{De algemene uitkering}

Bij de algemene uitkering uit het Gemeentefonds raakt de directe afweging van nut en offer verder uit het zicht. Dit geldt niet zozeer voor de beleidsafwegingen die bij de bestemming van deze geldmiddelen gemaakt moeten worden, maar voor de wijze waarop de gemeenten deze omvangrijke categorie van inkomsten verwerven. $\mathrm{Zij}$ hoeven zich hierbij niet rechtstreeks te verantwoorden tegenover de belastingbetalers, maar zij krijgen deze geldmiddelen volgens een bepaalde verdelingssystematiek van het Rijk. Het Rijk bepaalt de omvang van deze geldmiddelen en ook de bestemmingsmogelijkheden zijn minder vrij dan die van de eigen inkomsten. Het egalisatiemotief van het Gemeentefonds dient ter compensatie voor gemeenten die met niet te beïnvloeden kostenfactoren te kampen hebben. Deze verevening kan de allocatie nog wel in die zin ten goede komen, dat de gemeenten niet door onbeïnvloedbare omstandigheden tot zeer verschillende heffingen en voorzieningen worden gedwongen. Omdat de ongelijkheden tussen de gemeenten bijzonder groot waren geworden, was dit destijds een van de belangrijke gronden voor de invoering van het Gemeentefonds.

Dit egalisatiemotief is nog steeds springlevend en is in de loop van de tijd zelfs veel zwaarder gaan wegen dan de motivering voor de eigen gemeentelijke inkomsten. Het totale volume van de algemene uitkering is inmiddels ruim tweemaal zo groot als het totaal van de eigen gemeentelijke inkomsten. Als belangrijkste reden werd hiervoor (naast de bovengenoemde ongelijkheid) voortdurend aangevoerd dat in een klein land geen grote lokale verschillen in heffingen en voorzieningen kunnen worden getolereerd, omdat het bestaan van plaatselijke 'belastingoases' al snel tot ongewenste ruimtelijke effecten zou voeren ${ }^{10}$. In de verhouding tussen de grote steden en de kernen in de stedelijke omgeving met hun contrasterende bevolkingskenmerken en behoeftepatronen zijn zulke ruimtelijke verschillen al gauw zichtbaar (met de zogenaamde 'spill-overs' waardoor de bewoners en bedrijven uit de omgeving profiteren van de voorzieningen van de centrale stad). Om deze reden wordt de centrumfunctie van de steden verrekend in de verdelingssystematiek van de algemene uitkering aan de gemeenten.

Vanuit allocatief oogpunt zijn de nadelen van de algemene uitkering ten opzichte van de eigen inkomsten echter niet minder manifest. In de eerste plaats verzwakt de verhouding tussen omvangrijke algemene uitkering en

$\left.{ }^{10}\right]$ Zie bijvoorbeeld het rapport van de Commissie Oud, Ropport betreffende een regeling van de financiële verhouding tussen het Rijk en de gemeenten voor 1958 en volgende jaren; 's-Gravenhage, Staatsdrukkerij, 1956. Zie ook: C. Goedhart, 'Naar een algemene theorie van de financiële verhouding'; opgenomen in: Openbare financiën in drievoud, opstellen aangeboden aan prof.dr. Th.A. Stevers; Zutphen, Thieme, 1989. 
geringe eigen inkomsten de gemeentelijke verantwoordelijkheid en dynamiek. Het bestaan van algemene uitkering is op zichzelf uiteraard te billijken met het oog op de verevening van niet te beïnvloeden plaatselijke verschillen in belastingcapaciteit, maar er zijn ook verschillen in belastingcapaciteit tussen gemeenten die wel zijn te beïnvloeden en die juist een prikkel zouden moeten inhouden voor het voeren van plaatselijk beleid gericht op het op peil te houden van de belastingcapaciteit (i.c. de sterkte van bedrijven en inwoners). Bij de huidige verhoudingen, volgens welke het niveau van de algemene uitkering ver uitstijgt boven de eigen gemeentelijke inkomsten, hoeven de gemeenten zich voor hun inkomstenbronnen slechts weinig waar te maken en hoeven de partijen in de stad die werven om de besteding van de algemene gemeentelijke geldmiddelen, zich - voorzover het deze bron van inkomsten betreft - niet te bekommeren om de hand die hen uiteindelijk voedt. De primaire zorg voor de gemeenten is hierbij slechts dat het Rijk de algemene uitkering op peil houdt en voor de aanwending van deze geldmiddelen zo weinig mogelijk nadere richtlijnen stelt.

Voor de verhouding tussen de gemeenten onderling (niet onbetekenend voor de afwijkende positie van de grote steden) komt hier nog de permanente aandacht bij voor de verdelingsmaatstaven van de algemene uitkering. Aldus zijn voor het op peil houden van de algemene uitkering de ogen gericht op het Rijk in plaats van op de ontwikkeling van de plaatselijke economische en sociale structuren.

Een tweede nadeel van voornoemde afhankelijkheid is dat het Rijk het volume en het jaarlijkse accres bepaalt van de algemene uitkering en hierdoor een belangrijke invloed heeft op het algemene niveau van de lokale voorzieningen. (Het Gemeentefonds is weliswaar een zelfstandig fonds en oorspronkelijk werden de middelen van dit fonds zelfs beschouwd als gemeentemiddelen, waarbij het Rijk alleen als intermediair optrad om een egalisatie tussen gemeenten te bevorderen, maar tegenwoordig wordt de algemene uitkering uit dit fonds beschouwd als reguliere rijksuitgaven.) Sinds op de algemene uitkering van het Gemeentefonds bezuinigingen werden doorgevoerd, trachten de gemeenten via bestuursakkoorden tegenspel te bieden. Voorts gaan stemmen op om de groei van het Gemeentefonds aan een vaste ratio te verbinden, zoals bijvoorbeeld de groei van het nationale inkomen ${ }^{11}$. Niettemin werden op het Gemeentefonds in de jaren '80 aanzienlijke bezuinigingen doorgevoerd. In 1990 reikt het accres voor het eerst in acht jaar weer uit boven de ombuigingen die op het Gemeentefonds werden doorgevoerd.

Tenslotte wordt ook de versleuteling van de algemene uitkeringen over de gemeenten door de wetgever bepaald. Volgens de FVW 1984 worden de grote steden in dit opzicht overigens relatief gunstig behandeld met een uitschieter naar boven voor Amsterdam ${ }^{12}$. Niettemin rekent de hoofdstad op de algemene uitkering een cumulatieve bezuiniging voor van ongeveer 180 miljoen gulden in de periode van 1982 tot 1989.

I] A.G.J. Haselbekke en A.P. Ros, Een nieuwe norm voor het gemeentefonds; Rotterdam, Erasmus Universiteit, 1989. Hierover heeft een verdergaande discussie plaats gevonden in het tijdschrift Openbore Uitgoven gedurende 1989 en 1990, laatstelijk in het maartnummer van 1990.

12] Door een versterking van de maatstaf 'woonruimte' en de terugdringing van de maatstaf 'aantal inwoners' kwam een herverdeling van de algemene uitkeringen tot stand, die zeer gunstig is voor de grotere steden (de vier grote steden samen hadden in tien jaar tijd 400.000 inwoners verloren). Tevens werden twee nieuwe bebouwingsmaatstaven ingevoerd die ook gunstig zijn voor de steden. Tenslotte werden de vier grote steden bij de zwaarwegende verdeelmaatstaf 'woonruimten' op aparte wijze ingeschaald. Wanneer de herverdelingsoperatie in 1993 is afgerond, zullen volgens deze opzet de vier grote steden structureel 3.65 procent meer inkomsten krijgen. Inmiddels is in 1985 weer een nuancering in deze opzet aangebracht. Amsterdam valt nu in een aparte schaal die het hoogst is. De andere drie grote steden vallen gezamenlijk in een andere schaal die hoger is dan de schaal van de overige gemeenten, maar aanzienlijk lager dan de schaal voor Amsterdam. Deze drie steden ontvangen nog een extra compensatie voor het verschil met Amsterdam. Voor Rotterdam loopt deze op tot $f 33$ miljoen in 1993. 
In de derde plaats zijn de gemeenten niet geheel vrij om de middelen uit het Gemeentefonds naar eigen inzicht te besteden, al bestaat in beginsel wel een grote bewegingsruimte. De algemene uitkering is bedoeld als tegemoetkoming in de kosten van de gemeentelijke huishouding, teneinde deze 'in redelijkheid' te kunnen voeren. Daarnaast stelt het fonds de gemeenten in staat om uitgaven te verrichten in het landsbelang. De algemene uitkering komt derhalve tegemoet zowel aan de autonome gemeentetaken als aan de taken in opdracht van hoger bestuur. Het gaat hier om een fragiele verhouding waarvan de feitelijke ontwikkeling in de jaren ' 80 hierna aan de orde komt.

\section{De specifieke uitkeringen}

Bij de specifieke uitkeringen bestaat geen verband meer met de allocatiefunctie. Er is geen ruimte voor afweging tegenover andere gemeentelijke uitgaven - zowel de herkomst van deze middelen, als de omvang en de bestedingsrichting worden vooraf bepaald door het Rijk. Het grote aandeel van de specifieke uitkeringen in de inkomsten van de gemeenten kan slechts ten dele verklaard worden uit de distributieve en de macro-economische beheersingsfuncties van deze uitkeringen. De groei hiervan verliep ongeordend; zij werd voortgestuwd door doelgerichte beleidsactiviteiten uit alle hoeken van de rijksdienst. De Financiële-Verhoudingswet van 1960 betrof niet de specifieke uitkeringen en besloeg derhalve slechts een derde van de geldstromen van het Rijk naar de gemeenten ${ }^{13}$. In de FVW 1984 en in de Gemeentewet zijn nu enige bepalingen opgenomen die beogen het aantal en de omvang van de specifieke uitkeringen te beperken.

Terugblikkend op het patroon van de gemeentelijke inkomsten kan geconstateerd worden dat de financiële verhouding tussen het Rijk en de gemeenten in de praktijk aanzienlijk afwijkt van de normatieve uitgangspunten die de wetgever bij de herziening van de FVW 1984 heeft gesteld. Weliswaar bieden de distributieve en macro-economische beheersingskenmerken van het beleid een zekere verklaringsgrond, maar de tegenstelling is wel erg groot. Slechts voor 10 procent van de gemeentelijke inkomsten wordt het principiële belang dat de wetgever aan de decentrale allocatiefunctie toekende, in de praktijk gebracht.

De uitgangspunten die bij de herziening van de Financiële-Verhoudingswet in 1984 werden gekozen, houden derhalve een opdracht in waarop beleid moet worden gevoerd. De precieze afbakening tussen de verschillende bronnen van gemeentelijke inkomsten zal altijd arbitrair blijven, ook wanneer de wetgever zulke duidelijke uitgangspunten heeft bepaald als in de FVW 1984, omdat bij de vele bronnen van inkomsten bijzondere overwegingen in aanmerking moeten worden genomen. Maar wanneer de verschillen tussen de beoogde en de feitelijke ontwikkeling van de financiële verhouding tussen het Rijk en de gemeenten zo groot zijn, kan over de te volgen koers geen misverstand bestaan.

In dit verband zijn twee beleidsoperaties vermeldenswaard.

De eerste operatie heeft betrekking op de sanering van specifieke uitkeringen. Deze operatie kwam op gang nadat de Raad voor de Gemeentefinanciën (RGF) in een geruchtmakende publikatie de dominantie van de specifieke uitkeringen in de gemeentelijke inkomsten aan de kaak had gesteld ${ }^{14}$. Sinds 1982 is het aantal specifieke uitkeringen ruimschoots gehalveerd van 514 tot slechts 243 in 1989 . In 1990 zou dit aantal tot 202 moeten zijn teruggebracht ${ }^{15}$. Maar in dezelfde periode is het totale bedrag dat met deze uitkeringen is gemoeid,

${ }^{13}$ ] J.W. van der Dussen, 'Vijfenzeventig jaar financiële verhouding rijk - gemeenten'; Economische Statistische Berichten, 27 mei 1987, jaargang 72, nr. 3607, blz. 497-500.

14] Raad voor de Gemeentefinanciēn, Heiligt het doel alle middelen? 's-Gravenhage, VNG, $198 \mathrm{I}$.

15] Miljoenennota 1990 (op. cit), blz. 321. 
niet navenant gedaald ${ }^{16}$. De reden voor deze ogenschijnlijke tegenspraak is dat het massieve gewicht van de specifieke uitkeringen wordt veroorzaakt door een klein aantal uitkeringen van bijzonder grote omvang. Reeds wanneer men de bijstandsuitkeringen niet zou meerekenen, komt het totaalbedrag van de specifieke uitkeringen in de buurt van het bedrag van de algemene uitkeringen. Hoewel veel kleine specifieke uitkeringen zijn verdwenen, is vooralsnog vanuit het oogpunt van de financiële verhouding dan ook geen sprake van een majeure operatie.

Het is opmerkelijk dat de RGF - de inspirator van de saneringsoperatie - geen grote ruimte ziet voor een overheveling van de dertig grootste specifieke uitkeringen (die samen $90 \%$ van het totaalbedrag van de specifieke uitkeringen vormen) en adviseert om de energie van de operatie te richten op de resterende kleine uitkeringen. Een belangrijke overweging is hierbij dat overheveling van de grote specifieke uitkeringen naar het Gemeentefonds (in de meeste gevallen de door het Rijk gekozen route) de gemeenten voor onbeïnvloedbare uitgaven zou kunnen plaatsen, waardoor onafwendbare kostenontwikkelingen niet meer binnen een sluitende begroting kunnen worden opgevangen ${ }^{17}$.

Hoewel de algemene uitkering in beginsel een grotere bestemmingsvrijheid aan de gemeenten laten dan de specifieke uitkeringen, leidt overheveling van specifieke uitkeringen naar het Gemeentefonds niet vanzelf tot een grotere bestemmingsvrijheid. Het hangt ervan af of de gemeenten de betreffende uitgaven kunnen beïnvloeden. In de praktijk kunnen de beleidsmarges zelfs kleiner worden, wanneer de gemeenten niet zelf voorwaarden kunnen stellen voor de desbetreffende voorzieningen. Als het gaat om uitgaven die de gemeenten moeten doen voor de uitvoering van rijksbeleid, kan de financiering daarom beter via specifieke uitkeringen van het Rijk blijven lopen. Maar als het gebruik van voorzieningen wel van gemeentewege beleidsmatig beïnvloed en gedifferentieerd kan worden, is het wenselijk hen tenminste voor een deel ook in financiële zin verantwoordelijkheid te laten dragen. In dit verband kan worden verwezen naar de opmerkingen die in hoofdstuk 4 zijn gemaakt over het eigen aandeel van 10 procent in de bekostiging van de bijstandsuitkeringen en over een eventueel aandeel van de gemeenten in de bekostiging van de individuele huursubsidies (IHS). Het betreft hier weliswaar centrale regelingen, waarvan het uitkeringsniveau op nationaal niveau wordt bepaald, maar op grond van andere beleidscompetenties (huisvesting, ruimtelijke ordening, sociaal en economisch beleid, voorzieningenbeleid, enz.) kan het lokaal bestuur het aantal mensen dat voor zulke uitkeringen in aanmerking komt (het aantal in- en uitstromers), terdege beïnvloeden. In het toerekenen van (een deel van) deze specifieke uitkeringen aan het lokaal bestuur - of zonodig een verhoging hiervan - ligt derhalve een prikkel besloten om de sociale structuur van de gemeente niet te onevenwichtig te laten worden en vanuit de eigen beleidsverantwoordelijkheden te bevorderen dat binnen het eigen gebied minder mensen van de sociale uitkeringen en subsidies afhankelijk zijn. De samenhang tussen de beleidsinhoudelijke en de financiële marges van het beleid kan nauwelijks treffender worden geillustreerd.

De tweede beleidsoperatie die hier aandacht verdient, heeft betrekking op de verruiming van de eigen inkomsten van de gemeenten. In dit verband is het beleid van belang dat in het verlengde ligt van de aanbevelingen van de Commissie Christiaanse uit $1983^{18}$. Deze commissie zag af van de mogelijkheden

16] Beheerscommissie Gegevensbestand specifieke uitkeringen, Overzicht specifieke uitkeringen 1989; 's-Gravenhage, Ministerie van Binnenlandse Zaken, 1989, blz. 6-7.

17] Brief van 10 februari 1988 (nr. 134/100) van de Raad voor de Gemeentefinanciën aan de Staatssecretarissen van Binnenlandse Zaken en van Financiën over de sanering van de specifieke uitkeringen.

18] Rapport inzake de herziening van het belastinggebied van provincies en gemeenten; 's-Gravenhage, Staatsuitgeverij, 1983. 
om de profijtheffingen van de gemeenten te verhogen (prijzen en bijdragen voor gemeentevoorzieningen) vanwege de druk die op dat moment reeds werd uitgeoefend op deze categorie van gemeentelijke inkomsten. Het aandeel van de lokale belastingen zou volgens de commissie wel kunnen groeien (in beginsel zelfs tot boven het aandeel van de algemene uitkering!). Voorshands beperkte de commissie haar aanbevelingen tot een verdubbeling van de lokale belastingen door verhoging van de onroerend-goedbelasting (voor de lokale inkomsten te neutraliseren door verlaging van de algemene uitkeringen). Voor de gemeenten kwam dit voorstel neer op een vermindering van de algemene uitkeringen die gecompenseerd moest worden door extra eigen fiscale inspanningen. Van gemeentewege werd aangetekend dat de lokale beleidsvrijheid door de beoogde verschuiving van inkomstencategorieën nauwelijks zou worden vergroot. In het kader van dit advies wordt hierbij aangetekend dat de betekenis van dit beleidsperspectief niet alleen beoordeeld moet worden naar de mate van een grotere beleidsvrijheid van de gemeenten om geldmiddelen te besteden, maar ook naar een grotere lokale verantwoordelijkheid voor de afweging tussen heffingen en voorzieningen. Overigens is de profijtgedachte enige jaren later door het Rijk opnieuw geintroduceerd, in de zogenaamde profijtkortingen op de algemene uitkering uit het Gemeentefonds, waarop de gemeenten met enige vertraging hebben gereageerd.

$\mathrm{Bij}$ de beleidsoperatie ter vergroting van het lokale belastinggebied is als gezegd de aandacht geconcentreerd op de verruiming van de OGB. De onroerend-goedbelasting is een impopulaire belasting waarvan de inning veel onbegrip wekt. Het aantal beroepsprocedures is bij de relatief kleine OGB tienmaal groter dan bij de zware inkomstenbelasting. De OGB bestaan uit de zakelijkgerechtigdenbelasting en uit de gebruikersbelasting. Met name de laatste belasting kan volgens de grote steden beter worden afgeschaft, want zij leidt in de praktijk tot grote (innings)problemen ${ }^{19}$. Na de recente wetswijziging is de OGB niet meer aan een wettelijke limiet gebonden, maar zijn het zakelijk tarief en de gebruikersheffing aan elkaar gekoppeld ${ }^{20}$. Vanaf 1993 mag het zakelijke tarief slechts 25 procent boven de gebruikersheffing uitstijgen; tot dat moment krijgen de gemeenten de gelegenheid de geldende tarieven in overeenstemming met deze norm te brengen. In Amsterdam was het zakelijk tarief de afgelopen jaren ongeveer 200 procent hoger dan het gebruikerstarief ${ }^{21}$. Voor gemeenten die de weinig draagkrachtige gebruikers tot dusverre hebben ontzien door middel van een laag gebruikerstarief, zou aan een eventuele verhoging van de eigen inkomsten uit OGB een zeer ingrijpende inhaaloperatie jegens deze bewoners vooraf moeten gaan. Op grond hiervan kan worden verwacht dat het verwijderen van de OGB-limiet niet snel tot excessieve belastingverhogingen zal leiden. Zo laat men in Amsterdam vooralsnog niet het gebruikerstarief stijgen, maar het zakelijke tarief dalen.

Uit het voorgaande kan de conclusie worden getrokken dat de in de praktijk gegroeide financiële verhouding tussen het Rijk en de gemeenten afwijkt van de leidraad die in dit advies ten aanzien van de financiële verhouding wordt gehanteerd. Verder is gebleken dat de beleidsoperaties die zijn opgezet om deze afstand te verkleinen (waaronder de sanering van de specifieke uitkeringen en de verruiming van de eigen gemeentelijke inkomsten), op zware barrières zijn gestoten. Deze kloof is in de afgelopen periode niet structureel kleiner geworden.

19] Gemeente Amsterdam, 'Commentaar op het rapport van de commissie Christiaanse inzake uitbreiding van het gemeentelijk belastinggebied'; Gemeenteblad 1984, bijlage D.

${ }^{20}$ ] Wet van 3 juli 1989; Stb. 1989, 302.

21] Bron: Amsterdam in cijfers; Jaarboek 1989; Amsterdam. Amsterdams Bureau voor Onderzoek en Statistiek, 1990, blz. 190 (tabel 11.4.2). Afgemeten an de voorheen geldende limieten had de gemeente Amsterdam door het lage gebruikerstarief een inkomsten'derving' van ongeveer 110 miljoen. 


\subsubsection{Trends in gemeentelijke uitgaven}

De beteugeling van de collectieve uitgaven in het macro-financiële kader heeft een grote invloed uitgeoefend op het financieel beleid van de gemeenten. Voor een inzicht in het feitelijk verloop van de gemeentelijke inkomsten en uitgaven is het niet alleen nodig om de omvang en de herkomst van de verschillende inkomstenbronnen te kennen, maar is het ook weer van belang na te gaan in hoeverre de gemeenten zelf de bestemming van de geldmiddelen kunnen bepalen. Een groot deel van de uitgaven van de gemeenten is immers autonoom in die zin dat de gemeente de desbetreffende eigen uitgaven niet of nauwelijks kan beïnvloeden.

Het gemeentelijke uitgavenpatroon ligt niet zonder meer in het verlengde van de principiële functies die hierboven bij de gemeentelijke inkomstenstructuur werden aangegeven. Feitelijk zijn ook hier beginsel en praktijk in de jaren ' 80 zelfs verder uit elkaar gegroeid.

In beginsel kunnen de gemeenten de eigen inkomsten vrij besteden. Ook de algemene uitkeringen kunnen in principe grotendeels naar bevind van zaken worden besteed. Slechts de specifieke uitkeringen van het Rijk zijn vooraf gekoppeld aan een bepaald doel. Als gevolg van de macro-financiële ombuigingen in de jaren ' 80 pakten deze beginselen in de praktijk echter anders uit.

a. De groei van de omvang van de specifieke uitkeringen werd beteugeld. De discussie over de vraag of de gekorte specifieke uitkeringen nog wel toereikend waren voor de effectuering van de voorzieningen die door het Rijk van de gemeenten werden verlangd, dan wel - andersom - dat de gemeenten een hoger niveau van voorzieningen nastreefden dan binnen het kader van de specifieke uitkeringen mogelijk was, heeft menige onderhandeling tussen het Rijk en de gemeenten gevoed. Wat hiervan zij, in de praktijk bleken de specifieke uitkeringen in toenemende mate ontoereikend om de kosten van de bedoelde voorzieningen te dekken.

b. De algemene uitkering moest hierdoor in hogere mate de tekorten van de specifieke uitkeringen opvangen. Maar ook op de algemene uitkering drukten de budgettaire heroverwegingen. Nadat op het accres van het Gemeente- en het Provinciefonds een aantal keren naar verhouding meer was omgebogen dan op de eigen uitgaven van het Rijk, moesten tussen het Rijk en de lagere overheden afspraken worden gemaakt over de 'evenredigheid' van de ombuigingen. Voorts werden door het Rijk van 1983 tot en met 1986 profijtkortingen op het Gemeentefonds toegepast. De gemeenten moesten hiervoor compensatie zien te vinden door de verhoging van de tarieven van de plaatselijke voorzieningen. Voor de vier grote steden samen waren deze kortingen in 1986 opgelopen tot 100 miljoen gulden ${ }^{22}$. Bij de inkomsten uit het tariefbeleid van de gemeentelijke bedrijven speelden in sommige gevallen problemen met de invordering, die de financiële weerbaarheid hebben uitgehold. Inmiddels lijken de grootste problemen hiermee opgelost te zijn. Verder werd de bestemmingsvrijheid van de algemene uitkeringen feitelijk beperkt doordat medebewindstaken gedeeltelijk of geheel uit de algemene uitkering moesten worden bekostigd. Een bekend voorbeeld is het gemeentelijk aandeel van 10 procent in de bijstandsuitkeringen. Tenslotte vinden veel toevoegingen en onttrekkingen aan de omvang van het Gemeentefonds plaats door wijzigingen van het Rijk in het gemeentelijk takenpakket. In de praktijk raakte de vrije bestemming van de algemene uitkering derhalve steeds verder ingesnoerd.

c. Door de ontwikkelingen van de specifieke en de algemene uitkering nam tenslotte ook de druk toe op de bestemmingsmogelijkheden van de eigen inkomsten van de gemeenten. Zelfs van deze inkomstenbron werden de vrije bestemmingsmogelijkheden voor de gemeenten beperkt. 
Aldus schoven de verschillende gemeentelijke inkomstenbronnen (in tegenstelling tot de beginselen) in elkaar. Het aandeel van de verplichte gemeentelijke uitgaven nam toe, de bewegingsruimte voor zelfstandig gemeentelijk beleid versmalde. Doordat de gemeenten nauwelijks bezuinigingen konden doorvoeren op de medebewindstaken, drukten de kortingen extra op de aanvullende of zelfstandige taken. Tegen deze achtergrond wordt duidelijk waarom de herallocaties binnen de gemeentebegrotingen in de jaren ' 80 soms zo'n onwaarschijnlijk verloop kregen. De ombuigingen van de gemeenten raakten immers geconcentreerd op de resterende 'vrije' beleidsruimte.

De bovengenoemde ontwikkelingen worden bevestigd door empirisch onderzoek. Zo komt uit een onderzoek van de Vereniging van Nederlandse Gemeenten naar voren dat de ombuigingstaken in het algemeen zwaarder blijken te wegen naarmate de gemeenten groter zijn ${ }^{23}$. In het algemeen hebben de gemeenten vooral de uitgaven verlaagd en niet zozeer de eigen inkomsten verhoogd. Opvallend is dat ondanks de druk op de gemeentefinanciën de theoretische 'profijtruimte' aanvankelijk niet optimaal werd benut. Hiervoor wordt in de VNG-studie als argument aangevoerd dat bij de gemeenten kennelijk een grote aarzeling bestaat voor tariefverhogingen in verband met de inkomenseffecten. Uit herhalingsonderzoek vier jaar later is gebleken dat de 'profijtruimte' inmiddels is afgenomen doordat de gemeenten geleidelijk tariefverhogingen hebben doorgevoerd en in veel gevallen de kosten van de voorzieningen hebben gedrukt door efficiency-maatregelen ${ }^{24}$. Ook uit de recente evaluatie blijkt echter dat de gemeenten eerder geneigd zijn om de druk op hun begroting op te vangen in de sfeer van uitgavenvermindering dan door de verwerving van extra inkomsten uit heffingen of lokale belastingen. Hierin ligt een expliciete keuze besloten voor een bepaalde vorm van sociaal beleid. Kennelijk laat men de inkomenseffecten zo zwaar wegen dat het achterblijven van de benodigde gemeentelijke investeringen op de koop toe wordt genomen.

De ombuigingen werden in de periode 1982-1986 vooral gerealiseerd door besparingen op het eigen gemeentelijk apparaat, door algemene kortingen op de beïnvloedbare uitgaven, door personeelsvermindering en door het afzien van investeringen. Nader onderzoek van de VNG en het Instituut voor Onderzoek van Overheidsuitgaven (IOO) biedt een meer naar uitgaven gespecificeerd beeld van de gemeentelijke ombuigingen in het midden van de jaren ' 80 . De opvallendste bezuinigingen vinden plaats op het gebied van cultuur en recreatie, de financieringsmiddelen, het algemeen beheer, onderwijs en infrastructuur. Veelal werd bezuinigd op de kwaliteit en op de exploitatie (bijvoorbeeld in de sfeer van het onderhoud) van gemeentelijke diensten en voorzieningen. Beëindiging van gemeentetaken heeft niet op grote schaal plaats gevonden. Uit deze gegevens blijkt hoezeer de herallocatie van de gemeentelijke uitgaven wordt beïnvloed door de mate waarin de gemeenten over een vrije bestemmingsruimte beschikken. De mogelijke verhoging van de eigen inkomsten wordt slechts aarzelend in deze afwegingen betrokken. De gemeentelijke ombuigingen moeten hierdoor vooral gerealiseerd worden in uitgaven die in het totaal van de gemeentelijke uitgaven van relatief geringe omvang zijn, maar binnen de beperkte ruimte van de door de gemeente te beïnvloeden uitgaven wel een zwaar gewicht dragen! Op het onderhoud van wegen, straten en pleinen, op groenbeheer, op cultuur en recreatie, maar ook op de apparaatskosten, de investeringen en de overige zelfstandige uitgaven is meer omgebogen dan men op grond van de relatieve positie van deze uitgaven binnen de gemeentebegroting zou verwachten. Ook uit andere publikaties blijkt hoezeer de

${ }^{23}$ ] Vereniging van Nederlandse Gemeenten, Gemeentelijke heroverwegingen; 's-Gravenhage, VNG, 1986. Zie ook Bank voor Nederlandsche Gemeenten, Gevolgen van gemeentelijke ombuigingen; 's-Gravenhage, VNG, 1986.

${ }^{24}$ ] Vereniging van Nederlandse Gemeenten, sectie SGBO, Gemeentelijke heroverwegingen, een evoluotie von de grote operoties op lokool niveou; VNG, 's-Gravenhage, 1990, blz. 100. 
netto-uitgaven van het Rijk en de gemeente verschillen. De vrije bestedingsruimte van de gemeente zou voornamelijk betrekking hebben op de 'zachte' voorzieningen (cultuur en recreatie, algemeen bestuur en sociale voorzieningen). Hierbinnen is onevenredig veel omgebogen ${ }^{25}$. Uit recenter materiaal blijkt dat de financiële positie van de gemeenten door de opleving van de economische conjunctuur minder nijpend is geworden. In het patroon van de plaatselijke herallocaties wordt echter in het algemeen geen grote afwijking gesignaleerd van het bovengeschetste beeld.

De evolutie van de Gemeentelijke Sociale Diensten geeft een illustratie van de metamorfose van de lokale dienstverlening als gevolg van de financiële ombuigingen in de jaren '80. Doordat de hoogte van de bijstandsuitkeringen centraal wordt vastgesteld (met als gezegd een eigen financiële verantwoordelijkheid van de gemeenten van $10 \%$ via de middelen uit het Gemeentefonds) kon niet worden bezuinigd op het niveau hiervan. Slechts de apparaatskosten (vooral de personeelsformatie) bieden in theorie financiële manoeuvreerruimte. In de praktijk moest het personeel echter worden uitgebreid vanwege de toename van het aantal uitkeringsgerechtigden (vooral tussen 1980 en 1983; in de grote steden is het aantal sindsdien ongeveer op dit zeer hoge niveau blijven steken) en vanwege de bewerkelijke stelselaanpassingen. De uitvoeringskosten van de Gemeentelijke Sociale Diensten vormden in deze periode dan ook vrijwel overal de enige echte groeier in het gemeente-apparaat, hetgeen echter niet voorkwam dat, bij een explosief toegenomen werkdruk, achterstanden ontstonden, ad-hoc verbanden werden gelegd en de kwaliteit van de dienstverlening zienderogen daalde. De volgende stap voerde onvermijdelijk naar een vervanging van de vakinhoudelijke dienstverlening door produkt-georiënteerd management. Als gevolg hiervan werden de uitkeringen wel efficiënter verstrekt, maar raakte de (arbeidsintensieve) bevordering van de uitstroom van de uitkeringsgerechtigden achterop. Eerst onlangs is in deze situatie door samenwerking met de arbeidsbureaus en - afzonderlijk door het Rijk gefinancierde - heroriënteringsgesprekken enige verbetering gekomen, maar van een omvangrijke uitstroom is in de grote steden nog geen sprake.

Deze ontwikkeling van de Gemeentelijke Sociale Diensten is illustratief voor de wijze waarop meer in het algemeen de dienstverlening van het gemeentelijk beleidsapparaat onder druk kwam te staan van de verschuivingen in het patroon van de overheidsuitgaven. Onder invloed van de heroverwegingen van het macro-financiële kader heeft op rijksniveau een aanzienlijke herschikking van beleidstaken plaatsgevonden, maar de herschikkingen van beleid op lokaal niveau moesten, vanwege de toegenomen druk op de gemeentebegroting, worden opgevangen binnen het relatief kleine beleidsgebied waarvoor de gemeenten een eigen financiële en beleidsmatige verantwoordelijkheid dragen. De verhoging van de eigen gemeentelijke inkomsten stuitte in de plaatselijke politiek op barrières vanuit het sociaal beleid. Binnen deze financiële verhouding zijn de herschikkingen op de gemeentebegroting grotendeels door het Rijk voorgestructureerd. Aldus moet worden geconcludeerd dat in het feitelijk verloop van de gemeentelijke uitgaven gedurende de jaren '80 een nog grotere afhankelijkheid van het Rijk is opgetreden dan uit de structuur van de gemeentelijke inkomsten en uitgaven reeds kon worden opgemaakt.

\subsubsection{De financiële positie van de grote steden}

Het patroon van inkomsten en uitgaven van de grote steden wijkt niet structureel af van dat van de andere gemeenten. Wel zijn er tal van bijzondere condities die de positie van de grote steden nader bepalen. $Z_{0}$ is in de sfeer van

25] H. de Groot, 'De rol van gemeentelijke uitgaven in de collectieve sector, Een analyse van de periode 1965-1985': Economische Stotistische Berichten, 27 mei 1987, jaargang 72, nr. 3607, blz. 497-500. 
eigen inkomsten een meer dan gemiddelde omvang gegroeid van de afdrachten van de gemeentebedrijven. Met name in Rotterdam zijn deze inkomsten vanwege de havenactiviteiten (via het havenbedrijf en het energiebedrijf) van gewicht. Daar evenaren de winstafdrachten van de bedrijven soms het niveau van de inkomsten uit de OGB. In de andere steden zijn deze winstafdrachten van veel geringere omvang. Het betreft hier overigens een sterk fluctuerende bron van inkomsten (in de jaren '70 traden bij de gemeentebedrijven frequent tekorten op). Ook voor de specifieke en de algemene uitkeringen zijn talloze bijzondere condities voor de grote steden van toepassing, waarvan de belangrijkste hierboven werden gememoreerd.

Op de geld- en kapitaalmarkt nemen de grote steden eveneens een aparte positie in. In tegenstelling tot de meeste andere gemeenten, die veelal zijn aangewezen op bemiddeling door de Bank voor Nederlandsche Gemeenten, kunnen de vier grote steden zelfstandig middelen aantrekken op de geld- en kapitaalmarkt. Met hun 'commercial paper'-programma's hebben zij snel ingespeeld op de deregulering van de financiële markten. Eind 1987 hadden deze programma's een gezamenlijke omvang van zo'n 925 miljoen gulden (zie tabel 6.3) ${ }^{26}$.

Tabel 6.3 Omvang van de "Commercial Paper Programma's" van de vier grote steden per 31 december 1987

\begin{tabular}{ll}
\hline Rotcerdam & $f 400 \mathrm{~m} / \mathrm{n}$. \\
Amsterdam & $f 300 \mathrm{~m} / \mathrm{n}$. \\
's-Gravenhage & $f 100 \mathrm{~m} / \mathrm{n}$. \\
Utrecht & $f 125 \mathrm{mln}$. \\
\hline
\end{tabular}

Bron: Bureau voor Economische Argumentatie.

Wat betreft de uitgaven moesten de vier grote steden in vergelijking tot de gemiddelde ontwikkeling van de gemeentelijke uitgaven eerder en vooral ook dieper buigen dan de meeste andere gemeenten. Zo werd Amsterdam reeds in 1982 tot een -6 procent-operatie genoodzaakt, -4 procent in 1984, en dan tot 1987 de - 17 procent-operatie en in 1987 en 1988 weer tweemaal - 4 procent. De voor de grote steden gunstige wijziging van de verdelingsmaatstaven voor de algemene uitkering volgens de FVW 1984 kon de stijgende uitgaven onvoldoende compenseren. Nadat de grote steden in het midden van de jaren ' 70 de grote financiële problemen uit de eerste helft van dat decennium hadden overwonnen, raakten zij vanaf het begin van de jaren ' 80 opnieuw in financiële problemen. Deze ontwikkeling blijkt uit tabel $6.4^{27}$.

Het oplopende rekeningtekort en de verslechterende reservepositie geven een indruk van de begrotingsproblematiek. De grootste financiële druk wordt veroorzaakt door het onevenredig grote beroep op de bijstandsuitkeringen in de grote steden. Eerst in 1984 werd voor het gemeentelijke aandeel in de kosten van de bijstand een zekere compensatie geboden voor de stijging daarvan (een vergoeding van tweederde via het Gemeentefonds). Zo rekent Amsterdam met een ongecompenseerde groei van 70 miljoen gulden (cumulatief van 1982 tot en met 1989) ${ }^{28}$. Later werden specifieke vergoedingen toegevoegd voor additionele apparaatskosten.

De oplopende kosten voor de stadsvernieuwing vormen een ander financieel knelpunt. De vier grote steden gaven voor en na de invoering van het stadsvernieuwingsfonds in 1985 meer uit dan de desbetreffende specifieke uitkeringen

26] Bureau voor Economische Argumentatie, Financiën van de vier grote steden, Inventoriserend vooronderzoek in opdracht van de WRR (interne publikatie 1988).

27] Ibid.

${ }^{28}$ ] Gegevens verstrekt door gemeente Amsterdam. 
toelieten. Deze tekorten werden enige tijd geactiveerd ten koste van het grondbedrijf (dat wil zeggen dat het desbetreffende onroerend goed op de balans tot de activa wordt gerekend). Slechts Amsterdam slaagde erin deze tekorten op het Rijk te verhalen (via een beroep op de oude artikel 12-status van 1985 tot en met 1989).

Tabel 6.4 Enkele financiële kengetallen van de grote steden ( $\mathrm{x} f 1 \mathrm{mln}$.)

\begin{tabular}{|c|c|c|c|c|c|}
\hline & 1970 & 1975 & 1980 & 1985 & 1988 \\
\hline \multicolumn{6}{|l|}{ Amsterdam } \\
\hline uitgaven & 1.478 & 2.078 & 4.458 & 5.814 & 5.183 \\
\hline rekeningsaldi & -115 & 64 & 4 & -41 & -45 \\
\hline vrije reserves * & 37 & -113 & 80 & 25 & -286 \\
\hline OGB-benutting ** & & $57 \%$ & $70 \%$ & $73 \%$ & $73 \%$ \\
\hline \multicolumn{6}{|l|}{ Rotterdam } \\
\hline uitgaven & 1.042 & 1.575 & 3.106 & 4.336 & 3.349 \\
\hline rekeningsaldi & -42 & 25 & 11 & -40 & -35 \\
\hline vrije reserves * & 178 & 42 & 97 & 52 & 14 \\
\hline OGB-benutting ** & & $65 \%$ & $71 \%$ & $89 \%$ & $85 \%$ \\
\hline \multicolumn{6}{|l|}{ Den Haag } \\
\hline uitgaven & 530 & 1.184 & 2.179 & 2.807 & 2.732 \\
\hline rekeningsaldi & 1 & 14 & -17 & -47 & -16 \\
\hline vrije reserves * & 154 & 137 & 322 & 49 & $115 * * *$ \\
\hline OGB-benutting** & & $50 \%$ & $51 \%$ & $61 \%$ & $85 \%$ \\
\hline \multicolumn{6}{|l|}{ Utrecht } \\
\hline uitgaven & 205 & 357 & 719 & 1.020 & 1.155 \\
\hline rekeningsaldi & -21 & 0 & $-2 \mathbf{I}$ & -32 & -10 \\
\hline vrije reserves * & 33 & -56 & 5.6 & -167 & -210 \\
\hline OGB-benutting ** & & $55 \%$ & $57 \%$ & $71 \%$ & $96 \%$ \\
\hline
\end{tabular}

Bron: Bureau voor Economische Argumentatie.

* exclusief bestemmingsreserves, fondsen, reserves van bedrijven.

** gemiddelde voor gebruikers en eigenaren.

*** inclusief boekwinst op privatisering van GEB.

Het is niet mogelijk gebleken om een accuraat overzicht te verkrijgen van de herallocaties waartoe de ombuigingen in de vier grote steden hebben geleid. Achter de cijfers gaat bovendien niet steeds dezelfde inhoud schuil en zij geven dus slechts een globale indicatie. Bij de afdeling Financiën van de gemeente Amsterdam wordt de schatting gehanteerd dat van het relevante bedrag waarop in theorie bezuinigd kan worden - ongeveer 1,8 miljard gulden - uiteindelijk zo'n 30 tot 40 procent wordt omgebogen op de variabele begrotingsposten. Hierbij heeft het op peil houden van de 'onrendabele' investeringen en de sociale zorg prioriteit ${ }^{29}$. De saneringen bij de gemeentebedrijven (grondbedrijf, havenbedrijf) leidden tot grotere afdrachten aan de gewone dienst. De gemeente Amsterdam heeft ernaar gestreefd om zoveel mogelijk te besparen door efficiencyverbetering, teneinde het niveau van de dienstverlening te behouden. Ook de binnengemeentelijke decentralisatie zou hiertoe bijdragen. Van Amsterdam werd het volgende overzicht verkregen (zie tabel 6.5). 
Tabel 6.5 Doorgevoerde bezuinigingen en volume van nieuw beleid in de Gemeente Amsterdam, 1982-1989 ( $x$ f 1 mln.)

\begin{tabular}{lcrrr}
\hline Jaar & Bezuinigingen & $\begin{array}{r}\text { Waarvan } \\
\text { efficiency- } \\
\text { besparingen }\end{array}$ & $\begin{array}{r}\text { Nieuw beleid } \\
\text { (structureel) }\end{array}$ & $\begin{array}{r}\text { Waarvan } \\
\text { kapitaal- } \\
\text { lasten nieuwe } \\
\text { investeringen }\end{array}$ \\
\hline 1982 & 59,0 & 33,5 & 26,8 & 8,7 \\
1983 & 62,2 & 22,9 & 27,5 & 7,8 \\
1984 & 85,0 & 31,8 & 31,4 & 9,1 \\
1985 & 86,7 & 43,0 & 41,0 & 8,2 \\
1986 & 65,9 & 27,3 & 15,5 & 8,0 \\
1987 & 57,5 & 43,6 & 29,0 & 7,0 \\
1988 & 69,2 & 51,4 & 23,4 & 6,1 \\
1989 & 66,4 & 42,6 & 24,6 & 15,0 \\
\hline
\end{tabular}

Bron: Gemeente Amsterdam.

Uit het overzicht blijkt dat de hoofdstad ondanks de aanzienlijke bezuinigingsdruk erin is geslaagd om middelen voor nieuw beleid te bestemmen, waarvan een groot deel voor nieuwe investeringen. Het overzicht laat echter niet zien in hoeverre de efficiencyverbetering ten koste gaat van de kwaliteit van de dienstverlening en ook niet of de nieuwe investeringen ten koste gaan van exploitatie en onderhoud van de bestaande voorzieningen. Dergelijke trends kwamen immers uit het landelijk onderzoek naar de begrotingsuitgaven van de gemeenten duidelijk naar voren. Niettemin is Amsterdam erin geslaagd om bescheiden extra middelen voor kapitaallasten te reserveren in een periode waarin de Bank voor Nederlandsche Gemeenten het ene naoorlogse dieptepunt na het andere signaleerde in het investeringsgedrag van de gemeenten ${ }^{30}$. Met investeringen in de onrendabele top van grote stedelijke projecten kunnen particuliere investeringen worden geïnduceerd, die blijkens verschillende onderzoekingen het vijf- tot tienvoudige bedragen. Ook bij de andere grote steden bestaat de neiging om naar uiterste kunnen te investeren in nieuwe infrastructurele voorzieningen (men vergelijke het aandeel van de steden in het mobiliteitsscenario) en in plannen voor stedelijke vernieuwing.

Ook in Rotterdam is de financiële positie van de gemeente in de eerste helft van de jaren ' 80 aanzienlijk verslechterd, al begint zich nu geleidelijk een verbetering af te tekenen. Net als de andere grote steden streeft de havenstad naar een sluitende begroting in 1990. Dit perspectief komt overeen met de landelijke trend vanwege het aantrekken van de economische conjunctuur, waardoor de rendabele investeringen toenemen ( $\mathrm{zo}$ is het algemene beeld dat de grondbedrijven na de aanzienlijke renteverliezen in de jaren ' $70 \mathrm{nu}$ weer winsten gaan boeken). Voor de financiële positie van Rotterdam geldt als bijzonderheid dat de algemene uitkeringen uit het Gemeentefonds laag zijn in vergelijking met Amsterdam, terwijl anderzijds de afdrachten van de gemeentebedrijven hoog zijn. Hierdoor is een deel van de inkomsten afhankelijk van de conjuncturele ontwikkeling van de bedrijfswinsten.

In Rotterdam wordt als vuistregel gehanteerd dat in beginsel ongeveer 1,2 miljard gulden voor lokale ombuigingen in aanmerking komt. In termen van bekostiging is dit bedrag te herleiden tot ruim 800 miljoen gulden uit de algemene uitkeringen, 300 miljoen uit de lokale belastingen en 100 miljoen winstafdrachten van de gemeentebedrijven. In de praktijk is van deze 1,2 miljard ongeveer 300 miljoen gulden werkelijk flexibel te maken vanwege de druk van de onbeïnvloedbare uitgaven voor de bijstandsuitkeringen ( $f 200 \mathrm{mln}$.) en voor de bejaardenoorden (ook bijna $f 200 \mathrm{mln}$.) en andere verplichtingen.

${ }^{30}$ ] Zie achtereenvolgende jaarverslagen van de Bank voor Nederlandsche Gemeenten. 
Van de flexibele beleidsruimte wordt met veel moeite ongeveer 25 miljoen gulden voor investeringen opzij gelegd ${ }^{31}$. Zoals eerder voor Amsterdam werd geconstateerd, gaat het derhalve nog altijd om relatief bescheiden injecties.

Utrecht en Den Haag volgen op enige afstand het patroon van de twee grotere steden. Opvallend is het verloop van de reservepositie in Den Haag. De opleving in 1988 is geheel en al te danken aan de privatisering van het gemeentelijk energiebedrijf, waarmee eenmalig een bedrag van 139 miljoen gulden aan de reservepositie werd toegevoegd (maar structureel inkomsten worden gederfd). Utrecht verkeert momenteel in zeer grote problemen, onder meer vanwege de oude gecumuleerde stadsvernieuwingstekorten van 200 miljoen gulden. Voor de rente en afschrijving van deze schuldenlast moet Utrecht reeds 10 procent van de algemene uitkering reserveren. Deze stad balanceert ondanks de presentatie van een sluitende begroting voor 1990 op de rand van de artikel 12-status.

\subsubsection{De steden in de context van Europa}

De financiële verhoudingen tussen de bestuurslagen in Nederland zijn in een internationaal-vergelijkend perspectief uniek. Nergens zijn de inkomsten van de gemeenten zo gecentraliseerd als in ons land. Nergens is het relatieve aandeel van de specifieke uitkeringen zo hoog en het aandeel van de eigen inkomsten zo laag. Bij deze constatering past weliswaar de nodige nuancering en relativering, maar dit maakt deze bevinding niet ongedaan.

Nuancering van de bovenstaande constatering is nodig omdat bij een internationale vergelijking tal van bijzondere omstandigheden in aanmerking genomen moeten worden. Zo is het van belang te signaleren dat het aandeel van de lokale inkomsten naar rato van het bruto nationaal produkt van land tot land verschilt (zie tabel 6.6).

In de tabel wordt aangegeven dat de gemeenten in de drie Scandinavische landen naar verhouding het hoogste inkomen hebben. De Nederlandse gemeenten scoren hoog in de middengroep ${ }^{32}$. De grote omvang van de inkomsten van de Nederlandse gemeenten is niet zo verrassend gezien de hoge welvaart in ons land en de omvang van de collectieve sector. Bovendien zijn de uitgaven van de Nederlandse gemeenten bijna even groot als de uitgaven van het Rijk, zoals reeds in paragraaf 6.2 .1 werd gesignaleerd. Bij zulke verhoudingen valt wel te verwachten dat het Rijk een grote invloed wenst te behouden op de inkomsten en uitgaven van de gemeenten.

Tabel 6.7 geeft een inzicht in de verdeling van de gemeentelijke inkomsten.

3i] Indicatieve opgave van de gemeente Rotterdam.

32] Voor de internationale vergelijking is gebruik gemaakt van:

* 'Gemeentelijke financiën: verschillen en overeenkomsten in Europa'; De Europese Gemeente, 1987, jaargang 22, nr. I, blz. 5-22.

* G.J.S. Uhl, 'Het gemeentelijk belastinggebied in internationaal perspectief; Bank en Gemeente, april 1989, jaargang nr. 4, blz. III-II5.

* Raad van Europa, Steering Committee on local and regional authorities, Study of the types of financial control exercised by central or regional government over local government; Droft study on control exercised in relation to specific grants; Strasbourg, Council of Europe, 1988. 
Tabel 6.6 Inkomsten van de lokale overheid in een aantal Europese gemeenten in procenten van het bruto nationaal produkt

\begin{tabular}{|c|c|c|c|}
\hline & 1981 & 1985 & 1987 \\
\hline België & 4,7 & 5.0 & - \\
\hline Bondsrepubliek Duitsland & 5,6 & 5,3 & 5,2 \\
\hline Denemarken & 31,0 & 29,8 & 27,6 \\
\hline Frankrijk & 5,8 & - & - \\
\hline Griekenland & 1.7 & 1.7 & 3,1 \\
\hline lerland & 4,5 & 5,1 & 4,8 \\
\hline Italië & 5,9 & 4,1 & - \\
\hline Luxemburg & 6,6 & 4,6 & $3,3^{2}$ \\
\hline Nederland & 11,3 & 12,4 & 11,8 \\
\hline Noorwegen & 15,2 & 14,0 & 19,0 \\
\hline Oostenrijk & 6,7 & 6,6 & 6.7 \\
\hline Portugal & 3,0 & 2,4 & 2,6 \\
\hline Spanje & 2,7 & 5,2 & 5.0 \\
\hline Verenigd Koninkrijk ${ }^{\text {b }}$ & $10,5^{c}$ & $9,7^{d}$ & $9,6^{\circ}$ \\
\hline Zweden & 22,8 & 20,9 & 20.9 \\
\hline Zwitserland & 7,0 & 6,8 & $7,0^{2}$ \\
\hline
\end{tabular}

Bron: Council of Europe, Types of financial control exercised by central or regional government over local government; Study Series Local and Regional Authorities in Europe; nr. 45; Strasbourg, Council of Europe, 1990, blz. 40-44.
a) Gegevens over 1986 .
b) Exclusief Noord-Ierland.
d) Gegevens over 1985/1986.
c) Gegevens over 1981/1982.
e) Gegevens over 1987/1988.

Tabel 6.7 Samenstelling van de inkomsten van gemeenten in een aantal Europese landen naar bron, 1981 - 1985 (in procenten van de totale inkomsten)

\begin{tabular}{|c|c|c|c|c|c|c|c|c|}
\hline \multirow[t]{2}{*}{ Land } & \multicolumn{2}{|c|}{$\begin{array}{r}\text { Lokale } \\
\text { belastingen }\end{array}$} & \multicolumn{2}{|c|}{$\begin{array}{r}\text { Algemene } \\
\text { uitkering }\end{array}$} & \multicolumn{2}{|c|}{$\begin{array}{l}\text { Lopende } \\
\text { specifreke } \\
\text { uitkeringen }\end{array}$} & \multicolumn{2}{|c|}{$\begin{array}{l}\text { Investerings- } \\
\text { uitkeringen }\end{array}$} \\
\hline & 1981 & 1985 & 1981 & 1985 & 1981 & 1985 & 1981 & 1985 \\
\hline België & 40,7 & 42,0 & 33,7 & 30,0 & 18,3 & 22,0 & 7,3 & 6,0 \\
\hline Bondsrepubliek Duitsland & 53,4 & 57,4 & 24,1 & 23,8 & 10,0 & 9,0 & 12,5 & 9,8 \\
\hline Denemarken & 44,0 & 46,6 & 17,7 & 10.7 & 38,1 & 42,6 & 0,2 & 0,0 \\
\hline Frankrijk & 53,0 & - & 25,2 & $\cdot$ & 14,2 & - & 7,6 & - \\
\hline Griekenland & 36,3 & 29,5 & 22,9 & 19,8 & 7,4 & 12,2 & 33,4 & 38,5 \\
\hline lerland & 20,5 & 16,1 & 38,9 & 34,1 & 28,4 & 35,0 & 12,2 & 14,8 \\
\hline Italië & 5,3 & 16,2 & 69,9 & 60,6 & $\cdot$ & 1,7 & 24,8 & 21,5 \\
\hline Luxemburg & 85,2 & 84,4 & 2,2 & 1,4 & 1,5 & 1,7 & 11,1 & 12,5 \\
\hline Nederland & 5,8 & 5,2 & 28,9 & 23,0 & $62,2^{a)}$ & 54,4 & $3,1^{x)}$ & 17,5 \\
\hline Noorwegen & 58,9 & 48,7 & 23,9 & 43,6 & 15,6 & 6,3 & 1,4 & 1.4 \\
\hline Oostenrijk & 78,4 & 65,6 & - & - & 15,1 & 18,0 & 6,5 & 6.4 \\
\hline Portugal & 18,9 & 21,8 & 76,7 & 75,0 & - & - & 4,4 & 3,2 \\
\hline Spanje & 61,2 & 72,2 & 29,9 & 19,9 & 1,3 & 1,8 & 7,6 & 6,1 \\
\hline Verenigd Koninkrijk & 39,9 & 39,8 & 41,6 & 34,1 & 17,1 & 24,9 & 2,0 & 1,2 \\
\hline Zweden & 66,6 & 68,1 & 8,5 & 6,1 & 23,6 & 24,9 & 1,3 & 0,9 \\
\hline Zwitserland & 88,4 & - & 5,0 & - & 6,6 & - & - & - \\
\hline
\end{tabular}

Bron: Raad van Europa.

a) De Woningwetleningen zijn in 1981 als lopende specifieke uitkering geboekt, in 1985 als investeringsuitkering. 
Uit dit overzicht blijkt dat de inkomsten van de Nederlandse gemeenten veel sterker door de nationale overheid worden beheerst dan de gemeentelijke inkomsten in de andere landen. Ook in combinatie met de vorige tabel blijken de eigen inkomsten van de Nederlandse gemeenten nog zeer gering te zijn. Het beeld wordt iets genuanceerder wanneer men de algemene uitkeringen optelt bij de eigen inkomsten van de gemeenten. (Hiervoor zou kunnen pleiten dat de hoge eigen inkomsten van gemeenten in andere landen - waaronder die in de Scandinavische landen en in de Bondsrepubliek - ook voor een deel worden verevend teneinde al te grote onbeïnvloedbare verschillen tussen gemeenten te voorkomen; in Nederland komt deze egalisatie van bovenaf tot stand via de algemene uitkeringen van het Gemeentefonds.) Maar zelfs na deze kunstgreep bevinden de Nederlandse gemeenten zich nog in de staartgroep, in gezelschap van de gemeenten uit Griekenland en België ${ }^{33}$.

Hoewel de ontwikkelingen in de financiële verhouding niet in alle Europese landen in dezelfde richting wijzen, tekenen zich internationaal enige opvallende trends af. Zo'n ontwikkeling betreft de invoering en de verhoging van prijzen en tarieven als middel om de lokale uitgaven te bekostigen. Deze ontwikkeling wordt nader gemotiveerd door de behoefte om de lokale belastingdruk te verminderen en ook wel om de vraag naar gemeentelijke diensten te reguleren en om de efficiency van het aanbod te verhogen ${ }^{34}$. Ook in een recente internationaal vergelijkende studie van Clarke wordt gewezen op de vernieuwingsdrang in de systematiek van de lokale heffingen onder de toegenomen 'fiscal stress'. De terughoudendheid van de Nederlandse gemeenten in dit opzicht wordt als uitzondering getypeerd, des te opvallender omdat de eigen inkomsten van deze gemeenten zo'n klein gebied bestrijken ${ }^{35}$.

De zorgvuldigheid van de Nederlandse gemeenten inzake de lastenverhogingen kan op zichzelf wel positief worden gewaardeerd, maar de combinatie met achterblijvende gemeentelijke investeringen wekt vanuit de invalshoek van dit rapport verontrusting. In de internationale voorbeelden ligt doorgaans juist in de noodzaak tot investering in de lokale structuur de prikkel besloten om - ook daar impopulaire - lastenverhogingen door te voeren. In de Nederlandse steden (met hun grotere variëteit van inkomsten, vooral uit de gemeentebedrijven) werd - zeker in vergelijking met het gemiddelde investeringspatroon in dit land - nog wel enige ruimte voor nieuwe investeringen vrijgemaakt. Maar het gaat hier om relatief bescheiden bedragen en er bestaan grote aarzelingen om voor dit doel de plaatselijke heffingen te verhogen.

Overigens bestaan in de Nederlandse lokale en stedelijke cultuur in dit opzicht wel grote verschillen tussen gemeenten. Zo voert Rotterdam binnen de grenzen van de gemeentelijke mogelijkheden een actieve structuurpolitiek, waarbij de profijtruimte van heffingen en zelfs van de impopulaire gebruikerstarieven van de OGB in veel ruimere mate worden aangewend voor een versterking van de sociale en economische structuur dan bijvoorbeeld in Amsterdam.

Een tweede opvallende internationale trend betreft de pogingen om het aandeel van de specifieke uitkeringen in de gemeentelijke inkomsten terug te dringen. Zo werd in Frankrijk in 1983 ongeveer de helft van het fonds dat geoormerkt was voor specifieke uitkeringen, ondergebracht in de 'dotation globale d'équipement', een soort algemene investeringsregeling. In Noorwegen heeft onlangs een vergelijkbare hervorming plaats gevonden. Hier werden 50 specifieke uitkeringen overgeheveld naar een algemene uitkering die nu 85 procent van de landelijke uitkeringen aan de gemeenten omvat. In Portugal en Spanje

33] G.J.S. Uhl, op. cit., blz. 112 .

34] Raad van Europa, Financial Resources for locol and regionol outhorities; Study series on local and regional authorities in Europe, nr. 34; Strasbourg, Council of Europe, 1985.

35] Urban innovation and autonomy; Ed. by S. Clarke, Newbury Park, Sage Publications, 1989, blz. 244. 
is de gemeentelijke autonomie op het vlak van de financiële verhouding het meest principieel doorgevoerd. Hier zijn de specifieke uitkeringen voorbehouden voor uitzonderingssituaties. Denemarken en Nederland voeren al enige tijd een beleid gericht op de sanering van specifieke uitkeringen, maar boeken hiermee - althans vanuit financieel gezichtspunt - tot dusverre weinig resultaat. Er zijn echter ook omgekeerde ontwikkelingen, zoals in Oostenrijk, het Verenigd Koninkrijk of België, waar het relatieve aandeel van de specifieke uitkeringen gedurende de jaren ' 80 bewust is verhoogd. Zeer recent volgt echter ook het Verenigd Koninkrijk de overheersende trend naar verdergaande financiële decentralisatie.

Op geen van de bovengenoemde gebieden loopt Nederland voorop om de uitzonderlijke financiële afhankelijkkheid van de grote steden te verminderen. Integendeel, in een periode waarin de overheidsuitgaven onder scherpe druk staan (zoals in de achterliggende periode) neemt de eenzijdige afhankelijkheid van de gemeenten binnen de gangbare financiële verhoudingen zelfs aanzienlijk toe. Op zichzelf is het natuurlijk wel begrijpelijk dat in een klein land grote lokale verschillen moeilijk worden verdragen, maar voor de grote steden, die in toenemende mate moeten samenwerken en rivaliseren met internationale steden die over een veel grotere beleidsmatige en financiële autonomie beschikken, worden de ons vertrouwde schaalniveaus en beleidspotenties rechtstreeks op de proef gesteld.

\subsubsection{Samenvatting en perspectief}

In het voorgaande werd nagegaan of de structurering van de financiële verantwoordelijkheden voldoende veerkracht geeft aan de grote steden in Nederland om tegen de achtergrond van de internationale verschuivingen van de positie van de grootstedelijke gebieden een nieuwe sterke positie te ontwikkelen. Hierbij ging het vooral om de vraag of de partijen in de stad zelf bij de huidige financiële verhouding voldoende rekenschap dragen voor de instandhouding van een solide stedelijke structuur. Eerder was immers gebleken dat de context waarin de grootstedelijke ontwikkeling tot stand komt, niet automatisch de krachten oproept om de verzwakking van de economische en sociale positie van de laatste vijftien jaar tegen te gaan. Eerst in de loop van de jaren ' 80 is het stedelijk herstelbeleid op gang gekomen en het is nog niet in alle opzichten optimaal. Mogelijk ligt in de financiële verhouding een van de oorzaken besloten voor dit gebrekkige reactievermogen.

In de analyse van de financiële verhouding - met speciale aandacht voor de positie van de grote steden - werd vastgesteld dat de gemeenten voor hun inkomsten en uitgaven in hoge mate afhankelijk zijn van het Rijk. Voor 90 procent van hun inkomsten worden de gemeenten door het Rijk gesubsidieerd. Dit aandeel bestaat voor 63 procent uit specifieke uitkeringen en voor 27 procent uit de algemene uitkering uit het Gemeentefonds. Voor de verwerving van de bovengenoemde inkomsten hoeven de gemeenten zich niet te bekommeren over de sociale en economische ontwikkelingen binnen hun grondgebied; maatgevend voor het verkrijgen van deze geldmiddelen zijn de criteria die het Rijk bij de toedeling hanteert. Voor de resterende 10 procent (eigen inkomsten uit belastingen en heffingen) bestaat wel een directe relatie met de situatie ter plaatse. De mogelijkheden tot het vaststellen van de aard en het volume van de eigen inkomsten zijn door de wetgever bepaald. 
Wat betreft de bestemmingsmogelijkheden van de gemeentelijke middelen wordt door het Rijk aan de specifieke uitkeringen een meer of minder gedetailleerde doelspecificatie meegegeven. De algemene uitkering uit het Gemeentefonds geeft aan de gemeenten in beginsel meer bewegingsruimte. Deze uitkering is bedoeld als tegemoetkoming in de gemeentelijke huishouding teneinde deze 'in redelijkheid' te kunnen voeren, alsmede om beleidstaken te kunnen uitvoeren in het landsbelang. In de praktijk blijkt de aldus verleende beleidsvrijheid echter beperkt door allerlei door het Rijk opgelegde bestedingsverplichtingen. Een belangrijk kenmerk van de algemene uitkering is het egalisatiemotief. De algemene uitkering wordt aan de hand van een sleutel onder de gemeenten verdeeld om de verschillen in onbeïnvloedbare plaatselijke kostenfactoren te verevenen. De eigen inkomsten tenslotte zijn in beginsel volledig volgens de inzichten van het plaatselijk beleid te bestemmen. Aldus bestaat ook in de sfeer van de gemeentelijke uitgaven een grote afhankelijkheid van het Rijk, zij het dat deze minder groot is dan bij het patroon van de gemeentelijke inkomsten.

Onder invloed van de ombuigingen van het nationale macro-financiële kader zijn de gemeenten in hun inkomsten en uitgaven steeds sterker afhankelijk geworden van het Rijk. De taakstelling van het Rijk in de jaren '80, om de collectieve uitgaven te beteugelen, heeft in de praktijk op nationaal niveau geleid tot een andere verhouding tussen het collectieve en het particuliere aandeel in de bekostiging van de voorzieningen. Deze trend zal in de komende periode mede gezien de samenhang met de internationale ontwikkelingen - zeer waarschijnlijk nog verder doorzetten.

Hoewel een groot deel van de collectieve uitgaven uiteindelijk via de gemeentebegroting loopt (exclusief de sociale verzekeringen ongeveer 40 procent) dragen de gemeenten geen eigen verantwoordelijkheid voor dit structurele ombuigingsproces. Hiervoor hebben zij te weinig greep op de geldstromen die via hun begroting lopen. De financiële positie van de gemeenten wordt derhalve primair bepaald door de verhouding met het Rijk. De gevolgen van de macrofinanciële ombuiging werken door in de bekostiging van de lokale voorzieningen. Dit gebeurt rechtstreeks via alle beleid waarop het lokaal bestuur geen nadere invloed kan uitoefenen en indirect via de structuur van de gemeentelijke inkomsten en uitgaven. Zo hebben de kortingen op de specifieke en de algemene uitkeringen de mogelijkheden van de gemeenten om hun inkomsten zelf te bestemmen aanzienlijk ingesnoerd. Dat aan financiële bijdragen van het Rijk een keerzijde van afhankelijkheid kleeft wordt vaak eerst goed zichtbaar wanneer op deze bijdragen wordt gekort. Ook de vroegere 'gouden koorden' worden knelbanden wanneer zij worden aangetrokken.

De herallocaties van de gemeentelijke beleidstaken zijn grotendeels voorgestructureerd door het Rijk. Door het grotere beslag van de verplichte uitgaven op de gemeentebegroting vonden onevenredig veel ombuigingen plaats in het resterende, lokaal te bestemmen deel van de begroting: de apparaatskosten, onderhoud en exploitatie van infrastructuur en andere voorzieningen, uitstel van investeringen, cultuur, recreatie, ruimtelijke inrichting en dergelijke. In het algemeen waren de ombuigingstaken zwaarder bij de grotere gemeenten. Overigens aarzelden de meeste gemeenten aanvankelijk om hun financiële problemen te verlichten door de maximaal toegestane ruimte voor eigen heffingen en belastingen te benutten, vanwege de hieruit voortkomende inkomenseffecten. Zo hanteerde Amsterdam tot voor kort een zodanig gebruikerstarief in de onroerend-goedbelasting, dat ongeveer 100 miljoen gulden minder werd geïnd dan wettelijk mogelijk was.

In afwijking van de meeste andere gemeenten zijn de grote steden er in de loop van de jaren ' 80 wel in geslaagd om extra middelen vrij te maken voor investeringen. Terwijl het investeringspeil van de Nederlandse gemeenten in deze 
periode een naoorlogs dieptepunt bereikte, zagen de grote steden kans om deze kwetsbare uitgavenpost in het kader van hun economisch herstelbeleid te versterken. Overigens gaat het om relatief bescheiden injecties, die in de twee grootste steden variëren van 15 tot 25 miljoen gulden opjaarbasis. De accentuering van de nieuwe beleidsprioriteit voor de economische revitalisering van de grote steden, zoals die in de plannen van de steden vanaf 1983 wordt uitgedragen (en die recentelijk weer wordt aangevuld met het sociale-vernieuwingsbeleid), heeft derhalve in de sfeer van de uitgaven niet tot een reusachtige koerswending geleid.

Bij de herziening van de Financiële-Verhoudingswet in 1984 heeft de wetgever zijn uitgangspunt in de financiële verhouding tussen het Rijk en de gemeenten gelegd bij de allocatiefunctie op decentraal niveau. Deze zou begrensd moeten worden door de distributiefunctie en de functie van macro-economische beheersing, waarvoor de verantwoordelijkheid op centraal niveau ligt. Het normatieve kader van de FVW 1984 houdt aldus de beleidsopdracht in voor een aanpassing van de huidige samenstelling van de gemeentelijke inkomstenbronnen. Met dit oogmerk zijn twee beleidsoperaties gestart.

- De operatie 'sanering specifieke uitkeringen' heeft weliswaar het aantal specifieke uitkeringen sterk teruggedrongen - een bestuurlijk succes - maar heeft vrijwel alle grote uitkeringen ongemoeid gelaten. In financieel opzicht heeft geen majeure wijziging plaatsgevonden.

- De tweede operatie betreft de vergroting van het lokale belastinggebied. Ook deze operatie - die in feite de verruiming van de OGB betreft - komt slechts aarzelend op gang en is aan stringente condities gebonden. Door de koppeling van de twee onroerend-goedbelastingen (de zakelijke en de gebruikerstarieven mogen niet teveel van elkaar verschillen) werd de beleidsruimte van het voornaamste lokale belastinginstrument meer dan nodig beperkt. De conclusie is dat de allocatieve grondslag in de bestaande financiële verhouding niet structureel is verbeterd sinds de wetgever zijn uitgangspunten terzake heeft bepaald.

In het laatste deel van de analyse werd de financiële verhouding belicht in de context van Europa. De structuur van de inkomsten en uitgaven van de Nederlandse gemeenten is uniek in de internationale vergelijking. Nergens is de financiële verhouding tussen het Rijk en de gemeenten zo gecentraliseerd. Hoewel de Nederlandse gemeenten naar verhouding veel uitgeven, is voor de allocatieve functie van het gemeentelijk beleid in de andere landen meer ruimte gecreëerd. Aan de internationale trend naar vergroting van de lokale inkomsten uit prijzen en heffingen doen de Nederlandse gemeenten niet mee. In de sanering van specifieke uitkeringen loopt Nederland evenmin voorop. Voor de Nederlandse steden die in toenemende mate in het internationale verkeer betrokken raken, zal de gebrekkige financiële en beleidsmatige autonomie een steeds grotere handicap worden.

\subsubsection{Beleidsopgaven}

Op grond van de voorgaande bevindingen adviseert de raad tot een verdergaande decentralisatie van de financiële verhouding Rijk-grote steden. Dit bevordert in het financiële beleid een zo direct mogelijke afweging tussen nut en offer, binnen de grenzen van wat de doelmatigheid van het macro-economisch beleid en de centrale verdelingspolitiek eisen.

De voortzetting van de sanering en overheveling van de specifieke uitkeringen ligt in de lijn van dit advies. Wel zal de aandacht in de komende periode toch meer moeten gaan naar de relatief kleine groep van ongeveer dertig omvangrijke doeluitkeringen, die tot dusverre buiten schot is gebleven. Daarnaast is de bestedingsvrijheid van de algemene uitkering een belangrijk uitgangspunt. De kern van de aanbeveling is dat de verschuiving van de gemeentelijke 
inkomstenbronnen vanuit de specifieke uitkeringen weliswaar als tussenstation via de algemene uitkering van het Gemeentefonds kan lopen, maar uiteindelijk toch vooral tot een versterking en verbreding van de bron van de eigen gemeentelijke inkomsten zal moeten leiden. Op den duur zal het totaal van de eigen gemeentelijke inkomsten meer in evenwicht kunnen komen met het totaal van de algemene uitkeringen uit het Gemeentefonds. Kort en goed is 'doordecentralisatie' de kern van het advies. De cijfermatige uitwerking ligt buiten de orde van dit rapport, maar te denken is aan een toekomst waarin het aandeel van de eigen inkomsten van het lokaal bestuur uit heffingen en belastingen zal oplopen tot 20 à 25 procent van de totale gemeentelijke inkomsten.

In het patroon van de gemeentelijke inkomsten wordt derhalve een verschuiving bepleit van de algemene uitkering uit het Gemeentefonds (feitelijk een rijksfonds) naar de eigen inkomsten van de gemeenten. De betekenis van de algemene uitkeringen wordt geenszins onderschat. De verevening van de onbeïnvloedbare plaatselijke verschillen in belastingcapaciteit is een principieel en behoudenswaardig motief van de algemene uitkering uit het Gemeentefonds, maar hiervoor is het niet nodig het totaal van de algemene uitkeringen twee- tot driemaal boven het geheel van de eigen gemeentelijke inkomsten te laten uitstijgen. De verevening van de algemene uitkeringen is het rekenschapsmotief van verantwoordelijk lokaal bestuur gaan overschaduwen en verklaart in belangrijke mate de gebrekkige weerbaarheid van het grootstedelijk bestuur die in de voorgaande hoofdstukken op een aantal strategische beleidsgebieden werd gesignaleerd. Voor alle partijen die verantwoordelijkheid dragen en nemen in de lokale bestuurscultuur dient de ordening van de financiële verhouding een zelfregulerend mechanisme te bevatten om de stedelijke structuur op niveau te houden. Vanuit de optiek die in dit rapport wordt ontwikkeld, vormt het motief om het risico en de verantwoordelijkheid van het lokaal bestuur voor de beïnloedbare plaatselijke verschillen in inkomstencapaciteit te vergroten, het belangrijkste argument om te adviseren tot een verhoging van het aandeel van de eigen inkomsten van de gemeenten.

Een dergelijke beleidskeuze zal uiteindelijk de positie van de gemeenten meer in het algemeen aangaan. Dit gegeven brengt een zeker voorbehoud mee bij de aanbevelingen, omdat het object van deze studie alleen de grote steden omvat en niet alle gemeenten. Evenwel doen de problemen die de aanleiding vormen tot dit advies zich doorgaans wel intensiever voor in de grote steden, maar zij zijn in veel opzichten een verdichting van zaken die elders in minder geconcentreerde en gecumuleerde mate ook aan de orde zijn. In dit opzicht is de financiele verhouding een goede 'testcase'.

Het heeft geen zin de financiële verantwoordelijkheden te decentraliseren wanneer de uitgaven voor het beleid niet op lokaal niveau beïnvloed kunnen worden. In dit rapport is als uitgangspunt genomen dat de inhoudelijke en financiële verantwoordelijkheid voor beleid zoveel mogelijk op plaatselijk niveau dient te liggen wanneer het beleidstaken betreft met een uitgesproken allocatief karakter. Ook dit uitgangspunt sluit nauw aan bij de normatieve beginselen die de wetgever bij de herziening van de Financiële-Verhoudingswet in 1984 reeds zelf heeft bepaald. De consequentie van deze keuze is dat op lokaal niveau naar gelang de omstandigheden en de plaatselijke prioriteiten verschillende beleidsafwegingen gemaakt zullen worden. Lokale beleidsdifferentiatie is derhalve geen weeffout van gedecentraliseerde verhoudingen, maar doelbewuste opzet.

Het beleidsperspectief van financiële decentralisatie is niet nieuw. In feite wordt al geruime tijd van vele kanten - niet in de laatste plaats van de zijde van de gemeenten - aangedrongen op meer armslag voor het lokaal bestuur. Meestal wordt hiermee echter gedoeld op de vergroting van de beleidsruimte van de gemeenten bij de bestemming van de uitgaven. Vanuit zo'n invalshoek 
kan de overheveling van specifieke uitkeringen naar de algemene uitkeringen beschouwd worden als financiële decentralisatie, voorzover tenminste deze geldmiddelen door het lokaal bestuur naar eigen behoeften aangewend kunnen worden. Gemeentelijke allocatie van de uitgaven is zelfs mogelijk bij specifieke uitkeringen van het Rijk, wanneer de bestemming van deze geldstromen door de centrale wetgever zo globaal is gehouden, dat de uitgaven in feite plaatselijk worden gespecificeerd. Dit is bijvoorbeeld het geval bij enige verbrede doeluitkeringen, zoals het populaire en als succesvol beschouwde stadsvernieuwingsfonds, bij de nieuwe 'decentralisatie' van de volkshuisvestingssubsidies en bij de sociale vernieuwing. Mooier kan het op het eerste gezicht, bezien vanuit het lokaal bestuur, niet. De inkomsten van rijkswege worden voorondersteld (ook de algemene uitkering uit het Gemeentefonds is een tegemoetkoming van rijkswege) en de beleidsbepaling wordt bij voorkeur zoveel mogelijk aan het lokaal bestuur overgelaten. Maar het is op zijn best slechts 'halve' financiële decentralisatie.

De raad is van oordeel dat dit vertrouwde patroon van financiële decentralisatie aan duidelijke grenzen is gebonden. Financiële decentralisatie vereist vooreerst ook de zorg en verantwoordelijkheid, het risico voor de verwerving van de inkomsten. Bij nader inzien is het ook niet zo zeker dat het voeren van gemeentelijk beleid onder tegemoetkoming van het Rijk wel altijd zo rooskleurig is voor het lokaal bestuur. In de jaren ' 80 voerde deze situatie tot een grotere afhankelijkheid van de herallocaties die op rijksniveau werden bepaald. Bovendien, en dat is de kern van de argumentatie, is het de vraag of de gemeenten hetzelfde uitgavenpatroon zouden verkiezen wanneer zij zelf voor een groter deel van de inkomsten moeten zorgen. Voor een deel wel, maar in elk geval zouden zij faciliteiten moeten creëren om te verhoeden dat hun belastingcapaciteit weglekt. Maar ook zouden plaatselijke groeperingen, bijvoorbeeld huurderscomité's een direct belang krijgen bij de vestiging van bedrijven of bij woningbouwprojecten voor bewoners met een hoog inkomen. In de bestuurscultuur van de Nederlandse steden komen dergelijke coalities zelden voor. In de Amerikaanse steden is de financiële decentralisatie veelal zover doorgeschoten, dat daar de omgekeerde situatie problematisch wordt geacht. Daar is de lokale bestuurspraktijk in veel gevallen eenzijdig afhankelijk van de plaatselijke belastingcapaciteit en wordt de verhoging van vereveningssubsidies van hoger bestuur urgent geacht.

De plaatselijke verantwoordelijkheid voor het tegengaan van de groei van onevenwichtigheden in de ontwikkeling van de stedelijke structuur kan ook worden vergroot door aan het lokaal bestuur een financiële medeverantwoordelijkheid te geven voor sociale uitkeringen met een distributief karakter, zoals bijstandsuitkeringen en individuele huursubsidies. Vanwege het distributieve kenmerk van deze specifieke uitkeringen wordt het niveau van de uitkering centraal bepaald. In zoverre als ook allocatieve aspecten aan de orde zijn, komt de verantwoordelijkheid in beginsel financieel en beleidsmatig toe aan het lokaal bestuur. De toe- en uitstroom van het aantal uitkeringsgerechtigden van bijstandsuitkeringen en van individuele huursubsidies is vatbaar voor velerlei lokale beleidsbeïnvloeding en het is derhalve functioneel deze allocatieve mogelijkheden in beleidsmatige en financiële zin te prikkelen.

Op de bovengenoemde gronden kan de verantwoordelijkheid van het lokaal bestuur uitkomen boven het huidige 10-procentsaandeel in de bijstandsuitkeringen. Met structurele onvermijdelijke ongelijkheden tussen 'sterke' en 'zwakke' gemeenten moet echter rekening worden gehouden. Een vergroting van de 'financiële' medeverantwoordelijkheid van het lokaal bestuur dient niet via de algemene uitkeringen gestalte te krijgen, maar bijvoorbeeld via 'lump sum' bedragen. Bij wijze van experiment zou in enkele grote steden tijdelijk een bedrag ter hoogte van het extra gemeentelijk aandeel beschikbaar moeten worden gesteld. Wordt de uitstroom met succes bevorderd, dan houdt de 
gemeente geld over. Tegen het risico van een toename boven het landelijk gemiddelde kan een waarborg worden gegeven. Uitstroom van uitkeringsgerechtigden wordt aldus gepremieerd in financiële en beleidsmatige zin.

Om de eigen inkomsten te verhogen, dient de gemeentelijke belastingcapaciteit te worden uitgebreid. Hiervoor komt in de eerste plaats de onroerend-goedbelasting in aanmerking. De geldende koppeling tussen het zakelijk en gebruikerstarief is vooral bedoeld als rem op de gemeentelijke belastinginkomsten. Conform de hoofdlijn van dit rapport adviseert de raad de centrale vaststelling van de verhouding tussen zakelijke en gebruikerstarieven ongedaan te maken. Ter verbreding van de lokale belastinginkomsten kan voorts de aandacht uitgaan naar bestaande belastingen als de baat- en aanlegbelasting en de bouwgrondbelasting en naar nieuwe lokale belastingbronnen. Ook tarieven en heffingen, internationaal veel gehanteerd, dienen voor verhoging van eigen inkomsten te worden gebruikt.

De lokale overheid moet meer gaan verdienen aan de plaatselijke groei van het bedrijfsleven en aan draagkrachtige huishoudens. Deze inkomstenbronnen moeten zo gevoelig zijn dat voor het lokaal bestuur een logische impuls bestaat om deze krachten aan de stad te binden. Nu is het nog zo dat investeringen in de infrastructuur en meer in het algemeen de stimulering van het ondernemingsklimaat de gemeentebegroting voornamelijk raakt in de sfeer van de uitgaven. De terugkerende inkomsten uit deze investeringen vloeien grotendeels naar het Rijk. Ook voor het op peil houden van de sociale structuur bestaan thans te weinig directe relaties. Bijvoorbeeld op het gebied van de huisvesting is het voor het verloop van de inkomsten en uitgaven van de gemeentebegroting betrekkelijk indifferent of de bestaande woningvoorraad wordt uitgebreid met woningwetwoningen dan wel met koopwoningen, zelfs wanneer 90 procent van de bestaande woningen zich in de sociale huursector bevindt, zoals in de twee grootste steden het geval is. Een vergroting van de eigen inkomsten van de gemeenten op dit gebied zou hun gevoeligheid voor het ontstaan van eenzijdigheden in de sociale structuur vergroten.

Wanneer een groter beroep op de lokale belastingcapaciteit wordt gedaan, ontstaat het probleem dat deze lokale bronnen verschillend verdeeld zijn. Maar in veel gevallen is de lokale belastingcapaciteit zeer wel vatbaar voor beleidsbeïnvloeding. De sociale en economische structuur van lokale gemeenschappen wordt gekenmerkt door grote plaatselijke verschillen, maar deze verschillen zijn niet gedetermineerd. Het motief voor financiële decentralisatie is in dit rapport juist de partijen in de stad en elders een direct belang te geven om te investeren in de plaatselijke belastingcapaciteit.

Dat bij financiële decentralisatie gemeenten met een zwakke lokale belastingcapaciteit worden benadeeld en die met een sterke belastingcapaciteit bevoordeeld, berust niet op een ongelukkige speling van het lot, maar vloeit voort uit de weloverwogen opzet om deze allocatieve prikkel (binnen redelijke grenzen) te activeren. Het gevolg is echter wel averechts wanneer deze verhouding wordt ingevoerd in een situatie die wordt gekenmerkt door een grote ongelijkmatigheid. De beoogde ordeningsstructuur van de financiële verhouding schept veel meer levenskracht dan de huidige organisatie van afhankelijkheid, maar het proces om daar vanuit de bestaande ongelijkheid te komen, vraagt veel bijsturing. Deze bijsturing moet er niet op gericht zijn om de verschillen in belastingcapaciteit toe te dekken (dan wordt de nieuwe verhouding nooit bereikt), maar dient - terugredenerend vanuit de beoogde ordening stap voor stap de benodigde middelen aan te reiken om tot versterking te komen. Voor de weg naar financiële decentralisatie is dit een conditio sine qua non. 


\subsection{De bestuurlijke verhouding}

\subsection{Uitgangssituatie}

De bestuurlijke verhouding, meer in het bijzonder de bestuurlijke organisatie van de grootstedelijke gebieden, staat op dit ogenblik volop in de belangstelling. In 1989 hebben de Externe Commissie Grote Stedenbeleid (Commissie Montijn) met haar voorstellen voor vier agglomeratiegemeenten en de Raad voor het Binnenlands Bestuur met een reeks van voorstellen, onder meer voor agglomeratie-autoriteiten met provinciale bevoegdheden, de discussie opnieuw aangewakkerd ${ }^{36}$. Voordat in de volgende paragrafen aansluitend bij de uitgangspunten en de optiek van het hier voorliggende rapport de overwegingen en conclusies over de bestuurlijke verhouding c.q organisatie in de grootstedelijke gebieden worden gepresenteerd, volgt eerst een overzicht van de uitgangssituatie.

Evenals in andere landen houdt de aanpassing van het bestuur van de grote steden c.q. de grootstedelijke gebieden, parallel aan de voortgaande schaalvergroting, samenhang en onderlinge verstrengeling van bebouwing, infrastructuur en functies, ook in ons land de gemoederen bezig over een lange periode. In alle westerse landen kan men al vanaf het begin van deze eeuw voorstellen tot aanpassing registreren. In Nederland geldt Struycken (1912) met zijn publikatie "De gemeenten en haar gebied; Eene studie over de vrijwillige en onvrijwillige samenwerking der gemeenten en de verandering der gemeentegrenzen" als de start in een reeks die tot deze tijd voortduurt ${ }^{37}$. Voor de Tweede Wereldoorlog zijn voorts M.J.W. Roegholt (1925), G.A. van Poelje (1924, 1928, $1933,1935)$ en $J$. in 't Veld (1929) belangrijke woordvoerders in het kader van de toen steeds meer internationaal gepropageerde gewestelijke plannen voor grootstedelijke gebieden (Internationaal Stedebouwkundig Congres te Amsterdam in 1924) ${ }^{38}$.

Direct na de Tweede Wereldoorlog kregen deze aanzetten een bekrachtiging in de voorstellen van de Commissie Koelma (1947) voor districten: een gewestelijke bestuursvorm voor grootstedelijke gebieden ${ }^{39}$. Terwijl voor de Tweede Wereldoorlog het accent in de bestuurlijke praktijk - ondanks de bijdragen van Van Poelje en anderen - steeds was blijven liggen bij grenswijzigingen, zette de Commissie Koelma de wissel om naar een aangepaste bestuurlijke organisatie in grootstedelijke gebieden. Toen al werd deze, evenals later bij diverse gelegenheden en tot op de dag van vandaag, afgewezen, omdat men er een vierde bestuurslaag in zag. Dat werd in het algemeen binnen de Nederlandse bestuur-

36] Grote steden, grote kansen; Rapport van de Externe Commissie Grote Stedenbeleid (Commissie Montijn); 's-Gravenhage, Ministerie van Binnenlandse Zaken, 1989; Raad voor het Binnenlands Bestuur, Advies over het bestuur in grootstedelijke gebieden; 's-Gravenhage, Raad voor het Binnenlands Bestuur, 1989.

${ }^{37}$ ] A.A.H. Struycken, De gemeenten en hoor gebied, Eene studie over de vrijwillige en onvrijwillige somenwerking der gemeenten en de verondering van gemeentegrenzen; Arnhem, S. Gouda Quint, 1912.

${ }^{38}$ ] M.J.W. Roegholt, Het stadsgewest, eene studie over de trek naar de steden en zijn gemeentelijke gevolgen, Wassenaar, 1925. In deze publikatie wordt voor het eerst het stadsgewest als fenomeen en begrip uitgewerkt. G.A. van Poelje, Preadvies voor het Internationaal Stedebouwkundig Congres Amsterdom, 1924. G.A. van Poelje, Wilde groei of orgonisatie; (oratie) Alphen aan den Rijn, Samsom, 1928. G.A. van Poelje, De moderne grote stod; voordracht 1933, herdrukt in: Vereniging van Nederlandse Gemeenten (red.). Wet en Wezen; Samsom, Alphen aan den Rijn, 1954. G.A. van Poelje, De eisch van zelfstandigheid in verband met de ontwikkeling der grote steden; Preadvies voor het Congrès Régional des Sciences Administratives, 1935, gedeeltelijk herdrukt in: Vereniging van Nederlandse Gemeenten (red.), Wet en Wezen; Alphen aan den Rijn, Samsom, 1954. J. in 't Veld, Nieuwe vormen van decentralisatie; Alphen aan den Rijn, Samsom, 1929. Dit overzicht is ontleend aan de bibliografie in: T.A.J. Toonen, Denken over binnenlonds bestuur, Theorieēn von de gedecentroliseerde eenheidsstoot bestuurskundige beschouwd; 's-Gravenhage, Vuga, 1987. Latere werken van G.A. van Poelje zijn: G.A. van Poelje, Hedendaags gemeentewezen; Alphen aan den Rijn, Samsom, 1963 en G.A. van Poelje, Metropolitonië; Alphen aan den Rijn, Samsom, 1966.

39] Rapport van de Commissie Koelma, 's-Gravenhage, Landsdrukkerij, 1947. 
lijke verhoudingen niet wenselijk geacht. De oplossing werd uiteindelijk gevonden in de Wet gemeenschappelijke regelingen van 1950 , waarmee voor grootstedelijke gebieden in eerste instantie door vrijwillige samenwerking een aansluiting bij schaalvergroting en samenhang tot stand moest komen. Een aantal pre-gewesten dat in de jaren '60 en '70 werd gevormd, was op deze Wet gebaseerd. De ironie wil dat deze voorziening die in de jaren '50 primair bedoeld was als oplossing voor grootstedelijke gebieden, vooral na de laatste wetswijziging in 1985 in het gehele land breed en doorgaans met succes wordt toegepast, behalve nu juist in de grootstedelijke gebieden.

De Commissie De Quay (1955) was de volgende schakel in de Nederlandse pogingen te komen tot een aangepast grootstedelijk bestuur ${ }^{40}$. In deze door zich bedreigd voelende randgemeenten (Contact Randgemeenten) gedragen commissie stond het probleem centraal hoe bij grote steden, in het bijzonder Amsterdam, omgesprongen moest worden met het bestuur bij het steeds maar verder groeien, omvattender en complexer worden van de stad. Was er niet zo iets als een optimale grootte in een dergelijk ontwikkelingsperspectief? Deze commissie - dat is geen verrassing - $\mathrm{kwam}$ dan ook niet met voorstellen voor bovengemeentelijk bestuur, maar beval een uiteenlegging aan van het bestuur binnen de grote stad, respectievelijk het grootstedelijk gebied, door binnengemeentelijke territoriale en functionele decentralisatie. Deze aanbevelingen vormen de tweede meest algemene variant naast die van de bovengemeentelijke bestuursvormen voor aangepast grootstedelijk bestuur, als men samenvoeging of annexatie buiten beschouwing laat. Ook deze oplossingsrichting, waarbij het bestuur van de grote stad werd opgerekt naar dat van de agglomeratie door grenswijziging/annexatie in combinatie met binnengemeentelijke decentralisatie, werd al aan het begin van deze eeuw benut (in de jaren ' 20 in Berlijn en Londen) ${ }^{41}$. Later, in de jaren '80, zou Amsterdam op deze formule teruggrijpen in een gecombineerd voorstel van binnengemeentelijke decentralisatie en stadsprovincie.

In 1959 verschijnen van de hand van respectievelijk S.O. van Poelje en Kolfschoten bij de Nederlandse Juristenvereniging twee preadviezen over de bovengemeentelijke bestuursorganisatie ${ }^{42}$. Deze preadviezen munten uit door een genuanceerde behandeling van de voors en tegens van de uiteenlopende varianten, door een beargumenteerde keuze, uitwerking en invulling van een bovengemeentelijke bestuursvorm voor grootstedelijke gebieden en een degelijke vergelijkende analyse, bij Kolfschoten, van lokale/regionale bestuursvormen in de Verenigde Staten, het Verenigd Koninkrijk en West-Duitsland. Opvallend genoeg blijken deze adviezen daarna zo goed als vergeten, terwijl toch de latere discussies en voorstellen zich uiteindelijk blijven bewegen binnen de daar geschetste dilemma's en oplossingsvarianten en er uiteindelijk geen nieuwe elementen aan worden toegevoegd.

In de jaren ' 60 tekent zich een intermezzo af, waarin vooral geografen en planologen belangrijke bijdragen leveren over de uiteenlopende varianten en vormen van verstedelijking in Nederland. Hierbij werden begrippen als agglomeratie, stadsgewest en conurbatie geijkt. Daarnaast werden de ruimtelijke ver-

40] Verslag van de Staatscommissie Bestuursvorm Grote Gemeenten (Commissie De Quay); 's-Gravenhage, Staatsuitgeverij, 1955.

4'] J. in 't Veld, Nieuwe vormen van decentralisotie; Alphen aan den Rijn, Samsom, 1929 verwijst al naar deze voorbeelden. Zie voor een algemeen historisch overzicht, vooral vóór de Tweede Wereldoorlog: F.M. van der Meer, J.C.N. Raadschelders, 'Urbane problematiek in Nederland'; Bestuurswetenschappen, november/december 1988, jaargang 42, nummer 7, blz.487-498.

42] S.O. van Poelje, 'Preadvies: Hoe behoort, anders dan door annexatie, het bestuur van een stedelijke concentratie, die de grenzen van één gemeente te buiten gaat, wettelijk te worden geregeld?'; Handelingen von de Nederlandse Juristen Vereniging I, 1959, 89e jaargang, blz. 1-75. H.A.M.T. Kolfschoten, 'Preadvies: Hoe behoort, anders dan door annexatie, het bestuur van een stedelijke concentratie, die de grenzen van één gemeente te buiten gaat. wettelijk te worden geregeld?'; Hondelingen von de Nederlondse Juristenvereniging 1 , 89e jaargang, blz. 77- 138. 
schijningsvormen van urbanisatie en suburbanisatie, de hiërarchie van centra en de bundeling van steden in agglomeraties, gewesten en conurbaties beschreven en benoemd (Van den Berg, 1957; Bours, Lambooy, 1970) ${ }^{43}$. Dit gedachtengoed vond snel zijn weg naar diegenen die betrokken waren bij de bestuurlijke aanpassing van de grootstedelijke gebieden en betekende een belangrijke steun en ook stimulans om de ontwikkelingen genuanceerd te benaderen (Brasz, Bours, Bulthuis, 1966; Van Ruller, 1972; Ruiter, 1976) ${ }^{44}$.

In de jaren ' 60 mondden al deze voorstellen uiteindelijk alleen uit in een bijzondere voorziening voor het grootstedelijk gebied van Rotterdam: het Openbaar Lichaam Rijnmond (1965), later aangevuld met een soortgelijke constructie voor de agglomeratie Eindhoven (1976). De voorstellen voor een dergelijke constructie ten aanzien van Groot-Amsterdam haalden het tenslotte niet, al was de bestuurlijke inzet daarvoor uitgesproken (de Commissie Kranenburg, $1967)^{45}$. De algemene terughoudendheid ten aanzien van een vierde bestuurslaag kwam tot uiting in het onthouden van daadwerkelijke bestuurskracht aan de nieuwe openbare lichamen, vooral ten opzichte van de centrumstad. Op de achtergrond speelde hierbij ook een belangrijke rol dat de toenmalige minister van Binnenlandse Zaken Toxopeus (1959-1965) het zwaartepunt van aanpassing legde bij een algemene gemeentelijke herindeling, die feitelijk geconcentreerd was op het terugbrengen van het grote aantal gemeenten door een streeksgewijze herindeling van vooral kleine gemeenten. Uiteindelijk bleken deze inzet en oplossingen van de jaren ' 60 niet bestand tegen uitholling en verzwakking door interne (vooral de centrumstad) en externe (vooral de provincie) krachten. Het openbaar lichaam Rijnmond en de agglomeratie Eindhoven werden dan ook beide opgeheven aan het begin van de jaren ' 80 .

In de jaren '70 start de operatie Reorganisatie Binnenlands Bestuur. Het kenmerkende van de operatie was dat deze het gehele land bestreek. Een alge-

43] G.J. van den Berg, 'Algemene Inleiding: Op zoek naar een kader'; Nieuwe steden in Nederland? Pre-adviezen aan het Nederlands Instituut voor Volkshuisvesting en Stedebouw, Publikatie no. LXII, Alphen aan den Rijn, Samsom, 1957. Onder red. van A. Bours en 1. Lambooy, Stad en stadsgewest in de ruimtelijke orde, Moderne geografie ten dienste van de planologische en bestuurlijke ontwikkeling; Assen, Van Gorcum, 1970. Deze publikatie bundelt de bijdragen van onder andere Steigenga, Van den Berg. Van Paassen, Wissink, Hoekveld, Bours en Kouwe, ingebracht in opeenvolgende congressen in die tijd. Te noemen zijn: het congres van het Nederlands Instituut voor Volkshuisvesting en Stedebouw 'Nieuwe Steden in Nederland', waarin de bovenvermelde in 1957 gepubliceerde preadviezen werden ingebracht, het lustrumcongres van de Vereniging van Utrechtse Geografische Studenten 'Regionale struktuur en interregionale functie' in 1957, het door dezelfde vereniging georganiseerde congres 'De stad in nieuwe vormen' in 1962, de Woudschotendagen van de Vereniging van Sociaal Wetenschappelijk Onderzoekers met als thema 'De stad als organisatiekader' in 1966. Tussen de begrippen: agglomeratie (aaneengesloten bebouwd gebied en conurbatie (een bundeling van grootstedelijke agglomeraties) wordt door Wissink opnieuw het begrip: stadsgewest geïntroduceerd (eerder in 1925 door Roegholt al gehanteerd) voorgesteld om het ruimere functioneel samenhangend grootstedelijk gebied tussen agglomeratie en conurbatie mee aan te geven. Daarnaast werden nog de begrippen: conurbo-provincie (een groep conurbaties die naar ligging en functie een sociaal-geografische eenheid vormen) en megalopolis (een nationaal en internationaal samenhangende verstedelijkte clustering) onderscheiden.

44] Zie bijvoorbeeld: H.A. Brasz, A. Bours, J. Bulthuis, Drie aspecten van de agglomeratieproblematiek; Serie Bestuurskundige Bouwstenen; Alphen aan den Rijn, Samsom, 1966 en later: H. van Ruller, Agglomeratieproblematiek in Nederlond; Alphen aan den Rijn, Samsom, 1972. D.W.P. Ruiter, Gewest en territoriale decentralisatie; Alphen aan den Rijn, Samsom, 1976.

45] Een duidelijk vernieuwingsgeluid klinkt door in het rapport van het Centrum voor Staatkundige Vorming van de KVP: Commissie S.F.L van Wijnbergen en anderen, Bestuursvoorzieningen voor stedelijke concentraties; 's-Gravenhage, Centrum voor Staatkundige Vorming, 1963. Hierin komt een krachtig pleidooi naar voren voor grote bestuurseenheden (districten). Tegenover de suggestie van de Commissie De Quay van onbestuurbaarheid stelt deze commissie kort en bondig: 'Voor een wegens haar grootte onbestuurbare stad behoeft men in Nederland niet bevreesd te zijn'. 
mene bestuurlijke reorganisatie werd nu beoogd ${ }^{46}$. Het eerste uitgangspunt lag hierbij in de gebundelde voorzet van de Rijksplanologische Dienst en het ministerie van Binnenlandse Zaken, in 1975 resulterend in een structuurschets voor de bestuurlijke indeling van Nederland met een indeling in 44 gewesten. Deze operatie onder de opeenvolgende ministers Beernink, Geertsema, De Gaay Fortman en Wiegel fluctueerde van de eerder genoemde 44 gewesten tot 26/24 en tenslotte 17 provincies (zo bleef men steeds binnen het vereiste geen nieuw bestuursniveau toe te voegen). Men kon niet tot een keuze komen en na meer dan tien jaar algemene bestuurlijke reorganisatievoorstellen voor geheel Nederland zorgde de volgende minister van Binnenlandse Zaken, Rietkerk, ervoor dat men weer terug keerde tot de orde van de dag onder de reeds langer beschikbare en voor dat doel in $\mathbf{1 9 8 5}$ geactualiseerde Wet gemeenschappelijke regelingen in 1984 .

Vanaf die tijd wrong de bestuurlijke situatie voor alles in de grote steden. De Wet gemeenschappelijke regelingen, gebaseerd op vrijwillige samenwerking, bleek een te vrijblijvende en onvoldoende dwingende bestuurlijke voorziening in de grootstedelijke gebieden. Tegen deze achtergrond begon Amsterdam met zijn bestuurlijk model, waarin de binnengemeentelijke decentralisatie (stadsdeelraden) complementair werd gezien aan een agglomeratiebestuur met provinciale status (het idee van de stadsprovincie, dat Amsterdam in 1982 zonder succes had voorgesteld ${ }^{47}$. De toenemende sociale problematiek in de grote steden, de noodzaak zich voortvarend economisch en cultureel te ontwikkelen en zich te meten met vergelijkbare metropolen in andere landen, maakten in de jaren ' 80 steeds meer manifest dat de bestuurskracht in de Nederlandse grootstedelijke gebieden ernstig tekort schoot. Tegen deze achtergrond waren in 1989 de gemoederen rijp voor de voorstellen van de Commissie Montijn en de Raad voor het Binnenlands Bestuur om het bestuur in de grootstedelijke gebieden te versterken.

\section{Bij dit overzicht valt het volgende op.}

Ten eerste kan worden vastgesteld dat in de loop van de tijd de inzet en voorstellen voor bestuurlijke aanpassingen steeds parallel lopen aan de bijzondere dynamiek in de verstedelijking. Vóór de Tweede Wereldoorlog blijkt de aandacht voor de bestuurlijke organisatie van de grootstedelijke gebieden het grootst in de periode 1910-1935 en na de Tweede Wereldoorlog in de periode 1955-1968. Dit weerspiegelt precies de piekperiodes in het verstedelijkingsproces in ons land. In de periode 1955-1968 is de druk door een groeiende bevolking en economisch functioneren niet meer beperkt tot de grote steden. Ze raakt nu ook het direct bij die grote steden aansluitende gebied. Men spreekt dan van het 'vollopen' van de grote steden en over de noodzaak om de 'overloop' in de Randstad en van de Randstad naar buiten in goede banen te leiden.

46] In 1969 verscheen een nota van de Vereniging van Nederlandse Gemeenten 'Bestuurlijke organisatie'. Daarin wordt de bestuurskracht van de gemeenten voorop gesteld. Daarnaast verschijnt in hetzelfde jaar 'Streekgemeenten en stadsgewesten', een rapport van de Wiardi Beckmanstichting, het wetenschappelijk bureau van de P.v.d.A. In dit laatste rapport werd een lans gebroken voor een coördinerend bestuur voor die taken die samenhang en ontwikkeling van het gehele grootstedelijke gebied betreffen. Daarnaast - en dat is uniek te noemen in de Nederlandse bestuurstraditie, beheerst door het uniformiteitsbeginsel van Thorbecke was dit het eerste rapport waar een differentiatie voor landelijke en stedelijke gebieden werd uitgewerkt: streekgemeenten en stadsgewesten. Deze aantekening is ontleend aan H.J.Th. Wilmer, Grote steden en hun bestuur, Besturen van 8 grootstedelijke gebieden vergeleken aon de hand van literatuur en gesprekken; Scriptie Rijksuniversiteit Utrecht; Utrecht, Vakgroep Stadsstudies, 1989.

${ }^{47}$ Een uitgebreid overzicht van de binnengemeentelijke decentralisatie in Amsterdarn, alsmede van de binnengemeentelijke constructies die in de andere drie grote steden tot ontwikkeling zijn gekomen, is opgenomen in J.G.B.M. van de Goor, Binnengemeentelijke decentrolisatie en deconcentratie in Amsterdam, Rotterdam, Den Haog en Utrecht; Werkdocumenten W39; 's-Gravenhage, WRR, 1989. 
De bestuurlijke problematiek wordt opnieuw actueel als in de jaren ' 80 de verstedelijking een nieuwe dynamische ontwikkeling doormaakt. Dan is de aard van de problemen echter veranderd. In de jaren ' 70 tekende zich immers voor het eerst een snelle en opvallende terugloop af van de grootstedelijke bevolking en een duidelijke verzwakking van de economische functie. Tegelijkertijd bleek het proces van stedelijke verspreiding te zijn doorgezet in omvang en territoriaal bereik. Vanaf de eerste inzet voor versterking van de grote steden aan het eind van de jaren ' 70 als reactie hierop, komt vervolgens naar voren dat hun ontwikkelingskansen verbonden zijn met hun positie in internationaal verband. Daarbij is niet meer de kwaliteit van de grote stad alleen, maar van de grote stad en zijn directe omgeving doorslaggevend. Tegen deze achtergrond moet men de huidige aandacht voor de bestuurlijke problematiek van de grote steden plaatsen.

In de tweede plaats komt uit het overzicht naar voren dat in Nederland al vanaf het begin van deze eeuw het nodige is verkend en voorbereid met betrekking tot een aangepast bestuurlijk kader voor grootstedelijke gebieden. De bijdragen tot en met de jaren ' 50 sporen in het algemeen met wat in andere landen aan gedachtengoed tot ontwikkeling kwam. Vanaf de jaren '50 worden in wezen geen nieuwe elementen meer toegevoegd aan de kenmerken, de naar voren gebrachte voors en tegens en de voorkeuren ten aanzien van de drie hoofdvarianten (naast samenwerking), te weten: a) samenvoeging/annexatie; b) de bovengemeentelijke bestuursvorm; c) territoriale en functionele decentralisatie in de grote stad en de grootstedelijke regio. Het gaat vanaf die tijd tot heden slechts om variaties op de vaste thema's. De voorkeur van de deskundigen, met uiteenlopende politieke achtergrond, blijkt overwegend uit te gaan naar een bovengemeentelijke bestuursvorm die een duidelijke eigen autoriteit heeft en die democratisch kan worden aangesproken. Doordat men de bestaande gemeente-, provincie- en rijksindeling intact laat en de bovengemeentelijke bestuursvorm vooral ziet als een bundeling en afgeleide van een groep gemeenten, wordt in een aantal gevallen verdedigd dat het niet om een vierde bestuurslaag gaat (bijvoorbeeld de Commissie Van Wijnbergen en anderen in een advies van het Centrum voor Staatkundige Vorming van de KVP, 1963). In andere gevallen wordt deze bovengemeentelijke bestuursvorm wel als vierde bestuursvorm gezien en met argumenten verdedigd (bijvoorbeeld de Commissie Kranenburg met voorstellen voor Groot-Amsterdam, 1968). De politieke en bestuurlijke wereld blijft zich echter overwegend met succes verzetten tegen een invoering van een bovengemeentelijke bestuursvorm met echte bestuurskracht. Met uitzondering van de lichte bovengemeentelijke varianten van het openbaar lichaam Rijnmond en de agglomeratie Eindhoven is dan ook in Nederland - als men samenwerkingsvormen op overwegend vrijwillige basis buiten beschouwing laat - de grenswijziging/samenvoeging of annexatie van gemeenten in Amsterdam, Den Haag en Utrecht het enige echt benutte instrument geweest voor aanpassing van het bestuurlijk kader in grootstedelijke gebieden.

In de derde plaats moet worden vastgesteld dat Nederland in vergelijking met andere westerse landen - en dit sluit aan bij het vorige punt - in de loop van de tijd achterblijft bij het beproeven of invoeren van specifieke varianten van bestuurlijke organisatie voor grootstedelijke gebieden. In de meeste andere landen zijn diverse constructies bedacht, ingevoerd, vernieuwd en soms ook weer ingetrokken. Doordat in Nederland de vele varianten op de tekentafel bleven liggen, is te weinig ervaring opgebouwd met bijzondere mogelijkheden in de praktijk en zijn de regionale bestuurlijke mogelijkheden voor het hele land eenvormig gebleven. 
Ter illustratie volgt hier een kort overzicht.

* In Frankrijk bestaan sinds kort negen communautés urbaines. Hierin zijn voor de gezamenlijke gemeenten in het grootstedelijk gebied taken, bevoegdheden, financiering en democratisch toezicht wettelijk geregeld.

* In West-Duitsland is het lokale en regionale bestuur een aangelegenheid van de deelstaten. Dat betekent dat er tussen de deelstaten verschillen zijn in de vorm en inrichting van onder andere het gemeentelijk bestuur. In de diverse grootstedelijke gebieden zijn uiteenlopende bestuursvormen tot stand gekomen. Hamburg, Bremen en Berlijn hebben als deelstaten eigen afspraken met het omringend grootstedelijk gebied, dat de deelstaatgrens overschrijdt. Frankfort en Hannover hebben een eigen agglomeratiebestuur in de vorm van een zogenaamd Zweckverband. Dat geldt ook voor Mannheim, Ludwigshaven en Heidelberg. Hier zijn naast de genoemde steden een groot aantal Kreise en ook de deelstaten Baden-Württemberg en Rheinland-Pfalz in de Zweckverbände betrokken. Daartegenover hebben de grootstedelijke gebieden München, Neurenberg, Ruhrgebied, Rhein-Sieg (Keulen-Bonn) de vorm van een Regierungsbezirk. Dit is een constructie waarin respectievelijk de deelstaten Beieren, Nordrhein-Westfalen en Baden-Württemberg ruimte bieden voor bestuurlijke deconcentratie in het desbetreffende gebied. In de Zweckverbände is overigens de coördinatie overwegend verticaal per beleidssector georganiseerd, wat vaak een onderlinge afstemming bemoeilijkt binnen en tussen sectoren.

* Groot-Brittannië voerde in de jaren '70 naast de bijzondere voorziening voor Londen (de Greater London Council) zes metropolitan counties in. Aanvankelijk was het de bedoeling deze besturen strak omschreven eigen bevoegdheden te geven. Uiteindelijk werden die bevoegdheden minder strak geregeld, waardoor de nodige wrijvingen in het 'two tier' stelsel met de inliggende gemeenten ontstonden. Door de huidige premier Thatcher werden deze 'met-counties' opgeheven, evenals de Greater London Council.

* Denemarken sluit aan bij de Britse formule. Er is daar een onderscheid tussen gewone gemeenten 'fælleskommun' (ongeveer 275 in totaal) en de grotere functionele gemeente 'amtskommun' ( 15 in totaal). De gewone gemeenten hebben een algemene bevoegdheid. De amtskommuner hebben een omschreven bevoegdheid. De gewone gemeenten mogen echter niet in de bevoegdheden van de amtskommuner treden. Voor het gebied van Groot-Kopenhagen (het hoofdstedelijk gebied) werd een apart bestuurslichaam ingesteld de zogeheten Hovestadtsraad (HR). Hierin werden 3 amter en 48 fælleskommuner en 2 centralkommuner Kopenhagen en Frederiksberg (tegelijkertijd amts- en fælleskommun) gebundeld. Deze constructie heeft onlangs schipbreuk geleden.

* In België werd als onderdeel van de federalisatie van de staatsstructuur het Brusselse grootstedelijke gebied een apart gewest. De stad Brussel bestaat uit 19 gemeenten. Deze 19 gemeenten en het gewest zijn onderling beleidsmatig verbonden door een uitgebreid netwerk van formele regelingen en informele betrekkingen. Het gewest Brussel staat onder de bijzondere protectie van de nationale staat om daar de tweetaligheid te garanderen en vanwege de status als nationale hoofdstad en zetel van de Europese Gemeenschap. Buiten het grootstedelijke gebied Brussel werd bij andere grote steden een gemeentelijke herindeling doorgevoerd: Antwerpen, Charleroi, Gent en Luik.

* In Canada berust de bevoegdheid voor het lokaal bestuur bij de besturen van de provincies. Per provincie heeft men op uiteenlopende wijze vorm gegeven aan het bestuur van grootstedelijke gebieden. Internationaal trekt het bestuur van het grootstedelijk gebied van Tbronto al langer de aandacht. Het gaat hier om een gebiedscorporatie van een uit 6 gemeenten bestaand grootstedelijk gebied: de metropolitan municipality of Toronto. Daardoor is een afstemming 
tussen beleidssectoren onderling vergemakkelijkt. De beleidsonderwerpen, die voor het grootstedelijke gebied van bijzonder belang zijn, zijn als zodanig benoemd en de bevoegdheden hiervoor zijn onttrokken aan de individuele gemeenten. Er is echter een grote terughoudendheid om beleidsonderwerpen deze status, zoals bij het verkeers- en vervoersbeleid, te geven. Daar komt bij dat het bestuur van het grootstedelijk gebied opgebouwd is uit de delegaties van de deelnemende gemeenten, zodat deze een stem blijven behouden. De bestuursraad voor het grootstedelijk gebied functioneert overwegend door middel van raadscommissies, zoals de Toronto Transit Commission, die het bestuur vormt van het metropolitane vervoersbedrijf.

* In de Verenigde Staten zijn er weer verschillende constructies per staat. Overheersend is de keuze voor functionele bestuurslichamen (Chicago kent ongeveer 1400 van deze besturen). Een aantal van deze bestuurslichamen wordt rechtstreeks uit en door de bevolking gekozen. Er bestaat in de meeste grootstedelijke gebieden een zekere mate (de verhoudingen zijn ook hier labiel) van 'checks and balances' tussen het bestuur van de grote stad zelf (Pittsburg, Chicago, Baltimore) en het bestuur van de county waarin deze steden gelegen zijn. In het geval van New York City geldt dit voor het bestuur van deze stad en dat van de State of New York. In Minnesota heeft de gouverneur onlangs een openbaar lichaam in het leven geroepen om de 'Twin Cities' Minneapolis en Saint Paul bestuurlijk te coördineren. Dit bestuurslichaam heeft de bevoegdheid gekregen over een aantal taken die onder verantwoordelijkheid van de gouverneur worden uitgeoefend ${ }^{48}$.

In ons land bestaat tegenover deze waaier van bestuurlijke differentiatie als gezegd slechts een bescheiden ervaring met verbijzonderingen voor het bestuur in de grootstedelijke gebieden. Als men samenvoeging en annexatie in de loop der tijd buiten beschouwing laat, kan alleen verwezen worden naar de tijdelijke constructies van het openbaar lichaam Rijnmond en de agglomeratie Eindhoven (lichte vormen van bovengemeentelijk bestuur) ${ }^{49}$.

\subsubsection{Uitgangspunten en algemene optiek}

Welke keuzen dienen zich nu aan voor de bestuurlijke organisatie in de vier grootstedelijke gebieden?

De belangrijkste leidraad voor de institutionele verhoudingen is dat de geledingen in de lokale gemeenschap - zonder deze geïsoleerd te zien van de vele ruimere verbanden waarin zij zijn opgenomen - een elementaire eigen verantwoordelijkheid (met het hiermee gepaard gaande risico) dienen te dragen voor het maatschappelijk functioneren van die gemeenschap. In de stad is dit niet anders dan in de kleinere gemeenschappen in het grootstedelijk gebied. Het feit dat deze verantwoordelijkheden in de stad en in de randgemeenten onder zeer uiteenlopende omstandigheden genomen moeten worden, neemt niet weg dat slechts op deze wijze in financiële en bestuurlijke mechanismen een 'existentiële drang' kan worden bepaald - zoals het eerder werd geformuleerd - voor plaatselijke partijen om in de structuur van de lokale gemeenschap te investeren. Omgekeerd moeten deze mechanismen de lokale partijen wakker houden als zij dreigen in te slapen.

${ }^{48}$ ] Dit overzicht is ontleend aan de eerder vermelde inventariserende studie van grootstedelijke bestuursvormen: H.J.Th. Wilmer, op. cit. Zie ook: de bijdrage van H.J.Th. Wilmer, '(Groot)stedelijk bestuur: bestuurlijke eenheid en afstemming; ervaringen in het buitenland', Studiedag 'Grensverleggend besturen: draagvlak en bestuurskracht in stadsregio's', Nijmegen, 7 juni 1990.

49] Voor een nadere analyse van de positie die Nederland in internationaal verband inneemt, zie: A.M.J. Kreukels en H.J.Th. Wilmer, 'Metropolitan Government in the Netherlands'; Tijdschrift voor Economische en Sociale Geogrofie; ter perse. 
Voor de vraag naar de inrichting van bijzondere bestuurlijke voorzieningen voor de grootstedelijke gebieden heeft dit uitgangspunt grote consequenties. De dynamiek die zo kenmerkend is voor het nemen van lokale verantwoordelijkheden, en voor de aanspreekbaarheid daarop door andere partijen, zoals het hoger bestuur, kan niet zo maar verstoord worden wanneer de vraag aan de orde is, hoe bestuurlijke voorzieningen ingericht moeten worden voor een conglomeraat van lokale gemeenschappen. Er bestaat wel reden voor een versterkt functioneren van dit conglomeraat met het oog op het intern functioneren en het functioneren naar buiten toe in zijn diverse verbanden op hogere schaalniveaus, zoals in het bestuurlijk circuit met 'het' Rijk. Maar voor de verhoudingen binnen het grootstedelijk gebied zou het onjuist zijn om uit te gaan van een onverdeelde constellatie.

Een dergelijke leidraad impliceert in principe een grote mate van beleidsconcurrentie, niet alleen tussen de grote steden onderling en met andere gemeenten in het land, maar ook binnen het grootstedelijk gebied (tussen de kernstad en de randgemeenten en tussen de randgemeenten onderling en alle partijen die hierin hun rol spelen). Behalve om concurrentie gaat het echter ook om samenwerking. Juist omdat de weerbaarheid van de diverse partijen als uitgangspunt wordt genomen, bestaat een degelijke basis voor samenwerking. Concurrentie en coöperatie sluiten elkaar niet uit, de concurrerende partijen hebben elkaar iets te vragen en te bieden. In de Angelsaksische literatuur spreekt men in dit verband van antagonistic cooperation. Voor de bestuurlijke inrichting van grootstedelijke gebieden houdt dit uitgangspunt een grote terughoudendheid in ten aanzien van grote ongelede bestuurlijke eenheden in grootstedelijke gebieden.

Er zijn echter grenzen aan deze elementaire uitgangspunten gesteld. In de eerste plaats is geen sprake van autonomie van lokale gemeenschappen in het grootstedelijk gebied. Ze maken onverbrekelijk deel uit van de nationale en daarbinnen van de provinciale samenleving en zijn als zodanig gebonden aan de algemene beleidsnormen en -condities die op uiteenlopende beleidsterreinen zijn vastgesteld.

De tweede inperking is nauw met de eerste verbonden. Daar waar gebiedseenheden in een vrije beleidsconcurrentie naar een optimalisering van hun belangen streven, ligt een afschuiven van negatieve externe effecten of lasten naar buiten toe voor de hand. Dit kan in de directe vorm van milieubelasting, verkeers-, huisvestings- en recreatiedruk, maar ook meer indirecte vormen zijn denkbaar. Daarnaast moet worden bedacht dat ook de landelijke gebieden vaak hun (negatieve) effecten en lasten naar de grootstedelijke gebieden transponeren. Te denken valt aan de trek naar de stad van jongeren zonder werk, van marginale groepen, van criminelen enzovoort uit stedelijke randgemeenten en ook uit landelijke gebieden of de periferie van het land. Naast deze externe effecten en lasten is er ook sprake van een patroon waarin op basis van een eenmaal ontstane asymmetrische verhouding tussen sterke en zwakke, rijke en arme, aantrekkelijke en achterop geraakte gemeenten, grote steden bijna vastgeklonken kunnen zijn aan grote concentraties van sociale achterstand, omvangrijke milieuvervuiling, verkeerscongestie enzovoort. Aldus ontstaat een bijna onontkoombare neerwaartse spiraal waarmee de grote steden in de vrije uitwisselings- en marktprocessen in een structureel nadeel verkeren. Op veel terreinen kan dan zonder correctie nauwelijks sprake zijn van een normale beleidsconcurrentie van de grote steden met er goed uitspringende dichtbij of verderaf gelegen groeigemeenten, forenzenplaatsen en de duurdere exclusieve woongemeenten. Ook in dit gegeven van een op bepaalde plaatsen eenmaal tot stand gekomen extreme scheefgroei kan een belangrijke reden gelegen zijn voor een al dan niet tijdelijke conditionering en inperking van vrije beleidsruimte en de bestuurlijke autonomie van lokale en regionale besturen in nationaal verband. Hierdoor kunnen voor deze structurele oneven- 


\section{Slotbeschouwing}

\section{I Uitgangsstelling en optiek}

Aan dit rapport ligt de vraag ten grondslag naar de zin en noodzaak van een extra beleidsinzet voor onze grote steden. Op basis van een internationale plaatsbepaling van stedelijke ontwikkelingen en op grond van onderzoek naar veranderingen in de economische en sociale structuur werd vastgesteld dat de grote steden in de komende periode een wezenlijke rol vervullen in de nationale economische en sociale structuur en om die reden extra aandacht behoeven. Ondanks de toenemende spreiding van stedelijkheid blijven de grootstedelijke gebieden als de communicatieve zenuwcentra van centraal belang; in de internationale economische en maatschappelijke ontwikkelingen ontstaan steeds meer rechtstreekse contacten tussen grootstedelijke gebieden. Het is in het belang van het hele land dat de grote steden als kern van voornoemde gebieden hun 'schakelfunctie' naar behoren kunnen vervullen. Daarnaast vragen de grote steden extra zorg en inzet vanwege de concentratie van sociale problemen, waaronder een toenemende desintegratie.

In de meeste westerse landen zijn de grootstedelijke centra verwikkeld in een proces van herpositionering. De westerse economieën maken een ingrijpend omschakelingsproces door dat overal leidt tot verplaatsingen en veranderingen in de aard van de bedrijvigheid. Tevens zijn omvangrijke internationale verhuisbewegingen gaande van de bevolking. Voor de stedelijke gebieden hebben deze exogene ontwikkelingen tot gevolg dat al tientallen jaren bestaande patronen van stedelijkheid structureel gaan veranderen, binnen en tussen landen en zelfs tussen werelddelen.

Deze ruimtelijke en functionele hergroeperingen lenen zich slechts ten dele voor beïnvloeding op stedelijk en/of nationaal niveau. Het gaat er nu om die processen te onderscheiden die wèl te beïnvloeden zijn, om zodoende aansluiting te vinden op de externe bewegingen. De belangrijkste vraag voor het grootstedelijk beleid is derhalve hoe de stedelijke gebieden in dit proces van ruimtelijke heroriëntatie in het internationale perspectief een nieuwe, markante positie kunnen ontwikkelen.

Een sterke nationale betrokkenheid bij de grootstedelijke economie wordt gerechtvaardigd door het relatief grote aandeel hiervan in de nationale economie, ondanks achterblijven van de grootstedelijke groei, alsmede door de centrale functie als overslagplaats van goederen, diensten en informatie. Stagnatie of achteruitgang van de stedelijke economie schaadt de nationale economie en leidt tot vertraagde aanpassingen aan de internationale concurrentie. Sociale stagnatie in bevolkingsrijke gebieden kan zich tot een zware last ontwikkelen.

In dit rapport worden de economische en de sociale ontwikkelingen in de stedelijke gebieden, alsmede de stedelijke voorzieningen, afzonderlijk en in onderlinge samenhang geanalyseerd. De sociale ontwikkelingen in de stedelijke gebieden zijn niet slechts een resultante van de economie. Zij hebben een eigen betekenis en dynamiek, die beperkingen maar ook mogelijkheden inhouden voor economische ontwikkeling. De ontwikkelingen in de sociale structuur van de Nederlandse grote steden hebben gedurende de afgelopen vijftien jaar de kansen voor economische ontplooiing verkleind. Weliswaar biedt de huidige sociale structuur meer mogelijkheden dan thans worden benut - daarover straks - maar uiteindelijk verdraagt geen enkele lokale gemeenschap dat het dragende kader van economische en maatschappelijke activiteit jaren achtereen wordt uitgedund. De steden (zij het onderling verschillend) hebben een 
'eliteprobleem', in de zin dat zij er niet in slagen bepaalde groepen van 'professionals' en ondernemende geesten aan zich te binden die in een samenleving het dragende kader vormen.

Ook voor de stedelijke voorzieningen (waarvan het onderwijs, de arbeidsvoorziening en de gezondheidszorg en maatschappelijke dienstverlening apart worden geanalyseerd) geldt dat deze vanuit hun eigen dynamiek hun invloed uitoefenen op het sociaal en economisch proces. Dit biedt overigens kansen om de moeilijk grijpbare economische en sociale processen toch te beïnvloeden in een meer gewenste richting.

Zowel met betrekking tot de sociale en economische ontwikkelingen als voor de stedelijke voorzieningen wordt in dit rapport geconcludeerd dat ons land, in vergelijking met andere westerse landen, laat inspeelde op de internationale herpositionering, namelijk pas omstreeks 1983/1984. Het besef van het strategisch belang van onze grote steden komt nu op, maar een nationaal beleid terzake dient verder te worden ontwikkeld.

De raad beoogt met het hier voorliggende rapport hieraan bij te dragen en aan te geven en uit te werken hoe een wijziging in de verhoudingen en werkwijzen het bereiken van de eerder genoemde markante positie door de grote steden kan bevorderen. In het verlengde van de aanbevelingen voor een structuurverbetering, zijn hierbij op onderdelen voorstellen uitgewerkt die de beoogde beleidsrichting aangeven.

\subsection{Het huidige profiel van onze grote steden}

Uit de analyses in dit rapport van de economische ontwikkelingen en de sociale problemen blijkt dat, anders dan menigeen denkt, de positieverslechtering van de grote steden ten opzichte van hun omgeving en de rest van Nederland van relatief recente datum is. De omslag ligt globaal gesproken pas in de jaren '70. Voor die tijd deden de grote steden het goed en was er geen sprake van oververtegenwoordiging van armoede en werkloosheid en van achterop lopen in de economische ontwikkeling.

De minder gunstige ontwikkeling in economisch en sociaal opzicht van de grote steden sinds de jaren ' 70 blijkt uit vrijwel alle cijfers. Ook al scoren onze grootstedelijke regio's per saldo niet negatief bij een internationale vergelijking, op het schaalniveau van de centrale steden is het beeld minder gunstig. De achterstand op de rest van het land neemt verder toe. Verontrustend is vooral dat de grote steden niet alleen - zoals wellicht te verwachten - achterblijven in de industriële bedrijvigheid, maar ook in de dienstverlening, waar zij toch de troeven in handen lijken te hebben. Er blijkt ook geen wijziging op te treden in de relatief zwakke economische positie bij een extrapolatie van de ontwikkelingen tot het jaar 2000 , zelfs niet bij een veronderstelde maximale nationale groei. Een uitzondering zijn de relatief hoge investeringen. Hiervoor is nog geen bevredigende verklaring gevonden. Het kan te maken hebben met een afwijkende sectorstructuur, een meer uitgesproken economische inhaaloperatie na de dramatische terugval in de jaren '70 of een afwijkend afschrijvings- en vervangingsregime van bedrijvigheid, omdat in de grote steden vaker vernieuwingen en experimenten voorkomen. De gegevens wijzen verder uit dat de relatief minder gunstige ontwikkelingen in de grote steden nog steeds aanhouden en dat hier niet vanzelf een omslag ten goede mag worden verwacht. Voorzover sprake is van een pril economisch herstel, blijft dit kwetsbaar.

Wat betreft het sociaal profiel, valt internationaal gezien op dat achter de relatief goede sociale voorzieningen (waardoor de armoede relatief minder nijpend is) een verslechterende sociale structuur schuil gaat (eenzijdige bevolkingssamenstelling en een hoge non-activiteit). Ook ten aanzien van de sociale 
structuur zijn er geen aanwijzingen voor een duidelijke verbetering. De extrapolaties van de demografische trends wijzen op een geringere toeneming van het aantal bejaarden dan in de rest van het land, maar het aantal hoogbejaarden blijft voorlopig nog stijgen. Er komen wellicht minder éénoudergezinnen doordat het aantal echtscheidingen daalt. Maar voorspellingen omtrent de stedelijke demografie zijn moeilijk, aangezien de (onbekende) migratiefactor zeer zwaar weegt. Aanwijzingen voor een afzwakking van de omvangrijke concentraties van lage inkomens en werkloosheid in de grote steden zijn niet gevonden. Het sociaal profiel van de steden wordt pas positiever wanneer men de positie van de randgemeenten in de beschouwing betrekt.

Tbch zit in economisch en sociaal opzicht ook veel potentieel in de grote steden besloten. De verkenning in dit rapport van de ontwikkelingsprofielen van een aantal grootstedelijke bedrijfsklassen verwijst naar 'verborgen kansen', in bijvoorbeeld de grafische industrie, de metaalnijverheid en de zakelijke dienstverlening. Ook bij de omvangrijke groep inkomensafhankelijken bestaat een onbenut potentieel: werklozen en bijstandsgerechtigden, die in een aantal gevallen en onder bepaalde condities kunnen worden losgehaald uit hun afhankelijkheid. Er blijkt ook een reservoir aan ondernemerschap. Voorts verblijven grote groepen afgestudeerde academici na hun afstuderen vaak kortere of langere tijd werkloos in de grote stad, terwijl bij de huidige behoefte aan hoog-gekwalificeerd personeel van deze groep profijt zou kunnen worden getrokken, onder andere door aanvullend en aanpassend onderwijs. De 'spin off' van bestaande bedrijvigheid en voorzieningen kan beter worden benut, door verbetering van ruimtegebruik, van de bereikbaarheid, van de werk- en leefomgeving en/of van het imago.

Het onbevredigende beeld van de grote steden komt opnieuw naar voren bij een analyse van maatschappelijke voorzieningen. Het onderwijs en de arbeidsvoorziening blijven qua output achter bij de rest van het land, en zijn geen 'motoren' voor nieuwe dynamiek en ontwikkelingen. Dit achterblijven geldt te meer als men de desbetreffende budgetten en menskracht in aanmerking neemt. De gezondheid van de stedelijke bevolking steekt in een aantal opzichten ongunstig af bij die van de gemiddelde bevolking van Nederland, wat nauw samenhangt met het sociale profiel (eenzijdige bevolkingssamenstelling, oververtegenwoordiging van lage inkomensgroepen, riskante leefstijlen) en niet direct is terug te voeren op slecht functionerende voorzieningen. Wel worden hier aansluitingsproblemen tussen vraag en aanbod gesignaleerd die zich bij de stelselherziening kunnen verscherpen.

Samenvattend en met het oog op de toekomst moet worden geconcludeerd dat de grote steden het in het algemeen minder goed doen dan gewenst is. Het grootstedelijk gebied als geheel (stad en randgemeenten) is er beter aan toe, doordat de meer welvarende randgemeenten het gemiddelde niveau optrekken naar het landelijk gemiddelde. De rest van het land steekt in het algemeen gunstig af, zeker ten aanzien van de situatie van de grote steden en op het vlak van de economie in een aantal gevallen zelfs bij de ruimere grootstedelijke gebieden. Wel moet in aanmerking worden genomen dat hier wordt gesproken over ontwikkelingsprocessen. Ook al scoren de steden in de groeiprocessen laag, hun relatieve gewicht is nog altijd groot.

De grote verschillen tussen de grote steden en de grootstedelijke gebieden vormen zelf een aandachtspunt bij de aanbevelingen en dwingen ertoe om bij de overige aanbevelingen de schaal steeds te benoemen. 


\subsection{De achterliggende verhoudingen en condities als aanknopingspunt voor een herstel}

De achterblijvende reacties op het grootstedelijk 'tekort' zijn vooral te wijten aan een geleidelijk ontstane scheefgroei in de institutionele verhoudingen. Dit is de belangrijkste vaststelling van de raad. De uiteenlopende suggesties voor beleidsinzet en beleidsaanbevelingen sluiten hierbij aan.

Met institutionele scheefgroei wordt het volgende bedoeld. In de verzorgingsstaat zoals die in de loop van de periode 1950-1990 in Nederland is gegroeid, zijn de grote steden een eigen positie gaan innemen, waarbij zij meer dan de steden in andere landen worden geconfronteerd met 'afstanden' binnen en tussen uiteenlopende beleidssectoren. De verschillende betrokken belangen zijn niet rechtstreeks van elkaar afhankelijk, maar spelen hun partij in het in hun beleidssector nationaal georganiseerd arrangement. Alleen getrapt via dat bestel kunnen in de meeste gevallen aangelegenheden die in de grote stad met elkaar in samenhang staan, worden afgehandeld.

Een verdienste van dit bestel is ongetwijfeld dat, ook ten tijde van de economische recessie en bezuinigingen in de jaren ' 80 , extreme vormen van verarming en gebrek aan elementaire zorg zijn voorkomen. De positie van onze grote steden is in dit opzicht gunstig in vergelijking met een groot aantal grote steden in andere landen.

Tegelijkertijd - en dat is met het oog op een toekomstige krachtige grootstedelijke ontwikkeling van doorslaggevend belang - is een zekere uitholling waar te nemen van de veerkracht, de alertheid en het actief worden van de partijen in de grote stad in de sociale en economische sfeer. De sociale en economische structuren van de grote steden zijn geleidelijk verzwakt en in enkele gevallen zelfs verkalkt, onder meer doordat een aantal categorieën inwoners in de grote stad ondervertegenwoordigd zijn of er een geringe binding mee hebben.

Waar in het verzorgingsbestel het Rijk garant staat voor de uiteindelijke regelingen en betalingen, blijkt de noodzaak weggevallen zelf rechtstreeks verantwoordelijkheid te dragen, risico's te lopen en te investeren in datgene wat de stad sociaal en economisch sterk houdt en hiertoe de vereiste voorzieningen beschikbaar te stellen. $\mathrm{Nu}$ op centraal niveau een grondige herallocatie van overheidsuitgaven heeft plaats gevonden, is de vrije bewegingsruimte op de lagere overheidsniveaus nog verder ingesnoerd. Zowel de opbouw als de geleidelijke beperking van de verzorgingsarrangementen krijgen op centraal niveau gestalte en maken het steeds moeilijker voor de overige bestuursniveaus hun eigen prioriteiten tot gelding te brengen.

Tegen deze achtergrond wordt in dit advies de remedie niet gezocht in het losmaken van de grote steden uit hun bestuurlijke omgeving en het vrijmaken van de grote stad uit het nationale bestel. In de westerse landen maken de grote steden onlosmakelijk deel uit van het nationaal bestel en hierin zal, naar het zich laat aanzien, voorlopig geen verandering komen. De raad bepleit echter wel meer eigen ruimte voor de grote steden binnen dit nationaal bestel, conform de situatie in vergelijkbare landen. Op deze wijze wordt de gelegenheid geboden voor meer rechtstreekse financiële en bestuurlijke aanspreekbaarheid en ook voor bestuurlijke concurrentie die meer energie kan losmaken dan nu het geval is.

Bij dit primaire uitgangspunt van een weerbaar en aanspreekbaar grootstedelijk beleid, dat de betrokkenen in de grote steden raakt en tevens betrekking heeft op de bestuurlijke verhoudingen tussen de grote stad en de hogere bestuursniveaus, sluit onmiddellijk een tweede uitgangspunt aan, namelijk een erkenning van de specifieke positie en functie van de grote steden, c.q. de grootstedelijke gebieden, in nationaal en internationaal verband. Dit kan neerkomen op het toekennen van een uitzonderingspositie, hetgeen - zoals 
steeds bij uitzonderingsposities - niet gemakkelijk ligt in de bestuurlijke en politieke cultuur van ons land. (Een 'ongemakkelijke' verhouding tussen de besturen van de grote steden en de nationale overheid komt in veel westerse landen voor. Ons land wijkt echter af door een beperkte bestuurs- en beleidsdifferentiatie ten aanzien van de grootstedelijke gebieden, wat terug te voeren lijkt op het eerder aangestipte gebrek aan besef van het nationaal belang dat de grote steden vertegenwoordigen.)

Voor een uitwerking van noodzakelijke differentiaties kan worden aangesloten bij de enkele beleidsmaatregelen waar dit nu reeds het geval is, zoals in het algemene financiële regime van het Gemeentefonds via de verdeelsleutel voor de algemene uitkering.

Wanneer de combinatie tot leidraad wordt genomen van enerzijds meer beleidsruimte voor de grote steden en anderzijds een gedifferentieerd beleid, aansluitend bij het nationaal belang dat de grote steden, c.q. grootstedelijke gebieden, vertegenwoordigen, zal het rollenspel tussen de rijksoverheid en de besturen van de grote steden bij een grote reeks losse en steeds weer nieuwe claims tot het verleden kunnen gaan behoren. Belangrijk is echter vooral dat op deze wijze energie en middelen vrijkomen voor de beleidsopgaven in de grote steden, die in de komende periode alleen nog maar zwaarder zullen worden dan nu.

Het derde uitgangspunt voor een adequaat grote-stedenbeleid is dat het primaat moet worden gelegd bij de krachten die in de vorm van een groot aantal instellingen en organisaties en individuele initiatiefnemers in de steden zelf aanwezig zijn. Er moet meer ruimte komen voor concurrentie en competitie tussen de betrokkenen onderling. Het bestuur van de grote steden zal zich met die wereld moeten verstaan en daarop aansluitend, - nu eens ondersteunend dan weer grensstellend - zijn eigen verantwoordelijkheid steeds opnieuw moeten bepalen. Ook tussen de besturen binnen de grootstedelijke gebieden zal meer sprake moeten zijn van beleidsconcurrentie (bedoeld is hier concurrentie tussen uiteenlopende organisaties en instellingen in de particuliere sector, maar ook van onderscheiden gemeenten en functionele bestuursorganen in de huisvestingssfeer, de gezondheidssector, het onderwijs, het openbaar vervoer enz.). Deze concurrentie is niet alleen een vereiste in de internationale positiestrijd tussen grootstedelijke gebieden, maar bevordert ook een dynamische ontwikkeling op regionaal niveau.

Deze drie uitgangspunten ten aanzien van de maatschappelijke en bestuurlijke verhoudingen in de grote steden vormen de grondslag voor de nu volgende onderdeelsgewijze uitwerking van de beleidsombuiging en beleidsontwikkeling die de raad vereist acht. Bij deze uitwerking wordt de indeling van het rapport aangehouden. Achtereenvolgens komen de economische ontwikkelingen, de sociale problemen, een aantal maatschappelijke voorzieningen en tenslotte de hierbij aansluitende financiële verhoudingen en bestuurlijke kaders aan de orde.

\subsection{Aanbevelingen}

\subsection{Economische ontwikkelingen}

Als gezegd, is de economische positie van de grote steden nog steeds niet sterk: niet in vergelijking met de rest van het land en evenmin in vergelijking met succesvolle grote steden in het buitenland.

Een versterking van de economie in de grote steden vraagt in eerste instantie een bestuurlijk stelsel waarin de winsten en verliezen direct ondergaan worden en daarmee de impuls vormen om tot snelle en alerte reacties te komen. 
De raad beveelt dan ook als eerste beleidsspoor bij dit onderdeel aan het belastingstelsel zodanig aan te passen dat in elk geval de grote steden door een groter aandeel van zelfstandig te bepalen inkomsten gevoeliger worden voor het floreren dan wel inzakken van de grootstedelijke economie. Voor de uitwerking van deze aanbeveling wordt verwezen naar hoofdstuk 6 .

Het tweede beleidsspoor heeft betrekking op de versterking van zowel concurrentie als coöperatie in de grootstedelijke gebieden. Door de gemeenten (zoals hierboven werd aanbevolen) een direct belang te geven bij economische ontwikkeling, ontstaat een goede stimulans voor de activering van de economie in deze gebieden. Naast versterking van concurrentie tussen lokale gemeenschappen bestaat tegelijkertijd in de stedelijke gebieden ook een belang bij goede onderlinge samenwerking. Het gaat dan om gemeenschappelijke belangen en om de gezamenlijke presentatie naar buiten. Dergelijke samenwerking kan alleen ontstaan wanneer de grote stad en de kerngemeenten er beide baat bij hebben; samenwerkingsverbanden gedirigeerd vanuit de grote stad zijn gedoemd te mislukken. Een van de beste illustraties van de meerwaarde die de combinatie van concurrentie en competitie kan bieden en van de innovaties die hieruit voortkomen, biedt in Nederland de samenwerking in het Westland.

Het derde beleidsspoor betreft het infrastructuurbeleid. Hiervoor is met de Vierde Nota over de Ruimtelijke Ordening een goede basis gelegd. Het Bereikbaarheidsplan Randstad en het Tweede Structuurschema Verkeer en Vervoer trekken deze lijn verder door. Er is echter meer nodig. Naar de opvatting van de raad dient het Rijk zich verantwoordelijk te stellen voor een infrastructuur in de grote steden en de Randstad, die zich kan meten met grootstedelijke gebieden in andere westerse landen en dit, waar nodig, als een nationaal belang voor zijn rekening te nemen, zoals dit ook in andere westerse landen gebeurt. Hiervoor is een geconcentreerde inzet vereist, met het ministerie van Verkeer en Waterstaat als spil. Toegankelijkheid van de grote steden kan een nadere regulering vereisen van met name het particuliere woon-werkverkeer, maar voorkomen moet worden dat door een concentratie bij de grote steden van tolheffing, spitsvignetten, rekeningrijden enzovoort hun concurrentiepositie verder wordt uitgehold.

Tot de infrastructuur die met voorrang en met het Rijk als belangrijkste verantwoordelijke en initiator tot stand moet komen om de internationale en nationale schakelfuncties van de grootstedelijke economie te versterken, behoren de volgende onderdelen.

a. De versterking van de zeehavens in Rotterdam en de luchthaven Schiphol onze twee mainports - is essentieel voor de aansluiting van de nationale economie en van het aandeel van de grootstedelijke gebieden daarin. Met name Schiphol vraagt een snelle uitbreiding van capaciteit en optimalisering van de toegankelijkheid. Een snelle en doortastende uitvoering van de hiervoor klaarliggende plannen wordt door de raad krachtig bepleit. De gevolgen voor het milieu dienen hierbij een zorgvuldige behandeling te krijgen, zoals thans gebeurt bij de voorbereiding van het Plan van Aanpak Schiphol en Omgeving. Met het oog op milieubelasting en verkeerscongestie dient het nieuwe zakengebied rondom Schiphol ruimer te worden gespreid dan nu in de plannen het geval is. Wel moet binnen dit gebied de bebouwing zoveel mogelijk bij de verkeersassen worden geconcentreerd.

b. Er dient een als zodanig herkenbare snelle en rechtstreekse interstedelijke railverbinding tussen de vier grote steden onderling en met Schiphol tot stand gebracht te worden, met op een klein aantal plaatsen een directe overstap op de internationale aantakking van de TGV of varianten daarvan (in elk geval bij Schiphol). Een dergelijke infrastructuur brengt de internationale snelle-railverbinding op het niveau waarvoor deze bedoeld is. Een snelle en rechtstreekse interstedelijke railverbinding brengt onze grote steden in dit opzicht op het niveau van het San Francisco Bay Area Rapid Transport-systeem (BART) en de 
combinatie van metro- en treinnet van Parijs en de Parijse stadsregio (Ile de France). Deze Randstadrail verbindt de vier grote steden onderling en Schiphol met elkaar en maakt het mogelijk optimaal te profiteren van de uiteengelegde stedelijke structuur in de Randstad. Ook de aansluiting op de internationale verbindingen wordt er aanzienlijk door verbeterd. Het huidige net kan als grondslag worden gebruikt voor een dergelijke directe railverbinding. Een aparte concessie voor een dergelijke verbinding zou tussen het Rijk en de NS een versnelde ontwikkeling, uitvoering en exploitatie kunnen bevorderen.

c. Op de kortst mogelijke termijn is een uitbreiding en optimalisering nodig van het openbaar vervoer in elk van de vier grootstedelijke gebieden, waarbij bus-, sneltram- en treinverbindingen dienen te worden afgestemd op elkaar en op de weginfrastructuur. De investering hierin is ook goed voor het milieu. Een en ander vergt in de grootstedelijke gebieden een organisatie van verantwoordelijkheden en van financiering voor de ontwikkeling en de exploitatie van de onderscheiden infrastructuur; de verschillende gebieden zullen bovendien goed op elkaar moeten aansluiten.

d. Tenslotte zal het niveau van de telematica-voorzieningen in de grootstedelijke gebieden moeten 'bijblijven' in Westeuropees verband door een gecombineerd ontwikkelingsbeleid vanuit het bedrijfsleven, de twee mainports en de PTT. Dit vraagt vooral in de bedrijfsorganisatie en de facilitaire sfeer een steeds opnieuw investeren en vernieuwen. Hierbij kan meer dan tot nu toe profijt worden getrokken van de kennis en ervaring in het bedrijfsleven. De rijksoverheid kan op dit vlak vanuit het ministerie van Economische Zaken het nodige stimuleren en bevorderen.

Het vierde beleidsspoor betreft het onderwijs. In veel grote steden in het buitenland wordt onderwijs benut voor de vernieuwing en verdere ontwikkeling van de grootstedelijke economie. Nederland bezit een goede basisinfrastructuur van onderwijs. Tbch zijn het juist de grote steden die in het voortgezette onderwijs en het beroepsonderwijs laag scoren. Een intensieve investering in deze onderwijscategorieën kan langs een aantal lijnen plaatsvinden. In de eerste plaats kan het door de overheid gefinancierde onderwijs meer dan tot nu toe op de specifieke situatie en vraag in de grote steden worden afgestemd. In hoofdstuk 5 (voorzieningen onderwijs) wordt hiervoor een aanbeveling gedaan. De raad onderschrijft de aanbeveling tot grotere inzet van scholen en bedrijfsleven in onderling verband zoals is bepleit door de Commissie OnderwijsArbeidsmarkt (Commissie Rauwenhoff). In de tweede plaats zou grotere vrijheid kunnen worden gelaten aan de commerciële onderwijssector en aan onderwijsvoorzieningen die vanuit of samen met het bedrijfsleven worden ontwikkeld en aangeboden. Tenslotte zou meer dan tot nu toe het gespecialiseerd en hoger onderwijs zich in nauwe samenhang met de economie en technologie van de vier grootstedelijke gebieden moeten kunnen specialiseren en differentiëren. Dit komt voor deze onderwijscategorieën neer op minder uniformiteit en binding aan nationaal nauw omschreven onderwijsstatuten. Het voorstel van de raad de banden tussen de universiteiten en de grootstedelijke regio's nauwer aan te halen, moet ook in dit licht worden beschouwd.

Het vijfde beleidsspoor betreft het economisch ontwikkelingsbeleid. Een hierop gerichte verkenning leert dat het economisch ontwikkelingsbeleid in de grote steden zelf, maar ook in de grootstedelijke regio's, niet goed uit de verf komt in vergelijking met middelgrote steden, bijvoorbeeld in Gelderland en Noord-Brabant. De beleidsinfrastructuur blijkt versnipperd en weinig gericht. Voor alles is vereist dat in de grote steden het bedrijfsleven en de zakenwereld zelf zich verantwoordelijk voelen en stellen voor dit beleid. Het is dan ook van het grootste belang dat de stedelijke besturen aansluiting zoeken bij initiatieven en netwerken en deze stimuleren in plaats van ze te vervangen door of te compenseren met overwegend bestuurlijke voorzieningen. Rotterdam vormt met de Rotterdamse Ontwikkelingsraad (ROTOR) een aardig experiment op dit vlak. 
Voor het economisch ontwikkelingsbeleid in de grootstedelijke gebieden is daarnaast en in relatie met de inzet op lokaal en regionaal niveau de betrokkenheid van het Rijk onmisbaar. Ook hier staat voorop dat het beleid niet de marktkrachten verzwakt, laat staan ervoor in de plaats treedt. Een accommoderend beleid in deze zin dient langs twee sporen te worden ontwikkeld. Het ene spoor komt neer op een krachtig en aangescherpt regionaal sociaal-economisch beleid. De eerste aanzet hiertoe in de recente nota voor regionaal sociaaleconomisch beleid 1991-1994: 'Regio's zonder grenzen' zou zo spoedig mogelijk moeten worden versterkt. Het andere spoor is dat van het structuurbeleid. Hier zou infrastructurele ondersteuning moeten worden geboden aan die bedrijven of bedrijfsinitiatieven die vooral in internationaal verband gezien doorslaggevend zijn voor de grootstedelijke economie.

Bij beide sporen dient bijzondere aandacht te worden besteed aan de vraag hoe dit beleid in de komende periode te profileren zonder overtreding van de voorschriften van de Europese Gemeenschap die concurrentieverstoring moeten tegengaan. Naast financiële steun is hierbij vooral te denken aan expertise en andere beleidsmatige ondersteuning. De aanzet in de nota 'Regio's zonder grenzen' is al genoemd. Voor het accommoderend beleid volgens het spoor van het grootstedelijk regionaal sociaal-economisch beleid kan voorts veel geleerd worden van West-Duitsland. Voor het accommoderend beleid volgens het spoor van het structuurbeleid valt te leren van projecten en programma's in Groot-Brittannië en Frankrijk.

Een belangrijk onderdeel van dit economisch ontwikkelingsbeleid betreft de bedrijfsvestigingen. Door onbereikbaarheid, onaantrekkelijkheid van de directe omgeving, maar vooral door ruimtegebrek zijn meer economische activiteiten uit onze grote steden vertrokken dan strikt nodig en dit proces zet zich voort. Ruimtegebrek - vooral een kwestie van extra reserves in de grote steden zelf - is voor een belangrijk deel veroorzaakt door een jarenlang overaccentueren van woningbouw en door de neiging om binnensteden en omringende gebieden bijna absoluut te conserveren in de huidige vorm. Op beide punten zou men in onze grote steden selectiever kunnen zijn en meer dynamiek vertonen, zonder dat historisch erfgoed wordt aangetast. Planologische overwegingen, die in de grote steden en in grootstedelijke regio's onontbeerlijk zijn, blijven hierbij gelden. Rotterdam, waar na het bombardement in de laatste Wereldoorlog veel reserveruimte bleef en waar deze recentelijk in belangrijke mate werd vrijgegeven voor binnenstedelijke ontwikkeling, illustreert een aanpak die ook in de andere grote steden, zelfs in Amsterdam, economische vernieuwing en ontwikkeling meer kansen kan geven.

\subsubsection{Investering in de sociale structuur}

In dit rapport gaat de aandacht uit naar twee kernproblemen, armoede en werkloosheid, die met veel andere achterstandsindicatoren gepaard plegen te gaan. Gesignaleerd wordt dat deze problematiek zich gedurende de laatste vijftien jaar heeft verscherpt bij bepaalde bevolkingsgroepen in de Nederlandse grote steden en vaak ook in bepaalde wijken. De sociale structuur van de grote steden is zeer verzwakt en de bevolking is eenzijdig samengesteld (veel alleenstaanden, ouderen en éénoudergezinnen).

Met de eerste twee beleidssporen voor de verbetering van de sociale structuur wordt beoogd, conform de algemene gedachtengang van dit rapport, meer verantwoordelijkheden bij de steden zelf te leggen. Dit correspondeert met de lijnen die voor het economisch beleid werden uitgezet. Het eerste spoor heeft betrekking op de vergroting van de financiële verantwoordelijkheid. Financiële verantwoordelijkheid houdt een 'aansprakelijkheid' in als de sociale structuur van de stad zich in ongunstige richting ontwikkelt. De financiële mechanismen in de verhoudingen tussen inkomsten en uitgaven moeten voldoende prikkels bevatten voor het lokaal bestuur om in de sociale krachten van 
de stad te investeren. Vanuit de internationale typering wordt met een zekere verwondering vastgesteld dat bij de gangbare financiële verhouding de steden in Nederland weinig existentiële drang ondervinden om de middengroepen aan de stad te binden, of om huishoudens die vanwege de overheid bijstand ontvangen of anderszins worden ondersteund, te helpen op eigen benen te staan.

Over de richting van de door hem gewenste verandering wil de raad geen misverstand laten bestaan. Het is van belang dat mogelijkheden voor verdergaande decentralisatie van de financiële verhouding worden geconcretiseerd en dat het eigen belastinggebied van de gemeenten, in het bijzonder van de grote steden, op zodanige wijze wordt vergroot dat het lokaal bestuur er een 'natuurlijk' belang bij krijgt om in de eigen sociale en economische krachten (belastingbronnen) te investeren.

Het tweede beleidsspoor sluit nauw hierop aan. De stad bevindt zich in een concurrentiepositie ten opzichte van de randgemeenten binnen en buiten het stedelijk gebied, waar het gaat om het vasthouden van de dragende bevolkingsgroepen. Wanneer bepaalde bevolkingscategorieën uit de stad wegtrekken (al dan niet met eigen voorkeur), is dit een signaal waarop beleidsreacties behoren te volgen. De steden dragen primair een eigen verantwoordelijkheid om hun attractiewaarde te vergroten. Wanneer deze primaire verantwoordelijkheidsmechanismen niet voldoende functioneren, moeten zij worden aangepast. Ook daarom is voor onze steden meer beleidsconcurrentie functioneel. Het lijkt niet verstandig om beloningen te verstrekken voor ongelijkheden die zich zowel in de kern als in de rand van de stedelijke gebieden voordoen, door vereveningsmaatregelen zoals een forenzenbelasting. Overigens kan het uitgangspunt van meer beleidsconcurrentie opnieuw goed samengaan met samenwerking. Maar partijen moeten elkaar wel iets te bieden hebben.

Het advies om de lokale gemeenschappen meer op eigen verantwoordelijkheden aan te spreken, brengt voor de partijen in de stad meer dan gemiddelde risico's mee vanwege de positieverslechtering van de stedelijke sociale en economische structuren. Een groter beroep op eigen mogelijkheden pleegt in eerste instantie de zwakken te verzwakken en de sterken te versterken. De ongunstige aanvangsomstandigheden mogen vergroting van de lokale autonomie niet in de weg staan, maar zij nopen het hoger bestuur wel tot aanvullende maatregelen. De raad denkt hierbij niet aan de volledige compensatie van stedelijke achterstanden omdat deze de eigen risico's van de steden ten onrechte zou afdekken. Het gaat vooral om maatregelen die de steden met hun onevenwichtige structuur in de gelegenheid moeten stellen om meer eigen verantwoordelijkheden te dragen. Bij het ruimtelijk beleid en het bijstandsbeleid worden voorbeelden van zulke flankerende maatregelen gegeven.

De eigen verantwoordelijkheid komt ook tot uiting in het uitgangspunt achter dit en de andere beleidssporen. Er kan geen sprake zijn van een confrontatie van de sociale problemen vanuit één hoofdspoor, of dit nu werkloosheidsbestrijding, bijstandsverstrekking, of algemeen maatschappelijk werk betreft. De onderscheiden werksoorten en tradities in de grote steden kunnen en moeten wel meer op lokaal en regionaal niveau op elkaar worden afgestemd (zoals ook met het sociale vernieuwingsprogramma wordt beoogd). Een zodanige prikkel hiertoe dat organisaties worden samengevoegd onder één vlag, die van de arbeidsvoorziening of bijvoorbeeld die van de sociale dienst, of die van een alles integrerende eenheid, is echter ongewenst.

Het derde beleidsspoor betreft het ruimtelijk beleid en de huisvesting. Geconstateerd wordt dat de steden - zij het in wisselende mate - kansen hebben laten liggen om de attractiewaarde van de stedelijke ruimte te verhogen, met name in de centra (achteruitgang kernwinkelgebieden, weinig vernieuwende architectuur, verval van openbare ruimten) en in de buitenwijken. De belangrijkste 
aanbeveling op dit vlak is de eenzijdige verdeling van woningwetwoningen (grote steden) en premie- en vrije-sectorbouw (grootstedelijke randgemeenten) om te buigen. Gezien het feit dat de woningvoorraad in Amsterdam en Rotterdam voor nagenoeg 90 procent uit sociale huurwoningen bestaat, adviseert de raad in de uitbreidingswijken van deze steden geen grote aantallen sociale huurwoningen meer te bouwen.

Dit advies brengt als aanvullend vereiste de noodzaak mee om op stadsregionaal niveau voor de reëel bestaande behoeften voldoende sociale huurwoningen te realiseren. Voor de volkshuisvesting is de regionale voorziening inzake programmering en verdeling van woonruimte allerminst optimaal. Hiervoor is een aparte bestuurlijke voorziening nodig, waarvoor een mogelijkheid wordt aangegeven in paragraaf 7.4.4.2. De raad adviseert voorts de werkgebieden van de woningbouwverenigingen te verruimen. Ook het ruimtelijk beleid voor de inrichting van de Randstad zal, meer dan bij de huidige beleidsvoorbereiding het geval is, oog moeten hebben voor de ruimtelijke consequenties van herstructurering van zowel de steden als de omliggende gebieden op het gebied van de huisvesting. De raad wijst er - overigens in het besef dat bij ruimtelijk beleid ook andere overwegingen een rol spelen - op dat gedurende de afgelopen decennia buiten de centrale steden slechts sociale huurwoningen van enige omvang gerealiseerd konden worden in de grotere groeilokaties.

Het vierde beleidsspoor betreft de minimuminkomens. In de steden zijn steeds meer huishoudens afhankelijk geworden van een minimuminkomen, in veel gevallen een periodieke bijstandsuitkering. Ook als dit niet geval is kan de Algemene Bijstandswet (ABW) via de voorziening van bijzondere bijstand voor de betrokkenen van belang zijn.

De ABW is sinds 1974 aan strakke landelijke normen gebonden. In de tijd van economische recessie en bezuiniging in de jaren ' 80 is de voorziening overeind gebleven, al werden toen de uitkeringen bevroren en de koppeling met de minimumlonen losgelaten. De flexibilisering en differentiatie die worden beoogd met de recent voorgestelde herinrichting van de $A B W$, worden in dit rapport toegejuicht met het oog op de concentraties van minima in de grote steden. Hieraan kan het volgende aandachtspunt worden toegevoegd. Gelet ook op het individualiseringsprincipe dat aan de $\mathrm{ABW}$ ten grondslag ligt dient opnieuw mogelijk te worden gemaakt dat de Gemeentelijke Sociale Diensten individuele achterstanden beoordelen, de normatieve uitgangspunten van de wet bewaken en zich niet beperken tot het uitsluitend verstrekken van financiële bijstand. Dit krijgt nog meer betekenis als straks het huidige gemeentelijke minimabeleid in de bijzondere bijstand wordt opgenomen. De 'verfijningsfactor sociale zorg' geeft de grote steden slechts een beperkte tegemoetkoming voor de uitvoeringskosten. De bezuinigingen hebben vooral het uitvoerend apparaat getroffen. Daarom wordt een financieringsregeling bepleit van de uitvoeringskosten die een minimum aan dienstverlening, conform het individualiseringsprincipe, bij de verlening van de bijstand en van de bijzondere bijstand, mogelijk maakt.

Het lokaal bestuur dient een grotere financiële medeverantwoordelijkheid te krijgen voor bijstandsuitkeringen. Met structureel onvermijdelijke ongelijkheden tussen 'sterke' en 'zwakke' gemeenten moet rekening worden gehouden. Een vergroting van de financiële medeverantwoordelijkheid van het lokaal bestuur dient niet via de algemene uitkeringen gestalte te krijgen, maar bijvoorbeeld via 'lump sum' bedragen. Bij wijze van experiment zou in enkele grote steden tijdelijk een bedrag ter hoogte van het extra gemeentelijk aandeel beschikbaar moeten worden gesteld. Wordt de uitstroom met succes bevorderd, dan houdt de gemeente geld over. Tegen het risico van een toename boven het landelijk gemiddelde kan een waarborg worden gegeven. Uitstroom van uitkeringsgerechtigden wordt aldus gepremieerd in financiële en beleidsmatige zin. 
Een volgend aandachtspunt is het woonlastenprobleem, juist in de grote steden een steeds belangrijker component van de minimaproblematiek. In de nota 'Volkshuisvesting in de jaren negentig' wordt ervoor gekozen het nieuwe woningaanbod meteen bereikbaar te maken voor de lage inkomensgroepen. Dit is mogelijk, mits de subsidie daartoe strekt. Het beleid is thans dat de kosten vervolgens achteraf (door jaarlijkse extra huurverhogingen) in rekening worden gebracht bij de desbetreffende huishoudens. Hier is sprake van een 'ingroeiproces'. Deze werkwijze is echter problematisch voor dat deel van de huishoudens dat geen inkomensverbetering doormaakt.

Het vijfde beleidsspoor betreft de bestrijding van werkloosheid. In de grote stad is de discrepantie tussen werkgelegenheid (vooral gekwalificeerd werk) en werkloosheid (vooral van niet of laag geschoolden) een bepalende factor. Daarnaast vormt ook de al dan niet vermeende geringe gemotiveerdheid van groepen werklozen juist bij de concentratie in grote steden een bijzonder probleem. Beide aspecten maken een individuele benadering wenselijk. De sociale en ruimtelijke mobiliteit van de betrokkenen verdienen in de grote steden bijzondere aandacht, omdat het gebrek aan mobiliteit een belangrijke oorzaak is van vooral de langdurige werkloosheid.

Aansluitend bij de huidige versterking van de werkloosheidsbestrijding in de grote steden in het kader van het sociale-vernieuwings- en het allochtonenbeleid, wordt in dit rapport een lans gebroken voor het meer tot gericht beleid komen vanuit de individuele bedrijven en de bedrijfssector zelf. Dit komt neer op een sterkere wisselwerking tussen werkgelegenheidsbeleid, scholing, arbeidsvoorziening en de betrokkenheid van commerciële bemiddelingsbureaus. Het vereist in de grote steden meer open relaties tussen deze onderscheiden blokken dan nu het geval is. In het kader van dit rapport ligt tenslotte een ondersteuning voor de hand van de formule die in de grote steden (Utrecht), maar ook daar buiten (Helmond, Enschede) werd ontwikkeld, waarbij de concrete werkzoekende en het concrete bedrijf tezamen het bemiddelings- en toegeleidingstraject bepalen. Deze aanpak is verwant met een grote reeks van projecten en programma's in de Britse steden, die daar over het algemeen succesvol bleken.

Het zesde en laatste beleidsspoor bevat een aanvullende benadering om de werkloosheidsproblematiek in de steden met kracht ter hand te nemen. De raad is van mening dat, naast de bovengenoemde intensivering van het arbeidsmarktbeleid, de ondernemingscultuur dient te worden bevorderd. Binnen dit kader dient ook uitdrukkelijk aandacht te worden besteed aan de werklozen in de steden. In een hiertoe strekkende studie kwam naar voren dat vooral in de Angelsaksische landen op dit vlak het nodige tot ontwikkeling is gekomen en dat daarmee de werkloosheid kon worden teruggebracht. Programma's waarvan lering kan worden getrokken, betreffen bijvoorbeeld de mogelijkheden voor starters om onder minder stringente beperkingen dan nu het geval is, zelf een bedrijfje te beginnen met behoud van uitkeringen (de zogeheten 'enterprise allowances'), de 'public-private partnerships' in de Amerikaanse steden en de gerichte inzet van de Task Forces die in de Britse steden voor specifieke doelgroepen de weg naar het ondernemerschap moeten bevorderen. In Nederland zijn voor 'starters' relatief royale faciliteiten beschikbaar, maar de drempels voor gebruik hiervan zijn hoger dan in de genoemde voorbeelden.

\subsubsection{Allocatie van maatschappelijke voorzieningen}

Door middel van maatschappelijke voorzieningen kunnen economische en sociale ontwikkelingen worden beïnvloed die niet of moeilijk rechtstreeks te sturen zijn. Het niveau van de maatschappelijke voorzieningen in Nederland is hoog en kan de toets van de internationale vergelijking in het algemeen goed 
doorstaan. Toch blijft het strategisch gebruik van deze voorzieningen in de stedelijke ontwikkeling achter bij wat in buitenlandse steden wordt gedaan. Een dergelijk gebruik is in Nederland tot dusverre voornamelijk beperkt gebleven tot de fysieke voorzieningen (infrastructuur, ruimtelijke inrichting, volkshuisvesting).

In dit rapport wordt de mogelijkheid onderzocht om de maatschappelijke voorzieningen nadrukkelijker te situeren in het kader van het grootstedelijk beleid. Hierbij viel de keuze op onderwijs, arbeidsvoorziening gezondheidszorg en maatschappelijke dienstverlening. De vraag waarom deze voorzieningen zo weinig benut worden om aan het sociale en economische ontwikkelingspad van de steden richting te geven, wordt in dit rapport beantwoord met een verwijzing naar het centrale institutionele motief. Op stedelijk niveau kan geen bijzondere inhoud gegeven worden aan de maatschappelijke voorzieningen, omdat de beleidsbepaling daaromtrent in hoge mate is gecentraliseerd. Mede doordat zoveel beleidsaspecten van deze voorzieningen een allocatief karakter hebben, kan in het huidige bestel onvoldoende worden ingespeeld op de lokale en in het bijzonder op de stedelijke dynamiek.

Op de drie genoemde gebieden zijn onlangs voorstellen tot stelselwijziging ingediend die een fundamentele decentralisatietendens inhouden. Bij onderwijs en arbeidsvoorziening betreft het vormen van functionele decentralisatie, bij gezondheid en maatschappelijke dienstverlening gaat het om een combinatie van functionele decentralisatie en marktwerking. In alle drie gevallen wordt weliswaar de positie van de lokale marktpartijen verstevigd maar blijft de centrale overheid tot dusverre de regisseur van de decentraliseringsoperaties. Op stedelijk niveau dient er ook ruimte te zijn voor allocatieve beleidsafwegingen om de plaatselijke dynamiek tussen de lokale marktpartijen en de lokale overheden tot haar recht te laten komen.

\subsubsection{Onderwijs}

In het buitenland en in het bijzonder in de Angelsaksische wereld wordt juist in de grote steden op dit ogenblik veel geïnvesteerd in het onderwijs, als sleutelmechanisme voor economische vernieuwing en ontwikkeling. Verwezen kan worden naar steden, zoals Boston, Chicago, Los Angeles, Londen, Newcastle. De desbetreffende vernieuwingen, met een meer geprononceerde bijdrage van de particuliere sector, blijken tevens mogelijkheden te bieden voor het bestrijden van sociale achterstanden in het onderwijs. Steeds belangrijker zijn voorts - juist in de grote steden als hoofdwissels in het internationale en nationale verkeer - de functies van het algemeen vormend onderwijs (cultuuroverdracht en talen) en het hoger en zeer gespecialiseerd onderwijs (wetenschapsontwikkeling en geavanceerde technologie).

In Nederland wordt met de 'autonome school' ook meer ruimte gegeven voor lokaal en regionaal gedifferentieerde ontwikkelingen en initiatieven, in het bijzonder in het basisonderwijs en het voortgezet onderwijs. De decentralisatie is hier echter zodanig aan de scholen zelf opgehangen - en daarmee aan het nationaal georganiseerde onderwijsveld - dat maar beperkt sprake kan zijn van een beleid waarbij het stadsbestuur impulsen kan geven aan een op interne en externe krachten afgestemde ontwikkeling.

Het rendement van het basisonderwijs en het voortgezet onderwijs in de grote steden springt er negatief uit, zo toont een vergelijking met de rest van het land aan. Ook de inzet van het beroepsonderwijs (lager, middelbaar en hoger) voor werkgelegenheid en werkloosheidsbestrijding blijkt teleurstellend. Tenslotte zijn in de grote steden de laatste jaren wel de banden aangehaald met het wetenschappelijk onderwijs en met hooggespecialiseerd onderwijs, maar de bestuurlijke verbindingen blijven beperkt en een door de desbetreffende instellingen en de grote stad tezamen ontwikkeld gericht beleid ontbreekt, op één uitzondering na. 
De raad acht het noodzakelijk het grootstedelijk basisonderwijs en algemeen vormend voortgezet onderwijs meer af te stemmen op de grootstedelijke ontwikkeling. Hiertoe zou de rol van de gemeente als vertegenwoordiger van het openbaar onderwijs moeten worden ontkoppeld van die van stimulator van het basis- en algemeen vormend onderwijs (waarbij de status van het openbaar onderwijs als een vanuit het openbaar bestuur gegarandeerd open onderwijsaanbod voor iedereen onverlet moet blijven). Het gemeentebestuur kan dan vrijer impulsen geven aan het onderwijs.

Daarnaast pleit de raad voor een krachtiger afstemming van het voortgezet beroepsonderwijs op de grote stad en de grootstedelijke regio, alsmede voor een bijbehorende differentiatie. Een grootstedelijke onderwijsraad, bestaande uit de belangrijkste betrokken partijen en adviserend ten aanzien van uiteenlopende onderwijszaken, zou een belangrijke impuls kunnen geven aan zowel basis- als meer gespecialiseerd onderwijs, zoals uit ervaringen in Utrecht en Rotterdam is gebleken.

Voor het gespecialiseerd en wetenschappelijk onderwijs adviseert de raad tenslotte meer ruimte te bieden voor een gedifferentieerd beleid per wetenschappelijke instelling door de bestuurlijke betrokkenheid van de desbetreffende instellingen en de grootstedelijke regio's te versterken.

\subsubsection{Arbeidsvoorziening}

De raad constateert dat de arbeidsvoorziening nog onvoldoende leeft in de context van de grote stad. Aannemelijk is dat de neiging tot verzelfstandiging, die zich in de loop van de tijd bij de arbeidsvoorziening heeft voorgedaan, hieraan (mede) debet is.

Er zijn verschillende manieren om de arbeidsvoorziening - zonder wijziging van de nieuwe Arbeidsvoorzieningswet, dus in aansluiting op de tripartisering en regionalisatie - responsiever te maken. Een mogelijkheid is op grootstedelijk niveau de ruimte te benutten die wordt geboden door de sociale akkoorden tussen regering en sociale partners. Ook zouden de steden onderling meer moeten concurreren op het punt van hun arbeidsmarktbeleid en zelf zonodig gebruik moeten maken van de diensten van de arbeidsbureaus, ook in andere regio's. Voorts zouden de steden tot vaste procedures moeten komen van advies en overleg over sociaal-economisch beleid met de organisaties van werkgevers en werknemers die voor de stad representatief zijn.

De arbeidsbureaus moeten hun hoofdtaak leggen bij de directe interventie op de arbeidsmarkt en bij de levering van 'maatwerk'. Activiteiten die hier deels los van staan, zoals de levering van scholingsprogramma's en van subsidies, moeten organisatorisch de kans krijgen om zich verder te specialiseren en te verzelfstandigen. Bovendien moet worden nagegaan of er niet meer mogelijkheden zijn voor het RBA om gebruik te maken van uitvoerende diensten van het bedrijfsleven, zoals personeelsafdelingen van grote bedrijven en van uitzendbureaus. Tenslotte verdient intensivering van de mogelijkheden tot terugkoppeling overweging.

\subsubsection{Gezondheidszorg en maatschappelijke dienstverlening}

De raad constateert dat, mede in aansluiting op initiatieven van de Wereldgezondheidsorganisatie, bij de gemeentelijke gezondheidsdiensten veel informatie wordt vergaard over het gezondheidsprofiel van de stedelijke bevolking. Hierop kan - intersectoraal - een actieve stedelijke gezondheidspolitiek worden gebaseerd. Voor het overige kan het grootstedelijk gezondheidsbeleid aanknopen bij de stelselhervorming in de zorgsector. Het betreft hier een decentralisatie die tot betere functionele samenhang tussen voorzieningen moet leiden en moet bevorderen dat de allocatie van voorzieningen plaatsvindt in het licht van lokale omstandigheden met directe betrokkenheid van de marktpartijen. 
Met betrekking tot de infrastructuur van het nieuwe zorgstelsel acht de raad een verbreding nodig ten aanzien van de thuiszorg. Te denken is aan aanvullende voorzieningen voor een zelfstandig bestaan in de eigen omgeving van hulpbehoevende ouderen of patiënten, zoals bijzondere woonvoorzieningen, de ruimtelijke inrichting van de woonomgeving, speciale vervoersmogelijkheden en de organisatie van hulp- en dienstverlening aan huis. Gemeentebesturen kunnen hun eigen verantwoordelijkheid hiervoor waarmaken door het aanbieden van aanvullende fysieke faciliteiten, zoals de dienstencentra, die als organisatiebasis dienen voor hulp- en dienstverlening. Het afsluiten van overeenkomsten tussen het grootstedelijk bestuur en de marktparijen vormt een belangrijk instrument voor een doelmatige en adequate allocatie van de thuiszorg.

Wat betreft de invulling van het verzekeringsstelsel en de financiële kaderstelling, is het grootstedelijk gezondheidsbeleid afhankelijk van de voorwaarden die op centraal niveau worden bepaald. Hierop kunnen evenwel door het Rijk differentiaties worden aangebracht op grond van de bijzonderheden van het stedelijk gezondheidsprofiel en op grond van de afwijkende betekenis van de voorzieningen in de steden.

Gezien de opvallende afwijkingen van het gebruik van de zorgvoorzieningen door de stedelijke bevolking en mede gezien de bovenregionale betekenis van veel zorgvoorzieningen in de steden, acht de raad aanpassing van de centrale normuitkeringen inderdaad wenselijk. Hiertoe zijn in de stelselherziening diverse mogelijkheden gecreëerd.

Bij de uitvoering van de stelselherziening zullen veel meer dan nu prijs, $\mathrm{kwali-}$ teit, volume en spreiding van de zorgvoorziening decentraal worden vastgesteld. De raad wijst op het risico dat de belangen van de relatief zwakste partij - de patiënt c.q. de verzekerde - onvoldoende worden veiliggesteld, doordat thans vooral aanpassingsmogelijkheden worden voorzien voor de dominante marktpartijen en de centrale wetgever. De positie van de verzekerde zal voornamelijk via de verzekeraar tot uitdrukking komen. In veel gevallen zal de centrale overheid de belangen van de verzekerde moeten waarborgen (de lokale overheden staan hier buiten spel). De centrale overheid is echter niet bij machte op alle lokale en regionale differentiaties adequaat te reageren. De raad meent derhalve dat de positie van het grootstedelijk bestuur hier meer aandacht verdient dan er tot dusver aan is gegeven.

De raad bepleit een passende mogelijkheid voor de lagere overheden, met voorrang in te voeren voor het grootstedelijk bestuur, om in aanvulling op de algemene marktordening van het Rijk nadere voorwaarden op te leggen aan de marktpartijen, teneinde de beoogde marktwerking te verbeteren. Tegelijkertijd moet voorkomen worden dat deze bevoegdheid aan de lagere overheden de mogelijkheid zou bieden de oude plannende en coördinerende taken weer op te pakken, die nu juist doelbewust werden ingetrokken. De lagere overheden moeten dus niet in de beleidsmatige verantwoordelijkheden van de marktpartijen treden, maar zij moeten wel de spelregels kunnen aanpassen wanneer deze bij de feitelijke ontwikkelingen in hun gebied niet meer adequaat blijken te zijn. Om deze bevoegdheid waar te maken moeten de lagere overheden het recht hebben zelf - bijvoorbeeld via de gemeentelijke gezondheidsdiensten - de benodigde informatie te vergaren en gebruik te maken van de ten behoeve van het $\mathrm{Rijk}$ bestaande informatiestromen.

\subsubsection{Financiële en bestuurlijke verhoudingen}

Het streven van dit rapport de partijen in de grote stad zelf verantwoordelijk te maken voor de instandhouding van een solide stedelijke structuur, komt vooral aan de orde bij de financiële en bestuurlijke verhoudingen. 
Met betrekking tot de financiële verhoudingen wordt vastgesteld dat, hoewel een groot deel van de collectieve uitgaven via de gemeentebegroting loopt (exclusief de sociale verzekeringen ongeveer 40 procent), de stadsbesturen weinig greep op deze geldstromen hebben. De financiële positie van de gemeenten wordt primair bepaald door het Rijk. Bij de herziening van de Financiële- Verhoudingswet in 1984 heeft de wetgever weliswaar de gemeentebesturen meer allocatieve functies toegedacht, maar in de praktijk blijft dit beperkt tot het geringe aandeel van de eigen gemeentelijke inkomsten. Hierbij aansluitend zijn ook de bestuurlijke mogelijkheden beperkt.

Naar in het rapport wordt vastgesteld, zijn de Nederlandse financiële en bestuurlijke structuren tamelijk uniek in de internationale vergelijking. Nergens is de financiële verhouding tussen het Rijk en de gemeenten zo gecentraliseerd. Hoewel de Nederlandse gemeenten relatief veel uitgeven, is voor de allocatieve functie van het gemeentelijk beleid in de andere landen meer ruimte gecreëerd. Aan de internationale trend naar vergroting van de lokale inkomsten uit prijzen en heffingen doen de Nederlandse gemeenten niet mee. In de sanering van specifieke uitkeringen loopt Nederland evenmin voorop.

Wat het bestuur betreft, heeft Nederland wel een lange traditie van discussie over bestuurlijke organisatie, maar terwijl in de meeste andere landen diverse constructies zijn bedacht, ingevoerd, vernieuwd en soms ook weer ingetrokken, is bij ons geen ervaring opgedaan met vormen van bestuurlijke differentiatie. Ook nu staat dit onderwerp overigens weer volop in de belangstelling, in verband met de suburbanisatieproblematiek en mede dankzij de recente rapporten van de Externe Commissie Grote Stedenbeleid (Commissie Montijn) en van de Raad voor het Binnenlands Bestuur.

Voor de Nederlandse steden die in toenemende mate in het internationale verkeer betrokken raken, zal de beperkte financiële en beleidsmatige autonomie naar de mening van de raad een steeds grotere handicap worden. De raad bepleit derhalve een reorganisatie met drie uitgangspunten, namelijk het primaire uitgangspunt van lokale weerbaarheid, gepaard gaande met concurrentie en coöperatie, het uitgangspunt van de hiertoe vereiste beleidsdecentralisatie in uiteenlopende beleidsvelden en tenslotte de bijzondere bestuurlijke inrichtingsvereisten in grootstedelijke gebieden.

Dat er drie uitgangspunten zijn betekent dat het accent voor de bestuurlijke aanpassingen van de grootstedelijke gebieden in dit rapport niet uitsluitend ligt op een bestuurlijke reorganisatie van de grootstedelijke gebieden. De eerste twee uitgangspunten raken, naast de algemene financiële en bestuurlijke verhoudingen, uiteenlopende beleidsvelden en op nationaal niveau uiteenlopende ministeries. Ze komen vooral neer op aanpassingen binnen die beleidsvelden en nopen in het algemeen niet tot aanpassing van de bestuurlijke organisatie van de grote stad of het grootstedelijk gebied.

7.4.4.1 Perspectief: rekenschap voor het lokaal bestuur

De raad adviseert tot een verdergaande decentralisatie van de financiële verhouding Rijk-grote steden, om een zo direct mogelijke afweging tussen nut en offer te bevorderen. Hiertoe zal de huidige verhouding ( $63 \%$ specifieke uitkeringen, $27 \%$ algemene uitkering en $10 \%$ eigen gemeentelijke inkomsten) moeten veranderen.

Op den duur zal het totaal van de eigen gemeentelijke inkomsten, ook door uitbreiding van de eigen belastingcapaciteit, meer in evenwicht moeten komen met het totaal van de algemene uitkering uit het Gemeentefonds. De raad acht het voorstelbaar dat de eigen inkomsten uit heffingen en belastingen zullen oplopen tot 20 à 25 procent van het totaal. Op die manier zal de aandacht van het lokaal bestuur voor de beïnvloedbare plaatselijke verschillen in belasting- 
capaciteit worden vergroot, terwijl de vereveningsfunctie van de algemene uitkering gehandhaafd blijft.

Voortzetting van de sanering en overheveling van de specifieke uitkeringen ligt in de lijn van dit advies. Meer dan tot dusver zal hierbij de aandacht moeten gaan naar de relatief kleine groep van omvangrijke specifieke uitkeringen. De bestedingsvrijheid van de algemene uitkering is een belangrijk aandachtspunt. De verschuiving van de gemeentelijke inkomstenbronnen zal weliswaar veelal via de algemene uitkeringen van het Gemeentefonds lopen (als tussenstation), maar uiteindelijk toch vooral moeten bijdragen aan een versterking en verbreding van de eigen gemeentelijke inkomsten.

Om de eigen inkomsten te verhogen, dient de gemeentelijke belastingcapaciteit te worden uitgebreid. Hiervoor komt in de eerste plaats de onroerend-goedbelasting in aanmerking. De geldende koppeling tussen het zakelijk en gebruikerstarief is vooral bedoeld als rem op de gemeentelijke belastinginkomsten. Conform de hoofdlijn van dit rapport adviseert de raad de centrale vaststelling van de verhouding tussen zakelijke en gebruikerstarieven ongedaan te maken. Ter verbreding van de lokale belastinginkomsten kan voorts de aandacht uitgaan naar bestaande belastingen als de baat- en aanlegbelasting en de bouwgrondbelasting en naar nieuwe lokale belastingbronnen. Ook tarieven en heffingen, internationaal veel gehanteerd, dienen voor verhoging van eigen inkomsten te worden gebruikt.

Het proces dat naar meer onafhankelijkheid leidt, vraagt veel zorgvuldigheid en zonodig flankerende beleidsmaatregelen. Het beleid moet er uiteraard niet op gericht zijn de verschillen in belastingcapaciteit toe te dekken (dan wordt de nieuwe verhouding nooit bereikt), maar dient - terugredenerend vanuit de beoogde ordening - stap voor stap de benodigde middelen aan te reiken om de overgang naar grotere eigen verantwoordelijkheid te kunnen maken. Voor de weg naar financiële decentralisatie is dit een conditio sine qua non.

Een beleidskeuze als hier bepleit zal de positie van de gemeenten meer in het algemeen aangaan. Dit brengt een zeker voorbehoud met zich mee bij de aanbevelingen, omdat dit rapport alleen gaat over de grote steden en niet over alle gemeenten. Evenwel doen de problemen die de aanleiding vormen tot dit rapport zich doorgaans wel intensiever voor in de grote steden (deze lopen hierdoor ook grotere risico's bij doorvoering van financiële decentralisatie), maar zij zijn in veel opzichten een verdichting van zaken die elders in minder geconcentreerde en gecumuleerde mate ook aan de orde zijn. In dit opzicht is de financiële verhouding een goede 'testcase'.

\subsubsection{Naar gedifferentieerd bestuur in het grootstedelijk gebied}

De mate waarin de eenheden binnen de grootstedelijke gebieden (kern- en randgemeenten) hun eigen bijdrage leveren en kunnen leveren binnen de centralistische beleidskaders, is in de loop van de jaren '60 en '70 zodanig uitgehold, dat het weer meer rekenschap dragen en aanspreekbaar zijn voor de situatie en ontwikkeling binnen de eigen jurisdictie, versterking behoeft. Dit geldt vooral voor de kernsteden.

Aanscherping van de eigen rekenschap in relatie met de financiële verhouding zal tevens leiden tot een meer uitgesproken differentiatie tussen de gebiedseenheden, iets wat in het kader van de beleidsconcurrentie positief te beoordelen valt. In dit verband kan worden geleerd van West-Duitsland, waar tussen de grote steden en grootstedelijke gebieden in dit opzicht uitgesproken verschillen bestaan.

Een aanpassing van de institutionele verhoudingen waardoor met name de band tussen de markt- en uitwisselingsprocessen wordt versterkt, zal naar verwachting van de raad leiden tot een alertere en minder receptieve bestuurs- 
cultuur. Ook de kwaliteit van het bestuur hangt mede af van de belangen die aan de orde zijn.

In hoofdstuk 5 werd een aanpassing van de institutionele verhoudingen uitgewerkt voor de grote steden, c.q. de grootstedelijke gebieden, voor drie strategische beleidssectoren: onderwijs, arbeidsvoorziening en de gezondheidszorg en maatschappelijke dienstverlening. In al deze beleidssectoren wordt een eigen profiel voorgesteld, in aansluiting op de huidige stelselherzieningen. In de onderwijssector wordt het zwaartepunt van decentralisatie naar de direct bij het onderwijs betrokkenen (de scholen en de vraag naar opgeleiden) aangevuld met een versterking van de beleidsmatige betrokkenheid van het grootstedelijk bestuur. Ook in de arbeidsvoorziening ligt bij de stelselherziening het zwaartepunt bij de direct bij deze voorziening betrokkenen, maar ook in dit geval adviseert de raad tot aanvullingen voor een grotere betrokkenheid van het bestuur van de grote stad en voor meer relaties met de vraag naar arbeid. Bij de gezondheidszorg en de maatschappelijke dienstverlening zou het zwaartepunt van decentralisatie, verbonden met vraag, aanbod en financiering, dienen te worden aangevuld door bijsturing (door het lokaal bestuur) op lokaal en regionaal niveau.

In elk van deze uitwerkingen is ook aangegeven hoe steeds het basisprincipe van beleidsconcurrentie wordt geconditioneerd door de eerder genoemde inperkingsgronden: nationale basisnormen en -condities, het tegengaan van mogelijke externe effecten en lasten en tenslotte het compenseren voor structurele onevenwichtigheden.

In aanvulling op de bepleite beleidsdecentralisatie is voor een snel en op voldoende niveau tot stand komen en functioneren van strategische infrastructuur en voorzieningen een aanpassing nodig, waardoor de lokale besturen in het grootstedelijke gebied nauwer worden samengebonden dan nu het geval is. Uitgaande van de in Nederland bestaande terughoudendheid ten aanzien van een nieuwe bestuurslaag, adviseert de raad niet over te gaan tot de vorming van grootstedelijke gewesten tussen gemeenten en provincie, maar beperkt hij zich tot een aantal mogelijkheden om verder te gaan dan de vrijwillige samenwerking die de Wet Gemeenschappelijke Regelingen kent.

De eerste en meest voor de hand liggende aanpassing is om daar waar de grenzen van gemeenten in de grootstedelijke gebieden aan de kernstad onvoldoende soelaas bieden voor de eigen ontwikkeling, tot wijziging van deze grenzen te komen. Deze situatie lijkt zich op dit ogenblik, bij de in dit rapport behandelde steden, alleen voor te doen ten aanzien van Den Haag en Utrecht.

In deze en de andere grote steden is vervolgens een aanpassing vereist op het schaalniveau van het grootstedelijk gebied. Dit kan gebeuren door een bundeling van de kernstad en randgemeenten in een regioverband, dat voor een beperkt aantal strategische taken binnen beleidsgebieden, zoals verkeer en openbaar vervoer, volkshuisvesting en milieubeheer een eigen verantwoordelijkheid draagt, die aan de onderscheiden gemeenten is onttrokken. Dit regioverband dient hiervoor een eigen bestuur en eigen diensten te krijgen. De democratische verantwoordelijkstelling blijft in deze constructie geconcentreerd bij de gemeenten die deel uitmaken van het regioverband. Gelet op het beperkt aantal functies is dit getrapte bestuursmodel verdedigbaar vanuit democratisch oogpunt en qua bestuurlijke afstemming optimaal aangescherpt. De betrokken grote steden komt in dit bestuur een eigen stem toe. Om enerzijds een te grote vrijblijvendheid te voorkomen en anderzijds toch weloverwogen deze bestuurlijke aanpassing aan te brengen, stelt de raad voor de Gemeentewet zo aan te passen dat voor die gemeenten die tot deze grootstedelijke gebieden in Nederland gerekend kunnen worden, de uiteenlegging van taken tussen gemeenten en regioverband mogelijk wordt gemaakt en in overleg met de desbetreffende grootstedelijke gebieden bij afzonderlijke wet 
(lex specialis) wordt gesanctioneerd.

Een dergelijke constructie maakt een specifiek grootstedelijk bestuur in Nederland mogelijk, zonder het basisstramien van de drie bestuurslagen geweld aan te doen. Het biedt tevens mogelijkheden om in de loop van de tijd mee te groeien met de nieuwe formaties van grote steden en grootstedelijke gebieden en per gebied te differentiëren. Deze aanpassing zou op korte termijn moeten worden gerealiseerd. Tezijnertijd zou deze nieuwe grootstedelijke constructie aangevuld kunnen worden met een aanpassing van de provincies aan een bestuursniveau dat zich meer concentreert op interregionale afstemming en op beleid tussen grootstedelijke gebieden onderling en landelijke gebieden. 


\section{Zakenregister}

Accountancy 62, 65-66, 68, 162

Activerend arbeidsmarktbeleid (WRR-rapport nr. 33) 136, 148

Afhankelijkheid

- op economisch terrein $17,24,26,29,37,64,80$

- op financieel terrein (van gemeenten t.o.v. Rijk) I9I, 197, 204, 205, 208, 209

- in sociaal opzicht 24, par. 4.3.3-4.4, II6, 225

- overigens 138, 21।

Agglomeratie 4I, 47, 54, 59, 73, 78, 100, 146, 156, par. 6.3

Algemene Arbeidsongeschiktheidswet (AAW) 103, 106

Algemene Bijstandswet (ABW) 106, 121, par. 4.5.3-4.5.5, 232

Alleenstaanden $91,202,230$

Allocatieve functie (van beleid) 29, 189, 192, 206, 237

Allochtone(n) 93, 96, 106, 110, 137, par. 5.2.2, 153, 161, 163

- beleid 233

Allochtonenbeleid (WRR-rapport nr. 36) 22, 93, 140, 174

Annexatie, zie onder: Samenvoeging

Arbeid(s)

- aanbod 39, 67, 74, par. 4.3.2, III, 162

- bemiddeling 34, $121-122$, par. 5.3

- beurzen 158, 160

- bureau par. 4.3.2, 4.5.5 en 5.3

- passende 123

- aanvullende -plaatsen III

- pool (voor havenwerknemers) 125

Arbeidsmarkt, passim (zie in het bijzonder: par. 4.3, 4.5 .5 en 5.3)

- Rapportage- 95, 101-102

- regio 102-103

Arbeidsvoorziening(s), passim (zie in het bijzonder: par. 4.5.5.2, 5.3 en 7.4.3.2)

- Centraal Bestuur (CBA) 160, par. 5.3.4

- Regionaal Bestuur (RBA) 121, 124, 148, par. 5.3.4, 235

- wet 120, par. 5.3

Armenzorg 158-160

Armoede 15, 22, 89, 93, 96, 108-109, 224-225, 230

Baltimore 26, 32, 216

Banenpool 108, 124, 157, 161, 163

Bankwezen 62, 64, 68

Basiseducatie 123, 127

Basisverzekering 207, 215

Basisvorming 147, 150, 152

Basisvorming in het onderwijs (WRR-rapport nr. 27) 147, 149

Bedrijfs

- georganiseerd -leven 87, 156, 160

- huisvesting $62,78,87-88$

- opleidingen 122

- vereniging 125,163

Bejaarden 23, 9I, 106, 202, 204-205, 213, 215, 225, 230, 236

- hoog- 169, 171, 225

- oorden I7|-172, 179, 200

Belasting(en) 25, 116,129 , par. 6.2, 238

- gemeentelijk -gebied I88, 193-194, 202, 206, 231

- gemeentelijke -capaciteit 37, 191, 207, 208-209, 237

- onroerend goed- (OGB) 188, 194, 209, par. 6.2.4-6.2.6, 238

Bereikbaarheidsplan Randstad 228 


\section{Beroeps}

- bevolking 34, 40, 78, 101-104, 109

potentiële 90-91, 95, 102-103

- gerichte kwalificatiecursussen 127

volwasseneneducatie 163-164

- keuze-advisering 163-164

- onderwijs 85, 103-104, par. 5.2, 229, 234-235

hoger 139, 145, 146

lager 85, 103-104

middelbaar 139, 146, 154-155

voortgezet $139,234-235$

- opleiding 103-104, 148-150

- oriëntatie 127, 163

Bestuurlijke differentiatie, zie onder: Agglomeratie, (bovengemeentelijke) Bestuursvormen en Samenvoeging/Annexatie van gemeenten

\section{Bestuurs}

- commissie krachtens artikel 61 van de Gemeentewet 184

- cultuur (politieke-) 25, 35, 36-37, I35, 140, 153, 184, 188, 207, 208, 219, 227, 238-239

- vierde -laag 210, 212, 214

- vormen, bovengemeentelijke 211

Bevolking(s)

- groei 4I, 90,97

- leeftijdsopbouw van de $90-91$

- omvang 40-4I, par. 4.2.I.I, 139, 140

- opbouw/samenstelling 23, 27, 40-4I, par. 4.2.1, 94, 96, 100, I39, 140, 224-225

Bijstand(s) 108, II2, par. 4.5.3-4.5.4, I2I, 123, 16I, 197, 198, 231-232

- bijzondere par. 4.5.3, 121, 232

- gerechtigde(n) $34,93,106,115,122,225$

- besluit Zelfstandigen 128

Birmingham 30, 131

Boston 22, 29, 32, 95, 234

Boventalligenregeling 153

Brussel 26, 55-56, 70, 215

Burgercultuur, zie onder Civic culture

CAO's (regionale) 149, 166

Centraal Bestuur Arbeidsvoorziening (CBA), zie onder Arbeidsvoorziening

Centrum voor Vakopleiding 127, 163

Chicago 29, 78, 142, 216, 234

'Civic culture'/burgercultuur 31, 36, 37, 79

Commissie

- Albeda 75, 171

- Christiaanse 193-194

- Dekker 173

- Hirsch Ballin 152

- Montijn 26, 75, 139, 210, 213, 237

- Rauwenhoff 137

Computerdienstverlening 62, 66-67, 73

Concentratie/cumulatie van problemen 96, 108-109

Consumptie (van medische voorzieningen) 170, 174, 180

Cultuur 17, 72, 145, 184, 196, 205

- overdracht 136, 138, 146, 149, 150, 155, 234

- voorzieningen $33,133,140,146$

Decentralisatie, passim (zie in het bijzonder par. 6.3)

- functionele 152, 154, 159-160, 211, 214, 234

- territoriale 151,212 
Deconcentratie

- bestuurlijke 215

- ruimtelijke 29, 41, 69-70,97-98, II0, 183

Demografische

- ontwikkelingen/processen/trends 17, 89-90, 94, I10, 202

- samenstelling, zie onder bevolkingsopbouw

Distributiecentra 98

Distributieve functie (van beleid) 29,189

Drop-outs 148, 162

Duale economie 22

Economisch(e)

- non-activiteit 102-103, 109

- ontwikkelingsbeleid/-programma's 85-88, I 30-131

- stadsvernieuwing 132

- Zaken, Ministerie van 68, 80-81, 86-87, 88, 132, 156, 229

Eénoudergezinnen 92-93, 106

Egalisatie (-motief) 208-209, 216, 190-191, 203, 207

Eigen inkomsten (van gemeenten) par. 6.2, 237

Eindhoven 13,24, 26, 173, 212, 214, 216

'Enterprise allowance' 128

Etnische minderheden, zie onder: Allochtonen

Europees Sociaal Fonds 164

Export 40, 48-49, 58-6I, 65-67, 85-86

Financiële verhouding(en) 25, 31, 35, 79, II7, 121, hfd. 6 passim, 227, 231, 236-238

Financiële-Verhoudingswet (1984) (FVW) par. 6.2.2, 198, 206, 207

Geboortenoverschot/-saldo 90

Gemeentefonds 76, 119, par. 6.2, 227, 237

Gemeentelijke Sociale Dienst (GSD) 93, 106, $115,118,125-126,162,166$

Gewestelijk arbeidsbureau, zie onder: Arbeidsbureau

Gezondheids

- bevordering 168, 172, 179

- diensten 171, 179, 181, 235-236

- grootstedelijk -beleid 169, par. 5.4.4, 235

- profiel/ -toestand van de stedelijke bevolking 169 - 170

- zorg 24, 60, 72, 79, 106, I34, par. 5.4, 218, 220, 224, 234, 235, 239

Glasgow 19,56, 132

Grafische industrie 62, 67, 225

'Health Promotion'/'healthy cities project' 172

Heroriënteringsgesprekken 120, 122, 127, 164, 197

Huishoudensstructuur 91-93, 100, 108

Huisvesting (van de stedelijke bevolking) 33, 93, par. 4.3.1, 108, III-1 12, 183

(zie ook onder: Volkshuisvesting en Woning)

Huur

- sector 99, III, 114, 209

- subsidie, individuele (IHS) 187, 193

- woningen 99, III, II 3-114, 232

Immigratie, zie onder: Migratie

Individuele

- begeleiding (van werkzoekenden) 117, 122, 126-127, 148

- hulpverlening 109, 116,118

Infrastructuur 82-84

Ingenieurs- en architectenbureaus 62, 65 
Inkomens (zie ook bij Minima)

- beleid/-politiek II5-117, 189

- cijfers/-patroon/-verdeling 24, par. 4.2.2, 96

- prijzen 107, 116

- subsidies 107

Innovatie 58, 78, 85-86, 137, 150

Intersectoraal grootstedelijk beleid (gezondheidszorg) 172

Investeringspeil

- van de Nederlandse gemeenten 205-206

- van regio's 49-5I

Jeugdwerkgarantieplan 120,123, 163

Jobcentra 159, 163

Kaderregeling Arbeidsinpassing 120, 163

Kamer(s) van Koophandel 5I-53, 80, 86, 149

Laaggeschoold(e)(n) 103-104, 127, 161

- dienstverlening 127-128

Leer- en arbeidsovereenkomsten 157

Leerlingwezen 127, 17I, 163

Liverpool 19, I31

Logistiek 15, 70, 72-73, 78, 80-83, 145

Londen $18,20,25,32,33,55,56,64,70,85,86,110,211,215,234$

Loonkostensubsidie(s) 95, 124

Los Angeles 29, 97, 142, 234

Luchthaven $21,43,73,82-83,218,228$

Maatregel Langdurig Werklozen (MLW) 164

Maatschappelijk(e)

- dienstverlening 72, 79, 107, 133, 135, par. 5.4, 218, 220, 220, 224, 234-236

- werk 15, 16, 89, 109, I18, $171,23 \mid$

- bijstands - 118

Maatwerk (bij werkloosheidsbestrijding) 29, 117, 164-165, 167, 235

Mainports 55, 63, 68, 74, 82-83, 218-228

Mantelzorg 168

Metaal-elektro-industrie 62, 67

Midden- en kleinbedrijf 27, 85, 126, par. 4.5.6, 145, 149, 163

Migranten 15, 22, 90, 93, 96, 110

Migratie 17, 40-41, 54, 90, 93, 110

- saldo 90

Milieu 37, 39, 59, 62, 80-81, 98, 228

- beheer 221, 239

- lasten 98

Minima (minimuminkomens) 106-108, III, par. 4.5.3, 134, 232

- beleid (gemeentelijk) 106, 116-117, 232

- zonder marge 107

Minneapolis 216

Mobiliteit 89, par. 4.3-4.4

-. geografische/ruimtelijke 32, 35, 80, par. 4.3.I, 233

- sociale $23,28-29,32,89,96-97,110-111,124-125,219$

New York 18, 19, 29, 70, 142, 216

Newcastle 30, 56, 85, 234

Normuitkeringen (gezondheidszorg) 174, 178-180, 236 


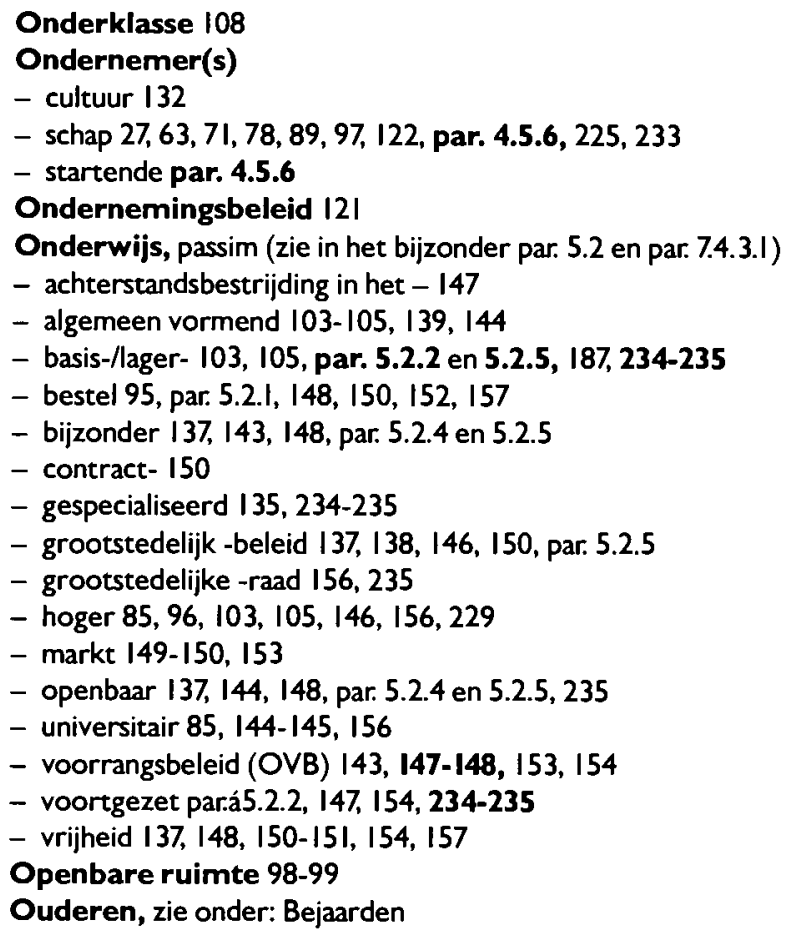

Pendel 104, 112, 193

Personeelsbeleid 119, 121, 125, 155, 162

Post-universitaire opleidingen 144

Poverty trap 107

Preventie (gezondheidszorg) 168, 17/-172, 174, 179

'Public entrepreneurship' 37

'Public-private partnerships' 37, 233

Quartaire sector $46-47,123-124,161$

Raad voor de Gemeentefinanciën (RGF) 192-193

Railinfrastructuur 83, 218

Regio Overleg Amsterdam (ROA) 219, 221

Regionaal Bestuur Arbeidsvoorziening (RBA), zie onder: Arbeidsvoorziening

Regioverband 221, 239

'Rekenschap' (van bestuur) 112, 226, 244, 219, 237-238

'Responsiviteit' 36, 121

Rotterdams(e)

- convenant (inzake werkgelegenheid) I2I

- Ontwikkelingsraad (ROTOR) 78-80, 156, 221, 229

Ruhrgebied 19, 215

Ruimtelijke ordening 13, 17, 27, 34, 41, 75, 81, I| 3-I14, 129, 193, 228

Rijksgroepsregeling Werkloze Werknemers (RWW) 106

Rijnmond 26, 40-41, 47, 50, 58, 59, 73, 90, 93, 100, 212, 214, 216

Samenvoeging/Annexatie van gemeenten par. 6.3.1

Sanctie(s) (voor uitkeringsgerechtigden) 115, 123, 160, 163, 165

San Francisco 26, 78, 83, 228

Schiphol I5, 17, 29, 41, 43, 48, 50, 63, 68, 73, 82-83, 145, 218, 228

Scholing(s) 67, 85, 103-104, 119-120, par. 4.5.5.2, 129, 131, I36, 148-149, 159, 163, 165, 168, 233

- faciliteiten/-programma's/-projecten 125, 130, 167, 235 
School

- advies- en begeleidingsdiensten 153

- autonome 134, 157, 281

- bestuur 151, 152-153

- De - op weg naar 2000 136, 152

- effectieve 148

- populatie 140

- prestaties 93

- verzuim 148

Socia(a)l(e)

- ongelijkheid 139, 141, 144

- problematiek/problemen 13, 14, 16, 17, 21-23, 29-30, 78-79, hfd. 4 passim, 213, 223-

$224,227,231$

- profiel/structuur 14, 2I-23, 26, 27-29, 30-31, 35, 89, 96, par. 4.4-4.5.I, 132, 183, 193, 209, 223-224, 230

- vernieuwing $31-32,147,148,155,208$

Spitsvignetten 81,228

Stadscultuur/stedelijke cultuur 17, 36, 133, 169, 203

Stadsprovincie 211,213

Stadsvernieuwing 31, 88, 98-100, 107, I10-111, 132, 133, 198-199

- fonds/-gelden 88, 98-100, 111, 132, 198-199, 208

Stelselherziening (gezondheidszorg) 169, 173, 176, 177, 179-181, 225, 234, 236, 239

Structuurschema Verkeer en Vervoer (Tweede-) 75, 228

Suburbanisatie 20-2I, $41-42,54,211$

'Task Forces' 127, 131-132, 233

Technologie 55-58, 73-74

Telematica 64, 66, 82-83, 84, 229

TGV 84,228

Thuiszorg 169, 179, 236

Toegevoegde waarde (naar regio's) 42-48, 61

Toerisme 62-63, 67

Tolheffing 81,228

Toronto $25,172,215-216$

Transport(sector) 18, 43, 46-47, 48-49, 50, 54, 61, 63-64, 68, 80-8I, 145, 162, 228

Uitkering(en) (aan gemeenten)

- algemene 28, 76, 115, 208, par. 6.2, 227, 232, 237

- bijzondere/doel-/specifieke II2, par. 6.2, 174, 180, 206-207, 237

Uitkeringsgerechtigde(n) 28, 106, par. 4.5.3-4.5.5, 197, 208, 232

Uitzendbureaus 105, 126, par. 5.3, 233, 235

'Urban field' $21,74,82$

Vacature(s)

- banken 159, 163

- moeilijk vervulbare 103-105

- verborgen 67, 103-104

Vereniging van Nederlandse Gemeenten (VNG) 196

Verevening, zie onder: Egalisatie

Vergrijzing 91,168

Verhuisbewegingen 14, 22-23, 223

Vervoer(s)

- infrastructuur $55,78,82-84$

- Openbaar 54, 83-84, 98, 218, 221, 227, 229, 239

Vestigings

- beleid 166

- klimaat 98-99

- plaats 42, 46, 53-54, 68, 74

Vierde Nota inzake de Ruimtelijke Ordening 13, 75, 81, 1 13, 228 
Volkshuisvesting 17, 24, 107, II 3-1 I4, II7, 133, 220, 193, 209, 212, 232-234, 239

Volwasseneneducatie 148, 153, 154, 156, 163-164

\section{Welzijnswet 119}

Werkervaringsplaatsen $111,120,122,164$

Werkgelegenheid(s) 20, par. 3.2.3-3.3, 101-103, par. 4.5.5.2, 4.5.6 en 5.3.2, 233-234

- beleid 132, 233

- projecten in de quartaire sector 123

- verruimende Maatregel (WVM) 126, 163

Werkloosheid(s) 14, 22, 77, 87, hfd. 4 passim, 148, par. 5.3, 224-225, 230, 233

- bestrijding 15, 104-105, 125-126, 129, 136, 148, 165, 231, 233-234

- ciffers $|4|$

- duurzame 96

- jeugd- 125, 161

Werklozen passim

- duurzaam 107

- geregistreerde 101, 104

- hooggeschoolde 104

- jeugdige 104

- langdurig 104, par. 4.5.5, 131, 148, 162-164

- part-time 102

Werkraat 119,122

Werving 55, 105

Westland 4I, 43, 46, 73, 228

Wet op de Arbeidsongeschiktheidsverzekering (WAO) 102-103, 106

Wet op de bejaardenoorden $|7|$

Wet Gemeenschappelijke Regelingen (WGR) 26, II4, 154-155, 21 I, 213, 221, 239

Wet werkloosheidsvoorzieningen (WWV) 106, 119, 164

Woning(en)

- bouw 27, 32, 87, II 3-114, 221, 230

- bouwcorporaties/-verenigingen I14, 135, 179, 232

- huur-, zie onder: Huur

- koop- 99-101, III, 209

- markt 97, 101

- voorraad 99-101, 111, 114, 209, 232

- wetwoningen 209, 232

Woon

- carriëre 101

- lasten(quote) 107, 117

- milieu/-omgeving 96, 98-99, 113, 179, 236

Zakelijke dienstverlening 19, 21, 40, 43, 54-55, 62, 64-65, 68-69, 86, 161, 162, 225 Zeehaven 83, 218 


\section{Rapporten aan de Regering}

\section{Eerste raadsperiode:}

Europese Unie*

Structuur van de Nederlandse economie*

Energiebeleid

Gebundeld in êén publikatie (1974)*

Milieubeleid (1974)*

Bevolkingsgroei (1974)*

De organisatie van het openbaar bestuur (1975)*

7 Buitenlandse invloeden op Nederland: Internationale migratie (1976)*

8 Buitenlandse invloeden op Nederland:

Beschikbaarheid van wetenschappelijke en technische kennis (1976)*

9 Commentaar op de Discussienoca Sectorraden (1976)*

10 Commentaar op de nota Contouren van een toekomstig onderwijsbestel (1976)*

II Overzicht externe adviesorganen van de centrale overheid (1976)*

12 Externe adviesorganen van de centrale overheid (1976)*

13 Maken wij er werk van?

Verkenningen omtrent de verhouding tussen actieven en niet-actieven (1977)*

14 Interne adviesorganen van de centrale overheid (1977)*

15 De komende vijfentwintig jaar - Een toekomstverkenning voor Nederland (1977)*

16 Over sociale ongelijkheid - Een beleidsgerichte probleemverkenning (1977)*

\section{Tweede raadsperiode:}

17 Etnische minderheden (1979)*

A. Rapport aan de Regering

B. Naar een algemeen etnisch minderhedenbeleid?

18 Plaats en toekomst van de Nederlandse industrie (1980)*

19 Beleidsgerichte toekomstverkenning

Deell: Een poging tot uitlokking (1980)*

20 Democratie en geweid

Probleemanalyse naar aanleiding van de gebeurtenissen in Amsterdam op 30 april 1980*

21 Vernieuwingen in het arbeidsbestel (1981)*

22 Herwaardering van welzijnsbeleid (1982)*

23 Onder invloed van Duitsland

Een onderzoek naar gevoeligheid en kwetsbaarheid in de betrekkingen tussen Nederland en de Bondsrepubliek (1982)*

24 Samenhangend mediabeleid $(1982)^{*}$

\section{Derde raadsperiode:}

25 Beleidsgerichte toekomstverkenning

Deel 2: Een verruiming van perspectief (1983)*

26 Warborgen voor zekerheid

Een nieuw stelsel van sociale zekerheid in hoofdlijnen (1985)

27 Basisvorming in het onderwijs (1986)

28 De onvoltooide Europese integratie (1986)

29 Ruimte voor groei; kansen en bedreigingen voor de Nederlandse economie in de komende tien jaar (1987)

30 Op maat van het midden- en kleinbedrijf (1987)

Deel I: Rapport aan de Regering; Deel 2: Pre-adviezen

31 Cultuur zonder grenzen (1987)*

32 De financiering van de Europese Gemeenschap; een interimrapport (1987)

33 Activerend arbeidsmarktbeleid (1987)

34 Overheid en toekomstonderzoek; een inventarisatie (1988)

\section{* Uitverkocht}


Vierde raadsperiode:

Rechtshandhaving (1988)

Allochtonenbeleid (1989)

Van de stad en de rand (1990)

Rapporten aan de Regering en publikaties in de reeks 'Voorstudies en achtergronden' zijn verkrijgbaar in de boekhandel of via de SDU uitgeverij, Christoffel Plantijnstraat 2, Postbus 20014, 2500 EA 's-Gravenhage, tel. 070-37899II. 


\section{'Voorstudies en achtergronden'}

\section{Eerste raadsperiode:}

$\checkmark$ I W.A.W. van Walstijn e.a.: Kansen op onderwijs; een literatuurstudie over ongelijkheid in het Nederlandse onderwijs $(1975)^{*}$

$\checkmark 2$ I.J. Schoonenboom en H.M. In 't Veld-Langeveld: De emancipatie van de vrouw (1976)*

$\checkmark 3$ G.R. Mustert: Van dubbeltjes en kwartjes: een literatuurstudie over ongelijkheid in de Nederlandse inkomensverdeling $(1976)^{*}$

$\checkmark 4$ IVA/nstituut voor Sociaal-Wetenschappelijk Onderzoek van de Katholieke Hogeschool Tilburg: De verdeling en de waardering van arbeid; een studie over ongelijkheid in het arbeidsbestel (1976)*

V 5 'Adviseren aan de overheid', met bijdragen van economische, juridische en politicologisehe bestuurskundigen (1977)*

V 6 Verslag Eerste Raadsperiode: 1972-1977*

\section{Tweede raadsperiode:}

$\checkmark 7$ J.J.C. Voorhoeve: Internationale macht en interne autonomie - Een verkenning van de Nederlandse situatie (1978)*

V 8 W.M. de Jong: Techniek en wetenschap als basis voor industriële innovatie - Verslag van een reeks van interviews $(1978)^{*}$

V 9 R. Gerritse/Instituut voor Onderzoek van Overheidsuitgaven: De publieke sector: ontwikkeling en waardevorming - Een vooronderzoek (1979)*

V10 Vakgroep Planning en Beleid/Sociologisch Instituut Rijksuniversiteit Utrecht: Konsumptieverandering in maatschappelijk perspectief (1979)*

VII R. Penninx: Naar een algemeen etnisch minderhedenbeleid? Opgenomen in rapport nr. $17(1979)^{*}$

V12 De quartaire sector - Maatschappelijke behoeften en werkgelegenheid - Verslag van een werkconferentie (1979)*

VI3 W. Driehuis en P.J. van den Noord: Produktie, werkgelegenheid en sectorstructuur in Nederland 1960-1985 Modelstudie bij het rapport Plaats en toekomst van de Nederlandse industrie (1980)*

VI4 S.K. Kuipers, J. Muysken, D.J. van den Berg en A.H. van Zon: Sectorstructuur en economische groei: een eenvoudig groeimodel met zes sectoren van de Nederlandse economie in de periode na de tweede wereldoorlog. Modelstudie bij het rapport Plaats en toekomst van de Nederlandse industrie (1980)*

VI5 F. Muller, P.J.J. Lesuis en N.M. Boxhoorn: Een multisectormodel voor de Nederlandse economie in 23 bedrijfstakken F. Muller: Veranderingen in de sectorstructuur van de Nederlandse industrie (1980**

VI6 A.B.T.M. van Schaik: Arbeidsplaatsen, bezettingsgraad en werkgelegenheid in dertien bedrijfstakken Modelstudie bij het rapport Plaats en toekomst van de Nederlandse industrie (1980**

VI7 A.J. Basoski, A. Budd, A. Kalf, L.B.M. Mennes, F. Racké en J.C. Ramaer: Exportbeleid en sectorstructuurbeleid Pre-adviezen bij het rapport Plaats en toekomst van de Nederlandse industrie (1980**

VI8 J.J. van Duijn, M.J. Ellman, C.A. de Feyter, C. Inja, H.W. de Jong, M.L. Mogendorff en P. VerLoren van Themaat: Sectorstructuurbeleid: mogelijkheden en beperkingen

Pre-adviezen bij het rapport Plaats en toekomst van de Nederlandse industrie (1980**

VI9 C.P.A. Bartels: Regio's aan het werk: ontwikkelingen in de ruimtelijke spreiding van economische activiteiten in Nederland

Studie bij het rapport Plaats en toekomst van de Nederlandse industrie (1980)*

* Uitverkocht 
V20 M.Th. Brouwer, W. Driehuis, K.A. Koekoek, J. Kol, L.B.M. Mennes, P.. van den Noord, D. Sinke, K. Vijlbrief en J.C. van Ours: Raming van de finale bestedingen en enkele andere grootheden in Nederland in 1985 Technische nota's bij het rapport Plaats en toekomst van de Nederlandse industrie (1980)*

P. Thoenes, R.J. In 't Veld, I.Th.M. Snellen, A. Faludi: Benaderingen van planning Vier pre-adviezen over beleidsvorming in het openbaar bestuur (1980)*

Beleid en toekomst

Verslag van een symposium over het rapport Beleidsgerichte toekomstverkenning deel I (1981)*

LJ. van den Bosch, G. van Enckevort, Ria Jaarsma, D.B.P. Kallen, P.N. Karstanje, K.B. Koster: Educatie en welzijn $(1981)^{*}$

J.C. van Ours, D. Hamersma, G. Hupkes, P.H. Admiraal: Consumptiebeleid voor de werkgelegenheid Pre-adviezen bij het rapport Vernieuwingen in het arbeidsbestel (1982)*

J.C. van Ours, C. Molenaar, J.A.M. Heijke: De wisselwerking tussen schaarsteverhoudingen en beloningsstructuur Pre-adviezen bij het rapport Vernieuwingen in het arbeidsbestel (1982)*

A.A. van Duijn, W.H.C. Kerkhoff, L.U. de Sitter, Ch.J. De Wolff, F. Sturmans: Kwaliteit van de arbeid

Pre-adviezen bij het rapport Vernieuwingen in het arbeidsbestel (1982)*

J.G. Lambooy, P.C.M. Huigsloot en RE. van de Lustgraaf: Greep op de stad?

Een institutionele visie op stedelijke ontwikkeling en de beĩnvloedbaarheid daarvan (1982)*

J.C. Hess, F. Wielenga: Duitsland in de Nederlandse pers - altijd een probleem?

Drie dagbladen over de Bondsrepubliek 1969-1980 (1982)*

C.W.A.M. van Paridon, E.K. Greup, A. Ketting: De handelsbetrekkingen tussen Nederland en de Bondsrepubliek Duitsland (1982)*

W.A. Smit, G.W.M. Tiemessen, R Geerts: Ahaus, Lingen en Kalkar, Duitse nucleaire installaties en de gevolgen voor Nederland $(1983)^{*}$

J.H. von Eije: Geldstromen en inkomensverdeling in de verzorgingsstaat (1982)* enige hoofdstukken over de Nederlands-Duitse betrekkingen in de jaren zeventig (1983)* 
M I J.M. de Meij: Overheid en uitingsvrijheid (1982)*

M 2 E.H. Hollander, Kleinschalige massacommunicatie: lokale omroepvormen in West-Europa (1982)*

M 3 LJ. Heinsman/NOS: De kulturele betekenis van de instroom van buitenlandse televisieprogramma's in Nederland Een literatuurstudie (1982)*

M 4 LP.H. Schoonderwoerd, W.P. Knulst/Sociaal en Cultureel Planbureau: Mediagebruik bij verruiming van het aanbod $(1982)^{*}$

M 5 N. Boerma, J.J. van Cuilenburg, E. Diemer, J.J. Oostenbrink, J. van Putten: De omroep: wet en beleid; een juridisch-politicologische evaluatie van de omroepwet (1982)*

M 6 Intomart b.v:: Etherpiraten in Nederland (1982)*

M 7 P.J. Kalff/Instituut voor Grafische Techniek TNO: Nieuwe technieken voor produktie en distributie van dagbladen en tijdschriften (1982)*

M 8 J.J. van Cuilenburg, D. McQuail: Media en pluriformiteic; Een beoordeling van de stand van zaken (1982)*

M 9 K.J. Alsem, M.A. Boorsma, G.J. van Helden, J.C. Hoekstra, P.S.H. Leeflang, H.H.M. Visser. De aanbodstructuur van de periodiek verschijnende pers in Nederland (1982)*

MI0 W.P. Knulst/Sociaal en Cultureel Planbureau: Mediabeleid en cultuurbeleid; Een studie over de samenhang tussen de twee beleidsvelden (1982)*

MII A.P. Bolle: Het gebruik van glasvezelkabel in lokale telecommunicatienetten (1982)*

MI2 P. te Nuyl: Structuur en ontwikkeling van vraag en aanbod op de markt voor televisieprodukties (1982)*

MI3 P.J.M. Wilms/Instituut voor Onderzoek van Overheidsuitgaven: Horen, zien en betalen; Een inventariserende studie naar de tockomstige kosten en bekostiging van de omroep (1982)*

MI4 W.M. de Jong: Informatietechniek in beweging; consequenties en mogelijkheden voor Nederland (1982)*

MI5 J.C. van Ours: Mediaconsumptie; Een analyse van het verleden, een verkenning van de toekomst (1982)*

MI6 J.G. Sappers, A.D. Reijnders, W.A.J. Möller. De werking van massa-media; Een overzicht van inzichten (1983)*

MI7 F.J. Schrijver. De invoering van kabeltelevisie in Nederland (1983)*

* Uitverkocht 


\section{Derde raadsperiode:}

V40 G.J. van Driel, C. van Ravenzwaaij, J. Spronk en F.R Veeneklaas: Grenzen en mogelijkheden van het economisch stelsel in Nederland (1983)*

V4I Adviesorganen in de politieke besluitvorming. Symposiumverslag onder redactie van A.Th. van Delden en J. Kooiman $(1983)^{*}$

V42 E.W. van Luijk, RJ. de Bruijn: Vrijwilligerswerk tussen betaald en huishoudelijk werk; een verkennende studie op basis van een enquête (1984)

Planning en beleid; verslag van een symposium over de studie Planning als onderneming (1984)

V44 W.J. van der Weijden, H. van der Wal, H.J. de Graaf, N.A. van Brussel, W.J. ter Keurs: Bouwstenen voor een geīntegreerde landbouw (1984)*

V45 J.F. Vos, P. de Koning, S. Blom: Onderwijs op de tweesprong; over de inrichting van basisvorming in de eerste fase van het voortgezet onderwijs (1985)*

V46 G. Meester, D. Strijker: Het Europese landbouwbeleid voorbij de scheidslijn van zelfvoorziening (1985)

V47 J. Pelkmans: De interne EG-markt voor industriële produkten (1985)

V48 J.J. Feenstra, K.J.M. Mortelmans: Gedifferentieerde integratie en Gemeenschapsrecht: institutioneel- en materieelrechtelijke aspecten (1985)

V49 T.H.A. van der Voort, M. Beishuizen: Massamedia en basisvorming (1986)

V50 C.A. Adriaansens, H. Priemus: Marges van volkshuisvestingsbeleid (1986)

V5I E.F.L. Smeets, Th.J.N.N. Buis: Leraren over de eerste fase van het voortgezet onderwijs (1986)

V52 J. Moonen: Toepassing van computersystemen in het onderwijs (1986)

V53 A.L. Heinink (red.), H. Riddersma, J. Braaksma: Basisvorming in het buitenland (1986)*

V54 Zelfstandige bestuursorganen; verslag van de studiedag op 12 november 1985 (1986)

V55 Europese integratie in beweging; verslag van een conferentie, gehouden op 16 mei 1986 (1986)

V56 C. de Klein, J. Collaris: Sociale ziektekostenverzekeringen in Europees perspectief (1987)

V57 R.M.A. Jansweijer. Private leefvormen, publieke gevolgen; naar een overheidsbeleid met betrekking tot individualisering (1987)

V6I H. van der Sluijs: Ordening en sturing in de ouderenzorg (1988)

V62 Verslag van de derde Raadsperiode 1983-1987* 


\section{Vierde raadsperiode:}

V63 Milieu en groei; Verslag van een studiedag op II februari 1988 (1988)

V64 De maatschappelijke gevolgen van erfelijkheidsonderzoek; Verslag van een conferentie op 16-17 juni 1988 (1988)

V65 H.F.L. Garretsen, H. Raat: Gezondheid in de vier grote steden (1989)

V66 P. de Grauwe e.a:: De Europese Monetaire Integratie: vier visies (1989)

V67 Th. Roelandt, J. Veenman: Allochtonen van school naar werk (1990)

V68 W.H. Leeuwenburgh, P. van den Eeden: Onderwijs in de vier grote steden (1990)

V69 M.W. de Jong, P.A. de Ruijter (red.): Logistiek, infrastructuur en de grote stad (1990)

V70 C.P.A. Bartels, E.J.J. Roos: Sociaal-economische vernieuwing in grootstedelijke gebieden (1990) 
